Historic, Archive Document

Do not assume content reflects current scientific knowledge, policies, or practices. 



\section{SEASON OF 1931 \\ GENERAL DIRECTIONS}

ORDER EARLY. We request our customers to order as early as possible on receipt of catalogue. We endeavor to ship all orders immediately on receipt, but during the busy season it is almost impossible; hence, the importance of ordering early.

Orders for Bulbs, Plants and Nursery Stock will be shipped in due time for planting in season.

PARCELS POST. We deliver free by Parcels Post all seeds, except Beans, Corn, Peas, Farm Seeds or Clovers. If these are wanted by mail, please add the cost of postage at zone rates.

Fertilizers, insecticides, sundries, trees and plants are, at all times, excluded from free delivery.

No charge for delivery to railroad station, steamer or express office.

ESTATE SUPERINTENDENTS, GARDENERS AND FARMERS. Parties requiring the services of reliable men, married or single, should consult with us, as we have the names of a number on our register, thoroughly experienced in every branch of the business. We have a large acquaintance among gardeners in this vicinity, and it is seldom that anyone who applies to us fails of getting the right party. There is no charge for this service.

\section{SPEGIAL NOTICE-PRICES}

The prices published in this catalogue are subject to market changes without notice. Owing to the fluctuating market in prices of all materials, we cannot bind ourselves on prices of any articles.

Payment. All orders should be accompanied by cash in the form of Draft, Cheque or P. O. Order Owing to the difficulty in collecting accounts, no order will be attended to unless accompanied by remittance from parties unknown to us or those whose accounts remain unsettled.

C. O. D. SHIPMENTS. We are always pleased to supply seeds to be paid for on delivery. Bulbs, Plants, Fertilizers, Insecticides and Perishable Stock will not be sent C. O. D. unless 50 per cent cash accompanies the order.

\section{WE ISSUE THE FOLLOWING CATALOGUES AND SPECIAL LISTS}

AGRICULTURAL IMPLEMENTS, MACHINERY, ETC. A complete list of farm tools.

BULB CATALOGUE. Ready about July 1st, containing a complete list of all bulbs for Fall planting and greenhouse forcing.

GOLF COURSE AND TENNIS COURSE EQUIPMENT. Illustrated list.

LILIES. A complete list of over 100 varieties described and illustrated. (See boxed paragraph below).

TRAINED FRUIT TREES. Illustrated folder with varieties and cultural instructions.

\section{HARDY GARDEN LILIES}

One of our specialties is "The Lily," and on that most interesting subject we have compiled the most comprehensive catalogue ever published and wherein all details of planting and culture will be found, including colored plates of nearly all the varieties in commerce. Owing to the great expense incurred in producing this valuable Lily book we are obliged to charge one dollar for same, which will be credited to the purchase of the first order for Lilies to the amount of three dollars or over. This means that credit slip for one dollar received with book should be sent with your first order for lilies amounting to $\$ 3.00$ or over.

\section{W. E. MARSHALL \& CO., Inc. 150 WEST 23d STREET, NEW YORK}

TELEPHONES: CHELSEA 3-3287, 3-3288

LOCATION OF OUR STORE-Our store, No. 150 West 23rd Street, is situated between Sixth and Seventh Avenues.

(Index, see page 128) 


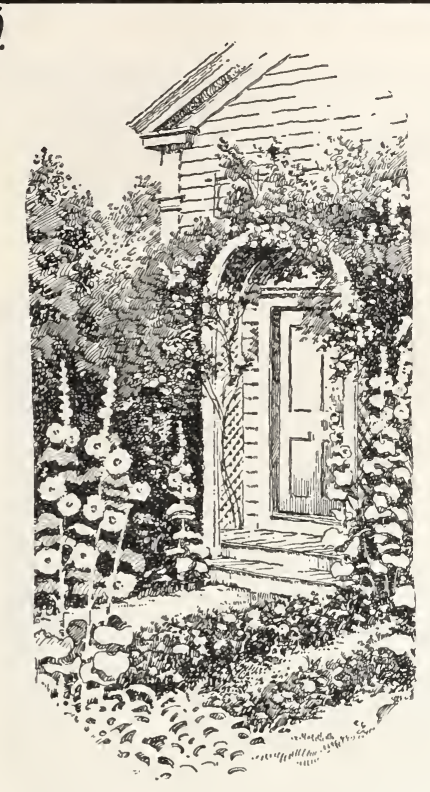

\section{foreword}

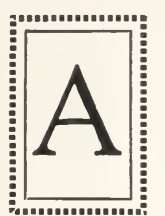
ing and illustrating is nothing as compared with the work involved in the preparation of the text. An organization such as ours, where each department is managed by a capably trained and efficient executive, must show continual progress all along the line through its offerings to the gardening public, in order to maintain its well-established reputation as a reliable and responsible institution.

Research in plant life, as in science, is one of the most potent impulses to progress. The seeking of new plants in their native haunts in distant and heretofore inaccessible regions, - the efforts of the hybridist to produce a new color or improved form of an already known type-the acceptance or discarding of an assumed novelty by our judgment of its merit-its worthiness to be pronounced distinct and unusual and to be classed as a novelty:-These are a few of the progressive steps that become problems to our executives and whose opinion can only be based upon their intimate familiarity, acquired by years of experience, with varieties and types already existing.

We aim to keep all our departments up to date. We include those items that show merit over older but similar types, which are discarded. Whether it be a flower, vegetable, plant or tree, each is given its true interpretation in color, size, character and general utility.

Research in Lilies alone has brought us in contact with some 110 or 115 varieties gathered in the distant regions of every continent in the world; these have been carefully classified, described and illustrated and are offered to our American friends, in such a comprehensive form, that the merest amateur can have lilies in his garden that were previously unheard of. Many of them are listed in this catalogue, but complete descriptions are given in our book "Consider the Lilies" devoted to Lilies exclusively (see page 64).

A careful glance through our lists of Vegetables, Flowers, Bulbs, Hardy Plants, Trees, Shrubs, and Horticultural Supplies, will demonstrate this same spirit of progress that has guided all our Department Heads in the preparation of their "copy" for this book, which is acknowledged to be one of the most authentic, "easy reference" gardening catalogues published in this country.

In closing, may we add that "quality" is considered above everything else in selecting the stocks we sell. Our domestic and foreign sources of supply are houses of known repute, our dealings with many of them dating back to the day "MARSHALL'S MATCHLESS SEEDS" was first inscribed in printer's ink. 


\section{Novelties and Specialties in Flower Seeds}

The growth of our Flower Seed Business is indicative of the discrimination of our clients, who recognize in our seeds a superiority not to be found in cheaper grades or strains. Prize winning or selected strains of flower seeds cost a little more than inferior grades but the results are infinitely superior.

\begin{abstract}
ANTIRRHINUM "Marshall's Rock Hydwarf strain. Blooming most profusely, they have a highly decorative effect in rock and alpine gardens. Early flowering. In mixture containing shades of rose, pink, purple, mauve and bicolors. Per packet 50c.
\end{abstract}

\section{AQUILEGIA Coerulea cuprea "Copper hybrids of the Columbine deservedly enjoy ever in- creasing popularity. A gorgeous new shade has been added to the riot of colors in which they are now available. A rich glowing coppery red with long spurs of deeper hue. The seed we offer can be relied upon to yield about 80 per cent true to type seedlings. Per packet 35c.}

CELOSIA "Marshall's Selected Thompsoni was imported at considerable expense two years ago and has been reselected since, the seed saved being only that from the finest formed and best colored plants. It produces large, upright plumes and makes a bushy plant. Exquisite shades of crimson, yellow, orange, scarlet, etc. Suitable for pot culture or outside. Mixed colors only. Per packet 50c.

DAHLIA Seed. Dahlia "fans" who "grow vast importance to them on page 58 .

DAHLIA Orchid Flowered. (Starfish). These DHLIA are single Dahlias of medium height. with twisted petals that give the flowers a star effect. The colors range from white, red, orange and yellow shades. Often the petals are dotted and blotched both on the top and the bottom so that, as the flower opens, the twisted petals gives it a bizarre effect. Per packet 50c.

\section{DELPHINIUM “Wrexham" Hybrids.} included in the category of novelties this superior strain of "hardy Larkspur" so far outclasses all other types, that we again wish to focus the attention of flower lovers on it. Massive broad based spires in many gorgeous shades. Our Wrexham strain is rapidly replacing the various other types hitherto offered, as the last word in Delphiniums. Wrexham Delphiniums are at their best silhouetted against a clump of Lilium Candidum. Per packet $\$ \mathbf{2 . 0 0}$. $1 / 8$ oz. $\$ 5.00$.

DIANTHUS Sweet Wivelsfield. (Dianthus Allwoodi x D. Barbatus). A remarkable hybrid that is quite distinct in method of flowering and habit of growth from the Annual Sweet William. It has a great variety of color and a very long season of blooming. Seeds sown in the early spring will flower during the late summer. Per packet 50c. FELICIA Bergeriana. Tufted grass-like foliage blue star-shaped flowers. A really pretty annual of unique beauty. Per packet 35c.

LINARIA “Canon Want.” A pale pink hardy LINARIA perennial Linaria, coming perfectly true from seed. $2 \frac{1}{2}$ to $3 \mathrm{ft}$. Per packet $35 \mathrm{c}$.

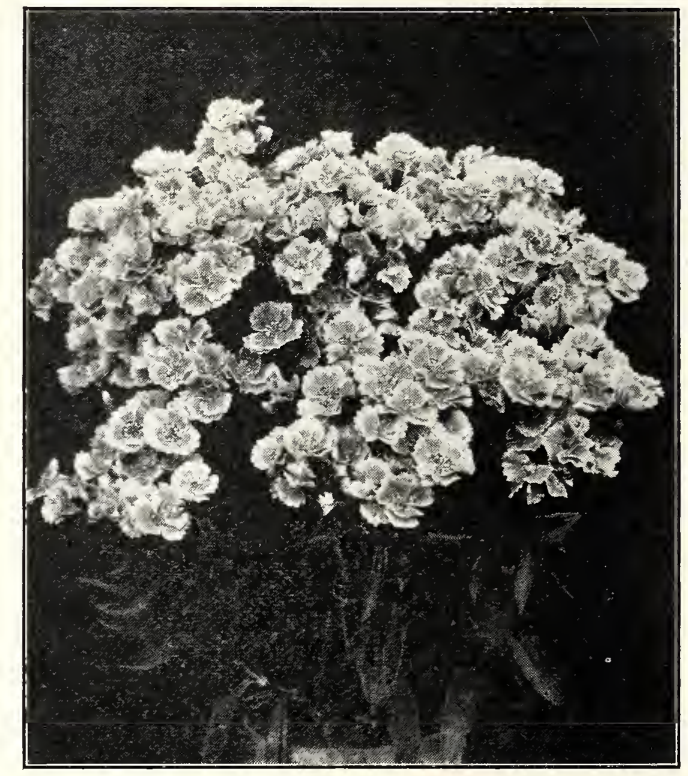

Dianthus, Sweet Wivelsfield

\section{LUPIN Northern Torchlight. A beautiful} warm carmine and cherry red, maintaining its glowing color right through the spike. Up to the present the nearest approach to scarlet. Per packet 75c.

\section{MARIGOLD "Marshall's Giant or Tree." In type it closely resembles a French Marigold but the colorings and size of flower are much superior. They grow from 4 to 5 feet high making a fine decorative plant and the flowers do not have the unpleasant odor of the Mari- gold. Per packet 35c.}

PANSY "Marshall's Apricot Bedder." Here we offer a splendid bedding Pansy of large size and of exceptionally fine color which is best described as a rich deep apricot deepening towards the center. This, grown in conjunction with Giant Pansy "King of the Blacks" (offered on Page 18) will provide an uncommonly beautiful color combination. Per packet 50c.

PETUNIA Dwarf California Giants. This proved to be an exceptionally fine type for bedding, forming sturdy, compact plants. The flowers are beautifully ruffled and fringed, with open, well marked throats. Our mixture contains a good assortment of exquisite colors. By far the finest strain of giant Petunias for pot culture. Per packet 50c. 


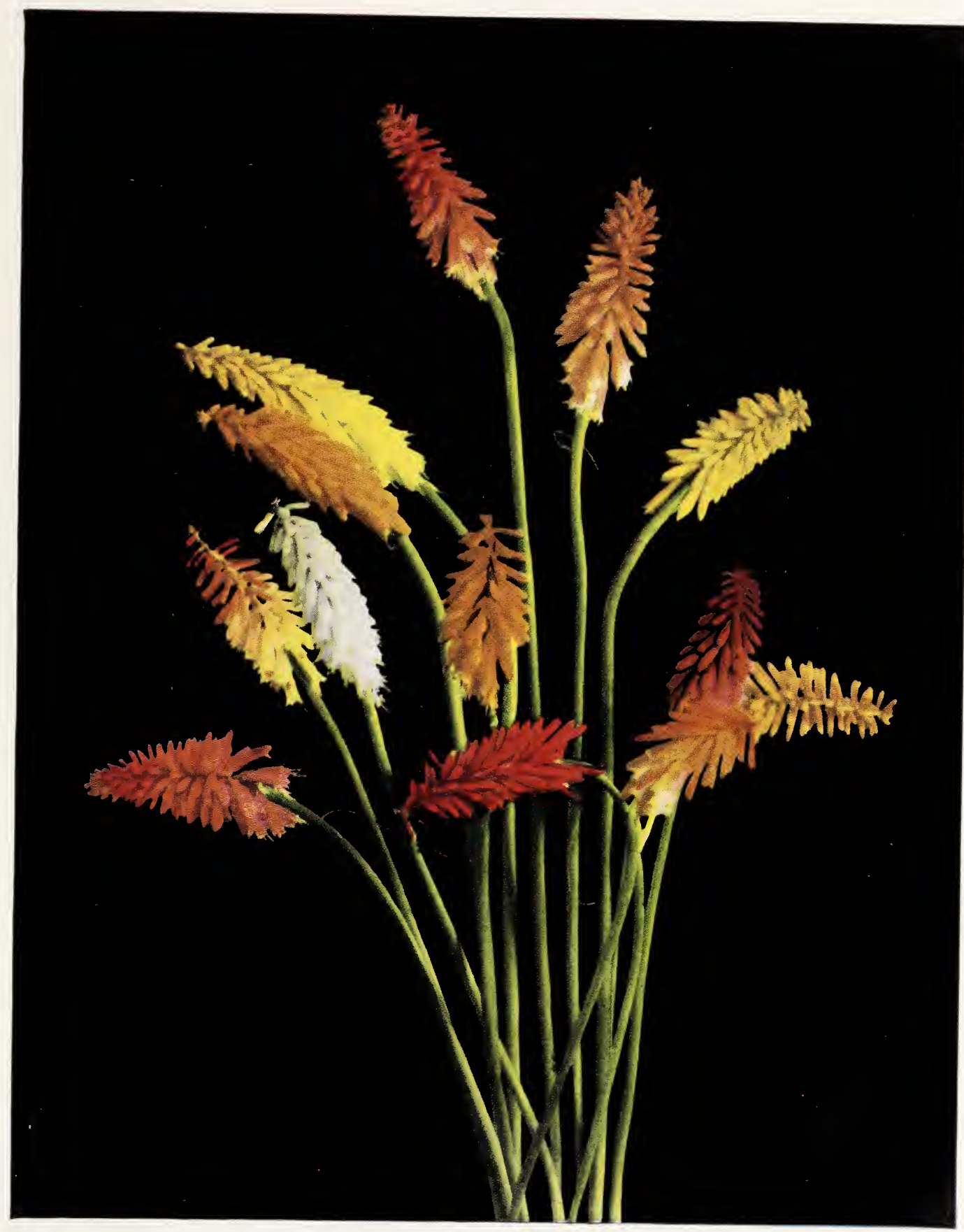

\section{TRITOMA RUFA $H Y B R I D S$}

An entirely new and delightful race of hybrid Tritomas. Splendid for cut flower or decorative use.

For further particulars see page 53

Price: $\$$ tor $\$ 2.00$; per doz. $\$ 6.00 ; 100$ for $\$ 40.00$ 


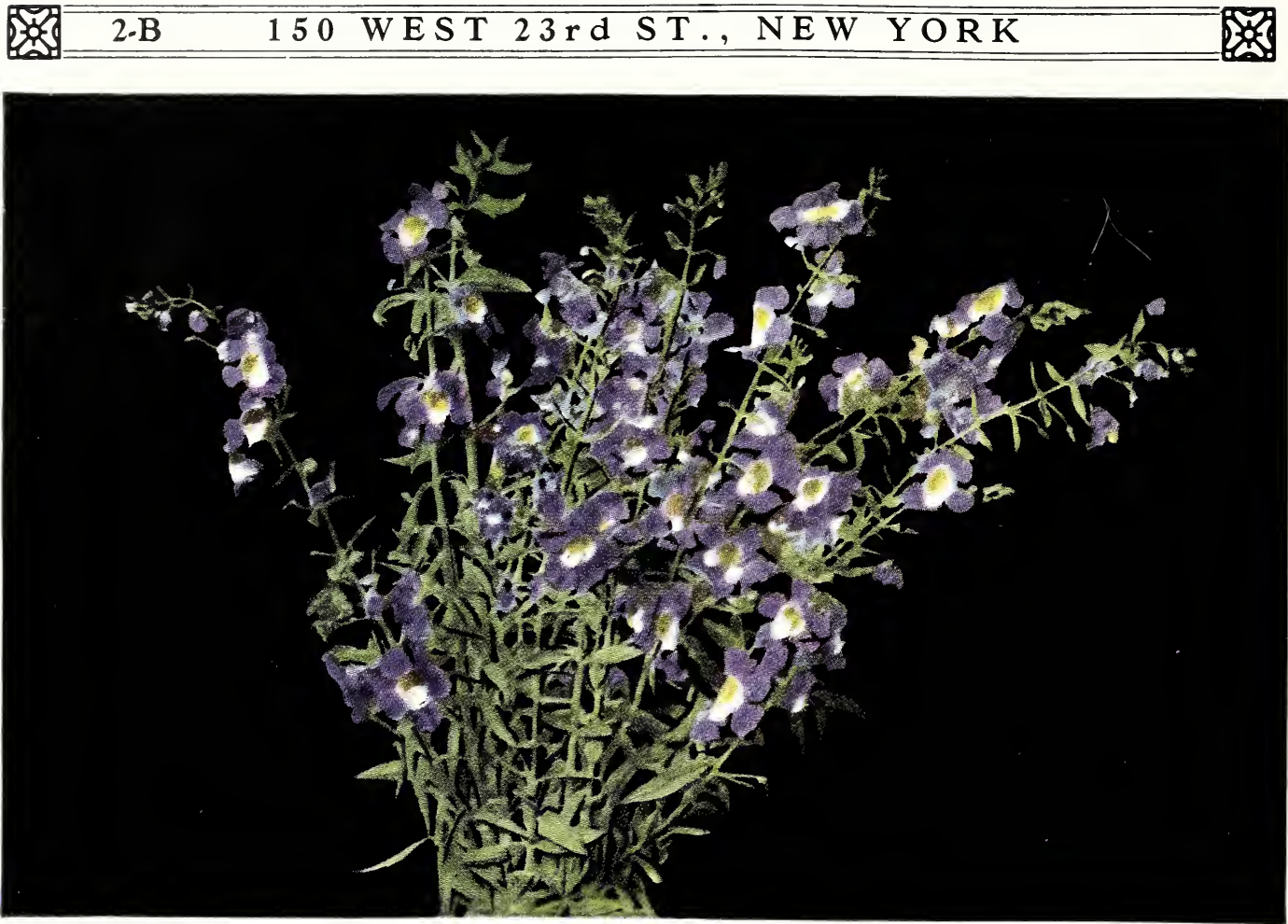

ANGELONIA SALICARIAEFOLIA (See page 3)

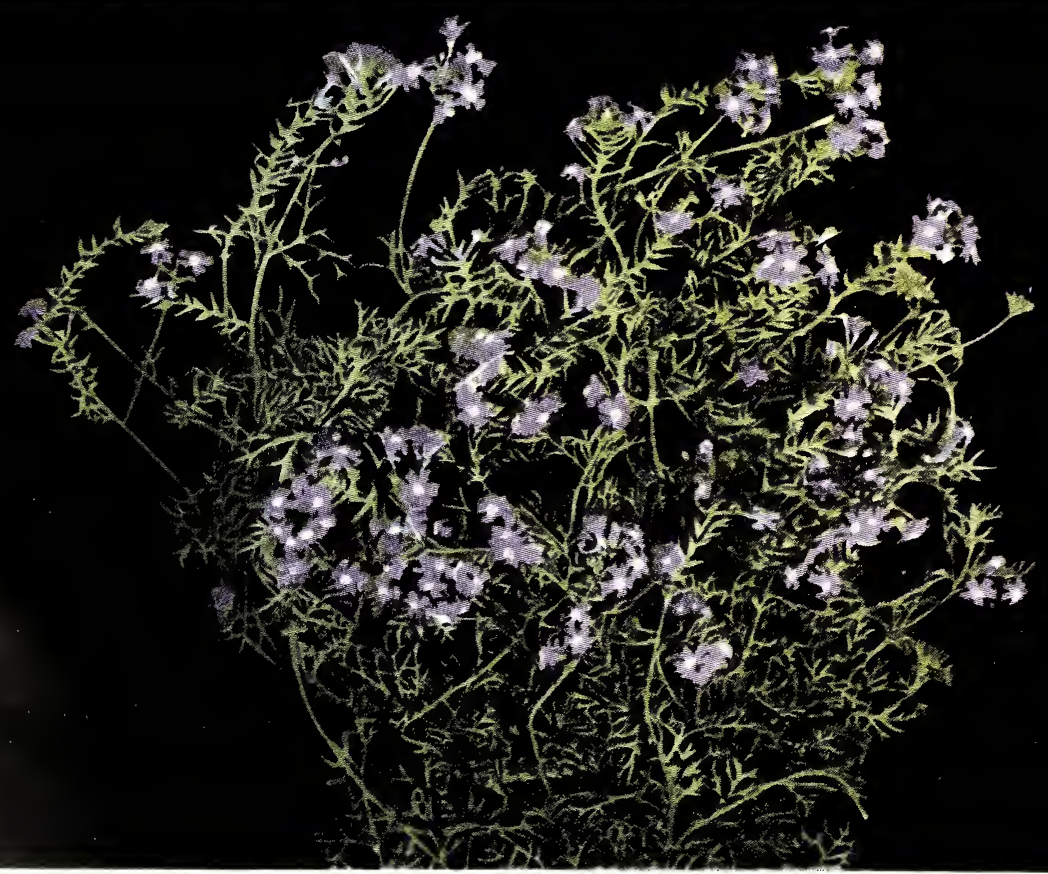

VERBENA ERINOIDES (See page 3) 


\section{FLOWER SEED SPEGIALTIES-Continued}

\section{SCABIOSA}

\section{Gian} beautiful type in cultivation. The color is most delicate salmon-rose. As a cut flower it is ideal. It has long stiff stems which make it desirable for bouquet purposes. Last, but not least, it is fragrant. Per packet 50c.

URSINIA Anethoides. A very attractive anNual, being easy to grow and is very showy for cutting or garden decoration. The Daisy like flowers are rich orange in color with a ring of deep purple at the base. Per packet 50c.

\section{VERBENA ERINOIDES Being a con- er it is most desirable for bedding or for the margin of the garden walk. Seeds should be sown early and seedlings transplanted in the open when the weather is suitable. Excellent results may also be obtained by sowing in the open border. (See color plate Page 2A) \\ Per packet 50c.: $1 / 8$ oz. for $\$ 2.00: 1$ oz. for $\$ 10.00$}

VERBENA New Dwarf "Compact Fireball." EA A compact Verbena, growing about 6 inches high, literally covered with bright scarlet blossoms. Excellent for borders or pot plants. Per packet 50c.

VENIDIUM Fastuosum. A half hardy South ENIDIUM African annual with flowers of brilliant orange with dark center and black-purple zone. Sown in February, will bloom indoors by the middle of May or outdoors in July. 2 to 3 feet. Per packet $50 \mathrm{c}$.

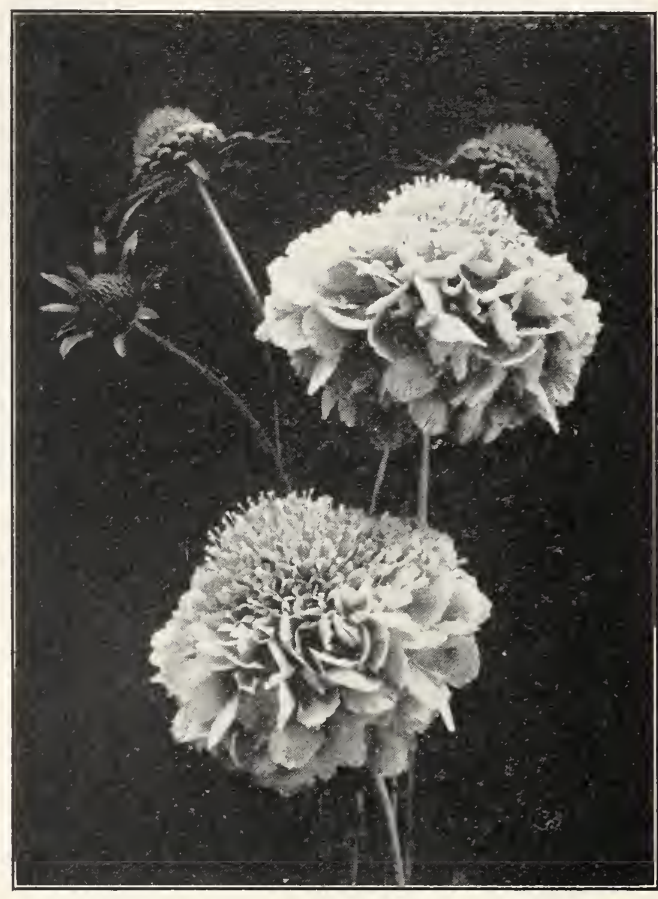

Scabiosa, Giant Loveliness

\section{NEW and DISTINCTIVE PLANTS and BULBS}

\section{ANGELONIA SALIGARIAEFOLIA}

A most fascinating tender perennial which may be used as a pot plant, but experience has proven it to be a most desirable bedding plant. It will bloom consistently throughout the season, will endure excessive drought and, on the other hand, has withstood heavy rain storms. The plant is well branched and festooned with Gloxinia-like blossoms of purplish blue with white throats. An admirable and worthy companion to Verbena Venosa as a bedding plant. 12 inches high. (See color plate Page 2a).

Plants from $2 \frac{1}{2}$ inch pots 3 for $\$ 1.75: \$ 6.00$ per dozen: $\$ 45.00$ per 100 . Six supplied at the dozen rate.

\section{LILIUM FARRERI "Pink Variety."} Another new and unusually fine Lily with fragrant, reflexed blossoms of rosy pink. Like its parent Lilium Farreri, it will thrive best if given the cultural directions outlined on page 42 of "Consider the Lilies." We have been fortunate in securing a limited supply of these bulbs. Price per bulb $\$ 6.00$.

\section{THE NEW RED RASPBERRY}

"CHIEF", "Chief" has been tested over a wide CHEF area in the past ten years and its behavior has been carefully watched. It has proven hardy - a heavy cropper of excellent quality, resistant to disease, and in addition is ten to twelve days earlier to ripen. It bridges the gap between strawberries
The New Red Raspberry "Chief" - continued

and ordinary raspberries. "Chief" was originated by the Minnesota State Fruit Breeding Farm and is a selection from 4000 seedlings of Latham. It possesses many good qualities of Latham, some of them to even a greater degree than the parent, the main point of difference being in season of ripening. Per $100 \$ 30.00$. 25 for $\$ 8.00$.

\section{LILIUM LANKGONGENSE ${ }^{\wedge}$ new come addition to our large and justly famous offerings of lilies with fragrant, nodding white blossoms flushed rose purple. It is rated very highly by lily experts and is, as yet, very rare. To secure the best results with this choice gem it should be cultivated in the same manner as Lilium Farreri. (See page 42 of "Consider the Lilies.") Price per bulb $\$ \mathbf{7 . 5 0}$.}

\section{PHLOX ARENDSII HYBRIDS.}

These Phloxes are hybrids between Canadensis and Decussata. They flower early in spring, and when cut come back several times during summer, they will continue to flower until late fall. Plants are of a spreading nature and grow about 1 foot high.

Emmy. Lilac with dark eye.

Hilda. White, suffused with lilac; pink eye.

Louise. Pale lilac with a light carmine eye.

Marianna. Dark bluish violet.

Price 3 for $\$ 2.50$. $\$ 8.00$ for 10 . 


\section{ALL FLOWER SEEDS ARE MAILED FREE AT PACKET, OUNCE AND POUND RATE TO ANY POST OFFICE IN THE UNITED STATES}

The following list contains a most complete assortment of the choicest and most popular flowers for either conservatory, greenhouse or garden culture.

Annuals grow from seed, flower, mature their seed, and die in one year, or, in other words, the same season.

Hardy Annuals are those which can be sown in the open ground.

Half-Hardy Annuals are those which should be started early in the house, conservatory or hotbed, and transplanted to the garden in settled warm weather.

Biennials grow from seed, sown from June to August, flower, ripen their seed and die the next year, though some varieties bloom the same season if sown early in gentle heat.

Hardy Biennials will winter in the open ground without protection.

Perennials grow from seed, and continue flowering annually for many years after the first season. Some varieties flower the first season if planted early in gentle heat.

Half-Hardy Biennials require the protection of a coldframe or cool house during Winter.

Hardy Perennials can remain in the open ground during Winter without protection.

Half-Hardy Perennials require the protection of a coldframe or cool house during the Winter.

Tender or Greenhouse Perennials require window or greenhouse culture, free from frost during Winter and thrive in the garden during the warm months.

\section{EXPLANATION OF FLOWER SEED ABBREVIATIONS}

H.A. designates Hardy Annuals-Lasting but one year.

H.H.A. Half-Hardy Annuals-Lasting but one year.

H.B. - Hardy Biennials-Lasting but two years.

H.H.B. - Half-Hardy Biennials-Require protection during Winter.

H.P. - Hardy Perennials-Lasting three or more years.
H.H.P.designates Half-Hardy Perennials-Require protection during Winter.

H.C. - Hardy Climber-Lasting three or more years.

G.P. * Greenhouse Plant.

H.A.C. " Hardy Annual Climber
ABRONIA umbellata. H.A. Trailing annual, pink flower trusses. 9 in........1/4 oz. $25 \mathrm{c}$.

ABUTILON. New Hybrids. G.P. Large bellshaped flowers. Mixed colors...............

ACACIA. G.P. Finest mixed, elegant Winter and Spring flowering plants.

ACHILLEA ptarmica, "The Peari."; " $\ddot{\mathrm{H}} . \ddot{\mathrm{P}}$ Double white flowers..........1/16 oz. $\$ 1.00$

ACONITUM napellus. H.P. Dark blue flowers in August.............. $1 / 4$ oz. $\$ 1.00$

Wilsoni. Light blue flowers in large trusses...

ACROCLINIUM. H.A. Pretty everlasting flowers; fine for Winter bouquets. $1 \mathrm{ft}$.

album. Pure white; double flowers. $1 / 4$ oz. 25c.

roseum. Bright rose; double flowers. $1 / 4 \mathrm{oz} .30 \mathrm{c}$

Finest Mixed Colors. ..........1/4 oz. 20c.

ADONIS a utumnalis. $\mathrm{H} . \mathrm{A}$. C Crimson flowers with dark centers. $1 \mathrm{ft} . \ldots \ldots \ldots 1 / 4 \mathrm{oz} .25 \mathrm{c}$

vernalis. H.P. Large, yellow; flowers in early Spring. 9 in ..............

AGATHAEA coelestis (Blue Marguerite) H.H.P. Pretty blue Daisy-like flowers. An excellent pot plant. $11 / 2 \mathrm{ft} . \ldots \ldots \ldots \ldots . .$.

AGERATUM. H.A. Blooms throughout the Summer; feathery flowers in clusters.

mexicanum. Fine for bedding or pot culture. Blue. $11 / 2 \mathrm{ft} . \ldots \ldots \ldots \ldots \ldots \ldots 1 / 8 \mathrm{oz} .30 \mathrm{c}$. mexicanum album. $A$ beautiful white variety $11 / \mathrm{ft} \ldots \ldots . . . . .1 / 80 \mathrm{z}, 30 \mathrm{c}$

Imperial Dwarf Blue. Extra neat; fine for edging. 9 in ................ $1 / 8 \mathrm{oz} .50 \mathrm{c}$

Imperial Dwarf White. Pretty for contrast; fine for edgings. 9 in..........1/8 oz. $50 \mathrm{c}$

Blue Perfection. Very fine dwarf. 9 in.

$1 / 8$ oz. $50 \mathrm{c}$

Little Blue Star. Light blue; fine for carpet bedding. 6 in ..............1-16 oz. $\$ 1.00$ Princess Victoria Louise. D Dwarf, light blue, white center, 9 in ..........1/8 oz. $\$ 1.00$

Swanley Blue. A fine, large-flowered sort. $1 \mathrm{ft} . . \ldots \ldots \ldots \ldots \ldots \ldots \ldots . \ldots 1 / 8$ oz. $50 \mathrm{c}$ AGROSTEMïA coelirosa (Rose of Heaven) H.A. Bright rose; excellent for cutting. 18 in.

coelialba. White.......... $1 / 4$ oz. 35c. coronaria (Rose Campion). 'H.P. Crimson flowers, silver foliage. $2 \mathrm{ft} . \ldots \ldots 1 / 4 \mathrm{oz} .35 \mathrm{c}$.

ALONSOA Warscewiczi compacta. H.A. For pot culture or outside planting. Foliage dark green with racemes of bright scarlet flowers.

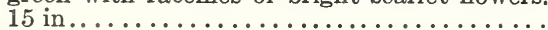

Pkt.

ALSTROEMERIA HYBRIDS.

Mixed. Lily-like perennials with clusters of flowers on long stems in yellow and orangered shades. $3 \mathrm{ft} \ldots \ldots \ldots \ldots \ldots \ldots \ldots \ldots . . \ldots . . \ldots$

AL YSSUM. H.A. Pretty little plants for beds, vases, baskets, edgings or rockwork; blooming profusely all Summer.

maritimum (Sweet Alyssum). Fragrant, white; flowers all Summer. 6 in.....oz. $50 \mathrm{c}$.

maritimum compactum, Little Gem. Grows erect; fine for edging........ oz. $\$ 1.00$

Benthami compactum, Lilac Queen. Pure lilac flowers, dwarf and compact growth. 6 in ...............

Benthami compactum lutescens. Yellowish flowers on strictly upright flower spikes. 6 in ............... oz. $35 \mathrm{c}$ procumbens (Carpet of Snow). Dwarf; pure white. 4 in ...............1/4 oz. 50c. saxatile compactum. H.P. Spring-blooming Alyssum with yellow flowers. 12 in $1 / 4 \mathrm{oz} .75 \mathrm{c}$.

saxatile, Silver Queen. An early Springblooming perennial with masses of pale lemon flowers. 6 in $\ldots \ldots \ldots \ldots \ldots \ldots \ldots \ldots$

AMARANTHUS. H..̈. Ornamental foliage plants, producing a striking effect either in the conservatory or flower garden.

caudatus (Love-lies-bleeding). Long drooping crimson spikes, $3 \mathrm{ft} . . . . . . . .1 / 4 \mathrm{oz} .35 \mathrm{c}$ salicifolius (Fountain Plant). Distinct variety, with graceful drooping leaves. $2 \mathrm{ft} .1 / 4 \mathrm{oz} .35 \mathrm{c}$. tricolor (Joseph's-coat). Leaves red, yellow and green. $2 \mathrm{ft} \ldots \ldots \ldots \ldots \ldots \ldots$ oz. $50 \mathrm{c}$

AMPELOPSIS Veitchi (Japanese Woodbine, or Boston Ivy). H.C............1/4 oz. 40c.

ANAGALLIS grandifiora. 'H.H.A. Mixed colors. Showy garden plant. 6 in. $1 / 4$ oz. $35 \mathrm{c}$.

ANCHUSA capensis. H.A. Flowers resembling large Forget-me-nots. $18 \mathrm{in}, \ldots \ldots 1 / 4 \mathrm{oz} .75 \mathrm{c}$ grandiflora (Dropmore Variety). H.P. Large flowered, dark blue. $5 \mathrm{ft} . . \ldots \ldots 1 / 8 \mathrm{oz} .50 \mathrm{c}$.

ANEMONE. H.P. A very pleasing perennial. producing large flowers. 12 in.

coronaria, $\mathbf{S t}$. Brigid.........1/8 oz. $50 \mathrm{c}$ japon1ca. Pink. 2 to $3 \mathrm{ft} . \ldots \ldots \ldots \ldots \ldots \ldots$

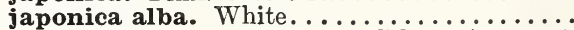

ANGELONIA grandiflora. G.P. A sweetscented greenhouse plant with dainty mauve sprays of flowers. $2 \mathrm{ft} . \ldots \ldots \ldots \ldots \ldots \ldots$

ANTHEMIS Kelwayi. H.P. Yellow flowers, $3 \mathrm{ft}$. 


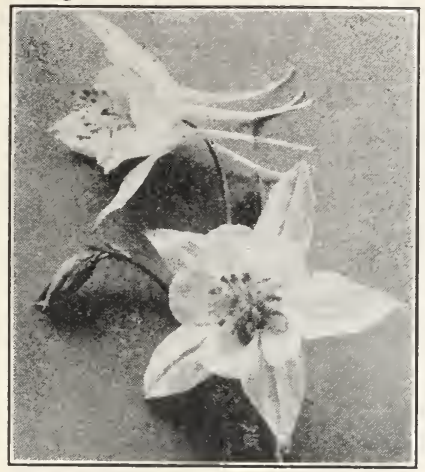

Aquilegia, Long-spurred

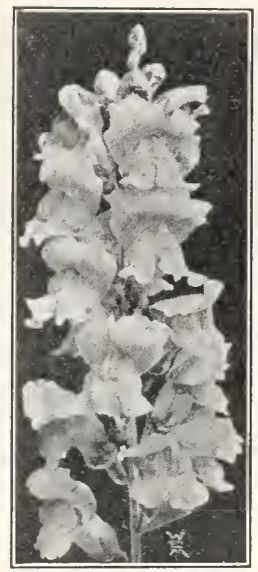

Antirrhinum Matchless

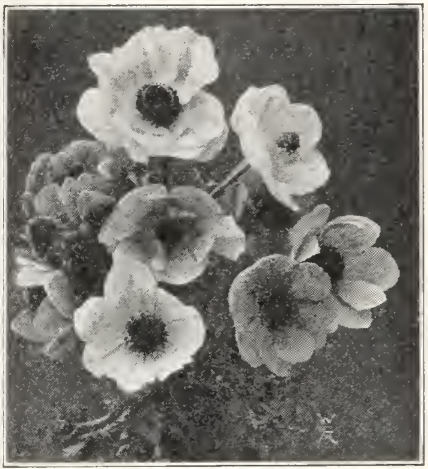

Anemone Coronaria

AQUILEGIA (Columbine.) H.P. Pkt

Fine, free flowering, hardy border plant-one of our most desirable perennials. Seed may be Their rich colors and keeping qualities as cut flowers make them most desirable.

Greenhouse Forcing Varieties:
Pkt.

A terglow. A splendid glowing bronze... \$\$1.00

Ceylon Court. A soft Mandarin yellow... 1.00 Geneva Pink. Exquisite deep pink....... 1.00

Helen. Glowing salmon................ 1.00

Jennie Schneider. Soft brilliant pink.... 1.00

Judd's Pink. A rich glowing shade....... .50

Judd's Rose. An unusually rich color..... . . .50

Matchless White. A selected strain ..... . .50

Matchless Yellow. A fine strain........ .50

Penn-Orange. Vivid orange with yellow and pink shadings.............. 1.00

Philadelphia Pink. $\ddot{A}$ beautiful pink. .50

Large-flowering Half-Dwarf Varieties. The best for bedding purposes, growing about 18 inches high.

Black Prince. Dark-leaved, blackish crimson purple...............1/8 oz. $50 \mathrm{c}$.

Defiance. Fiery scarlet..........1/8 oz. 50c. Golden Queen grandiflora. Pure yellow.

$1 / 8 \mathrm{Oz} .50 \mathrm{c}$. roseum superbum. Rosy-pink..1/8 oz. $75 \mathrm{c}$. Silver Queen. A distinct color of pure silvery lilac. A beautiful color under

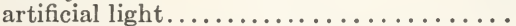

The Bride. White, changing to delicate $\ddot{\text { rose. }}$

$1 / 8$ oz. $50 \mathrm{c}$.

Fine Mixed. All colors..........1/4 oz. 60c. Collection of six above varieties.........

Marshall's Giant-flowering Varieties. These grow about 3 feet high and are all of the largeflowering types.

Bonfire. Bright cinnabar red, yellow blotch. $1 / 4 \mathrm{oz} .75 \mathrm{c}$. Coral Red. Rich, with red throat. $1 / 4$ oz. $75 \mathrm{c}$. Defiance. Fiery scarlet..........1/4 oz. 75c. Firefly. Scarlet and yellow.........1/4 oz. 50c.

Indian Summer. A rich velvety and glossy copper color...............1/8 oz. $\$ 1.00$

Queen Victoria. Large white....1/4 oz. 50c. roseum. Rose..................1/4 oz. 50c.

Ruby. Pure ruby red.............1/4 oz. 50c.

Salmon Pink. Very large-flowering. $1 / 4 \mathrm{oz} .75 \mathrm{c}$.

Striped. Odd and pretty ..........1/4 oz. 50c.

Venus. Delicate rose on white ground.

$1 / 4$ oz. 50 c. .15

Giant Yellow..................1/4 oz. 60c.

Giant Large-flowered Mixed. Fine variety of colors.................1/4 oz. 50c. .10

Collection of six distinct varieties........ .75

Collection of twelve distinct varieties ...... 1.50 planted in the open ground early in Spring and will in some varieties bloom in the same season. Best results, however, are obtained by planting in August for the next season's blooming.

Marshall's Matchless Long-spurred Hy * brids. A grand variety of colors of the longspurred and large-flowered forms. $3 \mathrm{ft}$. $1-16$ oz. $\$ 1.00 \$ 0.25$

caerulea hybrida. Large flowered blue hybrids, $3 \mathrm{ft} . . . \ldots \ldots \ldots . \ldots 1 / 8 \mathrm{oz} .75 \mathrm{c}$ chrysantha. Long-spurred, golden yellow.

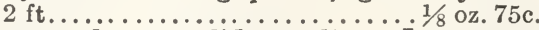
chrysantha grandiflora alba. Large pure white. $2 \mathrm{ft} . \ldots \ldots \ldots \ldots \ldots \ldots \ldots$ oz. $\$ 1.00$ glandulosa vera. Dark blue and white. 12 in. . Marshall's Rose Queen. A beautiful selection of long-spurred rose shades..........

Skinneri. A beautiful scarlet, tipped green. $2 \mathrm{ft} \ldots \ldots \ldots \ldots \ldots \ldots \ldots \ldots \ldots \ldots 1 / 8$ oz. $\$ 1.00 \quad .25$ Collection of five choice varieties ...... 1.00

Single, Mixed colors............1/4 oz. 75c. .15 Double-flowering. Mixed colors..1/4 oz. $75 \mathrm{c}$. .15

ARABIS alpina. H.P. Excellent for borders or rockwork. Pure white. 6 in....1/4 oz. 50c.

ARCTOTIS grandis. H.A. Daisy-like flowers; white shaded blue. $2 \mathrm{ft}$.......1/4 oz. $50 \mathrm{c}$.

ARMERIA, Giant Thrift. H.P. A pretty edging plant with deep pink flowers, $12 \mathrm{in} .1 / 4 \mathrm{oz} .75 \mathrm{c}$.

ASPARAGUS plumosus nanus. G.P. Graceful and feathery bright green foliage. $8 \mathrm{ft}$. 100 seeds $\$ 1.00$ prengeri. A handsome variety of rapid growth for hanging baskets. $3 \mathrm{ft}$.

100 seeds $50 \mathrm{c}$.

ASPERULA odorata (Woodruff). H.P. The

ASTER. (Perennial.) Michaelmas Daisy. Delavayi. H.P. A charming new introduction with large lavender flowers and center disc of

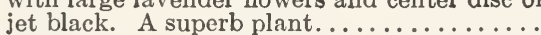

Farreri. H.P. The flowers are single with violet-mauve petals and a large goldenorange disc, often $21 / 2$ inches in diameter produced on long, stiff naked stems. Commencing to bloom in May.............. white flowers and foliage are perfumed. 12 in. 政

Michaelmas Daisy. H.P. Large flowering, hardy mixed, Fall flowering varieties; rich shades of purples, lavenders, etc. $21 / 2 \mathrm{ft}$.

5

5

\section{5}

.

5




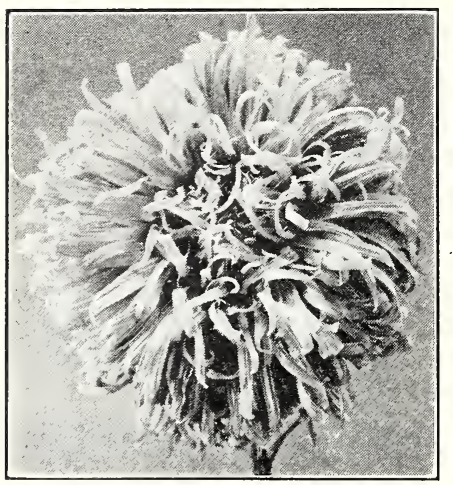

Aster, Ostrich plume

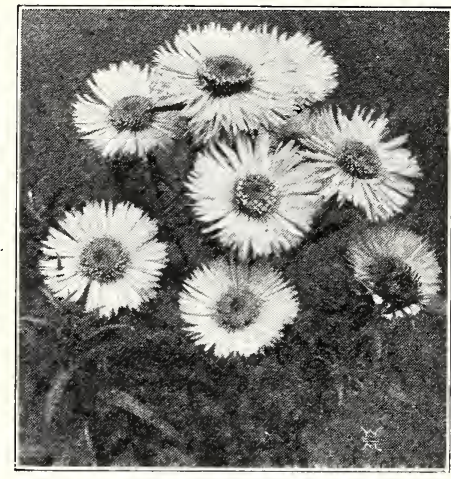

Aster, Perennial

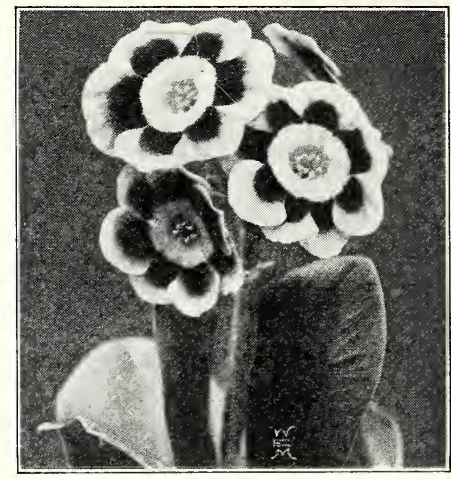

Auricula

\section{ASTERS}

Plants from seeds sown in the open ground in May bloom finely in September and October, when the flowers are seen at their best. For July and August flowers sow in March or April, in coldframe, spent hotbed, or pots and boxes in the house. Cover the seeds about half an inch deep with rich, light soil, and when the plants have three or four leaves, transplant about 18 inches apart each way into well prepared beds.

\section{CHR YSANTHEMUM - FLOWERED.}

Dwarf. A splendid variety of com pact habit. 12 in. $\quad \ldots \ldots \ldots \ldots \ldots \ldots 1 / 4 \mathrm{Oz}_{25} \begin{aligned} & \mathrm{Pkt} \text {. } \\ & \$ 0.15\end{aligned}$

Apple Blossom $\ldots \ldots \ldots \ldots \ldots \ldots \ldots \ldots \ldots \ldots \ldots \ldots \ldots \ldots \ldots \ldots \ldots$
Dark Blue $\ldots \ldots \ldots \ldots \ldots \ldots$

Fiery Scarlet. $\ldots \ldots \ldots \ldots \ldots \ldots \ldots \ldots \ldots \ldots$
Light Blue $\ldots \ldots \ldots \ldots \ldots \ldots \ldots \ldots \ldots \ldots$

Light Blue $\ldots \ldots \ldots \ldots \ldots \ldots \ldots \ldots \ldots \ldots \ldots$
White $\ldots \ldots \ldots \ldots \ldots \ldots \ldots \ldots \ldots$

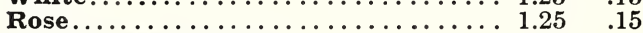

Finest Mixed Colors.............. $1.00 \quad .15$

GrANTS OF CALIFORNIA. An improved form of Crego with flowers 6 inches across, packed with broad petals. 24 in.

Dark Purple. . . . . . . . . . . . . . . 1.25

Deep Rose. . . . . . . . . . . . . . 1.25

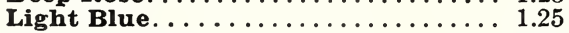

Peach Blossom. . . . . . . . . . . . 1.25

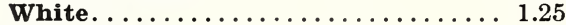

Finest Mixed.................... 1.00

GIANT BRANCHING COMET. A Giant

Comet type of Branching Asters. All large, full flowers. $2 \mathrm{ft}$.

Crimson.

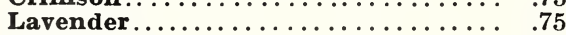

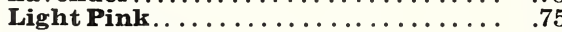

Royal Purple.................. .75

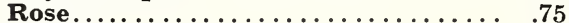

White...................................

Finest Mixed Colors.............. $\quad .75$

IMPROVED GIANT BRANCHING. The flowers are large, fine for cutting. $2 \mathrm{ft}$.

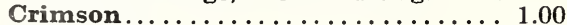

Dark Blue .............................

Light Blue ................. 1.00

Rose.

Shell Pink.................. 1.00

White....................... 1.00

Finest Mixed. All colors............. 1.00

Collection of Six Varieties............

MARSHALL'S KING. Upright growth; large flowers, long, narrow petals. $2 \mathrm{ft}$.

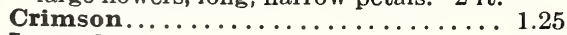

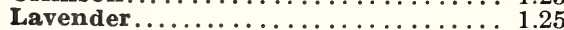

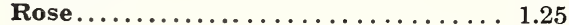

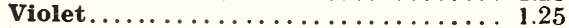

White....................... 1.25

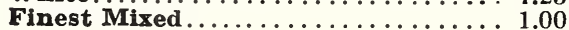

\section{ASTERS-(Continued.)}

OSTRICH PLUME: Splendid class, fine for cutting. $18 \mathrm{in}$. $1 / 4 \mathrm{Oz}$. Pkt. Crimson ........................ $\$ 1.00 \$ 0.10$

Light Blue ...................... 10

Rose.........................

White ....................... $1.00 \quad .10$

Finest Mixed Colors............... $1.00 \quad .10$

QUEEN OF THE MARKET. The earliest of all; 18 in.

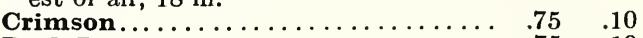

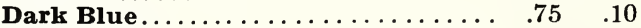

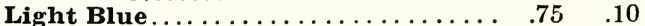

Pink.................

Rose..................... .75 .10

White.......................

Choice Mixed. Äll colors............ .60 $\quad .10$

SINGLE SINENSIS. Popular for cut flowers. 18 in.

Light Blue .................... $1.00 \quad .15$

Pink ........................... $1.00 \quad .15$

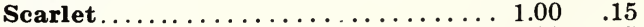

Violet.......................

White .................... $1.00 \quad .15$

Finest Mixed Colors.............. . . . .
.15

.15

.15

.15

.15

.10

.10

.10

.10

.10

.10

.10

.10

.10

.10

.10
.10

.50
SUNSHINE or Improved Anemone Flowered. Fine for cutting. 24 in.

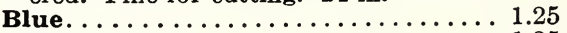

Lilac............................ 1.25

Pink $\ldots \ldots \ldots \ldots \ldots \ldots \ldots \ldots \ldots$

white............................. 1.25

Finest Mixed $\ldots \ldots \ldots \ldots \ldots \ldots \ldots \ldots \ldots \ldots$

VARIOUS ASTERS.

Beauty. Late flowering. 30 in. Finest Mixed...................... $1.00 \quad .15$

Daybreak. A delicate pink Aster. 2 ft.. $1.25 \quad .15$

Enchantress Pink. A delicate pink. . . $1.25 \quad .15$

Everlasting Flesh. Resembles a large Helichrysum..................

Heart of France. Rich dark red, nicely branched. 24 in................. 1.25

Purity. Pure White. $2 \mathrm{ft} . \ldots \ldots \ldots \ldots 1.25$

Yellow Fancy. Canary-yellow. 2 ft... 1.25

ASTERS-Perennial varieties-See Page 5.

AUBRIETIA. H.P. Suitable for rockwork and herbaceous borders. 9 in.

graeca. Purple; trailing............. . .25

Leichtlini. Carmine; trailing ............ $\quad .25$

hybrida grandifiora. Finest mixed colors . . $\quad .25$

AURICULA, Finest Mixed. H.P. Flowers resemble the polvanthus primrose. Many lovely shades of yellows, garnets, and purples with lighter centers. 6 in..

BACHELOR BUTTON. (See Centaurea cyanus).

BALLOON VINE. H.H.C White flowers, followed by balloon-like seed pods

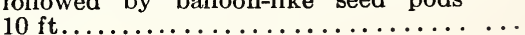




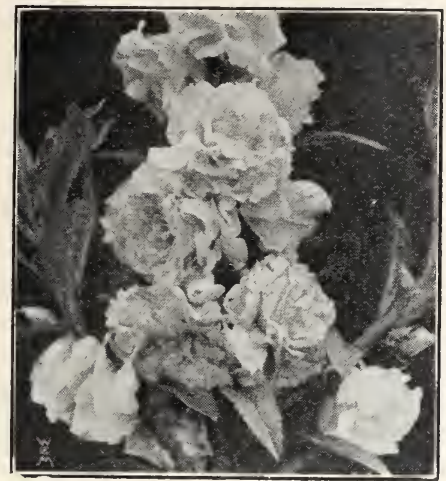

Balsam, double

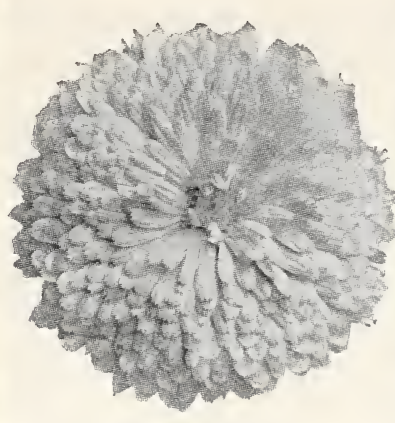

Calendula 'Campfire'

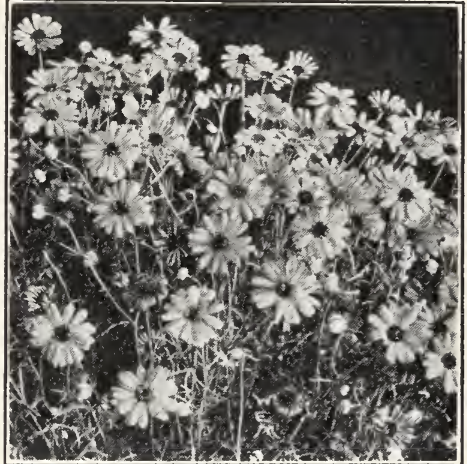

Brachycome
Pkt

BALSAM (Lady's Slipper). H.A. Showy and easily grown annuals. 18 in.

Double Dark Blue... . . . . . . . . 1/4 oz. 50c. $\$ 0.10$

Double Salmon...............1/4 oz. 50c. .10

Double Scarlet.................1/4 oz. 50c. .10

Double Yellow................1/4 oz. 50c. .10

Double White..................1/4 oz. 50c. .10

Mixed Colors. Extra choice; double oz. $\$ 1.00 \quad .10$

Collection Camellia-flowered. Six separate colors .....................

BARTONIA aurea. H.A. Large single yellow flowers. 12 in................1/4 oz. 30c.

BEGONIA, Bedding Varieties. H.H.A. The following are of the Semperflorens type. Dwarf Vernon. Rich scarlet. 6 in. $1-16 \mathrm{oz} . \$ 2.00$ Erfordi. Carmine bedder. 6 in. 1-32 oz. $\$ 4.00$ gracilis rosea. Delicate rose. 9 in ........

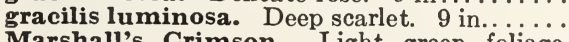
Marshall's Crimson. Light green foliage, with large crimson fiery-red flowers. . . . . . . . . gracilis Mignon. Scarlet flowers, foliage deep green, with red spots and border. 6 in.......

gracilis "White Pearl." Pure white flowers, with light green foliage. 9 in . . . . . . . .

Salmon Queen. Bright salmon flowers. 6 in. .

Vernon. Bronze foliage with scarlet flowers. 9 in ................... 1-16 oz. $\$ 2.00$

BEGONIA, Tuberous-rooted. G.P. Produce magnificient flowers; grown either in pots or for bedding.

Marshall's Giant Single, Mixed. 12 in.. . . . 1.00

Marshall's Giant Double, Mixed. 12 in... . 1.00

Rex Varieties. Ornamental leaves. 12 in... . . 1.00

BELLIS perennis fi. pl. (Double English Daisy). H.P. Spring-flowering perennial. 6 in.

Longfellow. Dark rose....... 1/8 oz. $\$ 1.00$

Snowball. Pure white......... 1/8 oz. $\$ 1.00$

Giant Red. Dark red............1-16 oz. $\$ 1.00$

Giant Mixed................ 1/8 oz. $\$ 1.00$

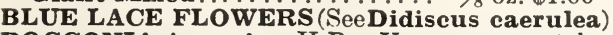

BOCCONIA japonica H.P. Very ornamental; flowers white. $6 \mathrm{ft} \ldots \ldots \ldots \ldots \ldots \ldots 1 / 40 \mathrm{oz} .50 \mathrm{c}$. BOLTONIA asteroides. $\ddot{H} . \dot{P}$. ${ }^{1 / 4}$ ure white Aster-like flowers, $4 \mathrm{ft}$.

latisquama. Pink flowers, tinged with laven-

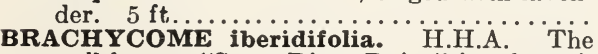
well-known "Swan-River Daisy" is a beautiful little, half-hardy annual; pretty blue flowers. 18 in..................1/8 oz. 50c.

iberidifolia, Mixed (Swan-River Daisy). For edging. 12 in ...............1/4 oz. 50c.

BROWALLIA. H. A. Profuse-blooming annual, highly prized for cutting. $2 \mathrm{ft}$.

elata caerulea. Bright blue.............

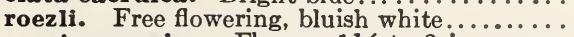

speciosa major. Flowers $11 / 2$ to 2 in. across;

blue, white throat....................

Pkt.

viscosa. The salvia-shaped flowers are of a bright violet-blue...............\$0.50

CACALIA coccinea (Tasselflower). H.A. Scarlet

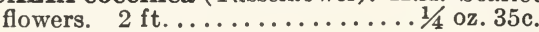

CALCEOLARIA hybrida grandiflora. G.P Highly prized plants for conservatory and house decoration.

Marshall's Matchless Strain. Rich and delicate colors, in the most marvelous variety of shades and marking.

Large Flowering "Dalkeith Park Strain."

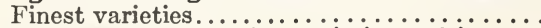

rugosa Mixed. Bedding varieties. $12 \mathrm{in} . .$. .

CALENDULA (Cape Marigold). H.A. Free and continuous flowering garden plants. 12 in

Campfire. The best orange......1/4 oz. $\$ 1.00$

Meteor. Double yellow, striped orange. oz. 50c.

Orange King. Double rich orange red flowers...................... . . 75c. Sulphur Crown. Double, yellow......... 75c. The Ball. Large, double orange. . $1 / 4 \mathrm{oz} . \$ 2.00$

Finest Mixed. All varieties....... oz. 50c.

CALLIOPSIS. H.A. Nothing is more effective than a large bed of these golden flowers.

atrosanguinea. Rich dark red. 18 in. $1 / 4 \mathrm{oz} .30 \mathrm{c}$. compacta, Crimson King. Deep bright scarlet. 18 in ................1/4 oz. $50 \mathrm{c}$

Golden Wave (Drummondi). Pure yellow flowers, very large and showy...1/4 oz. 50c.

marmorata. Maroon and gold. $18 \mathrm{in} .1 / 4 \mathrm{oz} .50 \mathrm{c}$ tinctoria. Large bright yellow and maroon flowers. $2 \mathrm{ft}$................... oz. $50 \mathrm{c}$. Dwarf, Finest Mixed. Ali shades of yellow, red and brown. 12 in..........1/4 oz. 30c. Tall Mixed. A grand variety for cutting. $2 \mathrm{ft}$. $1 / 4$ oz. $30 \mathrm{c}$.

CALLIRHOE involucrata. (Poppy Mallow) H.P. Beautiful trailing plant; flowers large, crimson. with white center. $12 \mathrm{in.} 1 / 8 \mathrm{oz} .75 \mathrm{c}$.

CAMPANULAS. H.P. All the Campanulas can be grown in ordinary gardens and will flower from seeds the following year.

carpatica. Deep blue; for rockeries, beds and edgings. $6 \mathrm{in} \ldots \ldots \ldots \ldots \ldots \ldots \ldots 1 / 4 \mathrm{oz} .50 \mathrm{c}$ carpatica alba. Flowers white. 6 in $1 / 4$ oz. $50 \mathrm{c}$. pyramidalis (Chimney Bell). Very conspicuous towering spikes, with clear blue flowers. $4 \mathrm{ft} . \ldots \ldots \ldots \ldots \ldots \ldots \ldots \ldots \ldots . \ldots \ldots$ oz. $\$ 1.00$ pyramidalis alba. Pure white, $4 \mathrm{ft} .1 / 4 \mathrm{oz} . \$ 1.00$ persicifolia grandiflora, Blue. Superb large flowers. $2 \mathrm{ft} \ldots \ldots \ldots \ldots \ldots \ldots \ldots 1 / 8$ oz. $\$ 1.25$ persicifolia grandifiora alba. $A$ white-flowered variety................ 1/8 oz. $\$ 1.25$ persicifolia Telham Beauty. China blue,

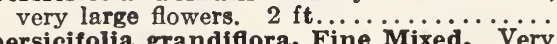
persicifolia grandiflora, Fine Mixed. Very showy. $2 \mathrm{ft} \ldots \ldots \ldots \ldots \ldots \ldots \ldots \ldots 1 / 8$ oz $\$ 1.25 \quad .25$ 


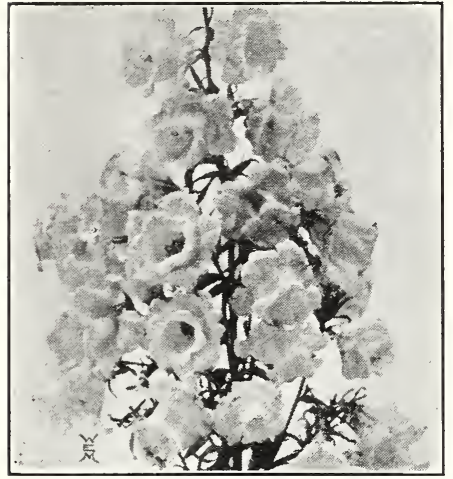

Campanula media

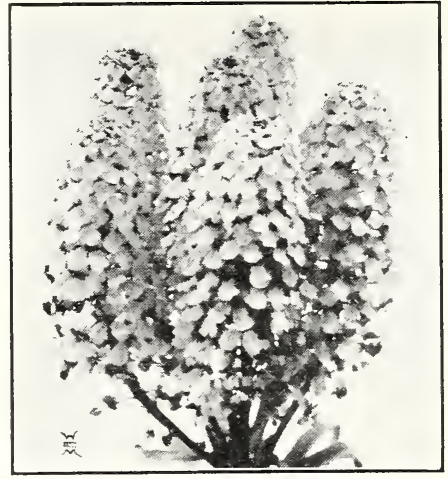

Candytuft, White Perfection

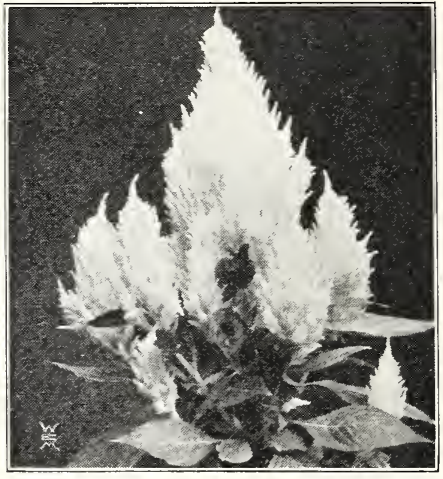

Celosia pyramidalis
CAMPANULA-(Continued)

media. H.B. (Canterbury Bells) Old-fashioned, hardy biennials; splendid for borders or for naturalizing in the wild garden. $2 \mathrm{ft}$. Single

Blue, Rose, Striped or White or all Colors mixed each..........1/4 oz. 50c. 0.10 Double

Blue, White or Rose. . . each $1 / 4$ oz. $\$ 1.00 \quad .15$

Mixed ...................1/4 oz. $75 \mathrm{c} . \quad .15$

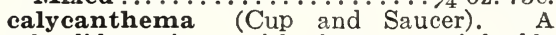
splendid variety with large, semi-double flowers resembling a cup and saucer. Fine for cut flowers or border use. $2 \mathrm{ft}$.

Blue, Lavender, Rose or White.

Mixed ............... $1 / 4$ oz. $\$ 1.25$

CANARY BIRD viNE. Ḧ. $\ddot{\text { C. }}$ Pretty climber, with yellow, butterfly-like flowers. $10 \mathrm{ft}$.

CANDYTUFT. H.A. Showy plants, much grown in masses in beds or for edging. 12 in.

coronaria Empress. A large-flowered variety of purest white, grown extensively for cut flowers. 12 in............... $1 / 4$ oz. 30c. coronaria Little Prince. Very large heads of pure white flowers. 6 in........1/4 oz. $50 \mathrm{c}$. coronaria Giant Hyacinth-flowered. White. $1 / 4$ oz. $30 \mathrm{c}$.

Marshall's White Perfection. A grand white variety................... oz. 50c. Queen of Italy. Rosy white. 6 in.1/4 oz. $35 \mathrm{c}$ Rose Cardinal. Bright rosy cardinal, a rich and striking color..............1/4 oz. 50c. umbellata dunnetti. Crimson... $1 / 4$ oz. $30 \mathrm{c}$. umbellata lilacina. Lilac-purple..1/4 oz. 30c. umbellata Dwarf Hybrids. Mixed colors; neat and pretty. 6 in.......... 1/4 oz. $50 \mathrm{c}$.

Mixed Annual Sorts............................. sempervirens. H.P. White flowers. 12 in. $1 / 8$ oz. $\$ 1.00$

Gibraltarica. H.P. Beautiful bluish-white. 12 in .............. $\ldots \ldots$ oz. $\$ 1.25$

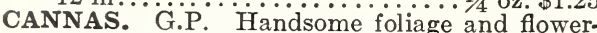
ing plants, producing striking effects in beds or borders. Soak the seed in hot water 24 hours before sowing. 3 to $4 \mathrm{ft}$. (For Canna roots see Page 51.)

Mixed. Dark-leaved variety...... oz. 50c.

Crozy's Large Flowering. D̈warf, mixed varieties....................... 60.

CANTERBURY BELLS. H.B. (See Campanula media.)

CARDINAL CLIMBER (See Ipomoea cardinalis). H.A.C.

CARNATION. Marguerite. H.H.P. The perpetual flowering Carnations produce a large proportion of double flowers in six months from sowing. 18 in.

Pkt.
CARNATION MARGUERITE-Continued

Marshall's Giant Double Pink. 1/8 0z. \$1.25\$0.15

Marshall's Giant, Double Scarlet

$1 / 8$ oz. $\$ 1.25$

Marshall's Giant, Double White. Large, perfect flowers. $1 / 8$ oz. $\$ 1.25$

Marshall's Giant, Double Yellow. A clear soft shade...............1/8 oz. $\$ 1.25$

Marshall's Giant Double Mixed. Extra large and perfect flowering, in a rich variety of colors................... 1/8 oz. $\$ 1.00$

Chabaud's Everblooming Mixed. Blooms in five months after being sown, and continues to flower in the greatest profusion indefinitely.

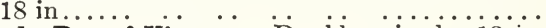

Early Dwarf Vienna. Double mixed. 12 in. $1 / 4$ oz. $75 \mathrm{c}$.

Grenadine Double Scarlet. Very early flowering $18 \mathrm{in}$

Finest Double Mixed. Border. Saved from extra fine flowers. $18 \mathrm{in} \ldots \ldots \ldots 1 / 4$ oz. $\$ 1.00$

CASTOR BEANS. (See Ricinus).

CELOSIA cristata, or Cockscomb. H.H.A. Popular annual of easy culture, producing Cockscomb-like heads.

Childsi (Chinese Woolflower). A variety of feathered Celosia with large globular flowerheads like balls of wool. $2 \mathrm{ft}$.

Childsi Crimson...............1/8 oz. 75c. .15

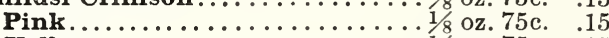
Yellow..................1/8 oz. 75c. .15

Mixed ....................1/8 oz. 50c. 15

Empress. Crimson combs; dark foliage. 9 in. $1 / 4$ oz. $\$ 1.25$

Glasgow Prize. Large, deep crimson. 12 in. $1 / 8$ oz. $\$ 1.00$

Queen of the Dwarfs. Very dwarf form, deep crimson 6 in ....... 1/8 oz, $\$ 1.00$

Dwarf. Mixed colors. Extra fine strain. 9 in. $1 / 4$ oz. $\$ 1.00$

CELOSIA plumosa, or Ostrich Plume. H.H.A. Producing large, graceful plumes. Makes fine plants for large beds or groups, and the plumes or flowers can be cut and dried for Winter bouquets. $3 \mathrm{ft}$.

pyramidalis magnifica aurea. Golden-yellow plumes...............1/4 oz. 75c. Kermesina. Crimson plumes.... . . $1 / 4$ oz. $75 \mathrm{c}$. coccinea. Scarlet plumes.......1/4 oz. $75 \mathrm{c}$. Thompson's Superb. Feathery plumes; dwarf habit. dark crimson......1/4 oz. $75 \mathrm{c}$. plumosa, Mixed. Feathered varieties in all colors.................1/4 oz. $75 \mathrm{c}$.

Pride of Castle Gould. All shades in choicest mixture; branching habit....... 1/8 0z. $\$ 1.00$

CELSIA arcturus. G.P. Long spikes of bright yellow flowers. Fine for pot culture in cool

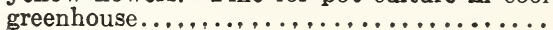




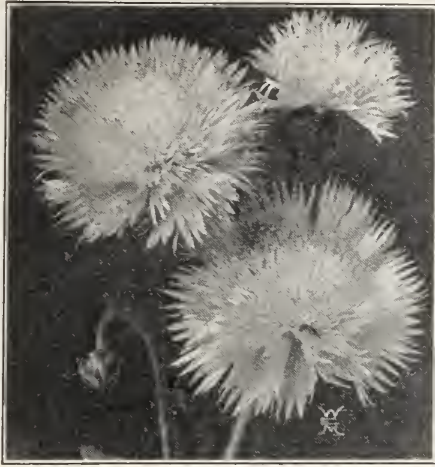

Centaurea, (Sweet Sultan)

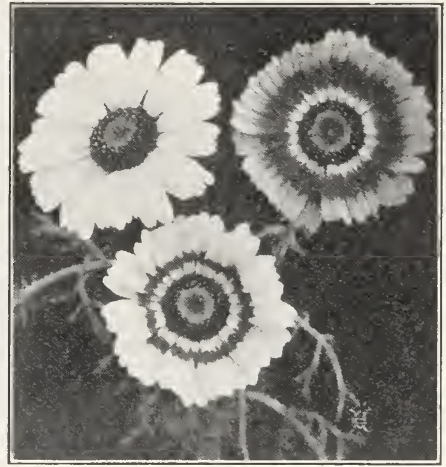

Chrysanthemum, Tricolor

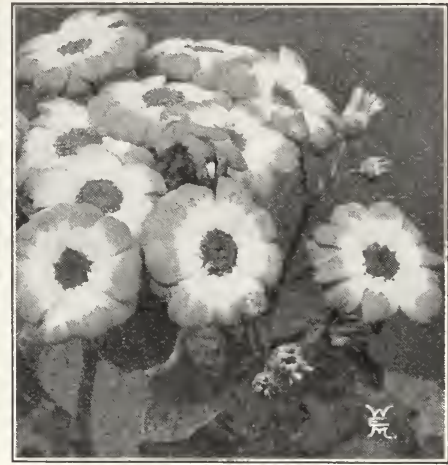

Cineraria, Matchless
CENTAUREA. H.A. Beautiful silvery foliaged bedding plants; used for bordering and edging. candidissima. Round, compact plants, white leaves, broadly cut. 12 in......1/8 oz. $75 \mathrm{c} . \$ 0.15$ gymnocarpa. Fine cut silvery foliage. 18 in. $1 / 4$ oz. 50c. .15

CENTAUREA. H.A. They flower finest in full sun and poor soil. Sow in the open ground in Spring.

Americana. Bushy garden plants; lavenderblue, fragrant. $3 \mathrm{ft} . . . \ldots \ldots \ldots \ldots 1 / 4 \mathrm{oz} .60 \mathrm{c}$. Ameriana alba.............1/4 oz. 60c. Chamceleon. Large; yellow and rose, 18 in. $1 / 4$ oz. $75 \mathrm{c}$.

Margaritae. Pure white, 21/2 inches across, exquisitely laciniated and delightfully scented. 18 in ...................... oz. 50... montana. H.P. Large flowers of deep purple, very showy. $2 \mathrm{ft} . \ldots \ldots \ldots \ldots \ldots$ oz. $35 \mathrm{c}$. suaveolens (Yellow Sweet Sultan). 18 in. An outstanding variety with fine, soft yellow flowers on long stems. For outdoor or conservatory use it is unsurpassed....1/4 oz. $50 \mathrm{c}$.

CENTAUREA cyanus (Bachelor Button, Cornflower, Blue Bottle, or Ragged Sailor). H.A. This is one of the most popular annuals; will grow in the poorest soil, either on seashore or mountain. 18 in.

Marshall's Double Blue. Fine for cutting. $1 / 4 \mathrm{oz} .75 \mathrm{c}$.

Liberty Blue. The true Emperor deep blue Bachelor Button.............1/4 oz. 50c. rosea, Double. Rose-pink........1/4 oz. 40c. White, Double. Very pretty.....1/4 oz. $40 \mathrm{c}$.

Finest Mixed, Double..........1/4 oz. 25c.

CENTAUREA imperialis, Giant Imperial Sweet Sultan. H.H.A. 3 ft. Fine for massing in borders and are unsurpassed for cut flower purposes. They also respond to indoor culture and provide a long succession of bloom for winter decoration.

Lilac.....................1/4 oz. 50c. Purple......................... 1/4 oz. 50c. Rose ........................ oz. 50c.

White..................1/4. oz. 50c.

White, shading to rose..........1/4 oz. $50 \mathrm{c}$.

Finest Mixed. All colors........1/4 oz. 40c.

CERASTIUM tomentosum (Snow-in-summer). H.P. A dwarf, white-leaved edging plant with small white flowers. Good rock plant. 6 in

CHELONE barbata. H.P. Long racemes of

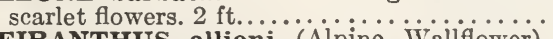

CHEIRANTHUS allioni (Alpine Wallflower). H.H.P. Excellent for rockery or border; brilliant orange flowers. 9 in. Very fragrant. $1 / 4 \mathrm{Oz} . \$ 1.00$

linifolius. This charming lilac Wallflower is seldom out of flower. Valuable for hardy borders and rock gardens. 12 in.........
Plkt.

CHRYSANTHEMUM, Annual Varieties. Showy, hardy annuals of easiest cultivation, blooming from July until frost. 12 to 18 in. coronarium compactum, White Pearl. Fine for cutting.................1/4 oz. $35 \mathrm{c} . \$ 0.10$ -Primrose Queen..............1/4 oz. 35c. .10 -Double White................1/4 oz. 35c. .10 - Double Yellow................. 10 -Double Mixed. Yellow, white, etc. $1 / 4$ oz. 35c. .10 inodorum plenissimum. Free flowering variety of spreading habit, with pure white flowers resembling Asters.........1/4 oz. 50c. tricolor, Lord Beaconsfield. White and rose. $1 / 4 \mathrm{oz} .35 \mathrm{c}$ -Morning Star. Large primrose flowers

-Northern Star. Large ivory white flowers with sulphur zone............1/4 oz. 50c. -Single. Finest mixed...........1/4 oz. $35 \mathrm{c}$

-Double-fringed Mixed, Very graceful double flowers................1/4 oz. 35c.

Collection of six varieties. Annual........

Pkt.

CHRYSANTHEMUM. Perennial Varieties. frutescens (The White Paris Daisy). Charming plant for greenhouse or Summer bedding outdoors. 18 in ............1/8 oz. $50 \mathrm{c}$.

Japonicum. From finest Japanese flowers, 3 ft. Extra choice mixture.

Japanese Mountain. H.H.P. A dwarf free Fall-flowering variety. Various colored flowers maximum "Perfection." Very free-flowering; pure white. 18 in.........1/4 oz. 50c. -grandiflorum (The Shasta Daisy). Pure white; very large. 18 in........1/4 oz. $50 \mathrm{c}$.

CINERARIA hybrida. G.P. One of the most gorgeous colored flowering plants for either greenhouse or conservatory. Seeds should be sown in July, August or September.

Marshall's Matchless Prize Mixed, Every shade of blue, crimson, violet and pink, both in self-colors and with white edge or center. The flowers are often 3 inches in diameter and the plants of excellent habit. $2 \mathrm{ft} . . .$. .

Cactus-flowered Mixed. Large flowers with narrow rolled petals radiating from the center. Fine for conservatory. $2 \mathrm{ft}$...........

grandiflora, Matchless Dwarf Prize Mixed. This strain is just as choice as above, but different in height. 18 in...............

hybrida multiflora nana. The dwarfest and most compact strain, with large flowers. 9 in.

stellata, Star-flowered. Tall, pyramidal plants, bearing star-like flowers. Very effective for the house and conservatory also very useful for cutting. $2 \mathrm{ft}$.

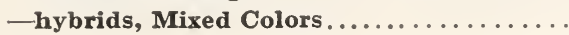

.10 .50 


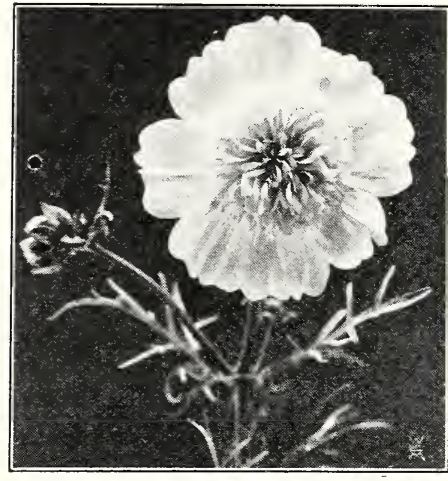

Cosmos, Crested

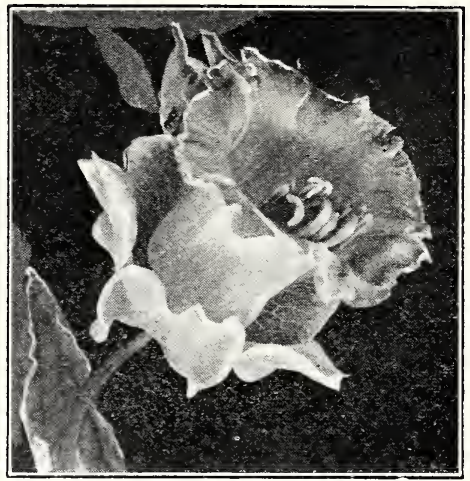

Cobaea Scandens

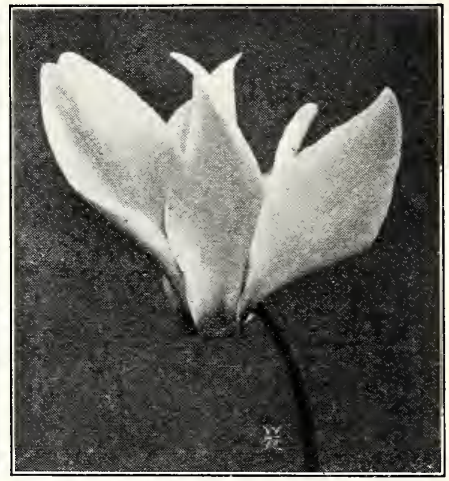

Cyclamen
CINERARIA-Continued

maritima candidissima. H.H.P. A whiteleaved "Dusty Miller," used for edging. $1 \mathrm{ft}$ $1 / 4$ oz. 35 c. $\$ 0.15$

CLARKIA. H.A. This pretty and easily grown annual does well either in sun or shade. $2 \mathrm{ft}$. Brilliant. Double salmon-scarlet flowers $1 / 4$ oz. $50 \mathrm{c}$.

Queen Mary. Very bright rose-carmine, double flowers.................... . . oz. 50c. rosea flore pleno. Double rose... 1/4 oz. 50c. Salmon Queen. Extra double, salmon-pink. $1 / 4$ oz. $50 \mathrm{c}$.

Scarlet Queen. Fine double, brilliant salmonorange-scarlet..............1/4 oz. 50c.

White. Very double, pure white flowers

$1 / 4 \mathrm{oz} .50 \mathrm{c}$.

$1 / 4$ oz. $35 \mathrm{c}$. EOME gigantea (Giant Spiderflower). H.A. beds or borders. $31 / 2 \mathrm{ft} . \ldots \ldots \ldots 1 / 4 \mathrm{oz} .50 \mathrm{c}$.

CLIANTHUS dampieri. G.P. (Austrian Glory Pea). Scarlet flowers...............

CLERODENDRON fallax. G.P. Erect growing greenhouse plant, with large spikes of

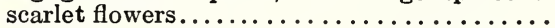

COBAEA scandens. H.A.C. Tender climber, large, bell-shaped blue flower. $20 \mathrm{ft}$.

White. Large white, bell-like flowers. $1 / 4 \mathrm{oz} .60 \mathrm{c}$. COCKSCOMB. See Celosia cristata.

COLEUS, Marshall's Matchless Mixed. G.P. Richly colored foliage plants...........

thrysoideus. Flowers light blue, borne in pan-

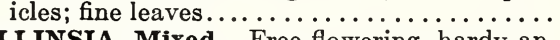

COLLINSIA, Mixed. Free flowering, hardy annuals of deserved popularity, blooming from June to October, and suited to dry situations.

COLUMBINE. (See Aquilegia). $1 / 4$ oz. $35 \mathrm{c}$.

CONVOLVULUS, or Morning Glories, (See also Ipomoea). H.A.C. Deservedly very popular, as they are of the most free-flowering and rapid growing plants in cultivation, thriving in almost any situation.

major. Mixed colors. Climbers of rapid

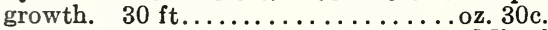

minor, or Bush Morning Glories. Mixed colors. 12 in.................... 30 c.

COREOPSIS. H.P. Long stemmed, large, single flowers. $2 \mathrm{ft}$. Fine cut flower.

grandiflora. Large flowers of rich yellow. $1 / 4$ oz. $35 \mathrm{c}$.

grandiflora fl. pl. An improved type with large double flowers of deep yellow........

CORN, Rainbow. H.A. Variegated leaves, striped in green, white and yellow. $5 \mathrm{ft}$.

oz. $50 \mathrm{c}$.

CORNFLOWER. (See Centaurea cyanus).

Pkt.
COSMOS. H.A. This is one of our most useful and beautiful Autumn flowers. To get it in bloom early, seed should be sown in May in the open ground where the plants are desired to bloom, and the seedlings allowed to grow and flower without being transplanted. $5 \mathrm{ft}$.

Double - crested, Early - flowering. Semidouble flowers in great profusion. $5 \mathrm{ft}$.

Crimson King. Bright red...... 1/4 oz. $\$ 1.50 \$ 0.25$

Pink Beauty. A lovely shade of pink, crested flowers.................... oz. $\$ 1.50$ White Queen. Pure white, crested flowers. $1 / 4$ oz. $\$ 1.50$ Crested Mixed. The above colors in mixture.
$1 / 4$ oz. $\$ 1.25$

Extra Early Giant-flowering. Flowers 4 to 5 inches across. $4 \mathrm{ft}$. Crimson...............1/4 oz. 60c. .10

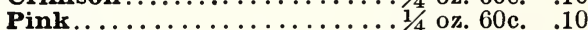
White...................1/4 oz. 60c. .10 Mixed Colors................. . . . . oz. 50c. $\quad .10$

Giant Late-flowering. Blooms in September and October. $5 \mathrm{ft}$

Lady Lenox. Pink..........1/4 oz. 50c. .10

Lady Lenox. White...........1/4 oz. 50c. .10

Red ..................1/4 oz. 50c. .10

Mixed. Ali shades.............. $1 / 4$ oz. 35c. $\quad .10$

Klondyke. Large flowered golden yellow $1 / 4$ oz. $50 \mathrm{c}$.

Hollywood Star. An odd and striking star shaped flower with red, pink and white flowers on long stems.........1/4 oz. $\$ 1.50$

CoWSLIP, Mixed (Primula veris). H.P. A Spring-flowering plant. Beautiful colors, rich brown, crimson and yellow. 6 in.........

CUPHEA platycentra (Cigar Plant). H.H.P. Valuable as a bedding and border plant. The flowers are scarlet with a black and white lip.

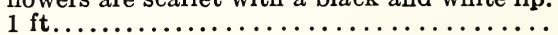

CYNOGLOSSUM amabile. H.A. Beautiful rich blue, sweet-scented flowers. Fine for cutting. $18 \mathrm{in} . \ldots \ldots \ldots \ldots \ldots \ldots 1 / 4$ oz. $\$ 1.00$

CYPERUS alternifolius (Umbrella Plant). G.P. Handsome plants easily raised from seed; used for table decorations and combining with palms; semi-aquatic. $2 \mathrm{ft} . . . . .$. .

CYPRESS VINE. H.A.C. A fast growing annual vine, with feathery, dark-green foliage and star-like flowers. $10 \mathrm{ft}$.

Bright Scarlet...............1/4 oz. 25c. .10

Finest Mixed...............

CYCLAMEN. G.P. These are among the choicest of flowering greenhouse plants. Seed should be sown from August until January.

Marshall's Giant Show. The seeds we offer are grown by a specialist in Europe who we believe has the finest strain for exhibition plants 


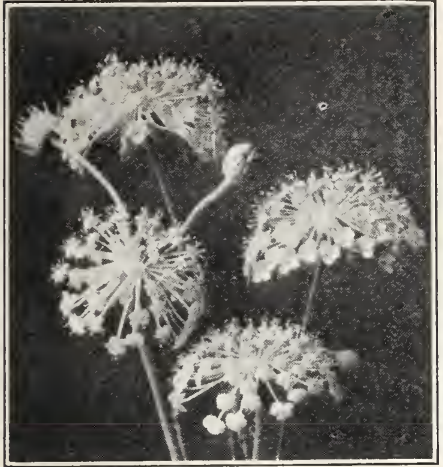

Didiscus Caerulea

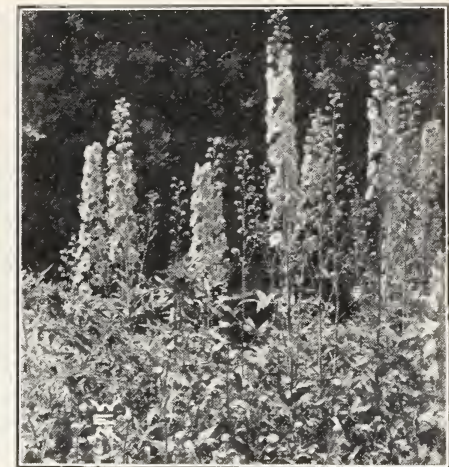

Delphinium, Matchless Hybrids

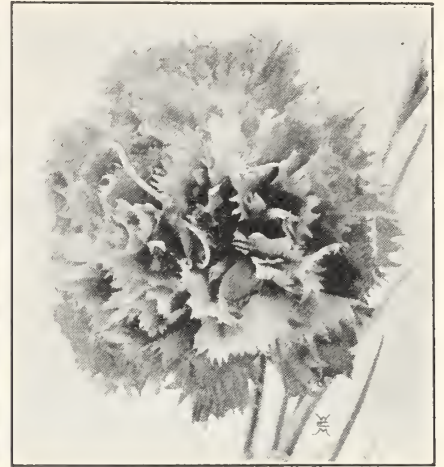

Dianthus, Double Annual
CYCLAMEN-Continued

100

Seeds

Bonfire.......................\$3.00

Bright Red. . .............. 2.50

Glory of Wandsbeck. Dark salmon.. 2.75

New Salmon Rose Improved....... 2.75

Pure White.................. 2.50

Pure Rose..................... 2.50

Rokoko Fringed Mixed ............ 3.00

Rose of Zehlendorf. Light salmon... 3.00

Saffron Red .................. 3.00

Salmon Scarlet. Christmas color. . . 3.00

Soft Rose with Carmine Eye ....... 2.50

White with Carmine Eye.........2.50

Mixture of Above Varieties........2.75

DAHLIA. H.H.P. This popular flower can be easily raised from seed, flowering the same season. Seed should be sown early in gentle heat. 4 to $6 \mathrm{ft}$.

CALIFORNIA HYBRIDS. See page 59.

Coltness Hybrids. Single varieties in many colors, growing from 18 to 24 inches in height.

Double, Large-Flowering. Double mixed

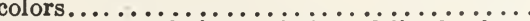

Cactus. New choice varieties. Mixed colors.

Single, Large-flowering. Mixed...........

DAISY, Double. (See Bellis perennis.)

DAISY, Single. (See Chrysanthemums.)

DATURA (Trumpet flower.) H.H.A. Robust garden annual, bearing large trumpet-shaped flowers, $4 \mathrm{ft}$.

Double-flowering (Fastuosa fl. pl.) Mixed. $1 / 4 \mathrm{oz} .40 \mathrm{c}$

Cornucopia (Horn of Plenty). Flowers white and purple................1/4 oz. $40 \mathrm{c}$.

DELPHINIUM (Larkspur). H.P. Delphiniums are hardy and can be grown in any garden. They are handsome plants for the herbaceous border and shrubbery and are splendid for cut flower use.

belladonna. Light azure blue....1/8 oz. $\$ 1.00$

velladonna, Cliveden Beauty. Pale blue...

belladonna, Fanny Stormonth. Light azure

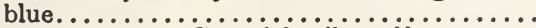

Blue Butterfiy. Graceful spikes of large azureblue flowers. .............1/8 oz. $\$ 1.00$

bellamosa. An improved Formosum which is not subject to mildew. Dark blue in color $1 / 80 z \$ 1.00$

chinensis album. Pure white. $18 \mathrm{in} .1 / 4 \mathrm{oz} .50 \mathrm{c}$. azureum. Azure blue. $18 \mathrm{in} . . . .11 / 4$ oz. $50 \mathrm{c}$. Mixed (grandiflorum). Shades of blue and pure white. 18 in ............1/4 oz. 50c.

Blackmore \& Langdon's Hybrids. A superior imported strain and contains a mixture of exceptionally choice flowers ranging in color from light blues through mauves and lavenders to deepest ultramarine. $5 \mathrm{ft}$..........
Pkt. $\$ 0.50$
DELPHINIUM.-Continued Pkt.

Marshall's Matchless Hybrids. Choice show hybrids, saved from the best named varieties. $1 / 8$ oz. $\$ 1.00 \$ 0.25$

Wrexham or Hollyhock Hybrids. Experts regard this strain as quite the finest in cultivation. It is conspicuous for its massive, broadbased spires of large individual flowers which are compactly arranged about the stems. The shades of blues and mauves are of exquisite clarity. Particularly effective in mass plantings with lilium candidum. 4-6 ft. $1 / 8 \mathrm{oz} . \$ 5.002 .00$

DIANTHUS (Chinese or Indian Pinks). H.H.A. These, although biennials, bloom the first season, and should be treated as hardy annuals. They flower early in Summer and continue until frost. They are excellent for small beds or edgings, flowering profusely and in great variety of colors. 12 in.

SINGLE ANNUAL PINKS.

Heddewigi. Large, attractive flowers of most brilliant colors. Finest Mixed....1/4 oz. 50c.

laciniatus Single Mixed. Fringed flowers of all colors....................1/4 oz. 50c.

DOUBLE ANNUAL PINKS.

chinensis fl. pl. (Chinese Pink). Large, double flowers in unlimited variety of colors. Finest Mixed................1/4 oz. 50c.

diadematus fi. pl. (Double Diadem Pink). Large, double flowers. Mixed....1/4 oz. 50c.

Heddewigi fl. pl. (Japanese Pink). Large, double flowers of exquisite colors. Finest Mixed......................1/4 oz. 50c.

"Fireball." Large double, brilliant red. $1 / 4$ oz. $75 \mathrm{c}$.

Pink Beauty (Heddewigi). A beautiful double pale pink annual variety.......1/4 oz. $\$ 1.25$

laciniatus "Salmon Queen.", Very striking double flowers, rich salmon scarlet. $1 / 4$ oz. $\$ 1.00$

"Snowball." Extra large, double, pure white. $1 / 4$ oz. $75 \mathrm{c}$.

laciniatus. fl. pl. Double-fringed flowers; beautifully striped. Mixed.....1/4 oz. $75 \mathrm{c}$.

Collection of Double Annual Pinks. Six varieties. .....................

HARDY PERENNIAL PINKS.

plumarius fl. pl. Pheasants-eye. Pretty, fringed double flowers..........1/4 oz. 75c. plumarius semperforens (Perpetual Pink). Mixed, single and double........1/8 oz. $\$ 1.00$

DICTAMNUS fraxinella. H.P. Handsome spikes of reddish flowers and fragrant leaves. $3 \mathrm{ft} \ldots \ldots \ldots \ldots \ldots \ldots \ldots \ldots \ldots \ldots \ldots . \ldots \ldots$ oz. $50 \mathrm{c}$.

DIDISCUS caerulea (Blue Lace Flower). H.A. An attractive annual, blooming from July until frost. Pale lavender flowers, valuable for cutting. 18 in................. $1 / 8$ oz. .50 


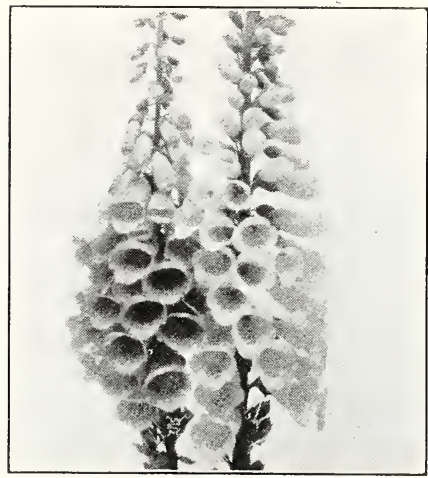

Digitalis

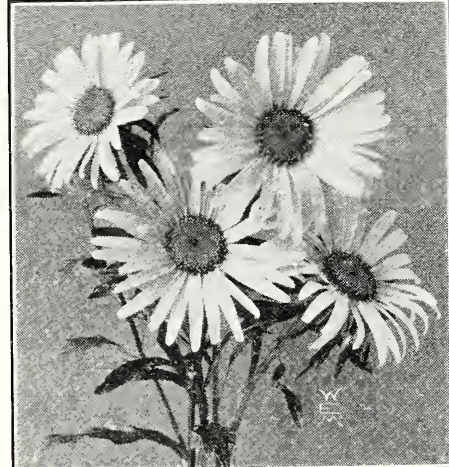

Dimorphotheca Salmon Beauty

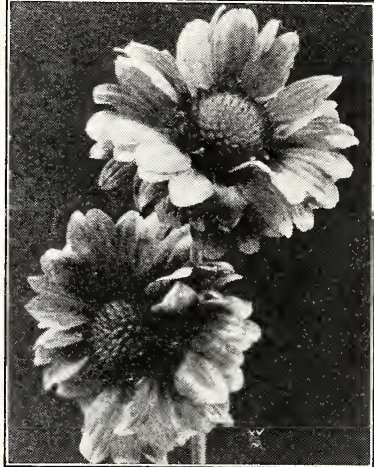

Gaillardia
DIGITALIS or FOXGLOVE. H.P. Producing long spikes of tubular flowers. Used extensively with good effect for naturalizing in shrubberies and half-shady places. $3 \mathrm{ft}$.

Marshall's Superb Purple........1/4 oz. 50c. $\$ 0.15$ Marshall's Superb Rose...........1/4 oz. 50c. .15 Marshall's Superb Yellow..........1/4 oz. 50c. .15 Marshall's Superb White.........1/4 oz. 50c. .15 Marshall's Superb Mixed. Ail colors.

monstrosa, Mixed. Very large flowers. 4 oz. 35 c. .15

$1 / 4$ oz. $75 \mathrm{c}$

Giant Shirley Hybrids. These hybrids are very large in size and vigor, growing from 5 to $6 \mathrm{ft}$................. $1 / 8$ oz. $\$ 1.00$

Isabellina. A beautiful sulphur-yellow......

DIMORPHOTHECA aurantiaca. H.A. Daisylike blossoms of a rich orange color; dark disc surrounded by black zone. $18 \mathrm{in.} 1 / 4 \mathrm{oz} .75 \mathrm{c}$.

Salmon Beauty. Large flowering. . $1 / 4$ oz. $\$ 1.00$ White Beauty. Large flowering. $1 / 4$ oz. $\$ 1.00$ aurantiaca hybrida. Mixed hybrids.

$1 / 4$ oz. $50 \mathrm{c}$.

eklonis. Large, star-shaped pure white flow. ers with a small, deep blue disc. $2 \mathrm{ft} . \ldots \ldots$.

DOLICHOS or HYACINTH BEAN. H.A.C. Annual climbers with clusters of Bean-like flowers. $10 \mathrm{ft}$.

lablab, Mixed. Purple and white..... Oz. 40c.

DRACAENA indivisa. G.P. For vases, pots, etc. Narrow green leaves.......1/4 oz. 35c.

ECHINOCYSTIS lobata (Wild, or California Cucumber). H.A.C. The fastest growing annual vine in existence; grows 20 feet in six weeks. Pretty foliage and inconspicuous white flowers................ 50c.

ECHINOPS ritro (Blue Globe-thistle.) H.P. Purple.................. oz. 35c.

EDELWEISS (Leontopodium). H.P. Silvery white everlasting flowers, fine for rock gar-

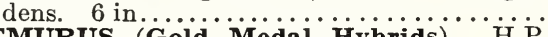

EREMURUS (Gold Medal Hybrids). ${ }_{\text {H.P. }}^{H}$. Stately plant with long spikes of flowers. $8 \mathrm{ft}$. Daisy). H.P. Pale mauve flowers with golden centers. Fine for cutting. 18 in........

ERYSIMUM arkansanum. H.A. Bright yellow flowers resembling the Wallflower. 18 in.

linifolius. (See chieranthus linifolius.)

pulchellum. H.P. Pale yellow flowers. Use-

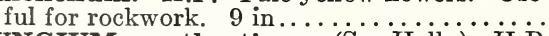

ER YNGIUM amethystinum (Sea Holly). $\ddot{H} . \ddot{P}$. Spiny foliage and small, amethyst-blue flowers in large panicles. $3 \mathrm{ft} . . \ldots \ldots \ldots 1 / 8 \mathrm{oz} . \$ 1.00$

ERINUS alpinus. H.P. Bright purple flowers, a choice rock plant. 6 in... ESCHSCHOLTZIA or CALIFORNIA POPPY.
H.A. Very attractive annuals for beds, edgings, masses; profuse flowering, fine cut, glaucous foliage; blooms from June to frost. 12 in. californica. Bright yellow. $1 / 4 \mathrm{oz} .30 \mathrm{c}$.
Pkt.

ESCHSCHOLTZIA-Continued californica alba. White.

$1 / 4$ oz. 30 c. $\$ 0.10$

red. $1 / 4$ oz. $35 \mathrm{c}$ Chrome Queen. A beautiful clear chrome yellow...................1/8 oz. $75 \mathrm{c}$. Crimson King. Beautiful crimson scarlet.

Dainty Queen. Blush-pink on cream ground.

$1 / 4$ oz, $75 \mathrm{c}$.

Golden West. Large flowers of deep yellow shade....................1/4 oz. 35c. Mandarin. Large, scarlet, inside orange.

$1 / 4$ oz. 35c. .10

Rose Cardinal. A distinct color. $1 / 4$ oz. 35c. $\quad .10$ The Geisha. Petals prettily fluted. Color inside golden and outside intense orangecrimson. Very beautiful.........1/4 oz. 50c.

Single Mixed. All colors............... $50 \mathrm{c}$.

EUCALYPTUS globulus (Blue Gum Tree). G.P. Used as greenhouse plant for decora-

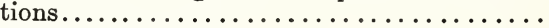

EUPATORIUM Fraseri. H.P. White, fine for cutting. $2 \mathrm{ft} . \ldots \ldots \ldots \ldots \ldots \ldots 1 / 4 \mathrm{oz} .50 \mathrm{c}$.

EUPHORBIA heterophylla (Fire-on-the-mountain). H.A. Leaves large and glossy green, often tipped with orange-scarlet. $3 \mathrm{ft}$.

$1 / 4$ oz. $50 \mathrm{c}$.

variegata (Snow-on-the-mountain). White and green bracts, excellent for bouquets. $2 \mathrm{ft}$.

$1 / 4$ oz. $35 \mathrm{c}$.

FERNS, Greenhouse Variety, Mixed. G.P...

FORGET-ME-NOT. (See MYOSOTIS.)

FOXGLOVE. (See DIGITALIS).

FOUR O'CLOCKS. (See MARVEL OF PERU.)

FRANCOA ramosa alba. H.B. Elegant sprays of pure white flowers. $2 \mathrm{ft} . \ldots \ldots \ldots \ldots \ldots$.

FREESIA, New Hybrids Mixed. G.P. Shades of pink, red, violet, yellow, etc..........

GAILLARDIA. H.A. Showy garden annuals; they flower uninterruptedly from early Summer until frost; the flowers are of large size and afford charming tints in their colors. $2 \mathrm{ft}$.

amblyodon. Blood red.........1/4 oz. 35c. .10 picta Mixed, Single. Annuals...1/4 oz. 35c. .10 lorenziana, Double Mixed ....... .1/4 oz. 35c. $\quad .10$ Portola Hybrids. Varied shades of redtipped golden. Long stiff stems. $1 / 8$ oz. $\$ 1.00$

Giant Hybrids, Mixed. Perennial. $1 / 4$ oz. 50c. Marshall's Matchless Hybrids. H.P. A grand new improved strain; enormous flowers and very strong habit. ........1/8 oz. $\$ 1.00$

GALEGA officinalis. H.P. A hardy plant producing a number of blue, miniature, pea-like flowers in sprays throughout the Summer. 3 ft...................1/4 oz. 35c. officinalis alba. White flowers...1/4 oz. 35c. .10 


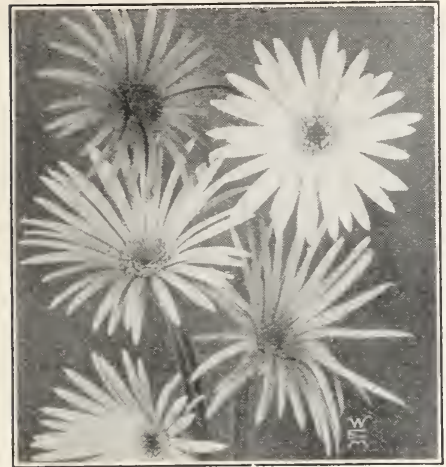

Gerbera Jamesoni

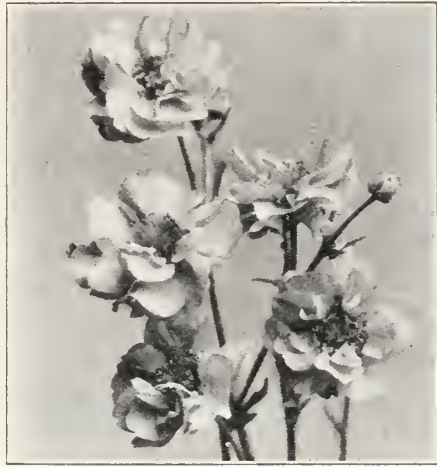

Geum, Lady Stratheden

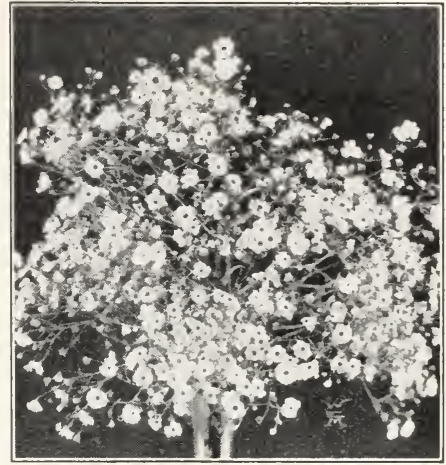

Gypsophila elegans
GAURA lindheimeri. H.P. Graceful spikes of

Pkt. rosy-white flowers. $3 \mathrm{ft} . \ldots \ldots 1 / 4$ oz, 50c.\$0.15

GERANIUM. G.P. Well-known plants for garden or pot culture.

zonale. Finest Mixed.

GERBERA Jamesoni hybrida (The Transval Daisy). H.H.P. Fine for cut flowers or bouquets. 18 in...........100 seeds, $\$ 1.00$

GEUM. H.P. Showy, hardy perennial of easy culture and well adapted for the flower garden; fine for cutting. $2 \mathrm{ft}$.

atrosanguineum. Large, double crimson flowers.................... $1 / 4$ oz. $50 \mathrm{c}$.

Lady Stratheden. Double yellow. $1 / 8$ oz. $\$ 1.00$

Mrs. Bradshaw. Double orange-scarlet flowers; very large and full.......1/8 oz. $75 \mathrm{c}$.

Orange Queen. A beautiful shade of orange.

GILIA capitata. H.A. A very graceful annual with lavender-blue flowers.......1/4 oz. 35c.

GLOBE-AMARANTH (GOMPHRENA). H.A. Clover-like heads of flowers; esteemed as everlastings. 12 in.

globosa alba. White.........1/4 oz. 35c.

globosa rubra. Purple.............

globosa. Mixed colors.............1/4 oz. $35 \mathrm{c}$.

GLOXINIA. G.P. Charming pot plants, flowering in Summer in greenhouse or window.

Marshall's Matchless. Erect, giant-flowering, mixed. Saved from the very choicest erect flowering sorts. A grand variety of colors...

GODETIA. H.A. Bushy annual, with showy large flowers. They grow quickly, bloom abundantly and are excellent for beds and borders. The double varieties are splendid for cutting. 18 in.

Brilliant. Glowing carmine......1/4 oz. 35c.

Double Rose. A delicate rose-pink. $1 / 4$ oz. $50 \mathrm{c}$.

Duchess of Albany. Satiny-white. $1 / 4 \mathrm{oz}$. 35c. Gloriosa. Compact, brilliant blood-red.

Rosy Morn. A lovely coral-pink, very double flowers.................. oz. $75 \mathrm{c}$.

Finest Mixed Colors................... 60

GOMPHRENA. (See GLOBE-AMARANTH).

GOURDS. H.A.C. Thrifty annual climbers, bearing "Ornamental Gourds." $10 \mathrm{ft}$.

Apple-shaped. Small fruit, striped yellow and dark green.............................. $40 \mathrm{c}$

Bottle-shaped. Fruit yellowish-white and dark green...

Calabash, or African Pipe Gourd...Oz. 50c.

Dipper-shaped.................. Oz. 40c.

Dishcloth (Chinese Loofa, or Sponge Gourd). Large, elongate fruit; spongy inside. Flowers deep golden yellow.................

Egg. Fruit white, resembles eggs...... Oz.40c

Hercules' Club. Enormous fruit, often $4 \mathrm{ft}$. long, thicker at the base............ Oz. 50c.
GOURDS.-Continued Pkt.

Mock Orange, or Orange-shaped...Oz. 50 c. $\$ 0.10$

Pear-shaped. Very pretty striped fruit

Sugar Trough................... Oz. 50c.

Mixed Ornamental Varieties........ Oz. 40c.

Collection of 10 Varieties of Gourds......

GRASSES, ORNAMENTAL. A most valuable class of plants for the lawn, shrub bed, border or tropical bed. The perennial varieties, many of which have variegated foliage, are excellent. The annual sorts are particularly pretty on account of the graceful, feathery flower panicles.

Agrostis nebulosa. H.A. Very graceful and pretty. 18 in ....................

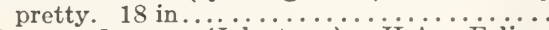

Coix lachryma (Jobs-tears). H.A. Foliage quite broad. Seeds prominent, very large

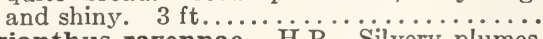

Erianthus ravennae. H.P. Silvery plumes, resembling Pampas Grass. $8 \mathrm{ft} . \ldots \ldots \ldots$.....

Eulalia zebrina. H.P. White striped foliage, very ornamental. $4 \mathrm{ft} . \ldots \ldots \ldots . .1 / 4 \mathrm{oz} .35 \mathrm{c}$.

Gynerium argenteum (Pampas Grass). H.P.
Beautiful silvery plumes. $10 \mathrm{ft} .1 / 4 \mathrm{oz} .35 \mathrm{c}$.

Hordeum jubatum (Squirrel-tail Grass). H.A. A pretty variety, with bushy panicles

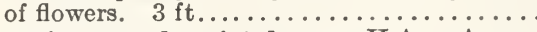

Pennisetum longistylum. H.A. Annual grass, gracefully drooping heads. $2 \mathrm{ft}$.

Pennisetum ruppelianum $1 / 4 \mathrm{oz} .35 \mathrm{c}$. perennial grass, growing $3 \mathrm{ft}$. high with violet-tinted silvery plumes. The deep green foliage is long and slender.......1/4 oz. 35c.

GREVILLEA robusta (Silk Oak). G.P. Graceful foliage plant. $4 \mathrm{ft} \ldots \ldots \ldots \ldots 1 / 4 \mathrm{oz} .50 \mathrm{c}$.

GYPSOPHILA (Baby's Breath). H.A. Extremely useful for bouquets. Flowers small and come in delicate sprays and panicles.

elegans alba grandiflora. An improved large flowering, pure white form of the annual Baby's Breath.................... Oz. 50c. elegans carminea. Carmine rose...... Oz. 60c. rosea grandiflora. Delicate rose..... Oz. 60c muralis. Bright rose...........1/4 oz. 35c. paniculata. H.P. One of the finest for cutting. Pure white flowers, very small and borne in large panicles. $2 \mathrm{ft}$............1/4 oz. $50 \mathrm{c}$ paniculata flore pleno. flowering variety, pure white. $2 \mathrm{ft} . . . \ldots$.

HELENIUM. H.P. Striking hardy plants, very useful for decorating.

Riverton Gem. Yellow, changing to red. Long stems. $5 \mathrm{ft}$............1/8 oz. $\$ 1.50$

HELIANTHUS. (See SUNFLOWER.) 


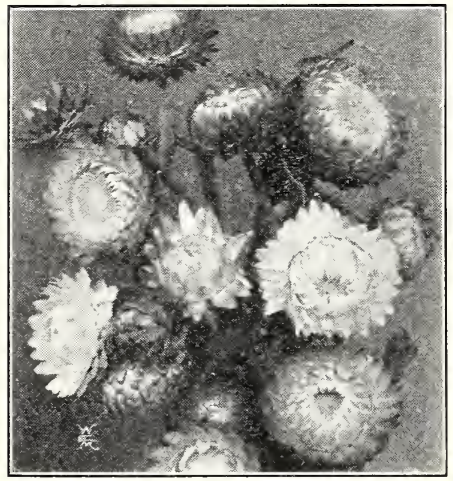

Helichrysum

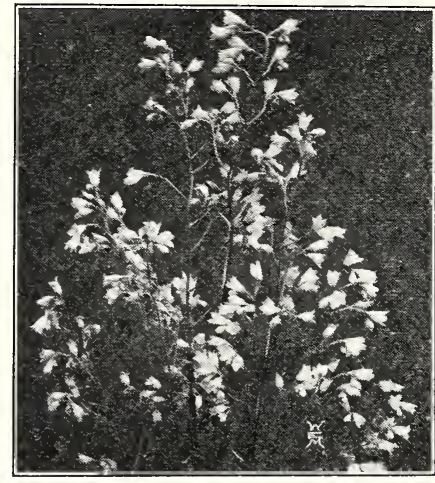

Heuchera sanguinea

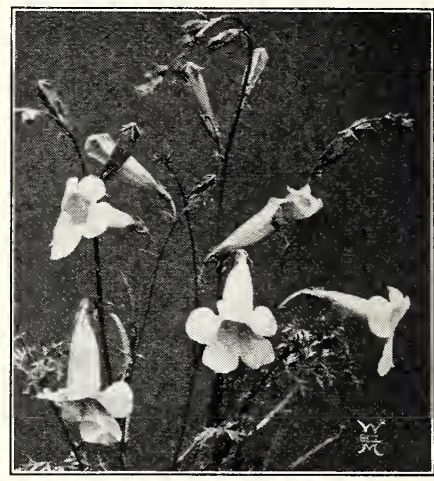

Incarvillea Delavayi
HELICHR YSUM, OI STRAWFLOWER. H.A. Large, double "everlasting" flowers. $2 \mathrm{ft}$. monstrosum, Fire Ball. Double red.

Golden Globe. Double yellow....1/4 oz. 50c. .15 Salmon...................1/4 oz. 50c. .15 Silver Globe. Glistening white. 1/4 oz. 50c. $\quad .15$ Large Flowering, Double, Mixed Colors.

HELIOTROPE. G.P. Well-known fragrant flowering plants for pots or gardens.

Marshall's Blue Perfection. Dark blue....

Anna Tureil. Light blue.................

White Lady. A popular white variety.......

Finest Mixed...............1/8 oz. $40 \mathrm{c}$

Lemoine's Giant Hybrids, Mixed ...........

HEUCHERA sanguinea splendens. H.P. Long spikes of fiery-red flowers. 18 in........... sanguinea hybrida. H.P. Fine for borders. 18 in. Mixed colors...

HIBISCUS. Showy plants of vigorous growth. Africanus. H.A. Yellow with black center. 18 in ............... Marshall's Rainbow grandiflorus hybrids. H.P. New giant-flowering Marshmallows. Very large flowers in various colors. $5 \mathrm{ft}$. moscheutos (Swamp Rose Mallow). H.P. Flowers of a light rosy-red, with dark center.

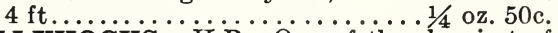
HOLL YHOCKS." H.P. One of the showiest of hardy garden plants. No garden is complete without these stately flowers. Hollyhocks are troubled of late with a rust, which can be prevented if plants are sprayed frequently in early Spring with Bordeaux mixture. $6 \mathrm{ft}$.

Marshall's Giant.

Double Apple Blossom ..........1/8 oz. 50c. Pink Queen. A pretty salmon pink.

Double Scarlet ............. $1 / 8$ oz. $\$ 1.00$ ........... $1 / 8$ oz. $50 \mathrm{c}$. Double Sulphur Yellow..........1/8 oz. 50c. Double White................ Double Violet Purple...........1/8 oz. 50c. Double Fine Mixed............1/8 oz. 50c.

Chater's Extra Choice, Double Mixed Colors ...................1/8 oz. $75 \mathrm{c}$.

Hybrid Everblooming, Double, Mixed. Flowers the first season from seed. Very fine colors.....................1/4 oz. 50c.

Collection of Double Hollyhocks, 6 colors. .

Marshall's Giant Single Mixed. . 1/4 oz. 50c. Hybrid Everblooming, Single Mixed.

HONESTY. (See LUNARIA biennis.)

HUMULUS japonicus (Japanese Hop). H.A.C. A climber with dense green foliage; $20 \mathrm{ft}$.
$1 / 4$ oz. 50 c. $\$ 0.15$ $1 / 4$ oz. $50 \mathrm{c}$.

$1 / 4$ oz. 40 c.

$1 / 4 \mathrm{oz}, 35 \mathrm{c}$.

Pkt.
HUMULUS-Continued japonicus fol. variegatus. Variegated foliage.

Pkt. $1 / 4$ oz. 35 c. $\$ 0.10$

HUNNEMANNIA fumariaefolia (Giant Yellow Tulip Poppy). H.A. Flowers are tulip-shaped, pure golden yellow. When cut and put in water they will last a full week. $2 \mathrm{ft}$.

$1 / 4$ oz. 30c.

HYACINTH-BEAN. (See DOLICHOS.)

IBERIS. (See CANDYTUFT.)

ICE PLANT. (SEe MESEMBRYANTHEMUM CR YSTALLINUM.)

IMPATIENS (Sultan's or Zanzibar Balsam). G.P. Charming plants for decoration of the greenhouse or table, producing waxy looking flowers profusely and continuously. $2 \mathrm{ft}$.

sultani. Flowers of brilliant rosy-scarlet color.

holsti Hybrids. Form strong, bushy plants covered with attractive flowers. As pot plants they bloom the year round. Choicest

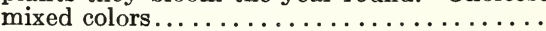

INCARVILLEA Delavayi. H.P. The flowers are borne on long, stout stems, tube-shaped. Color bright rose. $2 \mathrm{ft} . . \ldots \ldots \ldots 1 / 8 \mathrm{oz} .75 \mathrm{c}$.

IONOPSIDIUM acaule. H.H.P. Pale mauve flowers adapted for rockeries and carpet bed. ding; very dwarf habit. 4 in.............

IPOMOEA (Morning-glory). (See also CONVOLVULUS.) H.A.C. Climbers of rapid growth, with beautiful and varied flowers; for covering walls, trellises, arbors or stumps of trees they are invaluable. $20 \mathrm{ft}$.

cardinalis (Cardinal Climber). A rapid growing annual, with deep cardinal red flowers and laciniated foliage..............1/4 oz. 50c. grandiflora alba (Moonflower). Large, heartshaped leaves and large, pure white flowers, which open only late in the evening. $1 / 4 \mathrm{oz} .35 \mathrm{c}$. rubro-caerulea (Heavenly Blue). Beautiful, sky-blue flowers............. setosa (Brazilian Morning-glory). Large, ornamental foliage, with bright rose flowers. $1 / 4$ oz. 30c.

Imperial Japanese, Mixed. A great improvement over the old-fashioned sorts... Oz.50c.

KENILWORTH IVY. H.H.P. Neat trailer for rock garden. Small snap-dragon like flowers. Attractive foliage. 6 in .............

KOCHIA tricophylla (Belvedere; Summer Cypress, or Mexican Firebush). H.A. Grows in a perfectly pyramidal shaped cypress bush, with small, feathery, light-green foliage. $\mathrm{Be}$ comes a lovely crimson hue about September. $21 / 2 \mathrm{ft} \ldots \ldots \ldots \ldots \ldots \ldots \ldots 1 / 4$ oz. $35 \mathrm{c}$.

KUDZU VINE (Pueraria Thunbergiana). H.P. A splendid climber for covering permanent verandas, dead trees, etc. Large green foliage and pea-shaped blossoms...1/4 oz. 50c. 


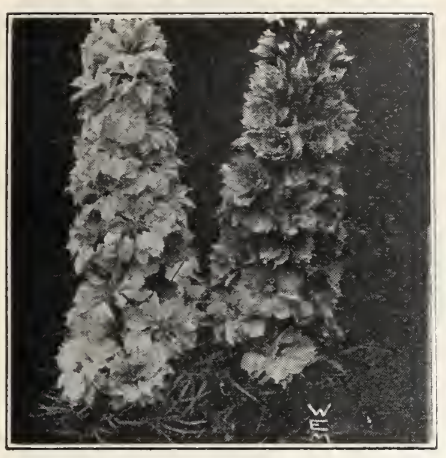

Larkspur, "La France"

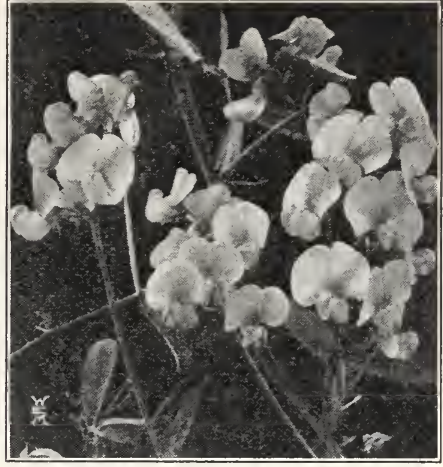

Lathyrus

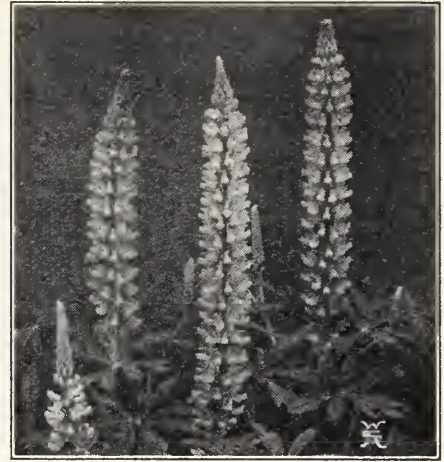

Lupinus polyphyllus
LANTANA. G.P. One of the most desirable greenhouse or bedding plants; constantly in bloom. $2 \mathrm{ft}$. Newest hybrids, mixed.

LATHYRUS latifolius, Perennial Sweet Pea. H.P. Hardy climbers. Fine for cutting. $6 \mathrm{ft}$. latifolius. Purplish-red........1/4 o: $50 \mathrm{c}$. White Pearl. A large flowering, robust growing variety of the above.......1/4 oz. $\$ 1.00$

Pink Beauty. Rosy pink........1/4 oz. 50c.

Finest Mixed. All colors.........1/4 oz. 30c.

LARKSPUR. H.A. Elegant and ornamental plants, producing in great variety of form some of the most beautiful flowers in cultivation.

Marshall's Invincible Branching. Double flowers; excellent for cutting Offered in the following choice of colors $2 \mathrm{ft}$.

Azure Blue.............. 1/4 oz. 50c. Dark Blue................ $1 / 4$ oz. $50 \mathrm{c}$ Carmine................ Flesh Color...............1/4 oz. 50c. Rose...................1/4 oz. 50c. White................. 1/4 oz. 50c. Finest Mixed............. 1/4 oz. 40c

Collection Invincible, Branching, 6 Var. Exquisite Pink. Soft rose pink... . 1/8 oz. $\$ 1.00$ La France. Lovely salmon pink....1/8 oz. $\$ 1.00$ Dwarf Rocket. Finest colors. Fine for bedding. 12 in ............... $1 / 4$ oz. $25 \mathrm{c}$.

Tall Rocket. Mixed. Long showy spikes.

$1 / 4$ oz. $25 \mathrm{c}$

LAVATERA splendens rosea (Pink Mallow). H.A. Bushy plants, produce large, open, pink, mallow-like flowers in great profusion. $3 \mathrm{ft}$. $1 / 4$ oz. $50 \mathrm{c}$

splendens alba. Large, glossy white flowers. $1 / 4$ oz. $50 \mathrm{c}$

Finest Mixed Colors..........1/4 oz. 50c.

LEMON VERBENA. (See VERBENA.)

LEPTOSYNE maritima. H.A. Large lemonyellow Marguerite-like flowers on tall stalks. $3 \mathrm{ft} . \ldots \ldots \ldots \ldots \ldots \ldots \ldots \ldots . . .1 / 4 \mathrm{oz} .75 \mathrm{c}$

LILY Seeds. See page 61.

LINARIA cymbalaria. (See KENILWORTH IVY.)

LINARIA. H.A. Very showy annual resembling Snapdragon. Used extensively as a Winter cut flower in greenhouses. $1 \mathrm{ft}$.

Choice Mixed Varieties...............

LINUM. H.A. Free flowering plants for borders. grandiflora rubrum. Single scarlet flowers. 12 in .................. oz. $25 \mathrm{c}$ perenne. H.P. A lovely plant with blue flowers. 18 in ................. $1 / 4$ oz. 35 c.
Pkt.

LOBELIA. H.H.A. Bushy plants, with pendant branches; very profuse flowering. Fine for baskets or edging borders. 6 in.

Marshall's Compact. The finest dark blue Lobelia; the plants are compact, covered with a profusion of bloom.......1-16 oz. $\$ 1.00 . \$ 0.25$ erinus compacta, Crystal Palace. Dark blue.

Emperor. Light blue...... $1 / 8$ oz. \$1.00 .15 erinus speciosa. Bright blue flowers. $1 / 8$ oz. $50 \mathrm{c}$. $\quad .15$ gracilis. Blue flowers; trailing.... $1 / 8$ oz. 50c. $\quad .15$ Mixed Colors. White, blue, rose, etc. $1 / 4$ oz. $50 \mathrm{c}$.

tenuior (Ramosa). Upright habit with large blue flowers; adapted for pots or borders.... Perennial Varieties:

cardinalis (Cardinal Flower). A native variety, with spikes of scarlet flowers; fine border plant. $3 \mathrm{ft} . . . . . . . . . . . .$. cardinalis Hybrids. Splendid hybrids, mixed LOPHOSPERMUM scandens. H.H.C. Dark rose. A rapid growing climber............

LOVE-LIES-BLEEDING. (See AMARANTHUS.) LOVE-IN-A-MIST. (See NIGELLA.)

LUNARIA biennis (Honesty). H.B. Attractive flowers followed by decorative seed pods which, when dried may be used for winter decoration. $2 \mathrm{ft} . \ldots \ldots \ldots \ldots \ldots \ldots$. $1 / 4$ oz. $50 \mathrm{c}$.

LUPINUS. Free flowering plants, with long spikes of flowers. The Annual and Perennial varieties are among the most useful of our garden flowers, either for mixed borders or house decorations. $2 \mathrm{ft}$.

Hartwegi Blue. A delicate shade.. 1/4 oz. 30c. White. Splendid for cutting..... $1 / 4 \mathrm{oz} .30 \mathrm{c}$. roseus. Rose............1/4 oz. 30c.

Tall Mixed, Annual Varieties....... Oz. 50c. Perennial Varieties: polyphyllus albus. White....1/4 oz. 35c. - caerulea. Blue............ $1 / 4$ oz. $35 \mathrm{c}$.

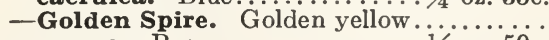
-roseus. Rose.............1/4 oz. 50c. Snow Queen. (Tree Lupine.) A grand variety; pure white..........1/4 oz. $75 \mathrm{c}$. Mixed Perennial Varieties......1/4 oz. 25c. Marshall's Matchless Mixed. Comprising a wonderful range of colors among perennial Lupines..................1/4 oz. $\$ 1.00$

L YCHNIS Chalcedonica. H.P. The old favorite Scarlet Lychnis. 18 in .......1/8 oz. 75c. Arkwrighti. Large brilliant flowers, color from orange-scarlet to soft salmon-pink. $1 / 4 \mathrm{oz} .50 \mathrm{c}$.

Haageana Hybrids, Mixed Colors. Bushy little plants. 12 in............1/8 oz. $75 \mathrm{c}$.

MALOPE grandiflora. H.A. Very showy border annual; large flowers. $2 \mathrm{ft}$.

Mixed Colors................ 1/4 oz. 25c.
Pkt 


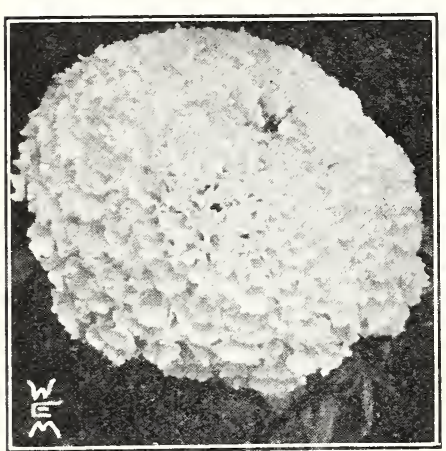

Marigold (Double African)

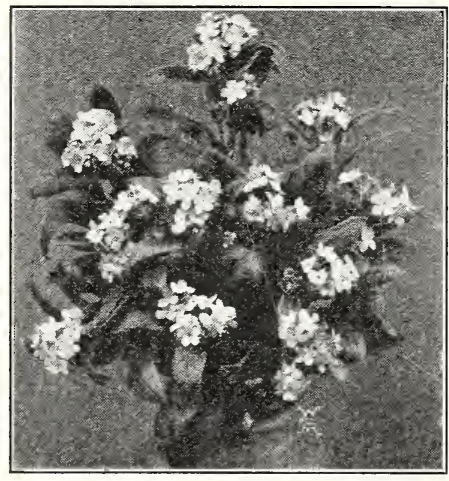

Myosotis, 'Blue Bird'

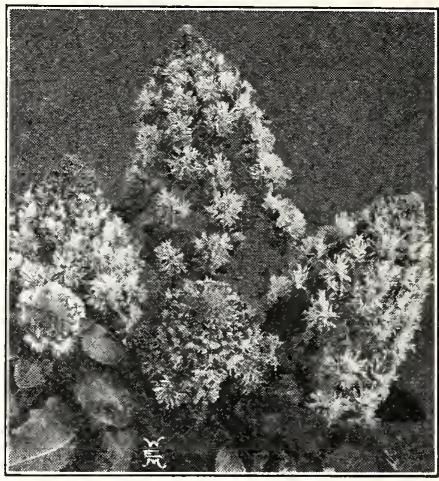

Mignonette, Defiance

Pkt. MIGNONETTE-Continued

Pkt.

MARIGOLD. H.A. Widely grown hardy annuals, invaluable for bedding and producing an elegant display of yellow, orange and brown flowers from early Summer till frost.

African Varieties. Showy flowers. $3 \mathrm{ft}$. Marshall's Lemon Queen. A charming shade.................1/4 oz. $60 \mathrm{c} . \$ 0.15$

Marshall's Prince of Orange. Beautiful orange color.............. $1 / 4$ oz. $60 \mathrm{c}$. Mixed Double.............1/4 oz. 50c. Collection Double African. Six colors se-

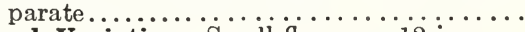

French Varieties. Small flowers. 12 in.

Dwarf Gold Striped. Rich and quaintly striped double flowers.........1/4 oz. $50 \mathrm{c}$.

Josephine. Single, dark brown flowers with edging of old-gold. $2 \mathrm{ft} \ldots \ldots \ldots 1 / 4 \mathrm{oz} .50 \mathrm{c}$

Legion of Honor. Single yellow blooms, marked with red ...........1/4 oz. 50c. Dwarf Mixed, Double.......... 1/4 oz. $35 \mathrm{c}$ Collection, Double French Dwarf. Six

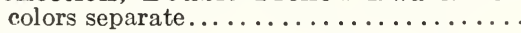

MARVEL OF PERU (Four-o'Clocks). H.A. A well-known, handsome, free flowering garden favorite; does well everywhere. $2 \mathrm{ft}$. Mixed. $\mathrm{Oz} .50 \mathrm{c}$.

MATTHIOLA bicornis (Evening Scented Stock). H.H.A. Very sweet-scented lilac flowers. 12 in ................... oz. $35 \mathrm{c}$

MATRICARIA (Feverfew). 'H.H.P. Low growing plants; for beds and edgings. 12 in.

capensis plena. Dwarf double white. $1 / 4 \mathrm{oz} .50 \mathrm{c}$ Golden Ball. Very striking double goldenyellow flowers............... $1 / 8$ oz. $\$ 1.00$ Silver Ball. Dainty double white, spherical flowers.............1-16 oz. $\$ 1.00$

MAURANDIA, Mixed Colors. H.H.P. Tender climber.

MECONOPSIS Baileyi A beautiful new per. nial originally found in Thibet in 1913. It bears an irregular cyme of nodding flowers of a glorious shade of sky blue, a ring of golden anthers adds to the beauty of the bloom...

Integrifolia. The flowers resemble the Oriental Poppy, but of a beautiful soft clear shade of

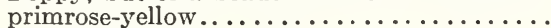

MESEMBR YANTHEMUM crystallinum (Ice Plant). H.H.A. A dwarf trailing annual plant: flowers white. 6 in......1/4 oz. $35 \mathrm{c}$.

MIGNONETTE, Large Flowering. H.A. The popular fragrant garden annual. The seed can be sown at any time, and if successive sowings are made, its fragrant, modest colored flowers may be gathered outdoors until November. 12 in.

Allen's Defiance. Full, round spikes of great length Bismarci.. Improved $\ddot{D}$ warf. Machet variety.

$1 / 4$ oz, $35 \mathrm{c}$
Crimson Giant. Deep red flowers. $1 / 1 / 1$ oz. $35 \mathrm{c} . \$ 0.10$

Goliath. Red; enormous spikes...1/4 oz. 50c. .10 Golden Queen. Compact yellow flowers...

Machet, Dwarf. Strong plants of pyramidal growth; long, broad spikes of deliciously scented red flowers. 9 in ........1/4 oz. $35 \mathrm{c}$

Majesty. Selected strain for pots or benches. $1-16$ oz. $\$ 1.00$

New York Market. The finest of all the fancy varieties of Mignonette for Winter forcing.

$1-16$ oz. $\$ 1.00$

Sweet-scented (Reseda odorata grandiflora). The large flowering garden variety. Oz. $50 \mathrm{c}$.

MIMOSA pudica (Sensitive Plant). H.H.A. An interesting plant with rosy-lilac flowers. The leaves close when touched. $12 \mathrm{in} .1 / 4 \mathrm{oz} .50 \mathrm{c}$.

MIMULUS. Showy, half-hardy annuals, with handsome flowers; excellent for pots or garden. 6 in.

tigrinus, Spotted, Mixed..............

moschatus (Muskplant). Fragrant; for pots.

$1-16$ oz. $\$ 1.00$

MINA lobata. H.A.C. Rapid climber, crimson and orange flowers. $10 \mathrm{ft} . \ldots \ldots \ldots \ldots \ldots$

MIRABILIS. (See MARVEL OF PERÜ.)

MOMORDICA. H.A.C. Trailing plants, with curious foliage and fruit.

balsamina (Balsam-apple). Orange fruit.

charantia (Balsam-pear). Copper- $1 / 4$ oz. 25c.

MoONFL OWERS.' (See IPÖMöEA grandiflora.)

MORNING-GLORIES. (See IPOMOEA and CONVOLVULUS.)

\section{MUSK. (See MIMULUS.)}

MYOSOTIS, or FORGET-ME-NOTS. H.H.P. Fine for edging or in beds. Seed may be sown any time from Spring until Midsummer. 9 in. alpestris, Blue..............1/4 oz. 50c. alpestris, Mixed Colors. White, blue, pink, etc. . . 1/4 oz. 50c. dissitifiora. Blooms very early; flowers blue. $1 / 8$ oz. $\$ 1.00$

palustris semperflorens. The true water Forget-me-not. Blooms from early Spring until Autumn. Dark blue..........1/4 oz. $\$ 1.00$

Marshall's Blue Bird. A very fine dark blue variety with long stems for Winter blooming. 1.00

Marshall's Royal Blue. Early and free flowering; color deep indigo blue. Fine for borders or cutting.................. oz. $\$ 1.00$

robusta grandiflora, Eliza Fonrobert. Strong growing variety ..............1/4 oz. $75 \mathrm{c}$.

Ruth Fischer. Compact growth; blue flowers.

Victoria. The plants are of dwarf, compact growth, with'a multitude of bright blue flowers in dense umbels.............1/4 oz. $\$ 1.00$ 


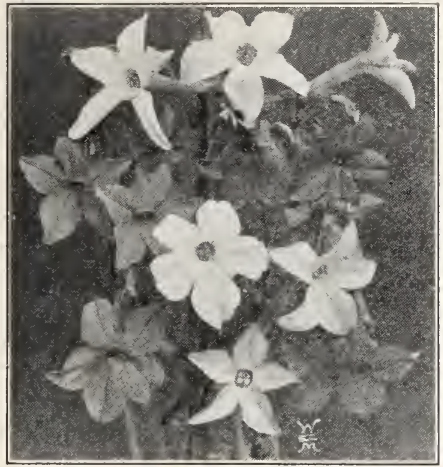

Nicotiana

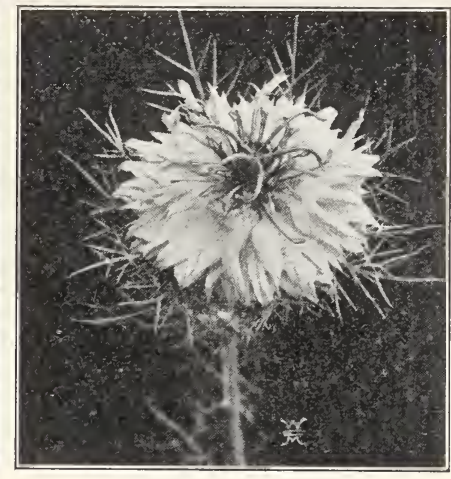

Nigella, Miss Jekyll

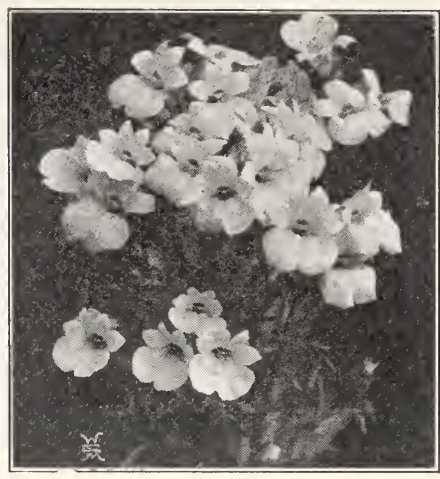

Nemesia strumosa
Pkt.

NASTURTIUM (Tropaeolum nanum). H.A. Tom Thumb, or Dwarf Varieties. These have a eompact habit and attractive foliage; bloom in two months from sowing, and most profusely the whole season. 12 in.

Aurora. Yellow-veined............. Oz. 25c.\$0.10

Beauty. Yellow and scarlet.......... Oz. 25c. $\quad .10$

Cloth of Gold. Scarlet, yellow foliage. Oz. 25c. $\quad .10$

Empress of India. Crimson, dark foliage.

King Theodore. Garnet, dark foliage. Oz. 25c. King of Tom Thumbs. Scarlet.....Oz. 25c. lu teum. Bright yellow; no blotches... Oz. 25c.

Pearl. Creamy white.............. 25c.

Rose Color ....................... 25 . 25c.

Marshall's Dwarf Rainbow Mixture. These contain all the leading named sorts, mixed.

$$
\text { Oz. } 20 \mathrm{c} ., 1 / 4 \text { lb. 60c., lb. } \$ 2.00
$$

Collection of 12 Varieties.

NASTURTIUM (Tropaeolum majus). H.A.C. Tall, or Climbing Varieties. Adapted for rockwork, banks, covering trellises or rustic work; the seeds, if picked young, are an excellent substitute for capers. $6 \mathrm{ft}$.

Chameleon. Various colors on one plant.

Oz. $25 \mathrm{c}$

Dark Crimson.................. Oz. 25c

King Theodore. Crimson; dark foliage.Oz. 25c.

Pearl. Creamy white.............. Oz. 25c.

Rose Von Moltke.................. Oz. 25c.

Scarlet........................... 25c.

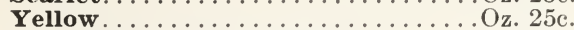

Vesuvius. Salmon-rose........... Oz. 25c

Marshall's Tall Rainbow Mixture. From the best varieties. Oz., 20c. $1 / 4$ lb. 60c., lb. $\$ 2.00$

Collection of 12 varieties.

LOBB'S NASTURTIUMS (Tropaeolum lobbianum). H.A.C. Very free blooming. The most brilliant colors, climbing about $6 \mathrm{ft}$. Excellent for window boxes, vases and hanging baskets. Lobb's Finest Mixture ............. Oz. 25c. Madame Gunther Hybrids. A French strain noted for wide range of fine colors.... Oz. 25c.

NEMESIA. H.A. Splendid for bedding or forcing in greenhouse.

strumosa grandiflora Suttoni. Mixed colors. Bushy plants; flowers of unique form. 12 in $1-16$ oz. $\$ 1.00$

compacta Blue Gem. Large flowers of a pretty Forget-me-not blue; a fine pot plant.

$1-16 \mathrm{oz} . \$ 1.00$

compacta Triumph. New dwarf, compact. 6 in. Finest mixture. . . . . . 1-16 oz. $\$ 1.00$

NEMOPHILA. H.A. Splendid, free flowering annual, with cup-shaped flowers of many bright colors. 12 in.

Mixed Colors................ 1/4 oz. 25c
NICOTIANA affinis. H.A. Fragrant, starshaped white flowers. $3 \mathrm{ft} . \ldots \ldots 1 / 4 \mathrm{oz} .35 \mathrm{c} . \$ 0.10$ affinis Hybrids. Large scented flowers, mixed shades..................1/4 oz. 50c.

Dwarf White. Adapted for pot work or borders, the sweet-scented flowers remain open all day. 18 in.....

Sanderae, Crimson King. Dark crimson red.

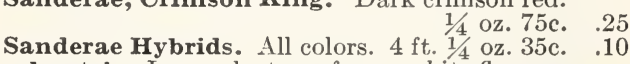
sylvestris. Large clusters of pure white flowers. $4 \mathrm{ft} . \ldots \ldots \ldots \ldots \ldots \ldots \ldots \ldots \ldots \ldots . \ldots \ldots$ oz. $35 \mathrm{c}$ NIEREMBERGIA frutescens. H.H.P. For hanging baskets or borders; large, cup-shaped lilac flowers ................1/4 oz. 50c.

NIGELLA (Love-in-a-mist). H.A. Beautiful border plants. 18 in.

Miss Jekyll. A lovely variety with cornflowerblue blossoms; splendid for cutting. $1 / 4 \mathrm{oz}$. 35c.

Miss Jekyll, White. Valuable for borders and cutting..................1/4 oz. $35 \mathrm{c}$.

Finest Mixed. Blue, white and purple.

$1 / 4$ oz. $30 \mathrm{c}$.

OENOTHERA (Evening Primrose). H.A. Useful for exposed sunny position, blooming the entire Summer.

Afterglow. Yellow with brilliant red calyx flowers. $3 \mathrm{ft}$.

Fraseri. H.P. Produces an abundance of yel-

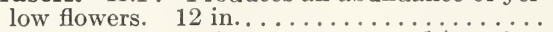

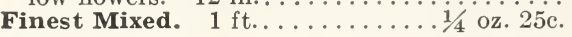

PANSY. H.H.P. The most popular flower grown. They thrive best in a cool, moist, but well-drained soil. Sow the seeds in April and May for Summer flowering and August for early flowers the following Spring. Our mixtures contain a large variety of colors.

Marshall's Special Mixture. Saved from only the largest and best shaped flowers of the richest colors. Fine for greenhouse flowering. $1-16$ oz. $\$ 3.001 .00$

.10 Marshall's Greenhouse Mixture. A selection Marshall's Greenhouse Mixture. A selection
of varieties adapted for growing under glass. $1-16 \mathrm{oz}$. $\$ 1.25$

Marshall's Matchless Mixture. This matchless strain consists entirely of the newest, best shaped and most handsome flowers, including an immense variety of brilliant colors. The seeds we offer are carefully 'saved from the largest, selected flowers........1/8 oz. $\$ 2.00$

Marshall's Superb Giant Mixed. A rich and most choicely varied mixture producing only the finest colors, largest flowers and beautiful forms .................. oz. $\$ 1.50$

Masterpiece. A beautiful strain of blotched and curled varieties.........1/8 oz. $75 \mathrm{c}$.

Giant Trimardeau, Mixed. Large flowers in a good variety of colors........1/4 oz. $\$ 1.00$
Pkt. 


18 MARSHALL'S MATCHLESS SEEDS

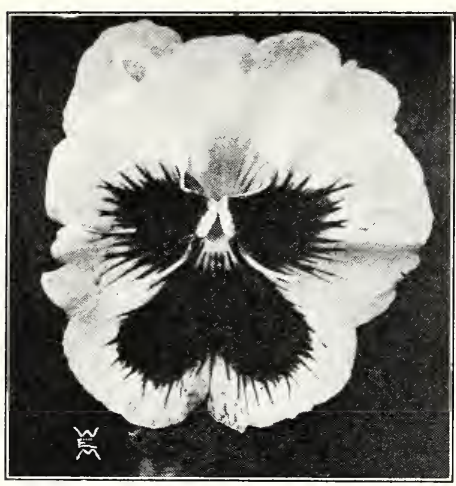

Pansy, Giant

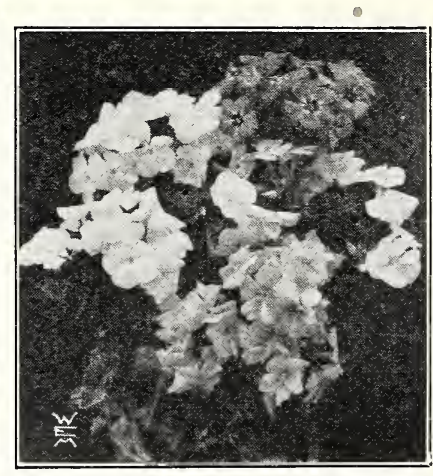

Phlox Drummondi

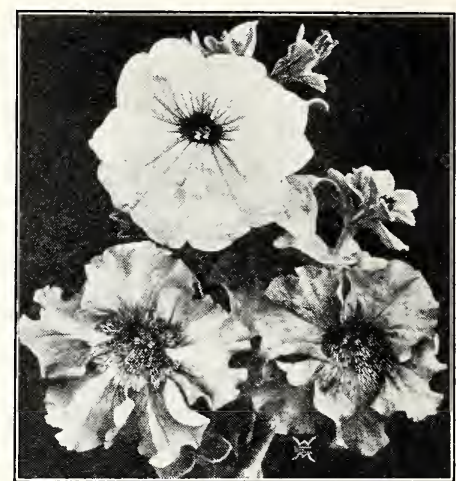

Petunia, fringed
PANSIES-Continued

GIAN'T PANSIES, In Varieties.

Giant Adonis. A beautiful light blue.

$1 / 8$ oz. 75 c. $\$ 0.15$

Giant Cardinal. A very brilliant red.

$1 / 8$ oz. $75 \mathrm{c}$. .15

Giant Emperor. Ultramarine blue. $1 / 8$ oz. $75 \mathrm{c} .15$

Giant Fire King. Crimson-purple and golden yellow..................1/8 oz. 75c. Giant Golden Queen. Beautiful pure yellow. $1 / 8$ oz. $75 \mathrm{c}$.

Giant Golden Yellow, with dark eye.

$1 / 8$ oz. $75 \mathrm{c}$

Giant King of the Blacks........1/8 oz. $75 \mathrm{c}$

Giant Lord Beaconsfield. Violet, shaded white........................ oz. 75c

Giant Orange King. Vivid orange. $1 / 8$ oz. $\$ 1.00$

Giant Prince Bismarck. Light brown shade with black eye..............1/8 oz. 75c. Giant Snow Queen. Pure white. $1 / 8$ oz. $75 \mathrm{c}$

Giant Striped. Variety of markings. $1 / 8 \mathrm{oz}$. $75 \mathrm{c}$.

Giant Victoria. Wine-red shades. . 1/8 oz. 75c

Giant White, with black eye.....1/8 oz. $75 \mathrm{c}$

Collection of 6 Varieties, Giant Named... .

Collection of 12 Varieties, Giant Named $\cdots, \quad .75$

PAPAVER. (See POPPIES.)

PASSIFLORA caerulea (Passionflower). H.H.C. Fast growing and free flowering, ornamental perennial climbers, with large, showy blue flowers, suitable for conservatory or outside in Summer...............1/4 oz. 75c.

PENTSTEMON. H.P. Highly useful and attractive hardy perennials, and much used in the hardy border. $2 \mathrm{ft}$.

gentianoides, Fine Mixed Colors. $1 / 4 \mathrm{oz} .75 \mathrm{c}$

gloxinioides "Sensation." A grand variety of colors. Will bloom from seed in June if sown early in March............1/8 oz. $\$ 1.50$

Marshall's Matchless Hybrids. A superb mixture of perennial sorts....1-16 oz. $\$ 1.00$

PERILLA Nankinensis. H.A. Ornamentalleaved plants. 18 in...........1/4 oz. 25c.

PETUNIA. H.A One of our easiest cultivated and freest flowering annuals. Will sucreed almost anywhere and give a continuity of the most brilliant bloom from June till killed by frost. 18 in.

Marshall's Double Giant, Fringed, Finest Mixed Hybrids. An exceptionally fine strain, remarkable for the large, beautiful, colored double flowors.....................

Single Varieties:

Marshall's Superb Large-flowered Mixed (California Giants). Magnificent flowers with throats beautifully veined..........

Marshall's Superb Large-flowered Fringed Mixed. Flowers with fringed and frilled edges; distinct and beautiful............

Large-flowered, Finest Mixed. Fine large flowers in superb mixture......1/8 oz. $\$ 1.00$
Pkt. PETUNIA-Continued

Fine Mixed. An assortment of medium-sized flowers; fine for bedding.......1/4 oz. 50c. $\$ 0.10$

Dwarf Calif. Giants. A sturdy growing type. [Flowers ruffled and fringed. Fine

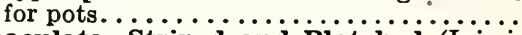
maculata, Striped and Blotched (Inimitable). Flowers quite large and handsomely striped and spotted. $12 \mathrm{in} . . .1 / 4 \mathrm{oz} .50 \mathrm{c}$.

Adonis. Very showy, fiery carmine, white throat, free blooming and compact growth. $1 / 8$ oz. $\$ 1.00$

Balcony Blue. Adapted for vases and window boxes...................1/8 oz. $\$ 1.50$

Balcony Rose.................. . . . . . $1 / 8$ oz. $\$ 1.50$

Balcony White................... oz. $\$ 1.50$

General Dodds. Fine dark red. $1 / 4$ oz. $\$ 1.00$

Marshall's Purple Bedder. A beautiful purple bedding variety........1/8 oz. $\$ 1.00$

Marshall's Violet Queen. A grand Petunia for bedding, growing about $18 \mathrm{in.} \mathrm{high} \mathrm{and}$

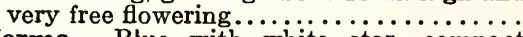

Norma. Blue with white star, compact habit, very showy...........1/8 oz. $\$ 1.00$

Rosy Morn. Soft carmine pink. $1 / 8$ oz. $\$ 1.00$

Rose of Heaven. Rose pink......1/ oz. $75 \mathrm{c}$

Snowball. Dwarf pure white; a fine bedding variety..................1/8 oz. 50 c. Snowstorm. Pure white; large flowering. .

PHACELIA campanularia. H.A. Showy, with bright blue, bell-shaped flowers. 9 in.

$1 / 4$ oz. $50 c$

PHLOX drummondi grandiflora. H.A. Improved, large-flowering strain of this famous garden annual. Prefers a light, rich loam in sun or semi-shade. Seed may be sown in the open ground any time after danger from frost is past. 12 in.

Blood-Purple...............1/4 oz. 75c. .15

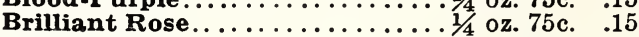

Chamois Rose...............1/4 oz. 75c. .15

Crimson .......................

Isabellina. Yellow or primrose... $1 / 4$ oz. $75 \mathrm{c} . \quad .15$

Vivid Scarlet...............1/4 oz. 75c. .15

White..................... oz. 75 c. .15

stellata splendens. Starlike crimson.

$1 / 4$ oz. 75 c. $\quad .15$

Choicest Mixed. Contains a very large variety of color.................1/4 oz. 50c.

PHLOX, Large-flowering, Dwarf Varieties. Effective for beds or borders. 6 in.

nana compacta, Fireball. Bright red.

$1 / 8$ oz. $\$ 1.00$

nana compacta, Snowball. Compact, pure white..................1/8 oz. $\$ 1.00$ nana compacta, Mixed Colors. Star-shaped flowers................... 1/8 oz. $\$ 1.00$

PHLOX, Hardy Perennial decussata. Most brilliant colored flowers in late Summer and Fall. $3 \mathrm{ft} . . . \ldots \ldots \ldots \ldots \ldots . \ldots 1 / 4$ oz. $\$ 1.00$ 


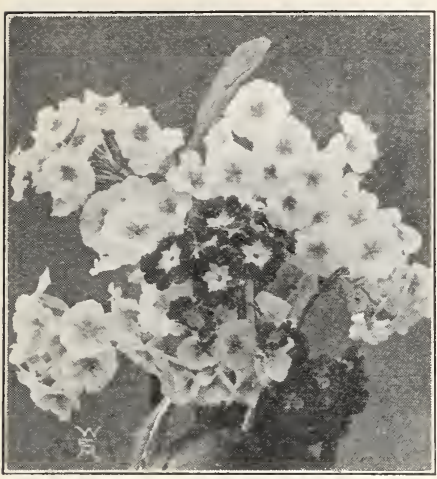

Polyanthus

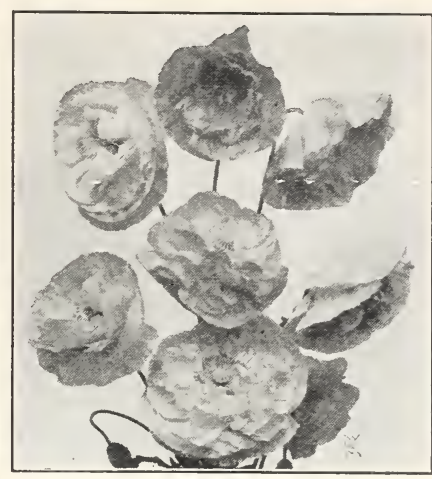

Poppy, Double Annual

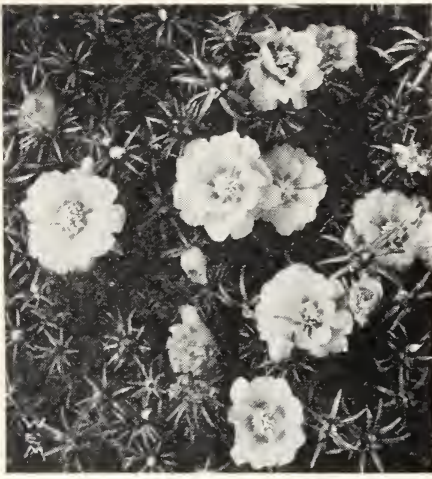

Portulaca
PHYSALIS francheti (Chinese Lantern). H.B. Balloon-like fruits. $3 \mathrm{ft} \ldots \ldots \ldots \ldots \ldots \ldots \$ 0.15$

PH YSOSTEGIA (False-dragonhead). H.P. $3 \mathrm{ft}$. virginica. One of the prettiest hardy perennials. It forms dense bushes bearing freely spikes of delicate pink tubular flowers.

$1 / 8$ oz. 50 c.

virginica alba. Pure white......1/8 oz. 50c. PINKS. (See DIANTHUS.)

PLAT YCODON. H.P. The large-flowering Chinese Bellflowers $2 \mathrm{ft}$.

grandiflorum. Large, steel-blue flowers.

album. Pure white variety.....1/8 oz. $50 \mathrm{c}$. mariesi. Dwarf, large-flowered blue. 12 in.

$1 / 8$ oz. $50 \mathrm{c}$.

POLEMONIUM coeruleum grandiflorum ( $\mathrm{Ja}$ cobs-ladder). H.P. Deeply cut foliage and clusters of handsome blue flowers. $2 \mathrm{ft}$.

$1 / 4$ oz. $\$ 1.00$

grandiflorum album. Pure white. $1 / 4$ oz. $\$ 1.00$

POL YANTHUS (Primula elatior). H.H.P. Desirable for greenhouse flowering or bedding out in the Spring. 9 in.

Marshall's Matchless Gold Laced. Saved from the largest flowers in a wide range of

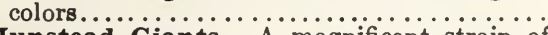

Munstead Giants. A magnificent strain of Bunch Primroses in shades of yellow and

POPPIES.. Showy, free blooming, old-fashioned flowers. Very effective in mixed borders.

Single Annual Varieties, 12-in.

glaucum (The Scarlet Tulip Poppy).1/4 oz. 35c.

King Edward. Free flowering, beautiful scarlet..................... oz. $35 \mathrm{c}$. Miss Sherwood. Flowers satiny-white and chamois-rose ...............1/4 oz. 30c.

Marshall's Extra Selected Shirley. A grand variety of colors, saved from selected flowers. Their brilliant, dazzling coloring and wonderful variety make a very effective display in the garden or for cut flowers........1/4 oz. 35c.

American Legion. Brilliant orange-scarlet, yellow anthers. Should be grown extensively for Poppy Day..............1/4 oz. 50c.

Blue Shirley. A splendid assortment of colors. $1 / 4$ oz. $50 \mathrm{c}$.

Rose Pink Shirley. A beautiful pink variety.

The Bride. A beautiful variety with large, pure white flowers...........1/4 oz. $30 \mathrm{c}$

virginia. Flowers white, edged soft pink; fringed ................. oz. $30 \mathrm{c}$.

Double Annual varieties.

American Flag. White, edged red. $1 / 4$ oz. 25c. Carnation-flowered. Mixed colors. $1 / 4$ oz. $25 \mathrm{c}$. Eldorado Double Mixed. A double form of Shirley Poppy, in choice mixture. $1 / 4$ oz. $35 \mathrm{c}$.
Pkt.
POPPIES-Continued

Pkt.

Mikado. White, edged scarlet....1/4 oz. $25 \mathrm{c} . \$ 0.10$

Paeony-flowered. Mixed colors...1/4 oz. 25c. .10

White Swan. Large, beautifully fringed white flowers....................1/4 oz. 25c.

Hardy Perennial Varieties:

bracteatum. Orange-scarlet, hardy Poppy

$1 / 4$ oz. $25 \mathrm{c}$

Iceland Poppies. While these are hardy perennials, they flower the first year from seed, blooming almost as quickly as the annual sorts. nudicaule (Iceland Poppy). Dwarf, bright yellow...................... oz. 50c. -aurantiacum. Orange..........1/4 oz. 50c. -album. Pure white..........1/4 oz. 50c.

- Coonara Pink. Long stemmed flowers in superb shades of rose and pink ....

Oriental Poppies, Mixed Hybrids. $3 \mathrm{ft}$. Finest shades.............1/4 oz. 50c.

PORTULACA. H.A. One of the freest flowering dwarf annuals, especially adapted for sunny locations. Flowers of the most brilliant colors. 6 in.

Single Rose..............1/4 oz. 50c.

Single Scarlet................ oz. $50 \mathrm{c}$

Single White.............1/4 oz. 50c.

Single Yellow..............1/4 oz. 50c.

Single Mixed. Ail colors............

Double Large Flowering. "Will produce a large percentage of double flowers in many colors.

Finest Mixed ............... 1/4 oz. $\$ 1.25$

POTENTILLA. H.P. Splendid hardy perennials with ornamental foliage and brilliant flowers in shades of yellow and red from June to August. $2 \mathrm{ft}$.

Single Mixed. Various shades of yellow and

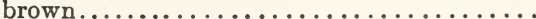

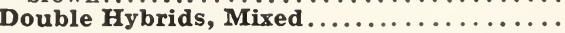

PRIMULA sinensis fimbriata (Chinese Primrose). G.P. A charming profuse flowering plant indispensable for Winter and Spring decoration.

Marshall's Giant. Deep blue......... .50

-Pure white...........................

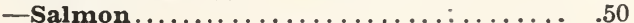

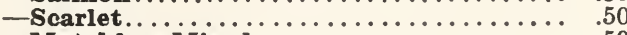

- Matchless Mixed....................

PRIMULA obconica. One of the most useful greenhouse plants.

obconica gigantea alba. White......... .50

-lilacina. Lilac......................$_{50}^{.50}$

-kermesina. Crimson................ 50

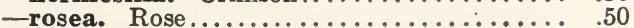

-Finest Mixed...........................

Eureka. A new giant form of obconica. Rich rosy carmine, shaded cerise, a clear yellow eye. 1.00 


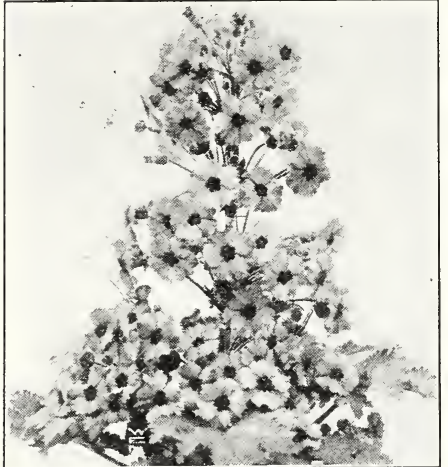

Primula malacoides

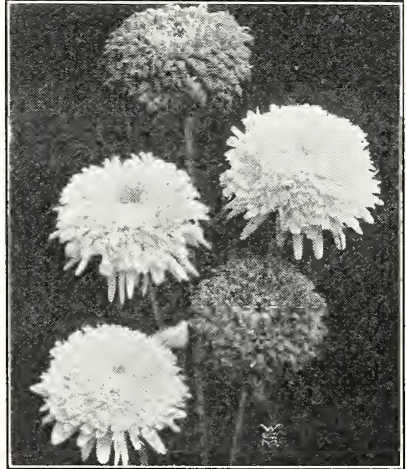

Pyrethrum, Double

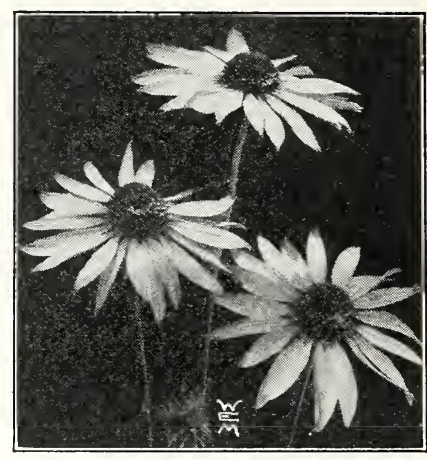

Rulbecki

manni
Pkt.

RIMULA-Continued

malacoides. A charming free flowering pot plant; delicate lilac.................\$0.50

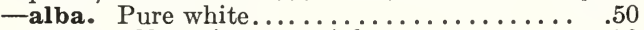

-rosea. Charming rose-pink................. 50

- superba. Larger flowers and much deeper in color than malacoides.............. .50

-robusta. A clear rosy-lavender shade with

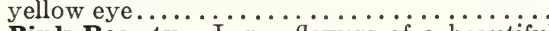

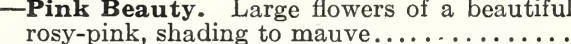
Kewensis. Bright yellow, fragrant flowers. . stellata (The Star Primula). Excellent pot plants for decoration purposes. Mixed colors. HARDY PRIMULAS or Primroses.

Beesiana. Very free flowering. Glowing vel-

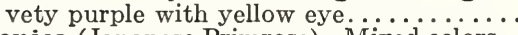

Japonica (Japanese Primrose). Mixed colors. . Marshall's New Blue. H.P. Many shades

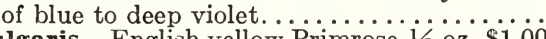
vulgaris. English yellow Primrose. $1 / 8$ oz. $\$ 1.00$ vulgaris Hybrids. Very choice hybrids of the

English Yellow Primrose......................
PYRETHRUM. H.H.P. Fine for edging and borders. 6 in.

aureum Golden Feather. Bright yellow foliage...................1/4 oz. 50c. aureum Golden Gem.......... hybridum. H.P. Large Daisy or Cosmos-like flowers; blooms in early Summer and late Fall. 18 in.

Single. Large-flowering, mixed colors.

$1 / 4$ oz. $\$ 1.00$

hybridum fl. pl., Double. Large-flowering, beautiful colors..............1/8 oz. $\$ 2.00$

REHMANNIA angulata. H.H.P. Flowers rosepurple with spotted throat. $3 \mathrm{ft} . \ldots \ldots \ldots$.

RHODANTHE (Swan-river Everlasting). H.A. Handsome pink and white, annual everlasting, excellent for bouquets of dried flowers. $1 \mathrm{ft}$. maculata. Rose with dark center. .1/4 oz. 35c. -alba. Pure white............1/4 oz. 35c. Finest Mixed .................

RICINUS (Castor Oil Plant). H.A. From seed they quickly attain gigantic proportions and are ornamental till destroyed by frost. $6 \mathrm{ft}$. cambodgensis. Maroon foliage...... Oz. 35c. gibsoni. Purplish leaves and stems... Oz. 35c. panormitans. Large dark brown leaves, blue powdered stems, upright habit...... Oz. 35c. sanguineus. Red stems.............. 3z. 35c. zanzibarensis, Mixed. Immense leaves. $8 \mathrm{ft}$. $\mathrm{Oz} .35 \mathrm{c}$

Mixed Varieties.................. 25 c

ROCKET, SWEET (Hesperis). H.P. A very interesting, useful, free-flowering plant. 18 in.

Purple. Beautiful purple color.....1/4 oz. 35c. White. Flowers rosy white........1/4 oz. $35 \mathrm{c}$

Finest Mixed Colors..........1/4 oz. 35c.
.50

.50

.50
ROMNEYA coulteri (The California Tree Poppy). H.H.P. Large, snowy white flowers. Requires protection in Winter. $2 \mathrm{ft} . . . . .$.

RUDBECKIA bicolor superba. H.A. Yellow flowers. $2 \mathrm{ft} . \ldots \ldots \ldots \ldots \ldots \ldots \ldots 1 / 4$ oz. $50 \mathrm{c}$. Newmanni. H... Bright orange with black

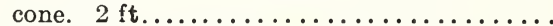
purpurea hybrida grandifiora. tiful large-flowered hybrids. $2 \mathrm{ft} . . . \ldots \ldots$...

Pkt.

SALPIGLOSSIS. H.A. One of the prettiest annuals, of easy culture; very showy in beds or borders. Orchid-like flowers from early Summer until late Fall. $2 \mathrm{ft}$.

Marshall's Matchless Varieties:

Chamois...............1/8 oz. 50c. Golden Yellow.................. Scarlet..................1/8 oz. 50c. Rose and Gold..............1/8 oz. 50c. Scarlet and Gold............. $1 / 8$ oz. $50 \mathrm{c}$. Violet..................1/8 oz. 50c. Violet and Gold..............1/8 oz. 50c. Yellow and white.............1/8 oz. 50c. Matchless Mixture. Aill colors...1/4 oz. $75 \mathrm{c}$ Large Flowering. Mixed colors.. $1 / 4 \mathrm{oz} .35 \mathrm{c}$. Collection of 6 Separate Colors...........

SALVIA (Flowering Sage). H.A. One of our most handsome Summer and Autumn-flowering plants, growing into compact bushes 2 to $3 \mathrm{ft}$. high and literally ablaze with brilliant flowers.

azurea grandiflora. H.P. Pretty sky-blue flowers in August and Sept. $4 \mathrm{ft} . .1 / 8 \mathrm{oz} . \$ 1.00$

America, or Globe of Fire. The earliest, freest and most continuous bloomer...1/8 oz. $\$ 1.00$

Blue Beard (Clary). Elegant plant with showy spikes of bright purple flowers....1/4 oz. 35c.

Bonfire. A splendid dwarf variety, with large, erect spikes of rich scarlet flowers. $1 / 8 \mathrm{oz} .75 \mathrm{c}$.

farinacea. H.H.P. Light blue flowers, long spikes...................1/8 oz. 75c.

Harbinger, Early Flowering. A dwarf variety which will come into flower in early Summer. Spikes of dazzling bright scarlet flowers. $1 \mathrm{ft}$.

Ostrich Plume. The plants are well covered with brilliant scarlet plumes. ....1/8 oz. $\$ 1.00$

Salmon Beauty. A superior strain with salmon colored blooms, $11 / 2 \mathrm{ft}$. high..........

splendens grandifiora (Scarlet Sage). A rich flowered bedder.......... 1/4 oz. $\$ 1.00$

Summer-flowering Fireball. A brilliant scarlet variety, July. $2 \mathrm{ft} . \ldots \ldots \ldots \ldots \ldots$.

Zurich. Early flowering; color brilliant scarlet. 12 in...................1-16 oz. 75c. patens. $\dot{H} . \dot{H} . \ddot{\text { Magnificent }}$ blue flowers

$1 / 8$ oz. $\$ 1.50,25$ 


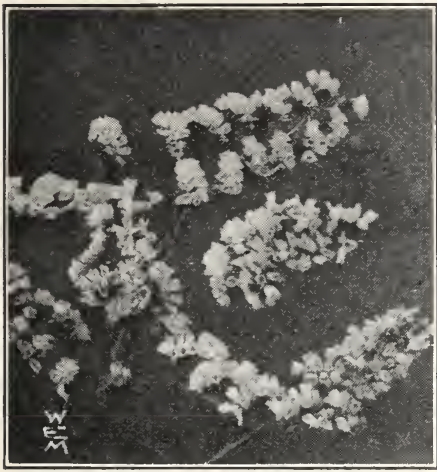

Statice Sinuata

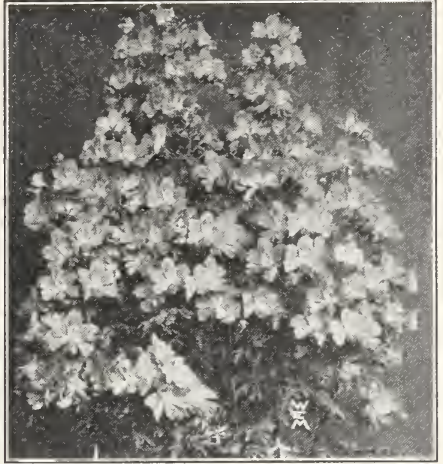

Schizanthus

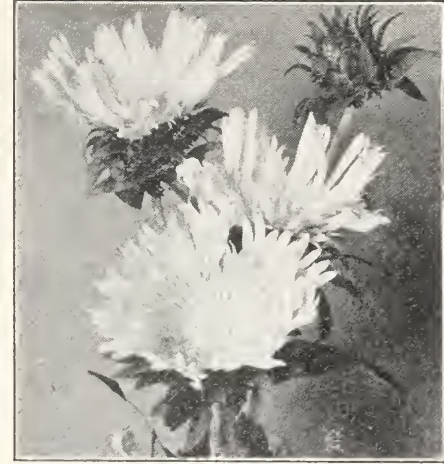

Stokesia cyanea
Pkt.

SANVITALIA procumbens fi. pl. H.A. Pretty bright double yellow flowers. 6 in. $1 / 4$ oz. 50 c. $\$ 0.10$

SAPONARIA calabrica. Dwarf annual with pink starry flowers. $2 \mathrm{ft} . \ldots \ldots \ldots \ldots 1 / 4 \mathrm{oz} .35 \mathrm{c}$. vaccaria. Graceful sprays of pale rose flowers. Also used as a greenhouse pot plant. $2 \mathrm{ft}$. $1 / 4$ oz. $35 \mathrm{c}$.

SCABIOSA, or MOURNING BRIDE. H. A. One of our best Summer flowering annuals. The rich and beautiful colored flowers are very handsome and excellent for cutting; profuse bloomer. June to October. $21 / 2 \mathrm{ft}$.

Large-flowering Tall Double Varieties: Cherry Red................. 1/4 oz. 40c. Fiery Scarlet................. . . . . . . . $40 \mathrm{c}$ King of the Blacks. Deep purple-black.

Lavender Blue $\ldots \ldots$. $1 / 4$. $40 \mathrm{c}$ Peach Blossom. A beautiful shade of peach blossom pink, of large size and long stems. An excellent cut flower.......1/4 Oz. $\$ 1.00$ Rose Pink................... 1/4 oz. 40c. Pure White.................... oz. 40. Finest Mixed. All colors............1/4 oz. 35c. Dwarf Double. Many colors mixed.

$1 / 4$ oz. $35 \mathrm{c}$.

Perennial Varieties: caucasica alba. Delicate white flowers. $2 \mathrm{ft}$. $1 / 8$ oz. $\$ 1.25$ caucasica. Silvery lavender-blue. $1 / 8 \mathrm{oz} . \$ 1.25$ Columbaria Lavender. Large flowers......

Columbaria Pink. A beautiful shade......

SCHIZANTHUS (Butterflyflower). H. H. A. Beautiful and showy, erect growing, hardy annuals for house or garden; very free- flowering, continuing through the Summer and Autumn. $11 / 2 \mathrm{ft}$.

Dr. Badger's Hybrids. Fern-like bright green foliage, covered with a beautiful range of colors. Grand for pot culture.............

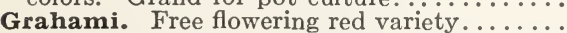
hybridus grandiflorus, Finest Mixed. ' $\ddot{\text { Very }}$ choice $1 / 1$ oz. $35 \mathrm{c}$

Pink Beauty. An exquisite shade of rose-pink.

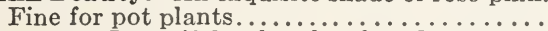

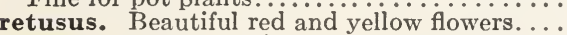
retusus albus. White blotched with golden

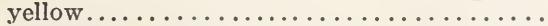
wisetonensis, Marshall's Select Hybrids. Flowers varying from white with yellow eye to rose with bronze center. Fine for pots....

wisetonensis compacta, Mixed. Beautiful

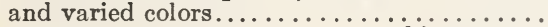

wisetonensis Snowflake. Pure white flowers, beautifully fringed.................

SENECIO elegans fi. pl. (Jacobaea). H.A. Free flowering pretty annual. Mixed colors. 18 in.
SENSITIVEPLANT. (See MIMOSA pudica.)

Pkt.

SHAMROCK. G.P. True small-leaved variety $1 / 4$ oz. 50 c. $\$ 0.15$

SIDALCEA, Stark's Hybrids. H.P. A hardy border plant. All shades from blush pink, rose, carmine and crimson. 2 to $4 \mathrm{ft}$.......

SILENE (Catchfly). Very pretty and profuse blooming plants.

compacta. H.A. Double. Mixed colors. $2 \mathrm{ft}$.

$1 / 4$ oz. 35c. rientalis. H.P. Large, globular heads of
bright rose flowers, which are clove-scented. Useful for cutting. $2 \mathrm{ft} \ldots \ldots \ldots \ldots 1 / 4 \mathrm{oz} .35 \mathrm{c}$.

SMILAX (Myrsiphyllum asparagoides). G.P. Popular greenhouse climber with small dark green foliage.............. $1 / 4$ oz. $25 \mathrm{c}$.

SNAPDRAGON. (See ANTIRRHINUM.)

SOLANUM capsicastrum nanum (Jerusalem Cherry). G.P. Ornamental plant for Winter decoration, with bright scarlet berries.

$1 / 4$ oz. $50 \mathrm{c}$.

Cleveland. Valuable as a pot plant. Brilliant

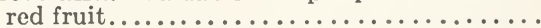

STATICE. H.A. Beautiful free-flowering plants adapted for beds or borders. The flowers, when dried, make pretty decorations for Winter use. $11 / 2$ to $2 \mathrm{ft}$.

bonduelli. Bright yellow flowers...1/4 oz. 35c. sinensis. Very graceful plant; flowers pure white with canary yellow........1/8 oz. 50c. sinuata Blue. A light shade of blue........ - candidissima. Pure white.............

-rosea superba. Fine bright rose........

-True Blue. Fine deep blue............... white and yellow............1/4 oz. 50c. suworowi. Flowers bright rosy color; fine for Winter decorations.............. $1 / 8$ oz. $50 \mathrm{c}$ incana hybrida nana Mixed. H.P. A charming variety of Sea-lavender. Fine for bouquets........................ oz. $50 \mathrm{c}$. latifolia. "H.P. Lavender-blue flowers.

$1 / 4$ oz. $50 \mathrm{c}$ perezi. H.H.P. A beautiful bright blue. Adapted for borders and greenhouse forcing. $11 / 2 \mathrm{ft} . \ldots \ldots \ldots \ldots \ldots \ldots \ldots \ldots \ldots \ldots . . . \ldots \ldots$

STEVIA serrata. G.P. A greenhouse plant with fragrant, tiny white flowers; exceedingly valuable for cutting. $2 \mathrm{ft} . \ldots \ldots \ldots 1 / 4 \mathrm{oz} .75 \mathrm{c}$.

STOKESIA cyanea. H.P. Lavender-blue flowers. $2 \mathrm{ft} \ldots \ldots \ldots \ldots \ldots \ldots \ldots 1 / 4 \mathrm{oz} . \$ 1.00$ Finest Mixed. A mixture of pink, purple, blue and white shades...........1/4 oz. 75c. 


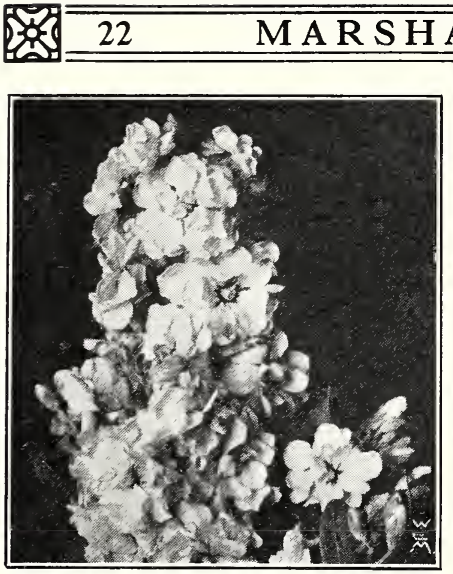

Stocks, Giant Perfection

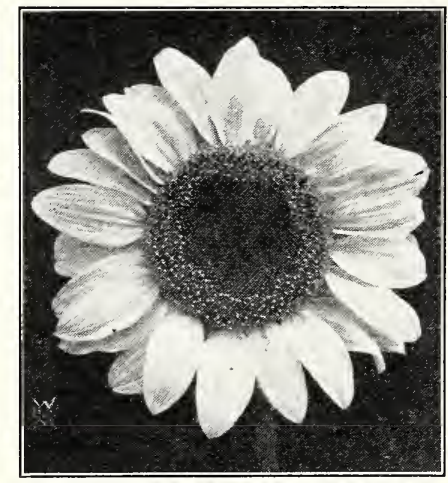

Sunflower

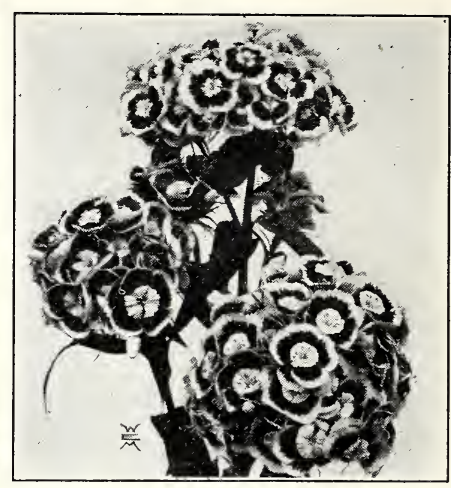

Sweet William
STOCKS (Gilliflower). H.A. One of the most highly prized of all our cultivated flowers. The delightful fragrance, free-blooming character and beautiful colors have made them as desirable for Winter cultivation in the greenhouse as for the garden in Summer; invaluable as cut flowers.

Marshall's Giant Perfection Ten-Weeks. A splendid double-flowered strain; especially adapted for bedding or pot culture.

Chamois Rose...............1/8 oz. $\$ 1.00 \$ 0.25$

Dark Blue ................. $1 / 8$ oz. $\$ 1.00 \quad .25$

Crimson .................. $1 / 8$ oz. $\$ 1.00 \quad .25$

Flesh Color..................

Light Blue ................. $\ldots \ldots \ldots$ oz. $\$ 1.00 \quad .25$

Pure White..................

Rose................... 1/8 oz. $\$ 1.00 \quad .25$

Scarlet................... $1 / 8$ oz. $\$ 1.00 \quad .25$

Yellow......................

Finest Mixed. All Colors..... $1 / 8$ oz. $\$ 1.00 \quad .25$

Collection of Six Colors............... 1.25

Collection of Nine Colors ................ 2.00

Large Flowering Ten-Weeks, Mixed Colors.

$1 / 8$ oz. $75 \mathrm{c}$

Blanche Fournier. Ashes of roses color. . . . . 1.00 Winter Flowering Stocks:

Cut - and - come - again, Princess Alice.

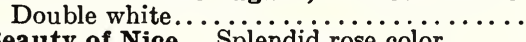
Beauty of Nice. Splendid rose color........ Crimson King. Brilliant fiery crimson..... Empress Elizabeth. Carmine-rose.......... Giant Abundance. Carmine-rose.......... Mont Blanc. Pure white............... Queen Alexandra. Delicate rosy lilac..... Summer Night. Deep blue........... White Lady. Large, double, snow-white. . . Yellow, Monte Carlo. Clear yellow....... Any of the above varieties.....1/8 oz. $\$ 1.25$

East Lothian. Valuable for beds or borders and for greenhouses during the Winter months. For early Summer flowering, the seed should be sown in the Fall and plants wintered over in frames.

Finest Mixed............1-16 oz. $\$ 1.00$ STREPTOCARPUS. ' Handsome greenhouse perennial, with Achimene-like flowers in clusters on slender stems. Treatment same as for Gloxinia.

Choice Mixed Hybrids.................

SUNFL OWER. H.A. Well-known hardy annuals, the small-flowering sorts being very useful for cutting, while the larger sorts are very ornamental and useful, blooming all Summer.

Double Californian. Deep yellow. $5 \mathrm{ft}$

Oz. 50c.

$6 \mathrm{ft}$.

$\mathrm{Oz} .30 \mathrm{c}$. Double Globe-shaped. Orange, $5 \mathrm{ft} . \mathrm{Oz}$. 35c.
Chrysanthemum-flowered. Rich golden yellow flowers. $5 \mathrm{ft} . \ldots \ldots \ldots \ldots \ldots \ldots . . .6 z .60 \mathrm{c}$.
Pkt. SUNFLOWER-Continued

cucumerifolius (Miniature Sunflower). Of pyramidal growth; covered with bright orange, small single flowers. $3 \mathrm{ft} . .1 / 4 \mathrm{oz} .25 \mathrm{c} . \$ 010$ cucumerifolius hybridus fl. pl. Splendid double varieties. $3 \mathrm{ft}$. ........1/4 oz. 30c.

Marshall's "Excelsior'; cucumerifolius $\mathbf{H y}$ brids. Shades of red, purple, mahogany and yellow. 4 ft. .......... Orion. A variety of Stella with twisted petals.

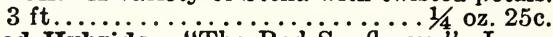

Red Hybrids. "The Red Sunflower." Large flowers in various shades of red and dark centers. $4 \mathrm{ft} . . \ldots \ldots \ldots \ldots \ldots \ldots 1 / 4 \mathrm{oz} .25 \mathrm{c}$.

Stella (Improved Miniature Sunflower). Yellow. $3 \mathrm{ft} \ldots \ldots \ldots \ldots \ldots \ldots \ldots 1 / 4 \mathrm{oz} .25 \mathrm{c}$. perennis Hybrids. Mixed hardy varieties.

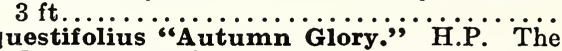
flowers are golden yellow. Plants grow about $6 \mathrm{ft}$. and bloom profusely in the late Fall.

$1 / 4$ oz. $\$ 1.00$

SWEET SULTAN. (See CENTAUREA.)

SWEET PEAS. (See pages 24 and 25.)

SWEET ROCKET. (See ROCKET.)

SWEET-WILLIAM (Dianthus barbatus). H.B.

Showy, of easy culture; splendid for beds and borders with their rich varied flowers. $11 / 2 \mathrm{ft}$.

Double-flowering, Mixed........1/4 oz. 50c. Carmine Beauty. Carmine........1/4 oz. 75c.

Crimson King. Crimson........1/4 oz. 50c.

Diadem. A deep rich crimson, with white eye.

Giant White. Pure white....1/4 oz. 40c. 10

Newport Pink. Salmon rose-pink flowers borne on long stems...........1/4 oz. 75c. .10

Pink Beauty. Very free flowering. . 1/4 oz. 75c. $\quad .10$

Scarlet Beauty. Intensely rich deep scarlet.

Single-flowering, Finest Mixed Colors.

$1 / 4$ oz. $\$ 1.00 \quad .10$

$1 / 4 \mathrm{oz}$. $25 \mathrm{c}$. Single Annual Mixed. Flowers of good size. Will bloom the first year. $12 \mathrm{in} . .1 / 4 \mathrm{oz} .50 \mathrm{c}$.

Collection of Sweet-William. Six varieties. .
.25

TAGETES signata pumila. H.A. A dwarf, bushy Marigold, with golden yellow flowers. Fine for bedding. 12 in........1/4 oz. $50 \mathrm{c}$.

THUNBERGIA. H.A.C. Beautiful, rapid-growing climbers. $5 \mathrm{ft}$.

Finest Mixed.............1/4 oz 50c.

TORENIA. H.H.A. Tender trailing plants for vases or baskets. 12 in.

fournieri. Velvety blue..............

"The Bride." White and rose.............

THALICTRUM. H.H.P. Graceful plants resembling Maidenhair ferns. Extensively used for bouquets.

adiantifolium. Yellow flowers. $1 \mathrm{ft} . . . . .$.

dipterocarpum. Rosy-purple with citronyellow anthers. $3 \mathrm{ft} . \ldots \ldots \ldots \ldots \ldots \ldots \ldots$,
Pkt. 


150 WEST $23 \mathrm{rd} \mathrm{ST.,NEW} \mathrm{YORK} 23$

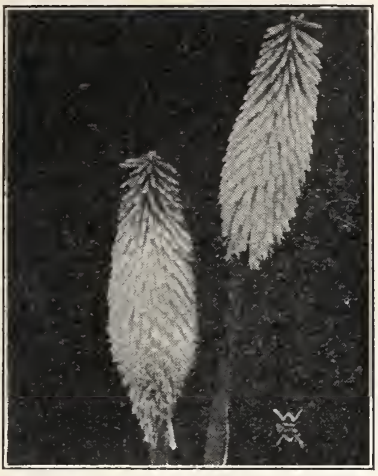

Tritoma

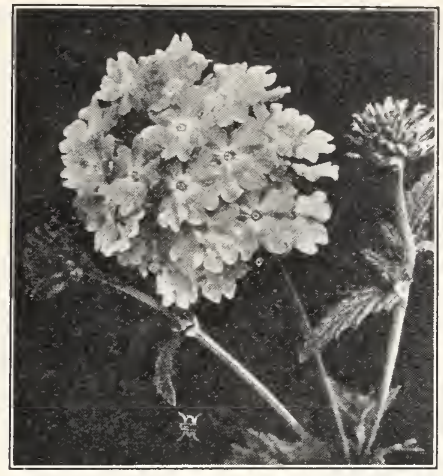

Verbena

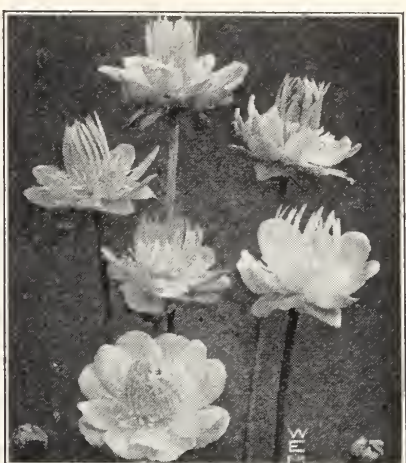

Trollius
TRACHELIUM coeruleum. G.P. A free-flowering plant with cloud-like heads of mauve

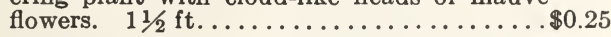

TRITOMA. H.H.P. Often called the Flameflower, useful for borders and cutting. Plants should be well protected in Winter. $3 \mathrm{ft}$. semperflorens. Orange-red.$\ldots \ldots \ldots \ldots \ldots \ldots \ldots$. flowering race. The colors embrace yellows

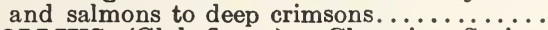

TROLLIUS (Globeflower). Charming Springflowering, hardy perennials with large, globular, Buttercup-like flowers varying in color from creamy white to orange. $2 \mathrm{ft}$.

Orange Globe Hybrids. Newest large-flowering varieties..$\cdots \cdots \cdots \cdots \cdots \cdots$

TROPAEOLUM lobianum. (See NASTURTIUM.)

VALERIAN, Red. H.P. Showy, hardy plant for the garden and rockery. $2 \mathrm{ft} .1 / 4 \mathrm{oz} .30 \mathrm{c}$.

VERBENA. H.A. The Verbena is a universal garden favorite, very fow plants making a more gorgeous display of brilliant flowers from Spring till late in the Autumn. 12 in.

grandiflora erecta Royal Bouquet. A valuable decorative plant for bedding or growing

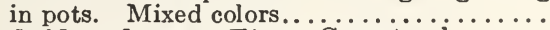

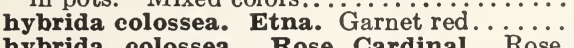

hybrida colossea. Rose Cardinal. Rose, white eye. . . . . . . . . . . . . . . . . . . . .

hybrida colossea. Royale. Deep royal blue. strain producing giant florets in many colors.

Mammoth candidissima. Large trusses of white flowers.................1/4 oz. 75c. coerulea. Bright blue and purple in various shades.................... 1/4 oz. 75c.

Helen Wilimott. $A$ very pretty bright salmonrose, with white eye. ..........1/4 oz. $\$ 1.00$

- Lucifer. Intense brilliant scarlet with no eye................... $1 / 4$ oz. 75 c. - Mayflower. A beautiful pink variety.

- Yellow. Primrose color......11/4 oz. $75 \mathrm{c}$. $75 \mathrm{c}$. - Finest Mixed. Extra choice......1/4 oz. 75c.

Lemon Verbena (Aloysia citriodora); Lemon

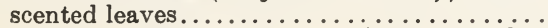
venosa. Purple flowers. Blooms the first year from seeds. ............1/4 oz. 50c.

VERBASCUM Miss Willmott. H.P. A lovely hardy plant with large, ivory-white spikes of flowers. $5 \mathrm{ft} . . \ldots \ldots \ldots \ldots \ldots \ldots . \ldots . \ldots . \ldots$ phoeniceum. $\dot{H} . \dot{P}$. Various colors, including white, pink, blue, mauve and purple. 12 in. $1 / 4$ oz. $50 \mathrm{c}$.

VERONICA H.P. Splendid, hardy perennials with showy spike of bright-colored flowers; fine border plant. $11 / 2$ to $2 \mathrm{ft}$.

spicata Blue. Bright blue........1/4 oz. $50 \mathrm{c}$
Pkt.

VINCA. H.H.P. Splendid plants for bedding and edging; glossy, dark-green foliage and pretty pink and white flowers. $2 \mathrm{ft}$.

alba pura. Pure white...........1/4 oz. $60 \mathrm{c} \$ 0.10$ alba rosea. White, crimson eye....1/4 oz. $60 \mathrm{c} . \quad .10$ delicata. A beautiful sof t rose color. $1 / 4$ oz. $60 \mathrm{c} . \quad .10$ rosea. Rose, dark eye...........1/4 oz. 60c. .10 Mixed ....................... oz. 60c. .10

VIOLA, Bedding Varieties. H.H.P. Large flowering, self colors. 6 in.

Mixed. From best named Scotch varieties. $1 / 8$ oz. $\$ 1.00$

VIOLA, Tufted Pansies. H.H.P. Valuable for bedding and may be grown in the same manner as Pansies. Very free flowering. 6 in.

Admiration. Soft purple, dark blotched. $1 / 8$ oz. $75 \mathrm{c}$.

Haslemere. A distinct variety with rosy-lilac

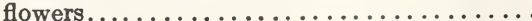

Jersey Gem. The flowers are a pleasing shade

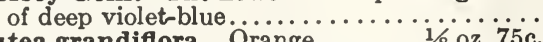
lutea grandiflora. Orange.........1/8 oz. 75c.

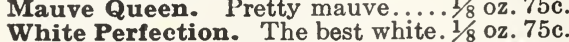

Finest Mixed. All colors....... $1 / 4 \mathrm{oz} . \$ 1.00$ VIOLET, Viola odorata. H.P. Sweet-scented Violet, blue. 6 in.................

VISCARIA. H.A. Showy and profuse blooming plants, very effective in small beds or borders. Finest Mixed................ 1/4 oz. 25c.

WALLFLOWER. H.H.P. Old fashioned fragrant plants blooming in early Spring. They should be protected in a coldframe in the Winter, and planted out in April. 12 in.

Allioni (Alpine Wallflower). (See CHEIRANTHUS.)

Kewensis. Very fragrant, sulphur-yellow flowers, passing to orange-yellow or purple-violet. Fine for Winter flowering in greenhouse.

$1 / 8$ oz. $75 \mathrm{c}$.

Single Fine Mixed. Hardy varieties. $1 / 4 \mathrm{oz} .35 \mathrm{c}$ Double Fine Mixed. Hardy. $1 / 8$ oz. $\$ 1.00$ Annual Varieties. If sown in heat during March these will flower during the Summer and Autumn. Excellent for forcing.

Annual Mixed. Summer flowering. $1 / 4$ oz. $50 \mathrm{c}$.

Early Wonder. A new double annual flowering type. Mixed colors.......1/4 oz. $\$ 1.00$

Early Paris Market. Bright brown. $1 / 4$ oz. 50c.

Blood-red...................1/4 oz. 50c.

WILD CUCUMBER. (SE ECHINOCYSTIS.)

XERANTHEMUM. H.A. Showy, hardy annual of easy culture, giving a profusion of flowers; well suited to drying as everlastings. $11 / 2$ to $2 \mathrm{ft}$.
Pkt 


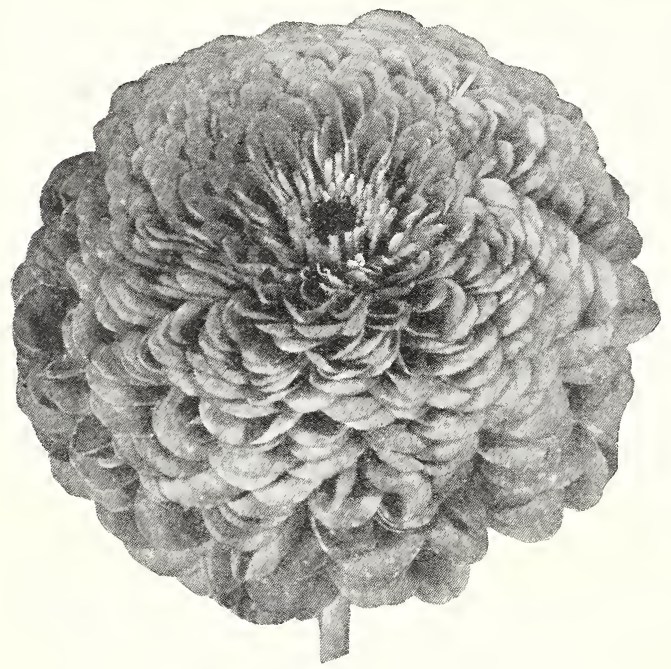

Zinnia, Dahlia-flowered

ZINNIAS (Youth and Old Age). H.A. These well-known garden favorites are one of the most brilliant Summer-flowering plants. The flowers are large, very handsome, and borne in great profusion. They succeed best in a sunny situation. $2 \mathrm{ft}$.

Matchless, Double Tall Varieties.

Double, Crimson...........1/4 oz. 75c.\$0.15

Lavender..................1/4 oz. $75 \mathrm{c} . \quad .15$

Purple.................. $1 / 4$ oz. $75 \mathrm{c} . \quad .15$

Rose.................1/4 oz. 75c. .15

Salmon. Light salmon rose....1/4 oz. 75c. $\quad .15$

Scarlet..................1/4 oz. 75c. $\quad .15$

White................1/4 oz. 75 c. .15

Flesh Pink............1/4 oz. 75c. .15

Yellow................1/4 oz. 75 c. $\quad .15$

Fine Mixed.............1/4 oz. $60 \mathrm{c} . \quad .15$

Collection of Six Colors, Matchless Double

Varieties.......................
ZINNIA-(Continued)

Victory. A very distinct variety with large densely double quilled flowers, the colors are mostly in russet, orange, old rose and other autumn tints...............1/4 oz. 60c. $\$ 0.15$

Giant Dahlia-flowered. These are similar to the Double Dahlia in size and shape of flowers. $21 / 2 \mathrm{ft}$.

Buttercup. Deep creamy-yellow......... Crimson Monarch. Largest of the red

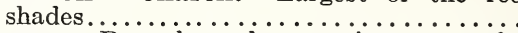

Dream. Deep lavender, turning to purple. Exquisite. Light rose, with center a deep

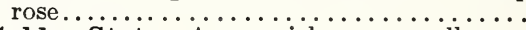

Golden State. A very rich orange-yellow.. Oriole. An immense orange and gold bicolor. Polar Bear. A very large pure white...... Scarlet Flame. A large, beautiful bright

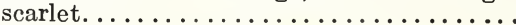

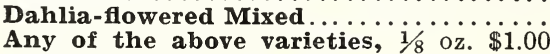

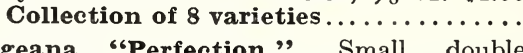

haageana "Perfection." Small, double flowers in many colors, makes a beautiful border. 9 in. Finest mixed...... 1/4 oz. $\$ 1.00$

Dwarf Double Varieties. Height $1 \mathrm{ft}$.

Dwarf Golden Yellow...........1/4 oz. 50c. .10 Dwarf Salmon Rose. A good bedder.

$1 / 4$ oz. 50 c. .10

Dwarf Scarlet Gem. Fine for bedding. $1 / 4$ oz.50c. $\quad .10$

Dwarf. Double mixed. Large flowering.

Tall Double Mixed. $1 / 4$ oz. 35c. .10 strain

\section{WILD GARDEN FLOWER SEEDS}

This mixture contains over 100 varieties of the oddest and choicest annuals imaginable. For naturalizing purposes or sowing broadcast, nothing approaches wild garden flower seeds for effect and cheapness. No care is necessary, and a never-ending succession of bloom and fragrance can be obtained throughout the entire Summer and Fall. Pkt. 10c., oz. 25c., 1/4 lb. 75c.

\section{Marshall's Early or Winter-Flowering Sweet Peas}

The following varieties are a selection of the best Winter flowering varieties. They are also suitable for outside planting.

$1 / 4 \mathrm{oz} . \mathrm{Oz}$

Aviator. Dazzling crimson scarlet.....\$0.35 $\$ 1.00$

Chevalier. True rose color................35 1.00

Columbia. Salmon rose, standard white

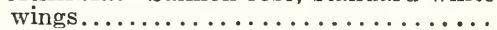

Early Ball Rose. Deep rose pink......

Early Giant Rose. A large flower of

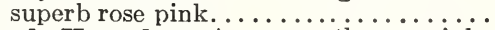

Early Hercules. A mammoth rosy pink.

Harmony. Clear lavender............

Mauve Beauty. Rosy mauve, beautifully waved, four flowers on stem..........

Meadow Lark. A chaste cream.........

Morning Star. A deep orange-scarlet, with rich orange-pink wings...........

Mrs. Kerr. A very large salmon...........

New Blue. A splendid deep blue........

Silver Blue. Light lavender-blue........

Snowstorm Improved. Th finest of all

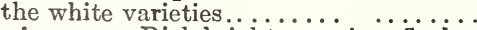

springsong. Rich bright rose pi. ${ }^{\prime}$ flushed salmon, almost a self color ..... .....
$.35 \quad 1.00$

$.35 \quad 1.00$

$\begin{array}{ll}.50 & 1.50\end{array}$

$.35 \quad 1.00$

$.35 \quad 1.00$

$.35 \quad 1.00$

$.35 \quad 1.00$

$.35 \quad 1.00$

$.50 \quad 1.50$

$.50 \quad 1.50$

.351 .00

$.35 \quad 1.00$

.602 .00
Superior Pink. A beautiful rose ${ }^{1 / 4} \mathrm{oz} . \quad \mathrm{Oz}$. very slightly shaded with salmon......\$0.50 $\$ 1.50$

Sweet Lavender. A soft lavender-lilac.. $\quad .35 \quad 1.00$

True Blue. A charming shade of true or light violet-blue.................. .35 1.00

vulcan. The most vivid scarlet....... $.35 \quad 1.00$

White Harmony. A first-class blackseeded white. Superb................ .50 1.50

Yarrawa. The finest pink forcer........... $35 \quad 1.00$

Zvolanek's Blue. A very bright blue... $.35 \quad 1.00$

Zvolanek's Orange. Orange-pink........... $.35 \quad 1.00$

Zvolanek's Rose. A beautiful self, rose 351.00

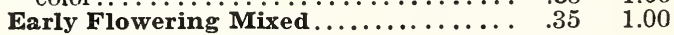

Each of the above varieties, pkt. $15 \mathrm{c}$.

\section{CUPID, or DWARF SWEET PEAS}

These grow about 9 inches high and are adapted for borders or beds.

Finest Mixed Colors. Pkt. 10c., oz. 30c., 1/4 lb. $\$ 1.00$. 


\section{MARSHALL'S SPENCER SWEET PEAS}

There are no Annual Climbers that are more popular or more universally admired than Sweet Peas. They are of the easiest culture, unrivaled for cutting, delightfully fragrant, while their colors are amongst the brightest and daintiest in the floral world. As soon as the ground can be worked in the Spring, sow the seed in trenches at least 6 inches in depth, then as the plants grow fill in the soil about one inch at a time until the trenches are full taking care not to cover the young plants. Liquid manure applied occasionally will be found very beneficial. Pick the flowers frequently, for if allowed to form seed the plants will soon stop blooming.

The following is a selection of the best varieties in each color.

Austin Frederick Improved: Large pure lavender.

Avalanche: Extra large white, good form.

Barbara: An unusually good salmon shade.

Carmelita: Rose pink on white ground.

Charming: Brilliant deep rose. Choice.

Chieftain: A superb shade of deep mauve.

Commander Godsall: Lovely violet-blue.

Crimson King: Striking shade of ox-blood crimson. A superb color.

Daffodil: Large flowers of deep primrose.

Dora: A chaste sort with standards of sof t pink; cream wings.

Doreen: Fine shade of carmine. Large.

Flamingo: Orange, scarlet, flushed cerise.

Fortune: A fine purple blue. Unusual.

Gleneagles: An exhibition sort with extra fine flowers of pale blue-lavender.

Hawlmark Cerise: Bright salmon cerise.

Hawlmark Salmon Pink: Fine rose pink flushed with salmon pink.

Hero: An exceptional shade of cerise.

Huntsman: A new shade of scarlet.

Idyl: A stunning shade of salmon pink.

Kitty Pierce: Light lilac, suffused pink.

Mammoth: Orange scarlet. A telling color.

Mary Pickford: Lovely cream pink suffused salmon pink.

Model: A black seeded white of fine size and texture. Mrs. Tom Jones: Lovely deep amethyst blue.

Olympia: Rich Tyrian purple.

Pinkie: Largest size rose pink. Extra fine.

Powerscourt: Still one of the best of the large size lavenders.

Prince of Orange: A fine flower of deep rich orange.

Reflection: One of the best in a clear shade of blue.

Rosabelle: A giant flower of fine deep rose.

Royal Pink: Shrimp pink, veined orange.

Splendor: A rich maroon.

Sunkist: Large cream picotee edge rose.

Supreme: An exhibition flower of large size, fine substance. Flesh pink.

Tangerine Improved: A very good salmon-orange.

The Prince: Clear crimson flowers of large size and good substance.

The Sultan: Large glossy black maroon.

Valentine: Blush pink flowers of large size.

What Joy: Primrose yellow shading to cream.

Wembley: A superior lavender blue.

White Spencer: A pure white which is hard to improve upon.

Youth: White with a picotee edge of rose.

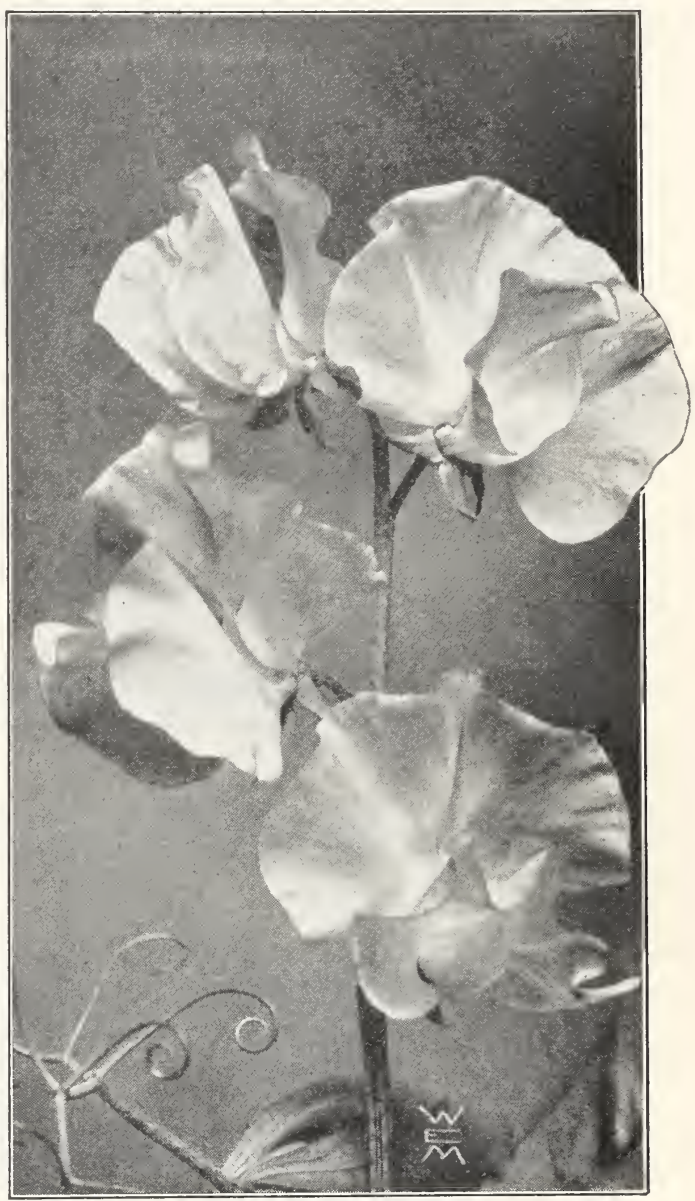

Sweet Peas, Spencer type

Any of the above varieties: Pkt. 10c., oz. 50c.. 1/4 1b. $\$ 1.50$.

\section{MARSHALL'S TWELVE EXHIBITION VARIETIES}

We have selected the following twelve varieties as being the best of the above list of Sweet Peas for exhibition purposes.

$\begin{array}{lll}\text { Avalanche } & \text { Idyl } & \text { Powerscourt } \\ \text { Charming } & \text { Olympia } & \text { Reflection } \\ \text { Gleneagles } & \text { Pinkie } & \text { Supreme }\end{array}$

One Pkt. each of the above 12 Exhibition Varieties for $\$ 1.00$

\section{MARSHALL'S MATCHLESS MIXED SPENGER HYBRIDS}

A mixture of 75 varieties of Spencers, the grower of which was awarded a Silver Gilt Medal of the National Sweet Pea Society of Great Britain. Pkt. 10c., oz. 35c., 1/4 lb. 75c., 1b. $\$ 2.00$.

\begin{tabular}{|} 
INOCULATE THIS \\
SEED WITH \\
STIMUGERM
\end{tabular}

\section{"STIMUGERM" FOR SWEET PEAS}

Sweet Peas flower earlier, longer and better treated with stimugerm. 


\section{FLOWER SEEDS FOR DIFFERENT PURPOSES AND SITUATIONS}

For description and prices, see general list.

\section{GLIMBING VINES FROM SEEDS}

$\begin{array}{ll}\text { Balloon Vine } & \text { Cypress Vine } \\ \text { Canary Bird Vine } & \text { Dolichos } \\ \text { Cobaea } & \text { Echinocystis } \\ \text { Convolvulus } & \text { Gourds }\end{array}$

$\begin{array}{lll}\text { Humulus } & \text { Kudzu Vine } & \text { Mormodica } \\ \text { Ipomoea } & \text { Lophospermum } & \text { Nasturtium } \\ \text { Lathyrus } & \text { Mina lobata } & \text { Passiflora } \\ \text { Kenilworth Ivy } & \text { Maurandia } & \text { Sweet Peas }\end{array}$

FRAGRANT FLOWERS FROM SEEDS

Alyssum Asperula Carnations Cleome

$\begin{array}{ll}\text { Mignonette } & \text { Scabiosa } \\ \text { Mimulus moschatus } & \text { Stock } \\ \text { Nicotiana affinis } & \text { Sweet Pea } \\ \text { Polyanthus } & \end{array}$

Polyanthus
Sweet Rocket

Sweet William
Thunbergia

Verbena, Lemon Violet

Wallflower

Ageratum
Alyssum
Armeria
Begonia

Armeria

Begonia

Abutilon

Acacia

Antirrhinum

Angelonia

Aralia

Asparagus

\section{PLANTS ADAPTED FOR EDGING BORDERS}

Bellis
Candytuft
Centaurea

Marigold
Myosotis
Nasturtium
Nemesia

Portulaca

Pyrethrum

Sweet William

Sweet Pea, Cupid
Tagetes

Viola

Zinnia Haageana

\section{GREENHOUSE AND POT PLANTS FROM SEEDS}

$\begin{array}{ll}\text { Begonias } & \text { Clerodendron } \\ \text { Calceolaria } & \text { Clianthus } \\ \text { Celosia } & \text { Coleus } \\ \text { Celsia } & \text { Cyclamen } \\ \text { Chrysanthemum } & \text { Dracaens } \\ \text { Cineraria } & \text { Geranium }\end{array}$

Ferns
Francoa
Greesia
Grexinia
Heliotrope

Impatiens

Lantana

Primula

Shamrock

Smilax

Solanum

\section{Stevia \\ Streptocarpus \\ Sweet Peas \\ Trachelium \\ Verbena}

\section{EVERLASTING FLOWERS FOR WINTER DECORATIONS}

Acroclinium

Edelweiss

Globe Amaranth

Honesty, Lunaria Rhodanthe

Statice

Xeranthemum Helichrysum

ORNAMENTAL FOLIAGE PLANTS FROM SEEDS

Amaranthus

Centaurea candi-

Centaurea gymno-

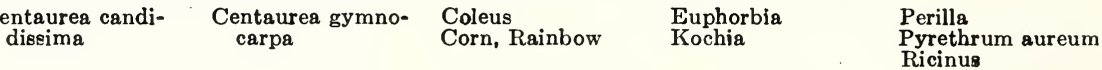

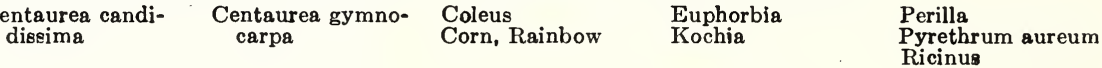

\section{PLANTS FROM SEEDS SUGCEEDING IN PARTIALLY SHADED PLAGES}

Anemone Antirrhinum Aquilegia Auricula $\begin{array}{ll}\text { Begonia, Tuberous } & \text { Cowslip } \\ \text { Bellis } & \text { Delphinium } \\ \text { Canterbury Bells } & \text { Digitalis } \\ \text { Coreopsis (Hardy) } & \text { Ferns }\end{array}$

Hardy Primrose

Linum

Matricaris

Myosotis

Oenothera

Pansy

Polyanthus
Poppies (Hardy)

Schizanthus

Torenia

Violet

\section{ANNUAL FLOWERS FROM SEED, SUITABLE FOR GUTTING}

$\begin{array}{lllll}\text { Agrostemma } & \text { Carnation } & \text { Dianthus } & \text { Hunnemannia } & \text { Phlox } \\ \text { Antirrhinum } & \text { Celosia plumosa } & \text { Didiscus } & \text { Larkspur } & \text { Poppies } \\ \text { Arctotis } & \text { Centaurea } & \text { Dimorphothecs } & \text { Lavatera } & \text { Salpiglossis } \\ \text { Asters } & \text { Chrysanthemums } & \text { Eschscholtzia } & \text { Lupinus } & \text { Scabiosa } \\ \text { Calendula } & \text { Clarkia } & \text { Gaillardia } & \text { Marigolds } & \text { Statice } \\ \text { Calliopsis } & \text { Cosmos } & \text { Godetia } & \text { Mignonette } & \text { Stocks, Ten Week } \\ \text { Candytuft } & \text { Dahlias } & \text { Gypsophila } & \text { Nigella } & \text { Zinnias } \\ \end{array}$

HARDY PERENNIALS WHIGH GAN BE RAISED FROM SEEDS

Achillea
Aconitum
Adonis
Agrostemm
Alstroemeria
Alyssum
Anchusa
Anemone
Anthemis
Aquilegia
Arabis
Asperula
Aster
Aubrietia
Auricula

Bellis
Bocconia
Boltonia
Callirhoe
Campanula
Candytuft
Centaurea
Cerastium
Chelone
Chrysanthemum
Coreopsis
Cowslip
Delphinium
Dictamnus
Dianthus

Digitalis
Echinops
Edelweiss
Eremurus
Erigeron
Erysimum
Erinus
Eupatorium
Gaillardia
Galega
Gaura
Geum
Grasses
Gypsophila
Helenium

Helianthus
Heuchera
Hibiscus
Hollyhocks
Incarvillea
Lathyrus
Linaria
Linum
Lobelia
Lupinus
Lychnis
Matricaria
Nierembergia
Pansies
Pentstemon

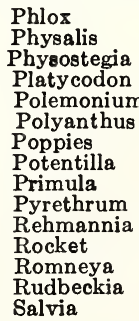

Scabiosa

Silene

Statice

Stokesia Sweet William

Trachelium

Tritoma

Trollius

Valeriana

Verbena

Verbascum

Veronica

Viola

Wallflower 


150 WEST $23 \mathrm{rd} \mathrm{ST.,NEW} \mathrm{YORK} 27$

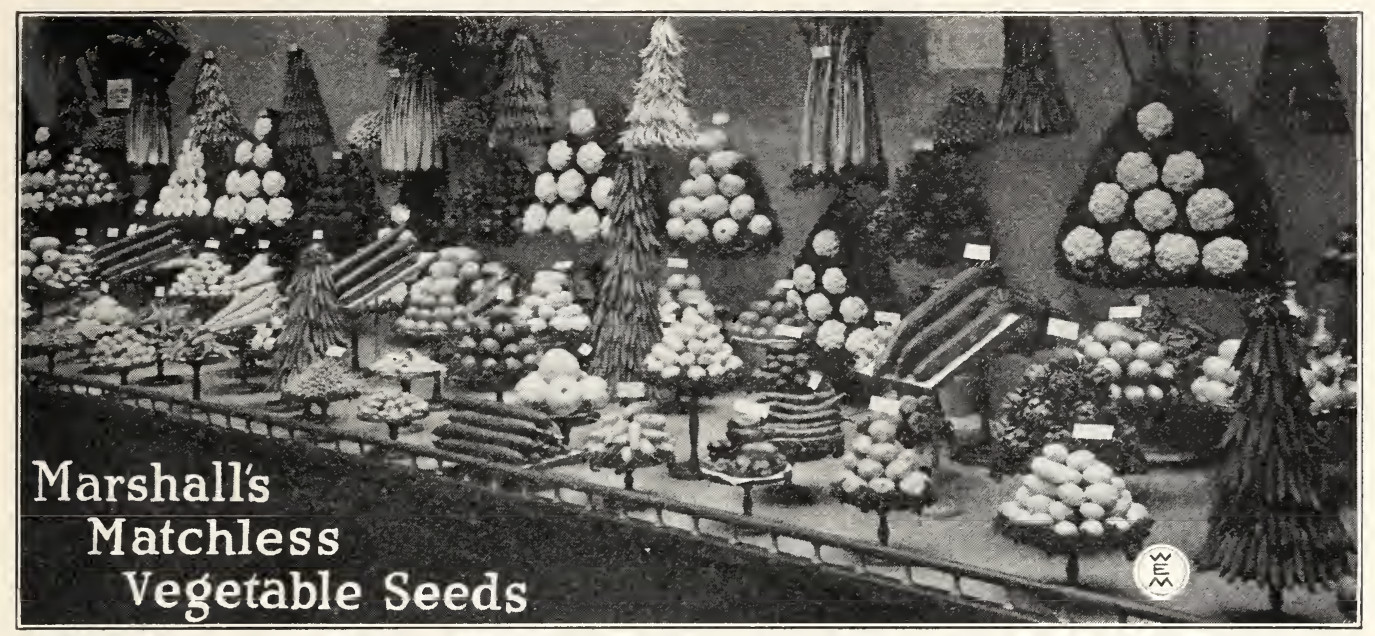

\section{Marshall's Vegetable Seeds}

\section{With General Directions for Gultivation}

We give no warranty, express or implied, as to description, purity, productiveness, or any other matter of any seeds, plants or bulbs we sell, and we will not be in any way responsible for them. If the purchaser does not accept the goods on these terms, they are to be returned at once. W. E. MARSHALL \& Co., Inc.

\section{SPEGIALTIES IN VEGETABLES}

BEAN Ideal Market Pole. The green-podded Pole beans. The pods are 5 inches long, round, slightly curved, stringless and borne in clusters of six; very tender and excellent quality. $1 / 2 \mathrm{pt}$. 25 c., pt. 40 c., qt. 80 c., 4 qts. $\$ 3.00$.

BROCCOLI Marshall's Green type of Broccoli with a delicious flavor, without the strong Cauliflower taste. It forms a small head with a branching habit, which are a dark green color from September until severe weather in December. (See illustration page 30.) Pkt. 25 c., $1 / 2$ oz. $\$ 1.50$, oz. $\$ 3.00$.

CABBAGE Chinese Chihli. The heading variety. Plant of upright growth producing long, solid, white cylindrical heads, two feet long. Leaves are broad fringed on edge with white broad mid-rib. Pkt. 10c., $1 / 4$ oz. 40c., oz. 75c.

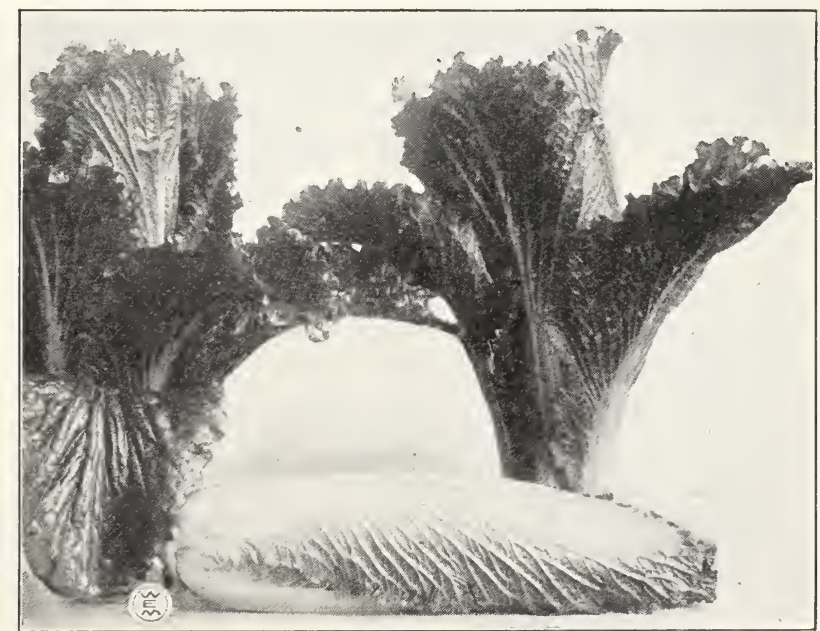

CABBAGE. Chinese Chihli
CABBAGE Marshall's Baby Head. Small, outer leaves, adapted for forcing in hotbeds or for early use in the garden. The small heads mature in six to seven weeks after planting. Pkt., $10 \mathrm{c} .1 / 2 \mathrm{oz}$. 60 c.. oz. $\$ 1.00$.
CORN $\begin{gathered}\text { Marshall's Earliest of all. An extra se- } \\ \text { lection of Red Cory, and the earliest Sweet }\end{gathered}$ Corn. Stalks grow about 4 feet high. Ears six inches long 8 to 10 rowed, grains white. $1 / 2$ pt. 20 c., pt. 40 c., qt. $75 \mathrm{c}$. 


\title{
SPEGIALTIES IN VEGETABLES-Continued
}

\begin{abstract}
CORN Golden SunGOrliest shine. The Bantam type, maturing a week to 10 days earlier than that variety. More dwarf in habit than Bantam, with ears 6 in. long. Containing 12 rows of broad, yellow, sweet grains. Especially valuable for its extreme earliness. (See illustration page 33 .) $1 / 2$ pt. $20 \mathrm{c}$. , pt $40 \mathrm{c}$, qt. $75 \mathrm{c}$.
\end{abstract}

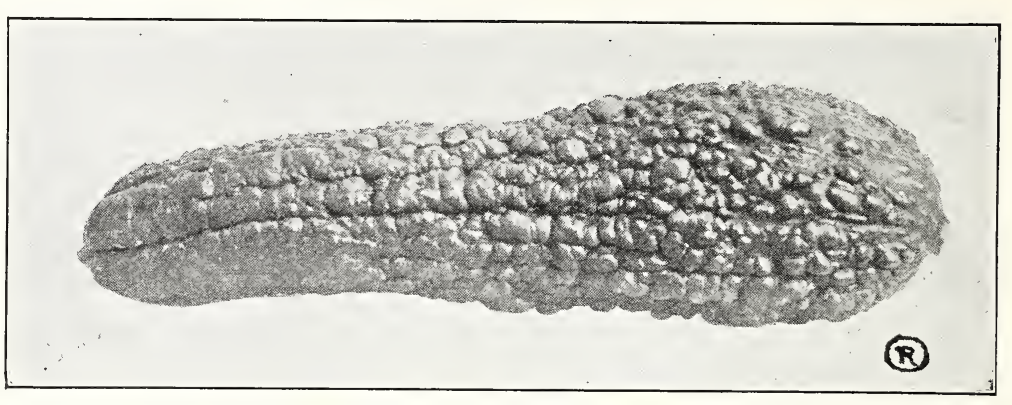

Squash Giant Summer Straightneck

LETTUCE Marshall's Matchless. This wonderful, tender, Lettuce which is a cross between a head by a private grower. It is the sweetest and tenderest variety grown. The crown portion of the head is slightly loose, with a small yellow head. It is an ideal variety for the home or private gardener. (See illustration, page 36 .) Pkt. 25c., oz. $\$ 1.00$.

PEPPER-TOMATO The scarlet, oval-shaped fruits are a cross between a Pepper and a Tomato. The cavity. The plant is a vigorous grower and should be given plenty of room for growth. Pkt. 25c.

SWISS CHARD Fordhook. A very superior introduction with large, wrinkled, savoy-like leaves of delicate flavor and very tender. The stalks which may be used like asparagus are pearly white. Pkt. 15c.; oz. 25c.; 1/4 lb. 60c.; lb. $\$ 2.00$.

SQUASH Giant Summer Straightneck. A decided improvement over the Giant Crookneck. Fruits Q ASH are intensely warted, about 18 inches long, deep orange color, flesh deeper and thicker with a more meaty neck than the old type. Pkt. 10c., oz. 50c., $1 / 4 \mathrm{lb}$. $\$ 1.50$.

\section{GENERAL LIST OF VEGETABLE SEEDS}

\section{ARTICHOKE}

One ounce will sow 100 feet of row, and produce about 500 plants.

A rich, sandy loam is best adapted for this plant. The seed should be sown in drills $11 / 2$ inches deep and 1 foot apart. Transplant to rows 3 feet apart. They reach maturity the second year. Protect in Winter by a covering of leaves or coarse manure.

Large French Globe. Heads large, fleshy and of rich flavor. Pkt. 25c., 1/2 oz. 60c., oz. $\$ 1.00$.

\section{ARTICHOKE PLANTS}

Large French Globe. Plants ready for shipment after April 1st. Doz. $\$ 2.50$, $100 \$ 20.00$.

Jerusalem. Grown for the tubers, which resemble Potatoes, and are cultivated in a similar manner, but the rows should be at leasr 4 feet apart. Qt. 30c., peck $\$ 1.75$

\section{ASPARÁGUS}

One ounce will produce about 200 plants.

Sow in Autumn or in Spring as soon as the soil is in good working condition. At one or two years transplant to permanent beds.

Conover's Colossal. Very prolific and tender Pkt. Oz. 1/4 lb.

Palmetto. A fine variety, producing large, green Asparagus. . $\quad .10 \quad .20 \quad \begin{array}{rr}\$ & .45\end{array}$

Giant Washington. A rust resistant variety, with long, dark

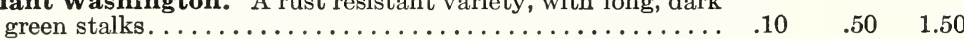

\section{ASPARAGUS ROOTS}

\section{It requires 100 plants for a single row of 150 feet.}

Culture.-The permanent bed should be trenched or ploughed very deeply, and well manured with rich, thoroughly decayed manure. Set the plants 18 inches apart in rows, carefully spreading out and separating the roots and deep enough to admit of the top of the plants being covered 6 inches. In November the plants should have their annual top-dressing of manure after the stalks have been cleared away.

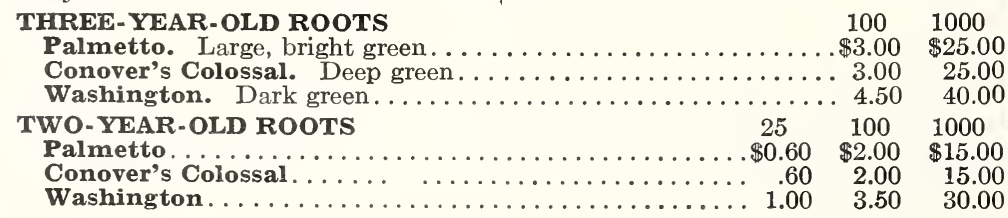

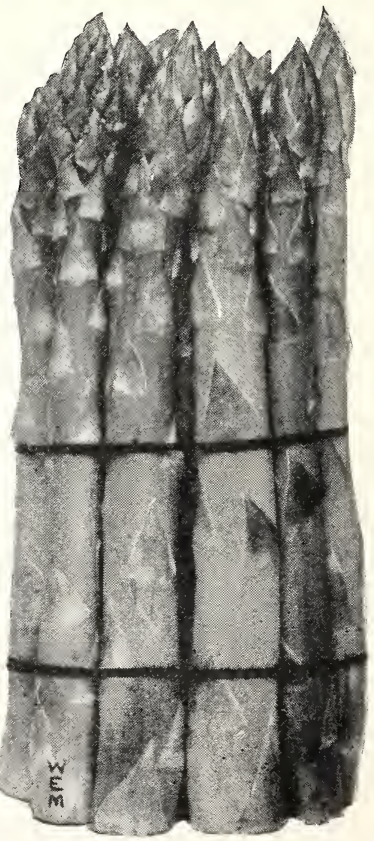

Asparagus 


\section{BEANS}

Beans like a well drained, rich and light loam. Plant about the middle of April when warm and favorable, and at intervals throughout the season for a succession, until the latter part of August. Bush varieties should be planted in drills 2 feet apart, and from two to six plants to the foot in a row. Keep them well cultivated and draw the earth up to the stem. For String Beans gather the pods as soon as fit for use.

\section{DWARF SHELL BEANS}

Sow in drills 2 feet apart as soon as warm weather has set in; soil should be light and rich; covering beans with about 2 inches of soil.

Boston Pea or Navy. Used when dry for cooking 1/2pt. Pt. Qt. $4 \mathrm{qts}$. purposes........................ \$0.20 $\$ 0.30 \quad \$ 0.60 \quad \$ 2.00$

Red Kidney. Similar to White Kidney, except $\begin{array}{llllll}\text { the beans are deep red............................ } & .20 & .30 & .60 & 2.00\end{array}$

$\begin{array}{llllll}\text { White Kidney. Excellent Shell, or String Bean. . } & .20 & .30 & .60 & 2.00\end{array}$

White Marrow. For use in a dry state in Winter,

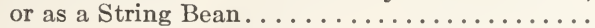

English Green Windsor. A nutritious, large Bean growing 3 feet high on stiff stems. Should

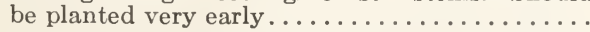

\section{$.20 \quad .30$}

2.00

$.25 \quad .45$

.90

3.25

\section{DWARF GREEN-PODDED BEANS}

\section{One quart will plant 150 feet of drill}

Black Valentine. Long, round, solid green pods; $1 / 2 \mathrm{pt} . \mathrm{Pt}$. very early. A popular bean.............\$0.25 \$0.45

Bountiful. Early, very prolific and long bearing;

flat, green pods, tender and stringless..........
Canadian Wonder. Large, green pods. Fine

for table or exhibition. . . . . . . . . . . . . . . . . . the Late Refugee; very prolific, long, round pods. .

Extra Early Red Valentine. One of the earliest. Round, thick, solid pods..................

Full Measure. A fine stringless bean with round, straight green pods..............................

Giant Stringless Green Pod. This Bean is absolutely stringless. The pods are round and

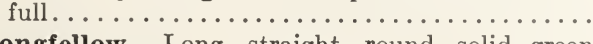

Longfellow. Long, straight, round, solid green

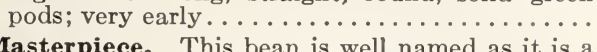

Masterpiece. This bean is well named as it is a masterpiece in this section of vegetables. Round, Superb for forcing and exhibition............

Refugee, Late, or $\mathbf{1 0 0 0}$ to 1. Medium to late; very productive and tender. Largely grown for

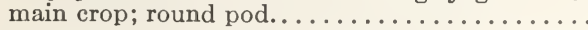

Stringless Green Pod (Burpee's). An early, round, green-podded Bean; stringless, remains firm, straight, stringless pods of luscious flavor.

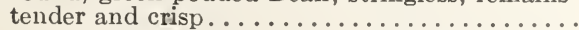

$\begin{array}{rrrr}.30 & .50 & 1.00 & 3.50 \\ .25 & .50 & 1.00 & 3.75 \\ .25 & .40 & .80 & 3.00 \\ .25 & .40 & .80 & 3.00 \\ .25 & .40 & .80 & 3.00 \\ .25 & .40 & .80 & 3.00 \\ .25 & .40 & .80 & 3.00 \\ & & & \end{array}$

$\begin{array}{llll}.40 & .75 & 1.50 & 5.00\end{array}$

3.00

3.00

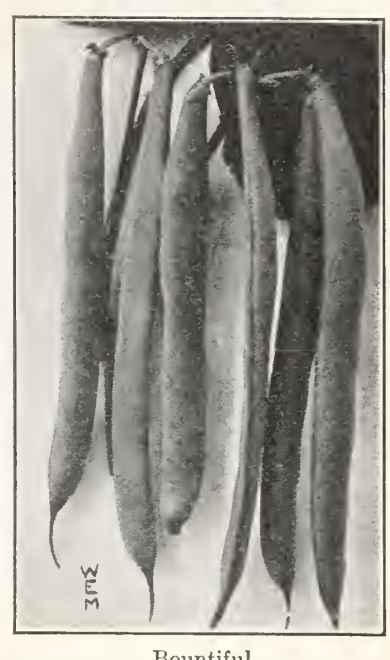

Bountiful

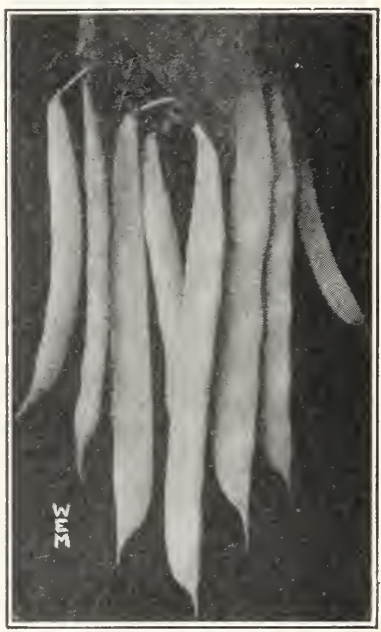

Hodson Wax

\section{DWARF WAX-PODDED BEANS}

Black Wax, Currie's Rust-Proof. Large, flat pods; early.....................\$ $0.25 \$ 0.40$

Brittle Wax, or Round Pod Kidney Wax. Round podded, stringless...............

Golden Wax, Improved. Very early; flat pods,

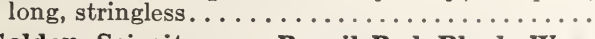

Golden Scimitar, or Pencil-Pod Black Wax. Long, round, yellow, stringless pods..........

Hodson Wax. (Valentine Wax). Handsome, thick, flat, yellow pods. Free from blight and

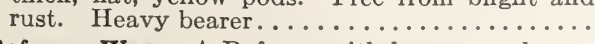

Refugee Wax. A Refugee with long, round, wax pods; stringless....................

Wardwell's Kidney Wax. Early; long, straight, flat, wax, stringless pods...............

\section{Pt.}

$.25 \quad .40$

$.25 \quad .40$

.25

.25

.25
.80
Qt. 4 qts.

$\$ 0.80 \$ 3.00$

.80

3.00

.80

3.00

.80

3.00

3.00

3.00

3.00

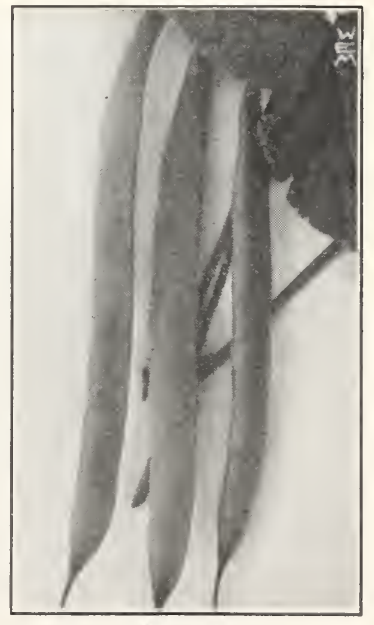

Masterpiece 


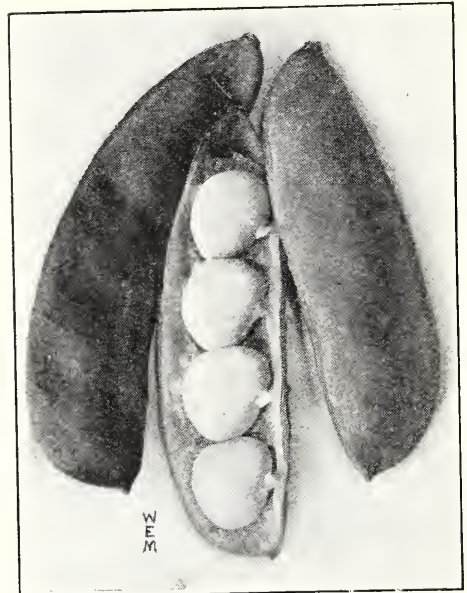

Fordhook Lima

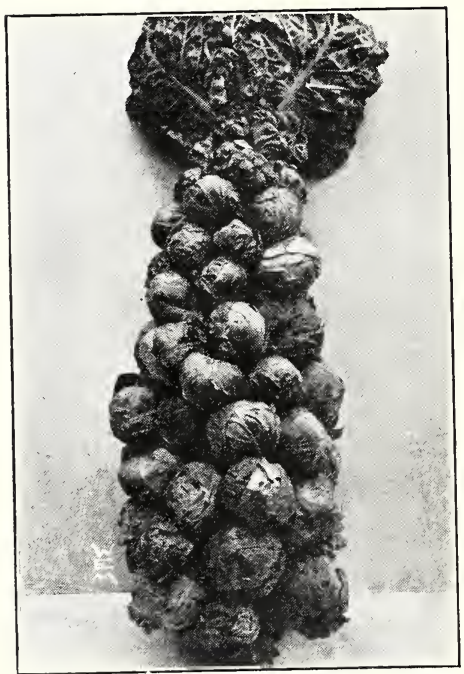

Brussels Sprouts

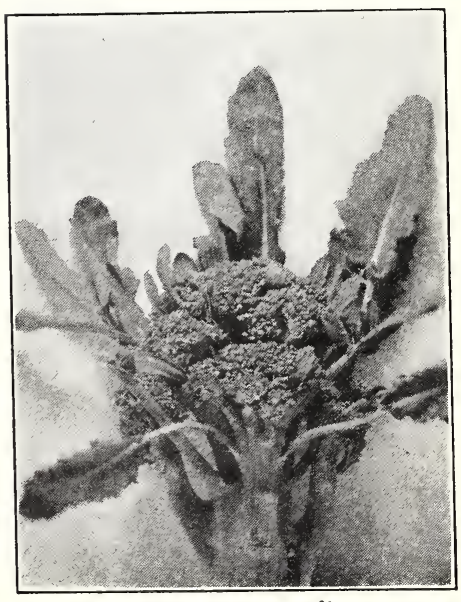

Broccoli Green Heading

\section{DWARF, OR BUSH LIMA BEANS}

Burpee's Improved Bush Lima. A bush

form of the large, flat Pole Lima . . . . .....

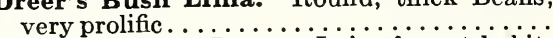

Fordhook Bush Lima. It is of erect habit; Beans very large, and heavy cropper. .....

Henderson's Bush Lima, or Dwarf Sieva. Very early small type with pods about 3 inches long.........................

Wilson's Improved Bush Lima. A week productive but not quite so large.

$1 / 2$ pt. Pt. Qt. $4 \mathrm{qts}$.

$\$ 0.30 \$ 0.50 \quad \$ 1.00 \quad \$ 3.50$

$\begin{array}{llll}.25 & .45 \quad .90 \quad 3.25\end{array}$

$\begin{array}{llll}.30 & .50 & 1.00 & 3.75\end{array}$

$.25 \quad .45 \quad .90 \quad 3.25$

\section{POLE, OR RUNNING BEANS}

Sow from the 1st of May (for all except Limas) to the latter part of May, in hills 4 feet each way. Limas should not be planted until warm weather has fairly set in. One quart of Limas will plant about 100 hills, allowing four or five beans to a hill, and of the smaller sorts about 200 hills. Poles 8 to 10 feet long should be firmly set in the hills before planting seed. Set poles 4 feet apart each way, and plant 4 to 6 beans about 1 inch deep around each pole. Thin out to three plants to a pole if the soil is rich; pinch off the ends of plants when they overrun the top of the poles, to effect more perfect growth below.

Carpenteria Lima. The beans have a greenish tint; vines vigorous and very productive.1/2 pt. $\quad$ Pt. $\quad$ Qt. 4 qts.

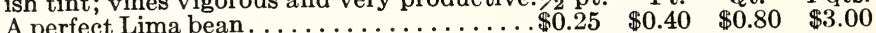
Challenger Lima. Thick and productive. Best of all ..........................

Large White Lima. One of the best shel beans grown. Matures in 90 days; very
popular. Our seeds of this variety are extra

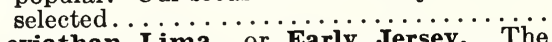

Leviathan Lima, or Early Jersey. The earliest variety of pole Lima. Produces
pods in clusters. A good variety where the

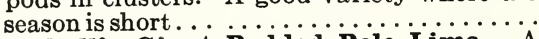

Marshall's Giant-Podded Pole Lima. A rapid growing, very large podded variety. The beans are e $\&$ tra large and thicker than

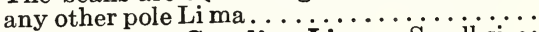
Small Sieva, or Carolina Lima. Small size;

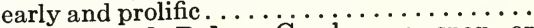

Horticultural Pole. Good as a snap or shelled Bean........................

Ideal Market $\mathbf{P}$ ole. The earliest and most prolific, round, green podded, stringless bean Kentucky Wond er (Old Homestead). Pods green, very long and flat. . . . . . . . . . . . . . .

Kentucky wonder Wax. Scarlet Runner. $A$ popular English pole

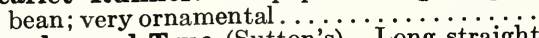

Tender and True (Sutton's). Long straight green pods, excellent for culture under glass.

$\begin{array}{llll}.25 & .40 & .75 & 2.50\end{array}$

$\begin{array}{llll}.25 & .40 & .75 & 2.50\end{array}$

$\begin{array}{llll}.25 & .40 & .80 & 3.00\end{array}$

$\begin{array}{llll}.30 & .50 & 1.00 \quad 3.50\end{array}$

$\begin{array}{llll}.25 & .40 & .80 & 3.00\end{array}$

$\begin{array}{llll}.25 & .45 & .85 & 3.00\end{array}$

$\begin{array}{llll}.25 & .40 & .80 & 3.00\end{array}$

$\begin{array}{llll}.25 & .40 & .80 & 3.00\end{array}$

$\begin{array}{llll}.25 & .40 & .80 & 3.00\end{array}$

$\begin{array}{llll}.25 & .40 & .80 & 3.00\end{array}$ A great yielder. ..

$\begin{array}{lll}.50 & 1.00 \quad 1.75\end{array}$ INOCULATE THIS The use of "Stimugerm" when planting SEED WITH STIMUGERM Small size, 25c. 1/2 bus. size, 35c. 1 bus. size, 60c.

\section{BROCGOLI OR GALABRESE}

(For Cultural Directions, see Cauliflower). white Cape. Heads compact and of a creamy white Pkt. Oz. 1/4 lb. hite Cape. Heads compact and of

Marshall's Green Heading. This luscious and nutritious vegetable should be in every garden. It ranks at the top of the list of health giving vege- $\mathrm{Pkt} . \quad \mathrm{Oz}$. tables. Our strain forms branching plants with small heads. Matures in September and later......

\section{BRUSSELS SPROUTS}

\section{One ounce will produce about 2000 plants.}

Sow in May in shallow drills 1 inch deep and 12 inches apart; transplant in July. A very hardy, delicious vegetable which should find a place in every garden; greatly improved by hard frosts.

Marshall's Exhibition. The finest variety Pkt. $1 / 2 \mathrm{oz} . \quad \mathrm{Oz} .1 / 4 \mathrm{lb}$. of all the Brussel's Sprouts. Very large and

$\begin{array}{lllll} & \\ \text { of all the Brussel's Sprouts. Very large and } & \$ 0.10 & \$ 0.50 & \$ 1.00 & \$ 3.00\end{array}$

Long Island Improved. " Solid, round

ong Island Improved. 


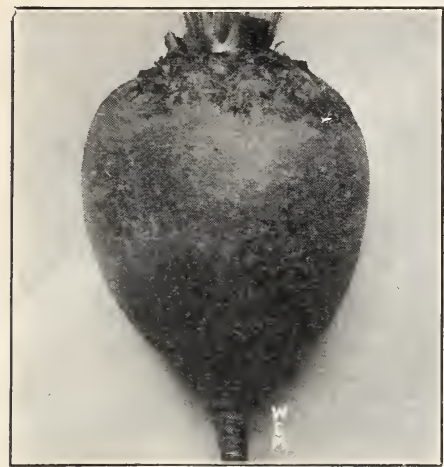

Beet Detroit

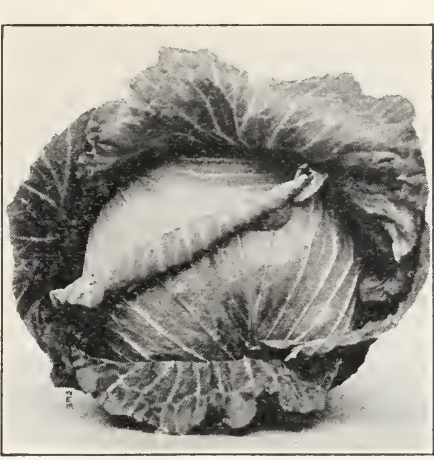

Cabbage Flat Dutch

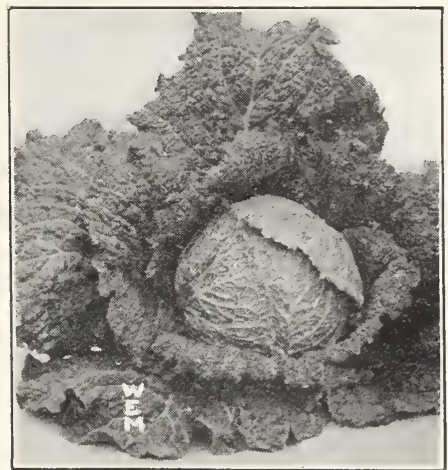

Cabbage Savoy Exhibition

\section{BEET}

One ounce will sow 150 feet of drill.

For early supply sow as soon as the ground is in working order, in drills 1 foot apart and 2 inches deep. For main crop sow the second week in May, and for Winter use sow in June. When the plants are well forward thin out to about 9 inches apart. The young Beets, with their tops, pulled out of the row, are excellent, used as Spinach.

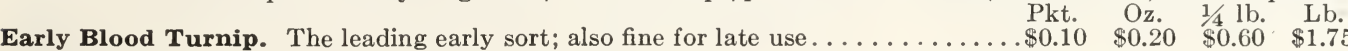

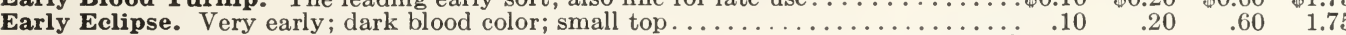

Extra Early Egyptian. The best for first crop out of doors. The root is very dark

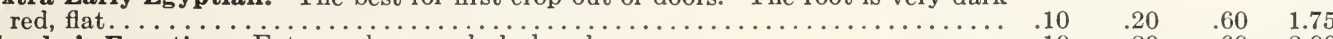

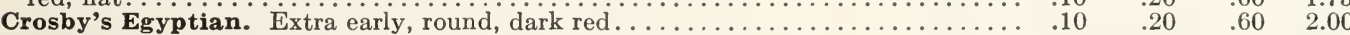

Crimson Globe. Fine globular shape; flesh deep purple; fine quality . . . . . . . . . .10 . $20 \quad .60 \quad 1.75$

Detroit Dark Red Turnip. Round; skin dark blood red; flesh bright red . . . . . . . . .10 . $\quad .0 \quad .60 \quad 2.00$

Long, Smooth Blood. A prolific variety, very dark in color . . . . . . . . . . . . . .

Marshall's Dark Leaved Globe. Perfect globe-shape, dark texture and leaf . . . . . $\quad .10 \quad .30 \quad .75 \quad 2.50$

Marshall's Exhibition Globe. Very carefully selected stock. Dark red and the

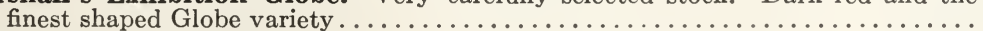

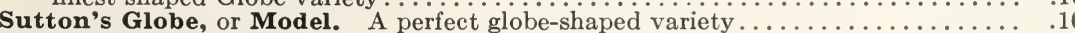

Swiss Chard. (See page 42.)

$\begin{array}{llll}.10 & .30 & .75 & 2.50 \\ 10 & 30 & .75 & 2.50\end{array}$

\section{MANGEL-WURZEL AND SUGAR BEET \\ Sow 6 to 8 pounds per acre.}

Champion Yellow Globe. Bright orange color; globe-shaped and of excellent quality .......

Giant Sludstrup. Color reddish-yellow, Roots intermediate in length. ...

Golden Tankard. An enormous yielder per acre. Flesh deep yellow . . . . . . . . . . . . . . . . . . .

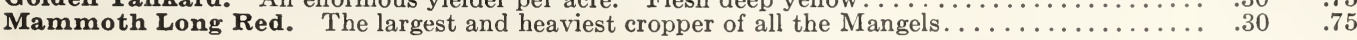

\section{CABBAGE}

One ounce will produce 3000 plants.

For early use, sow the seeds in hotbeds in February or March. Transplant as soon as the ground can be worked, in rows 2 feet apart, and the plants 18 inches apart in the rows. For late or Winter use, sow the seed in May.

Marshall's Baby Head. Small, round, solid heads; fine for forcing or early use... Marshall's First Crop. An ideal variety for the private garden, producing solid

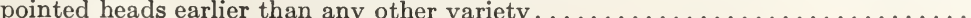

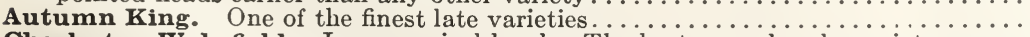

Charleston Wakefield. Large conical heads. The best second early variety. . . . .
Chinese Chihli. The earliest and most sure heading variety. Long, solid, white heads two feet in length . . . . . . . . . . . . . . . . . . . . . . . . .

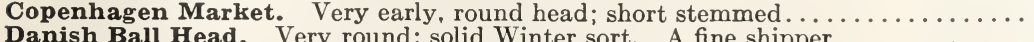

Danish Ball Head. Very round; solid Winter sort. A fine shipper $\ldots \ldots \ldots \ldots \ldots$

Early Spring. An extra early Cabbage with a round, flat head. . . . . . . . . . . . .

Early Jersey Wakefield. Standard early variety, conical shape; few outside leaves... . .10

Improved Early Summer. A superior second early sort. . . . . . . . . . . . . . . 10

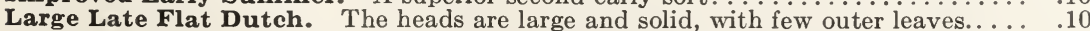

Late American Drumhead. One of the largest and best keeping varieties. Fine keeper

Succession. A week later than Early Summer. Large, solid heads.............

Savoy Marshall's Exhibition. Medium sized heads and matures early. The best

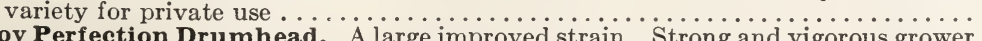

Savoy Perfection Drumhead. A large improved strain. Strong and vigorous grower

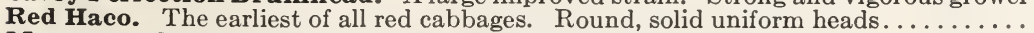

Mammoth Rock Red. The largest red Cabbage; color deep red. . . . . . . . . . . . . .

Pkt. 1/20z. Oz. 1/4 lb.

Red Stonehead. Medium size, but very solid heads. . . . . . . . . . . . . . . .

$\begin{array}{llll}25 & .60 & 1.00 & 3.00\end{array}$

$\begin{array}{llll}10 & .40 & .70 & 2.50\end{array}$

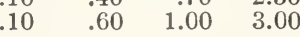

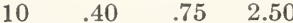

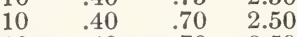

$\begin{array}{lll}40 & .70 & 2.50\end{array}$

$\begin{array}{lll}40 & .70 & 2.50\end{array}$

$50-1.00-3.00$

$\begin{array}{lll}.40 & .70 & 2.50\end{array}$

$\begin{array}{lll}40 & .70 & 2.50\end{array}$

$40-70 \quad 2.50$

$\begin{array}{lll}40 & .70 & 2.50\end{array}$

$\begin{array}{lll}50 & 1.00 \quad 3.00\end{array}$

$\begin{array}{lll}40 & .75 & 2.50\end{array}$

$\begin{array}{lll}.40 & .75 & 2.50 \\ .70 & 2.50\end{array}$

$\begin{array}{lll}60 & 1.00 & 3.00\end{array}$

$\begin{array}{lll}40 & .75 & 2.50\end{array}$

$\begin{array}{lll}.40 & .75 & 2.50\end{array}$




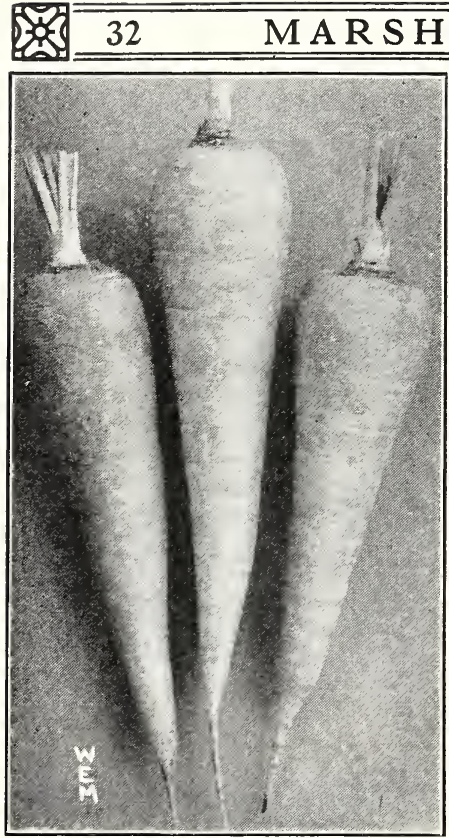

Carrot, Long Red Surrey

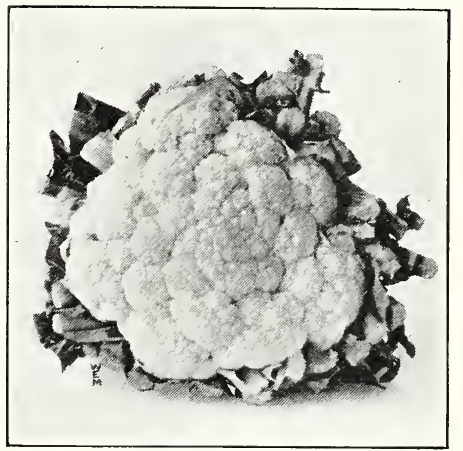

Cauliflower, Snowball

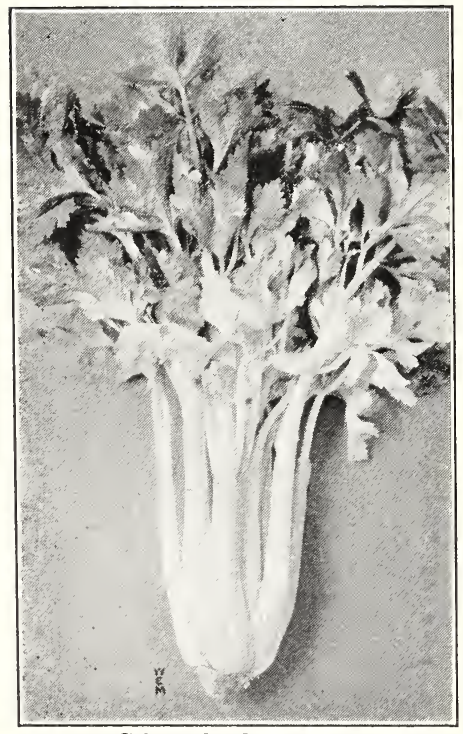

Celery, Golden Plume

\section{GARDOON}

Large Solid. Grows about 4 feet high; leaves nearly free from spines. Pkt. 10c., oz. 35c.

\section{CARROTS}

One ounce will sow 200 feet of row.

For early crops sow as soon as the ground can be worked, and for later crops from the beginning until the end of May, in rows 15 inches apart and $1 / 2$ inch deep. Thin out the young plants to 5 inches.

Early French Forcing. Tender and fine, best Pkt. Oz. 1/4 lb. Lb.

for early crops and frames. . . . . . . . . . . $\$ \$ \begin{array}{llll}\$ 0.10 & \$ 0.50 & \$ 1.50 & \$ 4.00\end{array}$

Early Scarlet Horn. Very thick roots; fine for frames. .......................... $10 \quad .25 \quad .75 \quad 2.50$ Chantenay Half Long Stump. Style of

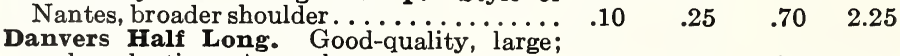
and productive. A popular sort........... Half Long Stump-rooted, Nantes Strain. Long orange. For garden and field crops] this is the best variety.... . . ............ Long Red Surrey. Long tapering, smooth Marshall's Exhibition. A superb intermediate variety; skin clear, bright red color.. Marshall's Intermediate. Fine exhibition

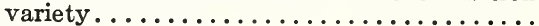

Oxheart (Guerande). Very thick and short,

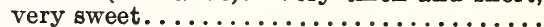
White Belgium. Very large; for stock......

$\begin{array}{lll}.10 \quad .25 & .70\end{array}$

$\begin{array}{llll}.10 & .25 & .70 & 2.25\end{array}$

$\begin{array}{llll}.10 & .25 & .70 & 2.25\end{array}$

$\begin{array}{llll}.10 & .40 & 1.25 & 4.00\end{array}$

$\begin{array}{llll}.10 & .30 & 1.00 & 3.00\end{array}$

$\begin{array}{llll}.10 & .30 & 1.00 & 3.00\end{array}$

$\begin{array}{llll}.10 & .25 & .70 & 2.25 \\ 10 & .20 & .60 & 2.00\end{array}$

\section{GAULIFLOWER}

One ounce of seed produces about 3000 plants.

By sowing the early varieties in a hotbed in February or March, or later in a coldframe, fine heads can be obtained quite early. When large enough transplant, making the rows about $21 / 2$ feet apart and 18 inches between the plants. Transplanting should be done in moist weather. Marshall's First and Best. The earliest and most Pkt. $1 / 4 \mathrm{oz}$. Oz. solid heading variety grown. Large snow-white heads............................... \$0.50 \$3.00 $\$ 10.00$

Earliest Dwarf Erfurt. The best and earliest for forcing under glass; very dwarf . . . . . . . . . . . $\quad .50 \quad 2.50 \quad 8.00$ Marshall's Extra Early Snowbali. One of the best

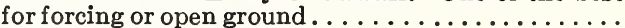

Dry Weather. Especially adapted for long, dry

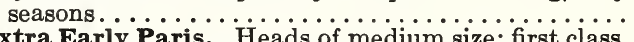
Extra Early Paris. Heads of medium size; first class.

Autumn Giant. Large, vigorous grower and late.... Algiers. An extra fine, late variety; suitable for mar-

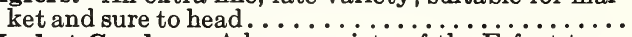
Market Garden. A large variety of the Erfurt type, solid white heads. A popular late sort..........

$\begin{array}{rrr}.50 & 2.50 & 8.00 \\ .25 & 1.50 & 5.00 \\ .25 & 1.50 & 5.50 \\ .10 & .60 & 2.00 \\ .20 & .60 & 2.00 \\ .10 & .60 & 2.00 \\ .10 & .75 & 2.50\end{array}$

\section{GELERY}

One ounce will sow about 300 feet of row and produce about 5000 plants.

Sow in the open border early in April, in rich ground. When the plants are 3 inches high transplant 4 inches apart into temporary beds of soft, rich soil until they acquire sufficient strength for planting out. Plant in rows 3 feet apart and set 8 inches apart in the rows. About the middle of August earthing up is necessary for blanching and whitening of that which is wanted for early use.

Easy Blanching. Blanches very easily, medium Pkt. 1/2 oz. Oz. dwarf, good flavor and a fine keeper . . . . . . . . . $\$ \$ 0.15 \quad \$ 0.60 \quad \$ 1.00$

Emperor or Fordhook. Dwarf, with large, light yellow heart; very crisp and good keeper............. $\quad .15 \quad .60 \quad 1.00$ Fin de Siecle. The best keeping Winter Celery...... $\quad .10 \quad \begin{array}{lll}.10 & .25 & .40\end{array}$

Giant Pascal. The stalks are solid and crisp; golden yellow heart. ............................... $10 \quad .25 \quad .40$

Golden Dwarf or Golden Heart. A distinct variety; crisp, solid; fine flavor. . . . . . . . . . . . . . Golden Self-Blanching. French grown; crisp, tender and of fine flavor. . . . . . . . . . . . . . . Market Red. Large and solid. Fine table variety.... Marshall's Golden Plume. Two to three weeks earlier than any other variety. Blanches easily, solid heart; sweet, crisp and tender ..............

Marshall's White Plume. A valuable early variety. Requires very little blanching. . . . ........... Winter Queen or Schumacher. Viery large; solid green, Winter variety; blanches well. . ..........

$\begin{array}{lll}.10 & .25 & .40\end{array}$




\section{CELERIAC, or TURNIP.ROOTED}

Grown mostly for its bulbous roots, which may be stored like Beets for Winter use.

Giant Prague. The finest variety. Very large roots

which are almost round..................\$0.10 \$0.25 \$0.40

\section{GHERVIL}

The Curled Chervil is cultivated like Parsley and used for garnishing and flavoring soups and salads.

Curled Chervil. The young leaves are used for Pkt. Oz. 1/4 lb. flavoring soups and salads.................\$0.10 $\$ 0.40 \quad \$ 1.25$

\section{CHICOR Y}

Large-Rooted Madgeburg. Used to mix with or as a substitute for coffee.......................... $10 \quad .50 \quad 1.50$ Witloof, or French Endive. The stalks when

blanched are used for salad . . . . . . . . . . . . . . . $10 \quad .50 \quad 1.50$ CHICORY ROOTS. Strong for forcing. Doz. $\$ 1.00 ; 100, \$ 7.00$.

\section{COLLARDS}

Sow Seeds, as for Cabbage, in June, July and August, for succession. Transplant when a month old in rows a foot apart each way, and hoe often. Georgia. Cabbage greens used as a substitute for Cabbage. Pkt. 10c., oz. 20c., 1/4 lb., 45c.

\section{CORN SALAD, OR FETTICUS}

One ounce will sow 150 feet of drill.

Sow in September in drills 8 inches apart, covering the seeds lightly, and protect from frost by light covering of hay and litter. The seed may be sown in Spring.

Large-Seeded. The most popular variety grown. Pkt., 10c.; oz., 25c.; $1 / 4$ lb. $75 \mathrm{c}$.; lb., $\$ 2.00$.

\section{CORN, SWEET}

One quart will plant 200 hills.

Plant in hills 3 feet apart each way, dropping five or six kernels in each hill, or in rows 3 feet apart, and the plants thinned out to 8 or 9 inches in the row. From May until the middle of July a succession planting can be made every two or three weeks, and a continued supply can be had until frost kills the plants.

EXTRA EARLY 1/2 pt. Pt. Qt 4 qts.

Marshall's Earliest of All. One of the earliest Sweet Corns. Ears 6 to 7 inches long, with

white grains. Height of stalk about 4 feet... $\$ 0.20 \quad \$ 0.40 \quad \$ 0.75 \quad \$ 2.50$

Charlevoix. An early yellow variety. Ears

about 7 inches long, eight-rowed; very fine

flavor................................... seeded varieties. Long, well filled ears......

Golden Bantam. Extra early; yellow, very

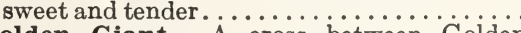

Golden Giant. A cross between Golden Bantam and Howling Mob. Medium growth. Ears 8 inches long. . . . . . . . . . .

Golden Rod. Very early, golden grains and

sweet flavor........................... $\quad .20 \quad .40 \quad .70 \quad 2.50$

Golden Sunshine. An improved Golden Bantam with 12 rows of luscious corn to each ear. Cobs measure $61 / 2$ inches long.

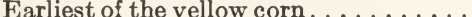

Howling Mob. An early variety of large size ears; white, sweet grains.

\section{SECOND EARLY}

Early Evergreen. Ripens about 10 days earlier than Stowell's Evergreen..........

Metropolitan. Large, handsome ears of fine quality.......... GENERAL AND LATE

Black Mexican. The sweetest and most delicious variety grown......................... Country Gentleman. Ears medium size; deep grains in irregular rows on cob and

Stowell's Evergreen. The most popular variety grown; ears large and very sweet.

The seed we offer has been carefully grown

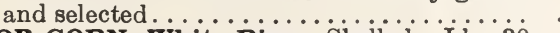

POP-CORN, white Rice. Shelled. Lib., 30c. Pkt. $1 / 2$ oz. Oz.

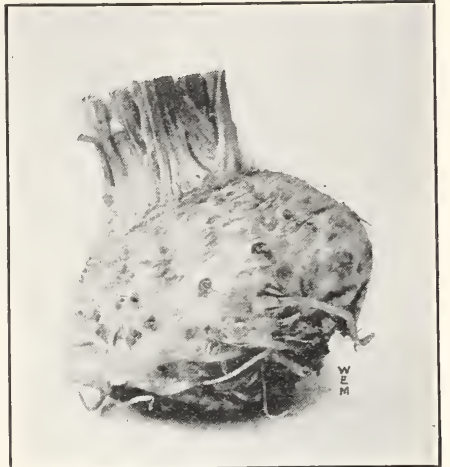

Cleriac, Giant Prague

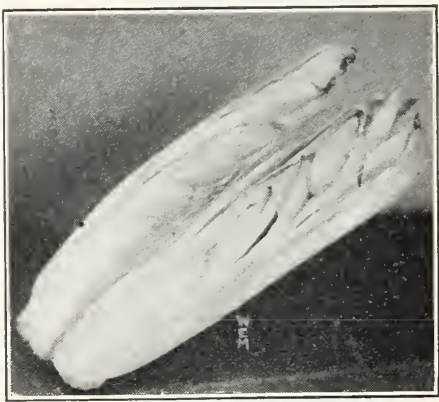

Chicory, Witloof

$\begin{array}{llll}.20 & .40 & .70 & 2.50\end{array}$

$\begin{array}{llll}.20 & .40 & .70 & 2.50\end{array}$

$\begin{array}{llll}20 & .40 & .70 & 2.50\end{array}$

$\begin{array}{llll}.20 & .40 & .75 & 2.50\end{array}$

$\begin{array}{llll}.20 & .40 & .75 & 2.50\end{array}$

$\begin{array}{llll}20 & 40 \quad 70 \quad 2.50\end{array}$

$\begin{array}{llll}.20 & .40 & .70 & 2.25\end{array}$

$\begin{array}{llll}20 & .40 & .70 & 2.25\end{array}$

$\begin{array}{llll}.20 \quad .40 \quad .70 & 2.25\end{array}$

$\begin{array}{llll}.20 & .40 & .70 & 2.25\end{array}$

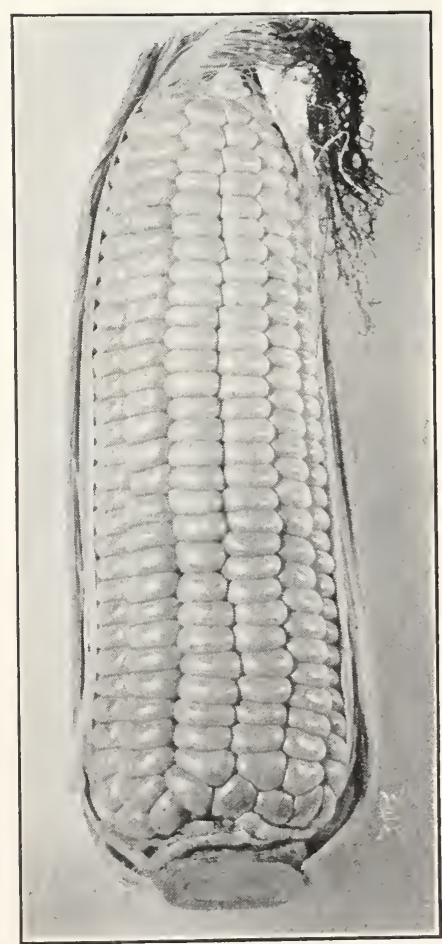

Sweet Corn, Golden Sunshine 


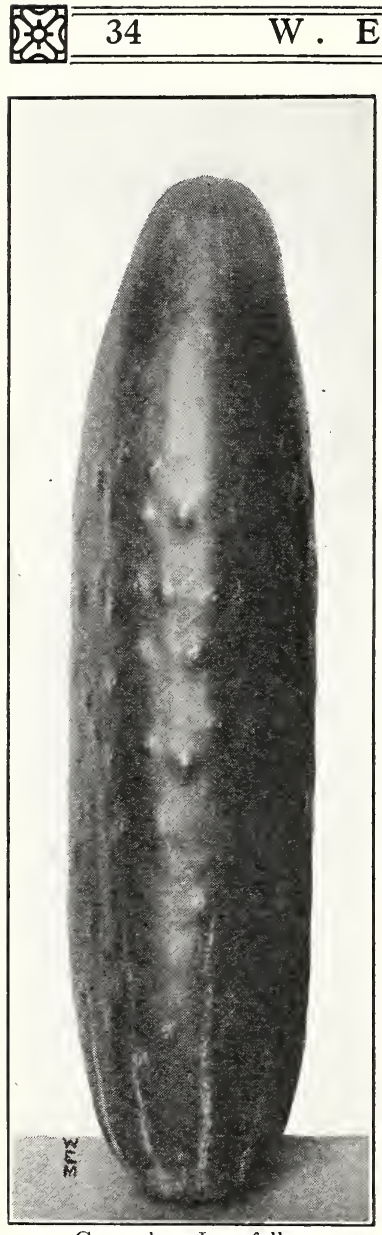

Cucumber, Longfellow

\section{GRESS, OR PEPPERGRASS}

One ounce will sow 150 feet of drill.

A popular salad which should be sown early in the Spring very thickly in shallow drills and at short intervals for succession, as it soon runs to seed.

Extra Curled. The best variety grown; leaves are beautifully cut and curled; highly prized for Pkt. Oz. 1/4 lb. Lb.

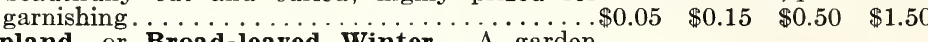

Upland, or Broad-leaved Winter. A garden substitute for Water Cress; crisp, tender and perfectly hardy. . . . . . . . . . . . . . . .

True Water Cress. Water Cress requires a stream of running water, ditch or pond, in which it will grow without care, except at first keeping weeds from interfering with it. . . . . . . . . . . .

.10 .15

.50

\section{CUCUMBERS}

\section{One ounce to 60 hills, 2 to 3 pounds to one acre.}

For very early use seed may be started in heat and the plants set out in May. Pieces of inverted sod are an excellent medium for starting and growing early Cucumber plants, as they can readily be lifted from the hotbed to the garden without disturbing the young plants growing upon them. For main crop plant in hills 4 feet apart at the end of May. Keep the young plants safe from the striped bug by dusting with dry plaster or powdered Hellebore. Leave four strong plants to each hill.

Cool and Crisp. A strain of White Spine; flesh peculiarly Pkt. Oz. 1/4 lb. crisp and tender . . . . . . . . . . . . . . . . . . . $\$ 0.10 \quad \$ 0.25 \quad \$ 0.75$

Davis' Perfect. An excellent variety both for outdoors and

forcing purposes..........................

Early Fortune. Very dark green skin, flesh thick, seed cavity small and excellent quality; for table use or pickles.

Everbearing. Valuable as a green pickler. . . . . . . . . .

Extra Long White Spine. Much longer than ordinary

White Spine; very prolific. . . . . . . . . . . . . . . . . . . . garden variety. The skin is a bright green...............
reen Prolific Pickling. Dark green; medium strength;

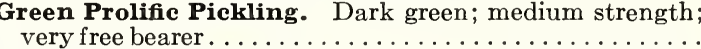

Improved Long Green. Long and crisp; a popular variety for pickles. White Spine. Early and good for table use or

Improved White Spine. Early and good for table use or for pickling; of medium length; dark green color and

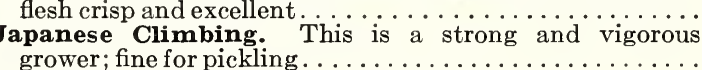
Marshall's Longfellow. Dark green color, 10 to 14 inches long. A good forcer. . . . . . . . . . . . . . . . . . . .
West Indian Gherkin. Used only for pickles; the smallest

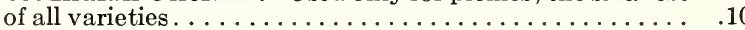

$\begin{array}{rrr}.10 & .25 & .70 \\ .10 & .25 & .75 \\ .10 & .25 & .70 \\ .10 & .25 & .70 \\ .10 & .25 & .75 \\ .10 & .25 & .70 \\ .10 & .25 & .70 \\ .10 & .25 & .70 \\ .10 & .25 & .75 \\ .10 & .50 & 1.50 \\ .10 & .25 & .75\end{array}$

\section{English Forcing Cucumbers}

\section{DANDELION}

The Dandelion affords one of the earliest and most healthful Spring greens or salads.

Improved French. Large thick leaves. Pkt. 10c., oz., $\$ 1.00 ; 1 / 4$ lb., $\$ 3.50$.

\section{EGG PLANT}

One ounce will produce about 2000 plants

The Egg Plant will thrive well in good garden soil. The seed should be sown in hotbed or warm greenhouse in March or April, and when about an inch high put in 2-inch pots. Plant about June 1st, $21 / 2$ feet apart. If no hotbed is at hand they can be grown in any light room when the temperature wil laverage 75 degrees.

Black Beauty. As large as New York Improved Pkt. 1/2 oz. Oz. but 10 days earlier . . . . . . . . . . . . . . .\$0.10 $\$ 0.40 \quad \$ 0.80$

Long Purple. Fruit longer and smaller than the above sort; hardy; productive............ $10 \quad .40 \quad .75$

New York Improved. Purple; the best variety; very large, oval, heavy fruit $\ldots \ldots \ldots \ldots \ldots \ldots \ldots \ldots . \quad .10 \quad .40 \quad .75$ 


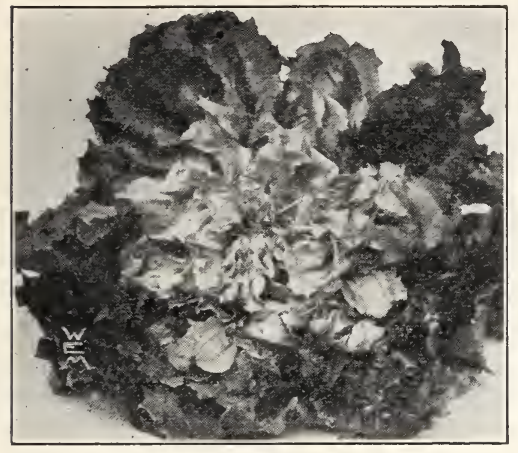

Endive Broad Leaved

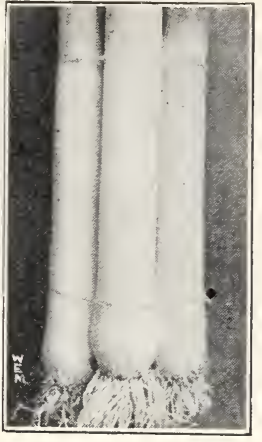

Leek Giant

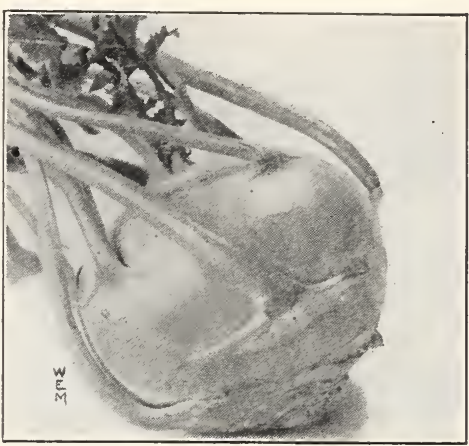

Kohl-Rabi White Vienna

\section{ENDIVE}

One ounce of seed for 100 feet of drill.

One of our best salad plants. For a first crop sow about the middle of April; for succession small sowings may be made every month till August, when the main planting is made. Set out the plants 1 foot apart in rows and when well grown blanch by folding the leaves.

Broad-leaved (Escarolle). Leaves long and broad: thick and succulent. . . . . . . . . $\$ 0.10 \quad \$ 0.35 \quad \$ 1.00$

Green Curled. Hardy, finely curled; easily blanched. One of the best. . . . . . . . . . . $.10 \quad .35 \quad 1.00$

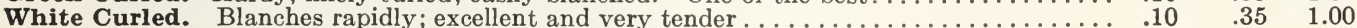

\section{HORSE RADISH SETS}

If planted in early spring, roots of sizeable use may be had by midsummer. Plant the roots in well fertilized soil about one foot apart and three inches deep. If space is a consideration, they may be planted between the rows of other low growing crops.

New Bohemian. A new variety which produces roots of enormous size and succeeds in every soil. Doz., 50c.; $100, \$ 2.00$.

\section{KALE, OR BORECOLE}

\section{One ounce will sow 150 feet of drill.}

Sow about the middle of April in prepared beds, covering thinly and evenly; plant out in June following the directions recommended for cultivating Cabbage.

Curled Dwarf Green Scotch. Very dwarf and spreading; best strain . . . . . . . . . . . $\$ 0.10 \quad \$ 0.30 \quad \$ 1.00$

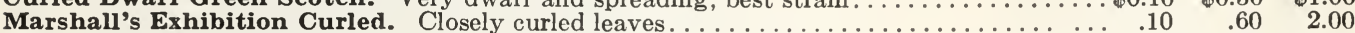

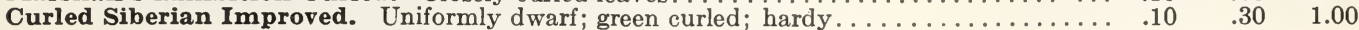

\section{KOHL-RABI}

One ounce will sow 300 feet of row.

This delicious vegetable should be in every vegetable garden. It forms a bulb at the base of the stem above the ground. Successive sowings should be made throughout the season and good cultivation is necessary. Use the bulbs of the Kohl-rabi when they are about the size of an apple as they become hard and stringy if grown too long. Early White Vienna. Very early and should be used before being fully grown. Pkt. 1/2 oz. Oz. 1/4 lb.

Flesh white with greenish white skin.........................

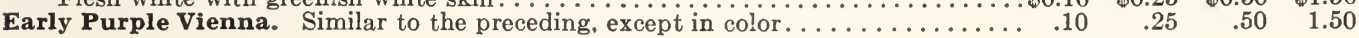

\section{LEEK}

One ounce will sow 200 feet of drill.

The leek is very hardy and easily cultivated; it succeeds best in light but well enriched soil. Sow as early in the Spring as practicable, in drills 1 inch deep and 1 foot apart. When 6 to 8 inches high transplant in rows 10 inches apart each way, as deep as possible, that the neck, being covered, may be blanched.

Marshall's Giant. The largest and best Leek for exhibition. Highly recommended as Pkt. Oz. 1/4 lb.

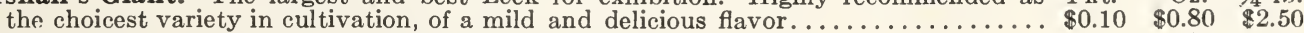

Large American Flag. The most desirable for market or family use . . . . . . . . . . $\quad .10 \quad .30 \quad 1.00$

Musselburgh, or Carentan. A very large variety of superior quality $\ldots \ldots \ldots \ldots \ldots \ldots \ldots . \quad .10 \quad .30 \quad 1.00$

Semesan is the most effective all-purpose disinfectant on the market. The use of this compound, either in dust or liquid form, not only provides control of disease, but hastens and improves seed germination. Its use provides vigorous growth in the seedling stage, thereby insuring sturdier plants and, as a result, heavier and better production.

Semesan controls organic diseases such as "damping off" and "stem rot." If you have had only fair success with your gardening activities try Semesan and you will always use it. Descriptive booklets on request.

Prices: 2 oz. 60c., 8 oz. $\$ 1.60,1$ lb. $\$ 2.75,5$ lbs. $\$ 13.00$. Postage extra.

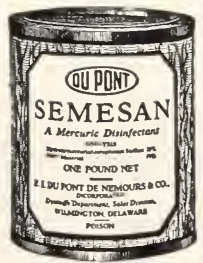




\section{LETTUCE}

One ounce will sow 200 feet of drill.

Sow in the open ground as early as possible, barely covering the seed. If the hotbed is used let it be started quite early. Give but little heat and plenty of water and air on fine days. Let plants in the beds be about 4 inches apart. As they increase in size thin them out or they will become weak. Plant for late use in a cool, partially shaded place in rich soil.

CURLED, or LOOSE-LEAVED VARIETIES Pkt. Oz. $1 / 4 \mathrm{lb}$.

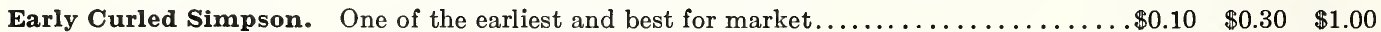

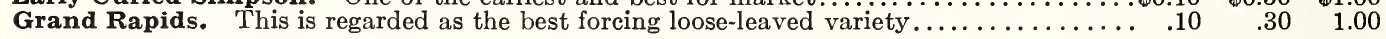

\section{CABBAGE, or HEADING VARIETIES}

All Heart. A beautiful yellowish green head Lettuce. Withstands intense heat........ $\quad .10 \quad .35 \quad 1.00$

All Seasons. Large, handsome, extremely solid head; color a light grayish green........ . $\quad .10 \quad .30 \quad 1.00$

Boston Market (White Seed Tennisball). Solid, crisp and compact. One of the best for

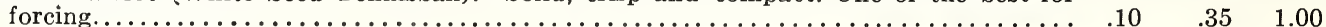

Big Boston. Fine for forc- Pkt. Oz. $1 / 4 \mathrm{lb}$ ing in coldframes or for open ground..........

Crisp as Ice. Medium size compact head, outer leaves tinged dark brown

Deacon. A splendid variety for standing the Summer heat; large, solid head.....

Giant Crystal Head, or Iceberg. Large, solid, outside leaves bright green, inside white. . ...

Golden Queen. A good forcing variety of a golden yellow color; heads solid...........

Hanson Improved. Heads large, hearts quickly, and stands the Summer well ..............

Marshall's Royal Summer. A large butter head, with thick leaves, dark green tinged and spotted brown. The inside of head is a rich yellow..............

.10

.10

.10

.10

.10

.10

1.00

.10

$.35 \quad 1.00$

$.35 \quad 1.00$

$.35 \quad 1.00$

$.50 \quad 1.50$
$.35 \quad 1.00$

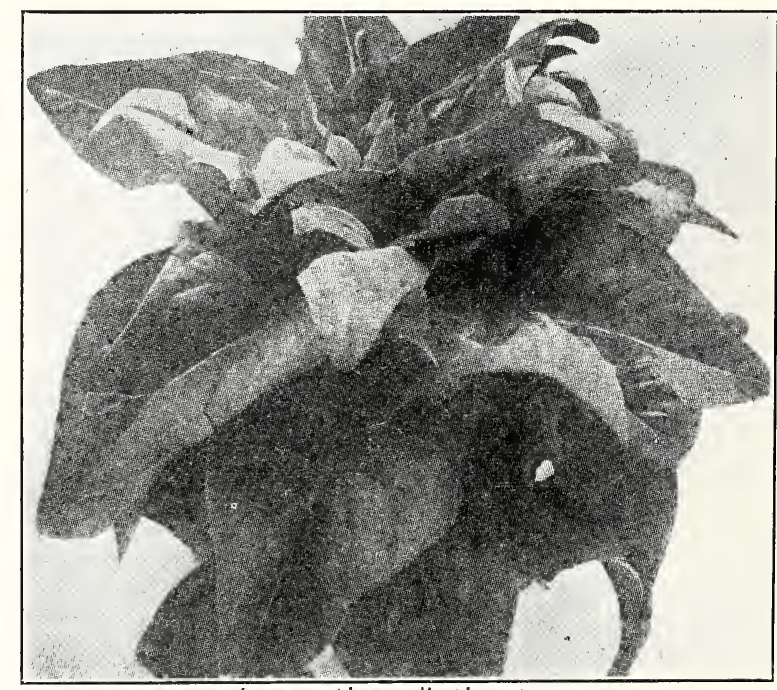

Lettuce, Mlarshall's Malchless

Marshall's Matchless. This lettuce is now conceded by criterions to be the finest lettuce introduced in many years. It is a cross between a head variety and the cos type. It forms a loose leaved head and its delicacy and flavor put it in a class of its own. If you have room for only one kind of lettuce we strongly recommend our Matchless. Per pkt. 25c; per oz. $\$ 1.00$.

May King. Extra large, solid heads; light green outside, with clear yellow heart; very tender Pkt. and of fine flavor; splendid forcer . . . . . . . . . . . . .

Oz. $1 / 4 \mathrm{lb}$. .351 .00

Mignonette. Distinct russet colored; very solid and compact. . . . . . . . . . . . . . .10

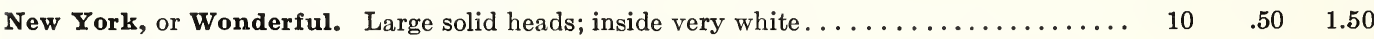

Tennis Ball (Black-Seeded or Salamander). A very distinct compact head with few outer

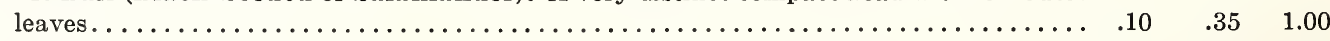

Way Ahead. The leaves are light green, heads blanched to a rich yellow tint.......... $\quad .10 \quad .35 \quad 1.00$

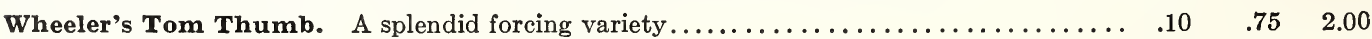

White Summer Cabbage. A fine Summer variety; heads of good size.............. $\quad .10 \quad .35 \quad 1.00$

\section{ROMAINE, or COS VARIETIES}

These are distinct from the ordinary Lettuce, and much liked on account of their crisp, tender quality. They produce long, narrow leaves, blanched by drawing in the outer leaves and tying.

Pkt. Oz. $1 / 4 \mathrm{lb}$.

Eclipse Cos. A perfectly distinct variety. It is the dwarfest Cos Lettuce............ $\$ 0.10 \$ 0.60 \$ 2.00$

Paris White, or Trianon Cos, Romaine. One of the finest varieties for Summer use.... $\quad .10 \quad .35 \quad 1.00$ 


\section{MELON, MUSK One ounce will plant}

After all danger of frost is over and the ground has become warm and dry, plant in hills 4 to 6 feet apart each way, 6 to 12 seeds to a hill. When up and all danger of insects has passed, pull out all but three plants. Cultivate until the vines cover the ground.

Emerald Gem. Small early. $\quad$ Pkt. Oz. 1/4lb.

. . . . . . . . . . \$0.10 $\$ 0.30 \quad \$ 1.00$

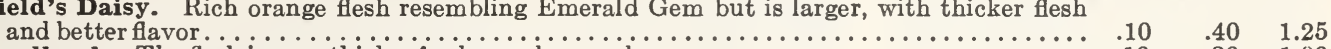

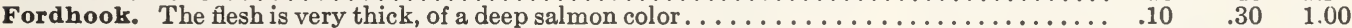

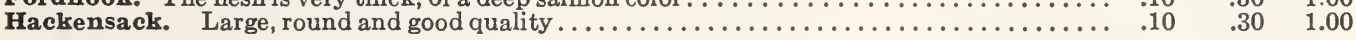

Harute. An outstanding melon which we recommend very highly. Solid firm flesh and of a pale yellow when ripe. The flavor is superb. A luscious fruit which should be

better known . . . . . . . . . . . . . . . . . . . . . . . . . . . . . .

Honey Dew. Large, round to oval in shape, skin smooth, hard and nearly white, flesh light Jenny Lind. Small, green fleshed; very early; good quality $\ldots \ldots \ldots \ldots \ldots \ldots \ldots \ldots \ldots \ldots \ldots \ldots \ldots$

Long Island Beauty. The earliest and finest in quality; green flesh . . . . . . . . . . . . . .

Marshall's Surprise. A very delicious, large salmon fleshed Melon. Shape oblong and

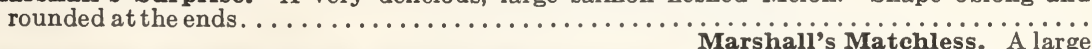

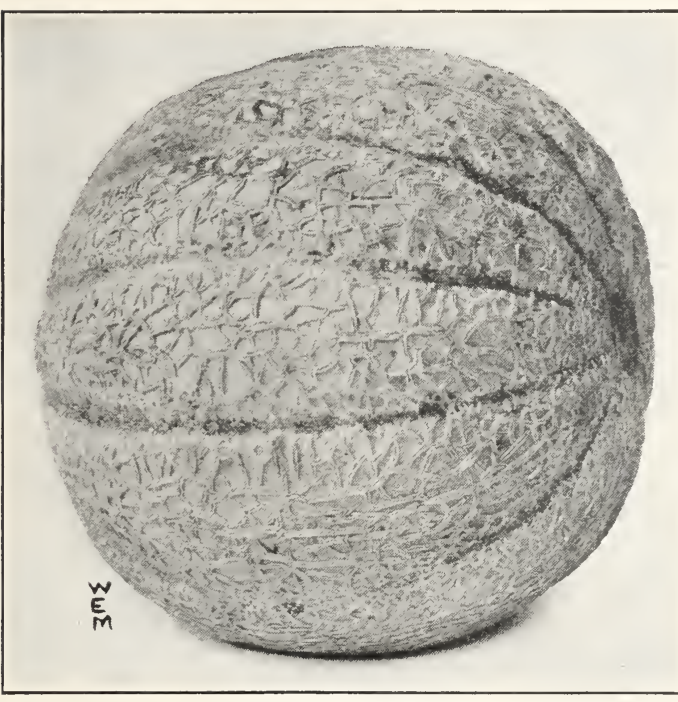

Musk Melon, Harute

luscious Melon. Flesh orange scarlet color, very thick.......

Montreal Market. Large, round netted; flesh thick and light green;late................. Osage, or Miller's Cream. A large oval, orange-salmon flesh Melon of superior quality. ....

Rocky Ford. Very sweet and fine flavored; oblong; light green flesh.

Tip Top. A slightly oval shape and yellow-flesh variety; fine flavor.

$\begin{array}{lll}.10 & .40 & 1.25 \\ .10 & .30 & 1.00 \\ .10 & .30 & 1.00 \\ .10 & .40 & 1.25 \\ & & \\ 25 & 2.00 & \ldots . \\ .10 & .30 & 1.00 \\ .10 & .30 & 1.00 \\ & & \\ .10 & .30 & 1.00 \\ & & \\ .10 & .30 & 1.00\end{array}$

\section{ENGLISH FORCING MELONS} superb flavor...................\$0.50

Diamond Jubilee. Greenish white flesh, good cropper............................

King George. Scarlet flesh, yellow skin, large, uscious fruits. ....................

Royal Sovereign. "Golden skin, white flesh, very thin rind $\ldots \ldots \ldots \ldots \ldots \ldots \ldots \ldots$ Sutton's A1. Rich scarlet flesh, large globular fruits, fine flavor............................... Flavor exceptionally fine, scarlet Superlative. Flavor exceptionally fine, scarlet .50

\section{MELON, WATER}

One ounce will plant about 30 hills.

Plant in hills as directed for Musk Melons, and treat in all respects the same, except that the hills should be 8 to 10 feet apart.

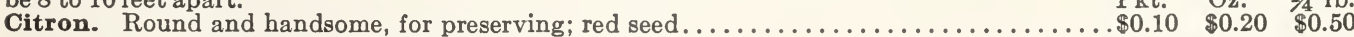

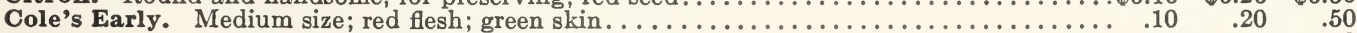

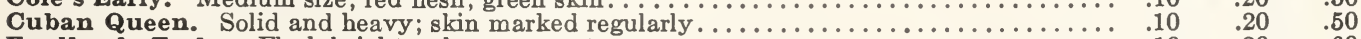

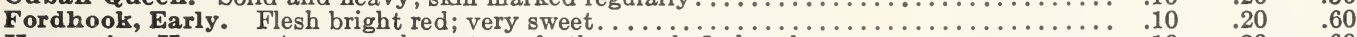

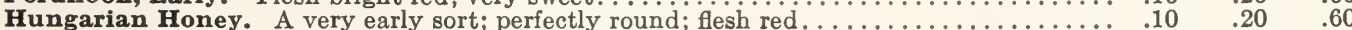

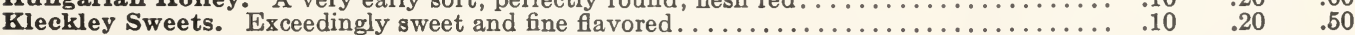

Mountain Sweet. Early, large, oblong, skin dark green, flesh red and sweet. A good variety $\quad .10 \quad .20 \quad .50$

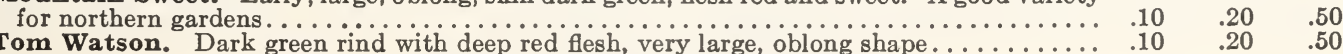
Mushroom Spawn (See Page 38)

\section{MUSTARD}

One ounce will sow 100 feet of drill.

For early crops the seed may be sown in a hotbed in March, and for general crop at frequent intervals through the Spring, in drills from 8 to 12 inches apart.

White London. The best variety for salad.

Pkt.

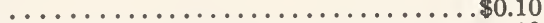

Giant Southern. Curled. Very large leaves....................... 10

Oz. 1/4 lb. Lb.

Fordhook Fancy. A mild variety, used for salads or cooked as Spinach. Leaves dark

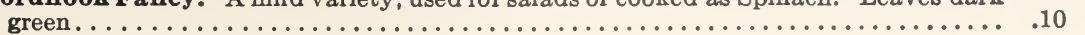




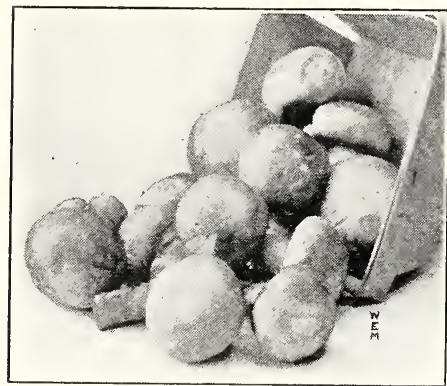

Mushroom

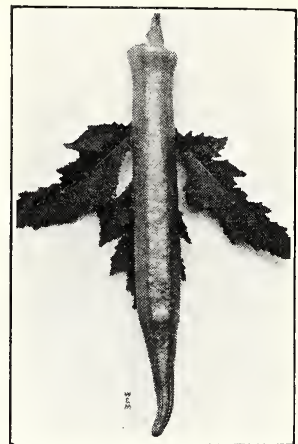

Okra

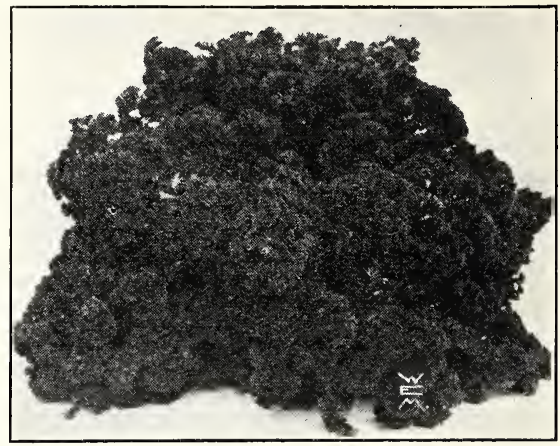

Parsley Crested Gem

\section{MUSHROOM SPAWN}

Ten pounds will spawn about 10 feet square.

Mushroom beds may be made in a warm, dry cellar, or in any building where the frost does not penetrate and in the open air during the Summer and Fall months. Having procured the spawn, the next thing to be attended to is to make preparation for the beds. About two or three weeks before the beds are to be made collect a quantity of fresh horse manure without the straw; place it in a heap under cover, and as it heats keep turning it over once or twice a week, until the fiery heat has become exhausted, which will require from ten to fourteen days' time. When the manure is in a condition to be made up lay out your bed, according to your requirements, say 3 feet wide, 10 feet long and from 2 to 3 feet deep; beat it down well with the back of the spade as the process of building goes on. When the bed has been made some time, say a week or thereabouts, and the heat sufficiently declined to a temperature of 65 or 75 degrees, the spawn may be put into it. Break the spawn in pieces 2 inches square, and put them 6 inches apart, all over the bed; then cover the bed with 2 inches of rich soil. If everything goes on well, you nay expect Mushrooms in about five or six weeks. When the soil looks dry give a gentle watering with tepid water, using a rose on the watering pot. Good crops of Mushrooms can be obtained by spawning the hotbeds in Spring.

Pure Culture Prolife Direct Bricks. An American-made spawn which produces large crops of large size, deep cream and excellent quality Mushrooms. Per brick, 45c.; 10 bricks for $\$ 3.50 ; 50$ bricks $\$ 15.00$.

Bottle Spawn. This spawn is very perishable and can only be kept in cold storage. Orders filled from the factory. Per quart bottle, $\$ 1.25 ; 12$ quarts for $\$ 12.00$.

\section{OKRA, OR GUMBO}

\section{One ounce will plant 100 hills.}

This plant is extensively cultivated for its green pods, which are used in soups and stews, and are very wholesome and nutritious. Sow about the middle of May in drills 3 feet apart and thin out the plants to 1 foot apart.

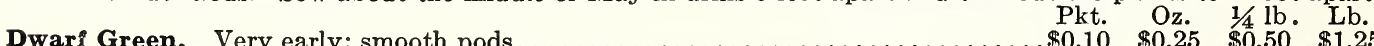

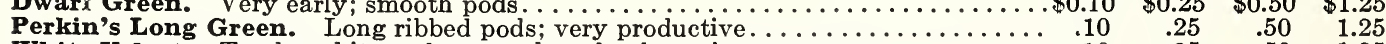

White velvet. Tender white pods; smooth and velvety in appearance................

\section{ONIONS AND ONION SETS (See page 39)}

\section{PARSLEY}

One ounce will sow 200 feet of row.

Sow as early as possible in Spring, first soaking the seed three hours in water; cover lightly, raking the soil fine and level on top. The drills should be about 15 inches apart. The plants appear in two to four weeks. Thin to 3 inches apart.

Marshall's Crested Gem. A very dwarf, compact variety. Intensely curled and very $\mathrm{Pkt}$. Oz. 1/4 Lb. dark green. Best for edging and home garden............................

Marshall's Dwarf Perfection. A dwarf and compact Parsley of bright green color, ex-

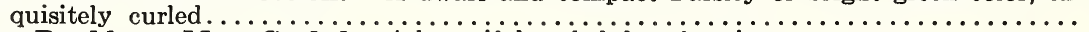
Turnip Rooted. Grown for its roots which are used in flavoring soups $\ldots \ldots \ldots \ldots \ldots \ldots \ldots$

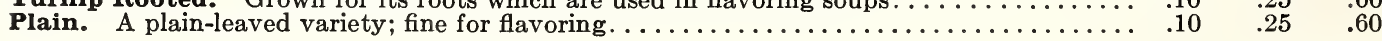

\section{PARSNIP}

One ounce will sow 200 feet of drill.

Sow Parsnip seed as early in the Spring as the weather will permit, in drills from 15 to 18 inches apart, covering with fine soil to the depth of half an inch. The soil should be rich and deep; manured if possible, the previous Autumn. Thin out the young plants to about 6 inches apart and keep the surface of the ground open and free from weeds. It is perfectly hardy and may remain in the ground through the Winter. Indeed, the fine sugary flavor is only perfected by a severe frost.

Marshall's Marrow. A grand selection, clean white, long roots; fine for exhibition Pkt.

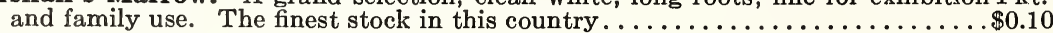

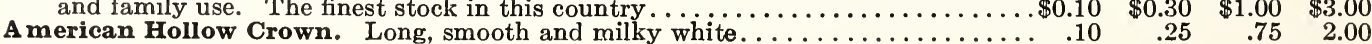




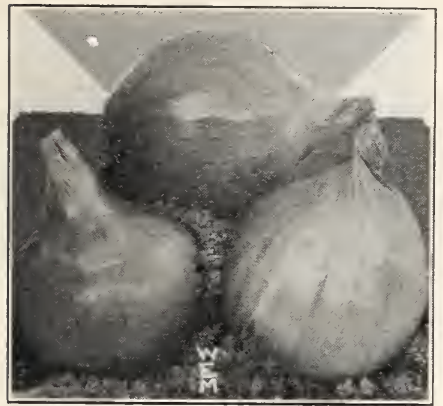

Onion Red Globe

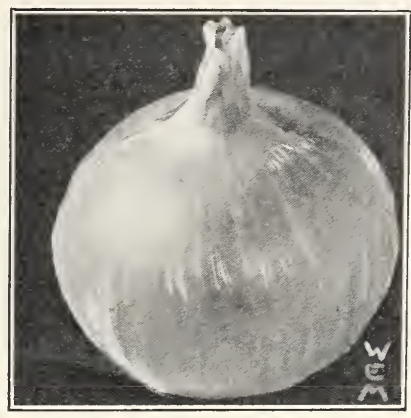

Onion Invincible Giant

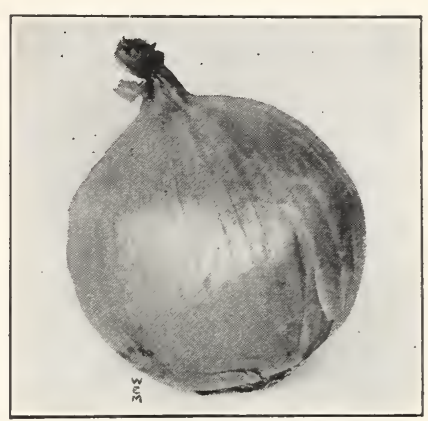

Onion Danvers Globe

\section{ONIONS}

One ounce will sow 200 feet of drill. 4 to 5 pounds to the acre.

Sow in drills 1 foot apart and cover about one-third of an inch, treading or rolling after sowing so that the hot, dry atmosphere may not destroy the sprouting seed. When 3 inches high thin to 2 inches apart. Stir the ground freely without disturbing the young plants and keep free from weeds.

\section{RED VARIETIES}

Large Red Wethersfield. A good sized onion of purplish red color. Splendid keeping Pkt. 1/2 Oz. Oz. 1/4 Lb. qualities and very productive . . . . . . . . . . . . . . . . . . . . . . . . .

Large Red Globe. (Southport Strain). Considered the finest type of red onion. Globe shaped, of a deep red purple color and its keeping qualities make it extremely

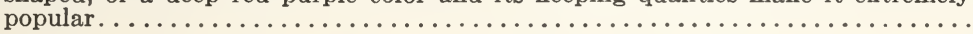

WHITE VARIETIES

Early White Barletta. A small White Italian variety much in demand for pickling. Matures early, flesh midly flavored. . . . . . . . . . . . . . . . . . .

Large White Portugal. For general use we recommend this popular variety. Its mild aromatic flavor and appetizing appearance appeal to all vegetarians. Flat

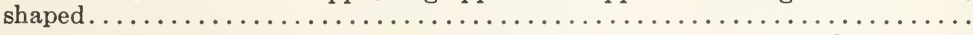

Marshall's Large White Globe. (Southport Strain). Here we offer what we consider the best flat white onion obtainable. For appearance, flavor and all round qualities this is unsurpassed. . . . . . . . . . . . . . . . . . . . . . . . .

Mammoth White Garganus or Silver King. Another superb medium sized white, flat onion of exceptional merit and worthy of trial. Mild flavor. Early ...........

White Bermuda. A very early flat variety which has maintained its popularity.

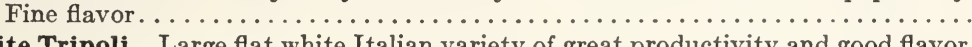

White Tripoli. Large flat white Italian variety of great productivity and good flavor.

\section{YELLOW VARIETIES}

Marshall's Ailsa Craig. One of the finest varieties for exhibition and general use. Oval shape with pale straw colored skin. Good cultivation will reward the grower

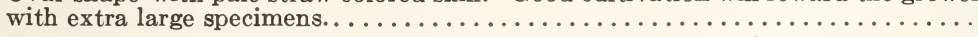

Danvers Yellow. A round, flat, standard sort; early and a good keeper...........

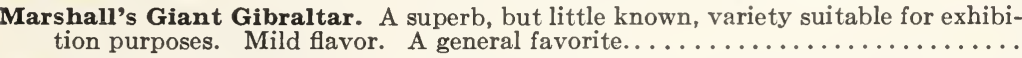

Marshall's Invincible Giant. Acknowledged by experts to be outstanding in quality and when well grown reaches an immense size of fine form and with pale yellow

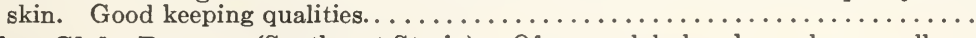

Yellow Globe Danvers (Southport Strain). Of more globular shape; keeps well ...

Yellow Prizetaker. Immense size; globe-shaped, pale yellow . . . . . . . . . .

$\begin{array}{rrrr}.25 & .50 & 1.00 & 3.50 \\ .10 & .30 & .50 & 1.50 \\ & & & \\ .25 & .50 & 1.00 & 3.00 \\ & & & \\ .25 & 1.00 & 2.00 & \ldots . \\ .10 & .30 & .50 & 1.50 \\ .10 & .30 & .50 & 1.50\end{array}$

\section{ONION SETS}

Three quarts will plant 100 yards of row.

Onion Sets should be planted early in the Spring in rows 12 inches apart, placing the sets 4 inches apart in the row. When raised from sets the Onion can be used in the green state in June, or they will be matured by July.

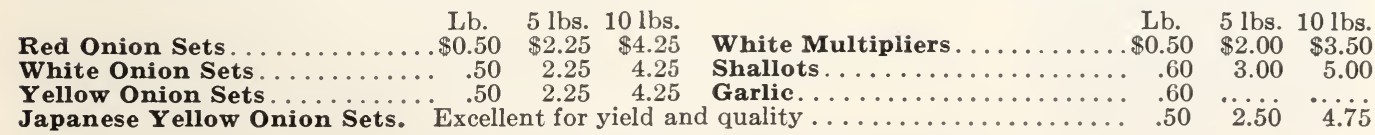




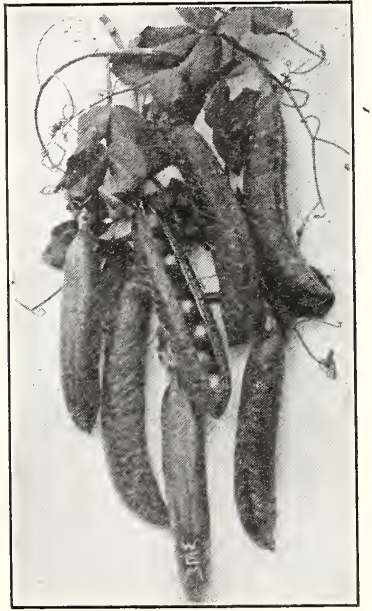

Peas, Earty Bird

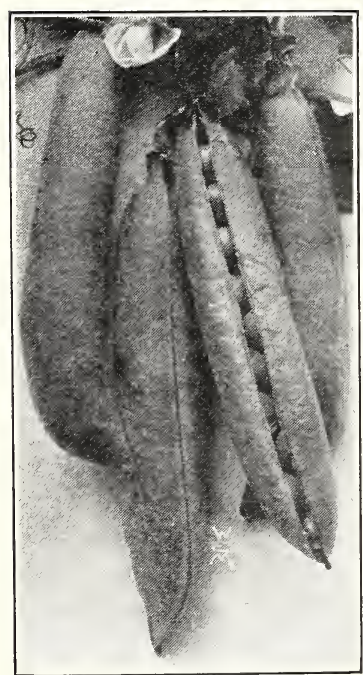

Peas, Perfect

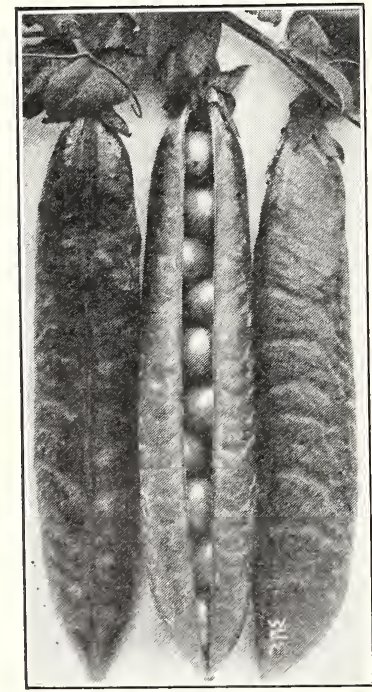

Peas, Quite Content

\section{PEAS One quart will plant \\ about 150 feet of drill.}

Peas mature earliest in a light, rich soil; for general crop a rich loam is the best. When grown in gardens sow in double rows 6 to 8 inches apart, the rows 2 to 4 feet apart, the tall ones requiring brush. Commence sowing the extra early varieties as early as the ground can be worked in February or March and continue for a succession every two weeks until July.

\section{EXTRA EARLY PEAS}

Height
in ft. Pt. Pt. Qt. 4 Qts.

Alaska. One of the very earliest blue Peas;

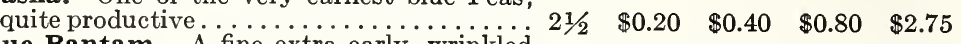

Blue Bantam. A fine extra early wrinkled

Pea. Large pods well filled with deep green,

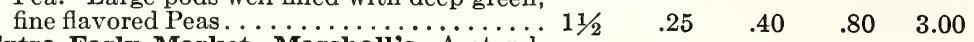

Extra Early Market, Marshall's. A standard extra early Pea; productive and profit-

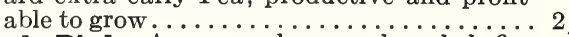

Early Bird. A very early, round seeded, fine flavored variety. Pods 4 inches long and well filled. Very scarce....................

Marshall's Little Giant. An excellent, extra early dwarf variety of highest quality. Pods with 6 to 8 large dark green peas...... 11

Gradus, or Prosperity. The finest extra early Pea. The pods are very large and well filled, with large wrinkled green Peas...... 3

Laxtonian. Very large, dark green, curved pods and Peas of finest flavor . . . . . . . . . 11/2

Laxton's Progress. An English wrinkled variety. A great bearer................. 2

Little Marvel. Very early, wrinkled peas,

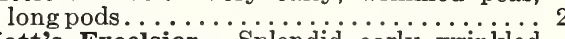

Nott's Excelsior. Splendid early wrinkled

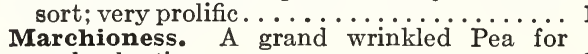
early planting....................... $31 / 2$

Peter Pan. A fine large podded dwarf Pea.... $11 / 4$

Sutton's Excelsior. An extra early dwarf wrinkled Pea; pods filled with large Peas of the finest flavor......................

Thomas Laxton. "Very productive. The pods are large and contain seven or eight large wrinkled Peas of the finest flavor...... 3

\section{MEDIUM CROP PEAS}

Admiral Beatty. An excellent medium early variety, wonderful bearer of large pods containing 8 to 10 peas.................4

Champion of England. "Well known standard variety. Sow thickly. .........4

Duke of Albany (American Champion). Immense pods................. 4

Onward. Decidedly the best pea of recent introduction. Pods are 4 inches long with 6 to 8 deep green sweet peas. About a week earlier than Telephone................. 3

Perfect. An English mid-season variety, with handsome long pods produced in pairs, very heavy bearer.................... 21/2

Sutton's Perfection. An excellent, immensely productive main crop variety. Pods with 8 to 9 large, sweet, green peas....3

$\begin{array}{rrrr}.30 & .50 & 1.00 & 3.50 \\ .20 & .35 & .70 & 2.50 \\ .25 & .45 & .80 & 3.00\end{array}$

\section{MAIN GROP PEAS}

Alderman, or Prince Edward. One of the finest of the large podded main crop varieties. Pods measure nearly 6 inches, well filled. 4

Quite Content. A giant podded variety; very prolific . ..................... 5

Telephone. A tall growing late sort, having pods of very large size, containing six or seven Peas of delicious flavor. . . . . . . . . 4

$\begin{array}{lll}.25 & .40 & .80 \\ .25 & .45 & .80 \\ .25 & .40 & .80\end{array}$

\section{SUGAR PEAS (Edible Pods)}

In Sugar Peas the pods are gathered, broken and cooked like string beans when the Peas start to develop in the pod or have reached about half their full size.

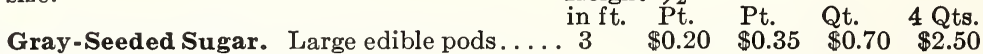
Tall, Melting Sugar. One of the best edible pod sorts.......................

$\begin{array}{llrrr}\text { Height } & 1 / 2 & & & \\ \text { in ft. } & \text { Pt. } & \text { Pt. } & \text { Qt. } & 4 \text { Qts. } \\ 3 & \$ 0.20 & \$ 0.35 & \$ 0.70 & \$ 2.50 \\ 5 & .20 & .40 & .80 & 2.75\end{array}$




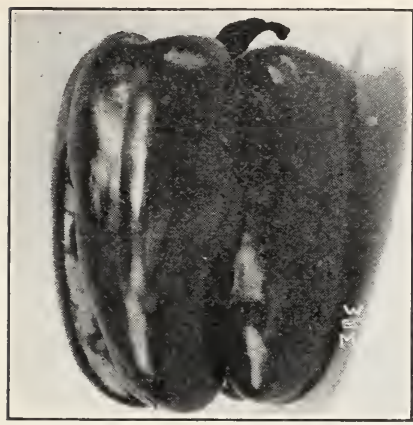

Pepper Marshall's Earliest

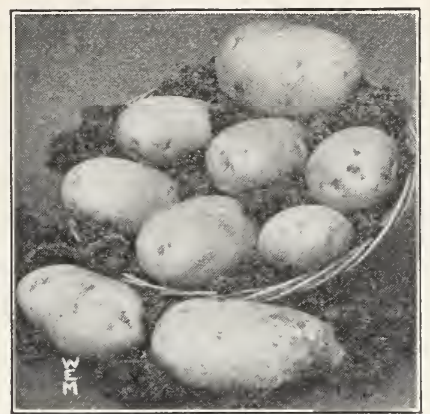

Potatoes

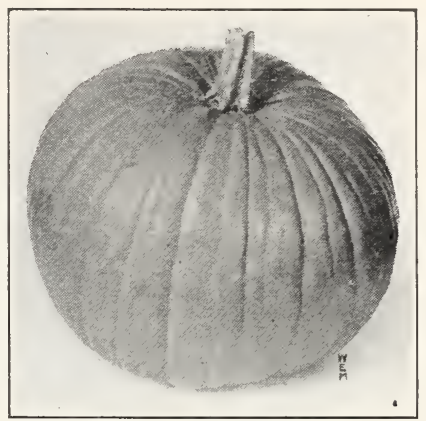

Pumpkin, Early Sugar

\section{PEPPER}

One ounce will produce 2000 plants.

Sow in hotbeds in March, and when the soil has become warm, set in rows 2 feet apart and 18 inches in the rows; hoe frequently. Plants may also be forwarded in small pots.

\begin{tabular}{|c|c|c|c|}
\hline yenne, Long Red. Bright red, slender pod & & & \\
\hline Chinese Giant. Very large, bright scarlet........... & .10 & .40 & \\
\hline arge Bell or Bull Nose. Large, bright red, largely used for pickling, mil & .10 & & \\
\hline agnum Dulce. Very large; flesh mild and sweet..... & .10 & .40 & \\
\hline y early large variety, dwarf compact growth; scarlet fruit & .10 & .50 & \\
\hline 5 inches long, three lobed, $n$ & .10 & .75 & \\
\hline $\begin{array}{l}\text { r-Tomato. A cross b } \\
\text { hili. Very productive }\end{array}$ & & & \\
\hline King. Bright red, 4 ts & & & \\
\hline k. A t & & .40 & \\
\hline ntain. & & & \\
\hline
\end{tabular}

\section{POTATOES}

\section{GROWN EXPRESSLY FOR SEED IN MAINE}

Peck will plant 100 foot row. Ten bushels cut tubers will plant 1 acre.

The Potato can be grown with varying success on soils of all kinds and in all conditions of fertility, but tho soil best suited to it is a sandy loam. Manure is applied either in rows or hills or broadcast over the hills and ploughed in: In highly enriched soils the plants are more liable to disease than when grown in soil that is naturally good. Plant as early in Spring as the ground can be had in fair working order, in hills or ridges, about 3 feet apart, cover lightly with soil about 4 inches deep.

Beauty of Hebron. Slightly flesh colored skin, with pure white flesh; very productive and of the finest quality. Bovee. Extra early; fine quality; flesh white.

Dibble's Russet. This is the best main crop Potato in cultivation. The tubers are round to oblong in shape, good size, white flesh and covered with a russet skin. The quality when cooked cannot be excelled. It also has great disease-resistant and blightproof properties.

Early Rose ("Spaulding's"). Very early; fine quality; very productive, skin shaded rose color.

Gold Coin. Very productive, fine table quality; flesh pure white and cooks very dry.

Green Mountain. Oval shape; white skin and flesh; heavy yielder; good for Winter use.

Irish Cobbler. One of the best extra early varieties.

At the time of going to press with this catalogue the Potato market is so unsettled that prices are subject to change.

We request those desiring Seed Potatoes to write for prices on the quantities wanted and we will give quotations by mail.

Unpriced orders will be filled at the prevailing market prices at time of shipment. Potatoes are forwarded by express or freight as directed, purchaser paying charges.

Du Pont Semesan. Potatoes treated with Semesan will be freer from disease and yield much larger crops See page 123

Red or Yellow variety Plants ready end of May. Per $100, \$ 1.00 ; 1,000, \$ 7.00$.

\section{PUMPKIN}

One ounce will plant 50 halls.

The common practice is to drop two or three seeds in every second or third hill in the Cornfield, but if cultivated on a large scale the seed may be sown in hills 8 feet apart each way, four plants to each hill, and otherwise treated in the same manner as Melons or Cucumbers.

Connecticut Field. Grown in Corn fields for stock .................\$0.10

Cushaw Striped. A splendid striped crook-neck variety $\ldots \ldots \ldots \ldots \ldots \ldots \ldots \ldots \ldots . . \ldots \ldots$

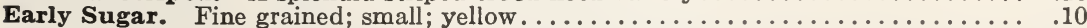

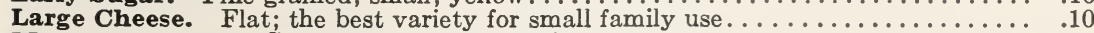

Mammoth King. Grows to an enormous size . . . . . . . . . . . . . . . .

Mammoth Tours. A very large French variety.......................

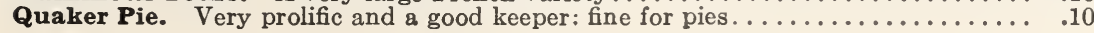

Oz. $1 / 4 \mathrm{lb}$

$\$ 0.20 \$ 0.60 \quad \$ 1.50$

.25

$.25 \quad .75 \quad 2.50$

$.25 \quad .75 \quad 2.50$

$\begin{array}{lll}.25 & .75 & 2.50\end{array}$

$\begin{array}{lll}.25 & .75 & 2.50\end{array}$

$\begin{array}{lll}.25 & .75 & 2.50\end{array}$ 


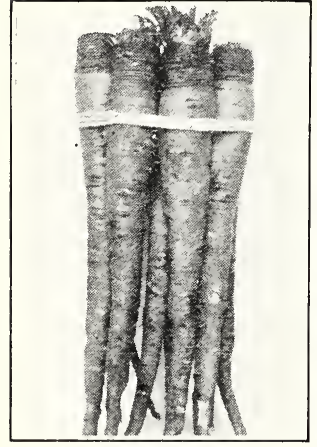

Salsify

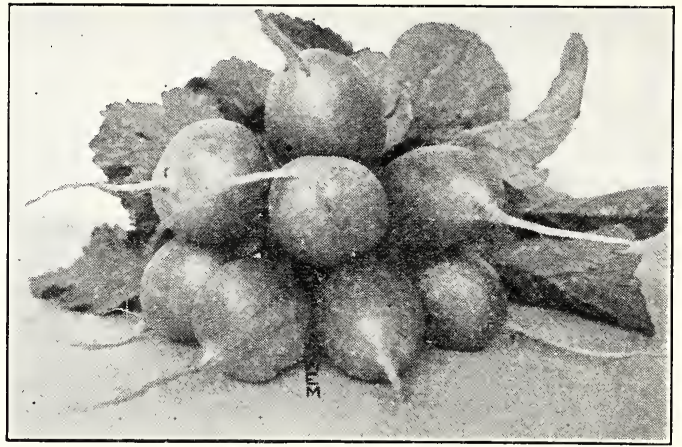

Radish Scarlet Globe

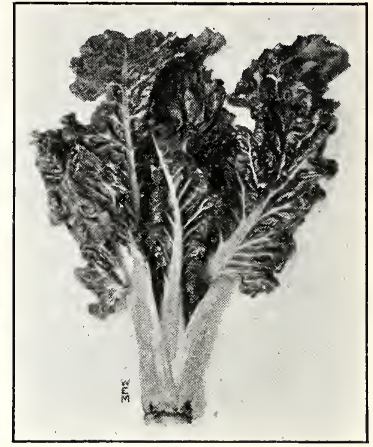

Swiss Chard Fordhook

\section{RADISH}

One ounce of seed will sow 150 feet of dritl.

Radishes require a light, loamy soil, moderately fertile, which should be deeply dug and well pulverized. The situation should be warm and sheltered. For an early supply sow in January or February in hotbeds, keeping well ventilated. In May they may be sown out-of-doors. Successive sowings should be made every two weeks. Radishes to be crisp and tender should make a rapid growth.

Winter varieties should be sown in July and August.

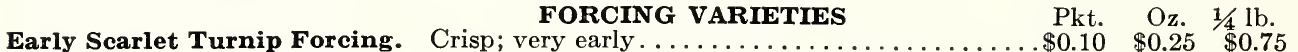

Deep Scarlet Turnip Forcing or Non Plus Ultra. Round, short leaved, crisp;

very early . . . . . . . . . . . . . . . . . . . . .

Early Scarlet Globe. Fine for forcing or open ground . . . . . . . . . . . . . . . $10 \quad .25 \quad .75 \quad 2.00$

\section{OUTDOOR VARIETIES}

Turnip, Marshall's Perfection. Brilliant red with white tip extending nearly half

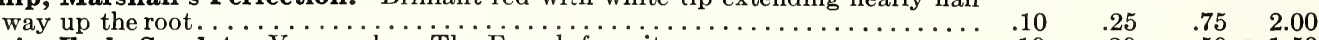

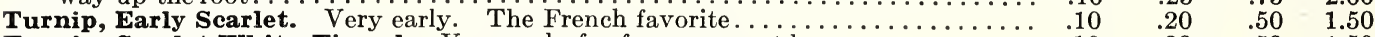

Turnip, Scarlet White-Tipped. Very early for frames or outdoors . . . . . . . . . . .

Turnip, Early White, or Box. Flesh pure white and sweet................ $\ldots . .25 \quad .60 \quad 2.00$

Turnip, Crimson Giant. Suitable for forcing or outdoors; flesh very tender and crisp $\quad .10 \quad .25 \quad .60 \quad 2.00$

Olive-Shaped French Breakfast. Pink and white; early . . . . ..........

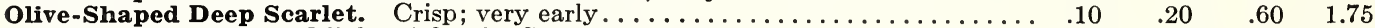

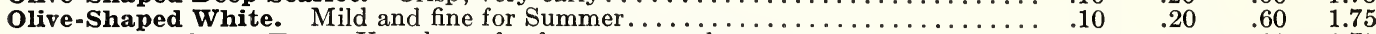

Long Scarlet Short Top. Very long; for frames or outdoors . . . . . . . . . . . . . . . . . .

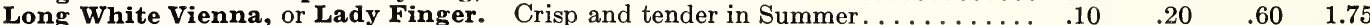

Long Icicle. Pure white; of fine flavor; suitable for forcing. . . . . . . . . . . . . . . .

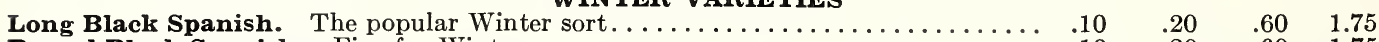

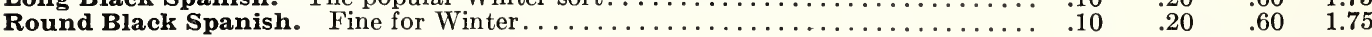

\section{RHUBARB}

One ounce will produce 1,000 plants.

Sow in drills 18 inches apart. When the plants are strong enough, thin out to 6 inches. In the Fall or following Spring, transplant the roots into deep, rich soil, 3 feet apart each way.

Victoria. Very large; later than the Linnaeus. Pkt. 10c., oz. 35c., 1/4 lb. \$1.00, lb. $\$ 3.00$.

Victoria Rhubarb Roots. Extra strong. Each 30c., doz. $\$ 3.50,100 \$ 25.00$.

\section{SALSIFY, OR OYSTER PLANT}

One ounce will sow 150 feet.

A most delicious vegetable. It is used stewed, boiled, or fried, and sometimes as a salad. When cooked it has an oyster flavor. Sow seed from April to May in drills 18 inches apart. Cultivate the same as for Carrots or Parsnips.

Mat. Oz. 1/4 lb. Mammoth Sandwich Island. True. Large and superior; very fine flavor . . . . . . . . $\$ 0.10 \quad \$ 0.40 \quad \$ 1.25$ Long Black, or Scorzonera. Resembles long white, but black in color . . . . . . . . . . . $\quad .10 \quad .50 \quad 1.50$

\section{SORREL}

One ounce will sow 150 feet of drill.

Used cooked as Spinach or to mix with salads. Sow in shallow drills 12 inches apart, and thin out the young plants to 6 inches.

Large-Leaved French. Pkt. 10c., oz. 25c., 1/4 lb. 75c., lb. $\$ 2.50$.

\section{SWISS GHARD}

This beet produces leaves only; excellent as greens. Cultivate the same as Spinach, sowing the seed in early Spring, in drills $11 / 2$ feet apart. Good cultivation will increase the delicacy and tenderness of the leaves.

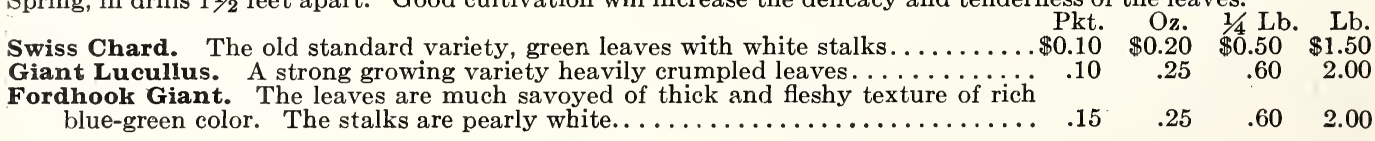




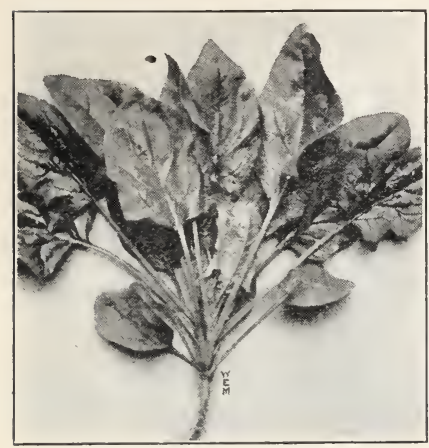

Spinach, Victoria

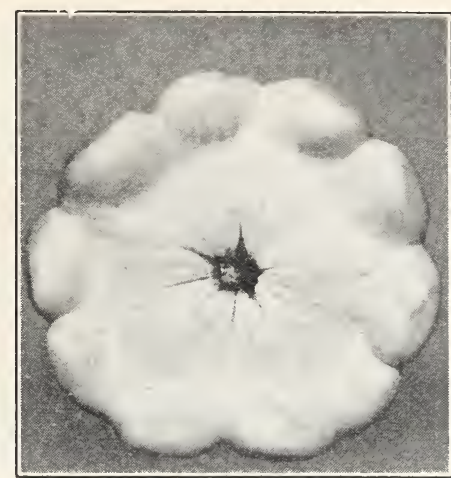

Squash, White Bush Scallop

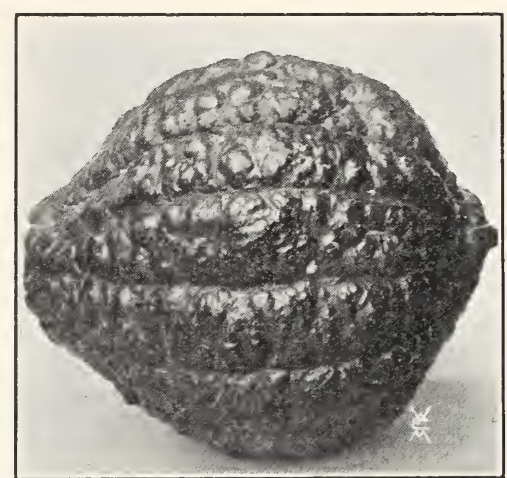

Squash, Warted Hubbard

\section{SPINACH}

One ounce will sow 200 feet of drill, 10 to 12 lbs. an acre.

This is best developed and most tender and succulent when grown in very rich soil. For Summer use sow early in Spring in drills 15 inches apart, and make successive sowings every two weeks. For Spring use sow in September, and cover lightly in November with light litter.

King of Denmark. A new variety for Spring planting. Dark green crumpled Pkt. Oz. $1 / 4 \mathrm{lb}$. Lb.

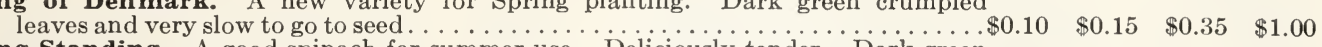
Long Standing. A good spinach for summer üse. Deliciously tender. Đark green

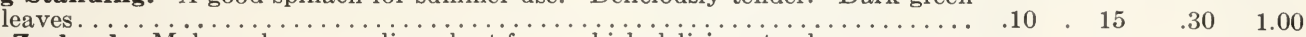

New Zealand. Makes a low spreading plant from which delicious tender greens can be gathered the entire Summer. Fine flavor. . . . . . . . . . . . . . . . . . . . $10 \quad .25 \quad .75 \quad 2.00$

Perpetual Summer, or Spinach Beet. A spinach of outstanding merit. Dark green leaves produced all summer long; of delicious flavor. It may be cut repeatedly during the season and it will grow again with renewed vigor. Hence
its name "perpetual". Highly recommended $\ldots \ldots \ldots \ldots \ldots \ldots \ldots \ldots \ldots \ldots \ldots \ldots \ldots \ldots \ldots$

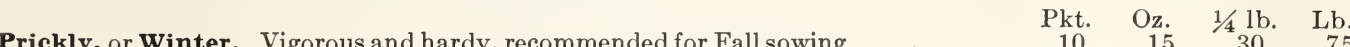

Princess Juliana. A very dark green, thick, round leaved type . . . . . . . . . . . . . . . . .

Savoy-Leaved, or Bloomsdale. Good sized curled leaves, tender and finely flavored... $\quad .10 \quad .15 \quad .30 \quad 1.00$

victoria. A variety with thick dark-green leaves. Best long standing Spinach...... . . $10 \quad .15 \quad .30 \quad .75$

Viroflay Thick-Leaved. A standard sort, equally good for early Spring or Fall

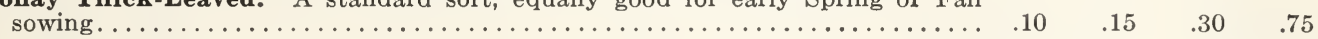

\section{SQUASH}

One ounce Early Squash will plant about 50 hills. One ounce Marrow Squash will plant about 25 hills.

The Squash succeeds best in good rich soil. It is not advisable to plant before May 15th. Sow in hills in the same manner as Cucumbers and Melons. Use seed freely, 8 to 12 seeds to the hill, to provide for losses by insects.

BUSH VARIETIES
Cocozelle Bush. A fine variety; oblong shape; skin smooth, dark green, marbled yellow or

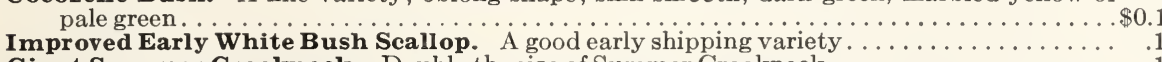

Giant Su mmer Crookneck. Double the size of Summer Crookneck . . . . . . . . . . . . . .

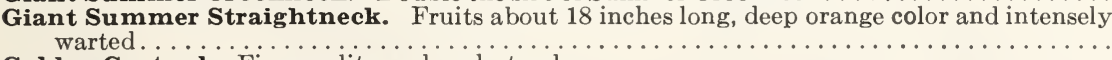

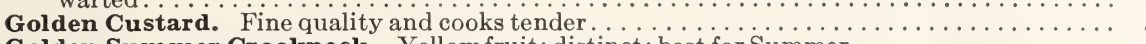

Golden Summer Crookneck. Yellow fruit; distinct; best for Summer . . . . . . . . . . . .

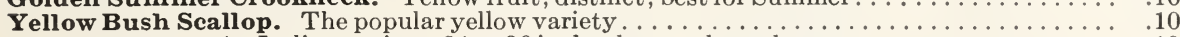

Zucca Pergola. An Italian variety, 24 to 36 inches long, color pale green. . . . . . . . . . 10

Pkt. Oz. $1 / 4 \mathrm{lb}$.

\section{RUNNING VARIETIES}

Boston Marrow. Oval; bright orange; flesh yellow and fine . . . . . . . . . . . . . . . 10

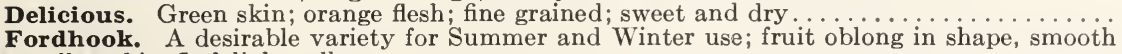

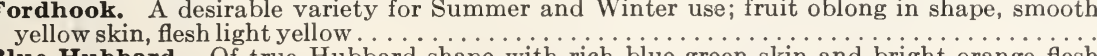

Blue Hubbard. Of true Hubbard shape with rich blue-green skin and bright orange flesh

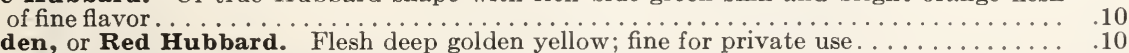

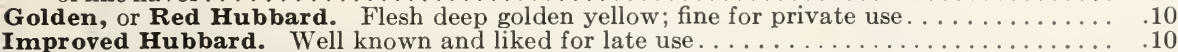

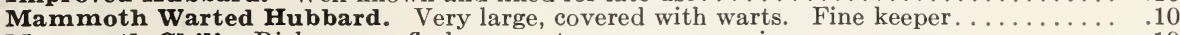

Mammoth Chili. Rich orange flesh; grows to an enormous size . . . . . . . . . . . . . 10 


44 MARSHALL'S MATCHLESS SEEDS

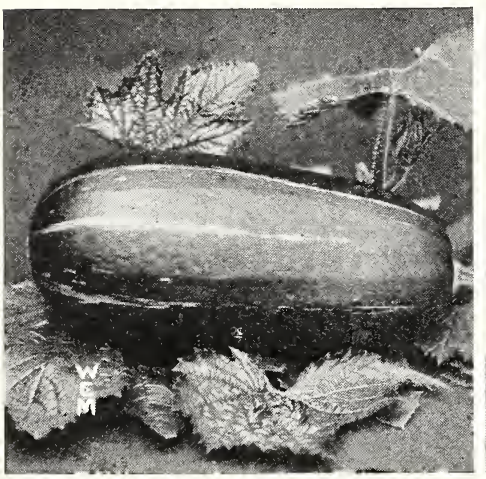

Marrow, Long Green

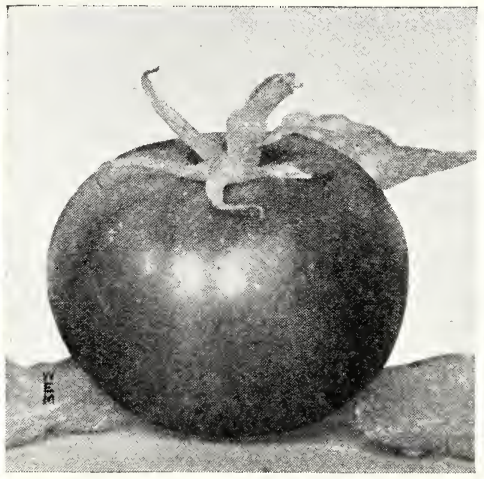

Tomato, National

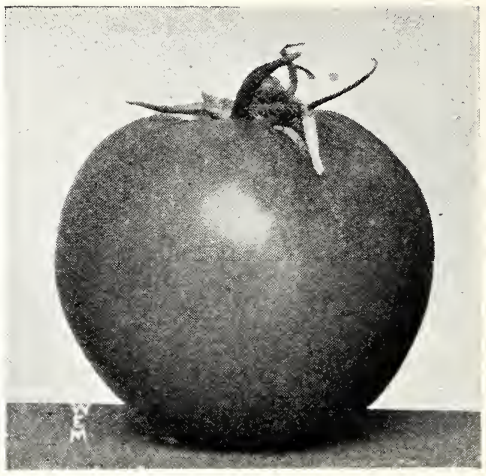

Tomato, Marglobe

\section{ENGLISH VEGETABLE MARROWS}

The following varieties are well adapted for growing in this climate.

Pkt.

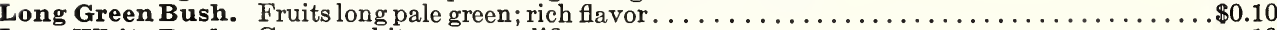

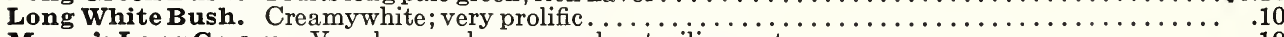

Moore's Long Cream. Very long, pale cream color; trailing sort. . . . . . . . . . . . . . . . . .

Vegetable Marrow. Skin greenish yellow; flesh white; trailing variety . . . . . . . . . . . . .

$\mathrm{Oz}$.

$\$ 0.40$

.40

.40

.30

\section{TOBACCO SEED}

One ounce will produce plants for one acre.

Connecticut Seed Leaf. Suitable for growing in these latitudes; used for cigar wrappers. Pkt., 10c.; oz., 30c.; $1 / 4$ lb., $\$ 1.50$.

\section{TOMATO}

One ounce will produce 1,000 plants.

Sow thinly about the first week in March in a hotbed, greenhouse, window or sitting room, where the temperature is never below 60 degrees. When 2 inches high, set out the plants in boxes about 4 inches apart, or pot singly. About the first of June they may be transferred to the open ground. Set them deeply 4 feet apart.

\section{FORCING VARIETIES}

Marshall's Prolific. The finest medium-sized Tomato for forcing or outdoor planting. It Pkt.

is an enormous cropper, producing large clusters of bright scarlet fruit............\$0.25

Comet. Beautiful, smooth, round fruit in great abundance. Color a rich scarlet red........25

Best of All. An excellent sort for forcing or early outdoor crop $\ldots \ldots \ldots \ldots \ldots \ldots \ldots \ldots \ldots \ldots .25$

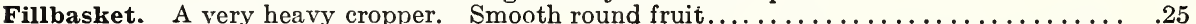

Princess of Wales. A variety of high merit. Plants robust in habit and laden with heavy

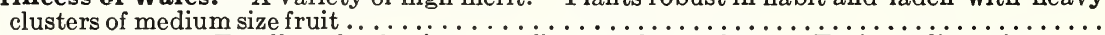

Stirling Castle. Excellent for forcing as well as outdoor culture. Fruit medium size.....

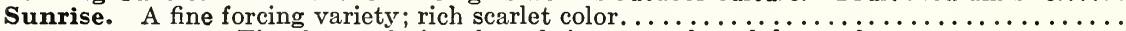

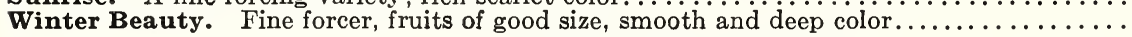

\section{OUTDOOR VARIETIES}

Bonny Best. A very early bright red variety. Smooth, solid and uniform ........... .10

Chalk's Jewel. An exceptionally fine early variety. Color crimson $\ldots \ldots \ldots \ldots \ldots \ldots \ldots \ldots . .10$

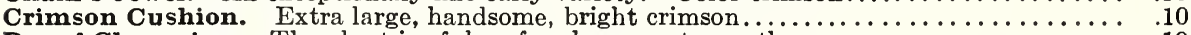

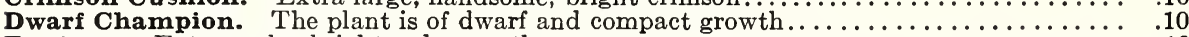

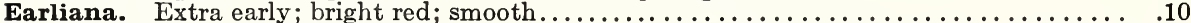

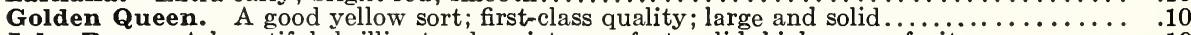

John Baer. A beautiful, brilliant red variety; perfect, solid, high crown fruits...............

Marglobe. Fruits are large, smooth and globular, meaty and almost coreless. Very productive $\quad .10$

Marshall's National. A very early, bright red, coreless variety . . . . . . . . . . . . . . .25

Matchless. Extra large, smooth and handsome; bright red; very solid $\ldots \ldots \ldots \ldots \ldots \ldots \ldots \ldots .10$

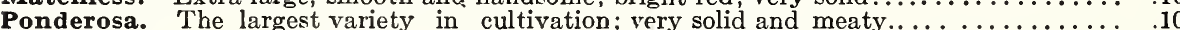

Stone. Very large, perfectly smooth; fine, bright scarlet......................10

$1 / 2 \mathrm{Oz} . \mathrm{Oz}$

\section{SMALL FRUITED TOMATOES}

Red Cherry. Small fruits; used for pickles; very handsome . . . . . . . . . . . . . .10

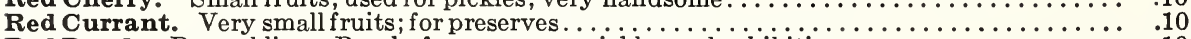

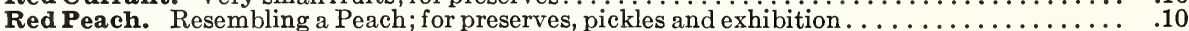

Red Pear. Fruit handsome and solid; fine for preserves $\ldots \ldots \ldots \ldots \ldots \ldots \ldots \ldots \ldots \ldots \ldots \ldots \ldots$

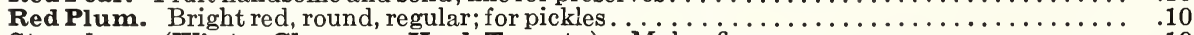

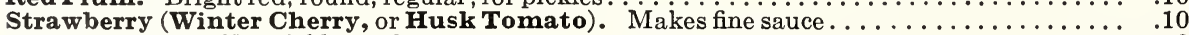

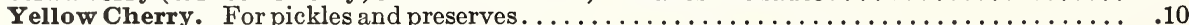

Yellow Peach. Beautiful clear yellow; perfectly resembles a Peach. $\ldots \ldots \ldots \ldots \ldots \ldots \ldots \ldots \ldots \ldots \ldots$

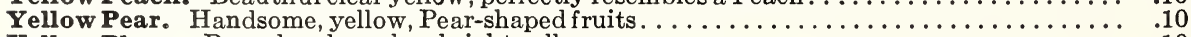

Yellow Plum. Round and regular; bright yellow $\ldots \ldots \ldots \ldots \ldots \ldots \ldots \ldots \ldots \ldots \ldots \ldots \ldots \ldots . .10$

$\begin{array}{rr}.25 & .50 \\ .25 & .50 \\ .30 & .60 \\ .25 & .50 \\ .25 & .50 \\ .25 & .50 \\ .40 & .75 \\ .30 & .60 \\ 1.00 & 2.00 \\ .25 & .50 \\ .25 & .50 \\ .25 & .50\end{array}$




\section{TURNIP}

One ounce will sow 200 feet of drill.

Turnips do best on highly enriched, light sandy or gravelly soil. Commence sowing the earliest varieties in April, in drills, from 12 to 15 inches apart, and thin out early to 6 or 9 inches in the rows. For a succession, sow at intervals of two weeks, until the middle of August.

Pkt. Oz. 1/4 lb. Lb.

Early Milan, Purple Top. Earliest of all, white with purple top .............\$0.10 $\quad \$ 0.30 \quad \$ 1.00 \quad \$ 2.50$

Early Milan, Pure White, Selected. Very handsome, pure white and as early as

the above; flesh very sweet and tender.................................... $10 \quad 30 \quad 1.00 \quad 2.50$

Early Snowball. Small, and rapid growth; pure white........................... $\quad .10 \quad .20 \quad .50 \quad 1.50$

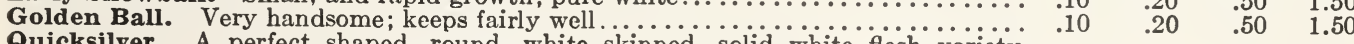

Quicksilver. A perfect shaped, round, white skinned, solid white flesh variety.

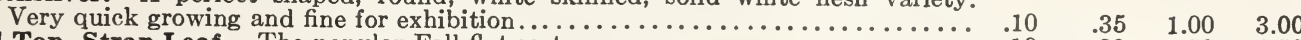

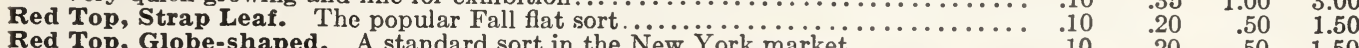

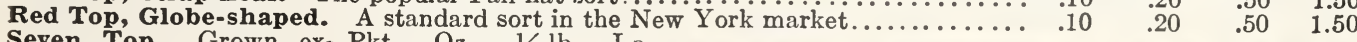

Seven Top. Grown ex- Pkt. Oz. 1/4 lb. L.? clusively for the tops,

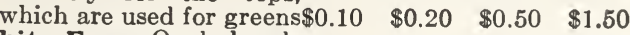

White Egg. Oval, hand-

$\begin{array}{lllll}\text { some and sweet......... } & .10 & .20 & .50 & 1.50\end{array}$

White Strap Leaf Flat. A good early white flat sort....................

Yellow Aberdeen.

hardy and productive variety of excellent quality...................

$\begin{array}{llll}.10 & .20 & .50 & 1.50\end{array}$

\section{RUTA-BAGA}

Seed should be sown the end of June or July. Desirable for table use and feeding stock.

\begin{tabular}{|c|c|c|c|c|}
\hline $\begin{array}{l}\text { Marshall's Matchless. A } \\
\text { purplish bronze variety, } \\
\text { with single tap root and }\end{array}$ & & $\mathrm{Oz}$. & & \\
\hline $\begin{array}{l}\text { small top. Excellent } \\
\text { quality } \ldots \ldots \ldots \ldots \ldots \ldots\end{array}$ & .10 & .25 & .75 & 2.50 \\
\hline $\begin{array}{c}\text { American Purple Top. } \\
\text { A strain of Purple top } \\
\text { yellow................. }\end{array}$ & 10 & 20 & 50 & 50 \\
\hline $\begin{array}{l}\text { vhite - Fleshed. Large } \\
\text { and productive......... }\end{array}$ & .10 & .25 & .75 & 2.00 \\
\hline
\end{tabular}

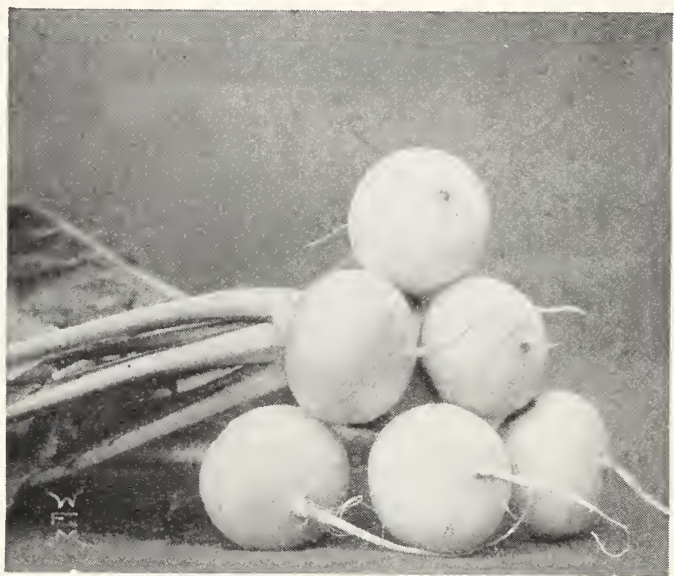

Turnip, Early Snowball

\section{HERBS}

\section{SWEET AND MEDIGINAL}

Plant in the Spring, when the ground is warm, in drills, covering lightly. When the plants are well up, thin out or transplant to about 4 inches apart. They should be harvested on a dry day just before the blossom develops, dried quickly and bottled, or closely packed in dry boxes with the air entirely excluded.

Anise. Annual. Used for flavoring and

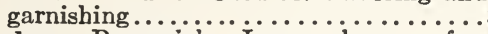

Balm. Perennial. Leaves have a fra-

grant odor and are used medicinally...
Basil, Sweet. Annual. Used for flavor.

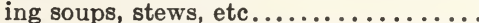

Borage. Annual. Leaves are used for flavoring, and bees are attracted by

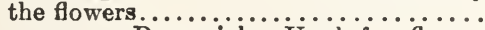

Caraway. Perennial. Used for flavor-

ing confectionery, bread, etc............ medicine........................

Coriander. Annual. Used in the manufacture of confectionery .............

Dill. Biennial. The seeds are aromatic and pungent. Used in pickling........

Fennel, Sweet. Perennial. Leaves when boiled are used in sauces..............

Fennel, Florence. The roots are boiled, also used as salad..................
Pkt. Oz.

$\$ 0.10 \$ 0.40$

$.10 \quad .50$

$.10 \quad .50$

$.10 \quad .50$

$.10 \quad .40$

$10 \quad .75$

$.10 \quad .50$

$.10 \quad .40$

$.10 \quad .40$

$.10 \quad .40$
Horehound. Perennial. Used medicinally, also for seasoning.............\$ \$0.10 \$0.75

Hyssop. Perennial. Used medicinally. The leaves have a pungent taste....... . . $\quad .50$

Lavender. Perennial. Yields an oil used in medicine and perfumery ........... . $10 \quad .50$

Marigold, Pot. For medicinal purposes. $\quad .10 \quad .50$

Marjoram, Sweet. Annual. Aromatic and fragrant. Much used in flavoring.

Mint. Plants only.

Rosemary. Perennial. Leaves Iragrant, with warm, pungent, bitterish taste...

Sage. Perennial. More used than any other herb for dressings and seasoning.

Summer Savory. Annual. Used for flavoring soups and dressings............

Thyme. Perennial. Used for seasoning. Also used medicinally ................

Wormwood. Perennial. Used medicinally and is beneficial for poultry.......
Pkt. Or.

$.10 \quad .75$

$.10 \quad .75$

$.10 \quad .50$

.75

3.00

$.10 \quad 1.00$

.10

\section{PLANTS OF HERBS}

To meet the increasing demand for plants of the most popular herbs, we can supply the following:

Balm, Chives, Horehound, Hyssop, Lavender (True), Marjoram (Pot), Mint (Peppermint), Rosemary,

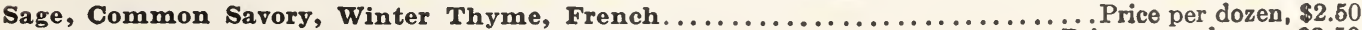

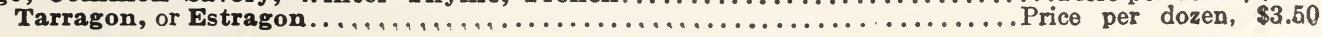




46 MARSHALL'S MATCHLESS SEEDS

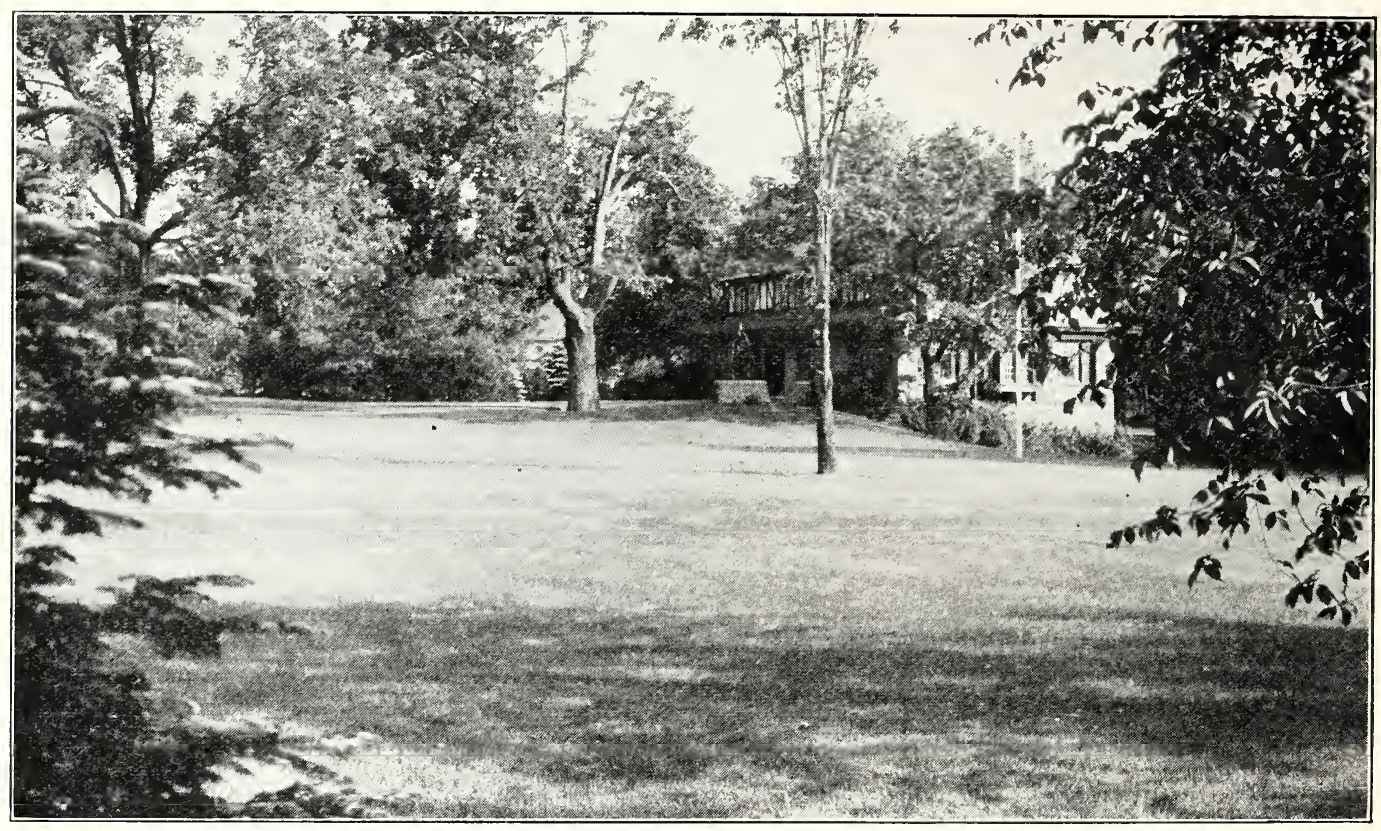

\section{MARSHALL'S “SPEGIAL" LAWN GRASS MIXTURE}

Marshall's "Special" Lawn Grass Mixture produces a perfect as well as permanent, lawn of luxuriant richness. It quickly forms a closely interwoven, firm and elastic turf ready for cutting in about 6 weeks from time of sowing. This "Special" mixture is the result of years of experimenting and is composed of the proper proportions of fine-leaved, deep rooting, perennial grasses which will thrive under varied conditions of soil and climate; maintaining a succession of growth during the different seasons of the year, thus insuring a rich, deep green, smooth and velvety lawn, free from clumps.

This is a scientifically blended mixture, containing only the highest grade of recleaned seeds of Red Top, Kentucky Blue, Chewing's Fescue, and Perennial Rye grasses, blended in proper quantities.

Price: Lb. 80c., 5 lbs. $\$ 3.50,20$ lbs. $\$ 13.00,100$ lbs. $\$ 65.00$.

\section{MARSHALL'S “GENTRAL PARK" LAWN GRASS MIXTURE}

Marshall's "Central Park" Lawn Grass Mixture still maintains a high place in the esteem of those who desire an even, dense growth of permanent sward very early in the season. This mixture contains no annual grasses so detrimental to a permanently good lawn. Only grasses of lasting value and extreme hardiness are used in this popular mixture and we exercise great care to use only the purest seed in the proper proportions in its blending. This mixture is recommended to those who desire a popular priced mixture for average conditions and requirements.

$1 \mathrm{lb}$. will sow $20 \times 20$ feet ( 400 square feet); $5 \mathrm{lbs}$., $40 \times 50$ feet (2000 square feet); $120 \mathrm{lbs}$., one acre.

Price: Lb. 60c., 5 lbs. $\$ 2.60,20$ lbs. $\$ 10.00,100$ lbs. $\$ 50.00$.

\section{MARSHALL'S “SHADY PLACE”' LAWN GRASS MIXTURE}

Usually it is quite difficult to obtain a satisfactory growth of grass under trees and in shady places; for sowing in such places we recommend the use of this special mixture. It will quickly produce an abundant and even growth of beautiful green grass. The grasses used in making this special mixture are only those adapted for growing in shade. It has been successfully used on some large operations where a green sward was desired on land partially shaded by old trees.

Price: Lb. 85 c., 5 1bs. $\$ 3.75$, bu. 20 1bs., $\$ 14.00,100$ lbs. $\$ 70.00$.

\section{SPECIAL LAWN GRASS MIXTURE FOR SEASIDE LAWNS}

A mixture of fine grasses peculiarly suited to seaside lawns and very sandy soils.

Price: Lb. 65 c., 5 lbs. $\$ 3.00,20$ lbs. $\$ 11.00,100$ lbs. $\$ 55.00$. 


\section{MARSHALL'S “TERRAGE” LAWN GRASS MIXTURE}

A special mixture of grasses for sowing on terraces and side hills-grasses that produce strong, spreading roots, thus preventing heavy rain from washing them out; that will withstand drought and exposure, thrive on shallow soils and produce a rich, green turf throughout the season.

Price: Lb. 80 c., 5 lbs. $\$ 3.50$, bu. 20 lbs. $\$ 13.00,100$ lbs. $\$ 65.00$

\section{Permanent Grass Mixtures for Golf Links MARSHALL'S "PUTTING GREEN," or "TENNIS COURT" MIXTURE}

A very carefully prepared mixture for use on putting greens croquet lawns, tennis courts, bowling greens and lawns. This mixture produces a very thick, soft growth, when sown on a well-prepared ground, and mowed short will allow a ball to roll in almost a direct line. We especially recommend this mixture to those who are particular to obtain the very best. Our mixture contains only the very fine-bladed species of grasses without Rye Grass. $25 \mathrm{lbs}$. will seed a putting green 75 feet square.

Price: 5 lbs., $\$ 5.00,20$ lbs. $\$ 18.00,100$ lbs. $\$ 90.00$

\section{MARSHALL'S FAIR GREEN MIXTURE}

Marshall's Fair Green Mixture is composed mainly of perennial native grasses and two very important European grasses which have proven of great value for Fair Green use. They are all of dwarf, spreading growth, forming a close velvety surface which improves from year to year if given proper care.

This mixture contains no Clover but will be added if desired in quantity of one-half pound per bushel of grass seed. Sow 100 lbs. per acre.

Price: 20 lbs. $\$ 12.00,100$ lbs. $\$ 60.00$

\section{Grass for Hay Grops and Pastures MIXTURES FOR HAY AND PERMANENT PASTURES}

The results obtained from our special Grass Seed mixtures are well known by the constantly increasing demand for them. Fall seeding is preferable, but Spring sowing will be successful if done early, while the land is cool and moist. In addition to the Grasses, we advise sowing $10 \mathrm{lbs}$. of Mixed Clover Seed per acre.

We recommend sowing 50 lbs. to the acre.

PERMANENT PASTURE MIXTURE NO. 1. For cool and light soils.

PERMANENT PASTURE MIXTURE NO. 2. For medium soils.

PERMANENT PASTURE MIXTURE NO. 3. For heavy soils.

Prices of any of the above Mixtures, 10 lbs. $\$ 5.50,100$ lbs. $\$ 50.00$.

\section{GLOVERS}

Prices subject to market changes.

Alfalfa, or Lucerne (Medicago sativa). Northwestern Pine Tree. One of for acre Per lb. bushel 100 lbs. the most valuable forage plants.......................... 20 lbs. $\$ 0.60 \$ 27.00 \$ 45.00$

Alfalfa, Grimm. Certified. Much hardier than any other variety........ 20 lbs. $\quad .75 \quad 39.00 \quad 65.00$ Alsike (Trifolium hybridum). The hardiest of all Clovers, can be cut several times in one season. Grows well on low, wet land . . . . . . . . . . . . . . 10 lbs. $\quad .50 \quad 24.00 \quad 40.00$

Grimson, or Scarlet Clover (Trifolium incarnatum). Pine Tree. An annual

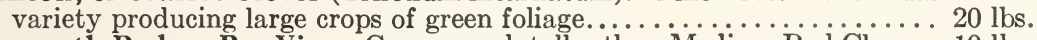

Mammoth Red, or Pea Vine. Grows much taller than Medium Red Clover. 10 lbs.

Medium Red (Trifolium pratense). Domestic Pine Tree. This is the common Red Clover so largely grown throughout the country........... 15 lbs.

Sweet Clover, Bokhara (Melilotus alba). Pine Tree. Will grow on very poor soils; useful for ensilage and plowing under. Grows from 3 to $4 \mathrm{ft}$.

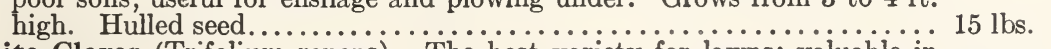

White Glover (Trifolium repens). The best variety for lawns; valuable in

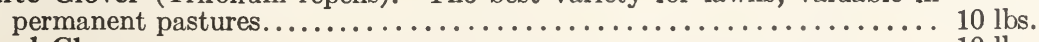

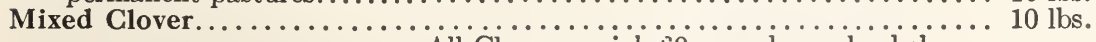
Ail Clovers weigh 60 pounds per bushel.

$\begin{array}{lll}.30 & 13.00 & 20.00\end{array}$

$\begin{array}{ll}.60 & 27.00 \quad 45.00\end{array}$

$\begin{array}{lll}60 & 27.00 \quad 45.00\end{array}$

$\begin{array}{lll}.25 & 11.00 \quad 18.00\end{array}$

$\begin{array}{lll}.70 & 36.00 & 60.00\end{array}$

$.50 \quad 24.00 \quad 40.00$ 


\title{
GRASS SEEDS
}

\author{
For Pasture, Mowing and Lawn
}

Prices subject to market changes. $\begin{gathered}\text { Weight } \\ \text { per bush. Lb. Bushel } 100 \mathrm{lbs} .\end{gathered}$

Bermuda Grass. Used in the southern states for Lawns.............. 35 lbs. $\$ 0.80 \$ 22.00 \$ 60.00$

Canadian Blue Grass (Poa compressa). A more rapid grower than Kentucky Blue Grass and equally good for pasture, but not as suitable for lawns. This is an excellent pasture grass for poor, dry land and should be

more largely used for this purpose $\ldots \ldots \ldots \ldots \ldots \ldots \ldots \ldots \ldots \ldots \ldots \ldots \ldots \ldots$
Creeping Bent Grass Mixed (Agrostis species). Desirable for mixing with other lawn or pasture grasses................................... Roots fibrous and tufted; perennial.

Grested Dogstail (Cynosurus cristatus). Roots fibrous and tufted; perennial.
This is a most valuable permanent pasture grass. For parks this grass is
well suited because of its fine, close growth and pleasant green color.....
English Rye Grass (Lolium perenne). Produces a strong growth in four or

Grested Dogstail (Cynosurus cristatus). Roots fibrous and tufted; perennial.
This is a most valuable permanent pasture grass. For parks this grass is
well suited because of its fine, close growth and pleasant green color.....
English Rye Grass (Lolium perenne). Produces a strong growth in four or five weeks after sowing. It cures into a hay that is rather hard, but having a sweet flavor and much relished by cattle and horses. Sow $60 \mathrm{lbs}$. to acre.

English Rye Grass (Pacey's). A carefully selected, short-seeded, dwarf-

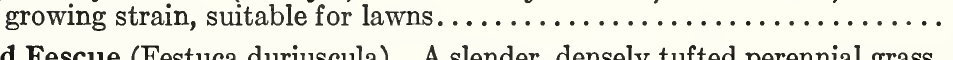

Hard Fescue (Festuca duriuscula). A slender, densely tufted perennial grass,

1 to $2 \mathrm{ft}$. high. Thrives on dry, sandy soils.............................
Italian Rye Grass (Lolium italicum). It is a very rapid grower, forms a dense turf, and is regarded as an excellent hay grass....................

Kentucky Blue Grass (Poa pratensis). A very widely distributed species, and without a rival as a pasture grass. Being of perennial habit, it will, when established, last indefinitely. One of the finest varieties of grasses

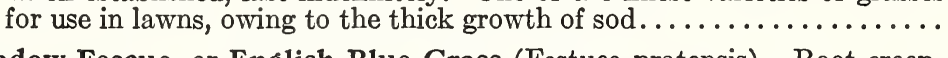

Meadow Fescue, or English Blue Grass (Festuca pratensis). Root creeping; perennial; flowers in July; one of the most valuable of the Fescue grasses. This grass is well adapted for permanent pastures. It grows rapidly in rich and rather moist soils and makes an excellent pasture grass, its long, tender leaves being much relished by cattle. It should be always

mixed with other grasses............................................... Resists extreme drought; thrives on inferior soils, gravelly banks and exposed hills. $25 \mathrm{lbs}$. to acre. $14 \mathrm{lbs}$.

$\begin{array}{lll}.60 & 10.00 & 50.00\end{array}$

$20 \mathrm{lbs}$.

$10.00,50.00$

24 lbs.

$5.00 \quad 20.00$

24 lbs.

$\begin{array}{lll}.30 & 5.50 & 22.00\end{array}$

14 lbs. $\quad .60 \quad 6.50 \quad 45.00$

22 lbs. $\quad .30 \quad 4.50 \quad 20.00$

14 lbs. $\quad .80 \quad 10.50 \quad 70.00$

15 lbs. $\quad .40 \quad 5.00 \quad 30.00$

Market price

Orchard Grass. A good grass for hay crop, yielding nearly the same amount as Timothy and almost equal in feeding value. Orchard Grass will grow on almost every soil. It prefers a moderately dry soil with considerable sandy material. One of the best grasses for sowing in shady places and among fruit trees in orchards. 35 to $40 \mathrm{lbs}$. required for one acre........

Red, or Creeping Fescue (Festuca rubra). Resists extreme drought, thrives on gravelly banks and exposed hills. Excellent for Lawns and Putting

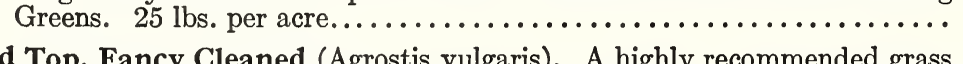

Red Top, Fancy Cleaned (Agrostis vulgaris). A highly recommended grass
for permanent pasture and as meadow grass for hay. Red Top is especially valuable for sour and acid soils, and meadow lands. Red Top makes one of the best grasses for lawn use, either sown alone or in connection with White Clover, or in a mixture with other grasses. Use 14 to 16 lbs.

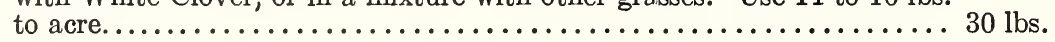

$\begin{array}{lll}.55 & 14.00 & 45.00\end{array}$

Rhode Island Bent (Agrostis tenuis). Fine for putting greens and lawns... 14 lbs. $1.50 \quad 18.50130 .00$

Rough Stalked Meadow Grass (Poa trivialis). A spreading, stoloniferous rooted grass. Adapted for shady lawns and pasture mixtures...........

14 lbs. $\quad .90 \quad 11.50 \quad 80.00$

Sheep Fescue (Festuca ovina). A small tufted, hardy grass, of value in mix-

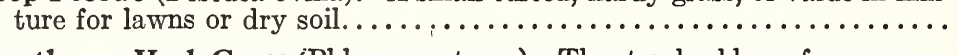

Timothy, or Herb Grass (Phleum pratense). The standard hay of commerce. The excellent quality of the hay and the ease of culture make it valuable. It is adapted to most soils, but succeeds best on moist loam and clay. Timothy sown alone requires about 20 lbs. per acre; when sown with Red

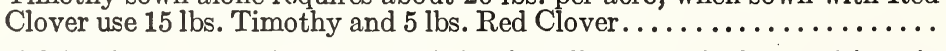
14 lbs. $\quad .60 \quad 7.00 \quad 46.00$

Wood Meadow Grass (Poa nemoralis). Excellent for shaded positions in lawns and woodland parks. Very hardy, resisting extremes of heat and cold. $14 \mathrm{lbs} . \quad 1.50 \quad 18.00120 .60$ 


\section{FARM AND FIELD SEEDS}

\section{BARLEY}

48 lbs. to the bushel, 2 bushels to the acre Bush

Oderbrucker. A six rowed bearded variety....\$4.00

\section{BEANS}

Sow $1 / 2$ to $3 / 4$ bushels to the acre

Soja Bean, E. Black Wilson. Valuable as a forage crop and for fertilizing the soil. Thrives well in hot and dry weather............. 6.00

\section{BEET, MANGEL-WURZEL \\ Sow 6 to 8 pounds to acre}

Champion Yellow Globe. Bright orange color; globe-shaped and of excellent quality .........\$0.75

Danish Sludstrup. A long, reddish yellow va-

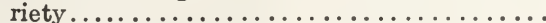

Golden Tankard. An enormous yielder per

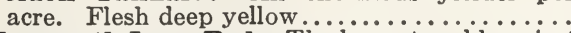

Mammoth Long Red. The largest and heaviest

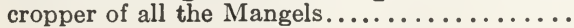

\section{BUCKWHEAT}

48 pounds to the bushel. Sow 1 bushel to the acre

Japanese. Earliest and most productive of the Buckwheats..............\$1.25 \$4.00

\section{FIELD GORN}

8 quarts will plant 1 acre in hills 3 bushels will sow 1 acre broadcast

FLINT VARIETIES Peck Bush

Golden Nugget. Very early, large ears, which average from 12 to 15 in. long...\$1.50 $\$ 5.00$

Longfellow. A large-eared Flint variety, grown extensively for its productiveness. Ears 8-rowed, often 14 to 15 in. long, with small cob and deep kernels.......

Luce's Favorite. Ears large and abundant foliage. Valuable for ensilage or as a shell corn....................... 1.50

\section{DENT VARIETIES}

Improved Leaming. Large ears, deepgrained and of a deep orange color. Early maturing, distinctly Dent, and a

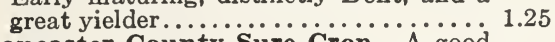

Lancaster County Sure Crop. A good variety for crib or silo. Long ears with deep yellow grains. ................... 1.50

FODDER AND ENSILAGE VARIETIES

Eureka. The plants grow 12 to $15 \mathrm{ft}$. high. Valuable for ensilage or as a yellow Dent

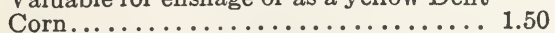

Southern Horse Tooth. $\ddot{A}$ large, leafy grower, especially valuable for ensilage. 1.25

Sweet Fodder. Succulent and nutritious for feeding green.................... 1.50

\section{MILLET}

Golden. Very large crop, though not so early as Hungarian. Grows 3 to $5 \mathrm{ft}$. high. Sow 1 bushel to the acre, $48 \mathrm{lbs}$. to the bushel ................. \$4.25

Hungarian. A favorite Summer forage crop. Sow in June, can be cut in about 60 days. Withstands heat and drought well. Plant about 3 pecks to 1 bushel per acre, 48 lbs. to the bushel. silage. Sown broadcast in the Spring at the rate of two bushels to the acre. $\$ 1.75 \mathrm{pk} ., \$ 6.00$. bus.

Cow Peas, Whippoorwill. A very early maturing variety of upright or bush growth. Sow 2 bushels per acre, $60 \mathrm{lbs}$. per bushel. Bus. $\$ 7.00$.

\section{RAPE}

Dwarf Essex. Fine for sheep pasture; valuable as a soil enricher. Plant in June or July in drills at the rate of 3 lbs. per acre, broadcast 5 lbs. per acre. Lb. 25 c., 100 ibs. $\$ 15.00$.

\section{RYE}

For grain, 1 bushel to the acre; for forage or soiling, $11 / 2$ bushels, 56 lbs. to the bushel.

Giant Winter. Popular as a cover crop. If allowed to mature will produce a heavy crop of grain, and a fine quality of straw if cut about July 1 . Pk. $\$ 1.00$, bus. $\$ 3.50$.

\section{SUNFLOWER}

Mammoth Russian. Very productive, large heads with large seeds. Valuable for poultry; 5 lbs. will plant 1 acre. Lb. 25c., 25 lbs. $\$ 4.50,100$ lbs. $\$ 16.00$.

\section{VETCHES, OR TARES}

Spring Vetches (Vicia sativa). Highly valuable for soiling or for green manuring. Sometimes grown with Oats for mowing and feeding to stock. Use 40 to 60 lbs. to the acre. Sow in Spring while ground is cool and moist, or in early Autumn. Lb. 20c., 100 lbs. $\$ 12.00$.

Winter Vetches (Vicia villosa). Also called Sand Vetch, or Hairy Vetch. Recommended for Fall sowing with Rye. A valuable food for stock in early Spring. Use 30 to $50 \mathrm{lbs}$. per acre. Lb. 40c., 100 lbs. $\$ 25.00$.

\section{WHEAT}

The seed Wheat we offer is grown in Pennsylvania by a very reliable grower, especially for seed purposes. Sow $11 / 2$ bushels to the acre.

Marquis Spring. A very early beardless Wheat that succeeds well in the East, producing larger yields than any other kind. Sow as early as possible about $21 / 2$ bushels per acre. Bus. $\$ 4.50$.

$\$ 8.00$ Leap's Prolific. A very hardy, bearless white chaff and dark amber grain. Market price.

Pennsylvania 44. A bearded, large red variety. Market price.

Trumbull. A medium size, red hard grain, beardless, great yielder, and stands up well. Market price. 


\section{SUMMER-FLOWERING BULBS}

\section{ACHIMENES}

Profuse blooming tender perennials for greenhouse or conservatory decoration during Summer.

Galatea. Large deep lavender.

Magnifica. A fine violet blue.

Purity. A superb pure white.

Purple King. A rich Tyrian purple.

Supreme. Large light blue, lighter center.

Price, $\$ 3.00$ per doz., $\$ 20.00$ per 100 .

Orchida. A lovely orchid pink color. Large flowers. Price, $\$ 5.00$ per doz., $\$ 40.00$ per 100 .

\section{AGAPANTHUS}

umbellatus (Blue Lily of the Nile). A most desirable plant for outdoor decoration; planted in large pots or tubs on the lawn or piazza. Pot-grown plants. 6-in. each $\$ 1.50$, doz. $\$ 15.00$.

\section{AMARYLLIS}

They should be grown in rich, sandy loam, with good drainage, and require abundant moisture when growing; but at their season of rest water should be given sparingly.

Hippeastrum, New Hybrids. The finest race of Amaryllis in cultivation. Each $\$ 1.00 \mathrm{do} z . \$ 10.00$. equestris (Barbados Lily). A garden variety with orange-scarlet flowers. Each 30c., doz. $\$ 3.00,100$ $\$ 20.00$.

equestris Double. Flowers bright scarlet, often 6 inches across. Each $\$ 1.00$, doz. $\$ 10.00$.

formosissima (Jacobean Lily). Brilliant scarlet. Each $\$ 1.00$, doz. $\$ 10.00$.

johnsoni. Deep rich crimson with white stripe on each petal. Each 50c., doz. $\$ 5.00$.

\section{BEGONIAS}

Splendid pot plants for the house or greenhouse, and especially valuable for bedding, flowering in the greatest profusion throughout the Summer. F'or bedding they should be started in hotbed in March and April.

\section{SINGLE TUBEROUS-ROOTED}

Separate Colors: Crimson, Pink, Salmon, White, Yellow or Mixed. Each 35c., doz. $\$ 3.50,100 \$ 25.00$. DOUBLE TUBEROUS-ROOTED

Separate Colors: Crimson, Pink, Salmon, White, Yellow or Mixed. Each 35c., doz. $\$ 3.50,100 \$ 25.00$.

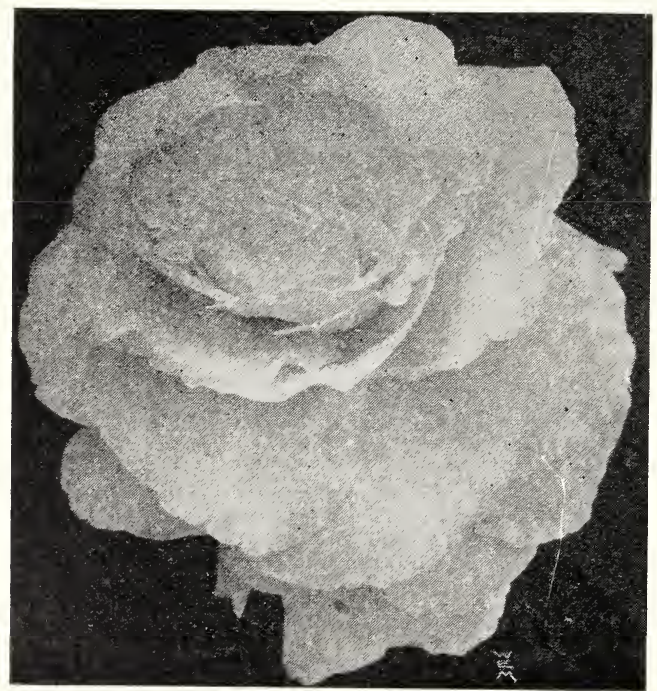

Begonia, Double Tuberous-rooted

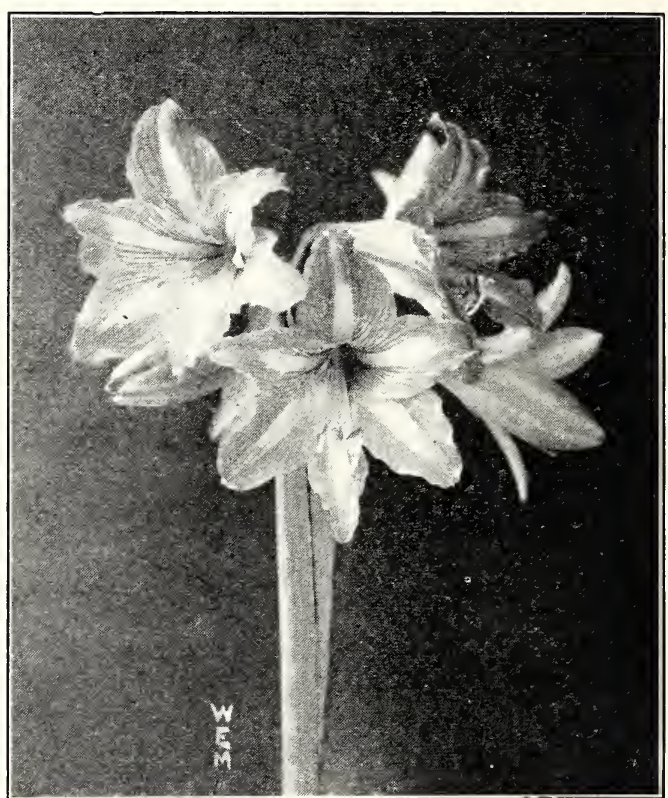

Amaryllis Johnson

\section{AMORPHOPHALLUS RIVIERI \\ African Lily}

The dark red Calla shaped flower preceeds the leaves on this interesting plant. The stem is mottled green and white. The foliage which appears later stands on a stalk resembling an umbrella and makes a very ornamental plant.

Extra large bulbs. Each $\$ 3.00$. Smaller size each $\$ 2.00$.

\section{ANEMONES}

Dainty summer flowering plants with flowers $21 / 2$ in. in diameter on strong stems.

Coronaria. St. Brigid. Double and semi-double. Doz. $\$ 1.20,100 \$ 8.00$.

\section{GALLAS (Richardia)}

Splendid as pot plants or for outside planting. They may be started inside and safely planted out in May.

Golden Roosevelt. A new yellow. Each Doz. 100

Foliage spotted............. \$0.60 \$6.00 \$50.00 Mrs. Roosevelt. White flowers tinged with yellow, leaves spotted. Will bloom continuously through the Summer......

$.35 \quad 3.50 \quad 25.00$

\section{GALADIUM ESGULENTUM}

\section{(Elephant's Ear)}

Grand, tropical plant. A favorite for specimens on the lawn. Height 3 to $4 \mathrm{ft}$. Each Doz. Large Bulbs, 7 to 9 in. in circum......\$0.25 $\$ 2.50$ Mammoth Bulbs, 9 to 11 in.......... $35 \quad 3.50$

\section{FANGY-LEAVED GALADIUMS}

Beautiful, variegated-leaved plants adapted for not culture or bedding if given sheltered positions. Bulbs planted in late May make a pretty display borders or for edging taller plants.

Fancy-leaved Mixed Varieties. Each 40c., doz. $\$ 4.00,100 \$ 30.00$. 


\section{SUMMER FLOWERING BULBS-Continued}

\section{GANNAS}

Cannas should not be planted until the warm weather sets in, or about May 15th. If planted too early the bulbs are apt to rot.

The following are a selection of the largest flowering varieties which we can recommend for bedding or borders. We shall be pleased to supply other varieties not named at catalog prices.

Fiery Cross. Very large, vivid scarlet. Foliage green. $5 \mathrm{ft} \ldots \ldots \ldots \ldots \ldots \ldots \ldots \$ 1.50 \quad \$ 9.00$ Hungaria. The ideal pink bedder: large trusses of flowers. $3 \mathrm{ft} . \ldots \ldots \ldots \ldots .2 .00 \quad 12.00$

King Humbert. Bronze foliage, with orange-scarlet flowers. $4 \mathrm{ft} . \ldots \ldots \ldots \ldots \ldots 1.50 \quad 10.00$

Panama. An attractive rich orange-red, with edge of golden yellow. $3 \mathrm{ft} . \ldots \ldots .1 .50 \quad 9.00$

The President. A gorgeous green leaf variety with great trusses of orange red

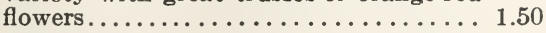

Yellow King Humbert. A beautiful yellow, lightly spotted red, with green foliage. $5 \mathrm{ft} . \ldots \ldots \ldots \ldots \ldots \ldots \ldots \ldots \ldots 1.50 \quad 10.00$

Mixed Varieties................... $1.20 \quad 8.00$ Not less than half dozen of any variety supplied.

\section{GINNAMON VINE}

DIOSCOREA batatas. A rapid growing Summer climber, with bright green, glossy foliage and spikes of cinnamon-scented white flowers. Each 15c., doz. $\$ 1.50,100 \$ 8.00$.

\section{GRINUMS}

Summer flowering bulbs, closely allied to Amaryllis They can be used as a pot plant or planted in the garden for the Summer and taken up in the Fall.

Fimbriatum. Pure white with lavender-Each Doz pink stripes through center of petals..\$0.75 $\$ 7.50$

Kirki. Flowers pure white, striped with

purple. Flower spikes $2 \mathrm{ft}$. high..... $1.00 \quad 10.00$

Powelli Pink. Peach blossom pink..... $1.00 \quad 10.00$

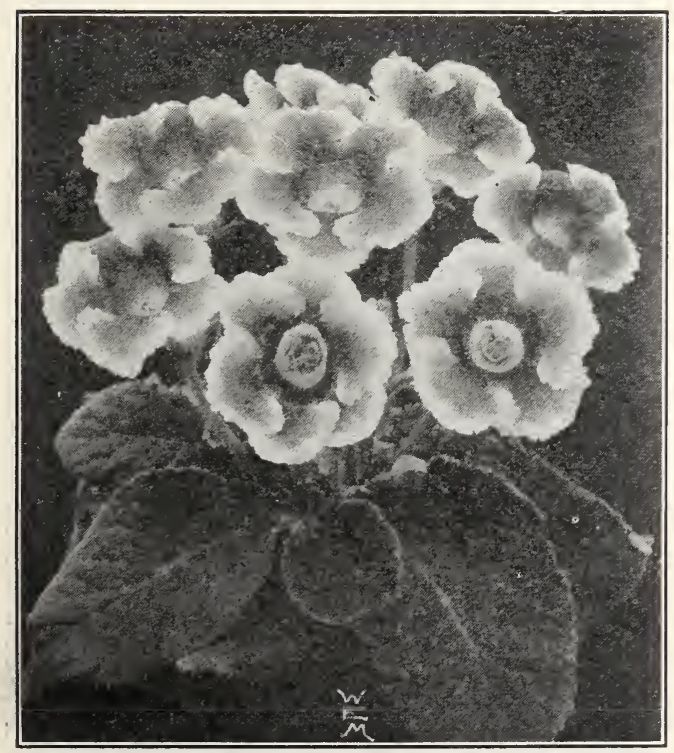

Gloxinia Hybrida

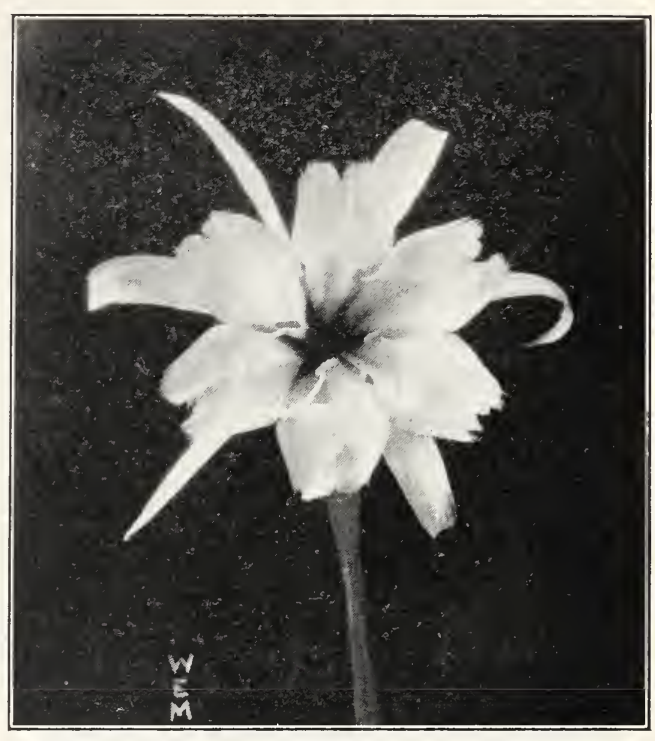

Ismene

\section{DAHLIAS}

See pages $54,55,56,57$ and 58 .

\section{GLADIOLUS}

See pages $60,61,62$ and 63 for illustrations, description and prices.

\section{GLOXINIAS}

Handsome Summer-flowering, tuberous-rooted plants adapted for pot culture. One bulb should be used for a 4-in. pot, using properly mixed soil and care being taken in watering. Each Doz.

Red, White or Blue .............\$0.50 \$5.00

Choice Mixed Colors................ .50 5.00

Bulbs ready for delivery in February

\section{HYACINTHUS CANDICANS (Cape Hyacinths)}

A snow-white Summer-flowering Hyacinth, growing 3 to 5 feet in height, gracefully surmounted with from twenty to thirty pure white, bell-shaped flowers. Extra Large Bulbs. Each 15c., doz. $\$ 1.50,100 \$ 10.00$.

If wanted by mail add 15c. per dozen for postage.

\section{ISMENE (Calathina Grandiflora)}

One of the best of our Summer-flowering bulbs. Clusters of large, fragrant, pearly white flowers, resembling the Amaryllis family.

Large Bulbs. Each 30 c., doz. $\$ 3.00,100 \$ 22.00$.

\section{THE BOOK OF BULBS}

A very useful book for all lovers of bulbs and their cultivation. Price $\$ 3.00$ postpaid. 


\section{SUMMER FLOWERING BULBS-Continued}

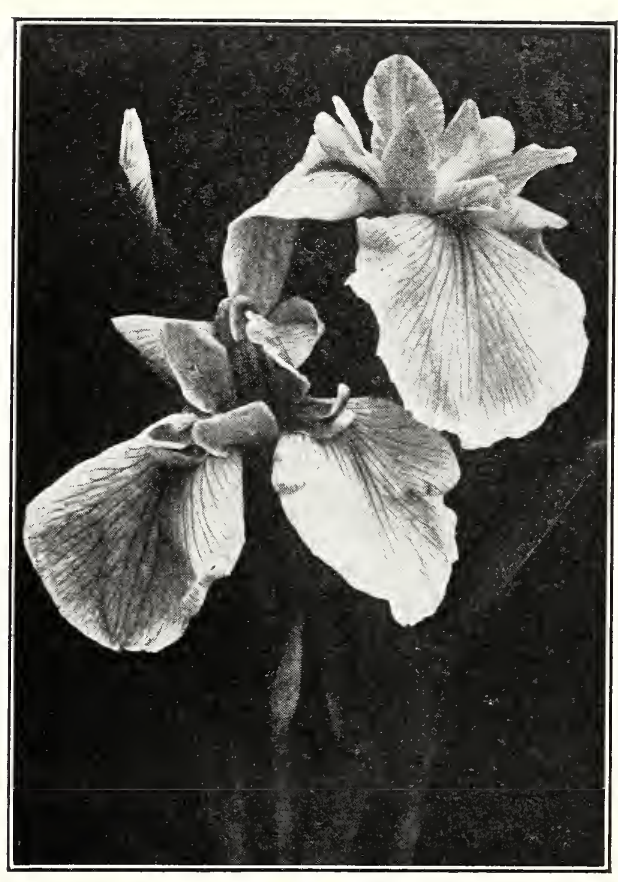

Japanese Iris

\section{IRIS, JAPANESE}

The Japan Iris is perfectly hardy and flowers in great profusion in July and August.

The large size of the flowers is noteworthy, as they often reach 6 to 8 inches across in most fascinating combinations.

Gold Bound. Large, pure white, yellow center.

Helen von Siebold. Reddish violet, veined white, three petals.

Oriole. Large double flowers of rich plum red, shaded deep purple.

Pyramid. Violet-blue, veined white in center of each petal.

Templeton. Double light blue, mottled rose and white.

Victor. White, veined violet-blue, purple center.

Prices of the above, strong clumps. Three for $\$ 2.00$. Dozen $\$ 7.00$.

\section{IRIS, SIBERIAN}

Narrow, glossy foliage, delicate flowers on tall stems. Excellent for cutting as the blooms keep well in water and can be used with other flowers.

Sibirica orientalis. Purplish blue. 2 to $3 \mathrm{ft}$. 3 for $\$ 1.50$. $10 \$ 4.00$.

Sibirica Perry's Blue. A large flower of clear blue with horizontal falls. $4 \mathrm{ft}$. 3 for $\$ 2.50$. $10 \$ 7.00$.

Snow Queen. Flowers pure white. A strong growing variety. 3 for $\$ 1.50$. $10 \$ 4.00$.

\section{LILIES}

See pages 64 to 68 for description and prices.

\section{LILY-OF-THE-VALLEY PIPS} FROM COLD STORAGE

We have in storage a large quantity of Dresden Pips for forcing at any season of the year.

Lily-of-the-valley can be forced in about four weeks from cold storage pips. We cannot supply less than 250 pips.

Marshall's Matchless Pips. Case of 250 for $\$ 17.50$.

\section{MADEIRA or MIGNONETTE VINE}

A rapid growing, beautiful and popular vine, covering a large space in a short time. Heart-shaped leaves of a light green, with numerous racemes of feathery flowers of delightful fragrance.

Mammoth Bulbs. Each 15c., doz. $\$ 1.50,100 \$ 10.00$.

\section{MONTBRETIAS}

Hardy Summer flowering bulbous plants which should be planted in the early Spring and will flower in September. Bulbs may be left in borders during the Winter, if well covered, and will flower earlier than Spring-planted stock.

Fire King. A glowing scarlet. Large Doz. 100

flowers of the finest quality..........\$1.25 $\$ 8.00$

George Davidson. Free flowering yellow $1.50 \quad 10.00$

His Majesty. An outstanding and decidedly meritorious variety. Immense size flowers of brilliant red with yellow center. A beautiful flower for cutting or decorative purposes. 3 for $\$ 1.003 .50$

25.00

King Edmund. Giant rich golden with brown markings in throat. Tall, sturdy grower................. 1.5010 .00

Lady Hamilton. A lovely large yellow, shading to apricot at the center..... $2.00 \quad 12.00$

Lord Nelson. A rich deep crimsonscarlet...................... 2.00 15.00

Queen Alexandra. Immense bright golden orange with contrasting crimson

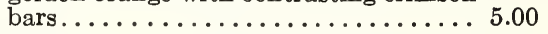

Westwick. District orange red with clear yellow eye, surrounded with a

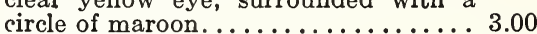

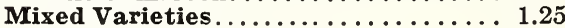
$1 / 2$ doz. sold at dozen rate.

\section{OXALIS}

No bulb is more valuable for edging the borders of walks or flower beds. Elegant foliage and pretty flowers, bloom quickly after planting. The bulbs should be taken up and stored in the Fall in Northern latitudes.

Dieppei. Pure white.

Lasiandra. Rosy pink, cut foliage.

Shamrock. Clover-like foliage; pink flowers.

Mixed Colors. Several varieties.

Mammoth Bulbs. Doz., 30c.; 100, $\$ 2.00$.

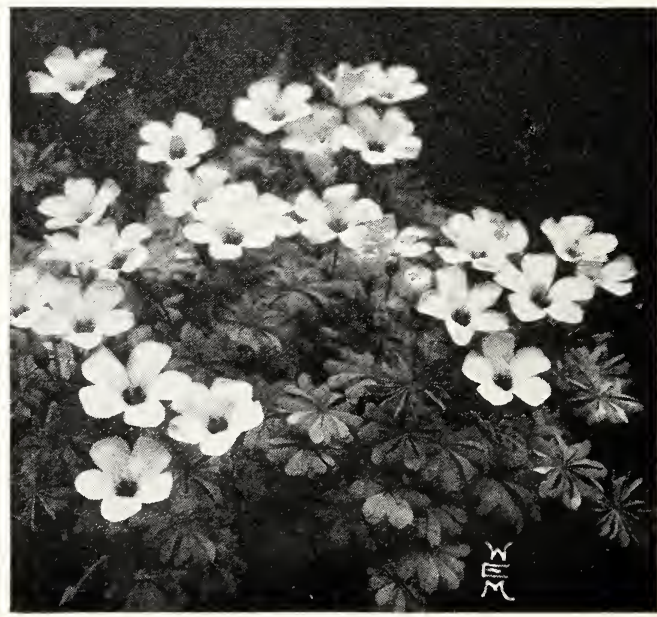

Oxalis 


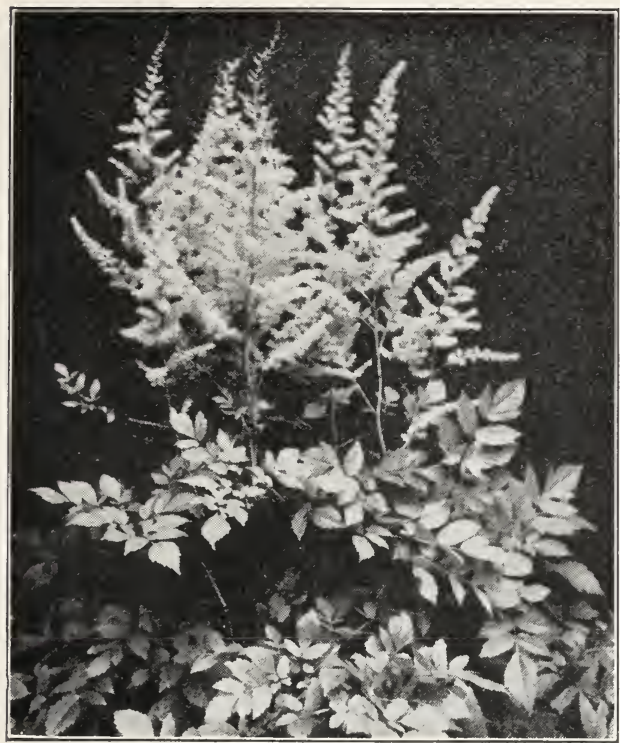

Spiraea Elegance.

SPIRAEA (Astilbe)

These hardy Astilbes will thrive in any good rich soil. flowering in June and July in showy panicles.

The following new introductions are, without doubt, the finest and most outstanding Spiraeas ever offered. Amy Cuperius. Huge drooping flower spikes of white flowers with pink center.

Amethyst. Erect branched, deep violet purple.

Elegance. A pastel shade of cattleya or orchid pink. A gorgeous color which must be seen to be appreciated.

Granat. Crimson flowers on strong spikes.

Hyacinthus. Large white compact spike.

Market Glory. A deep rich crushed strawberry pink or rose carmine. From seven to ten handsome flower spikes.

Good plants for outdoor planting, each 75c., doz. $\$ 7.50$

America. Charming lilac rose flowers.

Gladstone. Fine spikes of pure white.

Philadelphia. Clear lavender rose.

Princess Mary. Deep rose pink, shaded lilac.

Queen Alexandra. Large fluffy pink spike.

Queen of Holland. Beautiful flesh color.

Rubens. Deep carmine-rose.

Large roots. Each 50c. Postage 15c. extra. Doz. $\$ 5.00$ by express.

\section{TRITOMA}

Valuable hardy border plants adapted for cutting and long flowering period.

The roots of Tritoma should be lifted in the Fall and stored in cool cellars or frames for the winter in all the northern states.

grandis (Pfitzeri). Free flowering orange scarlet, shading to salmon rose at the edge. Height 2 to 3 feet. 3 for $90 \mathrm{c}$. 10 for $\$ 2.50$.

Rufa. A very dainty yellow flower for cutting; and constant bloomer from June until frost. Height $2 \frac{1}{2}$ feet. 3 for 90 c. 10 for $\$ 3.50$.

Rufa Hybrids. Hitherto we have only offered these miniature "torch lilies" in one shade. However, we have now been able to secure them in a very delightful and charming range of colors. From a pure white they run into pale and deep yellows, bronzes, oranges, terra-cotta, coral, deep pinks and reds. A galaxy of artistic shades which will find a ready welcome from gardening enthusiasts seeking the unique and unusual.

Price 3 for $\$ 2.00$; per doz. $\$ 6.00 ; 100$ for $\$ 40.00$.

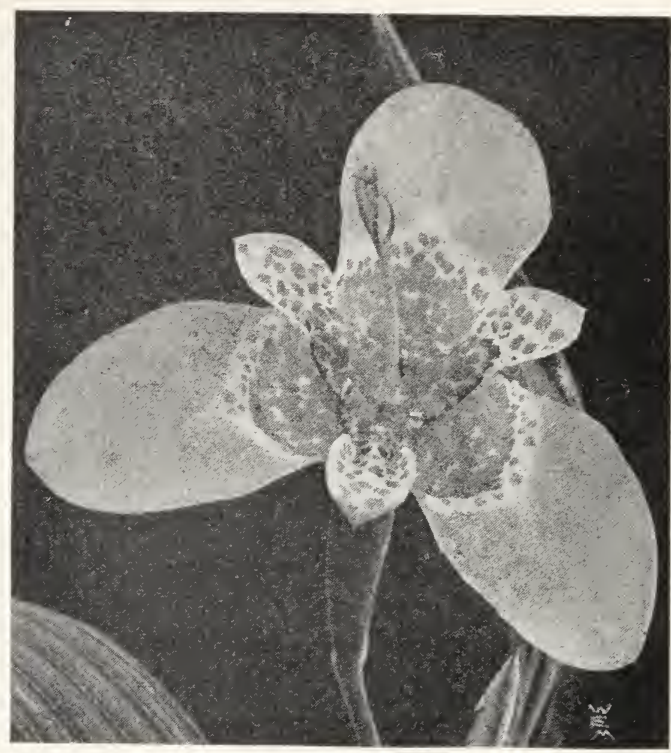

Tigridia

\section{TIGRIDIA (Shell Flower)}

Very showy summer flowering bulbs growing about 24 inches in height. Bulbs should be planted 2 inches deep and 6 inches apart and treatment similar to gladiolus should be given them.

\section{Pavonia rosea}

A very handsome flower with salmon-rose, spotted flowers. 2 for $50 \mathrm{c}$.; doz. $\$ 2.50 ; 100 \$ 18.00$.

Mixed colors: 2 for 50 c.; doz. $\$ 2.50 ; 100 \$ 18.00$.

\section{TUBEROSES}

One of the most fragrant and popular of the Summer flowering bulbs. May be started in hotbeds or pots, or planted in open ground after first day of May

Excelsior Double Pearl. Extra

fine bulbs................. \$0.15 $\$ 1.25 \$ 8.00$ Armstrong's. The single ever-

blooming Tuberose........... $\quad .15 \quad 1.25 \quad 8.00$

\section{ZEPHYRANTHES}

\section{ZEPHYR FLOWER OR FAIRY LILIES}

A hardy, dwarf, bulbous plant, flowering in great profusion in the Summer. Bulbs should be lifted and stored in the Fall in Northern latitudes.

rosea. Beautiful clear rose, very large flowers. 3 for 60 c.; doz., $\$ 2.00 ; 100, \$ 15.00$.

candida. The fall flowering white variety. 3 for $50 \mathrm{c}$.; doz., $\$ 1.50 ; 100, \$ 10.00$.

\section{THE BOOK OF BULBS}

"The Book of Bulbs," by Frederick Frye Rockwell, by means, of lucid, readable text and many excellent illustrations takes the reader into the garden and reveals to him the possibilities in the utilization of bulbous plants in any type of garden development. This is not a botanical survey of bulbs but, as the illustrations will reveal on the first hasty turning of the pages, a garden book for everyone from the amateur enthusiast to the professional horticulturist.

Price, postpaid, $\$ 3.00$. 


\section{GACTUS DAHLIAS}

The following varieties comprise the cream of the novelties which have proved to be of extra merit.

The Incurved varieties are marked I.C.; Recurved or straight varieties, R.C.; Fully double varieties, S.C.

Varieties marked with asterisk (*) are most suitable for cutting.

Ambassador. R.C. Soft yellow shaded salmon

pink. Each $\$ 1.50$

American Triumph. I.C. A bright shade of oriental red. Flowers deep and good substance. 7.50

*Attraction. R.C. Clear lilac rose.......... $\quad .75$

Chemar's Masterpiece. I.C. A beautiful orchid pink.

*Chemar's U. S. A. R.C. Apricot buff suffused gold.

Cigarette. R.C. White, tipped and splashed burnt orange.

*Edna Ferber. S.C. Color glistening coral, shading to old gold at the base of the petals.........

*Fort Monmouth. R.C. Giant, crimson maroon. 5.00

Francis Lobdel. S.C. Mallow pink and white. . . . .75

F. W. Fellows. R.C. Orange and terra cotta. . . . . .75

Gladys Sherwood. R.C. A giant white. . . . . . 1.00

George Walters. R.C. Salmon pink, shaded gold. $\quad .75$

*Golden Trumpet. I.C. Golden yellow. Free flowering. . .

Ian. R.C. Clear yellow, shading to pink . . . . . . 1.00

Jean Hare. I.C. Golden yellow changing to golden

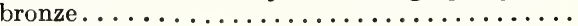

Jean Trimbee. R.C. A rich petunia violet shade, very large flowers, stiff straight stems. . . . . . 7.50

Jersey's Mammoth. R.C. Golden mahogany... . 1.00

*Jersey's Sweetheart. I.C. Pink with white

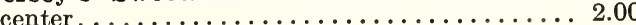

Kalif. R.C. Vivid turkey red.............. .50

Lilian Sheridan. I.C. Bronzy red with yellow tips............................ Pure white, free

*iarshall's White. I.C. Pure white, free 10.00

Minnie Eastman. R.C. Bright flame....... 5.00

Papillion. R.C. Old rose with gold tints . . . . . . 1.00

Pierrot. I.C. Deep amber tipped with white. . . . . .75

Robert E. Lee. I.C. Cardinal red. . . . . . . . . . 10.00

Silverado. I.C. A large white, shading to silvery lavender towards the center............. 2.00

Siskiyou. R.C. Pink tinged mauve......... 2.50

Snowdrift. I.C. A giant pure white.......... 1.00

*Springfield Rose. R.C. Rose overlaid salmon. . 1.00

*Supreme Beauty. I.C. Thulite pink, with extreme base of petals picric yellow........... 1.00

The Grizzly. R.C. Dark velvety maroon . . . . . . 1.00

Venus. I.C. White suffused pink. . . . . . . . 1.00

*White Sister. R. C. Pure white . . . . . . . . . 2.00

\section{ENGLISH CHARM DAHLIAS}

Miniature Dahlias of Peony-flowered Type

The newest type from Europe. They form bushy plants, $21 / 2$ to $3 \frac{1}{2}$ feet in height and are literally covered with flowers all season. The medium sized, semi-double blooms are carried on rigid, wire-like stems well above the foliage, making ideal garden plants. As cut flowers they are superb, keeping fresh in water for many days.

Boutinier. Brilliant red.

Electron. Rich carmine red, shaded orange base.. $\quad .75$

Fedora. Cerise, salmon and gold . ..........75

Judith. A very odd shade of rusty red....... $\quad .75$

Marcella. A soft deep glowing rose, with golden base.

Nora Bell. Orange red, yellow base

Pink Pearl. A beautiful deep pink.

Robin. Old rose; with yellow center

\section{ROSETTE DAHLIAS}

\section{Miniature Decorative Dahlias}

Here we offer a distinctly different class of dahlias than those listed elsewhere. They have aptly been called the "vest pocket" editions of the huge flowering decorative types. Compact and sturdy in habit, they are perfect gems for cutting and no collection of dahlias can be considered complete without a quota of these charming miniatures. We think so highly of them that we have made a colored plate of some of the best, see opposite page.

Charlotte. Bright fawn, on long stems. . . . . . 1.00

Cigarette Jr. White and light red......... 1.00

Clown. Dark maroon evenly striped white..... 1.00

Coronna. A clear white................. 1.00

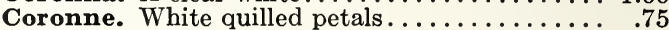

Cupedo. Lilac rose with long stems. Choice. . . . 1.00

Electron. Bright russet. . . . . . . . . . . . 1.00

Garden Love. Brilliant carmine pink. Superb . . . 1.00

Glow. Brilliant orange-scarlet. Extra fine. . . . . 1.00

Irene. Exquisite old rose . . . . . . . . . . . .50

Little Jewel. Pastel pink shade; perfect form . . . . 1.00

Our Annie. Pleasing shrimp pink, shaded with

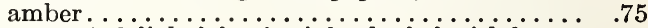

Peach. A delightful soft pink, shaded with lemon

at base......................... 100

Pride. Light orange extra fine for cutting........ 1.00

Rainbow. Old rose with a rusty red base. . . . . . 1.00

Red Sea. A bright red on a good stem.. . . . . . . . 1.00

Rhoda. A glowing orange and rose pink....... 1.00

Tipsy. A pure brilliant, rich red............. 1.00

Wemco. Buff suffused pink, small flower.......... 1.00

White Aster. Immaculate white. Very choice... 1.00

\section{SINGLE DAHLIAS}

These have become very popular for cutting purposes. We list a few of the best varieties.

Ami Barillet. Brilliant scarlet, dark foliage... Each

Apple Blossom. Soft pink tipped carmine..... . . 1.00

Belle of Mexico. Rose shaded to yellow in center. 1.00

*Blizzard. (Duplex). A large white. . . . . . . . . 1.00

Dakota. Orange flame, large flower . . . . . . . . 1.00

Eckford. White suffused and tipped crimson..... 1.00

Fragrance. The fragrant Dahlia. Each petal snow white with margin of bright scarlet. . . . . 2.00

Fugi San. Bronze yellow with crimson ring...... 1.00

*Indian. Indian red, free flowering. $2 \mathrm{ft} . \ldots \ldots \ldots .1 .00$

Jack Century. Scarlet, extra fine ........... 1.00

Marshall's Fire Flame. A brilliant flame on a

long stem. Free flowering. . . . ........... 1.00

Marshall's Gloria. A pure white with each petal edged with bright rose. Fine for cutting. ...... 1.00

Newport Angel. White, large pointed petals. . ... 1.00

Newport Triumph. Bronze, shaded salmon pink 1.00

Newport Wonder. A beautiful rose pink. . . . . . 1.00

Purity. The best white single................ 1.00

Rose Pink. Rose pink, long stems. . . . . . . 1.00

Sambo. Dark maroon. Extra fine . . . . . . . . .

Splashed Gem. White, splashed and streaked with rosy red; long stems, free flowering. . ...... 1.00

Surrey Star. Old rose, shading to orange in center, long stems........................ 1.00

Tango Century. A very large bronze......... .50

Wildfire. Brilliant flame. Very showy......... 1.00

\section{BALL OR SHOW DAHLIAS}

These are fully double flowers, two inches or more in diameter. Valuable for cutting

Each

Francis Butler. Clear picric yellow ........... 75

Jean Kerr. Pure white. . . . . . . . . . . . . . . . .50

Jersey's Beacon Ball. Scarlet orange.... Plants 1.00

Maud Adams. White tipped pink. ...........

Rose Bud. White, edged and tipped rose...........75

Zebra. White, heavily edged and tipped lavender. $\quad .75$ 


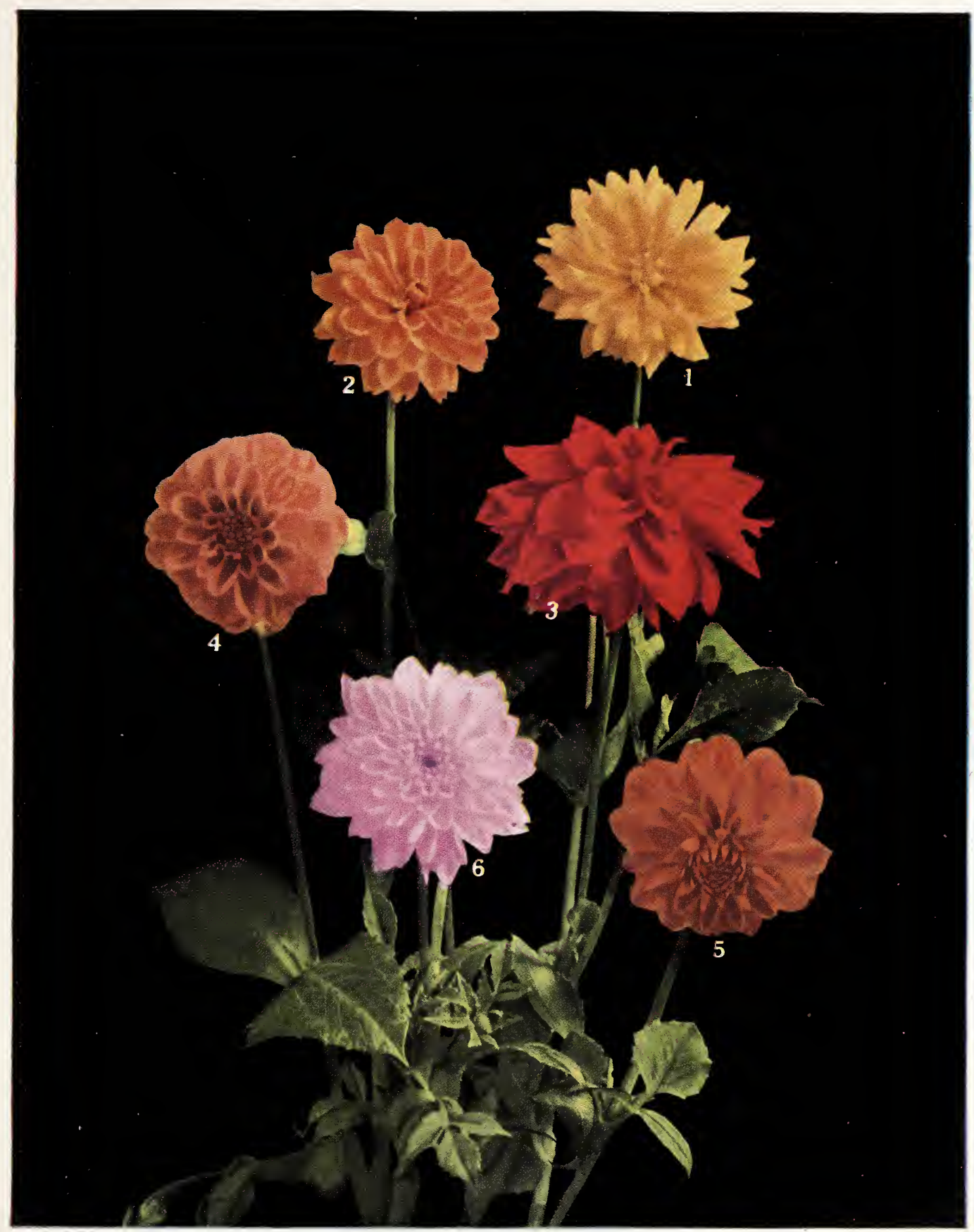

\section{MARSHALL'S ROSETTE DAHLIAS}

The above, like our pompoms, are becoming increasingly popular for use as decorative cut flowers or for landscape purposes. The key numbers to the above varieties are as follows:

1 -Charlotte

2-Pride
3 - Red Sea

4-Glow
5-Wemco

6 Little Jewel

For prices and descriptions see page 54 


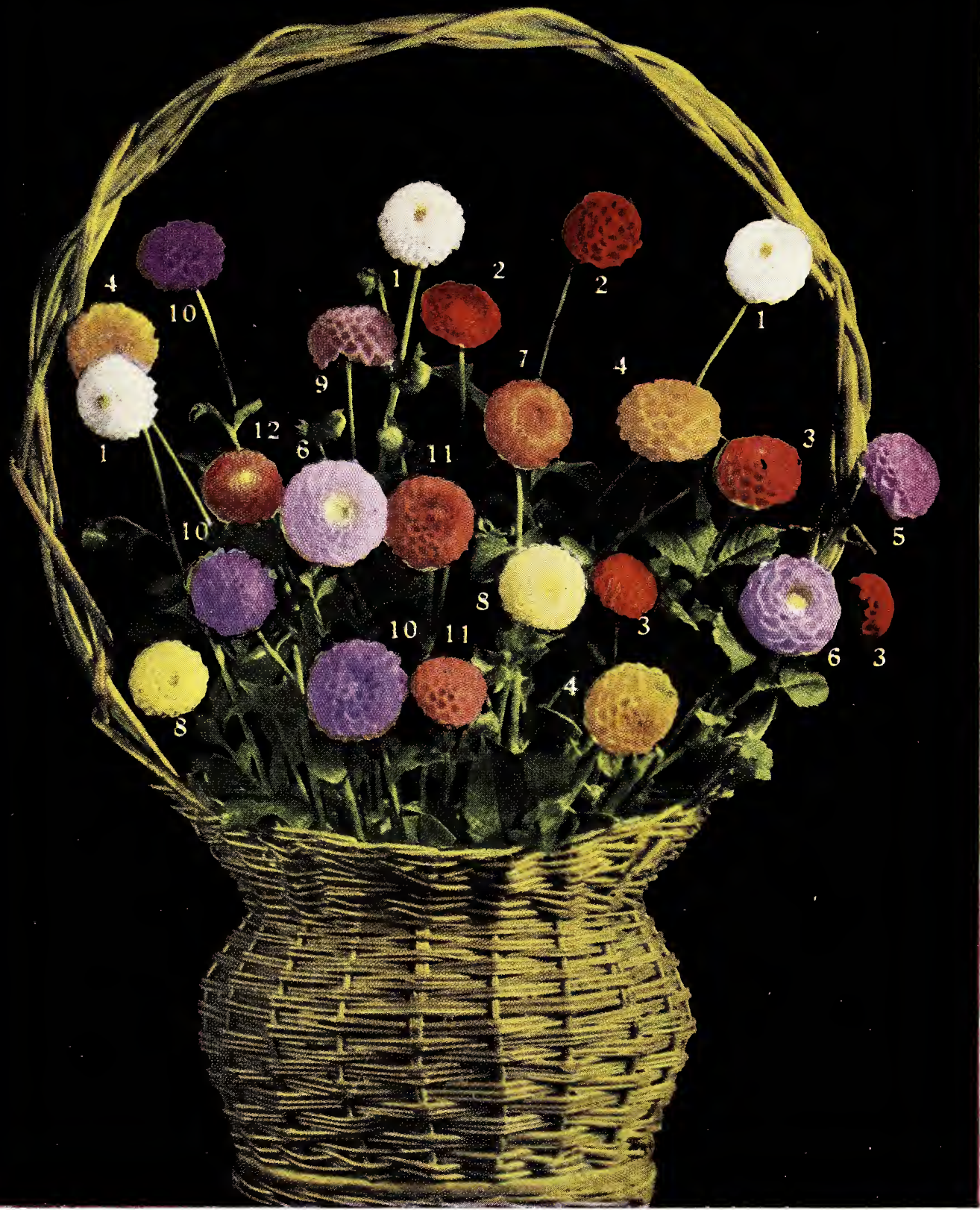

MARSHALL'S POMPOM DAHLIAS

We emphasize the fact that these are $R E A L$ pompom dahlias-not more than 2 inches in diameter. The varieties shown in color above correspond to the following numbers:

1-Wee Grace

2-Johnny

3-Ernest Harper

$\begin{array}{ll}\text { 4-Dot } & \text { 7-Sunset } \\ \text { 5-Helen Anita } & \text { 8-Catherine } \\ \text { G-Virginia Rute } & \text { 9-Isabel }\end{array}$

For prices and descriptions see page 55
10-Girlie

11-Belle of Springfield

12-Mike 


\section{POMPOM DAHLIAS}

Pompom Dahlias, long forgotten and neglected, have staged a "come back" and the reception accorded them by the visitors to our exhibit at the last New York Dahlia Show augurs well for their popularity. Easier to grow than their larger kindred, giving more prodigally of their brilliant blooms, they will be found most useful either as a cut flower or for permanent garden decoration. Being of rather dwarf growth they require very little support and disbudding is quite unnecessary. The popular prices of these little beauties will enable all lovers of flowers to grow a wide selection of varieties.

Varieties marked * are small or exhibition flowers, under 2 inches in diam.

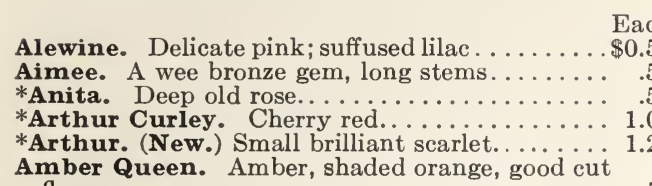

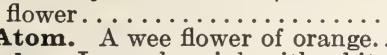

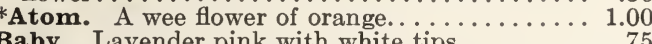

Baby. Lavender pink with white tips............... .75

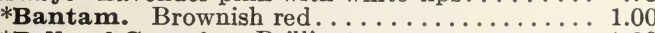

*Belle of Georgia. Brilliant orange.......... 1.00

*Belle of Springfield. Crushed strawberry . . . . .50

Billie. Dark crimson................ 1.00

Billy Tessie. Old gold edged apricot.

*Billy Fletcher. A very small Rose.

*Bobbinette. A cream white, edged with laven-

Bobby. Rich plum color; very effective. . . . . . . . . .

Bronze Beauty. Golden apricot.

Candy Kid. Coral pink suffused lavender.

Catherine. Bright canary yellow; long stems.

Charming. Exquisite lavender pink. .

* Clara Elizabeth. Extra fine Deep scarlet...

Clara Harsh. Yellow, daintily tipped crimson. . . . .50

Cora May. Salmon pink shading to primrose yellow, with a rose eye. A beauty .............. 1.50

Cybelle. Quilled red with white suffusion . . . . . . .50

*Cyril. Dark red................... 1.00

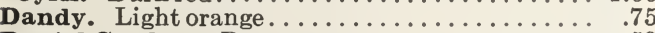

Daniel Gordon. Burnt orange............. . . . . . . . .

Darkest of All. Dark Maroon; almost black.... . . .50

Darkness. Almost black................ . . . . . .

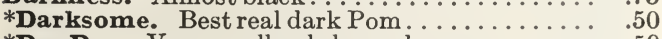

*Dee Dee. Very small pale lavender............ . .50

Dimples. Golden apricot, dark (brown) center. 1.00

Dolores. Striking deep pink of one tone....... 1.50

*Dot. Small amber..................... 1.00

Edith Bryant. Amber with rose edge . . . . . . . . . . .50

Emily Hopper. A beautiful yellow . . . . . . . . . . . .50

*Ernest Harper. Brilliant cherry red ........... . . . . . .

Fascination. An extra fine shade of pink . . . . . . .50

Fashion. A brilliant orange............ . .50

Gandy mede. A blending of sof mauve and tan. . $\quad .50$

Gene. Light gold with a brown center . . . . . . . . 1.00

George Ireland. A beautiful shade of mauve. . . . $\quad .50$

*Girlie. Lilac or mauve............... 1.00

Glow. Light rose pink or coral. Very pretty...... .50

*Goldie. A pure dot of gold ... . . . . . . . . . . 1.00

Goldilocks. Pure gold. . . . . . . . . . . . . . . 1.00

Graus Aus Wein. Crushed strawberry; a splen-

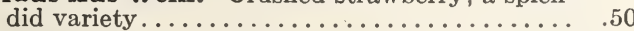

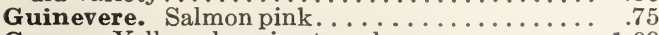

Gypsy. Yellow changing to red...................... 1.00

Harry Snook. White slightly suffused lavender. 1.00

Helen Anita. Lavender with white center . . . . . . .75

$\begin{array}{ll}\text { *Helen Cottrell. A perfect gem of baby pink. . . } & .50 \\ \text { Herbitlosse. Yellow base edged red........... } & .75\end{array}$

*Hiawatha. Extra good bright scarlet. . . . . . . 1.00

*Hilda Searl. Small bright orange... . . . . . . .75

*Ideal. Bright yellow; fine form. One of the best. $\quad .75$

Isabel. Ashes of Roses. . . . . . . . . . . . . . . .75

Joe Fette. The best and smallest white. . . . . . . .50

*Johnny. A small flower in maroon . . . . . . . . . . . 1.00

Kim. An exceptionally fine bright orange...... . . . . . . . . .

Klein Domitea. A fine light bronze... . . . . . . . .50

Lassie. Yellow base; old rose shadings. . . . . . . . . .50

Little Beauty. Neat, small pink . . . . . . . . . . . .50

Little Beeswing. Golden base, tipped red . . . . . . .75

Little Belle. Pink with white center . . . . . . . . . . 1.00

*Little Bobby. Small plum color. .
*Little David. One of the smallest oranges. . . . $\$ 0.75$

Little Dorothy. Light pink and white......... . . . .

*Little Frances. Brilliant flame red; long stems. 1.00

Little Herman. Dark red, petals tipped white... $\quad .50$

*Little Lloyd. Orange, shaded and edged rose . . . $\quad .50$

*Little Mildred. Salmon orange. . . . . . . . . 1.00

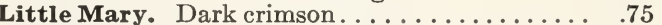

Little Sweetheart. Bright red, tipped white.... . .50

Madeline. Primrose yellow, edged rosy purple. . . $\quad .50$

Marshall's Plum. Plum shade. Plants....... 1.00

*Midget. Soft salmon, suffused violet. . . . . . . . . .50

*Mike. None smaller in burnt orange. . . . . . . . 1.25

Nea tness. Salmon with cream center ........ . . . . . .

Nerissa. A rich Cattleya or orchid pink. . . . . . . . .50

*Nora Reynolds. A tiny flower of Indian red. . . . 1.00

Oleta. Subdued Oriental red; extra long stems... . $\quad .50$

*Omega. Lavender................. 1.00

Pansy. King Tut purple................ 1.25

*Pee Wee. Yellow slightly edged with rose . . . . . . . 75

Petite. A lovely new shade of amethyst........ $\quad .75$

*Phoebe. Bright orange, very small. . . . . . . . . 1.00

*Phyllis. Deep yellow, edges red, very fine ..... 1.00

Pixy. Very small deep yellow, heavily tipped Indian red.

Pride. Extra fine scarlet. . . . . . . . . . . . . . . . . . . . .

Prince Charming. Cream tipped purple, one of the best.

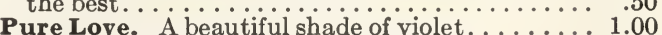

*Ralph. A wee red in perfect form . . . . . . . . . . 1.00

*Regulus. Bright purple; small and compact.... . $\quad .50$

*Rose Penelope. Crushed strawberry, amber

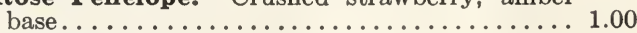

*Ruth Marshail. Variegated red and white.....

*Sizel. A wee flower almost black. . . . . . . . . 1.00

Snicker. Dark maroon; almost black. . . . . . . . 50

Snowball. Pure white. ............... .50

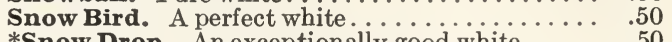

*Snow Drop. An exceptionally good white. . . . . . .50

Snow Clad. Pure white.................. .50

*Sunset. Bright orange one of the best................ 1.00

Sunshine. Red scarlet (bright) . . . . . . . . . .75

Susie. Brilliant red. Fine stems for cutting. .... 1.00

Suzanne. A pretty lavender............. 1.50

*Tiny Tim. A pretty peach pink ................... 1.00

Tom. Yellow tipped red............... 1.00

*Tom Thumb. Dull scarlet. . . . . . . . . . . . . . . 1.00

Virginia Rute. Light lavender, very small . . . . . . 1.00

*Vivid. Brightest scarlet. Extra fine... . . . . . . . . . 50

*Wee Grace. A charming little pompon of white. 1.00

*Wee Willie. Creamy white.............. 1.00

\section{COLLECTION OF POMPON DAHLIAS}

This collection is made up from varieties that sell for $50 \mathrm{c}$ to $75 \mathrm{c}$ each. Each variety is named and will include a range of all colors. Collection of 10 tubers for $\$ 3.00$. Postpaid.

\section{DAHLIA BOOKS}

Dahlias, by F. F. Rockwell. Illustrated, 80 pages. Postpaid.......................\$1.10

Modern Dahlia Culture, by W. H. Waite, Illustrated, 131 pages. Postaid................60

\section{DAHLIA PLANTS}

We offer plants of many varieties. For prices etc., see page 59 


\section{MARSHALL'S DEGORATIVE DAHLIAS}

The Decorative Dahlias have very large flowers with broad petals; they all flower freely on long, strong stems. Our list of varieties is selected from the best adapted for exhibition and cutting.

The varieties marked F.D. are Formal Decoratives and varieties marked I.D. are Informal Decoratives.

\begin{tabular}{|c|c|}
\hline $\begin{array}{l}\text { MATCHLESS COLLECTION } \\
\text { The six varieties in this collection are all recent } \\
\text { introductions of special merit. } \\
\text { Jane Cowl. I.F.D. Bronzy buff and old gold. } \\
\text { Kathleen Norris. I.F.D. True rose pink. } \\
\text { Marshall's White. I.C. A magnificent white. } \\
\text { Mrs. Alf. B. Seal. F.D. Glowing old rose. } \\
\text { Regal. F.D. Bronze and old rose. } \\
\text { Violet Wonder. F.D. The best violet Dahlia. } \\
\text { The above collection, one tuber of each, value } \\
\text { \$39.50, mailed free for } \$ 25.00 \text {. } \\
\text { Delivery after March } 1 \text { st. }\end{array}$ & $\begin{array}{l}\text { SPECIAL COLLECTION } \\
\text { This collection contains six wonderful varieties } \\
\text { for cut flowers or exhibition and are all outstanding } \\
\text { novelties of recent dates. } \\
\text { Edyth Beryl. F.D. Gold and apricot. } \\
\text { Francis Larraco. F.D. Creamy yellow. } \\
\text { Orange Beauty. F.D. Salmon orange. } \\
\text { Oyster Bay Beauty. F.D. Rich dark velvet. } \\
\text { Treasure Island. F.D. Apricot and old gold. } \\
\text { White Sister. R.C. A beautiful white. } \\
\text { The above collection, one tuber of each value, } \\
\text { \$17.00, mailed free for \$10.00. } \\
\text { Delivery after March 1st. }\end{array}$ \\
\hline
\end{tabular}

\section{SUPREME DEGORATIVES}

All varities preceded by asterisk $(*)$ are recommended for cutting.

America's Glory. Scarlet tipped white on long

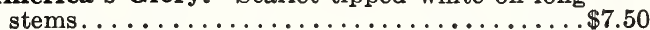
Anna Catherine Green. F.D. Orange and old

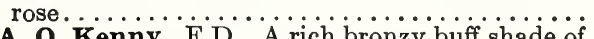
one tone, with center tinted bronze. . B........ great depth and size. Color a pinkish lavender shading to creamy white center, with reverse petals of pinkish lavender. A wonderful keeper.

* Charlotte La Frenze. I.F. Beautiful shades of yellow salmon and apricot. .............. *Chavacano. F.D. Enormous, deep bloom of rich gold

* Chelsea. I.F. Red gradually changing to white on the broad ends of the petals. Perfect large flower.......................... Plants

Chemar's Biue Gem. F.D. A glowing bluish purple, almost a Royal Purple. Stems 12 to 20 in. long.

Chemar's Giant. F. $\dot{D}$. $\ddot{A}$ very large orchid color on the best of stems. Can be grown 10 in.......

Chemar's Delight. F.D. The color is clear lemon yellow . ...................... 3.00

*Chemar's Eureka. F. D. This wonderful white was seen in its magnificent form and admired by all last year. Long stiff stems. . . . .........

*Chemar's Purity. F.D. A perfect white decorative.

Chemar's Snow white. F.D. An outstanding pure white, robust grower, large deep flower on $3 \mathrm{ft}$. cane stiff stem................. Plants 7.50

* City of Trenton. F.D. An autumn color of rich glowing tangerine, reverse strawberry red......

* Clara Fisher. F.D. Golden yellow with light rose suffusion. Excellent for cutting

Cora Butterworth. F.D. A clear silver yellow with long waved petals on extra good stems.....

Cherokee Warrior. F.D. Very large dark velvety red, never burns. An improved Fort

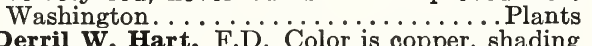
*Derril W. Hart. F.D. Color is copper, shading

tint... $\ldots$ stone. F.D. $\ddot{A}$ shade lighter than

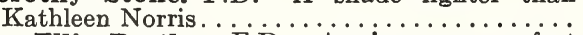

Dr. Ellis Bartley. F.D. An immense perfect flower of orchid pink. A 12-inch flower.Plants 5.00

Dr. John Carman. F.D. Tyrian rose tipped

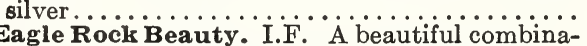

*Eagle Rock Beauty. I.F. A beautiful combination of pink and cream. Immense blooms...... verse petals........................ 2.00

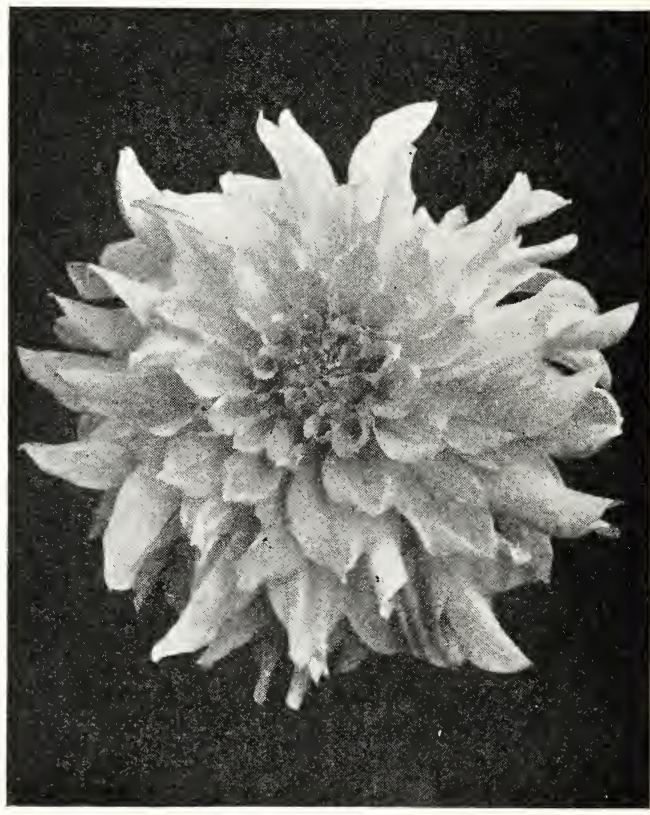

Dahlia, Jane Cowl

\section{DECORATIVES - Continued}

Edyth Holloway. F.D. Color deep scarlet, Each shaded red, tipped yellow, reflex veined lighter. Plants........................ \$4.00

*Eliza London Shepard. I.F. Deep orange gold, reflex a deeper shade of the same color . . . . .... 10.00

El Rey. F.D. A rich salmon of J. Beauty type... 5.00

Eshcol. F.D. A beautiful dark, rich velvety reddish bronze. Stems are long and stiff...........

Fairmount. I.F. A pure pink in a beautifully
proportioned bloom. Healthy vigorous grower. 5.00

Firefly. I.F. A fine petaled flower of fiery orange. 3.00

*Fireman. I.F. Bright flame scarlet, does not burn, large flower on good stem............ 3.00

Fordhook Gold Crest. I.F. Salmon pink, yellow center....................... 2.50

Fort Washington. F.D. Dark mahogany red flowers, strong robust grower . . . . . . . . . 2.00

Fordhook Radiance. I.F. A bright peach red, suffused with bronze flowers of immense size .... 2.50

*Francesca. I.F. A perfect decorative form, color brilliant bronze with lots of bright orange through it, reverse of petals a brilliant orange... 3.00 


\section{DECORATIVE DAHLIAS-Continued}

*Francis Larraco. F.D. Creamy yellow, 8 inch flowers on a 30 inch stem. .

*Frank Miller. F.D. A very large bright lemon yellow on a long straight stem. Slight suffusion at base of petals. Winner of the Gold Medal at the Atlantic City Show

Fort Morgan. I F A very dark red.large flower 8.00

Fred. W. Patterson. F.D Lavender pink with deep amaranth pink reverse, long stiff stem. .

*Golden Sceptre. F.D. A wonderful clear

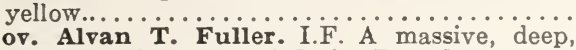
Gov. Alvan T. Fuller. I.F. A massive,

Grace Ricords. I.F. Large full, high center flowers, tipped and suffused lavender on white ground.

Harry Mayer. F.D. A beautiful silvery pink with a deep rose pink on reverse petals .

Helen Irins. F.D. A beautiful orchid lavender.

*Jane Cowl. I.F. By far the finest Dahlia seen at the Exhibitions in 1930. Deep massive blooms of bronzy buff and old gold, blending deeper towards the perfect center.

Jersey's Masterpiece. F.D. Strawberry pink suffused gold at base of the florets...........

Judge Leon McCord. F.D. An enormous flower of the deepest shade of gold with shading of

Judge Shinn. F....$\cdots$ A combination of gold and

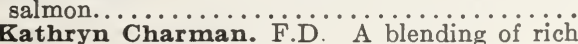

bronzy red to golden bronze in the center........

* Kathleen Norris. I.F. True rose pink, deepening later to mallow pink with central petals a lighter shade. Blooms held erect on long

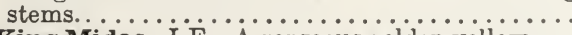

*King Midas. I.F. A gorgeous golden yellow... 7.50

Lavendula. The best lavender shade. Strong grower............................ 5.00

Mabel S. Douglas. $\dot{I} . \ddot{F}$ A clear pastel lavender. 7.50

Margaret F. Wylie. I.F. A bright vermillion rosy red, with the reverse of each petal rose and silver.

* Marshall's Blue Gem. F.D. The color is the nearest approach we have to blue. Perfect

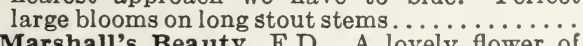

* Marshall's Beauty. F.D. A lovely flower of bright shell pink, shading lighter at the tips of the petals. At the base is seen a slight golden sheen. One of our best exhibition and cut flower varieties. ......................... Marshall's Matchless. I.F. A huge stag horn
decorative of light orchid shading to Cattleya in center. Can easily be grown 12 inches in diameter and cut with a four-foot stem........
Marshall's Pink. F.D. A wonderful shrimp

* Marshall's Pink. F.D. A wonderful shrimp grower, and one of the best for cutting. ........

*Marshall's Sentinel. F.D. Deep old rose, stems like a stake, 5 feet long. Very large flower.............................

May Trower. i.F. Color palest gold to golden apricot. A large deep flower..

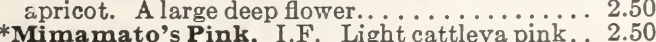

* Miss Delaware. F.D. A magnificent pink, a shade lighter than Kathleen Norris and much larger flower than Kathleen Noris and much

* Monmouth Champion. F.D. A large xan-

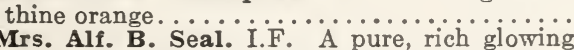

* Mrs. Alf. B. Seal. I.F. A pure, rich glowing ld rose without a trace of any other color. Undoubtedly the largest in its color produced...
Mrs. A. E. Wheeler. F.D. A wonderful decorative. The color is beautiful, fuchsia, shading to magenta with reverse of petals striped white showing in the center. Stem long and stiff......

*Nathan Hale. F.D. A shade darker than Sagamore.......................Plants. 4.00

old Hickory. F.D. Large blooms almost ball shaped of madder red with apricot suffusions. .

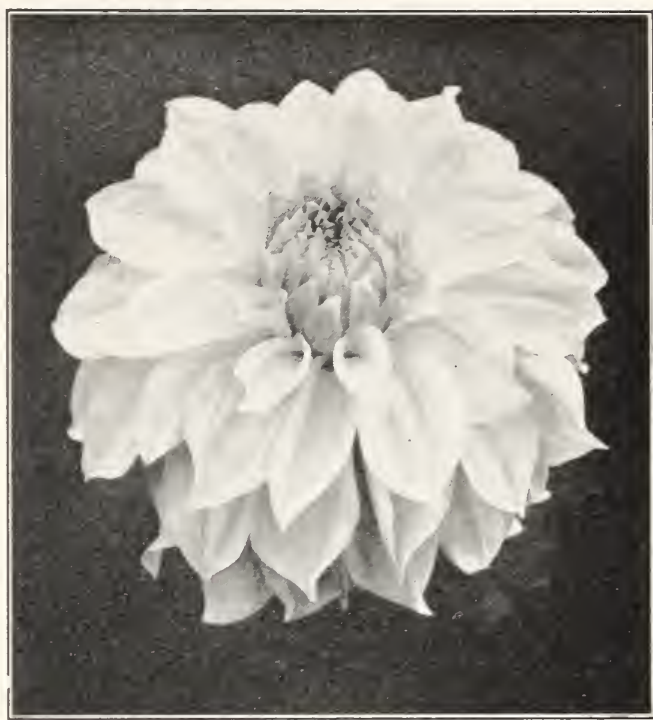

Orange Beauty

Each

*Orange Beauty (Chemar's). I.F. A wonderful salmon orange sport of Jersey's Beauty. Flowers are carried on long stiff stems making it a valuable variety for cutting. Long keeping qualities.

Orinda. I.F. A dark mauve pink. 7 feet.....7.50

President Hoover. F.D. Peach red, blending to begonia rose. A very bright color. . . . . . . 5.00

Prince of Pilsen. A striking maroon. Very large deep flower...........................

Regal. F.D. A bronze, heavily suffused old rose, shading to old gold at center.

8.00

Rose Stilson. I.F. A beautiful dark rose....... 4.00

Santa Barbara. I.F. Soft rose pink..... Plants.10.00

*Seal's Californian. F.D. Bright golden yellow at center, shading at outer petals, tips suffused very lightly with bronze rosy pink. Strong

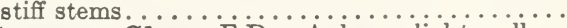

*Supreme Glory. F.D. A large light yellow, suffused rose, on a long stem.

The Spirit of St. Louis. F.D. A rose color that will not fade or burn in the sun. Flower has great depth with long stem............. Plants 2.50

*Treasure Island. F.D. One of the brightest autumn shade dahlias. Color bright apricot with old gold and rose suffusions and shadings. .

*The World. F.D. An unusually rich, deep rosy magenta overlaid with garnet.

*Violet Wonder. F.D. The best violet colored Dahlia. Fine strong stems and perfect flower...

*Watchung Chief. F.D. A combination of autumn shades.

Watchung Maroon. A beautiful ma............. 5.50

Watchung Prince. F.D. A large bright yellow.. 5.00

*Watchung Sunset. F.D. A large flower of deep shade of old rose. .

*Watchung Sunrise. F.D. "Golden amber, reverse petals and edges rose pink............

*Waldheim's Sunshine. F.D. A true deep yellow with deeper reflex. An ideal grower. ...

*Western Giant. I.F. Very bright orange with tints of gold, reverse of petals are salmon rose. . 10.00

*White Empress. F.D. A large white....... 4.00

* Yankee Queen. I.F. Silvery pink, long stem... 5.00

* Yankee King. Intense flame with rose reverse. Large flowers on bold erect stems. . . . . . . . . 2.00

Yellow Beauty. F.D Pure empire yellow, seedling of Jersey's Beauty.

* York \& Lancaster (War of Roses). F.D. The best red and white in commerce. Very effective.

\subsection{0}

5.00 


\section{DECORATIVE DAHLIAS}

The following are selected as being some of the best of the popular varieties.

Our large stocks of these enable us to offer all at popular prices.

Varieties marked thus (*) are most suitable for cutting.

*Avalon. F. Pure canary yellow.

*Amun Ra. F. Copper and orange.

Black Beauty. I.F. Dark velvety maroon.

Casper Ware. F. A bright clear violet rose.

*Couronne. I.F. Bright salmon pink.

*Dakota. F. Coral red with coppery suffusion. . .\$0.75

Dr. Tevis. I.F. Old rose suffused with gold.

*Eldorado. F. Golden yellow.

*Eleanor Vanderveer. F. Satiny rose pink.

Eliza Clark Bull. F. A very large white.

*El Toredor. F. A glowing crimson on good stem.

$*$ F. T. D. F. A rich tyrian rose color.

Flowerfield Beauty. F. Red and white.

*Florence Finger. F. A wonderful orchid.

*Golden Beacon. F. A Jersey's Beacon in gold.

*Hearts of Gold. F. Pink with golden center.

Halvella. F. A beautiful rose pink.

*Jerseys Beacon. A Chinese scarlet. . . . . . . . $\quad .75$

*Jersey's Beauty. F. A real rose pink. . . . . . .75

Jersey's Jewel. F. A monstrous mallow pink.

Judge Marean. F. Salmon pink, orange and gold.

*J. M. Goodrich. F. Pink, shaded to orange in center.

*Lilian Baldwin. F. A bright distinct watermelon pink.

*Kitty Dunlop. F. Rose pink. Good stems.

*Margaret Masson. F. A beautiful silvery rose pink.

Mordella. F. A bright apricot buff color.

Monmouth Jewel. F. Lemon chrome shading to orange.

*Mr. Dix. F. Bright orange on long stem.

*Mrs. Chas. Whitman. F. A pleasing creamy pink.

*Mrs. Jos. Svarz. F. Scarlet with each petal edged gold.

*Mrs. I. DeVer Warner. F. A deep mauve pink. $\$ 0.75$

*Oyster Bay Beauty. F. A very large maroon flower.

*Pax. F. Champagne, with rose suffusion.

*Patrick O'Mara. F. Orange and bronze... . . \$0.50

Paul Michael. F. Bright orange shading to gold.

*Paul Revere. F. Rich bright velvety red.

*Pride of Stratford. F. Copper, reflex dark coral red.

Raven. I.F. Very dark, almost black.

*Robert Scott. F. Bright apricot yellow, suffused rose.

*Robert Treat. F. American Beauty rose color.

*Rose Fallon. F. Dark orange tinted amber and salmon.

*Rosa Nell. F. Clear bright rose.

*Roman Eagle. F. Roman gold.

*Sanhicans King. F. Bright tawny gold, shading to bronze.

*Salback's White. F. Pure white.

Susan G. Trevis. F. A mulberry shade.

*Sylvia Dickey. F. Silver pink.

The Giantess. F. Buff suffused old rose.

*Tommy Atkins. F. Flaming scarlet.

The Emperor. F. An enormous purple maroon.

*Trentonian. F. A perfect flower in brown tones.

Wizard of Oz. F. A very large amber pink.

Worlds Best White. F. One of the best whites.

Tubers of any of the above except where noted.
Each..... \$1.00
Joż......\$10.00

The following list contains many of the newer varieties which we offer at reduced prices.

Altesse. I.F. Bright buttercup yellow.

Barbara Redfern. I.F. Old rose and gold.

Calvin Coolidge Jr. F. Bright rose-pink edged gold.

Champagne. F. Shades of copper and chamois.

Herald Tribune Elite. I.F. A rich pure white.

Jersey's Matchless. I.F. A beautiful golden buff.

Marie Dostal. F. A shade lighter than Champagne.

Marie. F. Deeper and brighter than Jerseys Beauty.

Marmion. I.F. Yellow with bronze suffusion.

Mrs. Francis Hadden. Yellow, free flowering.

Natures Jewel. F. A charming baby pink.

Sagamore Beauty. F. A Jerseys Beauty with violet center.

Sanhicans Delice. A true deep pink.

Sanhicans Nymph. F. Creamy yellow.

Spottswood Beauty. F. Chatney pink, edged orange

Virginia Irwin. I.F. Bright tangerene, shading apricot in center. Large flower.

Tubers of any of the above..........Each $\$ 2.00$

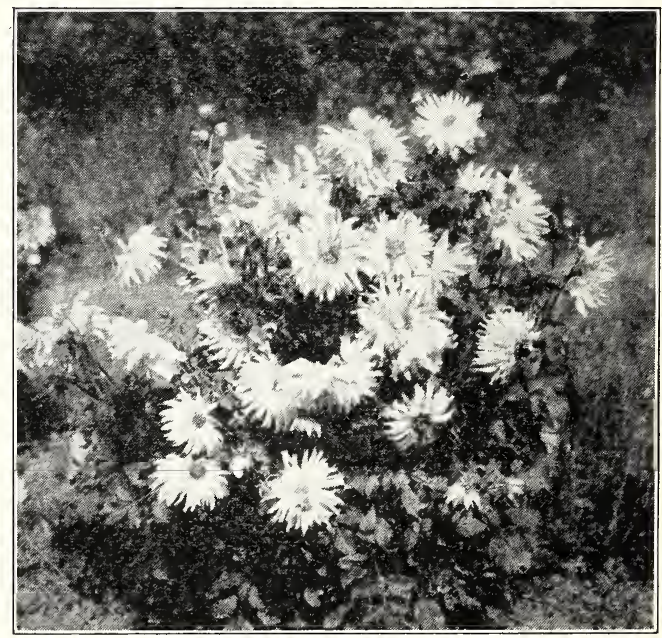

Land scape Gem Dahlia

\section{LANDSCAPE DAHLIAS}

The following varieties are best for landscape effect or use in borders. They are profusely free flowering grow about 3 to $4 \mathrm{ft}$. high and do not show any seed pods on the old flower stems.

Autumn Beauty. Dec. Tones of browns, oranges and yellows. $5 \mathrm{ft}$.

Autumn Gem. Color a rich burnished gold shading to a reddish bronze center. $31 / 2 \mathrm{ft}$.

Countess of Lonsdale. Cactus. Deep salmon red.

El Toredor. Dec. Bright ruby red. $3 \mathrm{ft}$. $\$ 0.50$

Landscape Beauty. Deep mauve, suffused lavender. $5 \mathrm{ft}$.

Landscape Gem. Cactus. Orange apricot. $3 \mathrm{ft}$.

Landscape Rose. Dec. A beautiful rose pink. $21 / 2 \mathrm{ft}$. Sanhicans Pink. A shade of ripe Calif. peach. $4 \frac{1}{2} \mathrm{ft}$.

Tubers of the above, Each. $\$ 1.00 \quad$ Doz.. $\$ 10.00$ 


\section{DAHLIA PLANTS}

We can supply green plants of all the varieties listed in this catalogue at $\$ 2.00$ or over for tubers. Dahlia Plants are not seedlings and will bloom absolutely true to the variety of tubers from which they are taken. Plants are ready for delivery from May 10th to June 20 th at the following prices.

Tubers $\$ 10$. Plants $\$ 5.00$. Tubers $\$ 7.50$. Plants $\$ 4.00$ Tubers $\$ 5$. Plants $\$ 2.75$. Tubers $\$ 3.50$. Plants $\$ 2.00$ Tubers $\$ 3$. Plants $\$ 1.75$. Tubers $\$ 2.00$. Plants $\$ 1.25$

All Plants sent by Parcels-Post prepaid.

Our experience and method of packing for Parcels-Post enables us to guarantee that they will arrive at destination in perfect condition.

All our Dahlia plants are grown and shipped in Firtex Pots.

\section{GUARANTEE}

While we exercise every care in digging and shipping that varieties are true to name we cannot guarantee stock sent out by us but we will replace any stock that may prove not true to name

If you receive any tuber that fails to show any growth kindly notify us and we will replace same.

\section{PRICES}

The prices in our list are regulated by the stock of tubers we have to offer in many cases and are often ower than many of our competitors.

\section{MARSHALL'S \\ ELITE COLLECTION OF DAHLIAS}

This collection consists of 12 named varieties of recent novelties. Each variety is carefully named and would retail from $\$ 1.50$ to $\$ 2.50$ each if purchased separately. The varieties are carefully balanced as to color and guaranteed true to name. Collection of 12 tubers $\$ 10.00$.

\section{SPECIAL COLLECTION OF DAHLIAS}

This collection is made up from varieties that retail for not less than $\$ 1.00$ each. Each variety is carefully named and comprises a wide range of color in 12 distinct varieties.

Collection of 12 tubers $\$ 5.00$. If by mail add $15 \mathrm{c}$. for postage.

\section{DOUBLE DAHLIAS}

We have some fine tubers of unnamed varieties in Lavender, Pink, Red, White or Yellow colors, separate. Each $25 \mathrm{c}$., doz. $\$ 2.50$.

All prices of Dahlias are for Tubers unless otherwise stated.

Tubers. We ship tubers in April unless otherwise ordered.

Any tuber that fails to grow, if returned to us in season, will be replaced free of charge.

Plants. We guarantee delivery of all plants to arrive in good condition; shipment will be made about the end of May.

\section{Dahlias from Seed}

Wonderful Dahlias may be grown from seed and they will bloom the first season, making as large plants and tubers as if grown from bulbs. Bear in mind that each seedling will be a new variety. This makes it the most fascinating part of growing Dahlias. They are seldom like the parent plant in type or color. All the fancy Dahlias of today were grown from seed. Many of them were produced by seed grown by amateurs and sold to growers at fancy prices.

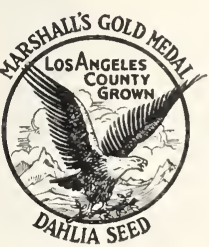

Seed produced in Southern California is superior to that from any other place, as the climate conditions are such that the extra large double varieties produce seed. This is due to the long, rainless seasons.

Growing Dahlias from seed is one of the most interesting stages of Dahlia cultivation. Our seed is carefully selected from the choicest varieties. We send postpaid to any post office in the United States, Dahlia seeds in packets.

We are offering $\$ 50.00$ for the best seedling grown from this seed and shown at the A. D. S. Show, Sept. 1930.

First Prize, $\$ 25.00$; Second Prize, $\$ 15.00$; Third Prize, $\$ 10.00$

\section{POMPON DAHLIA SEED}

We offer a strain saved from the best of the named varieties of Pompons.

Mixed Pompons. 50 seeds for $\$ 1.00$.

\section{ROSETTE DAHLIA SEED}

Seeds saved from Little Jewel plants

Rosette. 50 seeds for $\$ 1.50$.

\section{MARSHALL'S GOLD MEDAL XXX SEED}

All pedigreed hand picked from selected flowers. Pods ripened on plants. You may buy rheaper seed, we doubt if you get better. We can supply seed from the varieties listed below with name of seed bearing parent on package or in mixture.

$\begin{array}{ll}\text { Aztec Glory } & \text { Jane Cowl } \\ \text { Barbara Ware } & \text { Kathleen Norris } \\ \text { Galli Curci } & \text { Mrs. A. B. Seal } \\ \text { Eagle Rock Jewel } & \text { Peper's Delight } \\ \text { Edna Ferber } & \text { Watchung Sunrise } \\ \text { Fort Monmouth } & \text { Mixture of above }\end{array}$

50 seeds (10 seeds of 5 varieties $\$ 5.00,100$ seeds (10 seeds of 10 varieties) $\$ 8.00$, mixture 50 seeds, $\$ 5.00$, 100 seeds $\$ 8.00$.

\section{MARSHALL'S XX. SOUTH} GALIFORNIA GROWER'S SEED
Ambassador

Champagne

Eleanor Vanderveer

Jersey's Beacon

Mrs. I. de Ver Warner Sagamore

\author{
Elite Glory \\ Faith Garibaldi \\ Jersey's Beauty \\ Shudow's Lavender \\ Marshall's Pink \\ Mixed Seed
}

50 seeds (10 seeds of 5 varieties) $\$ 3.00,100$ seeds (10 seeds, 10 varieties) $\$ 5.00,300$ seeds (30 seeds, 10 varities) $\$ 10.00$, mixture 50 seeds, $\$ 3.00,100$ seeds $\$ 5.00$.

\section{SINGLE DAHLIA SEED}

Any of the Single varieties are easily grown from seeds and will bloom profusely the same season. Pkt. Coltness Hybrids. Mixed .............\$0.50 Coltness Yellow. Clear yellow.................... .50 Coronata. Sweet scented, orange, scarlet on outer

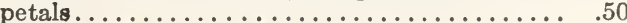
Mignon Mixed. English dwarf ................ .50 


\section{GLADIOLUS}

There are no other Summer-flowering bulbs so satisfactory, needing so little attention and thriving so well in almost any ordinary soil as the Gladiolus. Set the bulbs from 3 to 6 inches apart in rows, or for massing 6 inches apart, and about 4 inches deep.

Our selection has been made from many varieties and includes all those of exceptional merit and a wide range of colors.

\section{BLUE, LAVENDER AND PURPLE SHADES}

Anna Eberius. Dark velvety purple, pansy-purple Doz. blotch in the throat. Beautiful variety.....3 for $35 \mathrm{c} . \$ 1.25$ Annie Laurie. A dainty delicate pink, semi-ruffled.

Baron Hulot. A fine violet-blue..... 3 for 60c. 2.00

Duchess of York. The best blue, large flower well placed

on long stems............................. 5 for $50 \mathrm{c} .00$

Henry Ford. Very dark Rhodamine purple. Flowers in two rows which face opposite............ 3 for $35 \mathrm{c} .1 .25$

Herada. Pure mauve with deeper markings on throat. 3 for $30 \mathrm{c} .1 .00$

Louise. Orchid lavender with deeper blotch in throat. Wide open flower on strong stem.......... 3 for $30 \mathrm{c} .1 .00$ Minuet. A self colored lavender, rich, very large flower of heavy substance................. for $\$ 1.006 .00$

Mr. Mark. Light blue with darker throat; robust grower. 3 for $40 \mathrm{c}$. $1.50 \quad 10.00$

Mrs. Fred C. Peters. Fine lilac-pink with purplish blotch in throat. Large flowers with long, erect stems. 3 for 40c. $1.50 \quad 10.00$ Muriel. An extra good light blue with darker throat blotch............................. 3 for $35 \mathrm{c} . \quad 1.25 \quad 8.00$

Persia. Velvety dark maroon, with a luminous sheen, buds shiny black, medium size flower, early and attractive............................... 3 for $35 \mathrm{c} .1 .25$

Prince of India. Color varies from light to deep smoky gray, banded and penciled with deep slaty blue, mottled white......................Each 50c. 4.50

100 $\$ 8.00$ 15.00 9.00 12.00 8.00 7.00 7.00 40.00 30.00

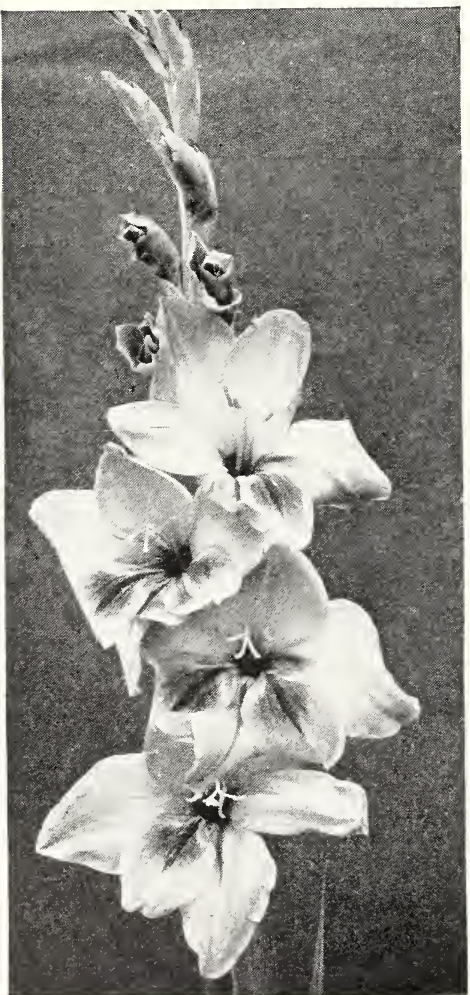

Gladiolus, Evelyn Kirtland

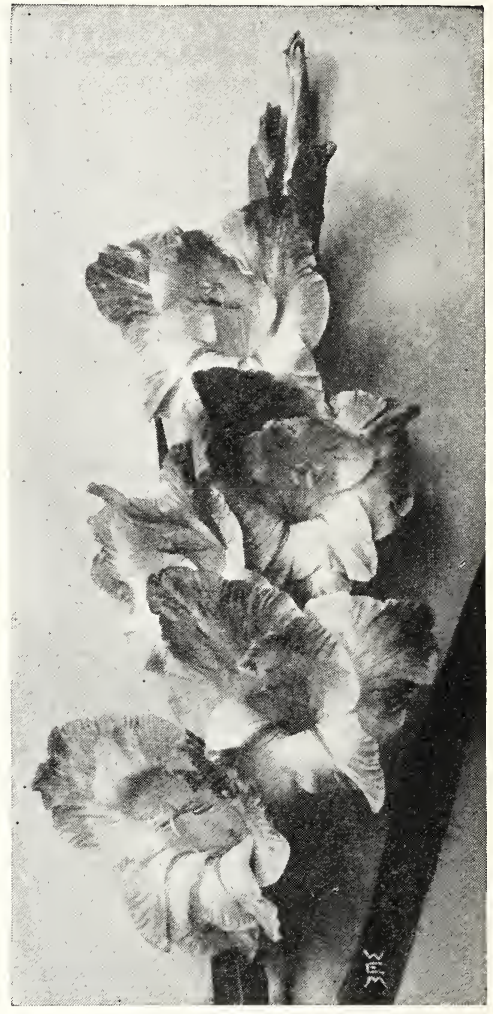

Gladiolus, Ruffled, Dearest
Purple Glory. Velvet maroon. Large ruffled flowers; doz. 100 extra fine spike...................... for 40. $1.50 \quad 10.00$ Rev. Ewbank. A fine porcelain blue................ for 50c. $2.00 \quad 12.00$

Saraband. Very large flower of rich velvety bordeaux with straw yellow blotch, feathered bordeaux. Each 30c.. $3.00 \quad 20.00$

violet Glory. Large flower, rich self-color of deep velvet, deeper throat. Medium ruffled.............3 for 50c. 2.0015 .00

\section{PINK, ROSE AND SALMON SHADES}

America. Large flower, beautiful flesh pink.....3 for 25c. $\$ 0.75$ Arlene. A uniform, pale rose-pink, shading in the throat to a pale flesh-pink, with deep crimson base. A beautiful variety...........................Each 50c. $4.50 \quad 30.00$ Arizona Rose. $\ddot{A}$ charming shade of light old rose. 3 for 30 c. $1.00 \quad 6.00$ Break of Day. A very clear light pink. Early and tall spike.

Byron L. Smith. A delicate lavender pink 3 for 35c. 1.258 .00 ground, yellow throat..................... w for 40c. 1.5010 .00

Evelyn Kirtland. Rose-pink, darker at the edges and fading to shell-pink in center..................... for 30c. $1.00 \quad 7.00$

Dearest. A glorious flower of most delicate tints. The ground is a flesh pink blending to a rich pink at the tips, mottled and striped with crimson. Flowers beautifully

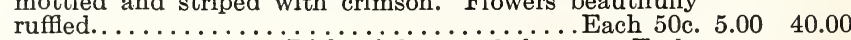

Dorothy McKibbin. Rich pink, mottled rose. Early flowering and beautifully ruffled.............. 3 for $35 \mathrm{c} .1 .25 \quad 8.00$

E. J. Shaylor. A beautiful, pure, deep rose-pink; tall, strong plant and large ruffled flowers................ for 30c. $1.00 \quad 6.00$

\section{All Gladiolus we offer are First Size Bulbs.}

6 bulbs sold at the dozen rate. 25 at the 100 rate. 


\section{GLADIOLUS-Continued PINK AND ROSE (Continued)}

Giant Nymph. Light rose pink color with creamy yellow throat......................... for $40 \mathrm{c} . \$ 1.50$ Halley. A very attractive delicate salmon-pink.

Kunderdi Glory. Creamy apricot with light tint of pink and red on the lower petals. Ruffled. 3 for $35 \mathrm{c} .1 .25$ La Couronne. Creamy white with throat blotched with dark maroon, bordered pale yellow..3 for 35 c. 1.25

Le Marechal Foch. Pure pink of immense size.

Longfellow. Entire flower of clear La France pink, prominent lighter mid-rib. A fine exhibition variety................................. for 60c. 2.00

Los Angeles. A beautiful grenadine or orange tinted pink. Also called the "Cut and Come Again" as it of ten sends up new spikes after being cut. 3 for $35 \mathrm{c} .1 .25$

Marietta. A delicate shade of light salmon, blended with light orange, lower petals shading to bright burnt orange....................2 for 40c. 2.00

Mrs. Dr. Norton. Pale pink, with primrose center yellow blotch on lower petals..........3 for 35c. 1.25

Mrs. Frank Pendleton. The flowers are very large, of lovely flushed salmon-pink, with brilliant carmine blotches in the throat. ...........3 for $25 \mathrm{c}$

Mrs. H. E. Bothin. Flesh salmon-pink, flame scarlet center. Beautiful combination of color. Ruffled.

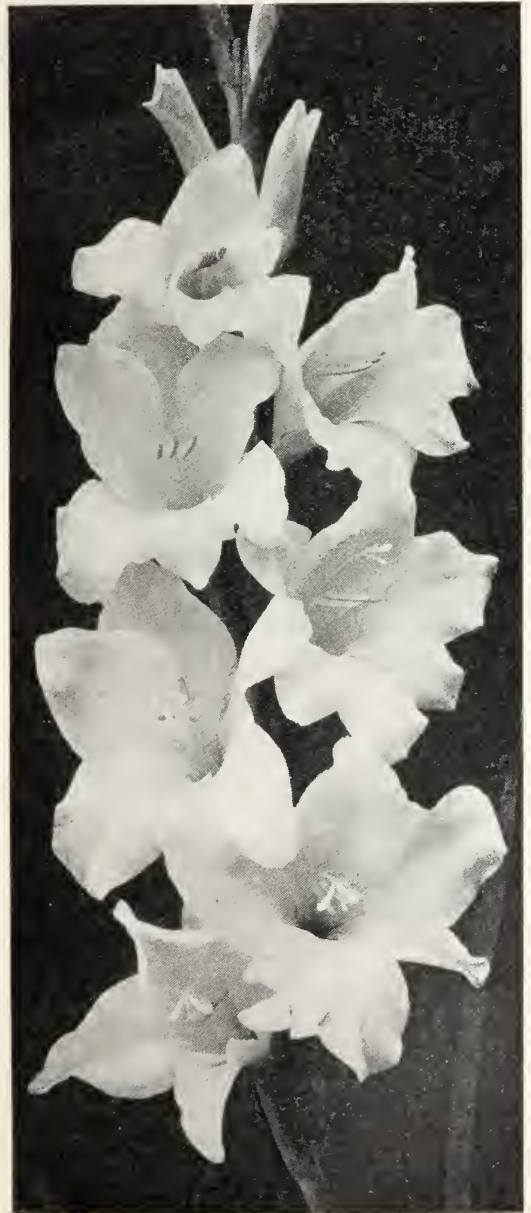

Gladiolus Pink Perfection

$$
3 \text { for } 25 \text { c. } \quad .75
$$
3 for 25 c. $\quad .75$

100

$\$ 10.00$

8.00

12.00

8.00

15.00

7.00

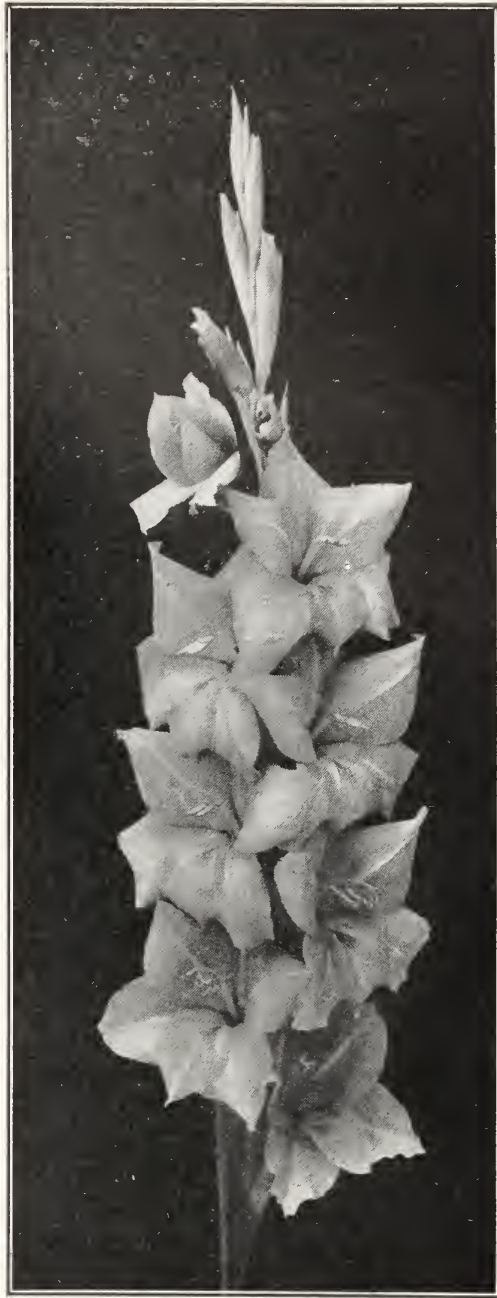

Longfellow

Doz. $\quad 100$

Mrs. Leon Douglas. Begonia rose striped with flame, lower petal pale lemon, speckled ruby. One of the largest glads in existence... . ..3 for 40c. $\$ 1.50 \quad \$ 10.00$

Mr. W. H. Phipps. La France pink, overlaid with salmon rose, lower petals faintly striped and speckled with ruby; enormous flowers and spike. 3 for 60 c. $2.00 \quad 12.00$

Nancy Hanks. Very rich peach-red to orange pink, with prominent grenadine tongue......2 for $40 \mathrm{c} .2 .00 \quad 15.00$ Odin. Deep salmon pink, with intense carmine blotch on lower petals; large flowers.......3 for 30c. $1.00 \quad 7.00$

Osalin. A lovely coral pink with soft orange markings in the throat.............................. 600

Pink Perfection. Bright pink.......... 3 for 35c. 1.25

Pink Wonder. A beautiful pink, slightly lighter than Panama................................... 1.25

Pride of Goshen. A very large salmon or flesh pink. Exceptionally tall spike. Ruffled.......3 for 35c. 1.25 Prince of Wales. Beautiful light salmon with orange shade, very early....................3 for 30c. 1.00

Richard Diener. Very live rose salmon with creamy yellow center. Spikes with 10 to 12 flowers open at one time........................ 3 for 50 c. 2.00

Rose Precose. A beautiful salmon-rose, slightly ruffled. Tall, straight spike...........3 for 50c. 2.00 Tyco Zang. Clear salmon pink with white throat. 


\section{GLADIOLUS-Continued RED, SCARLET, TYRIAN \& ORANGE SHADES}

American Beauty. American Beauty Rose color, rose throat. One

of the garden aristocrats........................... for 50c. $\$ 2.00 \$ 12.00$ Ashes of Roses (Rose Ash). Corinthian red, fading to ashes of roses on the outer edge. Flowers well set on a very large, tall spike.

Crimson Glow. A perfect scarlet of a deep tone on a tall spike.

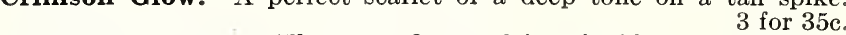

Dr. F. E. Bennett. The most fiery red imaginable. A monster in

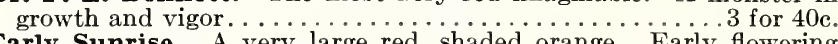
Early Sunrise. A very large red, shaded orange. Early flowering and a fine forcing variety...........................

Flaming Sword. A brilliant red with orange overtone.....3 for 35c.

Furnace. A beautiful salmon orange, with a crimson scarlet throat,

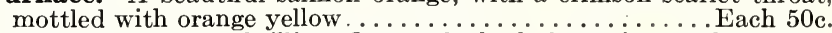

George J. Joerg. A brilliant flower, the bud of carmine-scarlet, toning as it opens to a beautiful salmon-pink with creamy yellow and scarlet

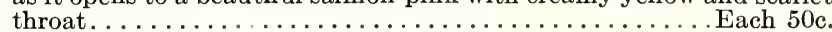

Joerg's Favorite. A pale cream, feathered and splashed with bright

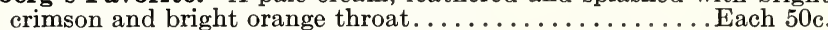

John T. Pirie. Mahogany brown with yellow bordered brown throat.

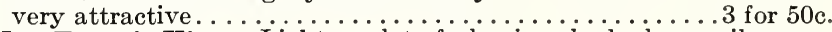

Mrs. Francis King. Light scarlet of pleasing shade; long spikes, one

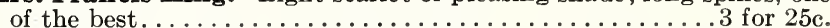

Orange Glory. Grand orange colored with beautiful lighter throat;

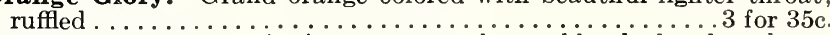

Pfitzer's Triumph. A giant orange salmon, blotched red on lower

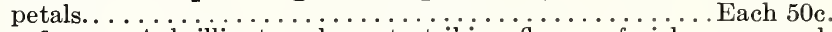

Scarlano. A brilliant and most striking flower of rich orange-red.

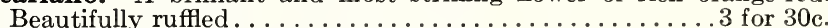

Rose Ash. (See Ashes of Roses).

Scarlet Wonder. Purest deep scarlet, mammoth flowers on tall stiff

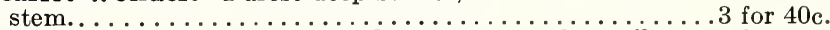

Sunnymede. A rare shade of Orange yellow, fine spike...3 for 60c.

Taro. Color deep American Beauty rose. A real beauty... 3 for $35 \mathrm{c}$.

Virginia (Scarlet Princeps). A very large spike of massive crimsonscarlet flowers. Five to six open at one time........... for 30c. $1.00 \quad 6.00$

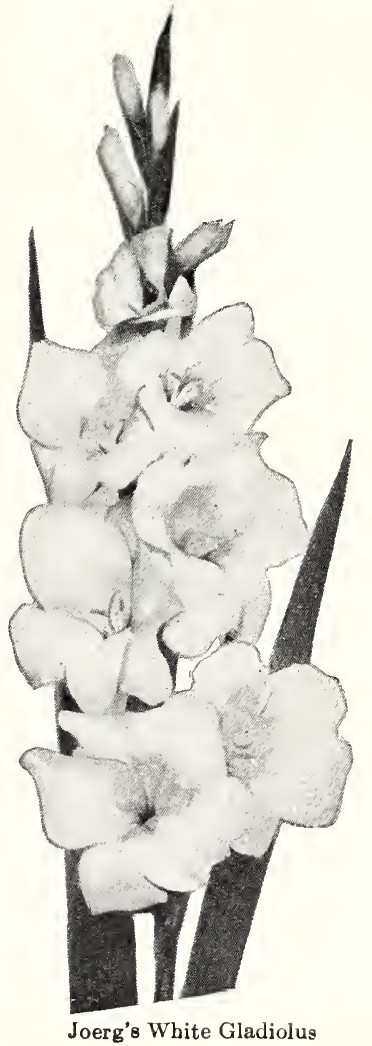

Doz. 100

1.25

1.00

8.00

$1.50 \quad 10.00$

$1.50 \quad 10.00$

$\begin{array}{lr}1.25 & 8.00\end{array}$

$4.50 \quad 30.00$

$4.50 \quad 30.00$

$5.00 \quad 40.00$

$2.00 \quad 15.00$

$.75 \quad 5.00$

1.258 .00

$5.00 \quad 40.00$

$1.00 \quad 6.00$

$\begin{array}{ll}1.50 & 10.00\end{array}$

$2.00 \quad 15.00$

$\begin{array}{lr}1.25 & 8.00\end{array}$

WHITE, CREAM AND BLUSH SHADES

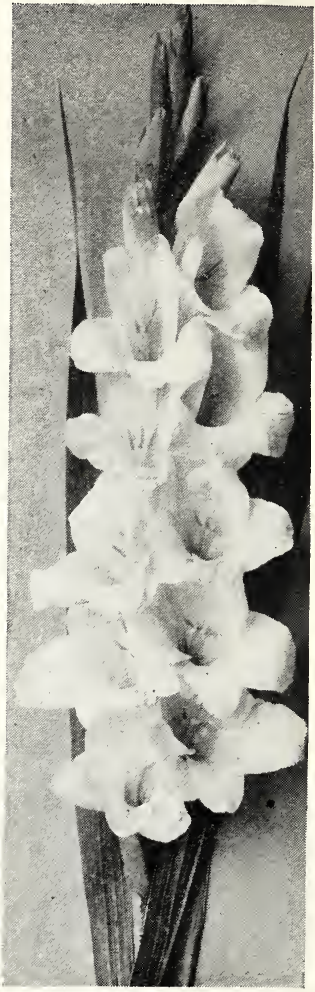

Gladiolus Delighted

Doz.

100

Captain Boynton. Color white, brushed with lavender and maroon blotch on lower petals..............

Delighted. Creamy white turning to pure white, with tint of fawn yellow in throat, veined crimson, blue anthers. A huge

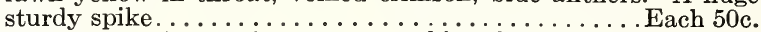

Fern Kyle. A massive creamy white, large flowers slightly ruffled ............................. 3 for $50 \mathrm{c}$

Joerg's White. This is one of the largest flowered Gladiolus and the finest and purest of all white varieties. Spikes 3 to $4 \mathrm{ft}$. high and flowers 5 in. across.................. Each $50 \mathrm{c}$

Lily White. A fine snow-white of good height and large flower. 3 for $30 \mathrm{c}$.

L'Immaculee. A beautiful pure white, very tall grower. 3 for $35 \mathrm{c}$.

Mary Pickford. A delicate creamy white. Throat finest sulphuryellow . . . . . . . . . . . . . . . . . . . . .

Miss Helen Franklin. A good white with faint lavender markings; ruffled flowers well placed on stem........... 3 for 30c.

Mona Lisa. Palest rose-pink or blush white. A gorgeous ruffled flower.

Peace. The flowers are large, white with a pale lilac feathering on the interior petals...................... White City. Very large, almost pure white flowers, spikes $5 \mathrm{ft}$. tall. A grand variety..................... 3 for $40 \mathrm{c}$

white Glory. A gorgeous pure white, with beautiful Iris-blue throat; ruffled....................... 3 for $40 \mathrm{c}$.

White Wonder. Pure white with faint lavender pink tints, large wide open flowers. ................... 3 for $30 \mathrm{c}$.

\section{YELLOW SHADES}

Gold. A very fine pure yellow.............. 3 for 40 c. Gold Measure. A magnificent yellow. Very large open flowers; - immense spike......................... 3 for $50 \mathrm{c}$ Golden Dream. A very tall clear deep yellow......... Each 40c. Niagara. Beautiful cream shade with lower petals blending to yellow inside; throat splashed carmine. ......... 3 for $30 \mathrm{c}$. schwaben. Delicate, pale yellow, dark blotch in center. 3 for $30 \mathrm{c}$.

Yellow Hammer. Pure Yellow, with a small red mark in the throat. A fine forcer.......................
$\$ 2.00 \quad 15.00$

$4.50 \quad 30.00$

$\begin{array}{ll}1.75 & 12.00\end{array}$

$4.00 \quad 30.00$

$1.00 \quad 6.00$

$1.25 \quad 9.00$

1.258 .00

$1.00 \quad 7.00$

$1.00 \quad 7.00$

$1.00 \quad 6.00$

$1.50 \quad 10.00$

1.5010 .00

$1.00 \quad 7.00$

$\begin{array}{ll}1.50 & 10.00\end{array}$

$3.50 \quad 25.00$

$1.00 \quad 6.00$

$1.00 \quad 6.00$

$1.00 \quad 7.00$
$1.50 \quad 10.00$ 


\section{GLADIOLUS-Continued PRIMULINUS GLADIOLUS}

This race of Gladiolus has come to be extremely popular: they are easy to grow, beautiful for decorations; the colors are very artistic and embrace shades of yellow, pink and scarlet.

Alice Tiplady. A grand, large, beautiful

Doz. 100

orange-safiron color......... 3 for $30 \mathrm{c} . \$ 1.00 \$ 6.00$

Dorothy Wheeler. Flowers richest rosepink with lighter throat. Very large and massive................... for 30 c. 1.00

Ethelyn. A beautiful shade of orangeyellow, petals tipped with bronze. Throws many side spikes..2 for 40c. 2.00

Golden Gate. Light yellow with faint red lines in throat. Ruffled showy flowers................... 3 for $35 \mathrm{c} .1 .25$

Jewel. A clear salmon-pink with golden throat. Tall, erect, early flowering.

Joerg's White Prim. Purest white in color and perfect Primulinus form. A sterling novelty........Each 50c. 5.00

Joerg's Yellow Prim. A new and distinct Primulinus. A flower spike $5 \mathrm{ft}$. high, carrying 12 to 18 large pure yellow flowers. Flowers large and wide open................... 3 for 60 c. 2.00

Maiden's Blush. Enchantress pink Well-shaped flowers on long, strong stems.................... for 30 c. 1.00

Ming Toy. Tall large, beautiful buff, yellow center...........3 for 30 c. 1.00

Myra. Deep salmon on yellow ground with faint lines in throat. Very large flowers on long stem.......3 for 30c. 1.00

Orange Queen. Large flowers, orange yellow, tinted apricot. A grand variety .................... 3 for 30 c. 1.00

Phantasy. A clear salmon pink with coral margin, buds are brilliant orangescarlet. The flower petals are pale yellow, edged pink, with crimson veined throat. The upper petal folds back. Early flowering..........3 for $40 \mathrm{c} .1 .25$

Primulinus Species. Small orange yellow flowers on long spikes. Very dainty for decorating.......... 3 for 50 c. 2.00

Salmon Beauty. Deep salmon with rich salmon-yellow throat....3 for 35c. 1.25

Shell Pink. Very large beautiful shell pink, almost self color. ....3 for 50 c. 1.50

Souvenir. A superb large flowering deep yellow.............. 3 for 30 c. 1.00

White Butterfly. A popular white with creamy white throat. Strong grower. ...................... 3 for 40c. 1.5010 .00

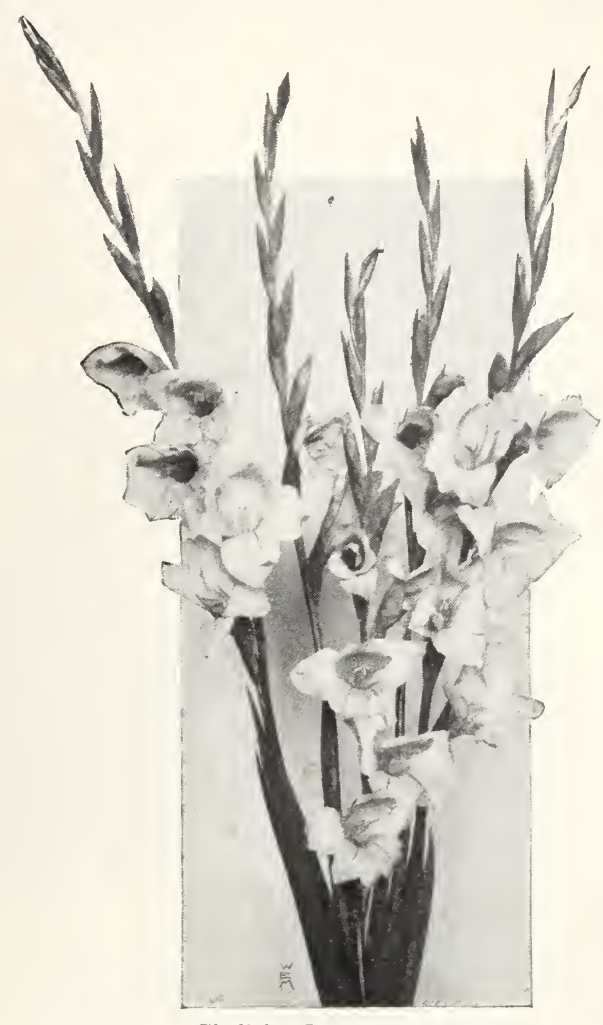

Gladiolus Joerg's Yellow Prim

\section{PRIMULINUS HYBRIDS}

$A$ very select mixture from the newest hybrids; the most beautiful and delicate tints are found among them and no race of Gladiolus contains such harmonious blendings of color.

Doz. $100 \quad 1000$

Selected Mixed Hybrids........\$0.60 $\$ 4.50 \$ 40.00$ We shall be pleased to supply any varieties not listed at advertised prices.

\section{GLADIOLUS IN MIXTURE}

Our mixtures are made up from fine varieties and are all selected first size bulbs. $\quad$ Doz. $100 \quad 1000$ Marshall's Matchless Hybrids. This is our general mixture and is composed of fine sorts in

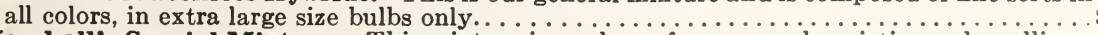

Marshall's Special Mixture. This mixture is made up from named varieties and seedlings.

They are splendid for cutting and borders............................ $1.00 \quad 7.00 \quad 60.00$

\section{GLADIOLUS FOR LATE PLANTING}

Gladiolus can be had in flower in late September and October if the bulbs are retarded in cold storage.

We are prepared to place in cold storage any varieties if ordered before the middle of April and ship at any date required for later planting.

Gladiolus bulbs dipped in a solution of Semesan will prevent hard rot and other diseases.

\section{GLADIOLUS by F. F. Rockwell}

This is a compact and handy work-book for the grower of Gladiolus, both for cut flowers and for pleasing effects in the home garden.

The suggestions on how and where to use "Glads" and types and varieties will be helpful in making out orders. The chapters on care and culture, increasing the stock, creating new varieties, growing and exhibition, and harvesting and storing, will bring pleasure and success throughout the growing season.

Mr. Rockwell is himself a grower of "Glads," has had life experience in the commercial production of the bulbs, and is the author of several books on gardening. 


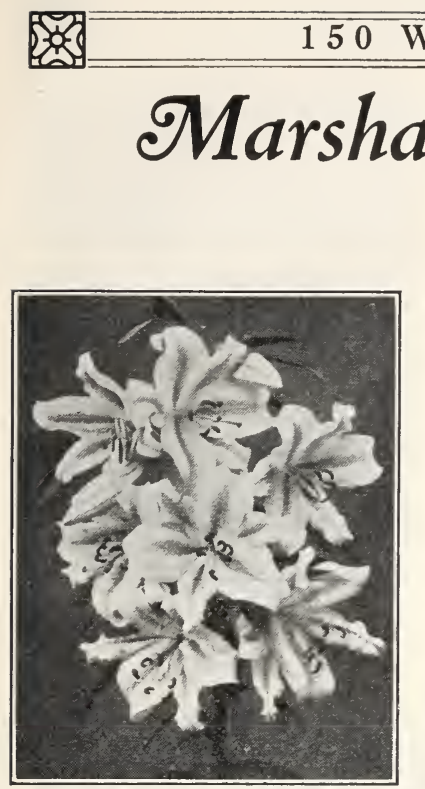

Lilium auratum platyphyllum

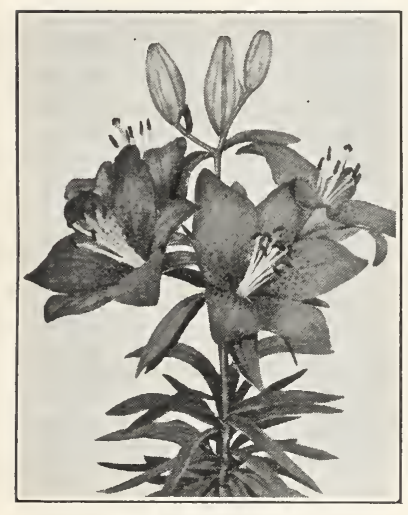

THAT WILL BLOOM

FROM JUNE TILL

LATE SEPTEMBER

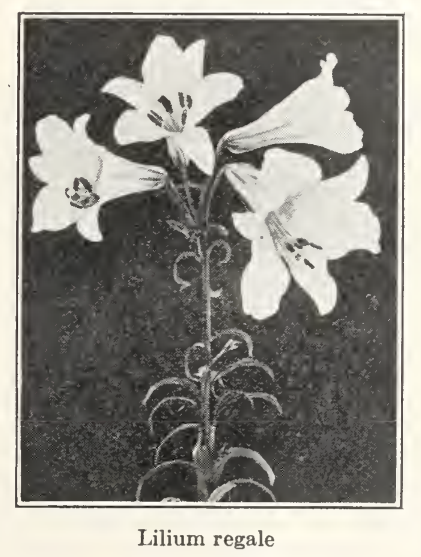

All absolutely hardy and sure to bloom the first year

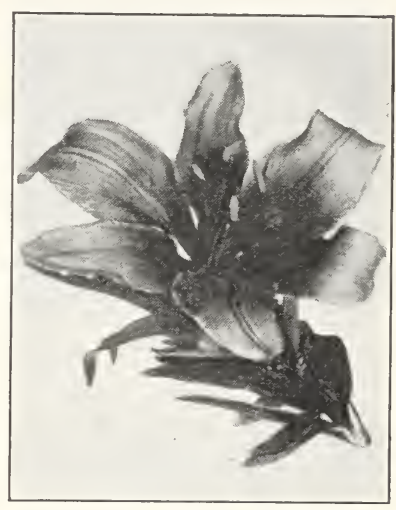

Lilium elegans atrosanguineum

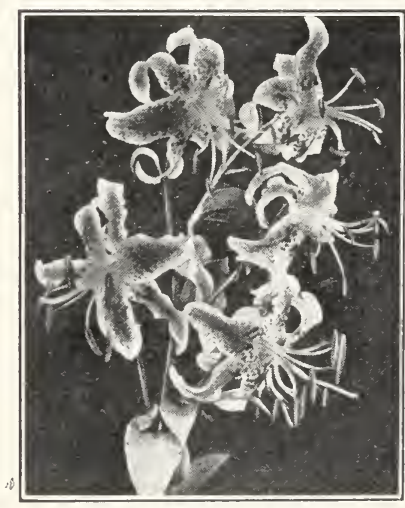

Lilium speciosum rubrum melpomene

We have prepared the following collection of eight varieties of Lilies that can be planted in Spring and that are positively sure of providing a continuous bloom from June to late September the first year if planting directions are followed in the book "Consider the Lilies."

3 large flowering bulbs of each of the following ( 24 bulbs in all):

AURATUM PLATYPHYLLUM, CROCEUM,

ELEGANS ATROSANGUINEUM, HENR YI, REGALE, SPECIOSUM

RUBRUM MELPOMENE, UMBELLATUM GRANDIFLORUM, COLUMBIANUM

The above collection, valued at $\$ 12.75$, mailed free for $\$ 10.00$.

In addition to this generous offer we will include the beautiful book "Consider the Lilies" as described on page 64. This valuable book will be mailed immediately on receipt of $\$ 10.00$ for the Lily Collection. The bulbs will follow at the proper time for planting.

A total value of $\$ 12.75$ for $\$ 10.00$, mailed free. 


\section{MARSHALL'S ORNAMENTAL LILIES}

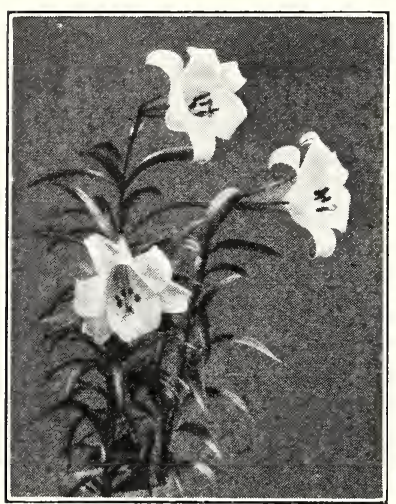

Lilium Browni

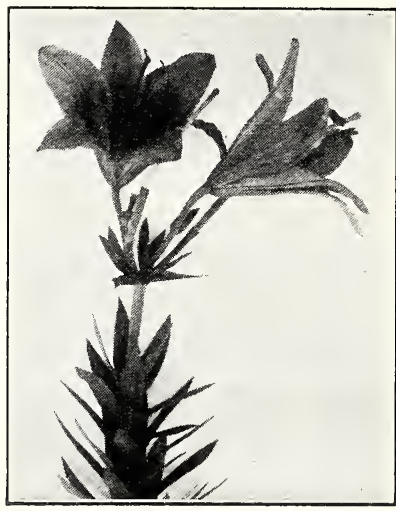

Lilium davuricum

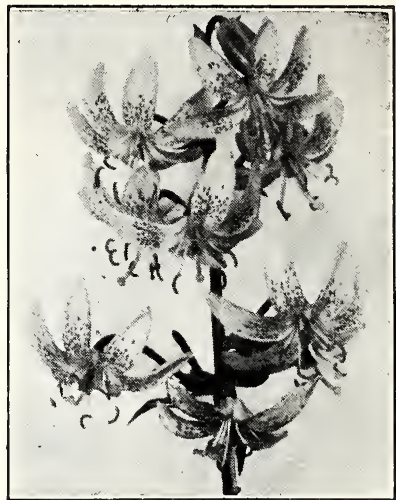

Lilium hansoni

\section{HARDY LILIES}

Among the stateliest of all hardy plants, Lilies during their respective flowering seasons, constitute the chief atraction in the hardy border. They prefer a well-drained soil, and should remain undisturbed for years. In the Autumn give the bulbs a heavy mulching of leaves; coarse manure or straw will prove highly beneficial. Plant all Lilies as early as possible in the Spring.

Auratum. (Goldband Lily), White with gold bands,

‘6

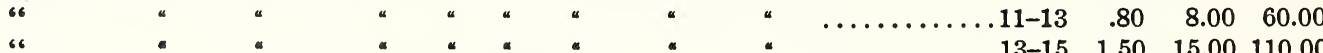

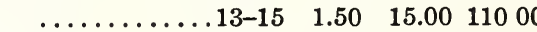

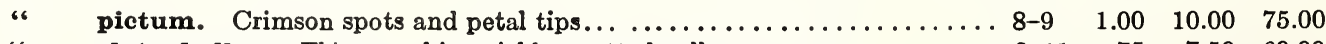

“ platyphyllum. Flowers white, richly spotted yellow............... 9-11 .75 $7.50 \quad 60.00$

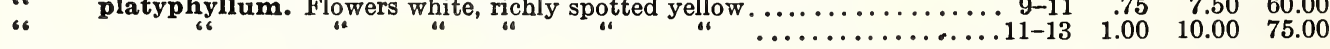

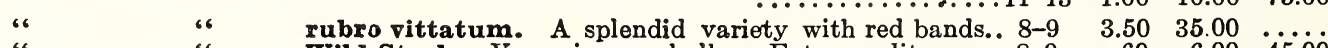

"6 " Wild Stock. Very vigorous bulbs. Extra quality.... . 8-9 $\quad .60 \quad 6.00 \quad 45.00$

wittei. :No spots, yellow bands......................... 8-9 $1.00 \quad 10.00 \quad 75.00$

" "Crimson Queen." A rare and beautiful hybrid. Choice........... 9-11 $6.0060 .00 \quad \ldots$.

Bakerianum. Greenish yellow flowers fading to creamy white; red spots....... . 4-5 $3.00 \quad 30.00 \quad \ldots$.

Batemanniae. Many apricot colored flowers on a stem.................... 6 -8 $\quad .40 \quad 4.00 \quad 30.00$

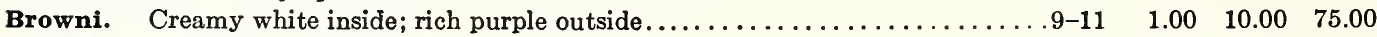

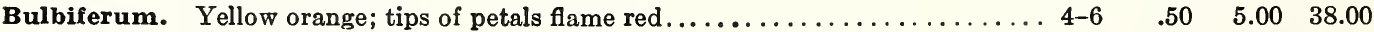

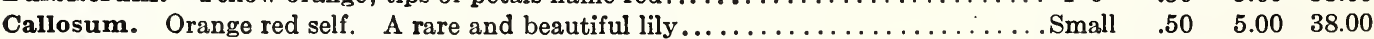

Centifolium. Immense white trumpets, striped brown on exterior......... 10.00

Cernuum. A deep lilac-pink, spotted wine color. Very fragrant.................. Small $\quad .60 \quad 6.00 \quad 45.00$

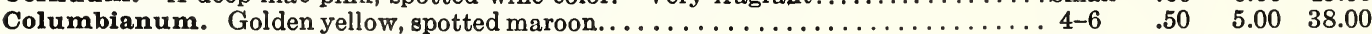

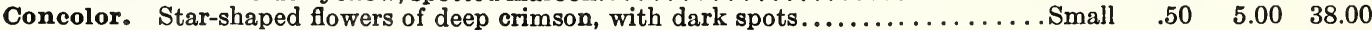

66 Dropmore Variety. A great improvement on the above.............

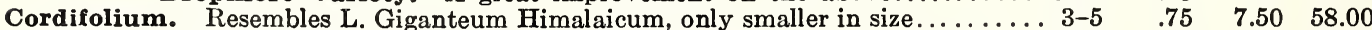

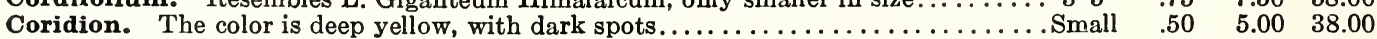

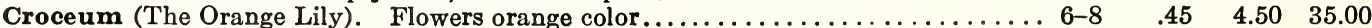

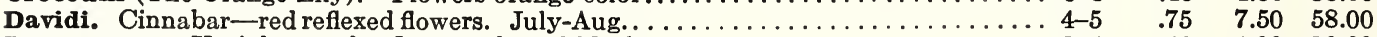

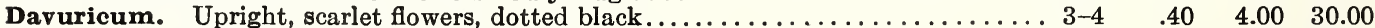

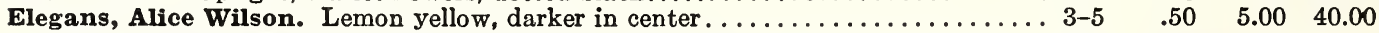

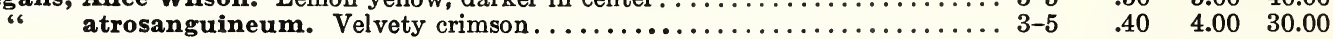

" bicolor. A choice variety, marbled flowers in rich tones of apricots,

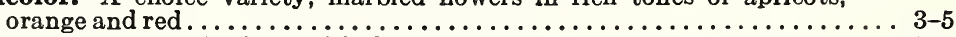

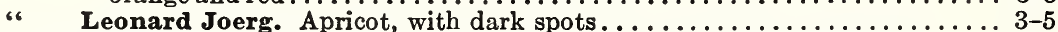

، Mahony. A new variety. Intense rich maroon, suffused mahogany......

" Marmoratum. Gorgeous chrome orange. Superb...............

"، Prince of Orange. Luminous, intense orange...............

" Peter Barr. An immense flower of purest yellow . . . . . . . . . . . . .

، Mixed. A splendid mixture of fine colors ...................

Farreri. A new lily, rare and choice. White with purple dots............... Small

Giganteum Himalaicum. Trumpet shaped white flowers with purple suffusion

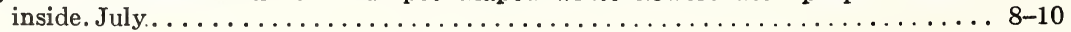

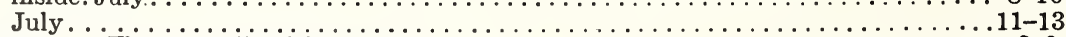

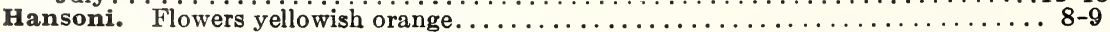

" " " " "

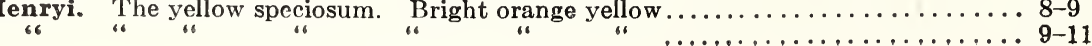

$3.50 \quad 25.00$

$4.00 \quad 30.00$

$7.50 \quad 58.00$

$3.50 \quad 25.00$

$3.00 \quad 22.00$

$6.00 \quad 45.00$

$2.50 \quad 16.00$

$30.00 \ldots \ldots$ 


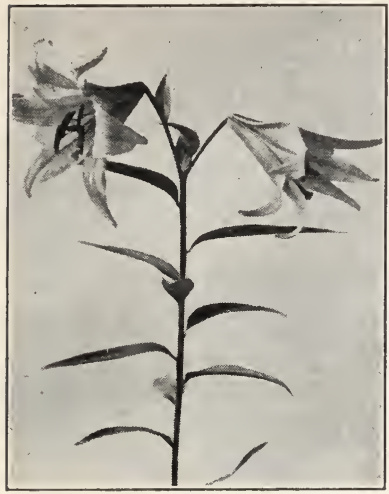

Japonicum Krameri

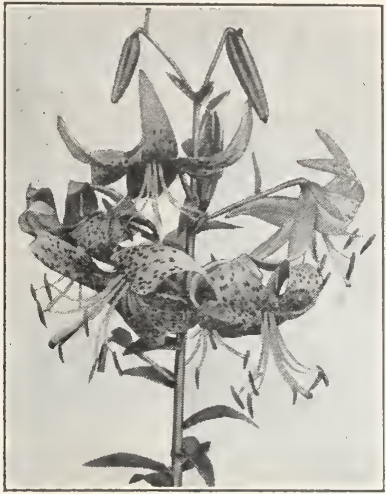

Tigrinum

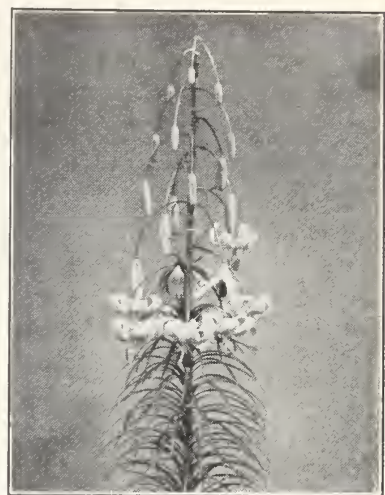

Wilmottiae

\section{HARDY LILIES-Continued}

Japonicum alexandrae. A charming Lilv with large white flowers ........... $4-6 \quad \begin{array}{lllll}\$ 0.75 & \$ 7.50 & \$ 55.00\end{array}$

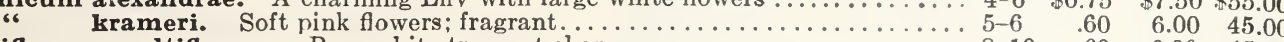

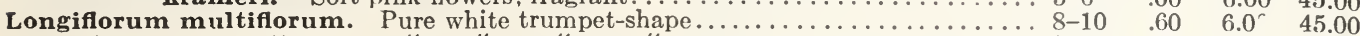
66 "6 "6 " "

distinct white margin on each leaf. June-July..... $3-4 \quad 1.00 \quad 10.00 \quad 75.00$

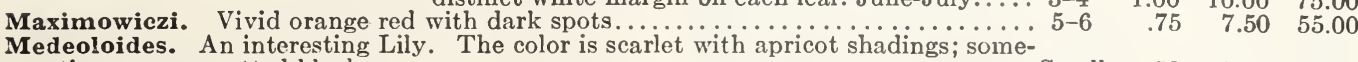

times come spotted black.................................. Small $\quad .50 \quad 5.00 \quad 35.00$

Monadelphum (Colchicum). Deep straw, spotted black..................... $7-9 \quad 1.00 \quad 10.00 \quad 75.00$

Nepalense (Ochraceum). A striking Lily of greenish gold with center of vinous purple. . 8-9 $2.50 \quad 25.00 \quad \ldots .$.

Nielgherrense. Fragrant trumpets of creamy white flushed yellow . . . . . . . . . . . 5 5 -6 $4.00 \quad 40.00 \quad \ldots$.

Philippinense formosanum. White with reddish brown exterior. . . . . . . . . . 4-5 $4 \begin{array}{llll}1.25 & 12.00 & 90.00\end{array}$

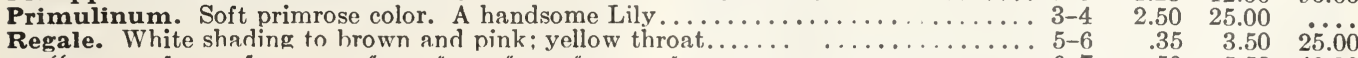

"6 " "

6 : " : " "

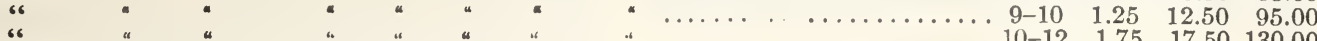

Rubellum. Rose-pink, with yellow anthers. . . . . . . . . . . . . . . . . . . . . .

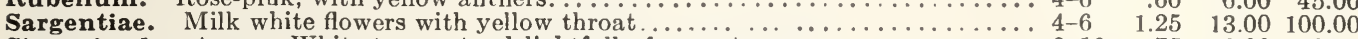

Sinensis pluratum. White trumpets; delightfully fragrant . . . . . . . . . . . . . 9-10 $\quad .75 \quad 8.00 \quad 60.00$

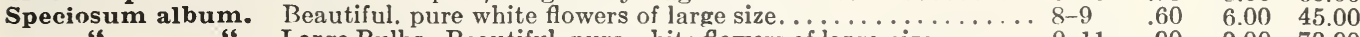

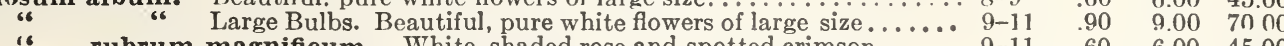

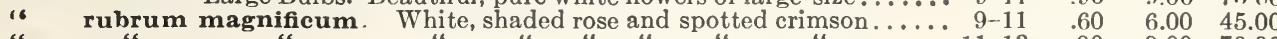

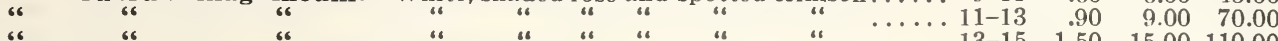

“ “ “

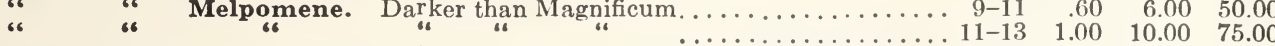

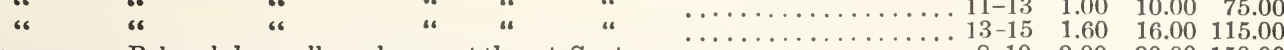

Sulphureum. Pale sulphur yellow, deeper at throat. Sept... . . . . . . . . . . . . . 8-10 2.00 20.00150 .00

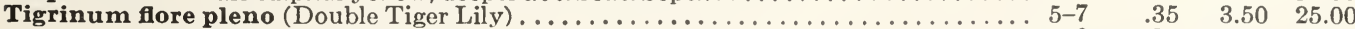

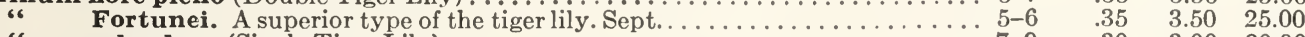

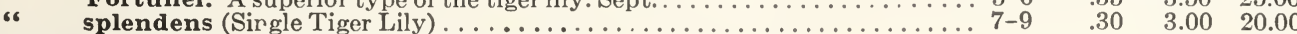

Umbellatum erectum. A splendid form. Rich red .... . . . . . . . . . . . . . . . 7-9 $\quad .35 \quad 3.50 \quad 25.00$

"G "Golden Fleece." Old gold, margined and tipped light scarlet.

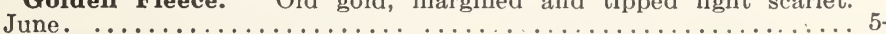

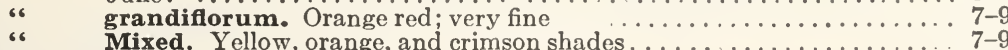

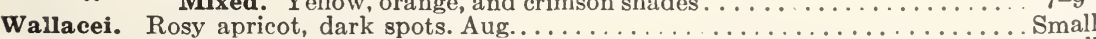

Wallichianum. White, tinged green on outside. Aug.-Sept . . . . . . . . . . . . . Small

Ward's Lily. The Pink Martagen "one of the choicest. . . . . . . . . . . . . . . . Small

Wilmottiae. Graceful heads of orange red flowers.

1.0010 .0075 .00

All bulbs offered by us are flowering size. Some of these may he quite small, while others are large owing to the nature of the Lily. By noting in the column "Size of bulb," we have tried to give the purchaser an approximate idea of what to expect. The figures give the size in circumference. For instance, $9-11$ means that the bulb: are 9 to 11 inches in circumference.

\section{LILIES FOR THE BEGINNER}

No garden, no matter how small should be without Lilies as they lend themselves to all phases of garden design. Therefore there is always room to plant a few amongst other flowers as their foliage takes little room and the top roots of the bulbs require the protection of other plants.

For spring planting we would recommend the following in the order that they would appear in succession of bloom. Elegans, Regale, Auratum, Henryi and Speciosum. If there is room for only one Lily then try Regale which can withstand a rigorous climate and at the same time thrives luxuriantly in the southern states. 


\section{GOLD STORAGE LILIES}

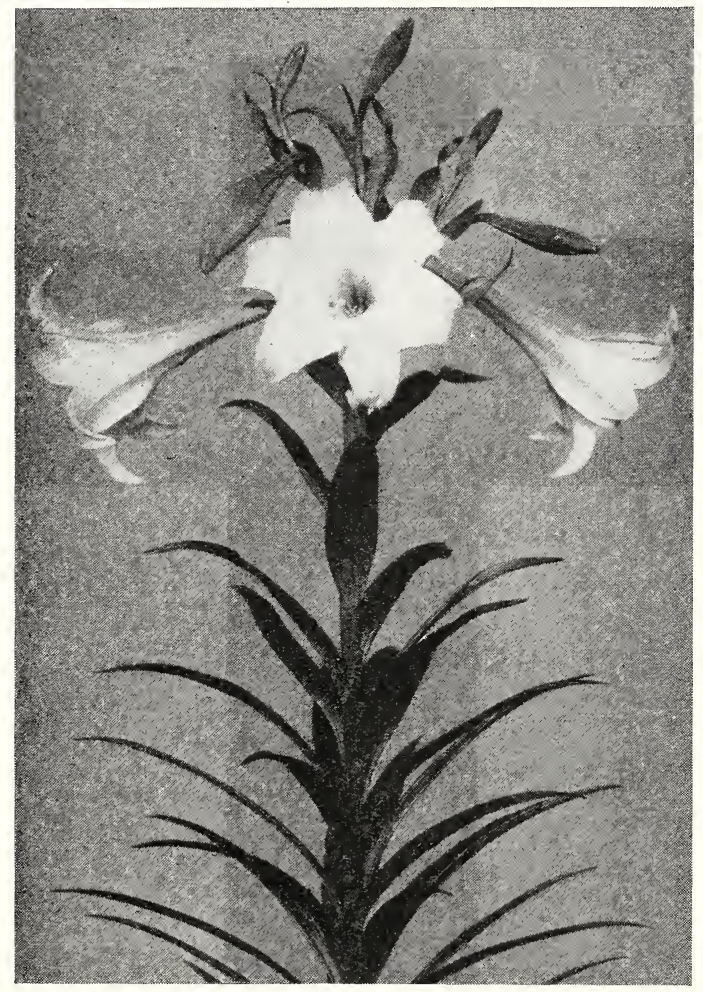

Lilium Formosum

\section{For Greenhouse Forcing}

We have in Cold Storage bulbs of the following Lilies available for shipment during the summer for late planting or greenhouse forcing.

\section{LILIUM AURATUM}

The well known Golden-banded Lily. White with gold bands, spotted maroon.

Bulbs, $11-13$ in. circum., 25 for $\$ 17.00,100 \$ 65.00$ Bulbs, $13-15$ in. circum., 25 for $\$ 30.00,100 \$ 110.00$ Not less than 25 sold.

\section{LILIUM AURATUM PLATYPHYLLUM}

\section{(THE GOLDEN-BANDED LILY OF JAPAN)}

Bulbs, $9-11$ in. circum., 25 for $\$ 17.00,100 \$ 65.00$ Bulbs, 11-13 in. circum., 25 for $\$ 22.00,100 \$ 80.00$

\section{LILIUM FORMOSUM (THE ERABU, BLACK-STEMMED VARIETY)}

We consider this variety most suitable for forcing into bloom in the early Fall, as these bulbs keep in excellent condition until about July 1 st. $9-11,25$ for $\$ 15.00,100 \$ 55.00$.

Bulbs, 11-13 in. circum., 25 for $\$ 22.00,100 \$ 85.00$ Not less than 25 sold. 50 at 100 rate.

\section{LILIUM HENRYI THE ORANGE SPECIOSUM}

Excellent results have been obtained by forcing this beautiful Lily into bloom in the late Fall when all Lilies have gone from the garden.

Bulbs, 9-11 in. circum., 25 for $\$ 22.50,100 \$ 80.00$ Not less than 25 sold. 50 at 100 rate.

\section{LILIUM REGALE}

After trials with this popular Lily we are convinced that it has the merits that no other Lily has for rapid forcing. The bulbs may be taken from cold storage, placed in a temperature of 60 and brought into flower in 60 days. The fragrant, white blooms show a tint of pink on the outside of the petals and a sulphur shading inside.

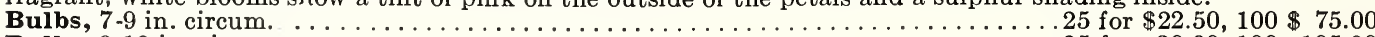

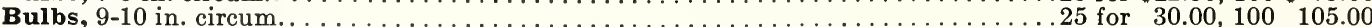

Bulbs, 10-12 in. circum..........25 for $40.00,100 \quad 140.00$

Not less than 25 sold. 50 at the 100 rate.

\section{LILIUM SINENSIS PLURATUM}

A new variety resembling Formosum in the individual flowers which are produced in profusion, from 3 to 4 spikes coming from one bulb. An excellent Lily for cold storage purposes.

Bulbs, $9-10$ in. circum. . . . . . . . . . . . . . . . . . . . . . . . . . . . . . . . .25 for $\$ 17.00,100 \$ 65.00$

\section{LILIUM SPEGIOSUM}

\section{RUBRUM MAGNIFICUM or MELPOMENE}

The favorite Lily for forcing into bloom for Christmas and during the Winter months.

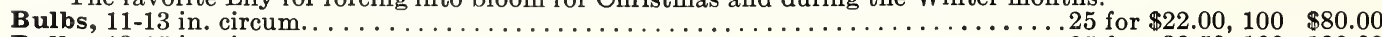
Bulbs, 13-15 in. circum........25 for $32.50,100120.00$

Not less than 25 sold. 50 at the 100 rate.

\section{LILIUM SULPHUREUM}

We have experimented with the beautiful Lily and find it is an excellent variety for cold storage and bringing into flower in the winter months.

Bulbs, 8-10 in. circum ................................. Doz. \$22.00, 25 for $\$ 42.00,100 \$ 160.00$

\section{LILIUM GANDIDUM in pots}

For some years past there has been a growing demand for Lilium Candidum or "The Madonna Lily," for planting in Spring. We have now endeavored to accommodate those desiring to make Spring plantings of this lily, by growing the bulbs in pots. These may be used for forcing or for planting out in the garden and we expect a heavy demand.

Potted Lilium Candidums, 25 for $\$ 20.00: 100$ for $\$ 80.00$

Not less than 25 sold. 


\section{NEW GREENHOUSE PLANTS \\ NEW ANTIRRHINUMS \\ NEW GARNATIONS}

Afterglow. The finest bronze yet introduced.

Happiness. A glorified Philadelphia Pink.

Rose Queen. Large flowering, new dark pink.

Plants from $21 / 4$ in. pots. $\$ 6.00$ for $25, \$ 18.00$ per hundred.

\section{BOUVARDIA \\ NEW GIANT PINK}

The flowers are as large as the white Humboldti. Color coral red. A beautiful variety for the greenhouse.

Plants from $2 \frac{1}{4}$ in. pots. Doz. $\$ 5.00,25$ for $\$ 8.00$, $100 \$ 24.00$.

\section{GALENDULA}

NEW CAMPFIRE OR SENSATION

A sensational color, petals brilliant orange with scarlet sheen, full yellow center.

Plants from $2 \frac{1}{4}$ in. pots. Doz. $\$ 2.50,100 \$ 12.00$.

\section{GERBERA}

\section{HYBRIDS MIXED}

The African Daisy, valuable for forcing for cut flowers and decorating.

Strong field grown plants. Doz. $\$ 15.00$.
Jane Sutherland. Best light pink on the market. Wonderful keeper and shipper.

Spectrum Supreme. Clear glowing red. Much better color and larger flower than Spectrum.

Wildfire. Another spectrum seedling. A brilliant, clear flame red.

Rooted cuttings, 25 for $\$ 8.00,100$ for $\$ 30.00$.

For other Carnations see Page 70.

\section{FUCHSIA}

\section{PRIDE OF ORION}

This new Fuchsia is a strong and upright grower, with white flowers which are extremely double, very large and attractive.

Plants from $2 \frac{1}{4}$ in. pots. Doz. $\$ 5.00,100 \$ 35.00$.

\section{PRIMULA}

OBCONICA GRANDIFLORA COMPACTA

Color dark brilliant rose, fine, compact habit and large flowering type. This is the best of the recent obconicas introduced from Germany.

Plants from $21 / 4$ in. pots. 25 for $\$ 6.00,100 \$ 16.00$.

\section{BEDDING PLANTS}

$25 \quad 100$

AGERATUM fraseri. Bright blue, 3-in . .\$5.00 $\$ 15.00$

Dwarf Blue. 3 in ...............4.00 12.00

ASTERS. Double assorted, 2 in ....... $2.00 \quad 6.00$

BEGONIA Chatelaine, red 21/4-in. pots. 5.0015 .00

Chatelaine Supreme. Pink, $2 \frac{1}{4}$-in.

pots.................... 5.0015 .00

Gustave Knaake. Crimson........ 7.50 20.00

Vernon, 3 in .................. 5.00 15.00

Luminosa, 3 in................. $5.00 \quad 15.00$

CANNAS. From 3-in. pots.

King Humbert. Red, bronze leaf ... $6.00 \quad 20.00$

Hungaria. The best pink.......... $6.00 \quad 20.00$

The President. Green leaf, red..... $6.00 \quad 20.00$

Yellow King Humbert. Green leaf... $600 \quad 20.00$

Mixed French Varieties............ $6.00 \quad 20.00$

CENTAUREA gymnocarpa $\ldots \ldots \ldots \ldots .4 .00 \quad 12.00$

COBAEA scandens. Blue........... 3.5010 .00

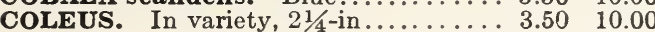

No order for less than 25 of a variety accepted

\section{ANTIRRHINUM. Snapdragon}

One of the most widely grown plants for greenhouse flowering and outside bedding.

Chapman's Yellow. The finest new yellow.

Ceylon Court. A beautiful yellow.

Chapman's Pink. Bright premier pink and uniform color. An early and free bloomer.

Cheviot Maid. Without doubt the earliest and best pink Winter flowering variety.

Giant Red. A fine red variety.

Golden Pink Queen. A superb variety.

Helen. A beautiful light pink.

Jennie Schneider. A beautiful rose-pink Winter flowering with spikes two feet long.
Judd's New Early Dark Pink. A beautiful rose-pink, similar to the Premier Rose.

Judd's New Early Light Pink. A magnificent pink similar to the Columbia Rose.

Penn-Orange. A striking vivid orange, with subdued yellow and pink shadings, which add to its attractiveness.

Philadelphia Pink. The best pink.

White Rock. Best forcing white.

Plants of any of the above in season, $2 \frac{1}{4} \cdot \mathrm{in}$. pots: 25 for $\$ 3.50,100 \$ 12.00$.

Not less than 25 of a variety sold. For New Antirrhinums, see above.

\section{GERMAN HYDRANGEAS}

This new type of forcing Hydrangeas is far superior to the French varieties. They are much easier to grow. The flowers are much larger and the coloring is much more brilliant.

\section{NEW LARGE FLOWERING}

America. Almost red, with slight white margin.

Freya. Glossy carmine, compact grower.

Odin. Deep carmine. Very early flowering.

Peer Gynt. Carmine rose, vigorous grower.

Prices of above, Summer delivery, 21/4-in. pots,

$\$ 10.00$ per doz., $\$ 70.00$ per 100 .

Fall delivery, 4 -in. pots, $\$ 1.50$ each, $\$ 15.00$ per doz.

\section{STANDARD GERMAN VARIETIES}

Elmar. A beautiful carmine red.

Gudrun. A compact growing light pink.

Helge. An exceptionally fine bright dark red.

Lancelot. Prettily fringed deep bright pink.

Loreley. Brilliant carmine red.

Wilhelm Pfitzer. Free flowering light pink.

Prices of above, $21 / 4$-in. pots, doz. (2 of each 6 vars.) $\$ 6.00,25$ for $\$ 12.00$ 


\section{CARNATIONS}

\section{Recent Introductions and Choice Varieties}

25100

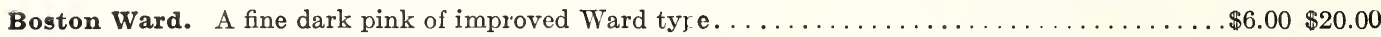
Dandy. A new rose-pink sport of Morning Glow. A wonderful producer of fine quality flowers . . . 6.00 20.00

Eldora. The best variegated variety on the market. $\ldots \ldots \ldots \ldots \ldots \ldots \ldots \ldots \ldots \ldots \ldots \ldots \ldots \ldots . \ldots \ldots$

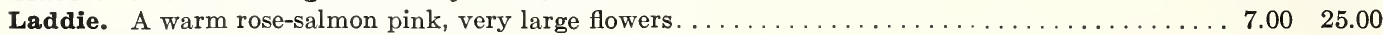

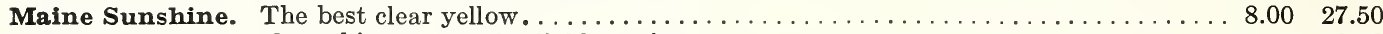

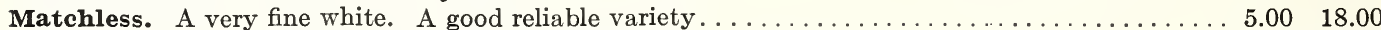

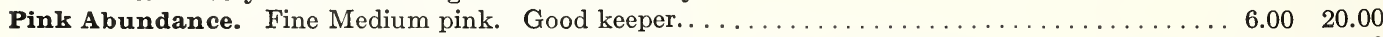

Radiolite. A brilliant scarlet, the winner of the Dorner Memorial Medal. . . . . . . . . . . . $7.00 \quad 25.00$

Sceptre. The best Carnation sent out in recent years. A seedling of Pink Delight; flowers as large as

Surprise; color salmon-pink and wonderful keeper and good grower . . . . . . . . . . . . . . . $6.00 \quad 20.00$

Sophelia. A pleasing shade of pink similar to Betty Lou. Long-stiff stems with full center, also

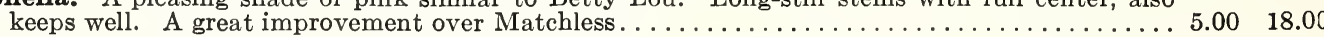

Spectrum. A magnificent scarlet, large, vigorous and free flowering $\ldots \ldots \ldots \ldots \ldots \ldots \ldots \ldots$

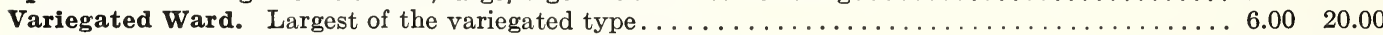

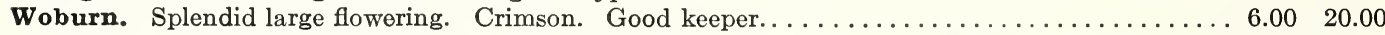

The above prices are for rooted cuttings: Spring delivery: not less than 25 supplied of any variety, For the best new Carnations, see page 64 .

\section{GREENHOUSE PLANTS}

ADIANTUM gloriosum. The hardiest Maidenhair. . . . . . . . . doz.\$10.00

ASPARAGUS plumosus nanus. Graceful, climbing Asparagus; beautiful, feathery

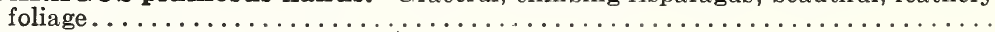

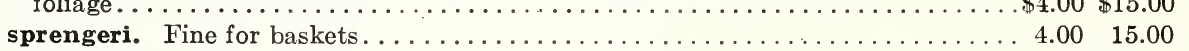

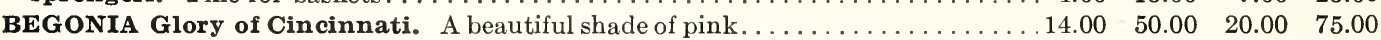

Gustav Knaake. Resembles Lorraine. Color crimson; wonderful for Christmas . . $6.00 \quad 20.00 \quad \ldots . . \quad \ldots$

Melior. A more vigorous type of Lorraine. . . . . . . . . . . . . . . . . . . . . . . . . . $14.00 \quad 50.00 \quad 20.00 \quad 75.00$

Mrs. J. A. Peters on. Deep pink flowers with red foliage . . . . . . . . . . . . . $14.00 \quad 50.00 \quad 20.00 \quad 75.00$

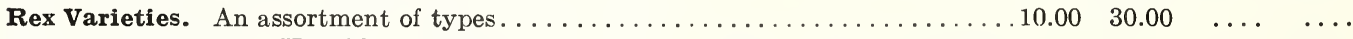

Winter Flowering. Hybrid type vars........... Each $\$ 2.50$, doz. $\$ 25.00 \ldots \ldots \ldots \ldots \ldots$

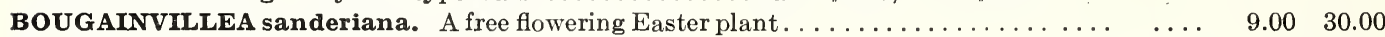

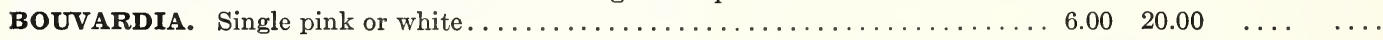

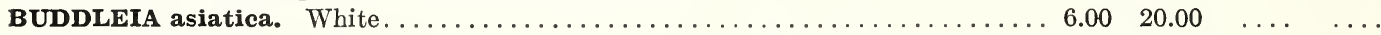

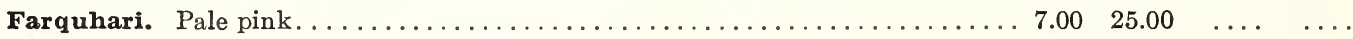

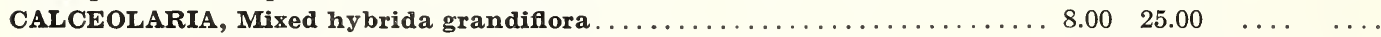

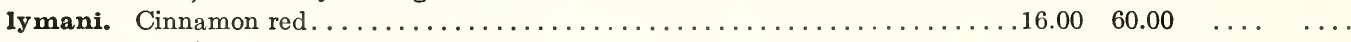

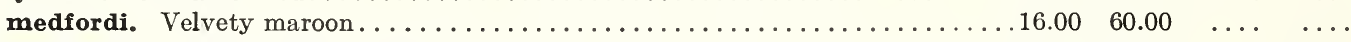

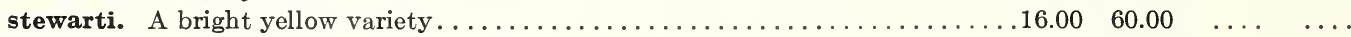

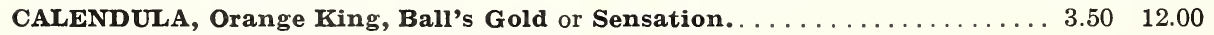

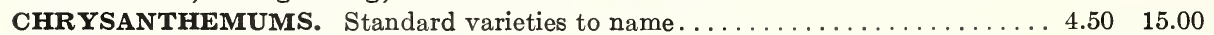

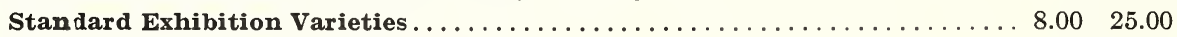

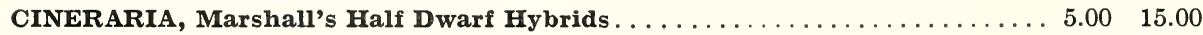

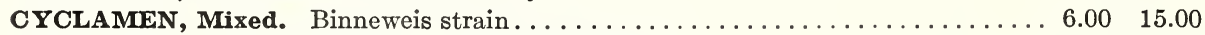

EUPHORBIA jacquiniaeflora. A Christmas plant. . . . . . . . . . . . . . . . . . $10.00 \quad 35.00$

FUCHSIA. Giant Pink. Large pink and white flowers. A wonderful pot plant. . 6.0020 .00

GARDENIA veitchi (Cape Jasmine) . . . . . . . . . . . . . . . . . . . . . . . . . . . . . . . . . $10.00 \quad 35.00$

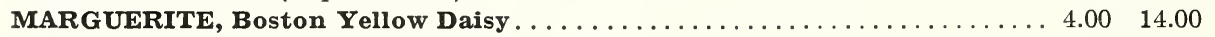

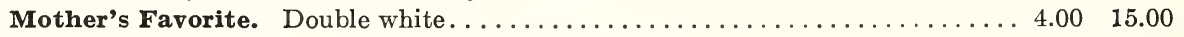

MYOSOTIS, Matchless. A true Winter flowering variety . . . . . . . . . . . . . . . $10.00 \quad 30.00$

POINSETTIA. Oak Leaf. An improved variety which does not drop its lower

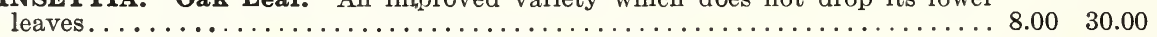

PRIMULA obconica grandiflora. Mueller's \& Mohnstien strain . . . . . . . . . . . 5.0015 .00

malacoides, American Legion. Large clear pink, yellow center . . . . . . . $4.00 \quad 12.00$

malacoides, Superba. Delicate lilac. Free flowering. . . . . . . . . . . . . 4.0015 .00

-lelandi. A beautiful lilac-pink with large yellow eye. Long, stiff stems for cutting . $10.00 \quad 25.00$

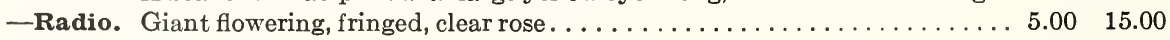

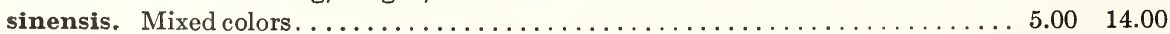

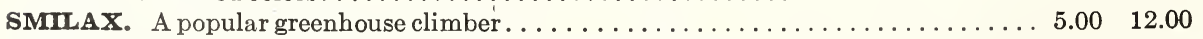

SOLANUM, Cleveland Red. An improved Jerusalem Cherry . . . . . . . . . . . . 5.0014 .00

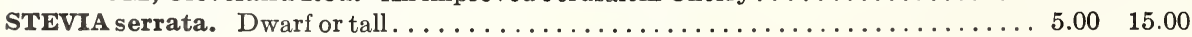

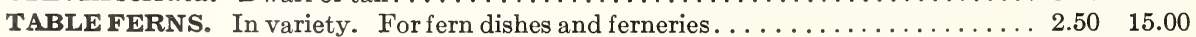

VIOLETS. See our Fall Catalogue.

Orders for any of the above plants will be shipped in their season of delivery. Prices subject to change.

Not less than 25 of a variety supplied. We do not pay transportation charges on plants. 


\section{WATER LILIES}

We are pleased to announce that we are again in a position to offer large plants of water lilies. These larger plants insure a longer blooming period, many of them bearing developed flower buds when shipped. We stress the fact that these are large roots and are packed and shipped in spagnum moss.

\section{TROPICAL DAY BLOOMING WATER LILIES}

Garden lovers are fast becoming acquainted with the superiority of the Tropical Water Lily over the old time Hardy Water Lily. The fragrant tropical blooms, with their great variety in color and shade, are larger and much more numerous than any of the Hardy variety. Their long stiff stems not only add to their beauty in the pool, but make excellent cut flowers.

Amethyst. Lovely amethyst blue, for tub or

large pools, new...................\$3 50

August Koch. Most satisfactory blueish lilac,

fragrant, prolific.......................... 3.00

Blue Beauty. Large and fragrant, deep blue. . . . 3.50

Blue Bird. Large, full petaled, cup shaped . . . . . 5.50

Blue Zanzibariensis. True blue, large star

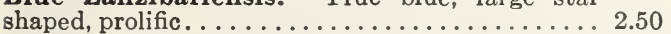

Elliot. New pink hybrid, opens wide, fine cut

flower, fragrant; a popular novelty . . . . . . . 5.50

Independence Pink. A fine pink hybrid....... 2.50

Janice. White bell shaped, leaf producer. . . . . 5.50

Mrs. C. W. Ward. Deep rose pink, star shaped, prolific, fine lily for every pool ............ 2.75

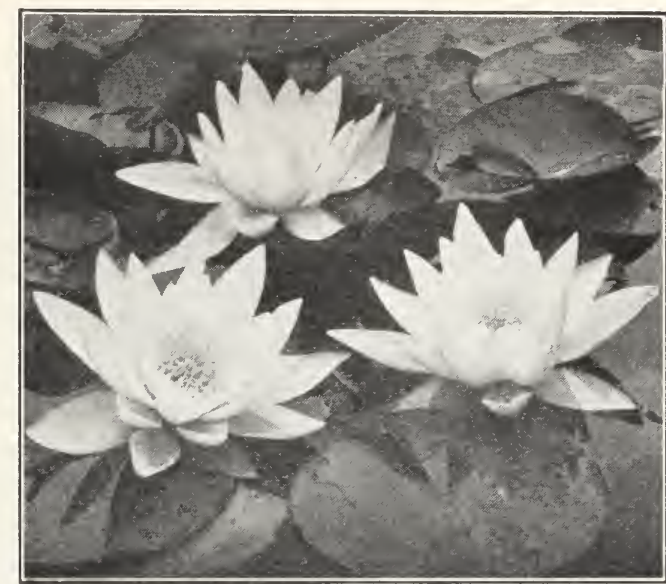

Nymphea

Each

Mrs. Ed Whitaker. Pale blue, large, heavy

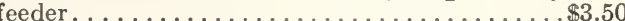
Mrs. Sawyer. Exquisite deep rose, novelty, a gorgeous full petaled flower on long stiff stems... 7.50

Panama Pacific. Lovely rich reddish purple, free flowering, stiff stems make it a fine cut flower . . 3.00 Pershing. Large orchid pink bloom, lovely...... 6.50

Pink Zanzibariensis. Large fragrant, long

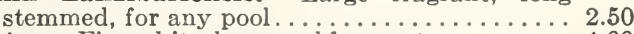

Pring. Fine white, large and fragrant.......... 4.00

\section{NIGHT BLOOMING TROPICAL WATER LILIES}

The Night Blooming Water Lilies flower in the early morning and evening and will remain open on cloudy days.

Juno. Very best white night bloomer, large and conspicuous in any pool.
Each

$\$ 3.00$
Omarana. Large rosy pink night bloomer.... . \$2.00

Rubra Rosea. Gorgeously brilliant crimson, a free bloomer....................... 2.00

Victoria Cruziana. Suitable only for very large pools........................... 10.00

\section{HARDY WATER LILIES}

The Hardy Water Lilies do best if planted in April and are not affected by the temperature changes. They are the earliest to bloom and easiest to care for in the winter season.

Comanche. Copper orange with red markings.. E E6.00

Gladstone. The best white hardy, excepting

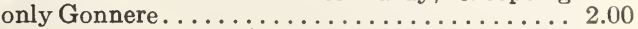

Paul Hariot. Large blooms, orange pink deepening to red, unique and decidedly one of the

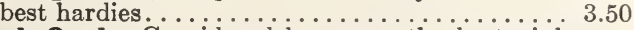

Pink Opal. Considered by many the best pink hardy......................... 2.50

\section{LOTUS}

American Lotus. Ivory yellow flowers which attain gigantic proportions............. \$2.50

Egyptian Lotus or Lily of the Nile. Attractive

pink flowers. Quite hardy and free grower... . . . 2.50
Sunrise. Immense bright yellow flowers, by far the finest hardy water lily...........\$ \$6.00

Yellow Texanus. Excepting Sunrise, the finest yellow lily grown; the fragrant deep yellow blooms, borne on stiff stems well above the water, should be in every collection.

When only one plant is ordered a packing charge of 25 cents will be made. 


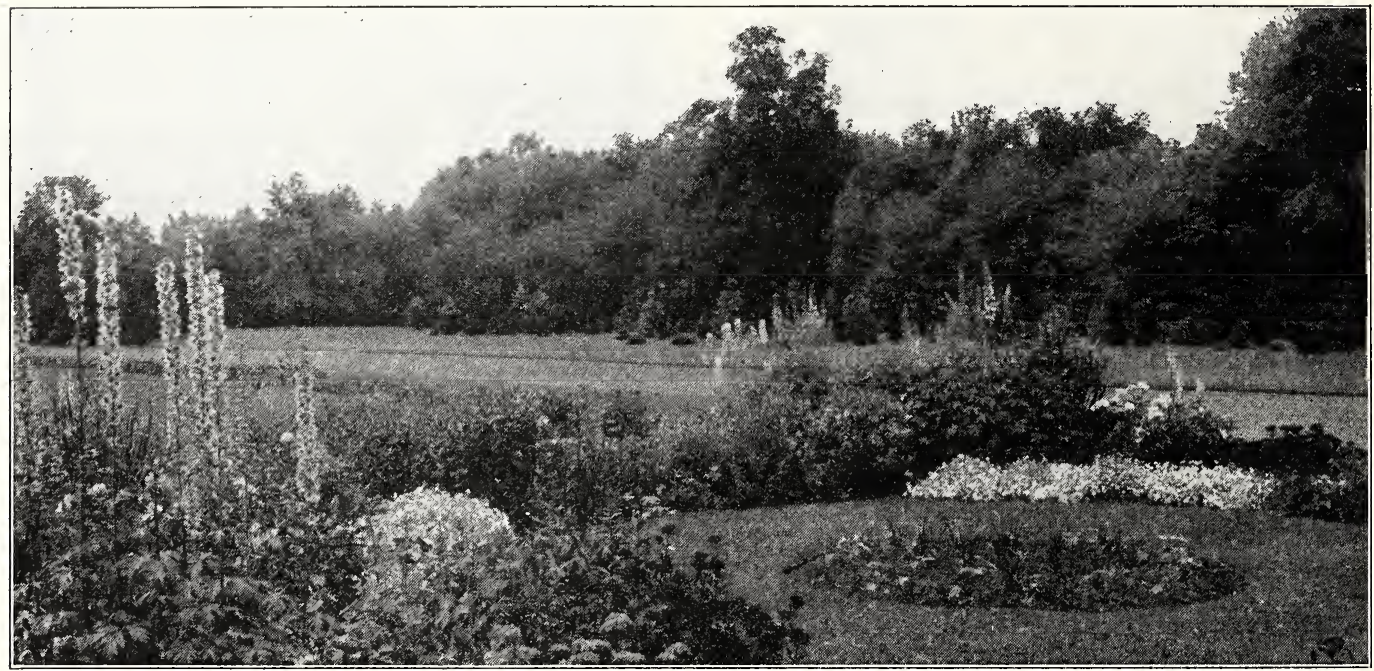

\section{Hardy Perennial Plants}

\section{For Permanent Planting in Open Borders}

Herbaceous plants should be used where a constant supply of flowers is desired, for, out of the large lists of herbaceous or perennial plants, such varieties may be selected as begin to flower very early, others that are almost continuous bloomers and some that continue to bloom even after frost sets in.

The approximate height of the Hardy Perennials in this catalog is represented in feet and inches and the flowering periods are taken in the vicinity of New York.

ACHILLEA Millefolium roseum. Pink flowers in compact heads. $2 \mathrm{ft}$. June-Sept.

flipendulina. Fern-leaved Yarrow; Milfoil. A showy variety with dense heads of yellow flowers. $3 \mathrm{ft}$. June, July.

Ptarmica Boule de Neige. Ball of Snow. An improvement on The Pearl with fuller and more perfect flowers.

Ptarmica, The Pearl. Double pure white flowers in great profusion. $2 \mathrm{ft}$. June-Sept.

ACONITUM a utumnale (Monkshood). Showy blue, helmet-shaped flowers. 3 to $4 \mathrm{ft}$. Aug., Sept.

Fischeri. Strong spikes of large, dark blue flowers. 2 to $3 \mathrm{ft}$. Sept., Oct.

Wilsonii. A tall variety from China, with violetblue flowers. 5 to $6 \mathrm{ft}$. Sept.

All Aconitums, 50c., each, $\$ 4.50$ for 10 .

AGROSTEMMA. See LYCHNIS.

ALYSSUM saxatile compactum (Rock Madwort, Golden Tuft). Compact masses of yellow flowers in early Spring. $1 \mathrm{ft}$. April, May.

AMSONIA Tabernaemontana. A strong, shrublike plant, with spikes of delicate blue flowers. $2 \mathrm{ft}$. May, June.

ANCHUSA italica, Dropmore. Large, gentianblue flowers. 4 to $5 \mathrm{ft}$. May-July.

-myosotidifiora. Bright blue Forget-me-not flowers. 10 to 12 in. May. 50c., 10 for $\$ 4.50$.

ANEMONE (Windflower). Japanese Anemones are among the best Autumn flowering plants. 2 to $3 \mathrm{ft}$. Sept., Oct.

japonica alba. Single, pure white.

Alice. Lovely rose pink.

Mount Rose. Semi-double pink

-rubra. Single, reddish rose.

-Whirlwind. Semi-double, white.

pulsatilla. The Pasque Flower of Europe. Flowers single, blue or reddish-purple, about 2 in. across. Height $1 \mathrm{ft}$. April to May. All Anemones 3 for $\$ 1.00,10$ for $\$ 3.00$.
ANTHEMIS montana (Marguerite). One of the most satisfactory perennials; flowers creamy white. $2 \mathrm{ft}$. June-Oct.

tinctoria Kelwayi (Golden Marguerite). Rich yellow; fine for cutting. $2 \mathrm{ft}$. June-Oct.

AQUILEGIA coerulea (Rocky Mountain Columbine). Large, blue and white, long-spurred flowers. $11 / 4 \mathrm{ft}$. chrysantha (Golden-Spurred Columbine). Flowers fragrant, yellow. 2 to 3 in. across.

Canadensis (American Columbine). A compact plant with red-and-yellow flowers.

Mrs. Scott Elliott Hybrids. There is not a better mixture grown in the world than by Mrs. Scott Elliott who has taken the highest awards at all the European exhibitions. Our stock is from seed, from this source, absolutely true strain.

Nivea grandiflora. A splendid robust growing large pure white.

ARABIS alpina (Rock Cress). Adapted for rock gardens; pure white. 5 in. April, May.

flore pleno. An improved double form of the above with pure white flowers which last over a long period. Fine as edging or for Rock Garden. 6 in. April-May, 3 for $\$ 1.00,10$ for $\$ 3.00$.

ARTEMISIA Abrotanum (Southernwood, Old Man). Usually grown for its handsome, pleasant-scented leaves. 2 to $3 \mathrm{ft}$. 3 for $\$ 1.50,10$ for $\$ 4.50$.

lactiflora. Large, branching panicles of sweetly scented, creamy white flowers. 3 to $4 \mathrm{ft}$. Aug., Sept. 3 for $\$ 1.25,10$ for $\$ 3.50$.

Silver King. Silvery white foliage. 3 for $\$ 1.25$. 10 for $\$ 3.50$.

Stelleriana (Old Woman). Foliage deeply cut; silvery white; a fine plant for rockeries. $11 / 2 \mathrm{ft}$.

ASCLEPIAS tuberosa (Butterfly Weed). Orangescarlet. $2 \mathrm{ft}$. July, Aug. 3 for $\$ 1.25,10$ for $\$ 3.50$.

ASPERULA odorata (Sweet Woodruff, Waldmeister). A sweet-scented herb; white. 6 to 8 in. May, June.

All plants, except where noted, 3 for $90 c ., 10$ for $\$ 2.50$. Not less than 3 of 1 variety sold. 


\section{HARDY PERENNIAL PLANTS-Continued}

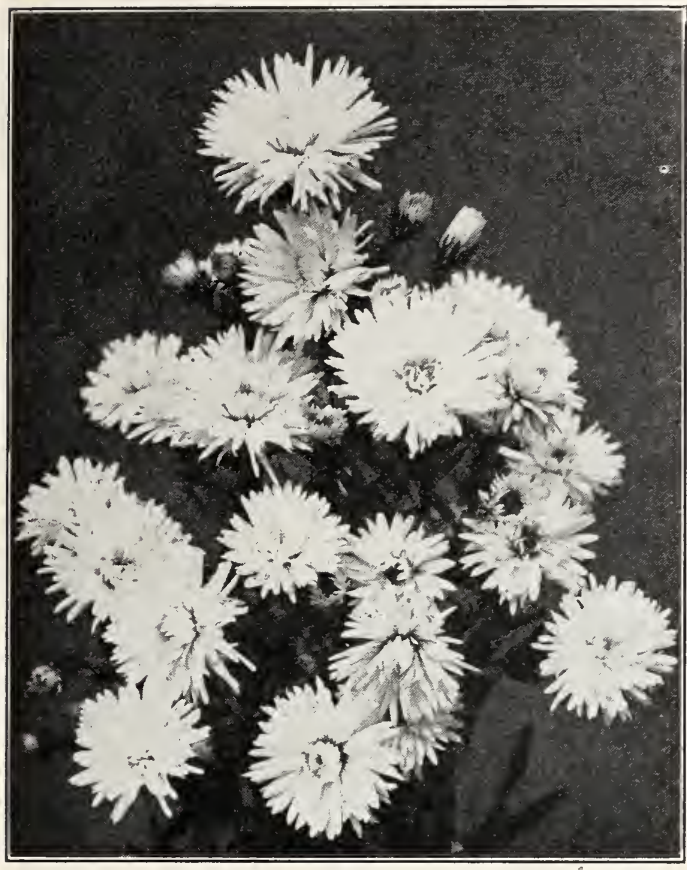

Hardy Aster or Michaelmas Daisy.

ASTER (Michaelmas Daisy).

Climax. Large, soft mauve flowers with golden center, 5 to $6 \mathrm{ft}$. Sept., Oct.

Beauty of Colwall. Clear, lavender-blue, semidouble flowers. $4 \mathrm{ft}$. Sept., Oct.

Feltham Blue. Splendid blue with yellow center. 3 to $4 \mathrm{ft}$. Sept., Oct.

Lady Lloyd. Clear rose pink. $3 \mathrm{ft}$. Sept., Oct.

Perry's Favorite. Bright, luminous pink. 3 to 4 ft. Sept., Oct.

Perrys White. Pure white free flowering. $5 \mathrm{ft}$.

St. Egwin. Pink, compact habit. $3 \mathrm{ft}$. Sept.

Tataricus. Tall straight growth, large violet flowers. $6 \mathrm{ft}$. Oct.

Mauve Cushion. A cushion-like plant with hosts of delicate mauve flowers from Oct. to Nov, 9 in. 3 for $\$ 1.00,10$ for $\$ 3.00$.

ASTILBE. Arendsii Hybrids. (New) July.

Gloria. A superb introduction with dense, feathery, dark pink plumes. A compact grower $2 \mathrm{ft}$. 50c. each.

Salland. Immense feathery sprays of rich red flowers $6 \mathrm{ft} . . . . . . . . .75 \mathrm{c}$ each

Vesta. A pretty plant with graceful blooms of

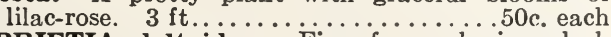
AUBRIETIA deltoidea. 'Fine for rockeries; dark violet. 6 in. April and May. 3 for \$1.25, 10 for $\$ 3.00$

BAPTISIA a ustralis (False Indigo). Lupine-like flowers, dark blue. 3 to $4 \mathrm{ft}$. May-July.

BOCCONIA cordata (Plume Poppy). Creamy white flowers. 6 to $8 \mathrm{ft}$. July, Aug.

BOLTONIA asterioides. Has pure white, Asterlike flowers. 5 to $6 \mathrm{ft}$. Aug., Sept.

latisquama. Similar to the preceding, with pinkish lavender flowers. 5 to $6 \mathrm{ft}$. Aug. Sept.

-nana. A dwarf form. $3 \mathrm{ft}$. Aug., Sept.

CALTHA palustris (March Marigold). Showy plant for wet places with bright yellow flowers. 12 in. June.
CAMPANULA (Bellflower). These are among the most important of hardy plants.

carpatica (Harebell). Flowers large, erect, light blue. 5 to 7 in. July, Aug.

-alba. A white form of the above.

glomerata. Globular, dark blue flowers. $11 / 2 \mathrm{ft}$. June, July. 3 for $\$ 1.25,10$ for $\$ 3.50$.

medium (Canterbury Bells). In blue, rose or white. $2 \mathrm{ft}$. June.

- calycanthema (Cup-and-saucer. Canterbury Bells). In blue, lilac, rose and white.

persicifolia (Peach-leaved Bellflower). Large, cupshaped blue flowers. $2 \mathrm{ft}$. June, July.

-alba grandiflora. White.

- Telham Beauty. Large, single blue flowers. A great improvement on the old Persicifolia type. Fine for culting. $21 / 2 \mathrm{ft}$. June-July. 3 for $\$ 1.50$, 10 for $\$ 4.50$.

pyramidalis (Steeple Bellflower) Long spikes of blue flowers. 4 to $5 \mathrm{ft}$. Aug., Sept. 3 for $\$ 1.25$, 10 for $\$ 3.50$

-alba. A white form of the above.

CARYOPTERIS incana, Mastacanthus (Blue Spiraea). Lavender-colored flowers. 3 to $4 \mathrm{ft}$. Sept., Oct. 50c. ea., 10 for $\$ 4.50$.

CASSIA marilandica. Bright yellow, odd-shaped flowers. 5 to $6 \mathrm{ft}$. July-Sept.

CATANANCHE coerulea bicolor. (Cupid's Dart) White flowers with slight suffusion of purple in center. $2 \mathrm{ft}$. June-Aug.

CENTAUREA dealbata. Compact habit; deep pink flowers. $11 / 2 \mathrm{ft}$. July, Aug.

macrocephala. The most showy Centaurea, with large, thistle-like yellow flowers. $3 \mathrm{ft}$. July, Aug. montana. (Perennial Cornflower). Large blue flowers. $2 \mathrm{ft}$. June-Sept.

-alba. A fine white form of the above.

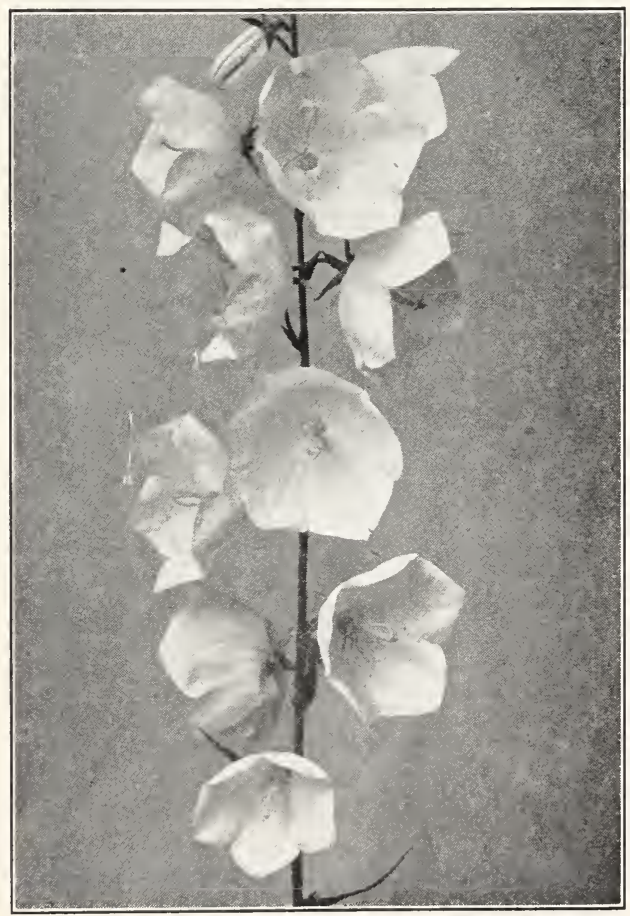

Campanula, Telham Beauty.

All plants, except where noted, 3 for $90 c ., 10$ for $\$ 2.50$. Not less than 3 of 1 variety sold. 


\section{HARDY PERENNIAL PLANTS-Continued}

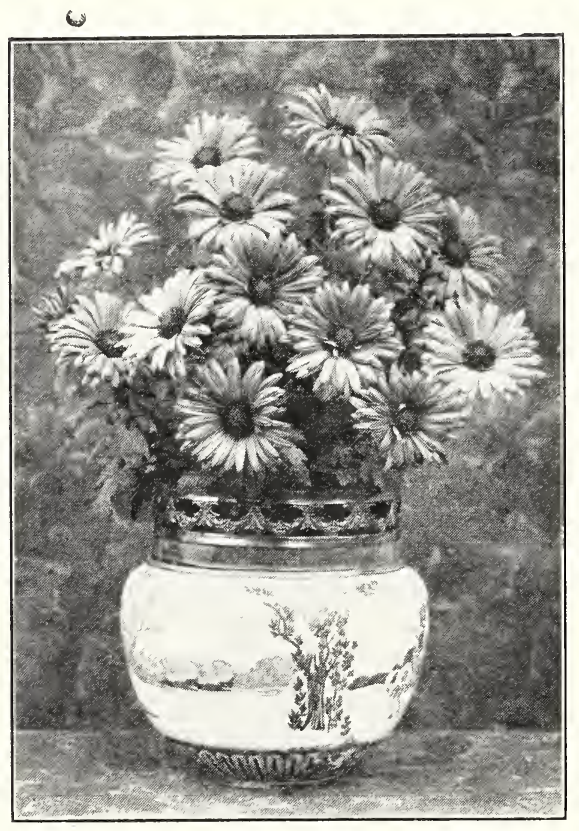

Single Chrysanthemums.

CHRYSANTHEMUMS, Hardy. These make a grand show late in the Fall; all colors. 2 to $3 \mathrm{ft}$. Sept.-Oct.

Prices of the following: Doz. $\$ 2.50,100, \$ 16.00$; not less than 3 of one variety sold.

LARGE FLOWERING, or ASTER VARIETIES Angelo. A beautiful light pink.

Florence Stanton. Large bronze flower; late.

Marie du Pont. Free flowering, pure white.

Queen of Whites. Pure white, very full.

Yellow Source d'Or. The best yellow.

Zelia. Old gold, large flower; bushy plant.

\section{POMPON VARIETIES}

Anna L. Moran. Bronze with yellow.

Fairy Queen. Large light pink, full center.

Firelight. Bright red. Pretty flower.

Frances Huckvale. Flesh with bronze center.

Juliana. Fine yellow, good grower.

Mrs. Chester Robinson. Pink shading to old rose.

Nellie. Golden yellow, very full.

Nellie Blake. A good deep red.

Petit Louis. Light pink, bronze center.

Uvalda. Large white, strong grower.

\section{BUTTON VARIETIES}

Davenport. Bronze tinged with red.

Helios. Reddish-bronze.

Ouray. Rich dark mahogany-brown.

\section{SINGLE FLOWERING VARIETIES}

Alice Howell. Orange-yellow.

Mrs. Roberts. Deep rose-pink.

Summer Gold. Large golden yellow.

\section{CHRYSANTHEMUMS-Continued}

arcticum (Arctic Daisy). Multitudes of white slightly tinged flowers, 2 in. wide. 12 to 18 in. Sept.-Nov.

maximum, King Edward. Marguerite-like flowers of glistening white. $3 \mathrm{ft}$. July to Oct.

maximum, The Speaker. Ivory white flowers nearly six inches in diameter. $2 \frac{1}{2} \mathrm{ft}$. July to Oct. 3 for $\$ 1.00,10$ for $\$ 3.00$.

maximum, Shasta Daisy. Large white flowers; blooms profusely all Summer.

CEPHALARIA alpina (Roundheads). Very tall. Flower heads pale primrose-yellow. $5 \mathrm{ft}$. June, July.

CERASTIUM tomentosum (Snow-in-Summer). Bright, silvery foliage, with white flowers. 6 in. May, June.

CIMICIFUGA racemosa. Tall, hardy and ornamental; white racemes of flowers. 4 to $5 \mathrm{ft}$. June, July.

-simplex. Tall, graceful spikes of white flowers, lasting a long time when cut. 2 to $3 \mathrm{ft}$. Sept., Oct. 75 c. each, $\$ 7.00$ for 10 .

CONVALLARIA majalis (Lily of the Valley). May, June. Field grown clumps. $\$ 2.50$ for $5, \$ 4.50$ for $10, \$ 40.00$ per 100 .

COREOPSIS lanceolata. Golden yellow; the flowers are borne on long, graceful stems, making them invaluable for cutting. $2 \mathrm{ft}$. June-Oct.

DELPHINIUM (Larkspur). June till late Fall.

Belladonna. Large, semi-double flowers, sky-blue, tipped lilac; dwarf growing.

English Hybrids. From the palest to the deepest blues; single and double.

-grandiflorum chinense (Chinense). Low-growing, with gentian-blue flowers.

- - alba. A pure white form of the preceding.

Wrexham Hybrids. Magnificent spikes of exquisite flowers compactly arranged along the stems. The choicest of all delphiniums. Each, $\$ 1.00 ; 10$ for $\$ 9.00 ; 100$ for $\$ 75.00$.

DIANTHUS (Hybrid Garden Pinks).

Abbotsford. Deep crimson marked with white.

Carmen. Light Pink, fragrant.

Essex Witch. Bright pink.

Mrs. Sinkins. Large white fringed fragrant flowers.

Barbatus (Sweet William). One of the oldest garden flowers which perpetuates itself by self sowing.

-Single Mixed.

-Newport Pink. Lovely salmon Pink.

-Scarlet Beauty. Deep rich scarlet.

Caesius (Cheddar Pink). Very sweet scented rose colored flowers. Fine rock garden plant. 3 for $\$ 1.25,10$ for $\$ 3.50$.

Deltoides (Maiden Pink). A dwarf variety with creeping habit, with sprays of pink flowers. Fine for rock garden.

Plumarius (Grass Pink). Single fringed flowers in mixed colors. $1 \mathrm{ft}$.

DICENTRA formosa. Rose color, with finely divided foliage. $1 \mathrm{ft}$. May.-Aug. 3 for $\$ 1.25,10$ for $\$ 3.50$.

spectabilis (Bleeding Heart). Long, drooping racemes of rose-crimson; useful for forcing. $11 / 2 \mathrm{ft}$. April-June. 75c. each.

DIOTAMNUS fraxinella (Gas Plant). This is also called Burning Bush. 2 to $3 \mathrm{ft}$. June, July. $50 \mathrm{c}$. each. 


\section{HARDY PERENNIAL PLANTS-Continued}

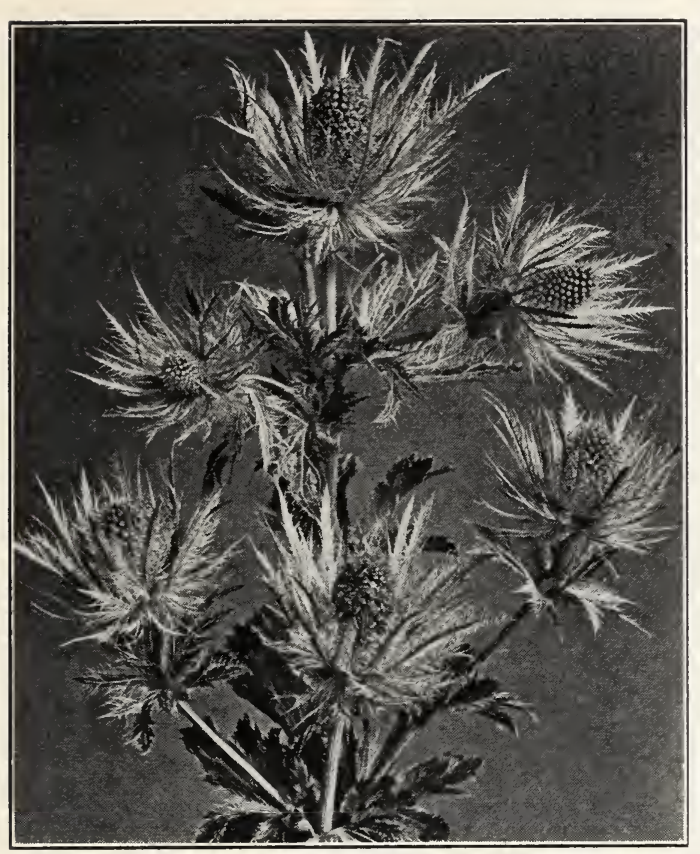

Eryngium amethystinum.

DIGITALIS (Foxglove). These old garden favorites produce bold masses of leaves and flowers.

lanata. Long, dense spikes of grayish or creamy yellow flowers. 2 to $3 \mathrm{ft}$. June, July.

purpurea gloxiniaeflora (Gloxinia-flowered Foxglove). Flowers spotted rose, purple and white. 2 to $3 \mathrm{ft}$. June, July.

-Shirley Hybrids. A giant variety of the Gloxiniaflowered type. Flower spikes $4 \mathrm{ft}$. long of purest white to deepest rose colors, handsomely spotted. 5 to $7 \mathrm{ft}$. June and July. 3 for $\$ 1.50,10$ for $\$ 3.50$

ECHINACEA purpurea (Purple Coneflower). Reddish purple flowers, 4 in. in diameter. 3 to $4 \mathrm{ft}$. July, Aug.

ECHINOPS Ritro (Globe Thistle). A showy plant, with globular heads of blue flowers, thistle-like foliage. 3 to $4 \mathrm{ft}$. July, Aug.

EPIMEDIUM (Bishop's Hat). Leathery bronze foliage, small yellow flowers. May. 3 for $\$ 1.75$, 10 for $\$ 5.00$.

EREMURUS. A complete collection of these is offered in our Fall catalogue.

ERIGERON speciosus (Fleabane). Large, handsome, blue flowers with yellow center resembling a Michaelamas Daisy. $11 / 2 \mathrm{ft}$. July-Aug.

ERYNGIUM alpinum (Sea Holly). Flowers 3 in. across, of a steel blue. $2 \mathrm{ft}$. July, Aug.

amethystinum. Beautiful thistle-like heads of glistening amethyst-blue. 2 to $3 \mathrm{ft}$. July-Sept.

EUPATORIUM coelestinum (Mist Flower). A good hardy plant, with light blue flowers, similar to Ageratum. $2 \mathrm{ft}$. Aug.-Oct. 3 for $\$ 1.25$, 10 for $\$ 3.50$.

purpureum (Joe Pye Weed). Purple; fine for wild garden. 6 to $7 \mathrm{ft}$. July-Sept.

urticaefolium (ageratoides) (White Snakeroot). White flowers; good for cutting. 4 to $5 \mathrm{ft}$. Aug. Sept. 3 for $\$ 1.25,10$ for $\$ 3.50$.
EUPHORBIA corollata (Flowering Spurge). Pretty littlo white flowers. 2 to $3 \mathrm{ft}$. July, Aug.

epithymoides (polychroma). Bears masses of yellow flowers in early Spring. 3 for $\$ 1.25,10$ for $\$ 3.50$.

FERNS, HARDY. Valuable for planting in shady, moist situations and under trees where blooming plants will not thrive. As a rule they should be grown in a moist, shady and protected place, in a soil composed of rich loam and leafmold.

Adiantum pedatum (Hardy Maidenhair Fern).

Aspidium acrostichoides (Christmas Fern). An evergreen variety with deep green fronds about a foot high.

-Filix-mass (Male Fern): A rare evergreen type, growing about $2 \mathrm{ft}$. high in rich soil.

-spinulosum. Another evergreen variety growing 18 to $24 \mathrm{in}$. high.

Asplenium angustifolium. A charming Fern with light green, graceful fronds 1 to $3 \mathrm{ft}$. high.

-Filix-foemina. A large, handsome Fern with finely cut foliage about 2 to $3 \mathrm{ft}$. high.

Dicksonia punctilobula. A variety which will grow in sun or shade, growing about 18 in. high. Where masses of Ferns are desired, this variety cannot be surpassed.

Onoclea struthiopteris (Ostrich Fern). A very handsome variety which resembles a palm, growing from 2 to $4 \mathrm{ft}$. high. A very good Fern for growing as a background for smaller varieties.

Osmunda cinnamomea (Cinnamon Fern).

-regalis (Royal Fern).

FUNKIA. Very handsome and will thrive in almost any position. $11 / 2$ to $2 \mathrm{ft}$. July, Aug.

coerulea. Purple flowers; large, green foliage.

lancifolia albo-marginata. Leaves edged with white.

-undulata variegata. It has ovate leaves, the margins deep green and center a beautiful creamy white.

plantaginea grandiflora ( $F$. subcordata grandiflora). Large, pure white flowers and bold foliage make this a very attractive variety. 3 for $\$ 1.75,10$ for $\$ 5.00$.

GAILLARDIA grandiflora (Blanket Flower). Yellow and orange-red. $11 / 2 \mathrm{ft}$. May-Nov.

Portola. A race of hybrids whose colors range from reddish bronze to deep gold. An excellent, large flowering strain.

GALEGA officinalis (Goat's Rue). Rosy purple flowers, 3 to $4 \mathrm{ft}$. 3 for $\$ 1.25,10$ for $\$ 3.50$.

-alba. White flowers; fine for cutting. 3 to $4 \mathrm{ft}$. July. 3 for $\$ 1.25,10$ for $\$ 3.50$.

GENTIANA Andrewsii (Closed, or Bottle Gentian). Flowers of a fine blue. 18 to 24 in. Aug., Sept.

GERANIUM sanguineum. Fire-red; very effective. 1 to $1 \frac{1}{2} \mathrm{ft}$. May-July.

GEUM atrosanguineum (Avens). Dark crimson. 1 to $2 \mathrm{ft}$. May-July.

coccineum, Mrs. J. Bradshaw. Double dark red flowers. $2 \mathrm{ft}$. June-Sept. 3 for $\$ 1.25,10$ for $\$ 3.50$.

Heldreichil. Orange; very free flowering; fine foliage. $11 / 2 \mathrm{ft}$. May-July. 3 for $\$ 1.25,10$ for $\$ 3.50$.

Lady Stratheden. The large double flowers are a rich gnlden color. Flowers the greater part of Sum mer and Fall. $2 \mathrm{ft}$. June-Sept. 3 for $\$ 1.50$, 10 for $\$ 3.50$.

All plants, except where noted, 3 for $90 \mathrm{c}$. , 10 for $\$ 2.50$. Not less than 3 of 1 variety sold. 


\section{HARDY PERENNIAL PLANTS-Continued}

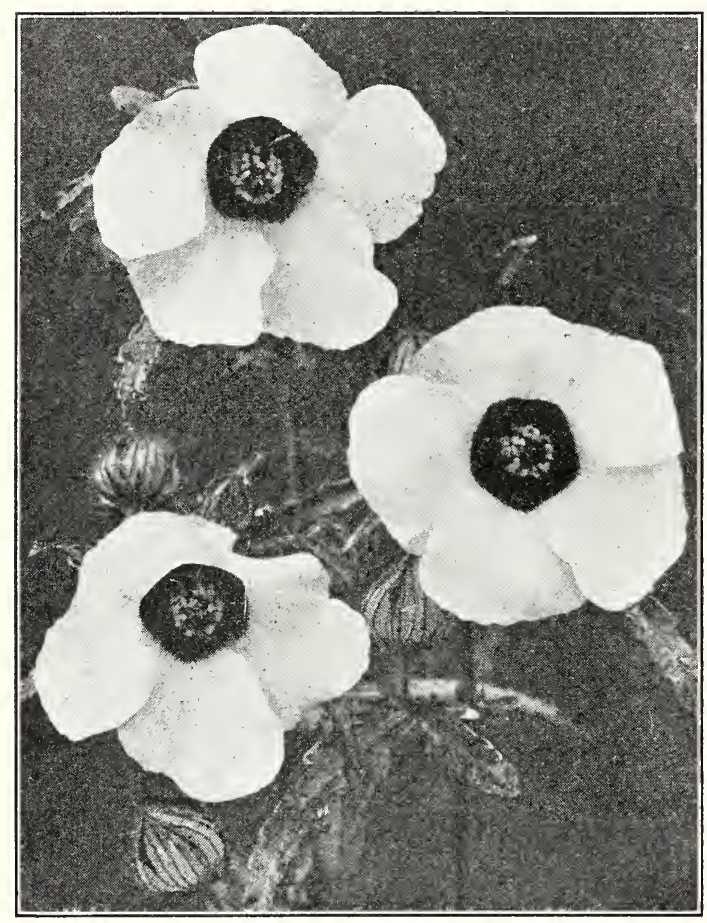

Hibiscus.

\section{GRASSES-}

Eulalia japonica variegata. Long, marrow leaves striped green, white, pink and yellow. 4 to $6 \mathrm{ft}$.

-japonica zebrina. Very striking with leaves banded transversely with pale yellow. 5 to $6 \mathrm{ft}$.

Festuca glauca. A pretty dwarf grass, with tufts of fine, bluish green foliage. $1 \mathrm{ft}$.

Phalaris arundinacea picta (arundinacea variegata). Variegated Ribbon Grass; Gardener's Garters. 2 to $3 \mathrm{ft}$.

G YPSOPHILA paniculata (Baby's Breath). Masses of minute, pure white flowers. 2 to $3 \mathrm{ft}$. June, July.

-Bristol Fairy. A new, double-flowering Babysbreath. Very early and blooms until Fall. Fieldgrown, grafted plants. Each, 75c., 10 for $\$ 7.00$.

-flore-pleno. Charming, double flowers borne on branched panicles in great profusion. July-Aug. 50 c. each, $\$ 4.50$ for 10 .

acutifolia (Chalk Plant). Rose-colored flowers. 3 to $4 \mathrm{ft}$. July, Aug.

repens. A lovely trailing variety with clouds of white or pale pink flowers in July and August.

Good rock plant.

HELENIUM autumnale superbum (Sneezeweed). A grand plant, with large, flat, lemon-yellow flowers. 4 to $5 \mathrm{ft}$. Aug., Sept.

Hoopesii. The earliest flowering of all the Heleniums and the only one with pure orange-colored flowers. 2 to $3 \mathrm{ft}$. May, June.

pumilum magnificum. A most useful border plant with large golden yellow flowers. July to Oct. 12 to 18 in. 3 for $\$ 1.50,10$ for $\$ 4.50$.
HELENIUM-Continued.

-Riverton Beauty. Rich lemon-yellow, with large purplish black cone. $5 \mathrm{ft}$. Aug., Sept. 3 for $\$ 1.25,10$ for $\$ 3.50$.

-Riverton Gem. Yellow, changing to red. $5 \mathrm{ft}$. Aug., Sept. 3 for $\$ 1.25,10$ for $\$ 3.50$.

HELIANTHUS (Hardy Sunflower). The large flowers on long stems are fine for cutting.

Maximilianii. One of the latest blooming of all; clear yellow. 6 to $8 \mathrm{ft}$. Oct., Nov.

mollis. Thick, velvety foliage of a silvery tinge; flowers lemon-yellow. $5 \mathrm{ft}$. Aug., Sept.

orgyralis. Graceful stalks, clothed with very long, willowy, drooping foliage; flowers deep lemonyellow. 8 to $10 \mathrm{ft}$. Aug.

Wolley Dod. Very free flowering, bright yellow semi-double. 6 to $7 \mathrm{ft}$. Sept.

HELIOPSIS Pitcheriana. The flowers are deep golden yellow, about 2 in. in diameter. 3 to $4 \mathrm{ft}$. July-Sept.

HEMEROCALLIS flava (Lemon Day Lily). Flowers lemon-yellow, sweet-scented. $3 \mathrm{ft}$. May. 3 for $\$ 1.25,10$ for $\$ 3.50$.

fulva. Large flowers of a rich bronze orange. 2 to $3 \mathrm{ft}$. June-Aug.

Middendorffii. Flowers deep orange-yellow. Desirable for cutting. 2 to $3 \mathrm{ft}$. June, July.

Thunbergii. Flowers lemon-yellow, very fragrant. $3 \mathrm{ft}$. July, Aug.

HEUCHERA sanguinea. The bright crimson flowers are borne in long. graceful, arching sprays. $11 / 2 \mathrm{ft}$. May-Sept. 3 for $\$ 1.25,10$ for $\$ 3.50$.

hybrida. Assorted colors. $1 \frac{1}{2} \mathrm{ft}$. May, Sept. 3 for $\$ 1.25,10$ for $\$ 3.50$.

HOLL YHOCK Althea rosea. 5 to $6 \mathrm{ft}$. July, Aug. Single. In crimson, rose, salmon, white or yellow. Double. In carmine-rose, crimson, yellow, rosesalmon and white colors.

HIBISCUS (Marvel Mallows). The flowers range in color from white to intense crimson. 5 to $8 \mathrm{ft}$. July-Sept. 3 for $\$ 1.25,10$ for $\$ 3.50$.

INULA ensifolia (Fleabane). Yellow: small flowers, 8 in July-Sept. 3 for $\$ 1.75,10$ for $\$ 4.50$.

glandulosa. Old-gold; pretty. 3 to $4 \mathrm{ft}$. July, Aug.

IRIS germanica (Garden Iris). See Fall catalogue,

IRIS Kaempferi (Japanese Iris), See Page 52.

LATHYRUS latifolius (Everlasting Pea). Flowers rose-colored, large, on many-flowered stems, similar to the annual Sweet Pea. $3 \mathrm{ft}$. June-Aug.

-albus. A variety of the preceding, with white flowers. Very desirable. $3 \mathrm{ft}$. June-Aug.

-White Pearl. With pure white flowers, which are double the size of the ordinary Lathyrus. 2 to 3 ft. June-Aug. 35c. each, $\$ 3.00$ for 10 .

LAVANDULA vera (Sweet Lavender). Fragrant blue flowers. $1 \frac{1}{2} \mathrm{ft}$. July-Sept. 3 for $\$ 1.25$, 10 for $\$ 3.50$.

LIATRIS pycnostachya (Kansas Gay Feather). Flowers purple, in dense spikes. 4 to $5 \mathrm{ft}$. July, Aug.

spicata (Button Snakeroot). Spikes 6 to 15 in. long; purple. 2 to $3 \mathrm{ft}$. July-Sept.

LINUM perenne (Flax). A lovely plant, with blue flowers. $11 / 2 \mathrm{ft}$. May-Aug.

-album. A white form of the above.

LOBELIA cardinalis (Cardinal Flower). Flowers intense scarlet. $3 \mathrm{ft}$. July, Aug.

syphilitica. Fine spikes of blue flowers. $3 \mathrm{ft}$. Aug., Sept.

LUPINUS polyphyllus (Lupine). Deep blue, peashaped. 3 to $4 \mathrm{ft}$. June, July.

-albiflorus. A white form of the above.

-Moerheimii. Color soft rose. June, July. 3 for $\$ 1.25,10$ for $\$ 3.50$.

All plants, except where noted, 3 for 90c., 10 for $\$ 2.50$. Not less than 3 of 1 variety sold. 


\section{HARDY PERENNIAL PLANTS-Continued}

L YCHNIS chalcedonica. Flowers bright scarlet, in dense clusters. $2 \mathrm{ft}$. June, July.

Coronaria (Agrostemma Coronaria). Flowers rich crimson, produced in great abundance on long stems. $2 \mathrm{ft}$. June, July.

viscaria splendens flore-pleno. A fine variety, with double, crimson flowers. $1 \mathrm{ft}$.

LYTHRUM salicaria roseum, Perry's Variety. A most beautiful shade of cherry red. 2 to $3 \mathrm{ft}$. July-Sept.

-Rose Queen. A remarkably free-blooming variety, with long, graceful spikes of rosy pink flowers. 2 to $3 \mathrm{ft}_{\text {: July-Sept. }}$

LYSIMACHIA clethroides (Japanese Loosestrife). A fine hardy variety from Japan, with long spikes of pure white flowers. $2 \mathrm{ft}$. July-Sept.

Nummularia (Creeping Jenny). Moneywort. Yellow flowering creepers. June-July.

MALVA moschata (Musk Mallow). Flowers rose; sweet scented. 1 to $2 \mathrm{ft}$. June-Sept.

-alba. A charming plant; flowers white. 1 to 2 ft. June-Sept.

MERTENSIA virginica (Virginian Cowslip). Flowers blue, funnel-formed, in nodding clusters. $11 / 2 \mathrm{ft}$. May, June.

MONARDA didyma. Compact heads of bright red flowers. $3 \mathrm{ft}$. June-Aug.

didyma, Cambridge Scarlet. Next to the scarlet lobelia, the most brilliant of our wild flowers.

didyma violacea superba. Deep amaranth-red.

MYOSOTIS palustris semperflorens (Forget-menot). Color blue; good for shady spots in the rock garden. 10 in. May-Sept.

NEPETA hederacea (Glechoma). Blue; a beautiful evergreen plant of creeping habit; fine for rockwork. 5 in. May, June.

OENOTHERA fruticosa major (Evening Primrose). Bright yellow flowers. $2 \mathrm{ft}$. June.

missouriensis. Large, yellow flowers, 10 in. JuneAug. 3 for $\$ 1.25,10$ for $\$ 3.50$.

PACHYSANDRA terminalis. One of the most valuable evergreen plants for derise shade. $2 \mathrm{yr}$. old field grown, $\$ 15.00$ for $100,21 / 4$ in. pots, $\$ 20.00$ for 100 .

PAPAVER nudicaule (Iceland Poppy). White, yellow, orange. 9 in. May-Aug.

orientale (Oriental Poppy). 2 to $3 \mathrm{ft}$. May, June.

-Beauty of Livermore. Deep crimson. $3 \mathrm{ft}$. May-June.

-Mrs. Perry. Pink. $3 \mathrm{ft}$. May, June.

- Perry's White. White. $3 \mathrm{ft}$. May, June.

- Princess Victoria Louise. Soft salmon-pink.

-Royal Scarlet. Brilliant scarlet. $3 \mathrm{ft}$. May-June. Price of any of the above. 3 for $\$ 1.50$. 10 for $\$ 4.50$.

PENTSTEMON barbatus Torreyi (Beard Tongue). Tall spikes of brilliant scarlet flowers. $4 \mathrm{ft}$. JuneAug.

Digitalis. White, tubular flowers with purple throat. $2 \mathrm{ft}$. July, August.

PEONIES. See Fall Catalogue.

PHLOX. Phloxes are among the very showiest and valuable of all hardy plants. Effective for planting in broad masses in the perennial border or for cutting for indoor decoration, their brilliant coloring places them in the front ranks of desirable flowers. 2 to $3 \mathrm{ft}$. June-Oct.

\section{Decussata}

Baron Von Dedem. Brilliant salmon red. B. Compte. Glowing Amaranth red. Commander-in-Chief. Splendid crimson red with darker eye.

Debs. The finest red variety. Color is bright fiery crimson.

Prices of above Phlox. 3 for $\$ 1.25,10$ for $\$ 3.50$.

\section{PHLOX-(Continued)}

Elizabeth Campbell. Immense trusses of bright salmon pink. One of the best.

Jeanne D'Arc. Massive spikes; pure white late flowering.

Jules Sandeau. A large, free flowering salmon pink.

Le Mahdi. Large heads of deep velvety purple.

Maid Marion. Soft lavender.

Michael Buchner. Dark purple.

Mrs. Jenkins. Large trusses of pure white. Early.

Mrs. Milly Von Hoboken. Bright pink, with soft mauve suffusion.

Rheinlander. Immense blossoms of salmon pink with a claret eye.

Tapis Blanc. A dwarf grower with immense heads of pure white flowers.

Thor. Rich salmon pink with crimson eye.

W. C. Egan. Large flowers; delicate lilac with red eye.

Phlox Suffruticosa. Miss Lingard. An early flowering type with large heads of white flowers with faint lilac eve. June-July. $3 \mathrm{ft}$.

Prices of above Phlox. 3 for $\$ 1.25,10$ for $\$ 3.50$.

Phlox, Dwarf Varieties:

amoena. A prostrate type with bright pink flowers in April and May. Good in rock garden. 4 inches.

Divaricata. (Canadensis). Masses of large fragrant lavender flowers in April and May. 10 inches. 3 for $\$ 1.25,10$ for $\$ 3.50$.

subulata. (Moss Pink). A prostrate creeping type with moss like foliage and profusion of pink flowers. 6 inches. April-May.

-Alba. The White Moss Pink. Very chaste.

-Vivid. Bright fiery rose. 3 for $\$ 1.75,10$ for $\$ 5.00$

PHYSALIS Franchetti (Chinese Lantern Plant). Enormous orange-colored fruits; useful for Winter decorating. $2 \mathrm{ft}$. April, May.

PHYSOSTEGIA virginiana (False Dragonhead). Strong spikes of delicate pink flowers. 2 to $3 \mathrm{ft}$. June, July.

-alba. Flowers pure white. 2 to $3 \mathrm{ft}$. June, July.

PLATYCODON grandiflorum (Balloon Flower). A dense branching plant of upright habit; flowers 3 in. across, blue. 1 to $2 \mathrm{ft}$. June, July.

-album. A white flowered form of the above.

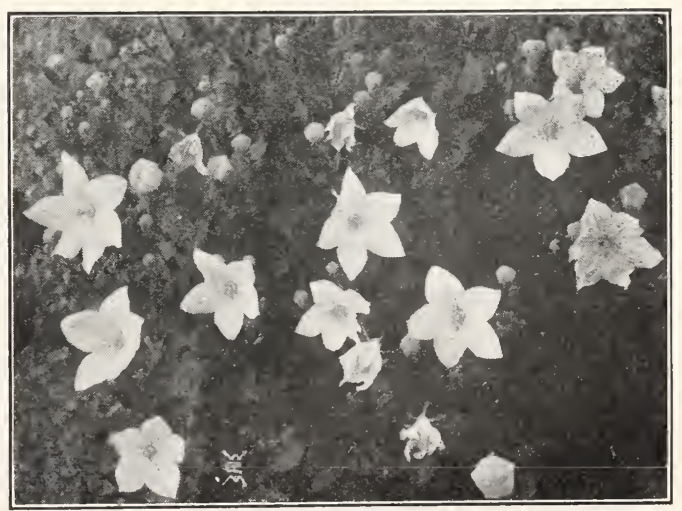

Platycodon All plants, except where noted, 3 for $90 \mathrm{c} ., 10$ for_\$2.50. Not less than 3 of 1 variety sold. 


\section{HARDY PERENNIAL PLANTS-Continued}

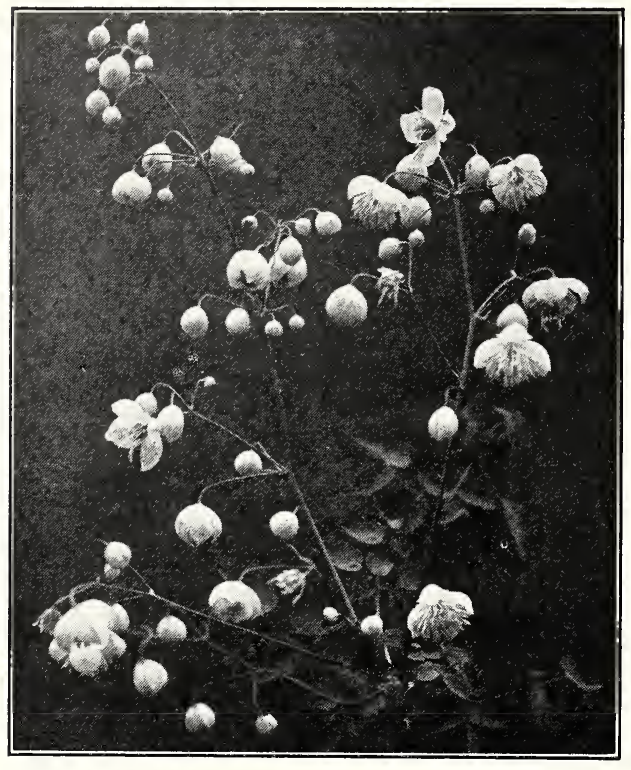

Thalictrum dipterocarpum

POLYGONATUM multiflorum (Solomon's Seal). Arching sprays of greenish white flowers; useful for cutting. $2 \mathrm{ft}$. May, June.

POLYGONUM Sieboldii. A strong-growing plant. Produces creamy white flowers; effective for massing. 3 to $5 \mathrm{ft}$. Aug., Sept. 3 for $\$ 1.25,10$ for $\$ 3.50$.

PRIMULA acaulis (vulgaris) (Common English Primrose). Bright lemon yellow and fragrant. 6 to 9 in. April, May. 3 for $\$ 1.25,10$ for $\$ 3.50$.

PYRETHRUM roseum. Single mixed varieties.

RUDBECKIA laciniata, Golden Glow. Masses of double, golden yellow flowers. 6 to $8 \mathrm{ft}$. Aug., Sept.

purpurea (Purple Cone Flower). See Echinacea purpurea.

speciosa (Newmannii). Dark orange-yellow flowers; fine for cutting. $2 \mathrm{ft}$. June-Oct.

subtomentosa. Densely branched masses of brilliant lemon-yellow flowers with dark purple centers. 4 to $5 \mathrm{ft}$. July-Oct.

SALVIA azurea grandifiora. A Rocky Mountain species, with pretty sky-blue flowers. 3 to $4 \mathrm{ft}$. Aug., Sept.

pratensis. Deep blue flowers. $2 \mathrm{ft}$. June, July. nemorosa (virgata nemorosa). An effective border plant, with dark blue flowers. $2 \mathrm{ft}$. May, June.

SCABIOSA caucasica. Beautiful, soft lilac flowers, vigorous grower, 2 to $3 \mathrm{ft}$. June-Aug.

-alba. Very rare; pure white; 2 to $3 \mathrm{ft}$.

The above two varieties 3 for $\$ 1.25,10$ for $\$ 3.50$.

japonica. Divided leaves, branching habit. Lavender-blue. $3 \mathrm{ft}$. June to Aug.

SEDUM acre (Golden Moss, Stonecrop). Flowers bright yellow. 2-3 in. May-July.

album. Foliage green; flowers white. 2-3 in.

Anglicum. Neat pretty trailer with white or pale pink flowers. 3-4 in.

pruniatum fosterium. One of the best with glaucus red tinted foliage. 3-4 in

reflexum. A rapid growing type. Yellow flowers, feathery green foliage. 6-7 in.

spurium (stoloniferum). A good type of fast growth with white or yellow flowers. 6-7 in.

spectabile (Stonecrop). Large heads of pink flowers. Fine border plant. $11 / 2 \mathrm{ft}$. Aug.-Sept.
SPIRAEA Filipendula ulmaria. White. $2 \mathrm{ft}$. June July.

Ulmaria fi. pl. Double white. $2 \mathrm{ft}$. June, July.

STACHYS lanata. Purple spikes of flowers; soft silvery foliage. $11 / 2 \mathrm{ft}$. June, July.

STATICE latifolia (Sea Lavender). Fine spreading panicles of lavender flowers.

STOKESIA cyanea (Cornflower Aster). Flowers 3 to 4 in. across, of a fine sky-blue. $2 \mathrm{ft}$. July-Oct. -alba. A white form of the above.

SWEET WILLIAM. See Dianthus.

THALICTRUM aquilegifolium (Meadow Rue) Graceful foliage and masses of pure white flowers 1 to $3 \mathrm{ft}$. May-July.

-adiantifolium. Leaves resemble those of the maidenhair fern; flowers yellow. $1 \mathrm{ft}$. June, July.

dipterocarpum. One of the handsomest Thalictrums, with graceful flowers on stems $4 \mathrm{ft}$. high rosy purple, citron-yellow anthers. Aug., Sept. 3 for $\$ 1.25,10$ for $\$ 3.50$.

THERMOPSIS caroliniana. A fine plant with clover-like foliage; long spikes of bright yellow, pea-shaped, lupine-like flowers. $4 \mathrm{ft}$. June, July. 3 for $\$ 1.25$, 10 for $\$ 3.50$.

THYMUS citriodorus aureus. Golden variegated foliage. 8 in. June-Aug.

TRADESCANTIA virginiana (Spiderwort). Long, grass-like leaves, violet flowers. $2 \mathrm{ft}$. May-Aug. -alba. White flowers. $2 \mathrm{ft}$. May-Aug.

TRITOMA Rufa. A very dainty yellow flower; a constant bloomer from June until frost; fine for cutting. $21 / 2 \mathrm{ft}$. June to Nov. $40 \mathrm{c}$. 10 for $\$ 3.50$. $100 \$ 30.00$.

- grandis (T. Pfitzeri). The freest flowering of all; orange-scarlet, shading to salmon-rose at the edge. 2 to $3 \mathrm{ft}$. Aug., Sept.

TROLLIUS europaeus (European Globe Flower). A pretty plant, with large, lemon-colored, buttercuplike flowers, 1 to $11 / 2$ in. across, on long stems. Should be planted in moist soil. $2 \mathrm{ft}$. May, June.

Orange Globe. A profuse bloomer, of robust growth; large orange flowers; very fine. $2 \mathrm{ft}$. May, June.

11l Trollius 3 for $\$ 1.75,10$ for $\$ 5.00$.

VALERIANA officinalis (Hardy Garden Heliotrope). Fragrant, light pink flowers. 3 to $5 \mathrm{ft}$. June, July.

VERBASCUM longiflorum pannosum (Mullein). Clear yellow, very ornamental; fine large, silvery foliage. $6 \mathrm{ft}$. June-Aug.

olympicum. Yellow flowers. Very attractive variety. $8 \mathrm{ft}$. May, June.

phoeniceum. Purple and pink flowers. $2 \mathrm{ft}$. June, July. 3 for $\$ 1.25,10$ for $\$ 3.50$.

thapsiforme (densifiorum). Large, yellow flowers. 2 to $5 \mathrm{ft}$.

VERONICA (Speedwell). All Veronicas love moist situations and are excellent for rockwork.

incana. Deep blue flowers with silvery foliage. $1 \mathrm{ft}$. July, Aug.

longifolia subsessilis (Blue). Attractive; blooms until late Fall. $2 \mathrm{ft}$. Aug., Sept. 3 for $\$ 1.25$, 10 for $\$ 3.50$.

spicata. Spikes of blue flowers. $11 / 2 \mathrm{ft}$. June, July. VINCA minor (Periwinkle). Evergreen trailer; fine for covering bare places. April, May.

VIOLA cornuta G. Wermig. This is a true Viola cornuta, with large blue flowers.

viola, Tufted Pansies.

Admiration. Soft purple, dark blotched.

lutea splendens. Golden yellow.

White perfection. White.

Jersey Gem. A valuable bedding Viols that will succeed in any good soil in sunny situation. Plant compact, growth sturdy with good stems, on which are pure violet flowers in great profusion. May to October. 3 for $\$ 1.25,10$ for $\$ 3.50$.

YUCCA filamentosa (Adam's Needle). Pyramidal clusters of creamy flowers. 4 to $6 \mathrm{ft}$. June, July.

All plants, except where noted, 3 for $90 c ., 10$ for \$2.50. Not less than 3 of 1 variety sold. 


\section{Plants and Seeds}

\section{Suitable for use in}

\section{ROCK GARDENS}

Being frequently asked to recommend seeds of plants not necessarily alpines-suitable for use in American rock gardens, we have compiled the following lists for ready reference. All those offered are of easy culture and can be relied upon to give greater general satisfaction than is usually obtained with the rarer and more difficult alpines.

While the veteran rock gardener may decry the use of annuals in the rock garden, we stress their utility for making a quick showing either in temporarily replacing losses or for immediate effect in newly constructed rock gardens.

\section{SEEDS OF PERENNIALS}

Adonis vernalis

Alyssum saxatile Silver Queen

Anemone coronaria

Aquilegia glandulosa

Aquilegia Skinneri

Arabis alpina

Armeria

Asperula odorata

Aubrietia (in va iety)

Auricula

Callirhoe involucrata

Campanula Carpatica

Carnation (dwarf Vienna)

Cerastium Tomentosum

Chieranthus Allioni

Chieranthus Linifolius

Cowslips

Dianthus plumarius

Edelweiss

Erysimum pulchellum

Erinus alpinus

Heuchera sanguinea

Linaria cymbalaria

Linum perenne

Myosotis (in variety)

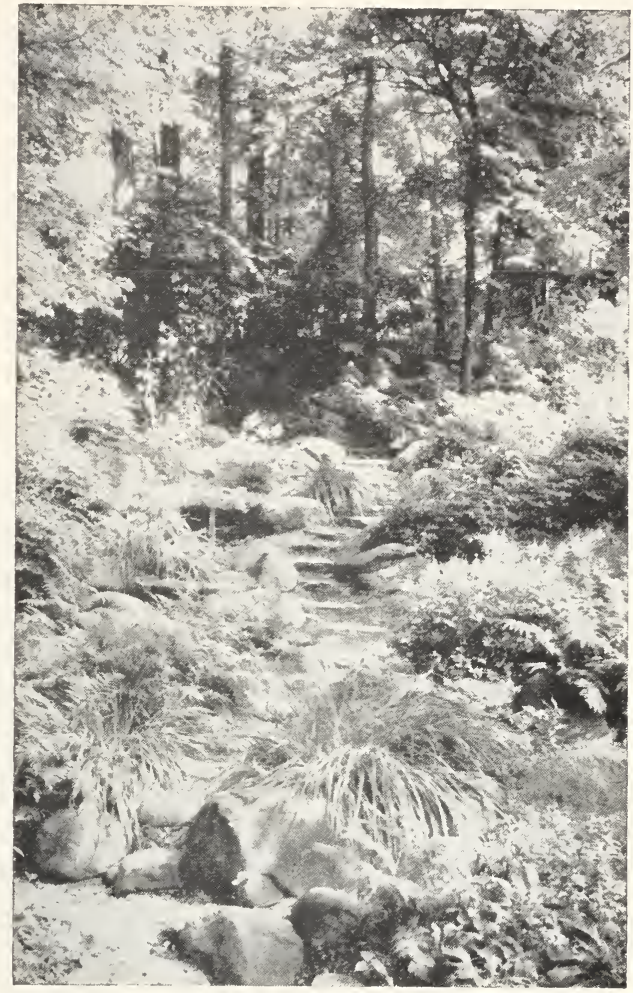

Platycodon mariesi

Polyanthus (in variety)

Primula Beesiana

Primula Japonica

Primroses (in variety)

Thalictrum adiantifolium

Viola odorata

Viola "Jersey Gem"

\section{SEEDS OF ANNUALS}

\section{Lobelia}

Marigold (dwarf)

Mesembryanthemum

Mignonette (dwarf)

Mimulus

Nasturtium (dwarf)

Nemesia compacta

Pansy (in variety)

Petunia (dwarf)
Phacelia

Phlox Drummondi (dwarf)

Portulaca

Sanvitalia

Tagetes

Verbena

Viola (in variety)

Viscaria

\section{A Selection of Easily Grown Rock Plants}

The following list of rock plants comprises only those of easy culture and which have been suggested by a veteran rock gardener as suitable for average use by the average rock garden enthusiast.

Achillea tomentosa

Alyssum saxatile compactum

Anemone pulsatilla,

Anemone sylvestris

Arabis alpina

Arenaria montana

Armeria Laucheana

Aster alpinus

Aubrietia, 3 for $\$ 1.25 ; 10$ for $\$ 3.50$

Campanula carpatica

Campanula muralis, 3 fo

Campanula rotundifolia

Cerastium tomentosum

Dianthus caesius

Dianthus deltoides

Dianthus deltoides

Geranium sanguineum

Gypsophila cerastoides

Helianthemum
Hepatica

Hypericum repens, 3 for $\$ 1.25 ; 10$ for $\$ 3.50$

Primula acaulis, 3 for $\$ 1.25 ; 10$ for $\$ 3.50$

Iberis Little Gem

Iris pumila, 3 for $\$ 1.25 ; 10$ for $\$ 3.50$

Iris cristata

Iris verna

eontopodium alpinum, 3 for $\$ 1.25$; 10 Primula veris

for $\$ 3.50$

Mertensia Virginic

Myosotis

ierembergia

Papaver alpinum, 3 for $\$ 1.25 ; 10$ for $\$ 3.50$

Papaver nudicaule

Phlox amoena

Phlox divaricata, 3 for $\$ 1.25 ; 10$ for $\$ 3.50$

Phlox ovats

Phlox subulata

Polemonium reptans
Primula Beesiana, 3 for $\$ 1.25 ; 10$ for $\$ 3.50$

Primula polyanthus

Primula Pulverulenta, 3 for $\$ 1.25 ; 10$ for $\$ 3.50$

Santolina

Saponaria Ocymoides, 3 for $\$ 1.25 ; 10$ for $\$ 3.50$

Saxifraga (in variety)

Sedums (in variety)

empervivum (in variety) 3 for $\$ 1.00$;

Silene alpestris, 3 for $\$ 1.25 ; 10$ for $\$ 3.50$

Thymus (in variety), 3 for $\$ 125 ; 10$ for $\$ 3.50$

Tunica saxifraga

Veronica (in variety), 3 for $\$ 1.25 ; 10$ for $\$ 3.50$

Viola (in variety)

All plants, except where noted 3 for $90 \mathrm{c} ., 10$ for $\$ 2.50$. Not less than 3 of 1 variety sold. 


\section{Hardy Vines and Climbers}

From a utilitarian as well as an ornamental viewpoint, hardy vines are most desirable. For beautifying pergolas, fences or rough banks nothing is quite so satisfactory. Our offerings embrace the choicest as well as the more reasonably priced varieties.

Field grown vines may be shipped in Spring or Fall; pot grown specimens are available throughout the year

ACTINIDIA arguta. Shining, dark green foliage. Flowers white, with purplish center...\$1.00 each

AKEBIA quinata. Numerous bunches of violetbrown flowers; does best in sunny places. . 75c. each

AMPELOPSIS heterophylla. Well adapted for covering rocks and low trelliswork.........75c. each quinquefolia (Virginia Creeper). Very large, green foliage, changing to brilliant scarlet in the Fall.

Engelmannii. Similar to the preceding, with smaller and more dense foliage........50 c. each

tricuspidata Lowii (Lowii) (New Japanese Ivy). The small, prettily lobed foliage changes to a brilliant crimson in Autumn. Pot grown plants, $\$ 1.00$ each.

Veitchii (Japanese or Boston Ivy). Rapid growing vine, handsome green foliage, assuming charming sun tints in the Fall.

Field grown plants, 2-yr....50c. each, $\$ 4.50$ for 10 Pot grown plants........ $\$ 1.00$ each, $\$ 9.00$ for 10

ARISTOLOCHIA Sipho (Dutchmans Pipe). A vigorous and rapid flowering climber. . .\$1.00 each

BIGNONIA radicans (Common Trumpet Vine) Brilliant orange-scarlet flowers in July and August....................75c. each

CELASTRUS scandens (False Bittersweet). A native vine, of rapid growth, with large leaves and yellow flowers.

Field grown plants.......\$1.00 each, 9.00 for 10

CLEMATIS. Beautiful and attractive vines.

Jackmanii. One of the best: large, rich, velvety purple flowers in profusion. $\$ 1.50$ each.

Henryi. Large, creamy white, fine form. $\$ 1.50$ each.

Mme. Edouard Andre. Bright red flowers. Pot grown plants................\$1.50 each

paniculata (Japanese Virgins Bower). The white flowers are very pretty, fragrant and resemble snowflakes in late Summer.

Field grown plants........50c. each, $\$ 4.50$ for 10

EUONYMUS radicans. Very hardy, dense growing trailing vine; dull green leaves, with whitish veins Field grown plants........60 c. each, $\$ 4.50$ for 10

variegatus. Fine vine, with clinging tendrils. Compact, variegated, small leaves.........75c. each

vegetus. Has round leaves and produces an abundance of showy red fruits with yellow pods.

$\$ 1.00$ each, $\$ 9.00$ for 10

HEDERA helix (English Ivy). This is the popular, small-leaved variety and has proved perfectly hardy. Pot grown plants.........50c. each, $\$ 4.50$ for 10 Extra strong plants.......75c. each, $\$ 6.50$ for 10 Specimens with many branches trained on sticks. 4 to $6 \mathrm{ft}$. $\$ 4.00$ each.

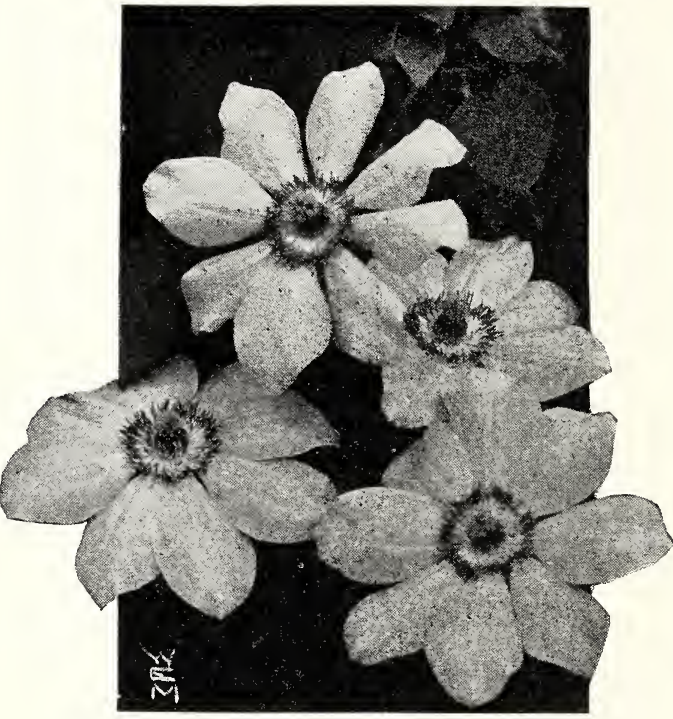

Clematis Jackmanii.

LONICERA japonica aureo-reticulata. Handsome foliage, netted and spotted bright yellow. 2 -year plants, 50 c. each, $\$ 4.50$ for $10, \$ 40.00$ per 100

- Halliana (Hall's Japanese Honeysuckle). A strong grower and constant bloomer. A choice variety.

2-year plants, 50c. each, $\$ 4.50$ for $10, \$ 35.00$ per 100

sempervirens. (Trumpet Honeysuckle). One of the best varieties. Its deep crimson flowers are borne profusely throughout the summer followed by scarlet berries..................75c. each

LYCIUM Chinensis. (Chinese Matrimony Vine). A vigorous climber, branching freely, bright purple star-shaped flower followed by brilliant scarlet berries. Fine for banks or retaining wall. 50c. each, $\$ 4.50$ for 10 .

POL YGONUM auberti (Silver Lace Vine). A useful climbing plant, perfectly hardy, a strong grower, covering itself with a sheet of snowy white flowers.....................\$1.00 each

PUERARIA Thunbergiana (Kudzu Vine). A most remarkable rapid growing vine, unparalleled for ornament and shade..............50c. each

SCHIZOPHRAGMA hydrangeoides (Climbing $\mathrm{Hy}-$ drangea). Has bright green, round leaves, and flowers similar to Hydrangeas.

Pot-grown plants............\$2.50 each

TECOMA. See Bignonia.

WISTERIA sinensis (chinensis) (Chinese Wisteria). Flowers sky-blue, in long, pendulous clusters. $\$ 1.00$ each Pot grown plants..............\$3.00 each -alba (chinensis alba) (White Chinese Wisteria). A choice variety with white flowers...\$1.00 each Pot grown plants................\$3.00 each

The prices given above are for field grown plants. We can supply pot grown plants, upon request, of the majority of varieties mentioned above. 


\section{ROSES-Hybrid Tea, or Everblooming}

This selection will produce a mass of Roses to cut from the entire season. The plants are two-year-old, and the varieties are the very best for outdoor culture; invaluable either for display or cutting and are hardy with protection.

Being almost as hardy as the June Roses, they can be treated in a similar way with regard to pruning.

All strong, two-year-old field grown plants, $\$ 1.00$ each, $\$ 9.00$ for 10 .

\section{SUGGESTIONS FOR SPRING PLANTING OF ROSES}

The soil should be thoroughly cultivated and a liberal supply of rotted manure added. In planting, dig a hole sufficiently large to accommodate the roots when spread out on the bottom of the hole. In filling in the soil, shake the plant lightly in order that the soil may mix between the roots. Fill in the soil and firm it in order that the plant may be solid. Be sure to see that the lower parts of the lower branches are below the surface of the soil. Do not plant in a mound, the surface should be level. Cut back the branches to within 4 to 6 inches of the surface of the ground. With this treatment the best results may be obtained.

\section{PINK AND ROSE SHADES}

Betty Uprichard. Very fine carmine pink. Spicy fragrance, strong grower.

Briarcliff. One of the most popular. Brilliant rose pink and fragrant.

Columbia. A large beautiful pink.

Jonkheer J. L. Mock. Carmine, changing to imperial pink. A variety of distinct merit.

Killarney Queen. A distinct clear pink.

Lady Alice Stanley. Deep coral rose on the outside of the petals, pale flesh on the inside.

Lady Ashtown. Pale carmine-pink, shading to golden yellow at base of petals.

Lady Ursula. Pastel shades of pink merging to yellow base, pleasantly fragrant

La Tosca. Silvery pink with deeper center, full flowers

Los Angeles. A luminous flame pink, toned with coral and shaded with translucent gold.

Margaret McGredy. Exquisite orange vermillion color. A superb rose.

Mme. Butterfly. Bright pink apricot and gold Large buds and flowers.

Mme. Caroline Testout. Bright, satiny rose, with brighter center; free flowering.

Miss Cynthia Forde. Large flowers of deep, brilliant rose-pink, with light rosy pink reflex.

Mrs. A. R. Barraclough. A glorious rose of large pure pink flowers. Very fragrant.

Mrs. Henry Morse. A lovely pink, shaded salmon, deeper at the base.

Ophelia. Delicate rose, heavily flushed but opening to a salmon flesh shaded with rose.

Premier. A handsome dark pink. The large full blooms are exquisite and very lasting.

Radiance. Beautiful carmine rose flushed with copper; large round flowers.

Willowmere. Coral-red buds opening to shrimp-pink.

William F. Dreer. Beautiful, shell-pink petals, with golden yellow bases.

\section{SCARLET, GARMINE AND GRIMSON SHADES}

Charles K. Douglas. Fine long pointed buds opening to large flowers of crimson-scarlet.

Etoile de France. A soft, velvety crimson, with a vivid shade of cerise.

Etoile de Hollande. Brilliant red bloom, fine size, very fragrant. A splendid rose.

Francis Scott Key. A glorious rose of blazing red. Perfectly formed, large size, fragrant.

General MacArthur. Bright crimson; large, free flowering; highly perfumed; very hardy.

George C. Waud. Distinct orange-red, with fine scent; large, full and well formed; very profuse.

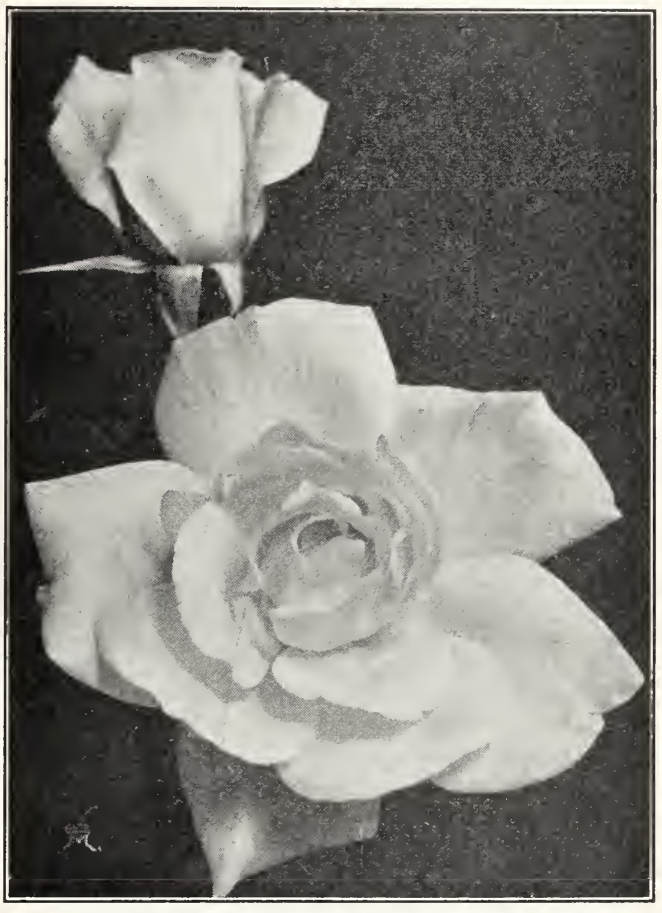

H. T. Rose, Independence Day.

\section{PURE WHITE AND WHITE SHADES}

Edel. A wonderful Rose, producing white flowers that open ivory-white.

Kaiserin Auguste Victoria. White, shading to primrose. A fine Rose; very vigorous.

Killarney, Double White. Very fine form of pure delicate appearance.

Gruss an Teplitz. Brightest scarlet crimson; satiny texture; very free flowering.

Hortulanus Budde. A fragrant bright red rose. Very popular.

H. V. Machin. Intensely black-grained, scarletcrimson blooms carried on rigid flower stalks.

John Russell. Large buds and immense crimson flowers. Strong and vigorous grower.

Laurent Carle. Brilliant, velvety carmine.

Red Radiance. Color deep red. The enormous, globular flowers are borne on heavy canes.

Innocence. Very large, single, pure white flowers, with prominent large, orange-red stamens. A strong upright grower.................\$1.50 each

Mme. Jules Bouche. Handsome white blooms, with centers shaded primrose.

Miss Willmott. White flowers of enormous size. 


\section{Roses, Hybrid Tea and Everblooming-Continued YELLOW, SALMON, COPPER SHADES}

Betty. Flowers ruddy gold; very large.

Constance. Orange buds, streaked crimson, developing large, rich yellow flowers.

Duchess of Wellington. Flowers saffron-yellow, which become deep coppery yellow as they open.

Eldorado. Buds golden yellow flushed red, opening to clear yellow, slightly fragrant.

Etoile de Feu. Exquisite flaming orange pink of fine form and texture.

Golden Emblem. A most desirable truly yellow Rose.

Golden Ophelia. Golden yellow in center, paling slightly at outer petals.

Harry Kirk. Clear yellow, sweetly perfumed.

Independence Day. Flame-colored flowers, show also petals of gold and apricot.

Lady Margaret Stewart. A perfectly formed rose of golden yellow.

\section{Hybrid Perpetual,}

These are commonly called the June Roses, owing to their greatest crop being borne in that month Require hard pruning annually. Our list of varieties is selected with a view to suit all lovers of the Rose who desire the best.

Extra strong, 2-year old, field grown plants, $\$ 1.00$ each, $\$ 9.00$ for 10 .

American Beauty. Deep pink to soft carmine.

Baroness Rothschild. Superb rose, of rich satiny pink.

Frau Karl Druschki. Fine snow-white; vigorous grower and very hardy.

General Jacqueminot. Brilliant scarlet-crimson superb flower.

George Arends. Strong grower with delicate pink flowers.

Hugh Dickson. Crimson, shaded scarlet.

J. B. Clark. Intense deep scarlet.

Magna Charta. Bright pink, suffused with carmine; a beautiful Rose.

Mrs. John Laing. Immense blooms of soft clear pink. A strong grower.

Paul Neyron. Deep rose; largest of all Roses; fine foliage.

Ulrich Brunner. Bright, cerise red; flowers large.

Any of the above Roses, $\$ 1.00$ each, $\$ 9.00$ for 10 .

\section{Climbing and Trailing Roses}

This class is easily distinguished by their peculiar habits. They may be grown either on trellis, pergolas or used in covering banks. The Roses in this class mostly flower in clusters.

Strong, 2-year-old plants, $\$ 1.00$ each, $\$ 9.00$ for 10 .

Aviateur Bleriot. Saffron buds and flowers streaked with crimson in small clusters.

Bess Lovett. Resembles Climbing American Beauty in shape of bloom, but is very much brighter in color and more fragrant.

Climbing American Beauty. Fragrant flowers of a rich crimson color.

Crimson Rambler. Small, ruffled flowers of dazzling scarlet-red borne in giant sprays on'a strong growing plant.

Dorothy Perkins (Hybrid Wichuraiana). Soft light pink, flowers profusely in large clusters.

Dr. W. Van Fleet. The long pointed buds are of a rich flesh-pink on long stems; vigorous grower.

Emily Gray. Golden yellow flowers like Marechal Neil. Very fragrant.
Mme. Edouard Herriot (Daily Mail Rose). Coralred, shaded with yellow and bright rosy scarlet, passing to shrimp-red.

Miss Lolita Armour. Chrome-yellow at base, shading to orange and copper hues.

Mrs. Aaron Ward. The color is a distinct Indian yellow, and as the flowers expand, they shade lighter to the edges.

Padre. Copper-scarlet with bright yellow at base of petals.

Rev. F. Page-Roberts. Copper-red buds of great length, opening to golden yellow.

Souvenir de Claudius Pernet. Fine buds of fadeless yellow.

Wilhelm Kordes. A recent introduction with long pointed buds of deep golden salmon, suffused copper and veined with red, very fragrant. A vigorous grower.

Any of the above varieties, except where priced, $\$ 1.00$ each, $\$ 9.00$ for 10 .

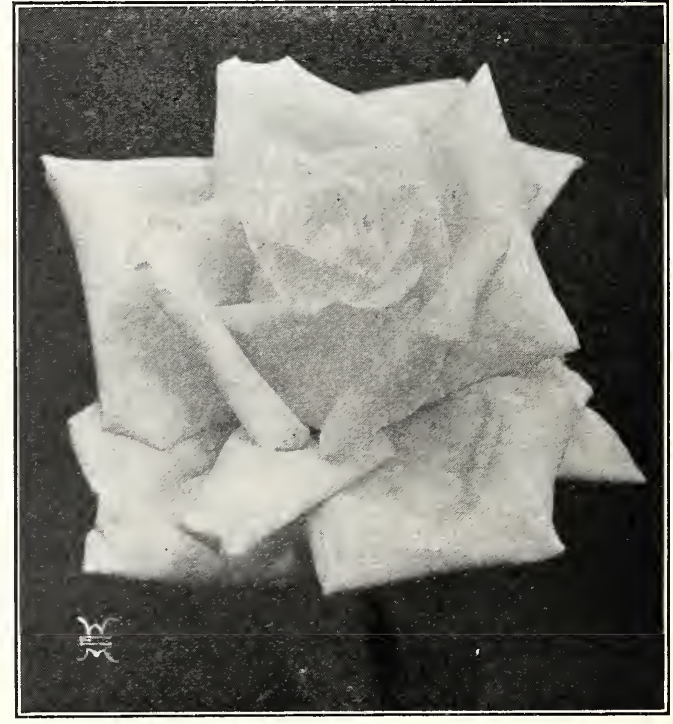

H. P. Rose, Frau Karl Druschki.
Excelsa (Wichuraiana). Intense crimson, with lighter edges, fine foliage.

Gardenia. Pleasing yellow buds, opening lighter.

Hiawatha (Single Wichuraiana). Brilliant scarlet flowers in large clusters; most brilliant and effective

Paul's Scarlet Climber. It is a vivid scarlet, shaded with bright crimson.

Roserie. A thornless Rose of deep pink.

Silver Moon. Semi-double, pure white flowers with bright yellow stamens; very profuse bloomer.

Star of Persia. Semi-double bright yellow flowers, borne in large sprays.

Tausendschoen (multiflora). Opening flowers pink, rosy carmine when expanded; clusters very large.

Any of the above Roses, $\$ 1.00$ each, $\$ 9.00$ for 10 . 


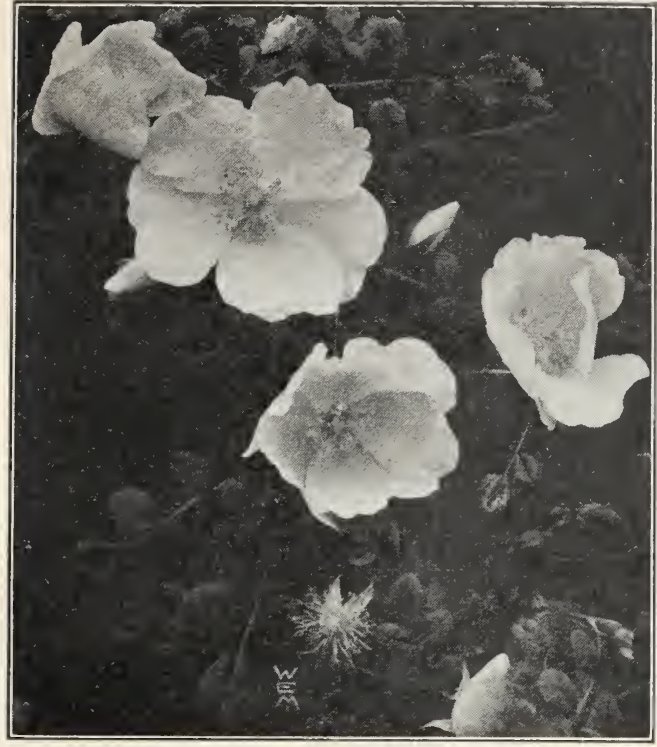

Rosa Hugonis

\section{MOSS ROSES}

The Moss Roses are very fragrant and bloom profusely in June.

Blanche Moreau. Pure snowy white.

Crested Moss. Pale, rosy pink, beautifully crested.

Red Moss. The color is a clear red heavily mossed with deep green.

Any of the above Roses $\$ 1.00$ each, $\$ 9.00$ for 10 .

\section{GREENHOUSE ROSES}

The Roses we offer for greenhouse culture are grown by reliable growers on grafted stock only. We guarantee fine, healthy stock will be sent on all orders entrusted to our care.

President Herbert Hoover. (New). Better than Talisman, more double, freer flowering, color a combination of cerise pink, flame scarlet and yellow.

Grafted. 21/4 in. pots. Doz. $\$ 8.00,100 \$ 75.00$.

Briarclift. The color is more brilliant than Columbia, being a true rose-pink.

Commonwealth. A beautiful dark pink. A wonderful rose for spring flowering.

Double White Killarney. The best white.

Golden Pernet. A greatly improved Pernet better color, perfect formation and less thorns.

Mrs. Calvin Coolidge. new The golden yellow.

Mrs. F. R. Pierson. A wonderful Rose. A fine sport of Premier with all its sterling qualities.

Mme. Butterfly. Bright pink, apricot and gold.

Ophelia. Clear salmon pink.

Premier Supreme. Rose pink, free and easy grower.

Rapture. An exquisite salmon shade, deeper than Butterfly, with the same golden flush at the base of petals.

Souvenir de Claudius Pernet. A beautiful yellow Pernetiana Rose. Grafted on Rosa odorata.

Talisman. The outstanding Rose novelty. Color a combination of gold, apricot, yellow and deep pink or old rose.

Tomplar. A clear bright red; very fragrant.

Grafted stock only. 21/2-in. pots, doz. $\$ 7.00,100$ $\$ 50.00,3$-in. pots, doz. $\$ 9.00,100 \$ 65.00$.

Greenhouse Roses ordered in advance will be shipped in due season for planting.

\section{DWARF POLYANTHAS}

The Polyanthas are a charming class of everblooming Roses, of a dwarf, bushy habit.

Eblouissant. Glowing dark red flowers of medium size, heavily shaded velvety crimson. Large trusses.

Ellen Poulsen. The flowers are large size and brilliant pink in color.

Gruss an Aachen. Large flowers of flesh pink overlaid with cream yellow; deep pink at base.

Miss Edith Cavell. A brilliant scarlet color

Orleans. Brilliant geranium-red, tinted pink, with creamy white centers.

Triomphe Orleanais. A bright, cerise-red.

Any of the above Roses $\$ 1.00$ each, $\$ 9.00$ for 10 .

\section{STANDARD ROSES}

We can supply many of the leading varieties in standard or tree form. Each $\$ 5.00$.

\section{MISCELLANEOUS ROSES}

Cabbage Rose. An old favorite. Large, full, rosypink, sweet scented flowers. Hardy and rugged. $\$ 1.00$ each.

Dr. E. M. Mills. Hybrid Hugonis. Small, semi-double primrose, shaded pink flowers. $\$ 1.00$ each.

Persian Yellow. Double yellow flowers in great profusion in Spring. 75e, each.

Rosa Hugonis. Fine for shrub planting, as it reaches a height of $6 \mathrm{ft}$. when fully matured. The long, arching branches are thickly set with the lovely single yellow flowers in May, and it is one of the earliest Roses to bloom. Makes a most spectacular show. Never winterkills, $\$ 1.00$ each.

Rosa rugosa, Conrad F. Meyer. A clear, silverypink, with double flowers. $75 \mathrm{c}$. each.

Rosa rugosa, F. J. Grootendorst. A continuols bloomer bearing red, double flowers in clusters. $\$ 1.00$ each.

Rosa Wichuraiana (Memorial Rose). Single. A handsome Rose for covering banks and rockeries. Fragrant, white flower clusters; half evergreen, glossy foliage. $75 \mathrm{c}$. each.

Rugosa Nova Zembla. Large double sweet-scented nearly white in color. $75 \mathrm{c}$. each.

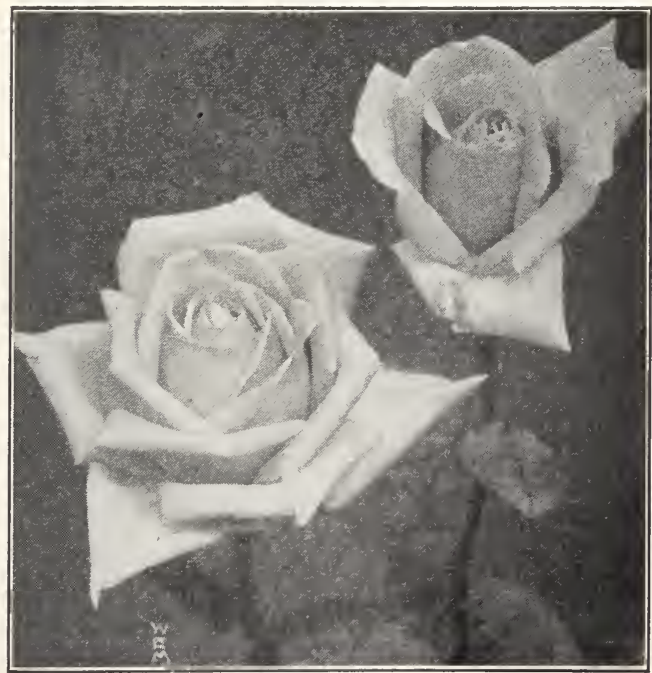

Rose, Ophelia 


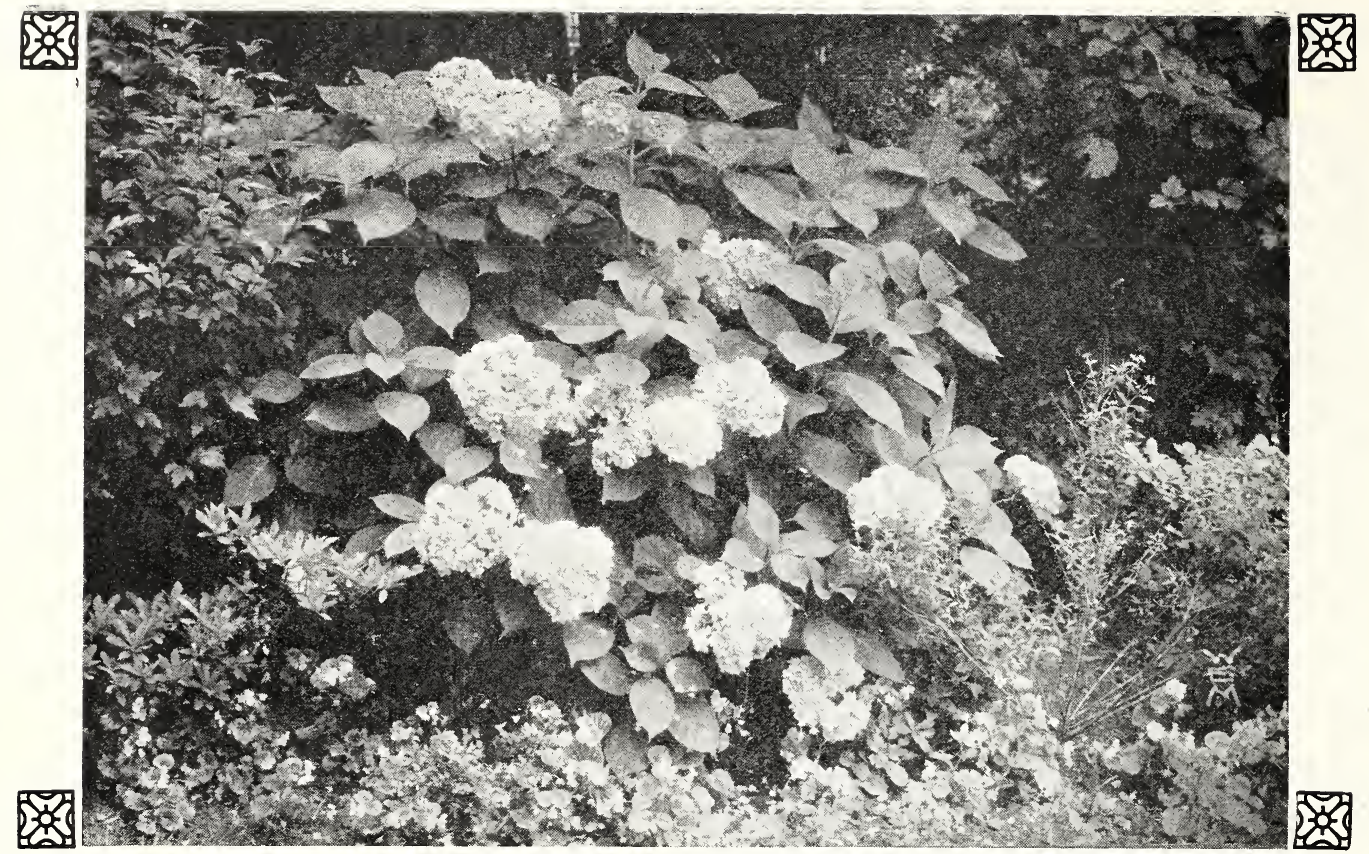

\section{Flowering and Foliage Shrubs}

Please note that the prices below are based upon actual values. Shape, buds and roots are what you want not merely height. We will send out only plants that are sure to give ultimate satisfaction. We have larger specimen plants, and if ordered, will supply them at proportionate rates.

ALTHAEA (Rose of Sharon). Strong, erect growing shrub of symmetrical habit. Very desirable for flowering all Summer.

Double Pink, Purple, Rose, or White.

2 to $3 \mathrm{ft}$.................... each, $\$ 6.50$ for 10

3 to $4 \mathrm{ft} \ldots \ldots \ldots \ldots \ldots \ldots \ldots 1.00$ each, $\$ 9.00$ for 10

AMELANCHIER canadensis (Dwarf Juneberry). White flowers in early Spring before the leaves.

2 to $3 \mathrm{ft} . \ldots \ldots \ldots \ldots \ldots \ldots \ldots \ldots \ldots 1.00$ each

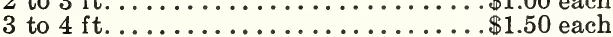

AMYGDALUS chinensis alba flore pleno (Double White Flowering Almond)

$3 \mathrm{ft} \ldots \ldots \ldots \ldots \ldots \ldots \ldots \ldots$ each -rosea plena (Double Pink Flowering Almond).

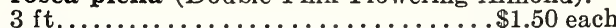

ANDROMEDA catesbaei. A valuable shrub for planting under trees, on the margins of woodland drives and in other shady positions. Flowers are fine white and are borne on long, pendulous racemes, with a characteristic fragrance.

15 to 18 in............ $\$ 2.00$ each, $\$ 17.50$ for 10 $11 / 2$ to $2 \mathrm{ft} . \ldots \ldots \ldots \ldots \ldots \ldots \ldots 3.00$ each, $\$ 27.50$ for 10

AZALEA amoena. Evergreen shrub of bushy habit and perfect hardiness. Flowers are of bright rosy purple.

12 to 15 in.................\$2.50 each

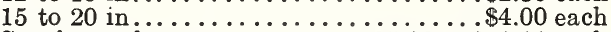
Specimen plants..........\$5.00 to $\$ 10.00$ each

hinodegiri. A bright scarlet form of the well-known and charming Azalea amoena.

12 to 15 in................\$3.50 each 15 to 18 in ................... \$5.00 each

viscosa (Swamp Honeysuckle). White, fragrant flowers in June and July.

12 to 18 in........... $\$ 2.50$ each, $\$ 20.00$ for 10

BENZOIN aestivale (Spicewood). Tall spreading bush with red berries in Summer and Autumn.

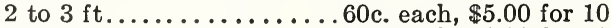
3 to $4 \mathrm{ft} . \ldots \ldots \ldots \ldots \ldots \ldots \ldots . \ldots \ldots$. each, $\$ 6.00$ for 10
BERBERIS thunbergi (Barberry). A beautiful Japanese variety of dwarf habit. Small foliage, changing to beautiful red in Autumn.

$11 / 2$ to $2 \mathrm{ft} . \ldots 50 \mathrm{c}$. each 2 to $3 \mathrm{ft} . \ldots .75 \mathrm{c}$. each

thunbergi atropurpurea (Red-leaved Barberry). The foliage is a rich bronzy-red with scarlet berries in the Fall. Should be planted in full sun exposure for hest coloring.

12 to 15 inches..........75c. each, $\$ 7.00$ for 10

Box Barberry. A perfectly hardy edging plant.

8 to 12 in ......... $\$ 4.00$ per $10, \$ 40.00$ per 100 12 to 15 in .........\$5.00 per $10, \$ 50.00$ per 100 15 to 18 in ..........\$6.00 per $10, \$ 60.00$ per 100

BUDDLEIA magnifica (variabilis magnifica). Purple-lilac flowers borne in long, graceful panicles, commencing to open in Midsummer and continuing until frost. 2 to $3 \mathrm{ft} \ldots \ldots \ldots \ldots . .50 \mathrm{c}$. each

CAL YCANTHUS floridus (Sweet Scented Shrub). 2 to $3 \mathrm{ft} . \ldots 75 \mathrm{c}$. each 3 to $4 \mathrm{ft}$...\$1.00 each

CERCIS canadensis (Japan Judas Tree, or Redbud).

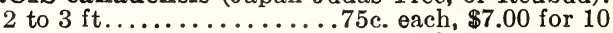
3 to $4 \mathrm{ft} . \ldots \ldots \ldots \ldots \ldots \ldots \$ 1.00$ each, $\$ 9.00$ for 10

CHIONANTHUS virginica (White Fringe). One of the most decorative of all the flowering shrubs. 2 to $3 \mathrm{ft}$...\$1.50 each 3 to $4 \mathrm{ft} . \ldots \$ 2.00$ each

CLETHRA alnifolia (Sweet Pepper Bush). $21 / 2$ to $3 \mathrm{ft} . \ldots \ldots \ldots \ldots \ldots 75 \mathrm{c}$. each, $\$ 7.00$ for 10 3 to $4 \mathrm{ft} . \ldots \ldots \ldots \ldots \ldots \ldots 1.00$ each, $\$ 9.00$ for 10

CORNUS alba sibirica (Red Osier Dogwood). 3 to $4 \mathrm{ft} . . . . . . . . . . . .75 \mathrm{c}$. each, $\$ 6.00$ for 10 florida. Pure snow-white flowers. 3 to $4 \mathrm{ft}$. . $\$ 1.75$ each 4 to $5 \mathrm{ft} . \ldots \$ 3.00$ each -rubra (Red Flowering Dogwood).

$11 / 2$ to $2 \mathrm{ft} . . \$ 4.00$ each 2 to $3 \mathrm{ft} . \ldots \$ 6.00$ each sanguinea. The well-known red-branched Dogwood. 3 to $4 \mathrm{ft} . \ldots \ldots \ldots .75 \mathrm{c}$. each, $\$ 6.50$ for 10

All Trees and Shrubs are shipped by express collect. No C. O. D. shipments made. 


\section{FLOWERING AND FOLIAGE SHRUBS-Continued}

CORYLUS americana (American Hazlenut). Useful for natural plantings.

2 to $3 \mathrm{ft}$., $\$ 1.00$ each. 3 to $4 \mathrm{ft}$., $\$ 1.50$ each.

CRATAEGUS coccinea (Scarlet Fruited Thorn). Crus-galli (Cockspur Thorn).

Oxyacantha (English Hawthorn). Single white flowers.

-alba plena. Double white flowers.

- fore rosea plena. Beautiful pink, double.

w. Paul's Scarlet. Rich brilliant scarlet flowers.

Prices of above varieties: 3 to $4 \mathrm{ft}$. $\$ 2.50$ each.

4 to $5 \mathrm{ft}$. $\$ 3.50$ each

CYDONIA japonica (Japan Quince). $11 / 2$ to $2 \mathrm{ft} . \ldots \ldots \ldots \ldots 75 \mathrm{c}$. each, $\$ 6.50$ for 10

DAPHNE Cneorum (Garland Flower). Sweet scented bright pink flowers. Trailing habit strong plants.

6 to 8 in. spread...... \$1.25 each, $\$ 11.00$ for 10 8 to 10 in. spread.....\$1.50 each, $\$ 14.00$ for 10

DEUTZIA crenata fi. pl. Flowers double, pinkish white.

2 to $3 \mathrm{ft}$..........60. each, $\$ 5.50$ for 10 3 to $4 \mathrm{ft}$..........75c. each, $\$ 7.00$ for 10

gracilis. A fine hardy shrub, forming a round and compact mass of white in June.

1 to $11 / 2 \mathrm{ft} . \ldots \ldots \ldots . .50 \mathrm{c}$. each, $\$ 4.50$ for 10 $11 / 2$ to $2 \mathrm{ft} . \ldots . \ldots \ldots .75 \mathrm{c}$. each, $\$ 7.00$ for 10

Lemoinei. 2 to $21 / 2 \mathrm{ft} \ldots \ldots \ldots \ldots \ldots 75 \mathrm{c}$. each

Pride of Rochester. Double white flowers, tinged pink.

2 to $3 \mathrm{ft} . \ldots \ldots \ldots \ldots 60.6 .6$ c. each, $\$ 5.50$ for 10

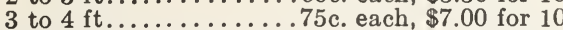

ELAEAGNUS longipes (Silver Thorn). The foliage is bright green above and silvery white beneath. 2 to $3 \mathrm{ft} . . . \ldots \ldots \ldots . .75 \mathrm{c}$. each, $\$ 7.00$ for 10 3 to $4 \mathrm{ft} \ldots \ldots \ldots \ldots \ldots . \$ 1.00$ each, $\$ 9.00$ for 10

EUONYMUS americana (Strawberry Bush) (Spindle Tree, or Burning Bush). An erect growing shrub with slender, green branches.

2 to $3 \mathrm{ft} . . . \ldots \ldots \ldots \ldots . . . . .75 \mathrm{c}$. each, $\$ 6.50$ for 10 3 to $4 \mathrm{ft} \ldots \ldots \ldots \ldots \ldots \ldots \ldots \$ 1.00$ each, $\$ 9.00$ for 10 alatus. The foliage is fine rose color in the Autumn. 2 to $3 \mathrm{ft}$. $\$ 1.00$ each.

3 to $4 \mathrm{ft}$. $\$ 1.25$ each

FORSYTHIA Fortunei (Golden Bell). Bark bright yellow; blooms in dense masses of golden flowers in April.

suspensa. (Weeping Golden Bell). Somewhat pendulous in habit.

viridissima. Blooms early in Spring, before the leaves appear.

2 to $3 \mathrm{ft} . . . \ldots \ldots \ldots . .60 .6$ c. each, $\$ 5.50$ for 10 3 to $4 \mathrm{ft} . \ldots \ldots \ldots \ldots \ldots . . . . . .65 \mathrm{c}$. each, $\$ 6.50$ for 10 4 to $5 \mathrm{ft} . \ldots \ldots \ldots \ldots \ldots . . \$ 1.00$ each, $\$ 9.00$ for 10

HALESIA tetraptera (Silver Bell) (Snowdrop Tree). A beautiful large shrub, with pretty, white, bellshaped flowers. 2 to $3 \mathrm{ft}$. $\$ 1.00$ each.

3 to $4 \mathrm{ft}$. $\$ 1.50$ each

HYDRANGEA arborescens grandiflora (Hills of Snow). Foliage green, bluish underneath. Flowers June and July. 2 to $3 \mathrm{ft}$. $75 \mathrm{c}$. each

3 to $4 \mathrm{ft}$. $\$ 1.00$ each

- paniculata grandiflora. This is a grand plant, showy and attractive, lasting in bloom for months. 2 to $3 \mathrm{ft} \ldots \ldots \ldots \ldots \ldots \ldots \$ 1.00$ each, $\$ 9.00$ for 10 3 to $4 \mathrm{ft} . \ldots \ldots \ldots \ldots \ldots . \$ 1.25$ each, $\$ 11.00$ for 10 Standards, 3 yr. head...............\$2.00 each

otaksa. Immense beads of either pink or blue flowers.

Extra heavy pot grown plants. $\$ 1.00$ to $\$ 2.00$ each Plants in tubs..... ...... $\$ 4.00$ to $\$ 10.00$ each Specimens............... $\$ 15.00$ to $\$ 25.00$ each

\section{French Varieties}

Baby Bimbenet. Very dwarf, free, and early; large, compact trusses of silvery rose flowers.

Eclaireur. Bright carmine rose.

General de Vibraye. Large; bright rose.

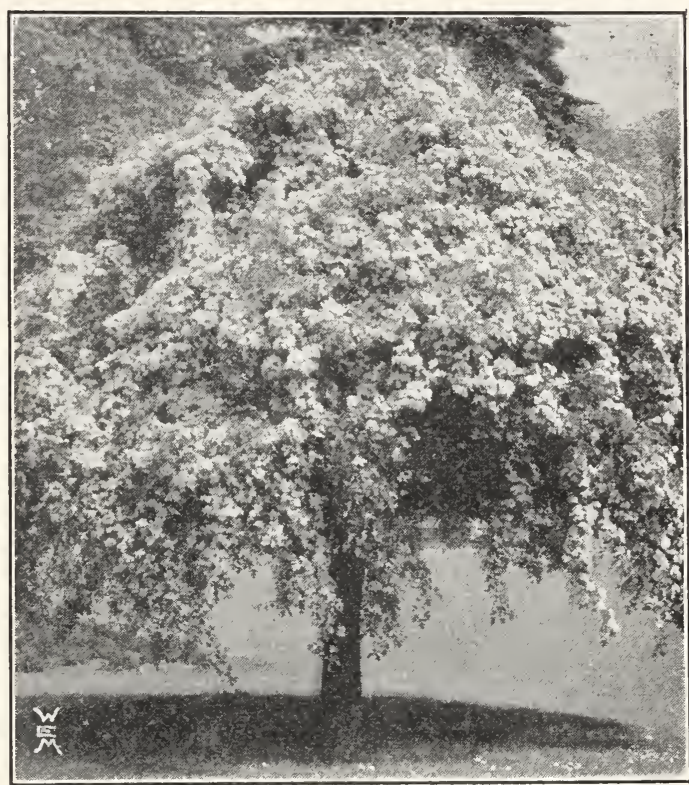

Flowering Thorn (Crataegus)

HYDRANGEA, French Varieties,-_Continued)

Lou is Foucard. Distinct, deep cheerful reddish carmine.

Mme. Maurice Hamar. Very good pink.

Souv. de Mme. E. Chautard. The most popular, early. free pink.

Pot grown plants........\$1.00 each, $\$ 9.00$ for 10

HYPERICUM aureum (St. John's Wort). Flowers of bright yellow, July to August.

Moserianum. Beautifu! golden yellow flowers, crimson stamens. Of dwarf habit.

All Hypericums..........50c. each, $\$ 4.50$ for 10

ITEA virginica (Virginian Willow). One of the prettiest native shrubs; produces racemes of pure white flowers during June, which bave a fragrance not unlike the Pond Lily.

$11 / 2$ to $21 / 2 \mathrm{ft} \ldots \ldots \ldots \ldots \ldots 60$ each, $\$ 5.50$ for 10

JASMINUM nudiflorum (Winter Jasmine). Golden yellow flowers very early in Spring, flowering before the foliage appears. 18 to 24 in. 75 c. each.

2 to $21 / 2 \mathrm{ft}$. $\$ 1.00$ each

KERRIA Japonica. A green-branched shrub conspicuous in winter; abundant yellow flowers from June to October.

$11 / 2$ to $2 \mathrm{ft} . \ldots \ldots \ldots \ldots . \$ 0.70$ each, $\$ 6.00$ for 10 2 to $3 \mathrm{ft} \ldots \ldots \ldots \ldots \ldots . \$ 1.00$ each, $\$ 8.00$ for 10 -Flore-pleno. Double yellow flowers.

$11 / 2$ to $2 \mathrm{ft} . . . . \ldots \ldots \ldots . . \$ 0.80$ each, $\$ 7.00$ for 10 2 to $3 \mathrm{ft} \ldots \ldots \ldots \ldots \ldots \ldots \ldots \ldots 1.25$ each, $\$ 10.00$ for 10

LIGUSTRUM amurense (Japanese Privet). Large, oblong, glossy green foliage, half evergreen; grows to $15 \mathrm{ft}$.

3 to $4 \mathrm{ft} . \ldots \ldots \ldots \ldots . \ldots 75$. each, $\$ 6.50$ for 10

Ibota (New Japanese Privet). Large, glossy, distinct foliage.

3 to $4 \mathrm{ft}$............60. each, $\$ 5.50$ for 10

ovalifolium (California Privet). Vigorous shrub of excellent habit.

3 to 4 ft...........50c. each, $\$ 4.50$ for 10 4 to $5 \mathrm{ft} . . . . . . . . . . . .75 \mathrm{c}$ each, $\$ 6.50$ for 10 Globe-shaped, clipped, $21 / 2 \mathrm{ft} \ldots \ldots \ldots \ldots \$ 4.00$ each $3 \mathrm{ft} . \$ 5.00$ each. $31 / 2 \mathrm{ft} \ldots \ldots \ldots \ldots \ldots . \$ 6.00 \mathrm{each}$ 


\section{FLOWERING AND FOLIAGE SHRUBS-Continued}

\section{LIGUSTRUM-(Continued)}

Regelianum. Splendid dense horizontal growing shrub. $11 / 2$ to $2 \mathrm{ft} . . . . .50 \mathrm{c}$. each, $\$ 4.50$ for 10 2 to $21 / 2 \mathrm{ft} . \ldots \ldots \ldots \ldots \ldots 75 \mathrm{c}$. each, $\$ 6.50$ for 10

LILACS. Syringa persica. Purple flowers. 2 to $3 \mathrm{ft} . \ldots \$ 1.00$ each. 3 to $4 \mathrm{ft} . \ldots \$ 1.25$ each rothomagensis. Large red flowers.

2 to $3 \mathrm{ft} . \ldots \$ 1.00$ each. 3 to $4 \mathrm{ft} . \ldots \$ 1.25$ each vulgaris. The common purple species.

2 to $3 \mathrm{ft} . \ldots .75 \mathrm{c}$. each. 3 to $4 \mathrm{ft}$. . \$1.00 each vulgaris alba. Fragrant single white.

2 to $3 \mathrm{ft}$....\$1.00 each. 3 to $4 \mathrm{ft} . \ldots \$ 1.25$ each

LONICERA (Bush, or Upright Honeysuckle).

fragrantissima (Fragrant Upright Honeysuckle). Graceful spreading habit, rich dark green foliage; fragrant flowers.

Morrowi. Pure white flowers; bright red fruit; August till late Fall.

tatarica (Tartarian Honeysuckle). Pink flowers -alba (White Tartarian Honeysuckle).

Prices of all varieties.

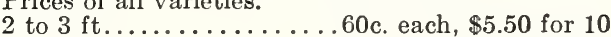

3 to $4 \mathrm{ft} . \ldots \ldots \ldots \ldots \ldots .75 \mathrm{c}$. each, $\$ 7.00$ for 10

MALUS atrosanguinea (Crab). Makes a good head; covered with deep carmine flowers.

floribunda (Profuse Flowering Crab). Forms a shapely bush or small tree; bud warm red, opening to light pink, delicately shaded.

ioensis (Bechtel's Crab). Finest of all. Large peach blush double flowers. Sweet scented.

scheideckeri (Double Flowering Crab). Has fine double flowers of a light rose color.

Prices of above, 3 to $4 \mathrm{ft}, \$ 1.50$ each, 4 to $6 \mathrm{ft}$., $\$ 2.50$ each.

PHILADELPHUS coronarius (Common Mock Orange). Flowers pure white and very fragrant. Blooms in June.

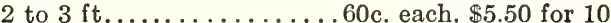
3 to $4 \mathrm{ft} . \ldots \ldots \ldots \ldots \ldots \ldots 75 \mathrm{c}$. each, $\$ 6.50$ for 10 - virginal. Erect growing, large double white flowers from June until Fall. 2 to $3 \mathrm{ft} . . \$ 1.00$ each grandiflorus. Flowers creamy white, vigorous shrub. 2 to $3 \mathrm{ft} . . . \ldots \ldots \ldots .6 .60 .6$. each, $\$ 5.50$ for 10 3 to $4 \mathrm{ft} . \ldots \ldots \ldots \ldots \ldots .75 \mathrm{c}$. each, $\$ 7.00$ for 10

PRUNUS Pissardii (Purple-leaved Plum). Vigorous, upright growth.

3 to $4 \mathrm{ft} \ldots \ldots \ldots \ldots \ldots . \$ 1.00$ each, $\$ 9.00$ for 10 4 to $5 \mathrm{ft} . \ldots \ldots \ldots \ldots \ldots . \ldots 1.50$ each, $\$ 12.00$ for 10 triloba (Double Flowering Plum).

2 to $3 \mathrm{ft} . \ldots \$ 1.25$ each. 3 to $4 \mathrm{ft} . \ldots \$ 1.50$ each

RHAMNUS cathartica (Buckthorn). A tall growing shrub or hedge plant. Lustrous green leaves and black berries follow the white flowers. Extremely hardy and very ornamental.

2 to $3 \mathrm{ft}$..............60. each, $\$ 5.00$ for 10 3 to $4 \mathrm{ft} . \ldots \ldots \ldots \ldots \ldots .75 \mathrm{c}$. each, $\$ 6.50$ for 10

RHODOTYPOS kerrioides (White Kerria). Showy white flowers in May followed by black berries that last all Winter.

18 to 24 in.............75c. each, $\$ 6.50$ for 10 2 to $3 \mathrm{ft} \ldots \ldots \ldots \ldots \ldots \ldots \ldots \$ 1.00$ each, $\$ 9.00$ for 10

RHUS cotinus (Sumach) (Furple Fringe, or Smoke Tree). A curious, large growing, shrub, forming broad, round headed bushes.

18 to 24 in ............. $\$ 1.00$ each, $\$ 9.00$ for 10 2 to $3 \mathrm{ft} \ldots . . \ldots \ldots \ldots . \$ 1.50$ each, $\$ 13.00$ for 10

typhina (Staghorn Sumach).

3 to $4 \mathrm{ft}$.................75c. each, $\$ 6.50$ for 10 4 to $5 \mathrm{ft} \ldots \ldots \ldots \ldots \ldots \ldots \$ 1.00$ each, $\$ 9.00$ for 10

- laciniata (Fern leaved Staghorn Sumach).

2 to $3 \mathrm{ft} . \ldots \ldots \ldots \ldots \ldots \ldots 60$. each, $\$ 5.50$ for 10 3 to $4 \mathrm{ft}$..............75c. each, $\$ 7.00$ for 10
ROBINIA hispida. (Rose Acacia). Drooping clusters of pea shaped rose colored flowers in May and June.

2 to $3 \mathrm{ft}$...\$1.00 each. 3 to $4 \mathrm{ft}$...\$1.50 each

SAMBUCUS (Elder). These are large, showy shrubs, ornamental in flower, fruit and foliage; of easy cultivation

canadensis (Common Elder).

nigra aurea. Golden yellow foliage.

2 to $3 \mathrm{ft} . \ldots \ldots \ldots \ldots \ldots 60 . \ldots 6$. each, $\$ 5.50$ for 10 3 to $4 \mathrm{ft} \ldots \ldots \ldots \ldots \ldots \ldots . \ldots \ldots$ c. each, $\$ 7.00$ for 10

SPIRAEA Bumalda. Very handsome; rose colored flowers. Dwarf. 18 in...75c. each, $\$ 6.50$ for 10

Anthony Waterer. Grows dwarf. The brightest colored of all the Spiraeas.

$11 / 2$ to $2 \mathrm{ft} . . .75 \mathrm{c}$. each. 2 to $3 \mathrm{ft} . \ldots \$ 1.00 \mathrm{each}$

opulifolia (Ninebark). Of vigorous growth, with flat clusters of white flowers.

2 to $3 \mathrm{ft}$.............60. each, $\$ 5.50$ for 10 3 to $4 \mathrm{ft} . \ldots \ldots \ldots \ldots \ldots . \ldots 75 \mathrm{c}$. each, $\$ 6.50$ for 10

prunifolia fi. pi. (Bridal Wreath). Small, double, white flowers, borne close to the branches.

2 to $3 \mathrm{ft} . \ldots 75 \mathrm{c}$. each. 3 to $4 \mathrm{ft} . \ldots \$ 1.00$ each

Thunbergii. Pure white flowers.

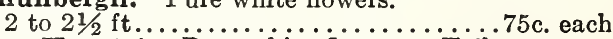

Van Houttei. Pure white flowers. Tall.

2 to $3 \mathrm{ft} . \ldots 75 \mathrm{c}$. each. 3 to $4 \mathrm{ft} . \ldots \$ 1.00$ each

STEPHANANDRA flexuosa. The leaves are finely and delicately cut. Flowers are creamy white. 2 to $3 \mathrm{ft} . . .75 \mathrm{c}$. each. 3 to $4 \mathrm{ft} . \ldots \$ 1.00$ each

STYRAX japonica. Leaves resemble those of the Dogwood; flowers pure white; bel!-shaped. 2 to $3 \mathrm{ft}$...75c. each. 3 to $4 \mathrm{ft}$...\$1.00 each

SYMPHORICARPOS racemosus (Snowberry). Small pink flowers in Summer, followed by large, waxy white berries in Autumn.

2 to $3 \mathrm{ft} . \ldots 75 \mathrm{c}$. each. 3 to $4 \mathrm{ft}$. . $\$ 1.00$ each vulgaris (Coral Berry). Vigorous and quick grower, covered with purple berries all Summer.

2 to $3 \mathrm{ft} . . .660 \mathrm{c}$. each. 3 to $4 \mathrm{ft} . \ldots .75 \mathrm{c}$. each

TAMARIX africana (Tamarisk). Strong, growing shrubs, with feather foliage and small, delicate flowers.

2 to $3 \mathrm{ft}$. ...60 c. each. 3 to $4 \mathrm{ft} . \ldots \$ 1.00$ each

VIBURNUM. A very popular shrub, known as the Snowball.

dentatum. Curious dentated leaves and greenish white flowers; pretty berries in Autumn. 2 to $3 \mathrm{ft} . \ldots \ldots \ldots \ldots \ldots \ldots . . . \ldots 5 \mathrm{c}$. each, $\$ 6.50$ for 10 3 to $4 \mathrm{ft} \ldots \ldots \ldots \ldots \ldots \ldots 1.00$ each, $\$ 9.00$ for 10

Lantana. The large white flower clusters open in May and are followed by red fruits.

2 to $3 \mathrm{ft} . . .75 \mathrm{c}$. each. 3 to $4 \mathrm{ft} . \ldots \$ 1.00$ each

Opulus (High Cranberry). Very fine in flower, and berries are scarlet. Leaves are three-lobed and coarsely toothed.

3 to $4 \mathrm{ft}$...............75c. each, $\$ 6.50$ for 10 4 to $5 \mathrm{ft} \ldots \ldots \ldots \ldots \ldots \ldots \ldots \ldots \ldots \ldots \ldots \ldots$ each, $\$ 9.00$ for 10

Opulus sterile (Snowball). A variety of the above with globes of pure white flowers in May.

3 to $4 \mathrm{ft} \ldots \ldots \ldots \ldots \ldots \ldots \ldots \ldots \ldots \ldots \ldots 1.00$

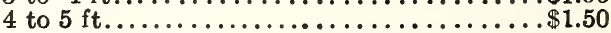

WEIGELA (Diervilla). A valuable, bold, graceful shrub. Flowers trumpet-shaped, varying in color from pure white to dark red.

amabilis. Vigorous and attractive shrub, with light pink flowers.

2 to $3 \mathrm{ft}$....75c. each. 3 to $4 \mathrm{ft}$... $\$ 1.00$ each candida. Flowers pure white; strong grower.

2 to $3 \mathrm{ft} . \ldots .75 \mathrm{c}$. each. 3 to $4 \mathrm{ft} . \ldots \$ 1.00$ each Eva Rathke. Rich reddish purple.

$11 / 2$ to $2 \mathrm{ft}$. . .75c. each. 2 to $2 \frac{1}{2} \mathrm{ft} . . \$ 1.00$ each rosea. Handsome rose-colored flowers.

2 to $3 \mathrm{ft} . . . .75 \mathrm{c}$. each. 3 to $4 \mathrm{ft} . \ldots \$ 1.00$ each - nana variegata. Leaves variegated with white. 2 to $3 \mathrm{ft} . . . \ldots \ldots \ldots \ldots \ldots . . \ldots 5 \mathrm{c}$. each, $\$ 6.50$ for 10 3 to $4 \mathrm{ft} \ldots \ldots \ldots \ldots \ldots \ldots \ldots \ldots \ldots 1.00$ each 


\section{Ornamental Evergreens and Conifers}

BOXWOOD (Buxus) sempervirens (Common Tree Box). A large shrub with thick, leathery dark green leaves. Bears shearing well and can be shaped in any form desired.

Bush Form. In various sizes. $\$ 2.00$ to $\$ 15.00$ each. Pyramids. In various sizes.... \$7.00 to $\$ 20.00$ each

BoxwoOD EDGING, Dwarf Box (suffruticosa) The well-known Box used for edging, and invaluable for that purpose.

4 to 6 in .................. $\$ 25.00$ per 100

6 to 8 in.................. \$50.00 per 100

JUNIPERUS (Juniper) excelsa stricta. Foliage glaucous and arranged around the branches in threes, dense and prickly.

$1 \mathrm{ft} . \ldots \ldots \ldots \$ 20$ each. $11 / 2 \mathrm{ft} . \ldots \ldots 3.00$ each $2 \mathrm{ft} \ldots \ldots \ldots \$ 4.00$ each. $\quad 21 / 2 \mathrm{ft} \ldots \ldots \$ \$ .00$ each

hibernica (Irish Juniper). A distinct and beautiful variety, of erect, dense, conical outline.

12 in.....\$1.50 each. 18 in.....\$2.25 each

pfitzeriana. Very distinct, being of striking, graceful habit; the color bright silvery green; perfectly hardy.

18 to 24 in. . $\$ 3.50$ each. 2 to $21 / 2 \mathrm{ft} . \$ 5.00$ each sabina (Compact Savin Juniper). Low, trailing habit and fine for massing.

12 in......\$2.00 each. 18 in.....\$4.00 each

virginiana (Red Cedar). Of medium compact growth. $3 \mathrm{ft} . \ldots \ldots . \$ 3.50$ each. $4 \mathrm{ft} . \ldots \ldots \$ 6.00$ each $5 \mathrm{ft} \ldots \ldots \ldots \$ 10.00$ each. $\quad 6 \mathrm{ft} . \ldots \ldots . \$ 12.00$ each - glauca (Silvery Red Cedar).

$2 \mathrm{ft} . \ldots \ldots \ldots \$ 4.00$ each. $3 \mathrm{ft} . \ldots \ldots \$ 7.00$ each

KALMIA latifolia (Mountain Laurel, or Calico Bush). 1 to $11 / 2 \mathrm{ft}$., nursery grown..........\$2.50 each $11 / 2$ to $2 \mathrm{ft}$., nursery grown..........\$5.00 each 2 to $3 \mathrm{ft}$., nursery grown.........\$6.00 each

Prices for carload lots of collected stock on application.

PICEA excelsa (Norway Spruce). Leaves dark green. very handsome; of pyramidal, lofty appearance; $11 / 2$ to $2 \mathrm{ft} . . \$ 2.00$ each. 2 to $3 \mathrm{ft}$...\$4.00 each 3 to $4 \mathrm{ft}$...................\$6.00 each pungens (Colorado Spruce). Leaves bluish.

18 to 24 in. $\$ 5.00$ each. 2 to $3 \mathrm{ft} . \ldots \$ 7.50$ each

PINUS austriaca (Austrian Pine). A robust, stately tree of rapid growth and very hardy. $2 \mathrm{ft} . \ldots \ldots \ldots 3.00$ each. $21 / 2 \mathrm{ft} . \ldots \ldots \$ 4.00 \mathrm{each}$ mughus (Dwarf Mugho Pine)

12 to 18 in. diam..............\$3.50 each $11 / 2$ to $2 \mathrm{ft}$. diam ........................... $\$ 5.00$ each strobus (White Pine). One of the best native Pines; pale light green foliage.

2 to $3 \mathrm{ft}$. .. $\$ 3.50$ each. 3 to $4 \mathrm{ft}$...\$5.00 each

sylvestris (Scotch Pine). Of rapid growth, with strong branches and short, stiff, bluish-green foliage.

$2 \mathrm{ft} . . . \ldots \$ 3.00$ each. $3 \mathrm{ft} . \ldots \ldots \$ 4.50$ each

RETINOSPORA filifera (Japanese Cedar). Threadbranched, drooping branches, bright green; very pretty.

$11 / 2 \mathrm{ft} \ldots . . \$ 3.50$ each. $2 \mathrm{ft} \ldots \ldots . \$ 5.00$ each -aurea. Golden; most attractive.

18 in., bushy shaped............\$4.00 each

obtusa. Graceful tree, foliage bright clear green.

$2 \mathrm{ft}$.....\$4.00 each. $3 \mathrm{ft} . \ldots \ldots . \$ 7.00$ each

pisifera (Sawara Cypress). Branches horizontal, with leaves feathery green above, whitish lines beneath.

$11 / 2 \mathrm{ft} . \ldots \ldots . \$ 3.50$ each. $2 \mathrm{ft} . \ldots \ldots . \$ 5.00$ each

$3 \mathrm{ft} . \ldots \ldots \ldots \ldots \ldots \ldots \ldots \ldots \ldots \ldots . \ldots \ldots$ each

- aurea. Golden feathery foliage.

$11 / 2 \mathrm{ft} . \ldots \ldots \$ 3.50$ each. $2 \mathrm{ft} . \ldots \ldots \$ 5.00$ each

plumosa. Graceful habit.

$11 / 2 \mathrm{ft} . . . . \$ 3.00 \mathrm{each} . \quad 2 \mathrm{ft} . . . . \$ \$ 4.00 \mathrm{each}$

$21 / 2 \mathrm{ft} . \ldots \ldots \$ 5.00$ each. $\quad 3 \mathrm{ft} . \ldots \ldots \$ \$ 7.00 \mathrm{each}$

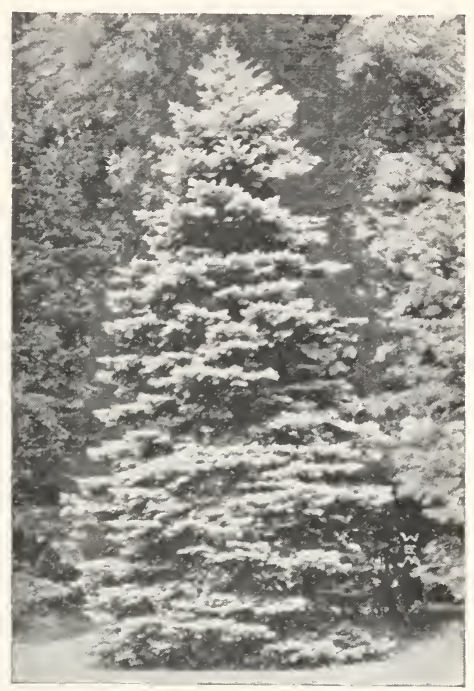

Picea Pungens

RETINOSPORA plumosa aurea. Golden foliage $11 / 2 \mathrm{ft} . \ldots . \$ 3.00$ each. 2 to $3 \mathrm{ft} . \ldots \$ 5.00$ each -squarrosa veitchi. Light bluish green foliage. $11 / 2 \mathrm{ft} . \ldots . \$ 3.00$ each. $2 \mathrm{ft} . . . \ldots . \$ 5.00$ each

RHODODENDRONS (Hardy Hybrid Varieties). Handsome grouping and border effects can be created by using these charming hybrids.

Prices on application.

maximum (Great I.aurel). Is admirably adapted to massing, will thrive in shady or exposed positions, and is perfectly hardy. Nursery grown.

2 to $21 / 2 \mathrm{ft}$. $\$ 5.00$ each. $21 / 2$ to $3 \mathrm{ft}$. $\$ 7.00$ each

3 to $4 \mathrm{ft} . . . . . .00$ each

Prices for carload lots of collected stock on application.

TAXUS baccata repandens (Yew). This is the hardiest of all prostrate varieties and will grow in almost any position. It is excellent for hedging, grouping and covering banks.

$11 / 2$ to $2 \mathrm{ft}$. diam..............\$4.00 each cuspidata. Spreading form.

12 to $18 \mathrm{in}$ high............\$3.50 each

18 to 24 in. high..............\$5.00 each

2 to $21 / 2 \mathrm{ft}$. high................ \$7.50 each

-nana brevifolia. Really an excellent Yew, with fine, spreading branches and rich deep green, short leaves. Highly recommended.

15 in......\$3.50 each. $11 / 2 \mathrm{ft} . \ldots \ldots \$ 6.00$ each $2 \mathrm{ft} \ldots \ldots \ldots \ldots . \ldots . . \ldots$ each

THUJA pyramidalis (Pyramidal Arborvitae). A most valuable, upright evergreen, of dense, compact habit. Foliage light green.

$21 / 2 \mathrm{ft} . \ldots \ldots \$ 4.00$ each. 3 to $4 \mathrm{ft} . \ldots \ldots \$ 7.00$ each 4 to $5 \mathrm{ft} \ldots \ldots . . . \ldots 10.00$ each occidentalis (Common American Arborvitae). 2 to $3 \mathrm{ft} . \ldots \$ 3.50$ each. 3 to $4 \mathrm{ft} . \ldots \$ 5.00$ each 4 to $5 \mathrm{ft} . . . . . \$ 7.50$ each

wareana occidentalis sibirica (Siberian Arborvitae). Large, bold, glaucous green foliage.

$2 \mathrm{ft}$......\$3.50 each. $21 / 2 \mathrm{ft}$....\$5.00 each

TSUGA canadensis (Common Hemlock). One of the most handsome and graceful evergreens.

18 to 24 in. $\$ 33.50$ each. 2 to $3 \mathrm{ft} . \ldots \$ 5.00$ each

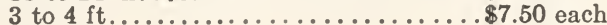




\section{Ornamental and Shade Trees}

ACER dasycarpum (White or Silver-leaved Maple). large sized tree, rapid grower.

8 to $10 \mathrm{ft} ., 11 / 4$ in. diam...........\$3.00 each 10 to $12 \mathrm{ft}$., $11 / 2$ in. diam............ $\$ 5.00$ each 12 to $13 \mathrm{ft} ., 13 / 4$ in. diam...........\$6.00 each

-wieri laciniatum (Wier's Cut-leaved Silver Maple). Very beautiful variety, with delicately cut leaves and graceful drooping branches.

8 to $10 \mathrm{ft} ., 11 / 4$ in. diam............\$4.00 each 10 to $11 \mathrm{ft} ., 11 / 2$ in. diam.............. $\$ 5.00$ each 11 to $12 \mathrm{ft} ., 13 / 4 \mathrm{in}$. diam...........\$6.50 each

platanoides (Norway Maple). Vigorous growing tree, of spreading rounded form.

8 to $10 \mathrm{ft} ., 11 / 4 \mathrm{in}$. diam........... \$6.00 each 10 to $11 \mathrm{ft} ., 11 / 2$ in. diam............... $\$ 7.00$ each 11 to $12 \mathrm{ft} ., 13 \frac{1}{4}$ in. diam...........\$9.00 each

saccharinum (Sugar, or Rock Maple). Of vigorous growth; more or less pyramidal form.

10 to $11 \mathrm{ft} ., 11 / 4 \mathrm{ln}$. diam........... \$5.00 each 11 to $12 \mathrm{ft}$., $11 / 2$ in. diam...........\$ $\$ 6.00$ each 12 to $14 \mathrm{ft} ., 13 \frac{1}{4}$ in. diam...........\$10.00 each

AESCULUS hippocastanum (European White-Flowering Horse Chestnut). A compact, handsome tree. Foliage appears very early in Spring. 10 to $12 \mathrm{ft} ., 21 / 2 \mathrm{n}$. diam........... $\$ 8.00$ each 12 to $14 \mathrm{ft} ., 3$ in. 31 am............. $\$ 10.00$ each

AILANTHUS glandulosa (Tree of Heaven). Will grow under most adverse conditions.

8 to 10 feet...................\$3.00 each

BETULA alba laciniata (Cut-leaved Weeping Birch). Silvery white bark, graceful drooping habit of growth.

4 to $6 \mathrm{ft}$. ...\$3.00 each. 6 to $8 \mathrm{ft} . \ldots \$ 4.50$ each

-alba (European White Birch). Known by its white bark.

4 to $6 \mathrm{ft}$..... $\$ 2.00$ each. 8 to $10 \mathrm{ft}$... .\$3.00 each

papyrifera (Paper, or Canoe Birch). Handsome tree; tall growing. Leaves large; bark silvery white.

6 to $8 \mathrm{ft} . \ldots \$ 3.00$ each. 8 to $10 \mathrm{ft}$. . $\$ 4.00$ each

CATALPA bungei. A rapid growing tree, with a dense mass of large, heart-shaped light green leaves. Excellent for formal effects. Handsome, globeheaded standards.

Medium heads................\$3.00 each

Large heads.................\$\$4.00 each

FAGUS americana (American Birch).

2 to $3 \mathrm{ft}$....\$3.00 each 3 to $4 \mathrm{ft}$. . .\$ \$4.00 each

FAGUS sylvatica (European or English Beech).

2 to $3 \mathrm{ft} . \ldots \ldots \ldots \ldots \ldots \ldots \ldots \ldots \ldots . \ldots \ldots$ each

sylvatica pendula (Weeping Beech).

$4 \mathrm{ft} . \ldots . \ldots \$ 6.00$ each. 6 to $8 \mathrm{ft} . \ldots \$ 10.00$ each

FRAXINUS americana (White Ash). A splendid tall growing tree.

8 to $10 \mathrm{ft} .1$ in. diam............\$3.00 each $10 \mathrm{ft} ., 1 \frac{1}{2}$ in. diam.............\$ \$4.00 each

GINKGO biloba (Salisburia adiantifolia) (Maidenhair Tree). A remarkable tree of spreading growth in age. Deep green, thick leaves, similar in shape to those of the Maidenhair fern. Rapid grower and very hardy.

6 to $8 \mathrm{ft} . . \$ 4.00$ each. 8 to $10 \mathrm{ft} . \ldots \$ 5.00$ each

KOELREUTERIA paniculata (Varnish Tree). Also called the Golden Rain Tree.

3 to $4 \mathrm{ft}$....\$1.50 each 4 to $6 \mathrm{ft} . . \ldots \$ 2.50$ each

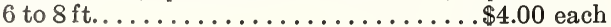

LIQUIDAMBAR (Sweet Gum Tree). A native tree of rapid growth, beautiful Fall color.

4 to $6 \mathrm{ft}$....\$2.50 each. 6 to $8 \mathrm{ft}$...\$4.50 each
LIRIODENDRON tulipifera (Tulip Tree). A noble looking pyramidal tree with clean trunk. Leaves are alternate and have long stalks.

6 to $8 \mathrm{ft}$....\$2.50 each 8 to $10 \mathrm{ft} . . \$ 4.00$ each 10 to $12 \mathrm{ft} . \ldots \ldots \ldots \ldots \ldots \ldots \ldots \ldots . \ldots \ldots$ each

MORUS pendula (Teas' Weeping Mulberry). A beautiful, hardy, ornamental tree; forms a perfect umbrella-shaped head.

5 to $7 \mathrm{ft} ., 1-\mathrm{yr}$. heads.............\$3.50 each

5 to $7 \mathrm{ft}$., strong, 2-yr. heads.......\$5.00 each

PLATANUS orientalis (Oriental Plane). A superb tree of gigantic proportions, extensively used in Europe, for park, street and avenue planting.

8 to $10 \mathrm{ft} ., 11 / 4 \mathrm{in}$. diam...........\$3.50 each 10 to $11 \mathrm{ft}$., $1 \frac{1}{2}$ in. $\operatorname{diam} . . \ldots \ldots \ldots \ldots \ldots \ldots 6.00$ each 11 to $12 \mathrm{ft}$., $13 / 4$ in. diam.............\$7.00 each

POPULUS carolinensis, syn. monolifera (Carolina Poplar). Rapid grower; very valuable for screening.

8 to $10 \mathrm{ft}$. $\$ 1.50$ each. 10 to $12 \mathrm{ft} . . \$ 2.25$ each 12 to $14 \mathrm{ft} . \ldots \ldots \ldots \ldots \ldots \ldots \ldots \ldots \ldots 3.00$ each fastigiata, or dilatata (Lombardy, or Italian Poplar). An ornamental and picturesque tree.

8 to $10 \mathrm{ft.,} 1$ in. diam.............\$2.00 each

10 to $12 \mathrm{ft.}, 11 / 2$ in. diam................ $\$ 2.25$ each

12 to $14 \mathrm{ft.}, 1 \frac{3}{4}$ in. $\operatorname{diam} \ldots \ldots \ldots \ldots \ldots \$ 3.50$ each

QUERCUS americana rubra (American Red Oak) Beautiful tree of rapid growth.

8 to $10 \mathrm{ft} ., 11 / 2$ in. diam............\$5.00 each 10 to $12 \mathrm{ft.,} 2$ in. $\operatorname{diam} . . \ldots \ldots \ldots \ldots \ldots \$ 8.00$ each

palustris (Pin Oak). A superb and very distinct tree, with graceful drooping branches.

$8 \mathrm{ft} ., \quad 11 / 4$ in. diam........... $\$ 5.00$ each 8 to $10 \mathrm{ft} ., 11 / 2$ in. diam ...............\$6.00 each

10 to $12 \mathrm{ft.,} 2$ in. diam........... $\$ 8.50$ each

SALIX babylonica (Babylonian, or Weeping Willow). A well known and graceful variety.

6 to $8 \mathrm{ft} . \ldots \$ 1.75$ each. 8 to $10 \mathrm{ft} . . \$ 2.50$ each 10 to $12 \mathrm{ft} . \ldots \ldots \ldots \ldots \ldots \ldots \ldots \ldots \ldots .50$ each caprea (Pussy Willow).

3 to $4 \mathrm{ft} . \ldots \$ 1.00$ each. $\quad 4$ to $6 \mathrm{ft}$... $\$ 1.50$ each elegantissima (Thurlow's Weeping Willow). Long, spreading branches, beautifully drooping.

6 to $8 \mathrm{ft} . \ldots \$ 1.50$ each. 8 to $10 \mathrm{ft}$.. $\$ 2.00$ each 10 to $12 \mathrm{ft} . \ldots \ldots \ldots \ldots \ldots \ldots \ldots \ldots . \ldots \ldots$ each pentandra (Laurel-leaved Willow). Broad glossy dark green leaves.

4 to $6 \mathrm{ft}$. ..\$1.00 each. 6 to $8 \mathrm{ft} . \ldots \$ 1.50$ each

SORBUS aucuparia (Mountain Ash). A fine tree, dense and regular; covered all Summer with great clusters of scarlet berries.

5 to $6 \mathrm{ft}$. . .\$2.50 each. 6 to $8 \mathrm{ft}$... $\$ 3.50$ each pendula (Weeping Mountain Ash).

$6 \mathrm{ft}$. stems, 3-yr. heads. ..........\$5.00 each

TILIA argentea (White, or Silver Linden). Distinct ornamental shade tree.

8 to $10 \mathrm{ft} ., 11 / 2 \mathrm{in}$. diam............\$5.00 each 10 to $12 \mathrm{ft.,} 13 / 4$ in. $\operatorname{diam} . \ldots \ldots \ldots \ldots \ldots 6.50$ each 12 to $14 \mathrm{ft} ., 2$ in. diam........... $\$ 7.50$ each platyphyllos (Broad-leaved European Linden).

9 to $10 \mathrm{ft} ., 11 / 2 \mathrm{in}$. diam...........\$7.00 each 10 to $12 \mathrm{ft} ., 13 / 4$ in. diam............\$10.00 each vulgaris (European Linden).

6 to $8 \mathrm{ft} ., 1$ in. 1 diam...........\$3.50 each 8 to $10 \mathrm{ft}$., $11 / 4$ in. diam............. $\$ 5.00$ each

ULMUS americana (American White or Water Elm). Very tall growing and stately.

8 to $10 \mathrm{ft} ., 11 / 4 \mathrm{in}$. diam............\$4.00 each 10 to $12 \mathrm{ft.}, 13 / 4$ in. diam............... $\$ 6.00$ each 12 to $14 \mathrm{ft} ., 2$ in. $\operatorname{diam} . . . \ldots \ldots \ldots \ldots \ldots \$ 8.00 \mathrm{each}$ 14 to $15 \mathrm{ft} ., 21 / 2$ in. diam............\$11.00 each 


\section{Marshall's}

\section{Trained Fruit Trees}

\section{Specially Budded on "Dwarfing" Under Stocks}

We issue a special folder on Trained Fruit Trees-Sent upon request

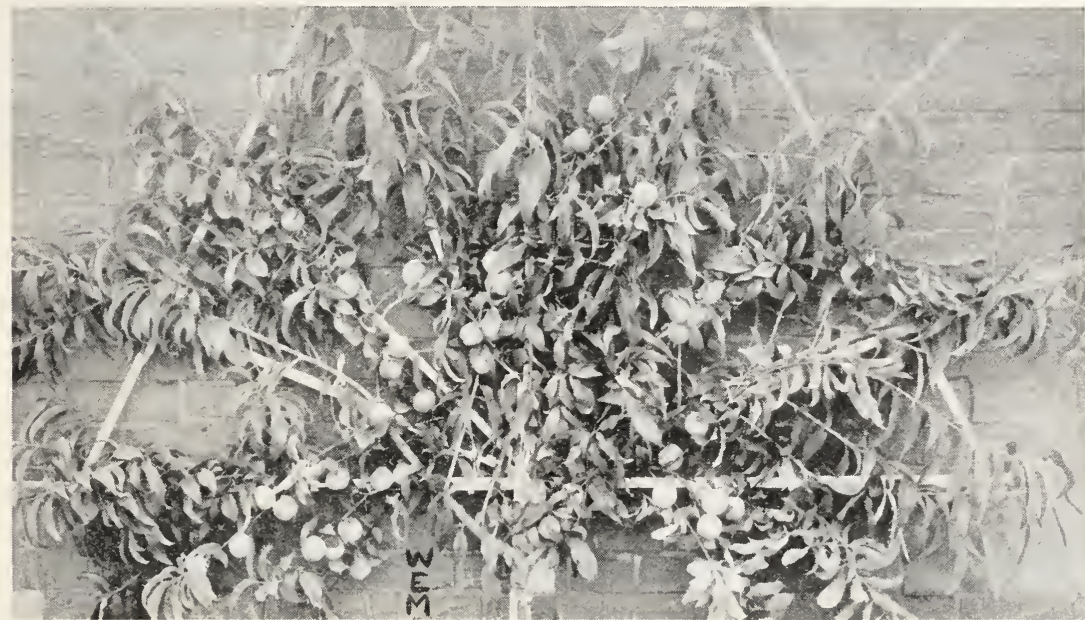

Fan Trained Peach Tree

In our constant effort to offer "Everything good for every good garden," we have made arrangements with a specialist to grow trained fruit trees for us.

We issue a special folder on the training, pruning and care of these trained fruit trees. A copy will be mailed to anyone requesting same. Our list illustrates some of the types grown and also gives particulars of the varieties in which they may be obtained.

\section{APPLES \\ BUDDED ON PARADISE}

Single Cordon, $\$ 3.50$ each; U-shaped, 4 ft., $\$ 6.00$ each; U-shaped, 5 - $6 \mathrm{ft}$., $\$ 7.00$ each; $8 \mathrm{ft}$., $\$ 9.00$ each Palmette Verrier, $4 \mathrm{ft}$. and double "U", $\$ 10.00$ each;

Palmette Verrier, 6-8 ft., $\$ 12.00$ each.

Six Armed Verrier or triple "U", $\$ 18.00$ each. Horizontal Cordons, $\$ 7.00$ each;

Horizontal Cordons, Single (for corners), $\$ 6.00$ each.

Specimen Fan shaped trees 6-10 ft.spread, $\$ 25.00$.

\section{APRICOTS}

BUDDED ON PLUM

U-shaped, $\$ 7.00$ each.

Specimen fan trained trees, $\$ 25.00$.

\section{GHERRIES}

BUDDED ON WILD CHERRY

Single Cordon, $\$ 3.50$ each;

U-shaped, 4 ft., $\$ 6.00$ each;

U-shaped, 5-6 ft., $\$ 7.00$ each; 8 ft., $\$ 9.00$ each. Palmette Verrier, $4 \mathrm{ft}$. and double "U", $\$ 10.00$ each

Palmette Verrier, 6-8 ft., $\$ 12.00$ each.

Six Armed Verrier or triple "U", $\$ 18.00$ each.

Horizontal Cordons, $\$ 7.00$ each;

Horizontal Cordons, Single (for corners), $\$ 6.00$ each.

Specimen Fan shaped trees $6.10 \mathrm{ft}$. spread, $\$ 25.00$.
NEGTARINES

\section{BUDDED ON PLUM}

U-shaped, $\$ 7.00$ each.

Double "U", \$12.00-\$14.00

Specimen Fan Trained Trees, $\$ 25.00$ each.

\section{PEACHES}

\section{BUDDED ON MAHALEB PLUM}

U-shaped 4 ft. $\$ 6.00 ; 5-6$ ft. $\$ 8.00$ each.

Double U-shaped, $\$ 12.00$ each.

Specimen Fan Trained Trees $7 \mathrm{ft}$. wide;

6 ft. high, $\$ 25.00$ each.

\section{PEARS}

BUDDED ON QUINCE

Single Cordon, \$3.50 each; Double U-shaped, $\$ 10.00$ each.

U-shaped, $4 \mathrm{ft} ., \$ 6.00$ each; 5 -6 ft., $\$ 7.00$ each Palmette Verrier, $4 \mathrm{ft}$., $\$ 10.00$ each; 5- $6 \mathrm{ft}$, $\$ 12.00$ each.

Six Armed Verrier or Triple "U", \$18.00 each.

Horizontal Cordons (double), $\$ 7.00$.

Horizontal Cordons (single-for corners), $\$ 6.00$ each.

\section{PLUMS}

Palmette Verrier or Double "U", $\$ 12.00$ each. 


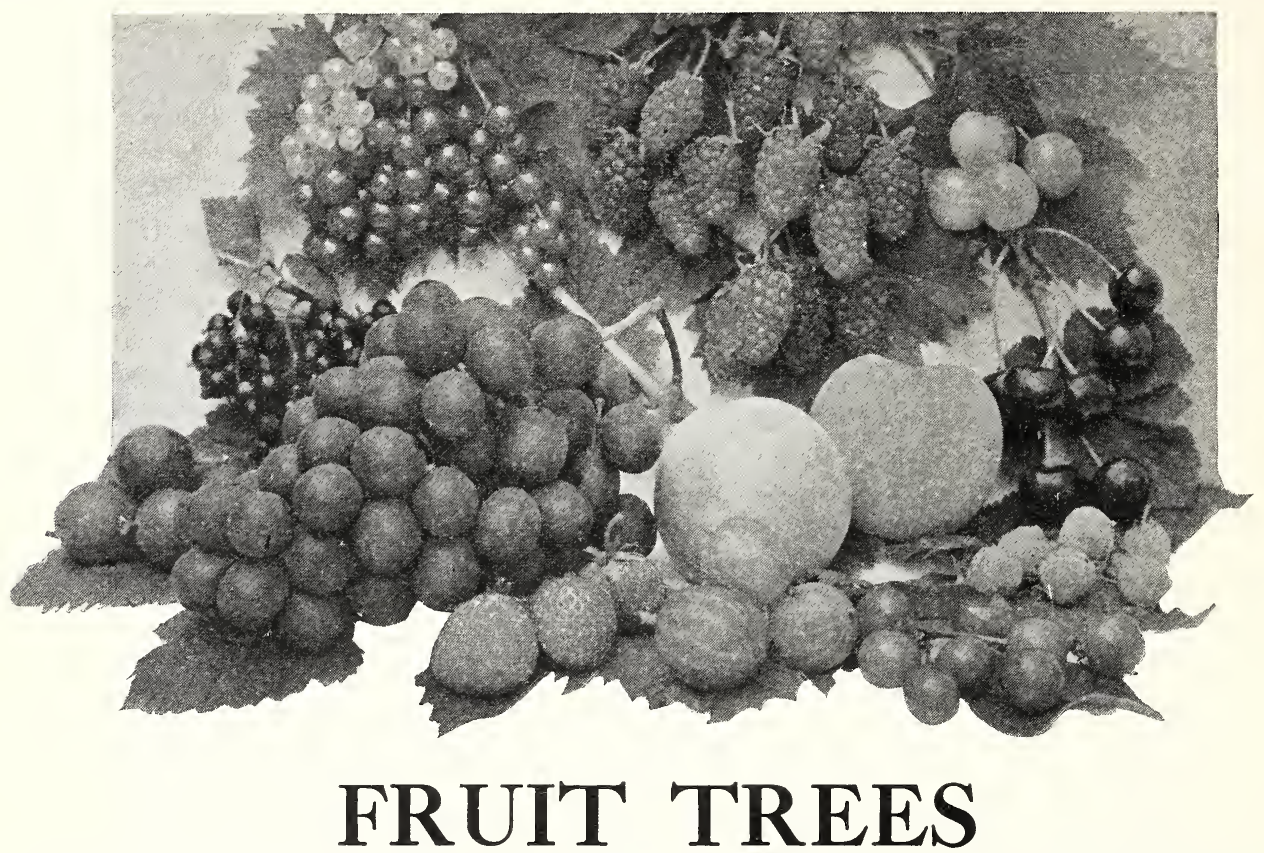

Planting.-Make the holes large enough to admit the roots without cramping or bending, and deep enough to set the trees to their natural depth. Fine surface soil should be used for covering the roots, and this should be carefully mixed among them. If the ground is dry, it is well to pour in some water when the hole is partially filled. See that the ground is firmly and solidly packed over all parts of the roots. Fill the holes full enough to to bo even with the surrounding surface after the fresh earth settles. Never use manure in contact with the roots.

\section{SUMMER VARIETIES}

* Early Harvest. Medium, yellow.

*Red Astrachan. Small, red.

* Yellow Transparent. Large, vellow

*Baldwin. Medium, red.

Greening. Large, greenish.

McIntosh. Large, red.

Prices on above standard trees. 1 -in. diameter, $\$ 2.00$ each; $11 / 4$-in., $\$ 3.00$ each; $11 / 2$-in., $\$ 4.00$ each.

Varieties marked with a star (*) can be supplied in Dwarf trees at the above prices.

\section{FALL VARIETIES}

Delicious. Yellow, striped red.

Gravenstein. Large, vellow and red.

Wealthy. Splendid red fruit.

\section{WINTER VARIETIES}

* Northern Spy. Medium crimson.

*Spitzenburg. Large, red.
PEARS

Flemish Beauty. Large, Sept.

Kieffer. Large, prolific. Oct.

Seckel. Small, Oct.

Sheldon. Good size. Oct.

*Beurre d'Anjou. Large greenish russet, late.

Clapp's Favorite. Large, August.

Duchess. Large, late.

Prices on above standard trees, 1 -in. diameter, $\$ 2.00$ each; 11/2-in., $\$ 3.00$ each.

Varieties marked with a star (*) can be supplied in Dwarf trees at the above prices.

\section{CHERRIES}

Montmorency. Red, sour. June.

Black Tartarian. Sweet, late June.

May Duke. Dark red, sour. June.

Napoleon. Yellow, sweet. July.

Prices, 1-in. diameter, $\$ 2.00$ each; 11/4-in. diameter, $\$ 3.00$ each.

\section{PEACHES}

Belle of Georgia. White Freestone. July.

Champion. White Freestone. Aug.

Stump of the World. White Freestone. Sept.

Mountain Rose. White Freestone. Aug.

Prices of above, 5/8-in. diameter, 75c. each; 3/4-i

Early Crawford. Yellow Freestone. Aug Late Crawford. Yellow Freestone. Aug.

Elberta. Yellow Freestone. Aug.

Carmen. White Freestone. Aug.

\section{PLUMS}

Abundance. Large, red. August.

Bradshaw. Large, dark red. August.

Burbank. Crimson-purple. August.

Coe's Golden Drop. Large, yellow, late

Lombard. Medium, violet. Sept.

Prices of above, 11/4-in. diameter, $\$ 2.00$ each; $11 / 2$-in. diameter, $\$ 3.00$ each.

\section{QUINGES}

Champion. Yellow. November.

Orange. Golden. November.

Prices of above, $8 / 8$-in. diameter, $\$ 1.50$ each; $3 / 4$-in. to 1 -in. diameter, $\$ 2.00$ each. 


\section{SMALL FRUITS}

\section{BLACKCAPS}

Kansas. Very large; ripens early; very sweet and of fine flavor. Pulpy, few seeds.

Plum Farmer. Very large, glossy berries; firm, juicy and sweet. Heavy cropper.

$\$ 1.25$ for $10, \$ 8.00$ per 100 .

\section{BLAGKBERRIES}

Eldorado. Medium size; jet-black; pleasant, melting flavor, sweet and rich. The vine is very hardy.

Kittatinny. Large; glossy black; sweet and juicy; excellent when fully ripe.

Strong plants, $\$ 1.25$ for $10, \$ 8.00$ per 100 .

\section{GURRANTS}

Fay's Prolific. A popular red Currant; very large and sweet. Productive.

Perfection. Bush vigorous, hardy and very productive; berries larger than Cherry, with large clusters; color bright red.

White Grape. An excellent white variety; of large size; very sweet.

Strong, 2-year-old bushes, $\$ 2.25$ for $5, \$ 4.00$ for 10 .

\section{GOOSEBERRIES}

Josselyn. Large red fruit.

Smith's Improved. Fruit greenish yellow.

Triumph. Fruit golden yellow.

2-year-old bushes, $\$ 2.50$ for $5, \$ 4.50$ for 10 .

\section{Grapes}

Brighton. Flesh rich, sweet and of the best quality; ripens early, with the Delaware. Very productive.

Caco. Large, wine red in color, bunches good size and extra good quality. 2-year, $\$ 1.00$.

Champagne. Very large amber berry. Fine for dessert or making wine. Each, 2-year-old, $75 \mathrm{c}$.

Concord. Fine black variety; splendid flavor; reliable and productive; one of the most popular.

Hubbard. Black, sweet and delicious. Berries and bunch large. 2-year-old. 75c. each.

Moore's Early. Bunch medium; berry very large, with heavy blue bloom; good quality.

Niagara. Bunch medium to large; berry large, roundish, uniform; skin thin, with a whitish bloom; flesh slightly pulpy; tender and sweet.

Extra strong, 2-year-old canes, 50c. each, $\$ 4.50$ for 10 .

\section{NEW GRAPE "FORTLAND"}

A new white and the earliest of all grapes. Large bunch and berry, flesh sweet and juicy and of fine flavor. 2 year old canes. Each $\$ 1.00$.

\section{RASPBERRIES}

Cuthbert. Deep, mch crimson.

Golden Queen. Large, amber-color, firm; fine quality. Remarkably productive.

June. The earliest variety, vigorous grower, hardy, fruits large and bright red in color.

Herbert. Very large berry and a heavy cropper. It has a distinctly rich flavor and is all meat.

St. Regis (Perpetual). Bright crimson; large berries all through Summer and Fall.

The above varieties are strong plants, 2-year old, 25 for $\$ 3.00, \$ 10.00$ per 100 .

Chief. A new red Raspberry from the West which ripens 10 days earlier than The Latham. 25 for $\$ 8.00,100, \$ 30.00$.

The Latham. Without doubt the best red Raspberry to plant today. Berries large in size and a rich red color, maturing very early. Canes hardy in northern latitudes. 25 for $\$ 3.50, \$ 15.00$ per 100 .

\section{Strawberry Plants}

For full description see our Fall Catalog

Barrymore, Brandywine, Campbell's Early, Gandy, Glen Mary, Hundred Dollar, Joe, McKinley, Marshall, New York, Nick Ohmer, Premier, Success, Stevens' Late Champion. Layer plants of above, 60c. for 25, $\$ 2.00$ per 100 .

Chesapeake, Early Jersey Giant, Lupton, Howard, No. 17, John H. Cook, William Belt.

Layer plants, $75 \mathrm{c}$. for $25, \$ 2.50$ per 100 .

Bushel Basket, Edmund Wilson, St. Martin, Pearl. Layer plants, $\$ 1.25$ for $25, \$ 4.00$ per 100 .

\section{EVERBEARING STRAWBERRIES}

If planted in Spring, a good crop of fruit will be picked in Fall.

Progressive. $\$ 1.00$ for $25, \$ 3.00$ per 100 .

Francis, Ideal, Superb. $\$ 1.25$ for $25, \$ 4.00$ per 100 .

Lucky Boy. $\$ 2.00$ for $25, \$ 6.00$ per 100 .

\section{POT GROWN STRAWBERRIES}

We can supply Pot Grown Plants for delivery in July, August and September. These plants will give a good crop of berries the following year. A list of varieties and prices will be found in our Fall Catalog Copy sent on request. Pot grown plants are shipped by express only.

\section{Deciduous Hedge Plants}

BERBERIS Thunbergii (Japanese Barberry). 9 to 12 in., 2 year old, 25 for $\$ 5.00,100$ for $\$ 18.00 ; 12$ to 18 in 3 year heavy, 25 for $\$ 11.00,100$ for $\$ 40.00$; 18 to 24 in., 2 year old, 25 for $\$ 11.00,100$ for $\$ 40.00 ; 18$ to 24 in., 3 year heavy, 25 for $\$ 16.00,100$ for $\$ 60.00$.

LIGUSTRUM Ibota (New Japanese Privet). Large, glossy, distinct foliage. $11 / 2$ to 2 ft., bushy, 25 for $\$ 5.50$, 100 for $\$ 20.00$; 2 to $3 \mathrm{ft}$., bushy, 25 for $\$ 7.00$, 100 for $\$ 25.00 ; 3$ to $4 \mathrm{ft}$., bushy, 25 for $\$ 10.00 .100$ for $\$ 35.00$.

ovalifolium (California Privet). Large, glossy, dark green foliage; one of the most popular hedge plants. Rugged and enduring in almost any situation; retains its foliage until late in Winter. $11 / 2$ to $2 \mathrm{ft}$., bushy, $25 \mathrm{for} \$ 2.50$, 100 for $\$ 8.00$; 2 to $3 \mathrm{ft}$., bushy, 25 for $\$ 3.50,100$ for $\$ 12.00$; 3 to $4 \mathrm{ft}$., bushy, 25 for $\$ 4.00,100$ for $\$ 15.00$.

amurense (Amoor River Privet). Large, oblong, glossy green foliage and clusters of white, fragrant flowers; half evergreen. A variety of sterling merit; useful for hedges. 2 to $3 \mathrm{ft}$., 25 for $\$ 7.00,100$ for $\$ 25.00 ; 3$ to 4 ft., 25 for $\$ 11.00,100$ for $\$ 40.00$. 


\section{Horticultural Tools and Requisites}

APRONS, Gardener's Waterproof, with bib; 34 in. long, 26 in. wide. Each $\$ 1.50$.

Gardener's. Blue drill with bib. Each $\$ 1.00$. Gardener's Rubber. Extra heavy, each $\$ 3.00$. English Blue Serge. Each $\$ 3.50$.

English Blue Serge. With bib and pocket. Each $\$ 4.00$.

ASPARAGUS BUNCHER.

Useful on all private estates.

It will not bruise the grass,

is easily and quickly adjusted to any length. Double band springs and knife guard. Each \$4.50.

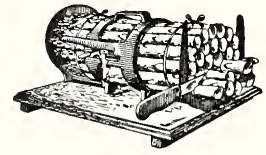

ASPARAGUS KNIVES, American. Can also be used as a weeder. Each $50 \mathrm{c}$.

AXES, Felling. With handle, 3 lbs. $\$ 2.75,4$ lbs. $\$ 3.00,5$ lbs. $\$ 3.50$.

BASKETS, Garden and Farm. See page 120

Hanging, Wire. Painted, 8 in. $35 \mathrm{c}, 10$ in. $40 \mathrm{c}$, 12 in. 50 c., 15 in. 60 c., 18 in. $\$ 1.00,21$ in. $\$ 1.35$ each.

BELLOWS, Powder.

Small, Single Cone.

Each $\$ 3.00$.

Large, Single Cone.

Each $\$ 500$.

Double Cone.

Each $\$ 6.50$.

See also pages 96 and 114 .

BIRD HOUSES (Rustic). See page 110.

BLAKE'S LEVER CLIPS. For fastening Rose wires.

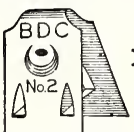
Per box of $500, \$ 1.75$.

BULL DOG CLIPS. Useful for fastening paper to pot plants, etc. Box of $1000 \$ 1.00$.

BOXES, Corrugated. Extra strong for shipping cut flowers.

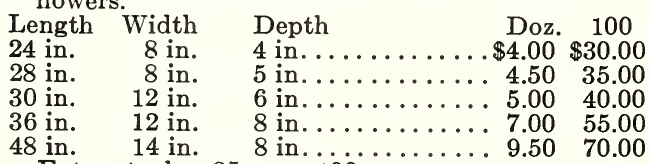

Extra staples, 25c. per 100.

BOXES, Folding. For cut flowers. Made of strong cardboard.

$\begin{array}{llll}\text { No. } 2 & 2 & \text { in. } 5 \text { in. } 3 \text { in.deep..... } \$ 0.75 . & \$ 4.00\end{array}$

No. 521 in. 7 in. $31 / 2$ in. deep..... $1.00 \quad 6.00$

No. 824 in. 8 in. 4 in. deep..... $1.50 \quad 8.00$

No. 1128 in. 8 in. 5 in. deep.... 2.0012 .00

No. 1936 in. 8 in. 5 in. deep.... 2.5015 .00

BOXES, Flower, Fiber or Leatheroid. Used for shipping cut flowers or fresh vegetables by express. Lock and keys with each case. Each 30 in. $x 14$ in. $\times 16$ in. with 3 wicker trays....\$45.00 34 in. $\times 15$ in. $x 16$ in. with 3 wicker trays.... 47.50 38 in. $\times 16$ in. $\times 16$ in. with 3 wicker trays.... 50.00

BROOMS, Birch. For lawns. Each 75c.

Barn or Floor. Corn with rattan center. Each $\$ 1.60$.

Kongo. Coir bass. Made with coir fiber. Illustrated page 105. Each $\$ 2.00$.

Rattan. Similar to birch broom. Useful for lawns. Each, \$1.00.

Tennis Court. Made with fiber, 36 in. long, for dragging dirt courts. Each $\$ 7.00$.

BRUSHES, Flower Pot, Cone-Shaped. Made of bristle, wood handle. Each $\$ 1.75$.

BRUSH HOOKS. With handle. Each $\$ 3.00$.

BURLAP. For Winter covering. 36 in. wide, 25c. yd., 42 in. wide, 28 c. yd., 48 in.. 30 c. $y d$. Price subject to market change.

\begin{tabular}{|c|c|c|c|}
\hline 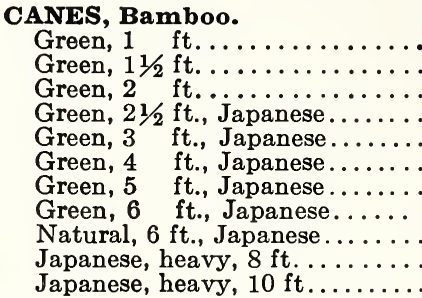 & $\begin{array}{l}\text { Doz. } \\
. \$ 0.10 \\
. \quad 10 \\
. \\
. \\
. \\
.10 \\
.10 \\
.15 \\
.20 \\
.20 \\
.20 \\
. \quad .40 \\
. \\
.50\end{array}$ & $\begin{array}{r}100 \\
\$ 0.50 \\
.60 \\
.65 \\
.70 \\
.75 \\
1.00 \\
1.25 \\
1.50 \\
1.50 \\
3.00 \\
4.00\end{array}$ & $\begin{array}{r}1000 \\
\$ 3.00 \\
4.00 \\
4.50 \\
5.00 \\
6.00 \\
8.00 \\
11.00 \\
14.00 \\
14.00 \\
25.00 \\
35.00\end{array}$ \\
\hline
\end{tabular}

CANES, Chinese Bamboo.

100

$4 \mathrm{ft}$. long, $1 / 4$ in. diam .............. $\$ 1.50$

$4 \mathrm{ft}$. long, $1 / 2$ in. diam..................... 3.00

$6 \mathrm{ft}$. long, $3 / 4$ in. diam ................ 5.00

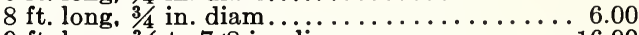

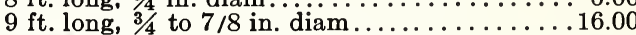

$6 \mathrm{ft}$. long, $11 / 2$ in. diam. for Dahlias; doz. $\$ 4.50$. 35.00 Chinese Bamboo Canes can be supplied dyed green at a small additional cost.

CARNATION BANDS, Rubber. 30 c. per oz.

CARNATION STAPLES. For split Carnations. $100050 \mathrm{c}$.

Cokely's Staples. $\$ 1.00$ per 1000 .

Cokely's Pliers for the above. Each $\$ 3.00$.

CARNATION SUPPORTS.

"Model Extension." Made with strong galvanized $\begin{array}{lll}\text { wire, neat and durable. } & \text { Doz. } 100\end{array}$

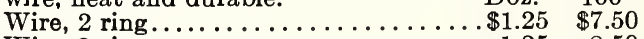

Wire, 3 ring..................... $125 \quad 8.50$

CARTS, "Handy" Garden. See page 101.

CELERY BLEACHERS. $7 \times 14$ in. Doz. 70c., $100 \$ 5.00$.

Celery Handler for above. Metal. Each $\$ 1.50$. Brass $\$ 2.50$.

CELER Y BLEACHING PAPER. Flexible, odorless and waterproof, in rolls of $100 \mathrm{ft} .12$ in. wide. Per roll, including 25 42-in. wire arches, $\$ 5.00$. Roll holders, each $\$ 1.50$.

CEL-O-GLASS. A high-grade substitute for glass. Adapted for coldframes, hotbed, sash, etc. Made with wire mesh cloth, transparent and indestructible. In rolls 36 in. wide and any length desired. Per sq. ft. 20c. In rolls of 300 sq. ft., $15 \mathrm{c}$. per $\mathrm{ft}$.

COTTON BATTING. Large sheets, 40x40 in. Doz. sheets $\$ 1.00$.

CORK BARK. For rustic work. Lb. 40c.

CORN PLANTERS. The "Segment" is a light, but strorg and efficient hand planter.

Each $\$ 2.75$.

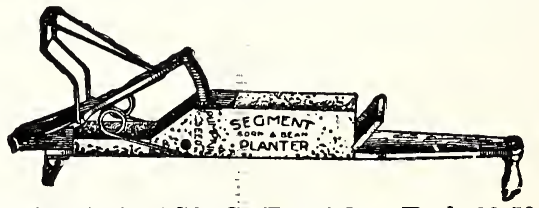

CUCUMBER GLASSES, English. Each $\$ 2.50$

CULTIVATORS. (See pages 104 and 105).

CUT WORM BANDS.: Made with cardboard to place around the young plant. $10030 \mathrm{c}$., $1000 \$ 2.50$.

DIBBLES. Iron point, with

wood handle, for transplanting. Small, 65c.; large, 75c.

DIRT BANDS, Harris Square

Locked. Used for transplanting

$\begin{array}{lll} & 100 & 1000\end{array}$

No. $18 / 4$ B, size $13 / 4 \times 13 / 4$, depth $21 / 2$ in. $\$ 0.50 \$ 3.50$

No. 2 B, size $2 \times 2$, depth $21 / 2$ in...... $\quad .60 \quad 4.00$

No. 3 B, size $3 \times 3$, depth 3 in ........ $\quad .70 \quad 5.00$

No. $4 \quad$ B, size $4 \times 4$, depth 3 in..........75 $\quad 5.50$

DUST GUN's. (See pages 96 and 114 ). 


\section{HORTICULTURAL TOOLS AND REQUISITES-Continued}

FIBER. Peat in bales. Each $\$ 1.50$ and $\$ 5.00$.

FLATS, Greenhouse. Made with wood. 3 in. deep. 12 in. wide, 20 in. long. Doz. $\$ 3.50,100 \$ 25.00$.

FLORISTS GUM. An English liquid gum used for cut flowers. Bottle $30 \mathrm{c}$.

FLOWER POTS, "NEPONSET."

Made of waterproof paper and are light, clean and unbreakable. Doz. 1001000

$21 / 4$ in ..........\$0.10\$0.60\$5.50

$21 / 2$ in .............. $10 \quad .70 \quad 6.00$

3 in ............ $15 \quad 1.00 \quad 8.00$

$31 / 2$ in $\ldots \ldots \ldots \ldots . .15 \quad 1.2011 .00$

4 in ................. .25 1.6014 .00

5 in $\ldots \ldots \ldots \ldots \ldots$. . .40 2.2020 .00

6 in.............. $60 \quad 3.0026 .00$

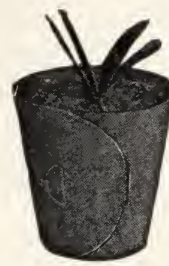

FLOWER POTS, Standard Earthenware.

We pack carefully but are not responsible for breakage in transit. All earthernware pots are shipped by freight only.

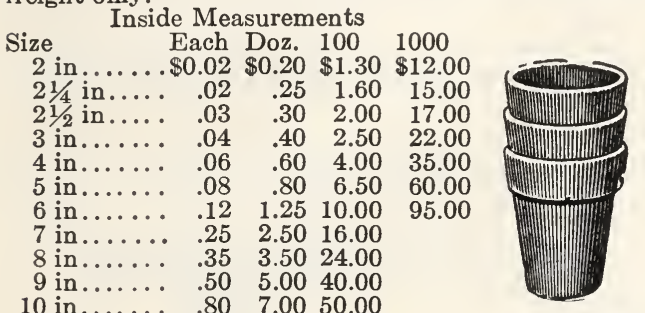

12 in $\ldots . .12013 .00100 .00$

AZALEA POTS. Earthenware.
Wide Deep
Each Doz. 100
6 in. $41 / 2$ in .............. \$0.15 $\$ 1.30 \$ 10.00$

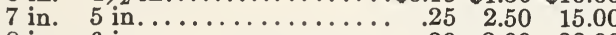
8 in. 6 in...................... $30 \quad 3.00 \quad 22.00$
9 in. 7 in ...................5 $50 \quad 5.00 \quad 40.00$
10 in. 8 in......................... $70 \quad 7.00 \quad 50.00$

ROUND BULB or LILY PANS.

Wide Deep Each Doz. 100

6 in. $3 \frac{3}{4}$ in ............. $\$ 0.15 \$ 1.50 \$ 10.00$

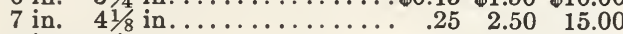

8 in. 4 in ............................. $30 \quad 3.00 \quad 22.00$

9 in. $\quad 41 / 4$ in......................5 $50 \quad 5.00 \quad 40.00$

10 in. $41 / 2$ in .................... $60 \quad 6.00 \quad 45.00$

12 in. $4 \frac{3}{4}$ in ................... $1.00 \quad 10.00 \quad 80.00$

FLOWER POTS "Fertex." Useful for seedlings,

Dahlia cuttings, etc. $21 / 4$ in. $100 \$ 2.00,1000 \$ 15.00$, 3 in. $100 \$ 2.25,1000 \$ 16.00$.

FLOWER POT SAUCERS, Earthenware.

Size Each Doz. Size Each Doz. 4 in ......\$0.04 $\$ 0.40 \mid 8$ in ...... \$0.12 \$1.10

5 in ........ $\quad .05 \quad .50 \quad 9$ in........

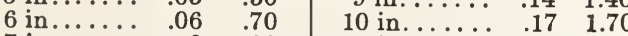

$\begin{array}{llllll}7 \text { in...... } & .10 \quad .90 \quad 12 \text { in...... } & .28 & 2.70\end{array}$

FLOWER POT SAUCERS, Fibre.

Fine quality; Mahogany finish.

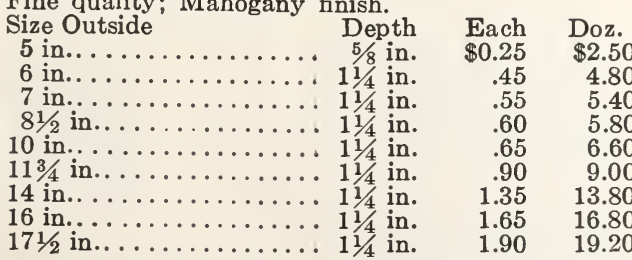

FLOWER VASES, Fiber and Metal. (See pages 99 and 100.)

\section{FORKS.}

Transplanting, Johnson's. 3 tine, length over all 11 in. Each 60c.

Transplanting. English make. A very superior, high grade tool

Short handle...... .85 Long handle..... 1.25

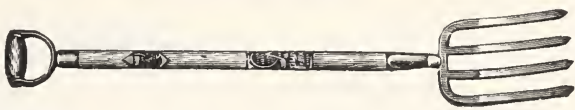

FORKS. Continued.

Digging or Spading, “Keen-Kutter." Each 4-tine, long or short handle............\$2.50 English, 4 square tine, short handle........ 3.50

Best Steel. 4-tine, long or short handle..... 2.25

Manure. 4-tine, short handle.............. 2.50 5-tine, short handle.

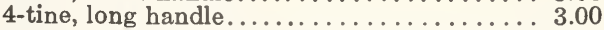

FROST PROOF PLANT PROTECTORS. (Page 105.)

FRUIT PICKERS. Galvanized wire, "Perfect." Each 60c.

Bamboo Extension Poles for above, $12 \mathrm{ft}$., in three sections. Each $\$ 1.00$.

FUMIGATOR, SULPHUR, Campbell's Patent. Designed to vaporize sulphur in greenhouses without danger of the sulphur taking fire or disfiguring the foliage.

No. 1, for houses up to $5,000 \mathrm{cu}$. ft., each $\$ 7.50$ No. 2, for houses up to $10,000 \mathrm{cu}$. ft., each 10.50 . Glass Balls for above, each 10c.

Yellow powder for above. Per can $25 \mathrm{c}$.

Metal containers for above. Each $\$ 4.00$.

FUMIGATOR, $\mathbf{X}$. L. Lamp and stand, $\$ 2.00$. Glass lamps, separate, each 60 c. Extra wicks, each $10 \mathrm{c}$.

\section{GARDENER'S GLOVES.}

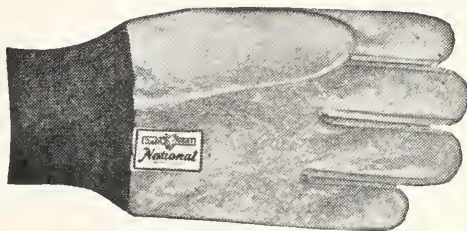

Goat Skin. Pliable and useful for all garden work. Per pair $\$ 1.00$

Hog Skin. With or without gauntlets. Pair $\$ 1.75$

Horsehide. Best quality. Pair $\$ 2.00$.

Ladies' Horsehide. Size 7 and $71 / 2$. Pair $\$ 1.75$.

GARDEN LINES. Finest braided hemp. $100 \mathrm{ft}$. $\$ 1.75,200 \mathrm{ft} . \$ 3.50$.

GARDEN PENCILS. Indelible black. Each $15 \mathrm{c}$.

GARDEN REELS for Garden Lines, wrought iron. Small $\$ 1.75$; large $\$ 3.00$.

\section{GLASS}

CUTTERS.

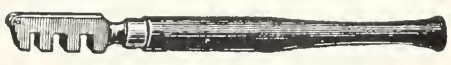

"Red Devil." No. 023, 25c.

Diamond. High quality finish. Each $\$ 7.50$.

GLASS FOR GLAZING SASH. Box of 50 sq. ft. Market price.

GLASSES, Magnifying. Each $\$ 1.00$.

GLASS CLOTH. For using on hotbeds or sash in place of glass. 36 in. wide, 1 to 10 yards, $45 \mathrm{c}$. per yard; 11 to 25 yards, $40 \mathrm{c}$. per yard; 25 to 50 yards $38 \mathrm{c}$. per yard; 50 to 100 yards, $35 \mathrm{c}$. per yard.

GLAZING POINTS, "Peerless." 1000 80c.

GLAZING POINT PLIERS for the above. Each 90c. GLAZING POINTS, Zinc. $5 / 8$ in. or $3 / 4$ in. Box 60 c. GRAFTING WAX. For grafting cuts and bruises on trees. $1 / 4$ lb. 25 c., $1 / 2$ lb. 40 c., lb. 60 c.

GRAPE BAGS, Paper. Made with patent metal clasp. $10075 \mathrm{c} ., 1000 \$ 6.00$. With string, 100 $\$ 1.50,1000 \$ 12.00$.

GRASS EDGING KNIVES. See knives. (Page 95.) 


\section{HORTICULTURAL TOOLS AND REQUISITES-Continued}

\section{GRASS HOOKS or SICKLES.}

Best English welded back Each

No. 2, medium ...............\$1.00

No. 3, large................ 1.15

American, large size.......... .35

GRASS SHEARS. See Shears.

GRINDSTONES. (See Implement Catalogue).

HAMMERS, GARDEN. With claw. Each $\$ 2.00$.

HAMPERS, Willow. For shipping vegetables. Furnished with rod, lock and two keys.

Size $24 \times 14 \times 14$ in .................\$15.00 Galvanized metal lined......................... 23.00

Size $26 \times 15 \times 15$ in .................. 16.50 Galvanized metal lined . . . . . . . . . . 26.00

Size $28 \times 16 \times 16$ in .................... 17.00 Galvanized metal lined.................. 28.00

HARROWS. (See pages 109, 119.)

HATCHETS. With claw. Each $\$ 2.00$.

HEDGE TRIMMER. (See page 103.)

HOES, DRAW. With handles. 5 in. $\$ 1.00,6$ in $\$ 1.10,7$ in. $\$ 1.20,8$ in. $\$ 1.30$.

HOES, SCUFFLE, or DUTCH. English make Handles, 50c. extra.

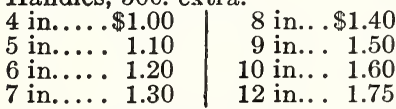

HOES, American Scuffle. 7 in. with handles, $\$ 1.35$ HOES, WARREN. Heart-shaped, $7 \frac{1}{2}$ in., $\$ 2.00$.

HORSE BOOTS. For lawns; made of heavy leather. Medium size, set of four, $\$ 18.00$; large size, $\$ 20.00$.

Baker's Metal. (See page 109.) $\$ 10.00$.

HOSE BANDS. Made of brass wire. For putting on couplings. Doz. 35c.

HOSE PLIERS for the above. Each 50c.

HOSE CLAMPS.

Bolt Pattern. Doz. 60c.

Snap-tite. Easily put on. $1 / 2$ in. or $3 / 4$ in. size. Each $15 \mathrm{c}$., doz. $\$ 1.50$.

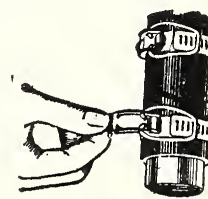

HOSE COUPLINGS. Brass for $1 / 2$ in. or $3 / 4$ in. hose Each 20c.

Clincher Style. $1 / 2$ in. or $3 / 4$ in. Each $30 \mathrm{c}$.

Rain King. Quickly snaps on without turning. Each 60c.

HOSE CONNECTION. Gooseneck for connecting hose to faucet. Each $\$ 1.00$.

HOSE CONNECTION. Siamese. For connecting two leads of hose. Each $\$ 1.25$.

HOSE HOLDER. Gem. For holding hose when watering. Each $30 \mathrm{c}$

HOSE HYDRANT ATTACHMENT. Used for connecting hose to smooth faucets. Brass, each $35 \mathrm{c}$

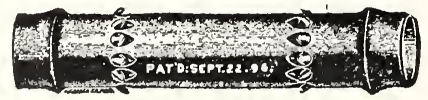

HOSE MENDERS.

Each Doz.

"Cooper's." (See cut.) Brass, 1/2 or

$3 / 4$ in........................ \$0.15 \$1.50

"The Perfect Clinching." $1 / 2$ or $3 / 4$ in... .20 2.00
HOSE NOZZLES

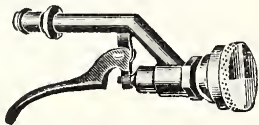

"Aquamatic." For sprinkling gardens, washing automobiles, etc. Wastes no water. Spray or stream. Each $\$ 2.00$. Nozzles only, each $40 \mathrm{c}$.

Fan Shower. Brass. Face $43 / 4$ in. Each 65c.

"Gem," or "Graduat-

ing." $3 / 4$ in. hose. Can

be regulated to give, three different streams. Each 60c.

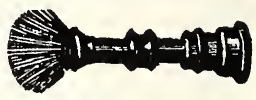

Hose Rose. Made with brass for $3 / 4$ in. hose. 3-in. face $\$ 1.50,4$-in. face $\$ 1.75$.

Magic Spray Pipe. A spray, stream or shutoff combined. All brass. Each $\$ 1.00$.

Rain King. Coarse or fine spray with only a slight turn of nozzle. Each $\$ 1.50$.

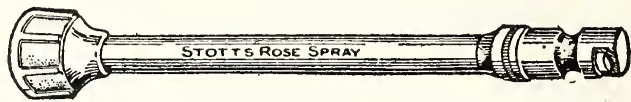

Stott's. A favorite among Rose growers. Single spray, each $\$ 1.75$, double spray $\$ 3.00$.

"The Boss." "Spray or stream, with shutoff. Each $\$ 1.10$.

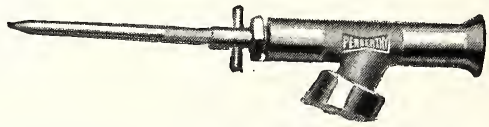

"Water Gun." A combined huse nozzle and lawn sprinkler. Makes a solid stream or spray. Each $\$ 1.50$.

HOSE, RUBBER.

$1 / 2$ in., braided...........\$0.20

"Marshall." 3/4 in., braided............ .21

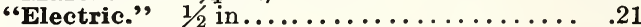

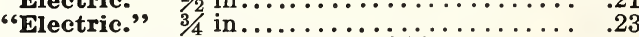

Special Spray Pump Hose. $1 / 2$ in ........ $\quad .30$

HOSE NOZZLES FOR SPRAY PUMPS.

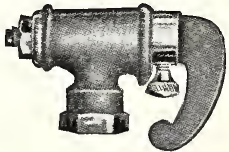

Bordeaux

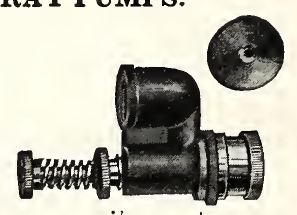

Vermorel
"Bordeaux," Adjustable. Each \$1.25.

"Vermorel.", A fine spray. Each $\$ 1.15$.

Kant Clog Nozzle. Each $\$ 1.10$.

Mystry, Jr. A fine spray. Each $\$ 125$

HOSE REELS. Made with tubular iron; strong and durable.

No. 10. For $100 \mathrm{ft}$., $3 / 4$ in. hose. Each $\$ 6.00$

No. 20. For $150 \mathrm{ft}$., $3 / 4$ in. hose. Each $\$ 6.75$.

No. 31. For $500 \mathrm{ft} ., 3 / 4$ in. hose. Each $\$ 18.00$.

HOSE REEL. Victor. All metal steel frame, 9-in. corrugated steel drum. For 100 feet of hose. Each $\$ 3.50$.

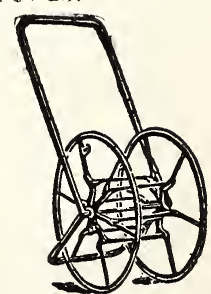

HOSE REEL. "Easy." Holds $375 \mathrm{ft} .3 / 4$ in. hose. All metal. Each $\$ 3.00$.

HOSE WASHERS. $3 / 4$ in. Doz. 10c., 100 50c.

HURDLES. Portable wooden. (See page 126.)

HYACINTH STAKES. Dyed green.

12 in. long.............. 100 35c., $1000 \$ 3.00$.

18 in. long............. 10040 c., $1000 \$ 3.50$.

INK. Indelible for Zinc Labels. Bottle 30c

KEEP OFF THE GRASS. Enameled metal sign.

Each 50c. 


\section{HORTICULTURAL TOOLS AND REQUISITES-Continued}

KNEE PADS. Made with rubber. Pair $\$ 2.00$.

KNEELING PADS. Made with sponge rubber Size $15 \times 7$ in. Each $\$ 1.00$.

KNIVES, ASPARAGUS, American. Each $50 \mathrm{c}$.

KNIVES, BUDDING

American. No. 2944 W. 2 blades with hanging

ring.

American. No. 40064. Two bladte brass lined. 2.00

American. No. R1568. Florists, snarp point, cocobolo round handle 4 in .long.......... 1.25

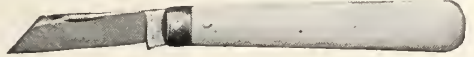

English, I. X. L. 7956B. Ivory handle, brass lined, sharp point................. 5.00

English, I. X. L. 7956B.S. Ivory handle, brass lined, round point................. 5.00

English I. X. L. 7954 Two blades........ 4.00

German, Henckels. No. 727 W. Two blades. 2.00

Dahlia Knife. For dividing tubers, blade $31 / 2$ in. long. Each $\$ 2.00$.

KNIVES, PRUNING.

American, No. R708, coco handle, medium size......................... 1.50

American, No. R3853, stag handle, two blades. 2.00 American. No. R1608. Blade $2 \frac{1}{2}$ in. Cocobola handle, 4 in. long................ 1.25

American, Allen's Metal Handle, 3 in. blade. 1.00 American, Keen Kutter, large size, wood handle, curved blade................ 1.50

English, No. 796A, stag handle, small size, one blade. Each $\$ 3.00$.

English, No. 928 , handle, large size, blade. Each $\$ 3.25$.

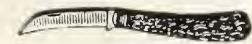

No.796A

No. 928

English. I. X. L. No. 7689. Stag handle, one blade....................... 2.50

English. I. X. L. No. 7703 . Stag handle, one blade..................... 4.00

German (Henckels). No. 769 , stag handle... 2.00

KNIVES, EDGING.

English. Best steel, handles 50c. extra; 8 in. $\$ 2.25 ; 9$ in. $\$ 2.50$.

American. With handles. $\$ 1.50$.

Each

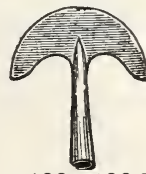

LABELS, POT and GARDEN, Wooden.

Painted $\quad \begin{array}{llll}100 & 1000 & \text { Painted } \quad 100-1000\end{array}$ $4 x^{5} / 8$ in .... $\$ 0.30 \$ 2.25 \quad 6 x^{5} / 8$ in ....... $\$ 0.50 \$ 3.00$ $41 / 2 \times 5 / 8$ in.. $.35 \quad 2.50 \quad 8 \times 7 / 8$ in ......... 1.008 .50

$5 \times 5 / 8$ in... . .40 $\quad 2.75 \quad 10 \times 7 / 8$ in......... 1.2510 .00

$12 \times 1 / 8$ in ..... 1.5013 .00

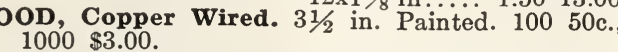

Clear View. Iron stake 26 inches long with card holder $31 / 2 \times 3 / 4$ in. Very durable and easily read. Doz. $\$ 2.50,100 \$ 18.50$.

"Indestructo." A superior, ever-lasting label made of copper metal. The name desired is permanently written with a metal stylus supplied in each box.

100

No. $1.3 / 4 \times 3 \frac{3}{4}$ in. $\$ 2.00$

No.2.11/8x5 in. 2.60
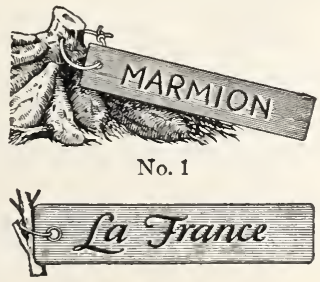

No. 2

Celluloid Hanging. With copper wires, $31 / 2$ in long by $11-16$ in. wide. Doz. 20c., $100 \$ 1.00$ $31 / 2$ in. long, $11 / 2$ in. wide. Doz. 75 c., $100 \$ 5.00$.

Celluloid Pot. No. 22.5 in. long, $3 / 4$ in. wide. Doz. 50c., $100 \$ 3.00$; No. 23,6 in. long by 1 in. wide, doz. 60c., $100 \$ 4.50$.
LABELS. Continued.

Magno Garden.

This label derives its name from the fact that its glass top enlarges the lettering on the card name, making it easy to read at a distance. It is $123 / 8$ inches long, rustproof, waterproof, sturdy and durable. Doz. $\$ 3.00$ $100 \$ 20.00$.

Seerite. A round glass label holder, with $41 / 2$ in. wooden peg to go in ground. Box of 8 for $\$ 1.00$.

LABELS, The Simplex. Waterproof Doz. 100

No. 1. $3 \mathrm{x}^{1 / 2}$ in .................. \$0.55 $\$ 3.00$

No. $2.4 x^{3} / 4$ in ........................ $75 \quad 5.00$

No. $3.5 \times 1$ in ........................... $1.00 \quad 7.00$

Simplex Garden. No. 10. With iron stake 24 in. long and metal ticket holder. Doz. $\$ 3.00,100$ $\$ 25.00$. Extra Cards, $100 \$ 3.00$

Simplex Weatherproof Ink. For Celluloid Labels. $1 / 2$ oz. bottle $\$ 1.25$.

Simplex Green Waterproof. No. 31. Hanging size $3 \times 1 / 2$ in. $100 \$ 2.50$.

Simplex Green Waterproof. No. 51. Pots or rockeries. Size $4 x \frac{5}{8}$ in. $100 \$ 3.00$.

Tree or Garden. Zinc. Per 100:

No. 1..\$3.00 No. 5..\$3.50 No. 13..\$1.50

No. $2 \ldots 3.00$ No. $6 \ldots 1.50$ No. $15 \ldots 2.00$

No. $4 \ldots 3.00 \quad$ No. $7 \ldots 1.50 \quad$ No. $21 \ldots 2.00$

Ask for shapes and Sizes.

INDELIBLE INK. For above. Bottle 30c.

LAWN CLEANERS. (See page 101.)

LAWN EDGERS. (See pages 95, 104 and 110.)

LAWN ROLLERS. (See page 109.)

LAWN SPRINKLERS. (See pages 116, 117.)

LAWN RAKES. (See Rakes.)

LAWN MOWERS. (See pages 106 to 108.)

LAWN MOWER SHARPENING COMPOUND. Per can, 60c.

LAWN MOWER SHARPENER, “Bergman." Each $\$ 1.00$.

LAWN SWEEPERS. (See page 101.)

LEAF-MOULD. 1 barrel bag, $\$ 2.00$.

LIGHTNING WIRE TIE CLIP. For fastening plants to wooden stakes. $10035 \mathrm{c} ., 1000 \$ 2.50$.

LINES. (See Garden Lines.)

MASTICA.For reglazing greenhouses.Qt.90c.,gal. $\$ 3.00$

MASTICA GLAZING MACHINE. Each $\$ 3.50$.

MATTOCKS.

"Oak Leaf."

Hoe, $4 \frac{1}{4}$ in.

Cutter, 3 in.

Each \$1.50.

Handles, 50c.

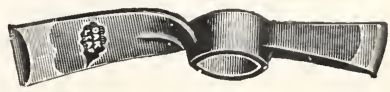

MATS, FROST-PROOF, Burlap. These mats are $76 \times 76$ in. square and made of strong burlap filled with cotton. Each $\$ 3.75$, doz. $\$ 44.00$

Size $40 \times 76$ in., each $\$ 2.75$, doz. $\$ 32.00$.

MATS, Hotbed. Waterproof one side, burlap on other $40 x 76$ in., each $\$ 3.50$, doz. $\$ 37.00 ; 76 \times 76$ in., each $\$ 6.00$, doz. $\$ 67.00$.

MATS, Milo Waterproof. Made from heavy burlap, felt and absorbent pulp, cemented together with a special waterproof compound. Impervious to rain, proof against frost and repellent to rats and mice. Size 80 by 78 in. Each $\$ 4.50$, doz. $\$ 50.00$.

MELON NETS. English make. Doz. $\$ 2.50$. 


\section{HORTIGULTURAL TOOLS AND REQUISITES-Continued}

MOLE TRAPS.

Schroeter Improved. Low built and self setting. Each $\$ 2.25$.

MO-LO. A preparation for destroying moles. Pkg. 25c.

MOSS, SPHA GNUM, Live. For orchids. Bag $\$ 2.50$

For packing, 5-bbl. bale, $\$ 4.00$.

Green. in sheets. Bag $\$ 4.50$.

Dyed Green, in sheets. Bag $\$ 7.00$.

MULCH PAPER. "Gator Hide." Used for mulching all kinds of flowers, vegetables and fruits.

Type B. Sample Roll. Heavy weight. 67 sq. ft. $\$ 1.00$.

Type B. Heavy weight. 18 in. wide. 150 yards long. Per roll $\$ 3.50$.

Type B. Heavy weight. 36 in. wide. 150 yards long. Per roll $\$ 7.00$.

NAILS, English Wall. $1 \frac{1}{2}$ in. Chandler's patent with lead tip to turn over vine. About 40 nails to $1 \mathrm{~b}$. Lb. 70c.

Cast Iron. $1 \frac{1}{2}$ in. About 140 nails to pound. Lb. $25 \mathrm{c}$.

NETTING, Bird, for Strawberry beds, etc.; 20 or 30 $\mathrm{ft}$. wide. Per lb. $\$ 2.75 ; 1 \mathrm{lb}$. will cover $200 \mathrm{sq}$. $\mathrm{ft}$.

NOZZLES. (See Hose Nozzles.)

OIL CANS. For lawn mowers, etc., brass bottom. 30c. PAPER.

Kraft. Sheets $40 \times 48$ in. or $30 \times 40$ in. Per lb. 15c.

Kraft. Rolls 18 in. or 24 in. wide. Per lb. $15 \mathrm{c}$.

Tissue. Ream (480 sheets.) $24 \times 36$ in. $\$ 2.00$.

Waxed Tissue. Ream (480 sheets), $24 \times 36$ in., $\$ 3.50$

Coarse. For parceling. Lb. 16c.

Prices of paper are subject to change.

PEAT MOSS. Small bale $\$ 1.50$, large bale $\$ 5.00$.

PEAT, Rotted. 1-bbl. bag $\$ 2.25$.

PEAT, Orchid. 1-bbl. bag. $\$ 2.75$.

PENCILS, GARDEN. For labels. Each $15 \mathrm{c}$.

PICK MATTOCKS, "Oak Leaf."

Hoe $41 / 4$ in.

Pick $81 / 2$ in.

Each $\$ 1.50$

Handles 50c.

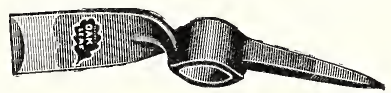

PICKS. Pointed both ends. 23 inches. Each $\$ 1.50$, handles $50 \mathrm{c}$.

PLANET JR. CULTIVATORS. (See page 104).

PLANT GUARDS. To protect plants against cutworms, etc. $10030 \mathrm{c} ., 1000 \$ 2.50$.

PLANT PROTECTING CLOTH. Valuable for protecting early plants from frost. Pieces contain from 40 to 60 yards.

Heavy Grade. By piece of 50 yds., per yd. 35c.

Medium Grade. By piece of $60 \mathrm{yds}$., per yd. 30c.

PLANT PROTECTORS. For Tomato or Egg Plants; wire with cotton covering. Each $25 \mathrm{c}$., doz. $\$ 2.50$. (See also Page 105.)

PLANT SPRINKLERS. (See Sprinklers.)

PLANT STAKES. Round, green, tapering (light).

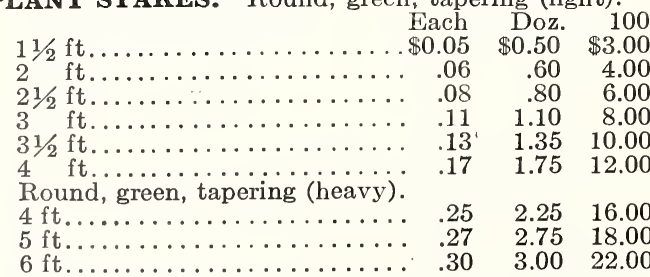

BEAN POLES. Cedar, pointed, $8 \mathrm{ft}$. to $9 \mathrm{ft}$. Doz. $\$ 4.00,100 \$ 30.00$.
PLANT STAKES-Continued

DAHLIA POLES. Heavy, round, green; tops painted white. Each Doz 100

$3 \mathrm{ft} \ldots \ldots \ldots \ldots \ldots \ldots \ldots \ldots \ldots \$ \ldots .20 \quad \$ 2.00 \$ 12.50$

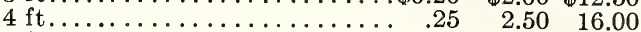

$5 \mathrm{ft} \ldots \ldots \ldots \ldots \ldots \ldots \ldots \ldots . .27 \quad 2.75 \quad 18.00$

$6 \mathrm{ft} \ldots \ldots \ldots \ldots \ldots \ldots \ldots \ldots . .30 \quad 3.00 \quad 22.00$

DAHLIA STAKES. Extra heavy. $7 / 8$ in. square at bottom tapering to $3 / 4$ in. at top, painted.

Doz. 100

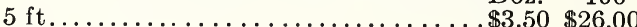

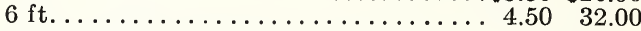

GALVANIZED WIRE, for Roses, etc. Plain or Anchored. No. 9 wire.

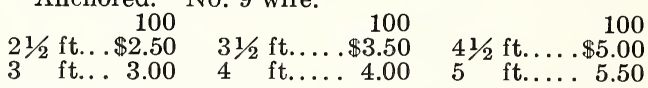

PLANT SUPPORTS. (See page 110.)

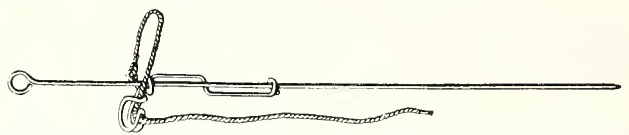

PLANT SUPPORT. The Timesaver. A galvanized iron stake with adjustable clip and fiber twine. Adapted for all kinds of flowers or shrubs. No. 2 . 3 ft., doz. $\$ 1.15$; No. 3.4 ft., doz. $\$ 2.20$; No. 4.5 ft., doz. $\$ 2.75$.

PAEONY SUPPORT. No. $3 \mathrm{~A} .31 / 2 \mathrm{ft} .5 \mathrm{ft}$. cord. Doz. $\$ 2.10$

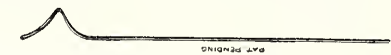

S. L. N. WIRE STAKE. A new and practical device for supporting flowers. The spiral end forms a circular hook for the flower. 36 in. long. Doz. $\$ 1.00,25$ for $\$ 2.00,100 \$ 7.00$.

PLOWS. See our Farm Implement Catalogue. (Sent on request.)

PLIERS. Side cutting, 6 in. $\$ 1.50 ; 7$ in. $\$ 2.00$.

POT HAN GERS. Made with galvanized wire. 18 inch. Each 25c. Doz. $\$ 2.00$. $100 \$ 12.00 .24$ inch. Each 30c. Doz. $\$ 2.50$. $100 \$ 18.00$.

POTATO HOOKS. Broad, round prongs. 4-prong $\$ 1.50,5$-prong $\$ 1.75$.

POTS. (See Flower Pots, page 93.)

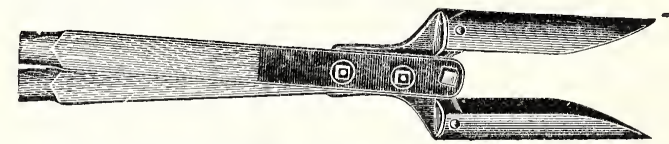

POST HOLE DIGGER. The blades are 9 in. long and the handles $5 \mathrm{ft}$. long. Each $\$ 2.50$.

POWDER DUSTER. For Slug Shot. Each 75c.

POWDER GUNS. (See pages 96, 114.)

Double Barrel Dust Gun. Each 75c.

Duster Brown. Powder Gun. Pint size $\$ 1.00$ Quart size $\$ 1.25$.

POULTRY SUPPLIES. (See pages 118).

PRUNER, or Lopping Shears.

Double Cut. Handles 30 in. long. Each $\$ 2.75$.

Handy Andy. A small lopping shear, 14 in. long. Very useful for small work. Each $\$ 2.00$.

"Keen-Kutter." Handles 22 in. $\mathrm{C} u \mathrm{r}$ v e d blade. Each $\$ 3.50$.

Eagle Lopping Shear. 20-in.handle Each $\$ 2.00$.

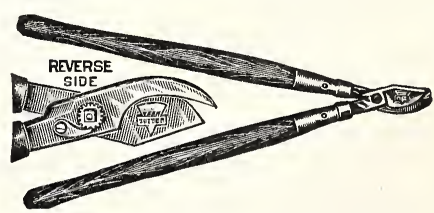

Rhodes'. Cuts on both sides and does not bruis the bark. Length 36 in. Each $\$ 6.50$. 


\section{HORTICULTURAL TOOLS AND REQUISITES-Continued}

PRUNERS, TREE.

Bartlett Compound Lever. Does double the work of any other pruner with less exertion. 10 foot. Each $\$ 5.50$. Extra blades 50 c.

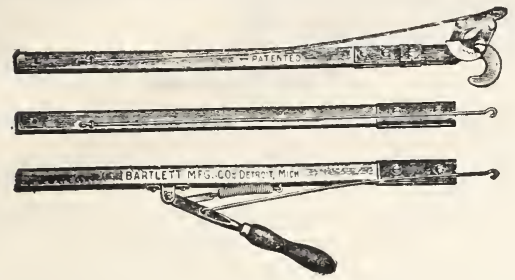

Bartlett No. 1 Jointed Tree Trimmer. A new and very efficient tree trimmer and pruner. The pole is made in sections of four feet each enabling the user to have a selection of an $8 \mathrm{ft}$., $12 \mathrm{ft}$. or $16 \mathrm{ft}$. pruner. Superior quality throughout. No. 1. $16 \mathrm{ft}$. jointed pruner. Each $\$ 8.50$.

Little Giant Prun. er Hook and Saw Combined. Attaches to pole of any length. Each $\$ 3.50$.

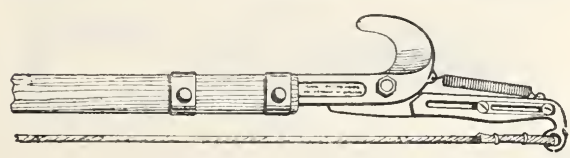

Hadley Pole Pruner. The only pruner with a two cutting blade. No. 2 with $5 \mathrm{ft}$. pole and 5 foot extension. Each \$7.75. Extra extensions $5 \mathrm{ft}$. Each $\$ 1.00$. No. 3 Pruner without pole or rope $\$ 6.00$.

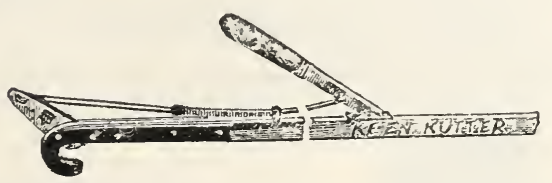

Water's Patent. (Keen Kutter). 10 foot handle $\$ 3.00 ; 12 \mathrm{ft}$. handle, $\$ 3.25$. Extra blades, $30 \mathrm{c}$. each.

PUMP, "The Kinney." For distributing water and liquid manure through the hose at the same time. Each $\$ 2.25$.

PUMPS. (See Spray Pumps, pages 112, 113, 114.)

PUTTIUM. A new glazing cement used in place of putty. Color gray. Gal. can $\$ 3.00$.

PUTTY BULB, Rubber. For glazing, $\$ 1.35$.

RAFFIA. The best material for tying plants. Per lb. 50c. Green, dyed, lb. $\$ 1.25$.

RAFFIA TAPE. Green, on spools of 100 yards. Each $\$ 1.50$.

RAKES.

Bamboo Lawn. Each 75c. Large size $\$ 1.00$. (See page 105.)

Garden. Best steel, 8 teeth, $\$ 1.00 ; 10$ teeth, $\$ 1.20$; 12 teeth, $\$ 1.30 ; 14$ teeth, $\$ 1.40 ; 16$ teeth, $\$ 1.50$; 18 teeth, $\$ 1.60$.

Gem Dandelion. 15 in. wide. Each $\$ 2.50$. (Illustrated on page 105.)

Hay. Wooden, 3 bows, 12 teeth, $\$ 1.10$.

Hoover. Flexible steel for leaves, etc. $\$ 1.00$. (Illustrated on page 105.)

Lawn. Wooden, 3 steel bows, 22 teeth, $\$ 1.25$.

Reversible. Galvanized, 24 teeth, $\$ 1.25$.

Rake and Hoe. A combination tool, $\$ 1.10$.

REELS, GARDEN. Each $\$ 1.75$ and $\$ 3.00$.

REFUSE BURNERS. (See pages 101 and 110.)
RIFLES, EMERY. For sharpening. Each 15c.

CARBORUNDUM. No. 57. Will sharpen any garden tool. 9 in. long with wood handle. Each $\$ 1.00$.

ROLLERS. (See page 109.)

RUBBER BANDS. For split Carnations. Oz. 30c.

RUBBER COATS. State size wanted. $\$ 9.00$.

RUBBER BOOTS, Gardeners and Farmers. State size when ordering. Per pair, hip length, $\$ 7.00$, knee length $\$ 5.50$.

SASH, HOTBED, Extra Strong.

Unglazed. Made of best cypress. Regular size $3 \times 6 \mathrm{ft}$., for using $6 \times 8$ in. glass. No. 4 , each $\$ 3.00$.

Glazed. (Packing extra.) Size $3 \times 6$ ft., using $6 \times 8$ in. glass. Painted two coats white. No. 4, each $\$ 6.00$.

Glazed. Size $3 \mathrm{ft} .2$ in. $x$ $6 \mathrm{ft} ., \mathrm{using} 8 \times 10$ in. glass. No. 9 , each $\$ 6.50$.

Glazed with $10 \times 12$ in. double thick glass. Size $3 \times 6 \mathrm{ft}$. Iron cross bar, No. 11, each $\$ 7.00$.

"Sunlight.", Double Glass. Glazed with $10 \times 12$ in. double, two layers thick glass painted two coats, white. No. 12 , each $\$ 11.00$.

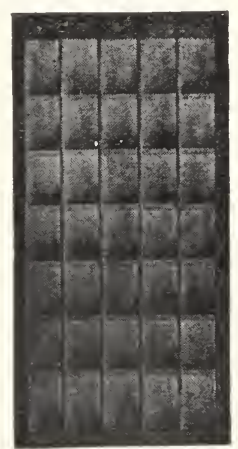

Hotbed Frames for Sash. Painted. For 2 sash, each $\$ 14.00$; for 3 sash, each $\$ 18.00$; for 4 sash, each $\$ 23.00$; for 5 sash, each $\$ 28.00$.

\section{SCISSO 2 .}

Grape or Vine. Best make, 7 in., $\$ 1.50$.

Flower Gatherers. quality. $6 \frac{3}{4}$ in., $\$ 1.75$.

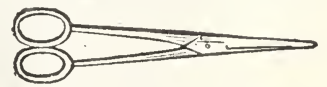

Flower Gatherers. No. 30. 6 inches. Each 50c. SCISSORS, PRUNING. English make, 4 in., \$2.25. 5 in., $\$ 2.50$.

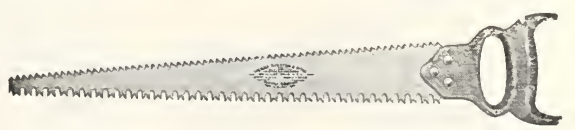

SAWS.

Pruning Disston. Single edge, 16 in. $\$ 1.50,18 \mathrm{in}$. $\$ 1.75,20$ in. $\$ 2.25$ Double edge, 16 in. $\$ 1.75$. 18 in. $\$ 2.00,20$ in. $\$ 2.75$.

Double Swivel. Blade 14 in. long. Very useful for pruning. Each $\$ 2.25$. Extra blades $35 \mathrm{c}$.

Crescent Pattern, "Keen-Kutter." 16 in., each $\$ 2.00$.

Hand or Pruning. 20 in. blade, each $\$ 2.25$.

Cross-cut, One-Man. Cuts easily and rapidly. $4 \mathrm{ft}$. Each $\$ 4.75$.

SAW FILES. Best make. Each 20c. and 25c. SCYTHES.

Lawn English. 30 to 34 in., each $\$ 3.00$.

Grass, American. 30 to 40 in., each $\$ 2.50$.

Brush or Weed. 18 to 21 in., each $\$ 2.25$.

SCYTHE SNATHS (or Handle.) Each $\$ 2.00$.

SCYTHE STONES. Flat, each 25c., doz. $\$ 2.50$.

Carborundum. No. 57. Each $\$ 1.00$.

English. Round pointed. Each 35c. 


\section{HORTICULTURAL TOOLS AND REQUISITES-Continued}

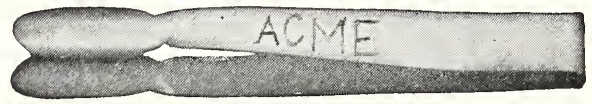

SEEDLING PRICKER. For transplanting seedlings. Each 25c. "Acme" see illustration.

SEEDERS. (See pages 103 and 104.)

SEEDERS, Sowrite. Fiberloid for fine flower seeds Each \$1.00. (See page 103.)

Sowrite. For all seeds to size of Sweet Peas. Metal, nickle plated. Each $50 \mathrm{c}$.

SHADING, Summer Cloud. English shading for greenhouses. $1 / 2 \mathrm{lb}$. pkg. $75 \mathrm{c}$. $11 / 2 \mathrm{lb}$. pkge. $\$ 2.00$.

\section{SHEARS.}

Grass Border.

English (with-

out wheel.)

8 in......\$5.50

9 in.....6. 6.00

10 in.....6.6.50

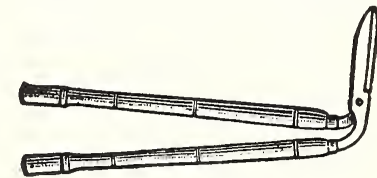

American. Without wheel. 9 in., $\$ 4.00$.

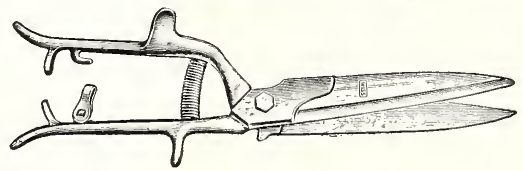

Grass, Wiss No. 600. 6 in. steel blades with 7 in. metal handle and spiral steel spring. $\$ 1.50$.

Grass or Sheep. Best trowel shank. $\$ 1.25$.

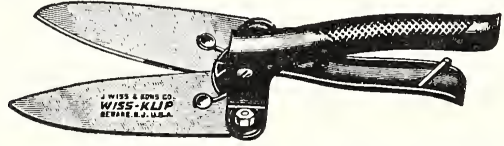

Grass. Wiss-Klip. No. 700. Six inch blade. $\$ 1.50$.

Hedge, English Make. 8 in., $\$ 3.00 ; 9$ in., $\$ 3.50$.

10 in., \$4.00. With notch, 35c, extra.

Extra Bolts, Nuts and Washers. Per set 25c.

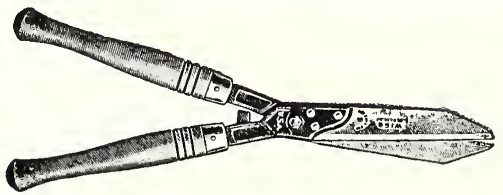

Wiss Hedge. Best steel concave blades, one serrated 8 in. $\$ 2.75$. 9 in. $\$ 3.00$. 10 in. $\$ 3.25$.

Lopping Shears. (See Pruners.)

SHEARS PRUNING.

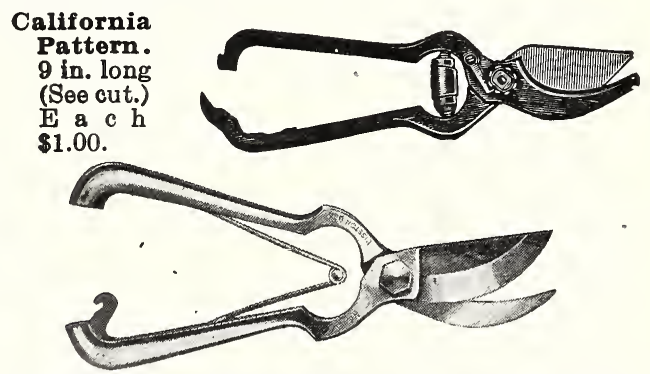

Disston Pruning No. 152. $8 \frac{3}{4}$ in., extra strong Each $\$ 3.50$

Draw Cut. Has a true drawing cut which gives greater ease in cutting. 8 in. Each $\$ 2.00$.
SHEARS, PRUNING-Continued

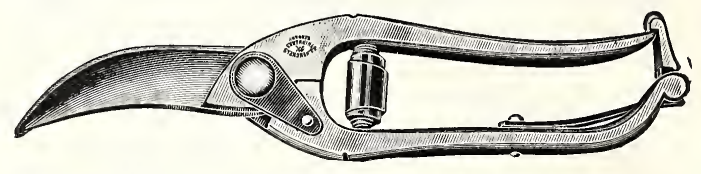

Henckel's Pruning. No. 192. Can be used for heavy or light branches. $81 / 2$ in. $\$ 5.00$.

Kunde Pattern. Henckel's. No. 191. $71 / 2$ in. Each $\$ 4.00$.

Lion Pruning. Double beveled cutting blade. Nickel-plated handle. 8 in. $\$ 2.50$.

Ladies' Pruning. $61 / 2$ in. Nickel plated, $\$ 1.50$.

Perfection Pruning. Cuts on both sides. $61 / 2$ in., $\$ 3.50 ; 71 / 2$ in., $\$ 4.00$; $81 / 2$ in., $\$ 4.50 ; 91 / 2$ in.; $\$ 5.00$.

Plucca Pruner. Made to hold the twig that is cut off. $\$ 3.00$.

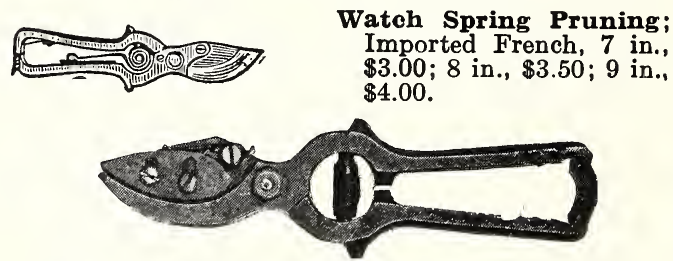

Wiss, Hand Pruning. (Solid Steel). 9 in., \$3.50. 10 in., $\$ 4.00$; extra blades, $\$ 1.00$ each.

Wiss Pruning No. 209. Blade and handle one piece of steel. 9 in. $\$ 1.50$.

Wiss Pruning No. 309. Forged steel blades 9 in. $\$ 2.50$.

SHARPENER, Self Grinding. For sharpening knives, shears, scissors, etc. Each $\$ 2.00$.

SHREDS, Medicated Gaxden. For nailing trees to walls etc. 3 in., 10060 c.; 4 in., 10075 c.

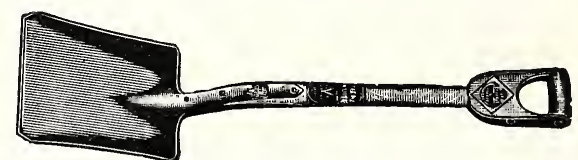

SHOVELS, "Keen-Kutter." Square and Diamond Pointed. Long or short handles. Each $\$ 2.50$.

Best Steel, Square or pointed. Each $\$ 1.75$.

SIEVES, WIRE. For sifting loam, gravel, etc. $1 / 8$ in., $1 / 4$ in., $1 / 2$ in., or $3 / 4$ in. mesh, 18 in. in diam., each $\$ 2.50$.

SIGN, "Keep Off the Grass." Metal with enameled letters. Size $3 \frac{1}{4} \times 19$ in. Each 50 c.

SILKALINE, Meyer's Green. Fast color. Spool 50c. Box of 8 spools $\$ 3.50$.

SMILAX TWINE. Green. Box of 8 balls $\$ 1.25$.

SOAP DISPENSER, “Wilson's Sanitary.” To use with Wilson's Liquid Soap. Each $\$ 2.50$.

SOD PERFORATOR. (See page 109.) $\$ 4.50$.

SOIL TESTER, "Soiltex." The new pocket soil tester, contains enough material for making 75 to 100 soil tests. Outfit complete. $\$ 1.00$.

SOWERS, Seed. (See pages 103 and_104.)

Fertilizer. (See page 109.)

SPADES. Best cast steel. Long or short handles Each $\$ 1.75$.

“Keen-Kutter," extra quality, each $\$ 2.50$. 


\section{HORTICULTURAL TOOLS AND REQUISITES-Continued}

SPRA YERS. (See pages 112, 113 and 114.)

SPRINKLERS.

Lawn. (See pages 116, 117.)

Rubber. Scollay's straight neck. No. 1, 12-oz. size, $\$ 1.50$.

Rubber Plant Spray. Angle neck. Small size \$1.00. Large size. $\$ 1.25$.

The Ideal. Made entirely of metal and fits any bottle; can be used at any angle for insecticides or water. Each \$1.00.

STAKES. (See Plant Stakes and Canes.)

STAKES, HYACINTH. Green. 18 in. long. Doz 5c., 10040 c., $1000 \$ 3.50$.

STEEL WOOL PADS. For cleaning all tools. Each 60c.

STICKS, Match. 18 in. long. $1000 \$ 3.00$.

STYPTIC. To prevent bleeding of vines. Bottles, each $\$ 1.25$.

SULPHUR VAPORIZER, Campbell's Patent. (See Fumigators, page 93.)

SUNDIALS. Made with cast bronze. Diam. 11 in. Each $\$ 10.00$.

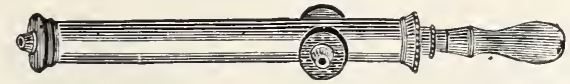

SYRINGES, GARDEN, Brass

No. C, length $141 / 2$ in., diam, $13 / 4$ in., one spray rose and stream. Each $\$ 4.50$.

No. 11, length 18 in., diam. $11 / 2$ in., two spray roses and one stream. Each $\$ 6.00$.

No. 5, length 18 in., diam. $11 / 2$ in., two spray roses and one stream, extra heavy and strongly mounted Each $\$ 8.00$.

Goosenecks. For syringes. Each $\$ 1.25$.

TAMPERS, Sod and Cement. (See page 109.)

TAN BARK. For walks. Per ton $\$ 30.00$.

TARRED FELT DISCS. For Cabbage plants. 100 50c.. $1000 \$ 4.00$.

TENNIS NETS. Single court, $27 \times 3 \mathrm{ft}$. Double court, $36 \times 3 \mathrm{ft}$., canvas bound. Prices on application.

TENNIS MARKER, No. o Dry Marker. For marking tennis courts. $\$ 3.50$.

\section{THERMOMETERS.}

Mushroom Bed. Wood with brass point, metal scale. Each $\$ 3.75$.

Mushroom Bed. Wood with brass point $\$ 2.00$.

Brooder, "Tycos." Each $\$ 1.00$.

Distance Scale. Metal frame. Each $\$ 1.00$.

Household. Wood frame. 8 or 10 in., 75 c. to $\$ 1.50$.

Incubator, Tycos. Each $75 \mathrm{c}$.

Japan Tin Case, Metal Scale. 8 in., 90 c; 10 in., $\$ 1.10$.

Maximum Registering. Wood frame. Each $\$ 2.75$.

Minimum Registering. Wood frame. Each $\$ 2.75$.

Porcelain Scale. For conservatory. Each $\$ 1.50$.

Self-Registering, "Tycos." frame. Size 10 in. $\$ 7.00$.

Self-Registering, "Hicks." English make, boxwood scale. 10 in. $\$ 8.00$.

Self-Registering. Imported, metal frame, 10 in. porcelain scale. Each $\$ 3.00$.

Temprite. Heavy metal, for greenhouse or outside. White with black figures. 9 in. Each $\$ 1.25$.

Window. Round glass with metal hangers. 8 in. Each $\$ 2.00$.

Magnets. For self-registering. 75c.
TINFOIL. Lb. 30c., violet or green, lb. 75c.

TOOL SETS, "Keen-Kutter." Fork, spade, hoe and rake. Set $\$ 3.50$.

Ladies Garden Beauty. Hoe, rake and trowel. $\$ 1.00$.

TOOTHPICKS. Wired. $100075 \mathrm{c}$.

TORCHES, Asbestos. For burning tent caterpillars. Each 60c.

Collin's Caterpillar Torch. A swinging lamp with attachment to pole with pan to catch the caterpillars that fall. Torch and catcher, $\$ 1.00 ; 12 \mathrm{ft}$. pole in 3 sections, \$1.00.

TOMATO SUPPORTS. Heavy galvanized wire rings. Each 40c., doz. $\$ 4.00$

Adjusto. (See page 111.)

Tomato Stakes. (See page 111.)

TRACTORS. Garden. (See page 108.)

TREE CLIMBERS. For attaching to the legs, to climb tall trees. With leather straps. Pair $\$ 5.50$.

TREE GUARDS, "Excelsior." Close mesh style.

Wires No. 9 horizontal, and No. 8 vertical. Fastens with hooks and eyes. Rustproof finish. Diameter 8 in., height $6 \mathrm{ft}$. Each $\$ 2.50$, doz. $\$ 27.50$

TREE SCRAPERS. Large iron with handle. Each $\$ 1.25$. Extra blades $60 \mathrm{c}$.

TRELLIS. (See page 111.)

TROWELS.

English. Finest quality throughout. Each Short handle.................... \$0.85 Long handle.............................

Steel. 6 in., $75 \mathrm{c} ; 7$ in., $80 \mathrm{c} . ; 8$ in., $90 \mathrm{c}$

Cast Steel. Ea. 35c.

Maynard. Heavy, one-piece steel. Each \$1.10.

Transplanting or Slim Jim. 6 in. $25 \mathrm{c}$., large 8 in. 30c TUBS, PLANT. (See page 102.)

rURFING IRONS. English, with handles. Each $\$ 8.00$.

American. With handles. Each $\$ 2.75$.

TWINE.

Cotton. White, per lb. $\$ 1.20$

Green Smilax. Box of 8 balls, $\$ 1.25$.

Marline (Tarred Twine.) Lb. 60c.

Marline. Small size. Per ball $\$ 1.00$ All sies. Lb. $\$ 1.00$.

Jute. Three- or four-ply, for trees. Lb. 50c.
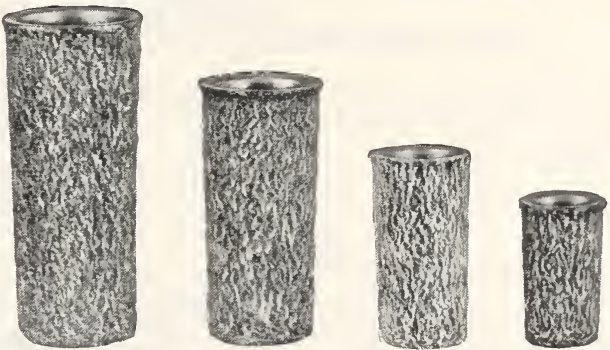

VASES FLOWER. Rustic bark like, green finish. Will not crack, chip or soften, absolutely waterproof.

No. 12

No. 12 1B

No. 15

No. 15 1B

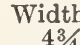

$\begin{array}{lr}4 \% \text { in. } & \text { Depth } \\ 8 \text { in. } & 12 \text { in. } \\ 51 / 2 \text { in. } & 15 \text { in. }\end{array}$

Each Doz. 12 in. $\quad 1.50 \quad 15.00$

VASES Flower, Galvanized.

Made with heavy galvanized metal, will not break or rust.

No. Width Depth Each Doz.

No. $\quad 51 / 2$ in. $\quad 91 / 2$ in ......... $\$ 0.50 \$ 5.00$

No.1A. $\quad 6$ in. $121 / 2$ in......... $70 \quad 7.00$

No. 2 A. $\quad 61 / 2$ in. $\quad 15$ in......... $.90 \quad$ I 9.00

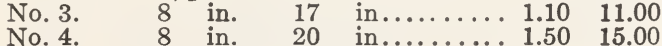

Painted green. 25c. each extra. 


\section{HORTICULTURAL TOOLS AND REQUISITES-Continued}

\section{VASES, Fiber Ware.}

Made with indurated fiber which is light, handy and durable. Smooth mahogany finish.

\begin{tabular}{|c|c|c|c|c|}
\hline No. & Width & Depth & Each & Doz. \\
\hline 44 & $31 / 2$ in. & 9 in. & $\$ 1.00$ & $\$ 11.00$ \\
\hline 1 & 6 in. & 10 & 1.35 & 15.00 \\
\hline 33 & $43 / 4$ in. & in. & 1.50 & 17.00 \\
\hline 0 & $83 / 4$ in. & $131 / 2$ in. & 1.75 & 21.00 \\
\hline 22 & $41 / 2$ in. & 15 in. & 2.25 & 24.00 \\
\hline 11 & 6 in. & 18 & 2.50 & 28.00 \\
\hline
\end{tabular}

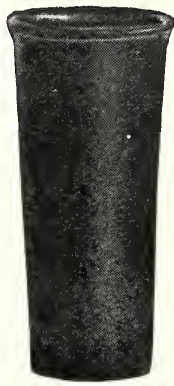

Inside measurements.

WATERING POTS or CANS. (See page 1U2.) WEEDERS.

"Adjustable." Three Prong (See Cut.) Each $75 \mathrm{c}$.

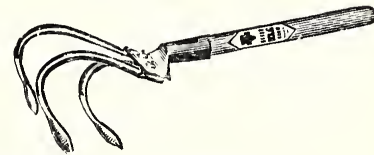

"Excelsior." Five-claw fingers. Each 20c.

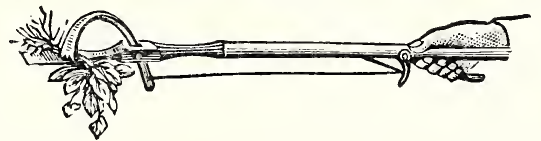

"Cleveland." Can be used ea ily and without stooping. (See cut.) Each $\$ 1.25$.

Dando-Killrite. Used for dropping liquid on Dandelions etc. Each $\$ 5.00$.

Dando-Killrite Filler for above. Can 60c.

"Eureka."' Very useful for garden purposes. Each 60c. Handy. Used with gasoline or
kerosene on Dandelions in lawns. Each $\$ 1.25$.

"Keen-Kutter." A light weight long handle weeder with four stationery prongs of tempered steel A tool that should be in every garden. As a cultivator or weeder it is equally effective. Each $\$ 1.00$.

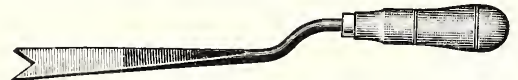

Lawn. For removing docks, dandelion, etc.; can also be used as an Asparagus 'knife. 50c.

Magic "D."

6 in. handle weeder and h o e co m bined. Four prongs. Each $50 \mathrm{c}$.

Magic "B.'

18 in. handle.

Three prongs.

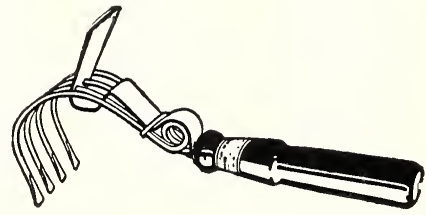

Each 25c.

Magic "H." Weeder and hoe combined. Handle, 48 in. Four prongs. Each $\$ 1.25$.

Spud Weeder. Fnglish, with 2 in. blade. Very handy for cutting out weeds in lawns or borders. Each $65 \mathrm{c}$.
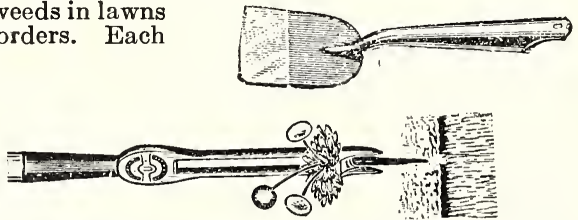

The Out-U-Come. A useful tool for pullin Dandelions, etc., from lawns. Each $\$ 1.00$.
WEATHER VANES, No. 170A. Made with copper. A rooster standing on an arrow. $14 \mathrm{in}$. high with 18 in. arrow. Each $\$ 15.00$.

\section{WHEELBARROWS.}

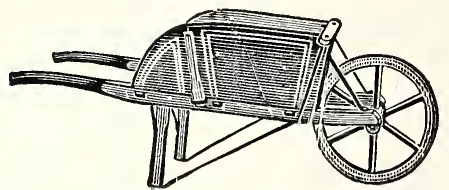

Garden. All nicely painted, iron leg braces thoroughly bolted. Wheels steel with 3 -inch treads.

No. 3. Small size. Box 24 n. long, 20 in. wide at handles.............. $\$ 7.50$ No. 4. Medium size. Box $261 / 2$ in. long, 20 in. wide at handles. ........... 8.50 No. 5. Large size. Box 28 in long, 24 in. wide at handles . . . . . . . . . . 9.50

Greenhouse Wheelbarrow. A very narrow style for use in greenhouses. Extreme width at handles only 20 inches........... 12.00

M etal Garden or Golf Barrow. Designed especially for garden or lawn work having 4 in tread on metal wheel and wide faced shoe on legs. The metal tray holds $31 / 2 \mathrm{sq}$. ft., is balanced to wheel easily, dumps quickly and will give lasting service............. 11.00

\section{WINDOW BOX. The "Savo."}

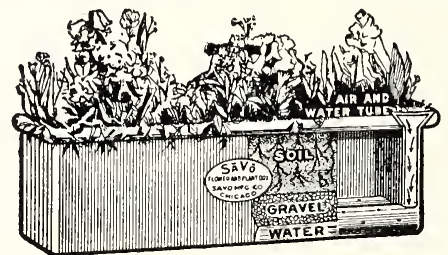

Self-watering and sub-irrigating for windows; porches, sun parlors, etc.

\begin{tabular}{|c|c|c|c|}
\hline & Height & Width & Length \\
\hline Model A. & 8 in. & $91 / 2$ in. & $23 \mathrm{in.}$ \\
\hline el B. & 8 in. & $91 / 2$ in. & \\
\hline $1 \mathrm{C}$. & $\begin{array}{l}8 \text { in. } \\
8 \text { in. }\end{array}$ & $\begin{array}{l}91 / 2 \text { in. } \\
91 \% \text { in }\end{array}$ & \\
\hline
\end{tabular}

WIRE, Annealed for Stemming.

Per lb.

No. 23. Coarse 18 in lengths $\ldots \ldots \ldots \ldots \$ 0.30$

No. 26. Coarse. 12 in. lengths .............40

No. 34. Fine hair. 12 in. lengths ...........60

\section{THE HARRIS DIRT BAND}

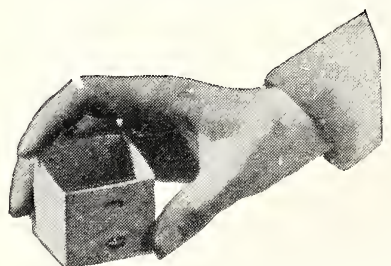

Plants grown in Dirt Bands are not injured in transplanting, as the root system is not disturbed. The bands being square they do not take up as much room as pots and do not dry out so quickly. Bands also make an ideal cut worm guard when placed around the plant in the garden. $100 \quad 1000$ No. $13 \frac{1}{4} \mathrm{~B}$, size $13 / 4 \times 13 / 4$, depth $21 / 2$ in.....\$0.50 $\$ 350$ No 2 B, size $2 \times 2$, depth $21 / 2$ in ........ $\quad .60 \quad 4.00$

No. $3 \quad$ B, size $3 \times 3$, depth 3 in ............. .70 5.00 No. $4 \quad$ B, size $4 \times 4$, depth 3 in ........... .75 5.50 


\section{LANSING HANDY GART}

This cart is well built of the best materials. The 36-inch wheels have 2 -inch tires with 12 spokes The axles and framework are of steel. It can be used for carrying milk cans barrels of feed or water, fodder, feed and other purposes. The platform is $28 \times 32$ inches. Price $\$ 13.00$.

\section{GOMBINATION WATER BARREL, TRUGK AND LEAF GART}

Barrel can be detached from truck without difficulty, or tilted to empty contents. Either barrel, leaf rack and box can be used. Furnished with wheels with 3 -inch tires.

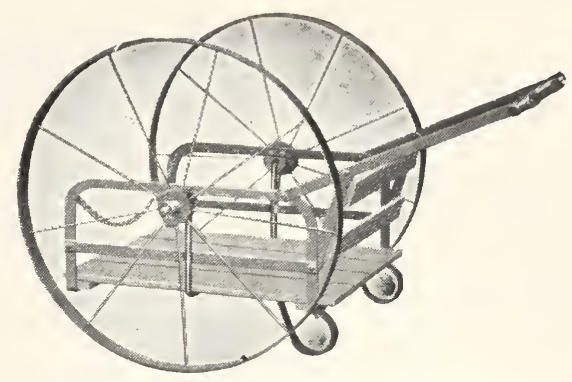

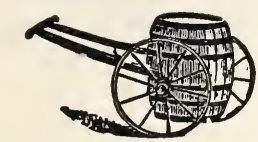

Fig. 6
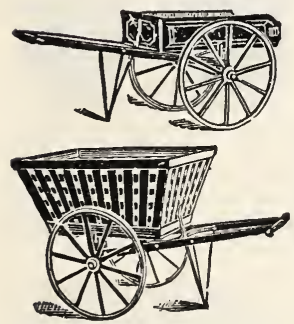

Fig. 162

TRUCK AND WATER BARREL

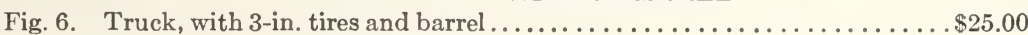
Truck without barrel, 3 -in. tires....................... 18.00

TRUCK AND LEAF RACK

Fig. 162. Truck, with 3 -in. tires........................... 33.00

TRUCK, BARREL, LEAF RACK AND CART

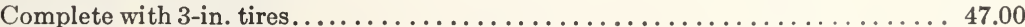

TRUCK, HANDCART AND BARREL

Fig. 7 Truck, with 3 -in. tires................................ 32.00

\section{ADDITIONAL ATTACHMENTS}

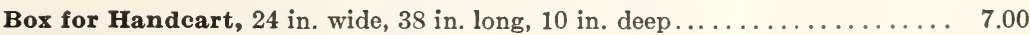

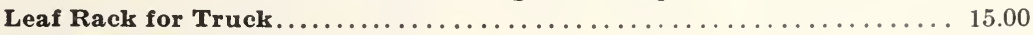

Extra Barrels with Trunnions.......................... 7.00

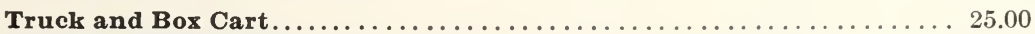

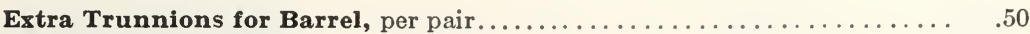

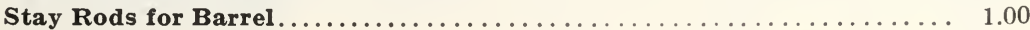

\section{WHEELBARROW LEAF-RAGK}

Can be attached to any style or size wheelbarrow with removable sides. Most convenient for gathering leaves, cut grass and rubbish. One of these attachments should be in use on every small suburban place, as well as the larger estates. Capacity 10 bushels; made of galvanized wire, with wood base to stand on wheelbarrow. Each $\$ 9.00$.

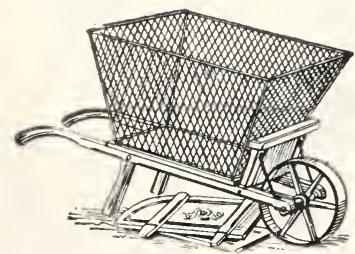

\section{PORTABLE REFUSE BURNERS}

A portable steel furnace for the rapid and convenient destruction of all leaves, refuse and waste matter In reality a two-wheeled hand cart (for which purpose it can also be used), made of strong steel angle iron and heavy steel netting, which is fireproof and guaranteed not to burn out. It is fitted with broad-tired wheels, which

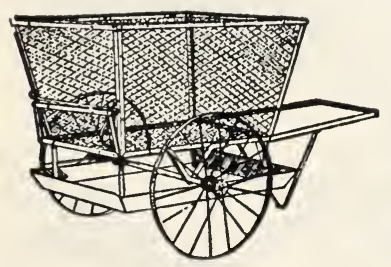
enable it to be pulled along with the cleaning up squad on lawns or soft ground without injury. A strong steel pan is fitted under the axle, which catches all the fire and ashes as they fall through the bottom. This pan can be easily emptied as needed.

Against the cost of hauling the leaves and rubbish to a convenient spot for burning, the leaf burner will pay for itself twice over in one season.

No. 1 , capacity 16 cubic feet......................... \$50.00

No. 2, capacity 11 cubic feet........................ 45.00

No. 3 , capacity 5 cubic feet......................... 40.00

\section{PENNSYLVANIA LAWN GLEANER}

A revolving fan with metal teeth creates an air current which carries into the canvas baskets all leaves, dead grass, stone, etc., that the rake encounters. It straightens up crab grass and other running weeds so that they may be cut by lawn mower. It combines strength and durability with light construction. 24 inches wide. $\$ 35.00$.

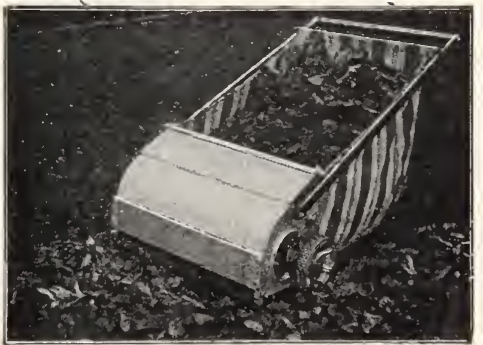




\section{NEW YORK GEDAR TREE TUBS}

Are made of cedar with extra heavy staves and hoops and will be found very strong and durable. Painted green in regular stock. Any color desired to order. Outside measurements.

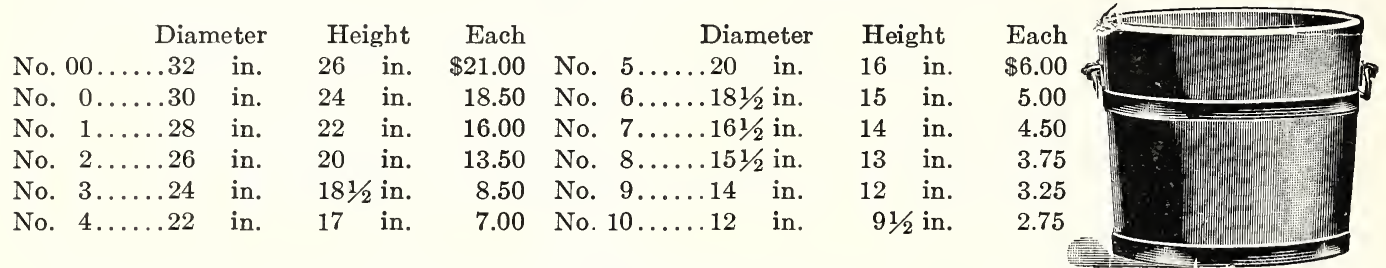

No. 00, 0, 1 and 2 have hook handles. Smaller sizes drop handles. Furnished without feet unless specially ordered. Four feet for Nos. 00, 0, 1, 2, 3 and 4, 50c. each foot. Three feet for all others, 35c. each foot.

\section{MARSHALL'S PLANT TUBS}

Made from selected Virginia white cedar, bound with electric welded wire hoops (galvanized). Painted drop handles if wanted at 30 cts. per pair. Inside measurements.

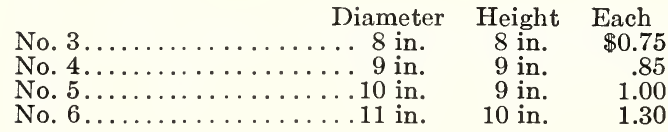

\section{SQUARE GEDAR PLANT TUBS}

Made entirely of Virginia White Cedar. Painted two shades of green. Made with plain or grilled panel.

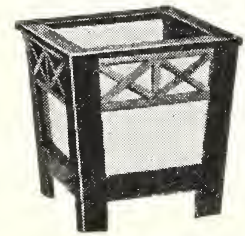

\begin{tabular}{|c|c|c|c|c|}
\hline No. & Top & Bot & om & \\
\hline & $8 \mathrm{in}$. & $\begin{array}{l}7 \\
9\end{array}$ & in. & 8 \\
\hline $\begin{array}{l}2 \\
3\end{array}$ & $12 "$ & $\begin{array}{r}9 \\
11\end{array}$ & " & $\begin{array}{l}12 \\
12\end{array}$ \\
\hline & 14 & 13 & " & 13 \\
\hline & $16 "$ & 15 & " & 16 \\
\hline & $18 "$ & 17 & " & 18 \\
\hline & 20 & 18 & " & 20 \\
\hline & & & & \\
\hline
\end{tabular}

For height over all add 3 inches.'
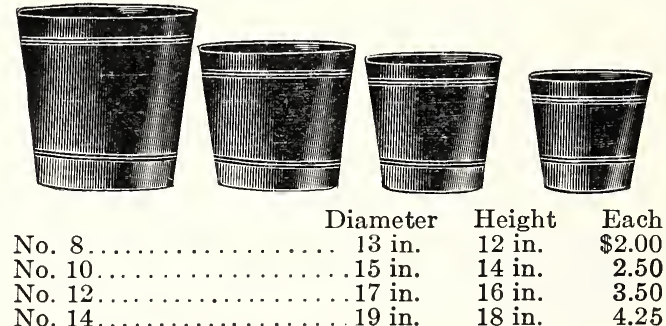

No. $14 \ldots \ldots \ldots \ldots \ldots \ldots \ldots \ldots \ldots$ in. 18 in. 4.25

\section{WATERING POTS}

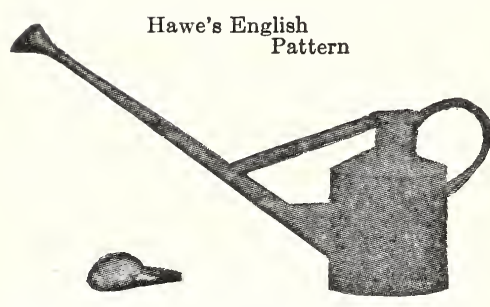

French Pattern, Oval. With long spout and brass bow handle. 2 roses. 6 qts. $\$ 6.00,8 \mathrm{qts}$. $\$ 6.50,10$ qts. $\$ 7.00,12$ qts. $\$ 7.50$.

Philadelphia Pattern, Round. With two copper-faced roses. 4 qts. $\$ 4.25,6$ qts. $\$ 5.25$, 8 qts. $\$ 5.50,10$ qts. $\$ 6.00,12$ qts. $\$ 6.50$

Extra Roses. Fine or coarse. Each 70c.

Galvanized Watering Pot. It is made with heavy galvanized material. $6 \mathrm{qts}$. $\$ 1.00,10 \mathrm{qts} . \$ 1.50$, 12 qts. $\$ 1.75$.

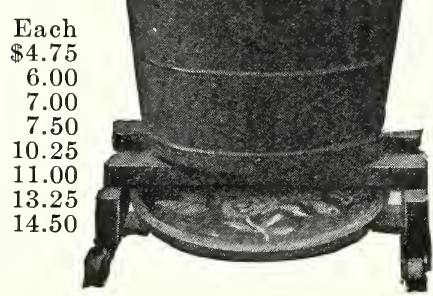

\section{WALSPEER FLOWER POT STAND}

A durable stand for large pots or tubs with four castors and drip pan. Its use will save floors and carpets, it is easy to wheel around the room.

Finished in lacquer with flower design.

Medium size, $10 \times 12$ in. Each $\$ 1.50$

Large size, $12 \times 14$ in. Each $\$ 2.00$.

Postage 15c extra. 


\section{THE "LITTLE WONDER" HEDGE TRIMMER}

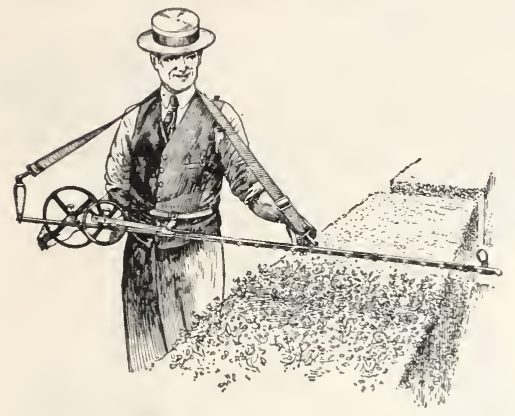

This trimmer entirely revolutionizes hedge trimming. It is wonderful how quick it cuts and how smooth a job it makes and how easy it operates. To get a beautiful thick hedge it is necessary to trim at least every three weeks. The "Little Wonder" makes the frequent cutting possible without practically any expense. It cuts from five to ten times as fast as by hand and does better work. Guaranteed for one year and complete instruction accompanies each machine.

30 -in., one-man machine. . . . . . . . . . . . . . Each $\$ 25.00$

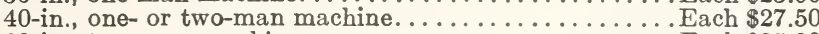

60 -in., two-man machine....................Each $\$ 35.00$

\section{THE ELECTRIC LITTLE WONDER HEDGE TRIMMER}

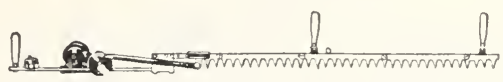

A marvel for hedge trimming. The most rapid and easy method yet devised. Saves untold hard labor and a tremendous amount of time. Operated with a one-tenth H. P. General Electric motor. Control switch on handle. Cord can be plugged into nearest light socket.

Electric Gear Head, with 100 feet of waterproof cord and gear frame, complete, all ready to be attached to cutting bar. Price $\$ 90.00$. 40-in. Cutting Bar (1 man), each $\$ 16.50 ; 60$-in. Cutting Bar (2 men), each $\$ 24.00$. Extra $100 \mathrm{ft}$. lengths of No. 18 wire, each $\$ 6.00$

\section{IDEAL HEDGE TRIMMER}

Makes trimming a pleasure. Eight oil tempered tool steel blades trim hedge in one-fifth time required with hedge shear. The loose trimmings are caught and removed at will, leaving a clean hedge. Cuts grass where a lawn mower will not reach. Weight $4 \mathrm{lbs}$. Each $\$ 6.50$.

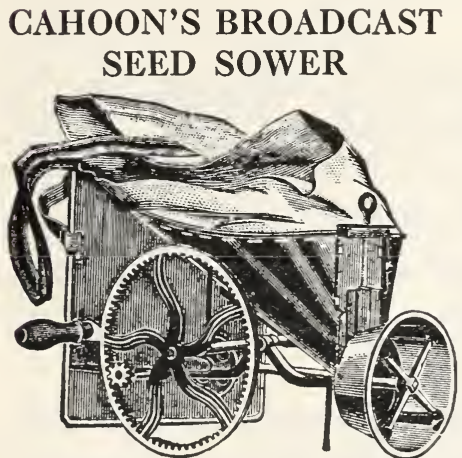

This machine will sow Wheat, Rye, Oats, Barley, Hemp, Timothy Clover, Millet and Hungarian Millet throwing from 8 to 20 feet on each side of the operator. $\$ 6.50$.

\section{DOUBLE HOPPER WHEELBARROW SEEDER}

This seeder will sow grass seeds as well as heavy seeds of all kinds. It can be regulated to sow any quantity per acre the whole length (14 feet) of the hopper and it does not clog up. Full directions with each seeder. No. 9. Price $\$ 20.00$.
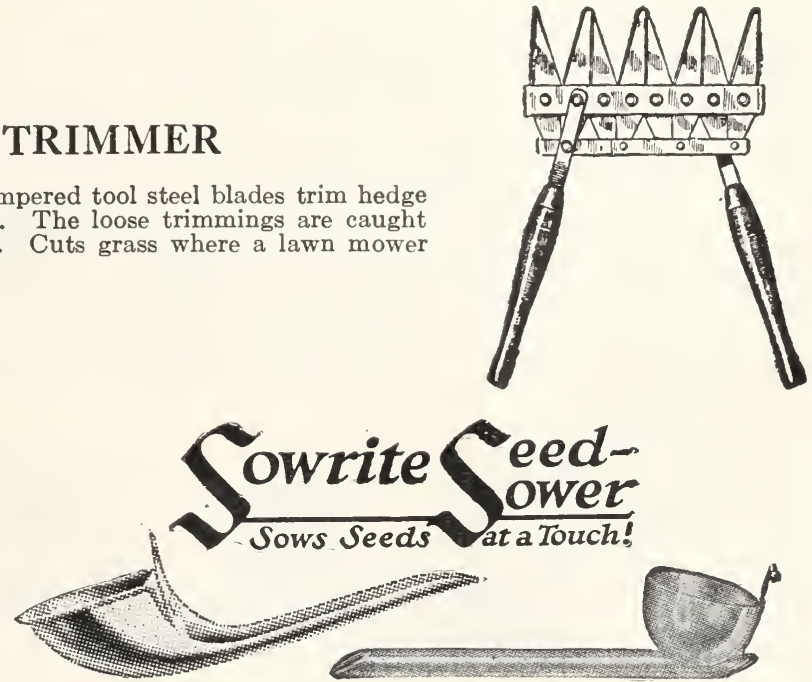

The Sowrite Seed Sower is operated with both hands. One hand holds the seed sower with the feeder tube extended over the back of the hand, with the other tapping it lightly. The slide in the cup regulates the opening according to the size of the seed, and the graduating hole controls the out-flow of even the finest seeds.

Model 1922 is used for sowing any of the fine seeds of flowers or vegetables. Made of fiberloid non-breakable. Each $\$ 1.00$.

Model 1923 will sow any seeds up to the size of Sweet Peas. Made of metal, nickel-plated. Each 50 cts. 


\section{PLANET, JR. TOOLS}

Products of 50 years' experience by a practical farmer and manufacturer who has made a science of tool building. All guaranteed. Illustrated catalogue FREE. Prices subject to change

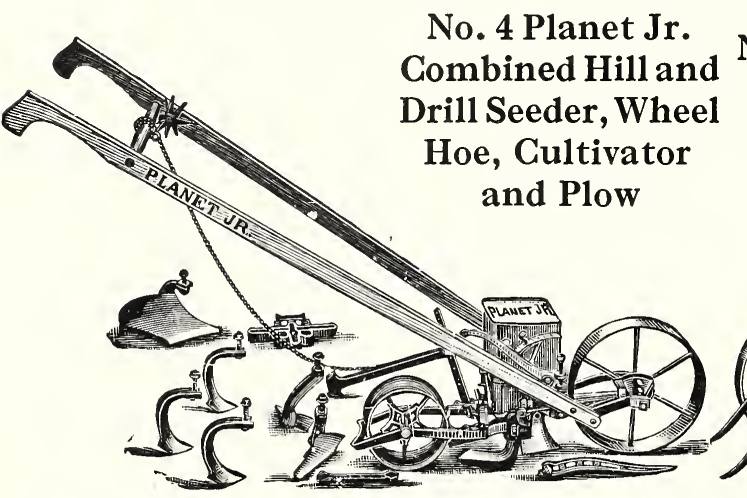

No. 4 , complete...................\$18.00

No. 4 D, as a Seeder only................. 14.25

Does the work of almost all garden tools combined. It sows accurately all garden seeds in drills or in hills $4,6,8,12$ or 24 inches apart, cultivates, furrows and plows.

\section{No. 25 Combined Hill and Drill Seeder and Double Wheel Hoe}

As a seeder it will sow in drills any thickness or drop in hills $4,6,8,12$ or 24 inches apart. It is thoroughly substantial and is accurate in planting all kinds of garden seeds in either hills or drills.

As a wheel hoe it is practically the same as the admirable Planet Jr. No, 12 Double Wheel Hoe, Cultivator and Plow. No. 25, complete. $\$ 21.50$.

\section{No. 35 Seeder Attachment}

The above can be attached to any Planet Jr. Single or Double Wheel Hoe. The Hopper holds a pint of soed, is indexed for all the principal seeds and will sow the last seed, so that a small packet can be sown without waste. Price, $\$ 6.50$

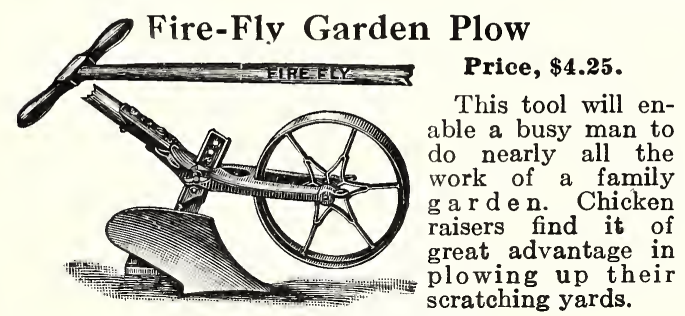

Planet Jr. No. 2 Lawn Edger

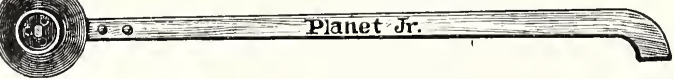

Every one who uses a lawn mower should have a Planet Jr. No. 2 Grass Edger. The cutting blade is made of the best quality steel and well sharpened. The handle is strong, being made of good quality wood. In order to have attractive lawns, keep the edges well trimmed. There is no better tool for this purpose than the Planet Jr. No. 2 Edger. Price $\$ 1.60$.
No. 11 Planet Jr. Double Wheel Hoe, Cultivator

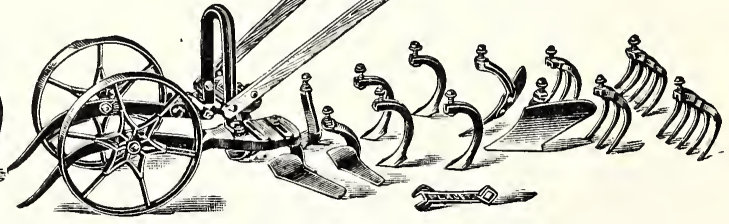

Price, with attachments, as in cut, $\$ 13.75$.

\section{No. 12 Double Wheel Hoe, Price $\$ 10.75$}

This is identical with No. 11 Wheel Hoe, except that it has one pair plows, one pair hoes, two pair cultivator teeth and a pair of leaf lifters only.

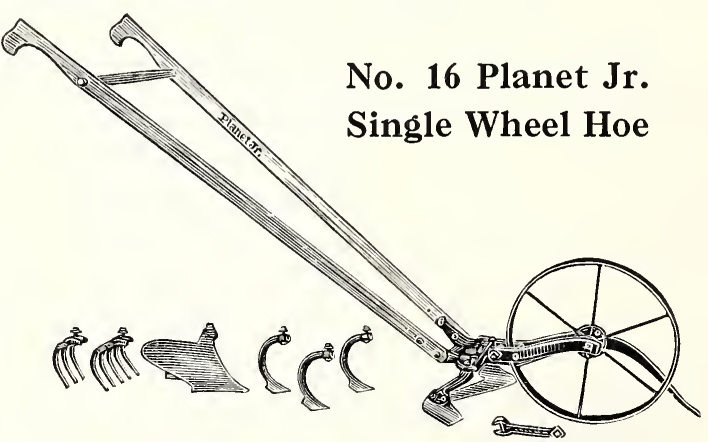

Price, with attachments, as in cut, $\$ 9.00$.

\section{No. 17 Single Wheel Hoe, Price $\$ 7.75$}

The No. 17 has a pair of 6-inch hoes, a plow and a set of cultivator teeth, an outfit sufficient for most garden work.

\section{No.8PlanetJr.Horse Hoeand Cultivator}

The above as illustrated can be used for cultivating almost every known crop in rows. Price, complete, $\$ 17.50$.

\section{Extra Parts for Planet Jrs.}

We shall be pleased to supply any parts or attachments shown on pages 30 and 64,65 and 66 of the regular Planet Jr. catalogue. Always give Number of Tool or send broken part when ordering.

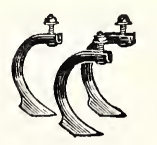

Cultivator 'Teeth.

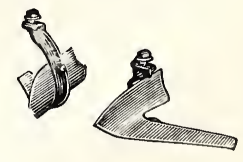

Hoes.
Cul tivator Teeth. Each 40c. Hoes 6-inch per pair, $\$ 1.30$. Plow for S. W. H., each, \$1.35. 


\section{BAMBOO LAWN RAKE}

\section{A Superior Make}

This rake cannot be compared with the cheaper quality that is often offered. The head is wired top and bottom and has a four-foot wood handle clamped onto the rake.

Made with split bamboo. Very light and flexible; for raking leaves, grass or paths. An excellent rake for removing crab or August grass in lawns.

Each 75 cts. Large size $\$ 1.00$

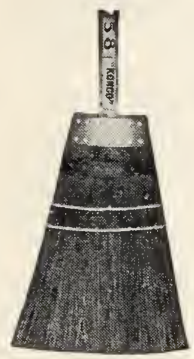

\section{"KONGO" COIR BASS BROOM}

This broom is made with Coir Fiber with a metal case fastening. It sweeps fine, is tough, impervious to hot or cold water and does not dry up and break off. Makes a fine broom for stable, garage, greenhouse work, also for cleaning gutters on roads. Each $\$ 2.00$

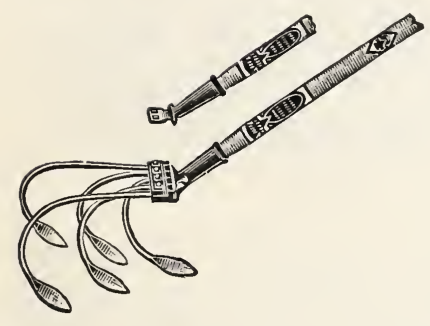

\section{ADJUSTABLE GARDEN GULTIVATOR}

The most useful hand garden tool on the market.

It will pull out the weeds, pulverize the ground thoroughly, leaving it level. It will work between the rows, or the center shovel can be removed and straddle the row if desired. It is adjustable in width by sliding the top plate. It is the lightest, weighing

but 3 lbs. complete with long handle.

The blades are forged out of a solid steel rod. 3 prong, $\$ 1.00 ; 5$ prong, $\$ 1.25$.

\section{THE GEM DANDELION RAKE}

A scientifically constructed tool for eliminating Dandelion and other seeds of weeds in lawns. It has fine, blade-like teeth that lie flat against the sod and clip off all buds and flowers. The self-cleaning attachment combs the teeth clean and is connected to a rod on the handle which cleans the teeth on a slight pull on the finger hook. The spring sending the cleaning bar back to its position. Width 15 in. Each $\$ 2.50$.

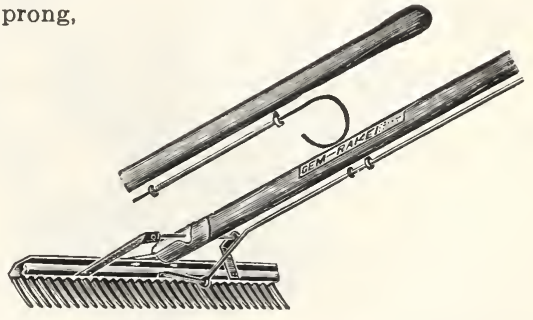

\section{EVER-READY FROST PROTECTOR}

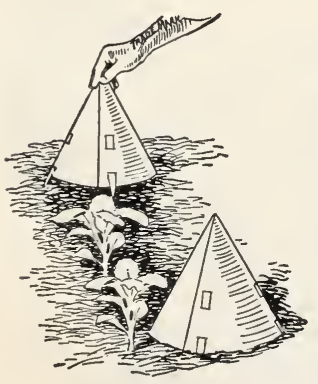

This Plant Protector is made from a black, weatherproof paper, which will last indefinitely. They come packed flat with stakes for locking the edges and anchoring the cone to the ground. Once assembled they can be nested for storage and used from year to year. They can also be used for shade and windbreaks for plants just set out. Doz. $60 \mathrm{c}$., 50 for $\$ 2.25,100$ for $\$ 4.00,1000$ $\$ 35.00$.

\section{Germāco

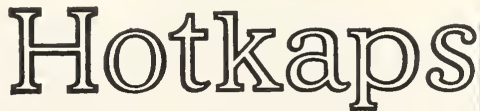

A wax paper cone that completely covers each plant. An "individual hothouse" for each plant. Hotkaps are quickly and easily set with the setter and tamper supplied with all orders.

100 Hotkaps with Setter and Tamper. . . . . . . . . \$2.50

250 Hotkaps with Setter and Tamper. . . . . . . . 4.00

1000 .

\section{FERGUSON'S SPRAYER}

Three roses-fine, medium and coarse Recommended for syringing under the foliage of plants where force is needed to keep down red spider, etc. Made of brass and screwed on the end of any $3 / 4$ inch hose, $\$ 8.00$

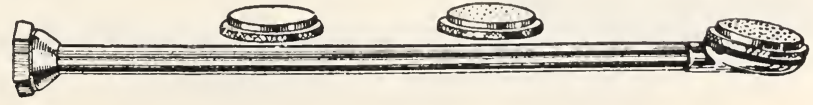




\section{COLDWELL'S IMPERIAL ROLLER- BEARING LAWN MOWER}

The lightest running machine. Has 101/2-inch wheels, five blades, standard Hyatt Roller Bearings, triple pawl ratchet gears and finest finished parts.

16 -inch. ... \$21.00 18-inch. ... \$23.00 20-inch. . . \$25.00

\section{COLDWELL'S JEWEL LAWN MOWER}

This machine has 8-inch driving wheels, four blades in the revolving cutter and double ratchet, fine cut gears. The bearings are provided with split brass bushings, by means of which all wear can be taken up.

14-inch..........\$8.50 16-inch.........\$ \$9.00

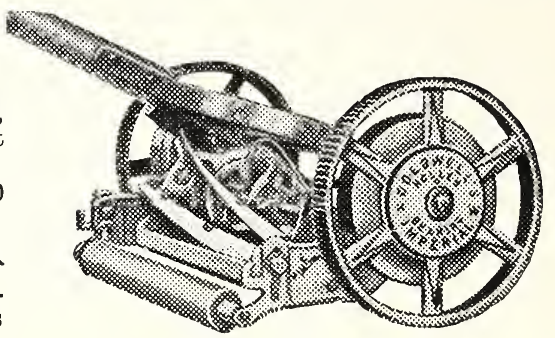

Imperial Roller-Bearing Mower

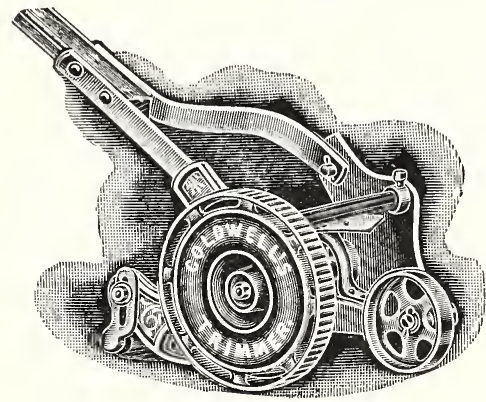

\section{COLDWELL REGAL MOWER}

The Regal stands at the head of the Coldwell Line. Wheels $10 \frac{1}{4}$ inches. Five blades, ball bearings, self sharpening bottom knife.

$$
16 \text { in.... } \$ 23.00 \quad 18 \text { in....\$24.00 } 20 \text { in... } \$ 25.00
$$

\section{COLDWELL'S LAWN TRIMMER AND EDGER}

Does what lawn mowers leave undone. It can be run close to wall and trees, cutting grass clean and quickly. Can also be used for trimming edges of walks, etc. It has four blades, 8 inches wide. $\$ 12.00$ each.

\section{GRASS CATCHERS}

Galvanized sheet metal bottom with heavy duck canvas sides.

Hooks to frame of Mower and handle. Easily detached for emptying.

Net prices: 12 -in., 14 -in., or 16-in., $\$ 2.50$; 18-in. or 20 -in., $\$ 2.75$.

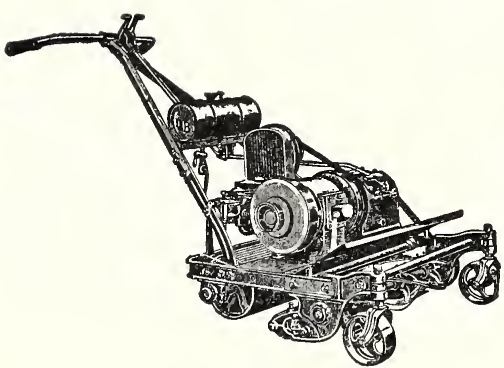

Cub Motor Mower

\section{COLDWELL'S GUB MOTOR MOWER}

The "Cub" Motor Lawn Mower is specially designed for small lawns. It cuts 21 inches, has 5 blades, full width drive roller, Timken roller bearings, automatic lubrication, and will cut close to trees or fences. The heavy duty engine will carry its full load on the hottest day. Weight 250 lbs.

Cub, 21 inch cut, $\$ 195.00$. Grass Box $\$ 10.00$ Ask for special illustrated circular.

\section{COLDWELL "L" JUNIOR MOWER}

A light weight, simple and dependable power mower and roller of good capacity at a moderate price.

Motor $1 \frac{1}{2}$ horse power, cutting unit 5 blade, width of cut 25 inches, capacity 4 to 6 acres per day. Weight 300 lbs. "L" Junior, 25 inch cut, $\$ 275.00$. Grass catcher. $\$ 12.00$.

\section{COLDWELL MODEL " $R$ " MOWER}

The Coldwell Model " $R$ " mower will cut from 6 to 10 acres of lawn per day, fuel consumption, 1 to $11 / 2$ gallons gasoline for 10 hours running. It has an 8-inch diameter, full width drive roller in two sections. Revolving cutter, 6 inches with 5 blades. It has also two gang units that can be attached, making an extreme cutting width of 60 inches. Weight $495 \mathrm{lbs}$.

Model R, 25 inches, $\$ 250.00$. Grass Catcher for Model R, $\$ 20.00$

\section{COLDWELL'S "L" TWIN MOWER}

The Coldwell Model "L" Motor Lawn Mower and Roller, twentyfive inch cut, has been designed with a view of combining the extreme flexibility of the hand lawn mower with the large cutting capacity rolling feature and other advantages and conveniences which can be obtained only with a motor mower.

This mower is adapted for use on private lawns, parks, cemeteries, public grounds and for fine cutting on tennis courts and bowling greens. Weight $380 \mathrm{lbs}$.

"L" Twin Motor Mower, 25 inch cut, $\$ 350.00$. Grass box, $\$ 12.00$. With gang attachment for 60 inch cut, $\$ 410.00$. Twin 30 inch cut, $\$ 400.00$. Grass box, $\$ 15.00$. Riding Sulky for above models, $\$ 20.00$.

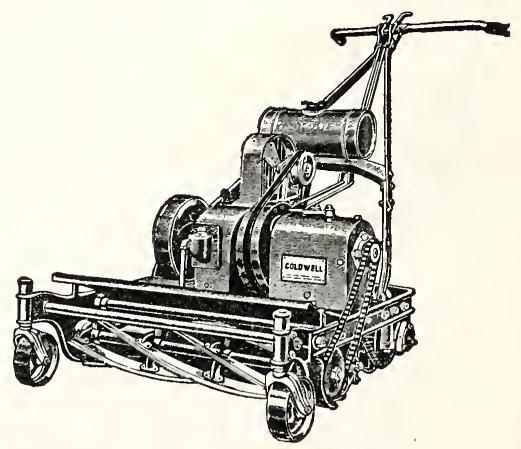

"L" Twin Motor Mower 


\section{PENNSYLVANIA STANDARD, OR JUNIOR LAWN MOWERS}

The Pennsylvania is the pioneer of all lawn mowers, having an open cylinder, open wheels and a train of gears. High wheel, 101/2inch diameter.

15-in., 4 blades..........\$30.00 17-in., 4 blades.........\$32.00

19-in., 4 blades......... $\$ 34.00$

\section{GREAT AMERICAN MOWER}

A double geared mower which gives fine results.

101/2-inch high wheel, 5-blade cylinder, ball-bearing.

15 -in .............\$20.00 19-in............\$26.00

17 -in . . . . . . . . . . $23.00 \quad 21$-in ............ 30.00

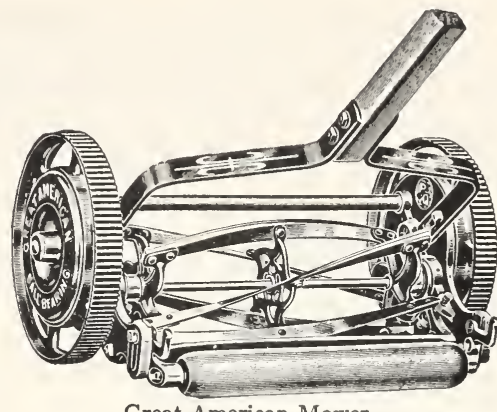

Great American Mower

\section{PENNSYLVANIA GOLF ARISTOCRAT MOWER}

Adapted for Putting Greens and Tennis Courts. Ball bearings, seven blades, $91 / 2$ inch wheels. 19 inch only $\$ 45.00$. Grass Catcher, $\$ 10.00$.

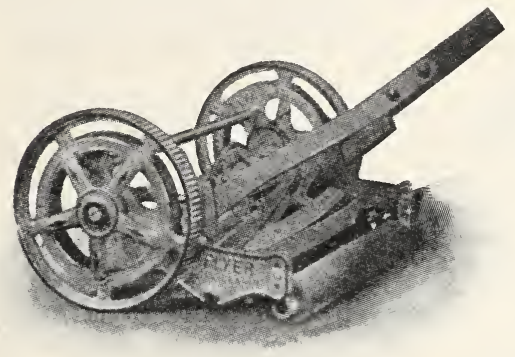

\section{TOWNSEND'S FLYER BALL-BEARING LAWN MOWER}

A good, free cutting, easy running mower with open wheel and frame, made on the two-gear principle. Gears well up from the ground and fully shielded so as to exclude dirt and cut grass. Has 9-inch wheels, four-bladed reel.

14 in ............................... \$12.00

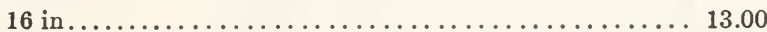

\section{"VICTORY" BALL-BEARING LAWN MOWER}

This mower is fitted with Ball Bearings. The gear is entirely closed, so that no dirt or cut grass can find its way into the pinions and clog them. The cutter bar is easily removed for sharpening without disturbing the frame. The knives cut the instant the mower is moved.

14 in. ...........\$18.00

18 in.............\$22.00

16 in ................... 20.00

20 in .................... 24.00

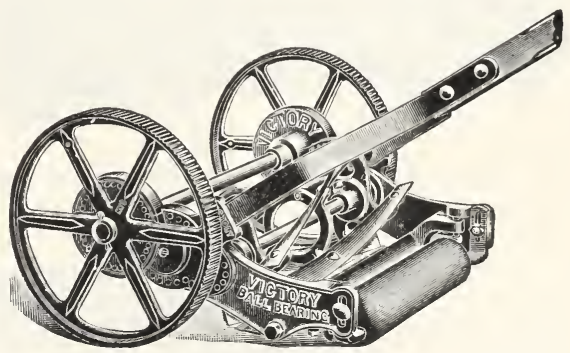

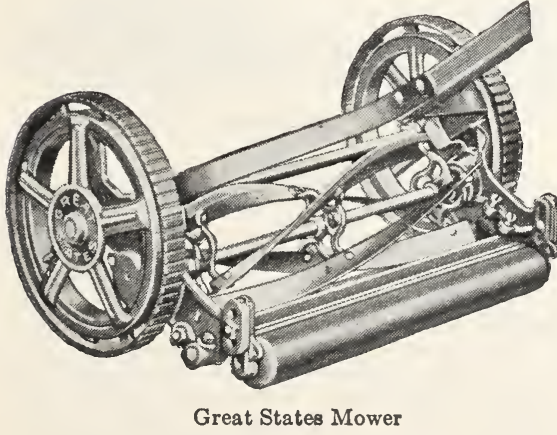

TOWNSEND'S GOLF WONDER MOWER

Especially designed for cutting Putting Greens and fine Lawns. Runs very easy, due to high speed; has gear drive and six-blade knife reel. 16 in. $\$ 28.00,18$ in. $\$ 30.00,20$ in. $\$ 32.00$. Grass Catcher, complete with elevator and deflector, $\$ 8.00$.

\section{GREAT STATES MOWER}

These Mowers have self-adjusting ball bearings and selfsharpening blades, are strongly built and have no complicated parts or adjustments. Cutting reel is $53 / 4$ inch with four blades. The drive wheels are $101 / 4$ inches with deep corrugations. Every machine is guaranteed to give satisfactory service.

14 in. ....\$11.00 16 in....\$11.75 18 in.... \$12.50

\section{"EASY" BORDER LAWN MOWER}

The only mower made that will cut borders, mounds, terraces, close to walls and fer zes, and all kinds of uneven surfaces with the same ease and efficiency as the smoothest lawn.

It has a steel open roller, four spiral blades, self-adjusting ball-bearings with detachable handle.

Net Prices. 12 in......\$25.00 14 in......\$27.00 16 in.....\$30.00

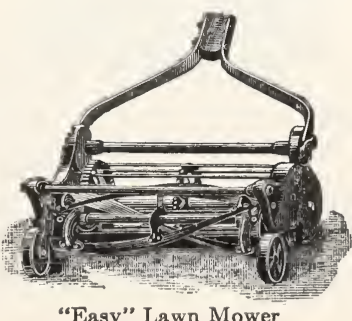




\section{IDEAL WHEEL TYPE MOWERS}

The Wheel Type Ideals are furnished in 2 models, 20 in. and 25 in. Wheel types are best suited to work on lawns where there is a large amount of turning and on lawns where steep hillsides are to be cut.

Ideal 20 in. Width of cut 20 inches, to cut 1 to 3 acres per day, 4 cycle, air cooled motor. Weight 275 lbs. Price $\$ 215.00$.

Ideal 25 in. Width of cut 25 inches, to cut 4 to 6 acres per day, 4 cycle air cooled motor. Weight 295 lbs. Price $\$ 290.00$.

Riding Trailer for the above, $\$ 25.00$.

Grass Catcher of the above, $\$ 5.00$.

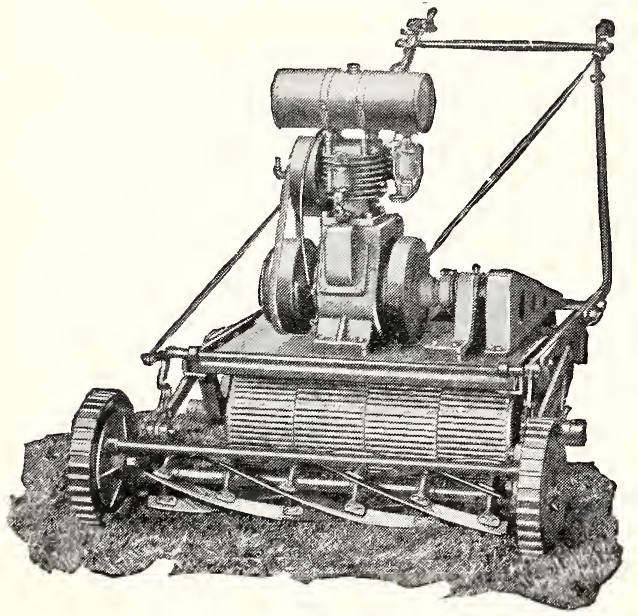

Ideal Roller Type Mower

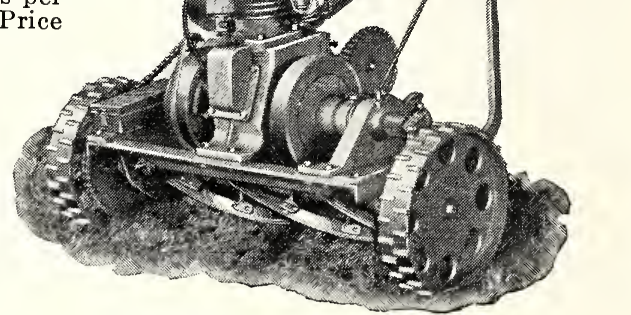

Ideal Wheel Type Mower

\section{IDEAL ROLLER TYPE MOWERS}

The Roller Types are made in two models, 22 in. and 30 in. The new models have many new mechanical improvements. A modern design engine and sturdier frame and more completely balanced.

Ideal 22 in. Width of cut 22 inches, capacity 3 to 4 acres per day, 5 blade cutting unit, roller in 3 sections, width 17 in., diameter 10 in., 4 cycle air cooled motor. Weight 455 lbs. Price $\$ 265.00$.

Ideal 30 in. Width of cut 30 inches, capacity 5 to 7 acres per day, 5 blade cutting unit, roller in 4 sections, width 24 in., 4 cycle air cooled motor. Weight $600 \mathrm{lbs}$. Price $\$ 385.00$.

Riding Trailer for the above, $\$ 25.00$.

Grass Catchers for the above, $\$ 10.00$.

\section{THE “COOPER”' POWER MOWER}

The Cooper Mower has, two speed reel, reversible reel, independent recl drive, all steel frame, independent traction drive, a four cycle, air cooled motor, all anti-friction ball and roller bearings. It will operate over level or rolling lawns and climb steep grades. It is extremely easy to operate and will be found highly efficient and a great labor saving necessity. Weight 200 lbs. Price $\$ 190.00$ f.o.b. factory. $\$ 195.00$ f.o.b. New York.

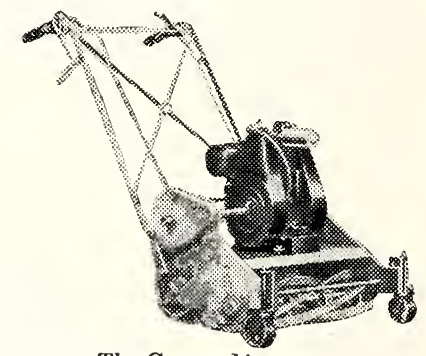

The Cooper Mower

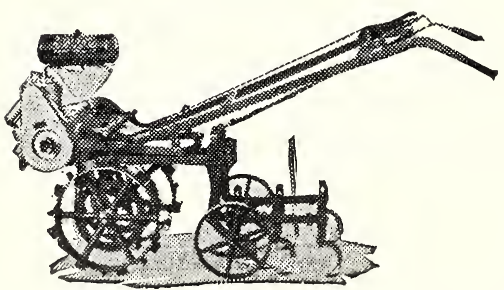

\section{BOLEN'S GARDEN TRAGTOR}

A light weight gasoline propelled power unit ready to hitch to a great variety of useful implements. It can be used for cultivating, hilling, hoeing, seeding, etc. The instant hitch attachment can be used with the interchange of tools. The speed is easily controlled with two driving sprockets from one to three miles per hour. The engine is air cooled and consumes about one gallon of gasoline in ten hours. The arched axle gives a clearance of 16 inches and the width of tractor is 18 inches. It has a double clutch drive with power turn for either wheel. Fully illustrated booklet mailed free on request.

Model D.J.O. Tractor without attachment or tools. $\$ 217.50$.

Model D.J.O. Tractor with D101 instant hitch, one and two row cultivator frame with tool holders, 2 pair wide angle 6 in. hoes and 6 cultivator teeth. $\$ 233.85$. For other attachments ask for special list.

Model D.Q.O. Tractor unit without attachments or tools. $\$ 289.50$.

Model D.Q.O. Tractor with DJ-101 instant hitch, one 6 in. plow D.J.-241 one pair each 6 in. and 8 in. angle hoes 6 cultivator teeth No. 2775. $\$ 321.00$. For lawn Mower, Seeder, Spraying and other attachments ask for special list. 


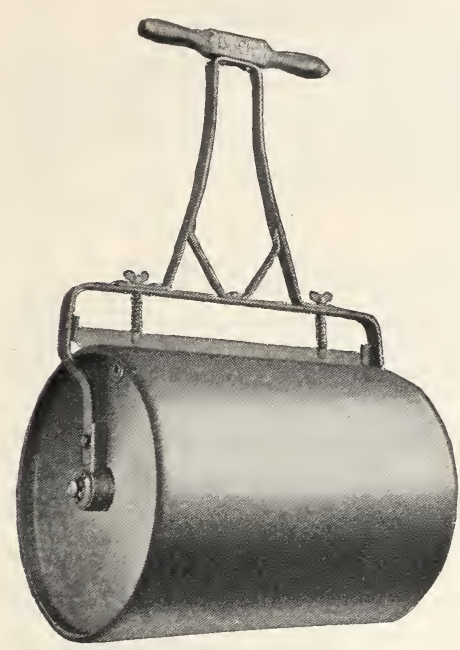

\section{WAT'ER BALLAST ROL- LER FOR LAWNS}

With a Water Ballast Roller, one can secure any weight desired by simply removing a cap and filling it with as much water or sand as may be required. When filled with sand they weigh $50 \%$ more than with water.

The "WB" type is fitted with a steel scraper, which is adjustable and san also be used to hold the handle in place when not in use.

\begin{tabular}{|c|c|c|c|c|}
\hline 5 & Diar & Length & Wgt. Filled & Price \\
\hline 10 & $14 \mathrm{ir}$ & 24 ir & $250 \mathrm{lbs}$. & $\$ 18.50$ \\
\hline 20 & $18 \mathrm{in.}$ & $24 \mathrm{ir}$ & $330 \mathrm{lbs}$. & 22.25 \\
\hline 3 & $24 \mathrm{in.}$ & $24 \mathrm{in.}$ & $440 \mathrm{lbs}$ & 25.7 \\
\hline & & & $590 \mathrm{lbs}$ & \\
\hline
\end{tabular}

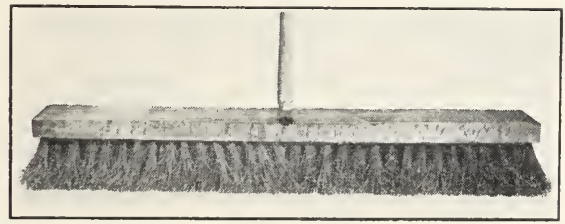

\section{FIBRE TENNIS BROOMS}

This Broom is made with fiber and is used for dragging Tennis Courts to smooth them after use or rain. Made in 36-inch width only. Each $\$ 7.00$.

\section{GRASS SOD OR CEMENT TAMPERS}

Useful for tamping down sod and uneven spots on lawns, tennis courts and golf grounds. Made of iron, with heavy wooden handle.

Square Pattern. Size 6 in. Weight 12 lbs. Each $\$ 2.25$. Size 8 in. Weight 17 lbs. Each $\$ 2.75$.

\section{BAKER'S HORSE LAWN SHOE}

It is made of a steel plate turned up at the toe to protect the turf, with two riveted prongs that fit the horseshoe in front and a clamp that sets up to the heel. In ordering please send size of horseshoe from toe to heel, or a tracing of the shoe to insure a good fit. Per set, $\$ 10.00$.

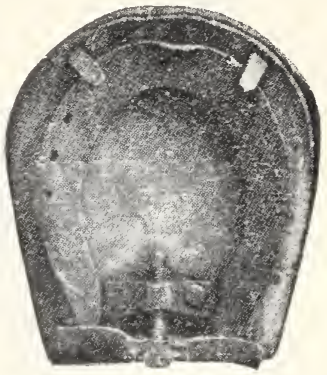

\section{LEATHER HORSE BOO'TS}

Made with double thick riveted soles and straps to go around the hoof. In ordering send outline of horse's shoe. Per set of four, $\$ 18.00$.

\section{SOD PERFORATOR}

Used for renovating bad spots in lawns, terraces, etc. In perforating the ground it permits the seeds to enter the soil and germinate quickly. Size 12 in.x 12 in. with handle. Each $\$ 4.50$.

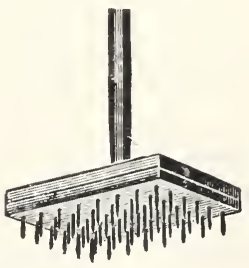

\section{HAND FERTILIZER SOWER}

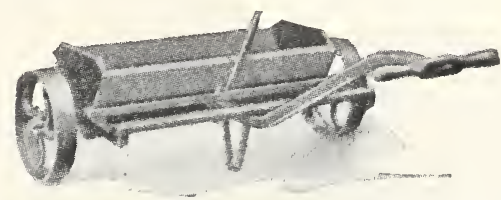

The Hand Sower is small, light, easily operated in close quarters, conveniently drawn by one man and well balanced, fills a need on the smaller place that no other fertilizer distributor can reach. Particularly in top dressing lawns and putting greens on golf courses is the Stevens Hand Sower a veritable necessity. The Hand Sower carries a wood hopper 34 in. long and with capacity of $11 / 2$ bushels. The weight without load is only 85 lbs. Great care has been exercised in its construction to provide for easy balance when loaded. One man easily handles it. Price $\$ 30.00$.

\section{SMOOTHING AND LEVELING HARROW}

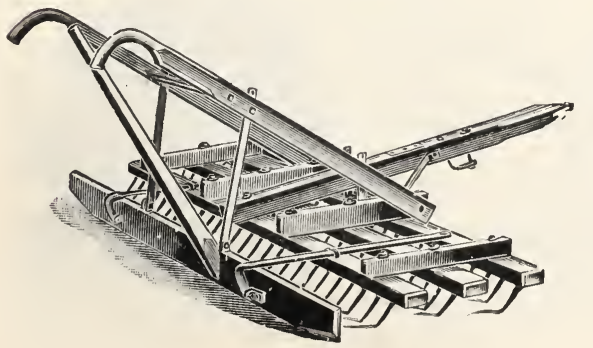

With this tool every field can be made smooth and the soil pulverized fine enough for a flower bed. This harrow is also a great road maker. One man, with team, can make a perfect trotting track of any road. It is adjustable with a lever, by which the entire action is controlled by the driver, and he can remove at will all the earth possible for the team to haul, taking it from hills or uneven places and putting it into hollows to level up the field.

No. 6 , one-horse, $6 \mathrm{ft}$., weight 140 lbs., $\$ 27.25$

No. 8, two-horse, $8 \mathrm{ft}$., $\$ 31.50$.

For other styles of Harrows see our Farm Equipment Catalogue. 


\section{THE DIEHL EDGER}

This Edger has a cutting disk of saw steel, tempered and sharpened to cut through the sod. The cutting disk is held between two disks which roll upon the grass and prevent the cutting disks from penetrating below the desired depth. A weight surrounds the disks to force the cutting disk through the sod as the tool is pushed along by the handle.

An adjustable plow attachment removes the cut sod for removal.

Each \$12.75.

\section{SPARK - PROOF INCINERATOR}

Made with a Self Lifting Cover which is controlled by a foot lever. It is guaranteed to efficiently dispose of all the refuse and garbage that accumulates in the average household. Made with 16 gauge metal and coated with aluminum.

Model A. Capacity $1 \frac{1}{2}$ bushels. Diam. of body 15 in. Height over all 36 in. Weight 40 lbs. Price $\$ 12.00$.

Model F. Capacity $23 / 4$ bushels. Diam. of body 19 in. Height over all 48 in. Weight 60 lbs. Price $\$ 18.00$

Model M. Capacity 6 bushels. Diam. of body 23 in. Height over all 62 in. Weight 90 lbs. Price $\$ 33.00$.

\section{BURN-ALL SPARK PROOF INCINERATOR}

For quick and safe disposal of rubbish, refuse and garbage for all home owners, private institutions, country-clubs, schools, farm houses, camps, resorts, parks, industrial plants, stores, estates, etc.

Made with 16 gauge sheet metal finished in aluminum color. It rests on strong metal legs and can be placed outdoor in any convenient place.

No. 1 A. Capacity $2 \frac{1}{4}$ bushels. Diameter of body 19 in. Height of body 26 in. Length of pipe 23 in. Price $\$ 30.00$. Weight crated $90 \mathrm{lbs}$.

No. 4. Capacity $4 \frac{1}{2}$ bushels. Diameter of body 24 in. Height of body $30 \mathrm{in}$. Length of pipe 26 in. Price $\$ 57.50$. Weight crated $135 \mathrm{lbs}$.
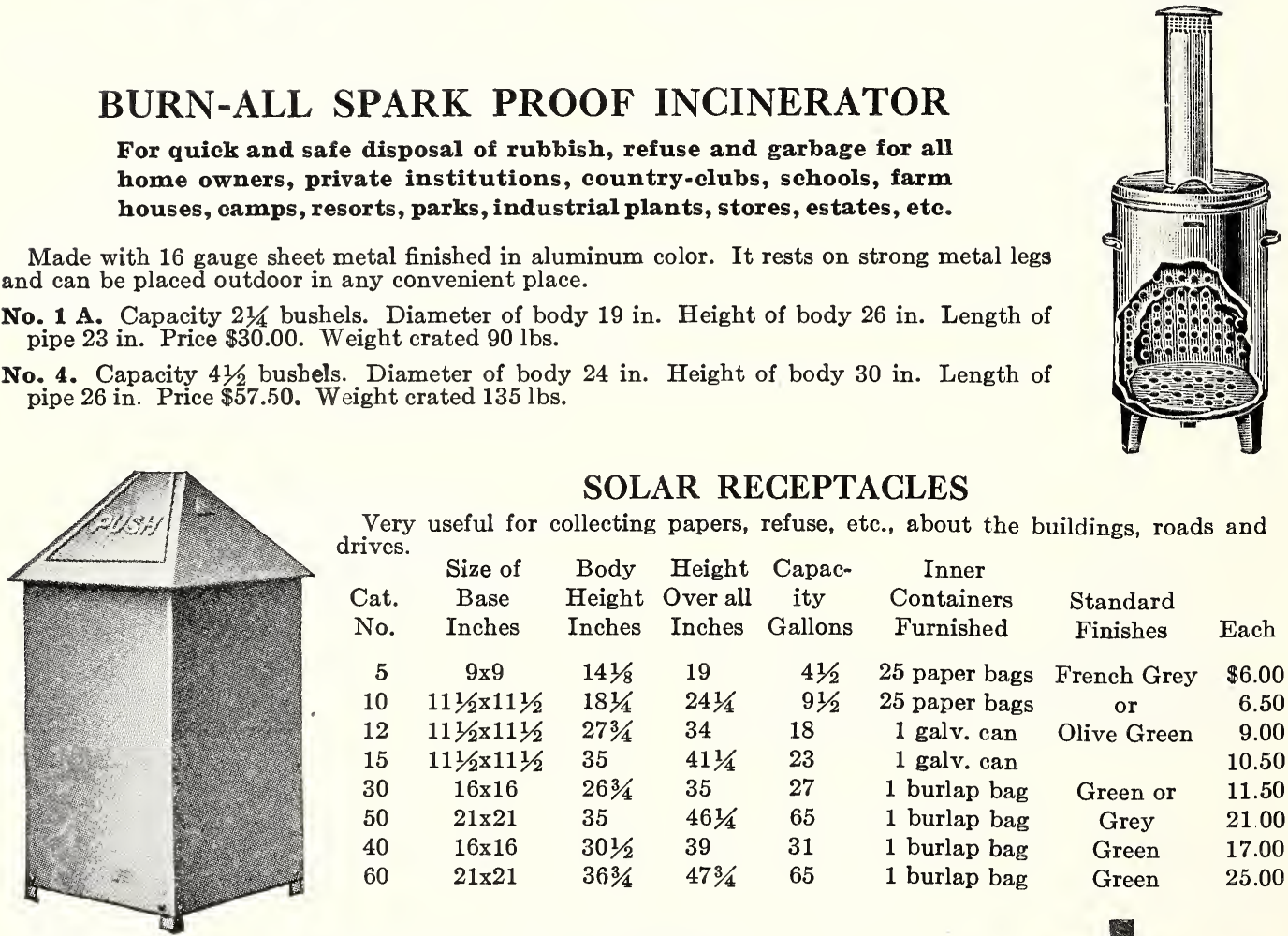

\section{SOLAR REGEPTACLES}

Very useful for collecting papers, refuse, etc., about the buildings, roads and drives.

\begin{tabular}{|c|c|c|c|c|}
\hline $\begin{array}{l}\text { Cat. } \\
\text { No. }\end{array}$ & $\begin{array}{l}\text { Size of } \\
\text { Base } \\
\text { Inches }\end{array}$ & $\begin{array}{l}\text { Body } \\
\text { Height } \\
\text { Inches }\end{array}$ & $\begin{array}{l}\text { Height } \\
\text { Over all } \\
\text { Inches }\end{array}$ & $\begin{array}{l}\text { Capac- } \\
\text { ity } \\
\text { Gallons }\end{array}$ \\
\hline 5 & $9 \times 9$ & $141 / 8$ & 19 & $41 / 2$ \\
\hline 10 & $111 / 2 \times 111 / 2$ & $181 / 4$ & $241 / 4$ & $91 / 2$ \\
\hline 12 & $111 / 2 \times 111 / 2$ & $273 / 4$ & 34 & 18 \\
\hline 15 & $111 / 2 \times 111 / 2$ & 35 & $411 / 4$ & 23 \\
\hline 30 & $16 \times 16$ & $263 / 4$ & 35 & 27 \\
\hline 50 & $21 \times 21$ & 35 & $461 / 4$ & 65 \\
\hline 40 & $16 \times 16$ & $301 / 2$ & 39 & 31 \\
\hline 60 & $21 \times 21$ & $363 / 4$ & $473 / 4$ & 65 \\
\hline
\end{tabular}

\section{Inner \\ Containers \\ Furnished \\ Standard \\ Finishes}

Each

25 paper bags French Grey $\$ 6.00$

25 paper bags

1 galv. can

1 galv. can

1 burlap bag

1 burlap bag

1 burlap bag

1 burlap bag

\section{RUSTIC BIRD HOUSES}

The Rustic Bird Houses are made with Rustic Cedar and are very ornamental and attractive to all birds.

No. 1 Log Cabin, one-family house, 10 in. wide, 10 in. high. .. $\$ 2.50$ and $\$ 2.75$ No. 2 Log Cabin, two-family house, 10 in'. wide, 12 in. high, 14 in. deep..... 4.00 No. 3 Log Cabin, two-family house, 14 in. wide, 12 in. high, 17 in. deep...... No. 4 Log Cabin, two-family house, 14 in. wide, 17 in. high, 16 in. deep...... No. 5. Wren House, four-family house, 14 in. wide, 18 in. high, 19 in. deep.... No. 6 Hera No. 7 Twelve- 22.00

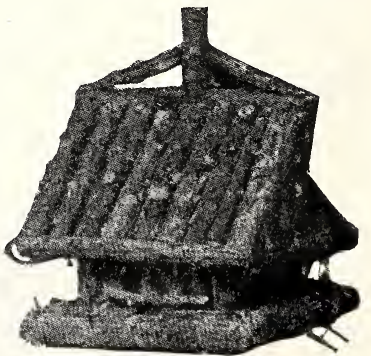

Bird House, No. 4 Log Cabin ] 


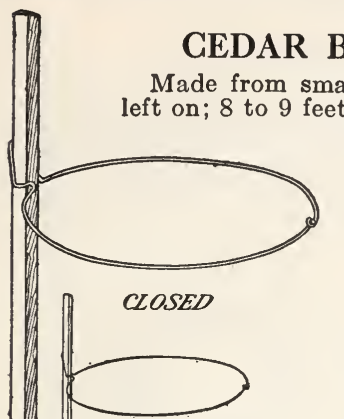
to conform to the plant's growth. It is indispensable for Tomatoes, Roses, $\mathrm{Hy}$ drangeas and Dahlias.

The stake is made of hardwood having a protecting coat of green paint; the heavy spring wire is also painted green and so will not rust. Wires 13 inches in diameter.

Stakes $7 / 8$ in. square,

$3 \mathrm{ft}$. height, complete,.....\$2.40 per doz. $4 \mathrm{ft}$. height, complete,.....\$3.00 per doz. $5 \mathrm{ft}$. height, complete,.....\$3.60 per doz. Extra 13 in. wire loops (for use on the taller stakes and plants,) $\$ 1.80$ per dozen.

$2 \mathrm{ft}$. stake with wire $4 \frac{1}{4}$ in.

diameter for pot plants and

Carnations. $100 \$ 9.50 \ldots \ldots . .12$

1.25

ADJUSTO STAKES ONLY

$3 \mathrm{ft}$ stakes only ............\$1.20 per doz. $4 \mathrm{ft}$. stakes only .............. 1.50 per doz. $5 \mathrm{ft}$. stakes only ............

\section{FLOWER GUARD}

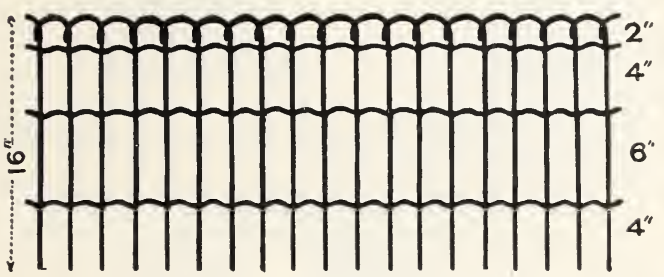

The Flower Guard forms an excellent protection to flower beds. The ends of pickets, extending below the lowest cable, are pushed in the ground and answer the purpose of posts.

Pickets No. 9 wire, spaced $27 / 8$ inches apart.

Made with steel wire and galvanized after weaving. Each scroll is welded.

16 inches wide, per linear foot.............\$0.14

22 inches wide, per linear foot................... 16

16 inches wide, per roll 100 feet long.............. 10.00

22 inches, per roll 100 feet long............. 12.00

\section{DUD'S GAS}

\section{A Liquid Cleaning Compound}

Dud's Gas can be used for cleaning greenhouse glass, skylights, cement, marble, stone or terra cotta statues, bird baths, steps or ornaments. It is easily applied and, will not injure the objects or harm the hands in using it. Qt. \$1.25, gal. \$5.00.

\section{SOILTEX SOIL TESTER}

A handy pocket outfit, containing enough material for 75 to 100 tests. Complete with color chart and lime tables. It determines accurately the degree of acidity of any soil and tells exactly how much lime should be applied. Complete outfit, $\$ 1.00$.

\section{FAN TRELLIS}

Very popular for training pot plants for windows or conservatories.

$\begin{array}{lrr}\text { Height } & \text { Width } & \text { Each } \\ 18 \text { in. } & 6 \text { in..... } \$ 0.40 \\ 24 \text { in. } & 10 \text { in } \ldots \ldots & .60 \\ 30 \text { in. } & 13 \text { in } \ldots \ldots & .80 \\ 36 \text { in. } & 16 \text { in } \ldots \ldots . & 1.40\end{array}$

All painted dark green.

\section{TOMATO STAKES}

Made with Cypress, 1 inch square, 5 feet long, pointed at end. Doz. \$2.50, $100 \$ 14.00$.

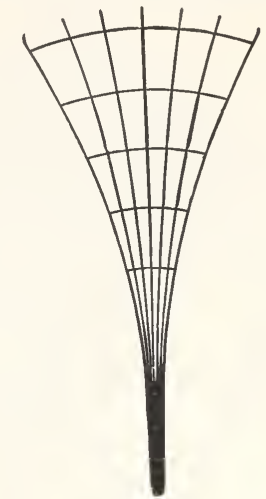

Fan Trellis

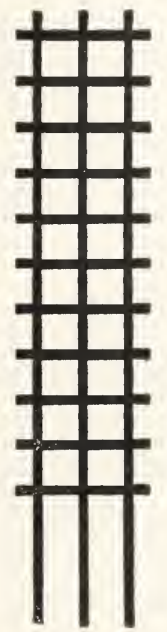

\section{LATTICE TRELLIS}

A substantial plant support for use around doors and windows for plants and vines. Made with three up. right supports. Painted green. $8 \mathrm{ft}$. high, 18 in. wide. Each $\$ 4.00$.

\section{VERANDA}

\section{TRELLIS}

Adapted for outdoor use for climbing vines and Roses. Painted green. 8 ft. high, 18 in. wide. Each $\$ 4.00$.

\section{TRELLIS}

Made with durable wood. Painted green. $8 \mathrm{ft}$. high, 24 in. wide; 4 uprights. Each $\$ 1.75$.
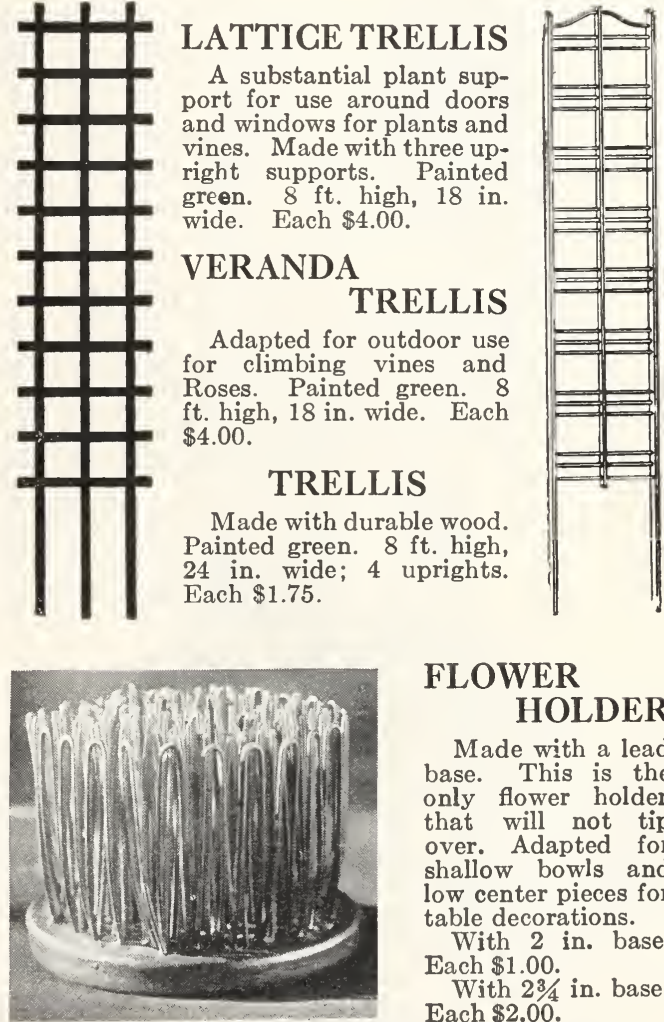

\section{FLOWER}

\section{HOLDER}

Made with a lead base. This is the only flower holder that will not tip over. Adapted for shallow bowls and low center pieces for table decorations.

With 2 in. base, Each $\$ 1.00$.

With $23 / 4$ in. base. Each $\$ 2.00$.

\section{Bergman Lawn Mower Sharpener}

An individual sharpener which is adjustable to all types and makes of lawn mowers. No danger of making low spots in the blades as with a file, as a long. sweeping stroke with a Bergman grinds the blade evenly. Each $\$ 1.00$. Postage_10c. extra 。

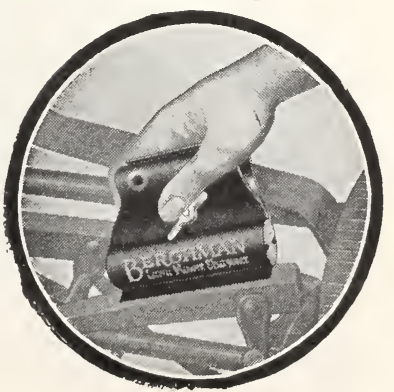




\section{AUTO-SPRAY PUMPS}

No other style of sprayer will do such a variety of work, and do it so well. We recommend it for trees, shrubs, and vines, greenhouses, poultry houses, hospitals and stables for disinfectants, for sheep and cattle dip and cattle fly oils.

It may be used where any bucket or knapsack Sprayer can be used, and with much more satisfaction. Even those who have commercial orchards and large power Sprayers need the "Auto-Sprayer" No. 9 for small work.

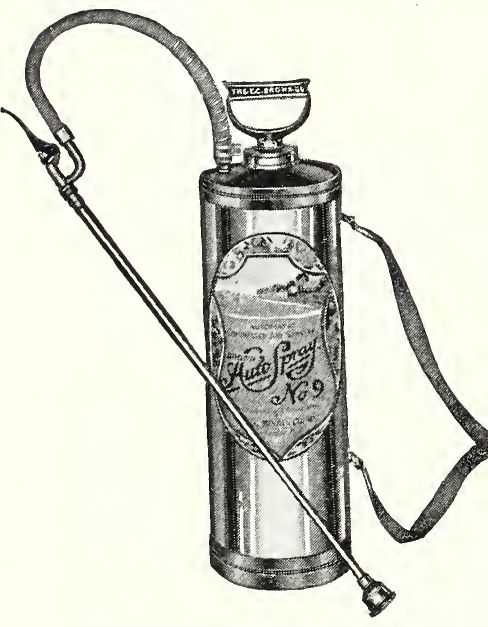

Auto Spray No. 9

No. 9 B. Brass tank, with "Auto-Pop" Nozzle, $31 / 2$ gals. Screw locking device. 24 in. extension rod. Weight empty $9 \mathrm{lbs} . \ldots \ldots \ldots \$ 9.25$

No. 9 D. Galvanized tank with "Auto-Pop" nozzle....................6.6.25

Auto-Spray, No. 50 B. Similar to No. 9 , with a capacity of $2 \frac{1}{2}$ gals. only....... 8.00

“Auto-Pop" nozzle with hose and connections 2.00

"Auto-Pop" nozzle.................. 1.50

Extension pipe, brass, $2 \mathrm{ft}$. lengths, each.... .60

Elbow extension, solid brass............ .35

Brass strainer.................. 150

Set of soft parts for No. $9 \ldots \ldots \ldots \ldots \ldots . .25$

Two row attachment, 1 nozzle.......... 1.50

AUTO SPRAYER NO. 3D

A general purpose sprayer that can be used for any purpose on the farm and garden. It has all steel truck handles and 2 -inch face wheel, 8 feet of $3 / 8$-in. hose, level shut-off and screen nozzle.

Auto No. 3D. Brass tank with compressed air chamber. Capacity 12 gals. Each $\$ 21.00$.

Extra extension pipes, 2 ft. 8 in........each $60 \mathrm{c}$.

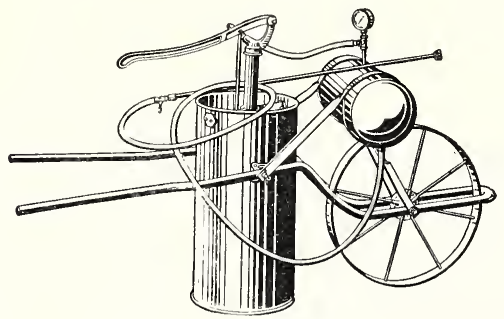

Brown's Mighty. Copper bearing galvanized steel tank, heavy duty pump, 18 in. wheel. $\$ 36.00$.

\section{SMITH No. 50 SPRAYER}

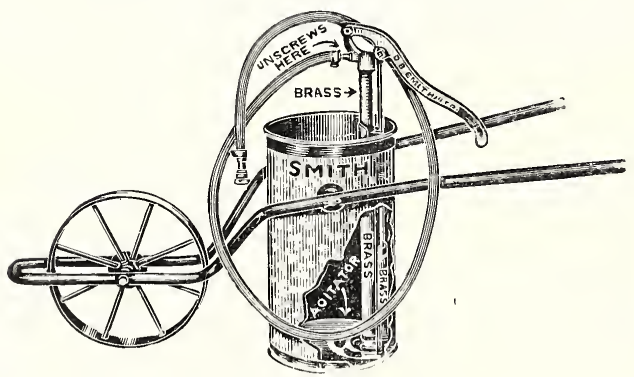

Smith No. 50 Sprayer

This Wheelbarrow sprayer may be used for spraying, whitewashing or for disinfectants. The pump is all brass, tank brass. Capacity, 12 gal., hose $8 \mathrm{ft}$. with brass nozzle. Price $\$ 25.00$.
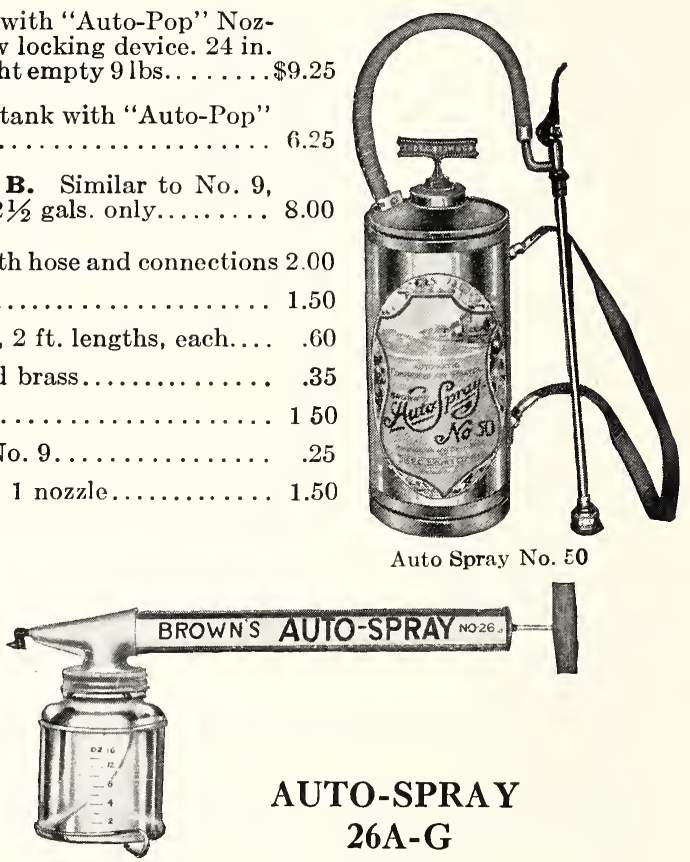

A continuous Sprayer with a glass tank which can easily be cleaned. Capacity one quart. Angle and straight nozzle. Each $\$ 1.25$.

\section{JIM DANDY HAND SPRAYER}

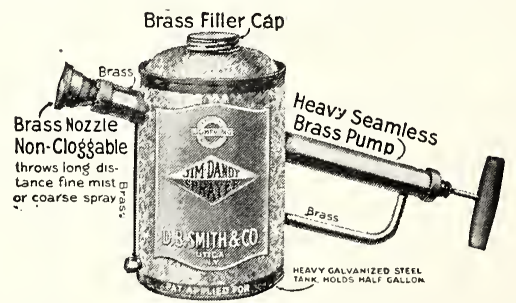

Adapted for spraying vegetables and flowers, small fruits, etc.; also valuable for spraying disinfectants in buildings. Capacity 2 quarts. Each $\$ 3.50$.

\section{No. 45 STURDY SPRAY PUMP}

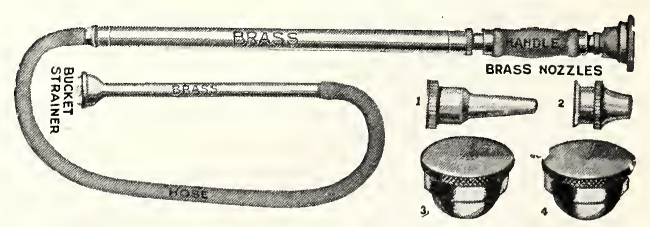

The sturdy is made with all brass parts, it may be used in pail or can. Four nozzles for all kinds of spraying. Easily operated by one man. Each $\$ 4.50$. Extension rods, 24 inches. Each $60 \mathrm{c}$. 


\section{"POMONA" BARREL SPRAY PUMP}

Very Powerful and Large Capacity-All Working Parts Bronze

The best orchard barrel Sprayer. It is unusually powerful and of large capacity, fully capable of supplying four leads of hose and eight nozzles. There is nothing about the Sprayer to get out of order, and with ordinary care it will last a lifetime.

Pump, with Agitator and Hose Coupling.................\$22.00

Outfit C. Pump with Agitator, one lead $15 \mathrm{ft}$., Discharge Hose,

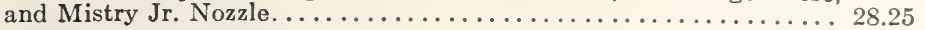

Outfit D. Pump with Agitator, two leads, $15 \mathrm{ft}$. each, Hose and two Mistry Jr., Spray Nozzles......................... 34.50

Barrel furnished for above and mounting. . . . . . . . . . . 11.00

Bamboo Extension. $10 \mathrm{ft}$. long. A brass tube inserted in a bamboo

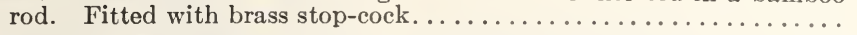

Iron Pipe Extension. $8 \mathrm{ft}$. long. Fitted with stop-cock. . . . . . . . 3.50

Barrel Cart. For mounting the above Sprayers. Wheels with 3 in. tires,

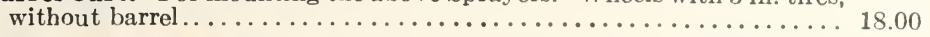

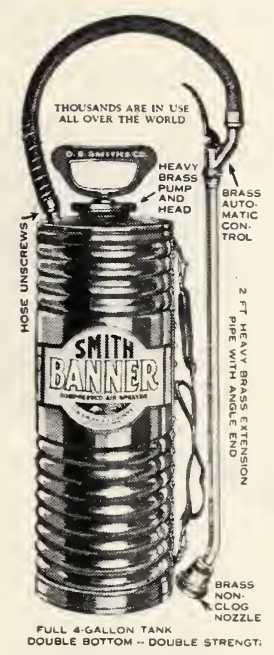

Banner Sprayer

\section{JUSTRITE SPRAYER}

A very handy sprayer for small work around the garden and whitewashing. Tank 17 in. by $61 / 4$ in. Capacity 2 gals. and automatic nozzle. Galvanized tank. Each $\$ 5.00$.

\section{BANNER No. 22 SPRAYER}

This sprayer is adapted for all spraying purposes, whitewashing and disinfecting. Tank 23 in. by $71 / 2$ in., capacity full 4 gals. Automatic nozzle for three different sprays. No. 22 Brass tank, $\$ 9.00$,

\section{PARAGON No. 3 SPRAYER}

For spraying trees, vegetables, whitewashing or water paints.

Mounted on a strong metal truck and can easily be wheeled to any desirable place. All liquid passes through the automatic, self-cleaning strainer before entering the pump, and cannot clog the nozzle when spraying.

Equipment: $10 \mathrm{ft}$. Special Spray Hose, $71 / 2 \mathrm{ft}$. Extension Pipe, one Mist Nozzle, one Steel Cap, one Straight Spray. Any additional length of hose can be furnished at a reasonable extra charge. Capacity, 12 gallons, galvanized tank. Price, $\$ 25.00$. Without truck, \$21.50.

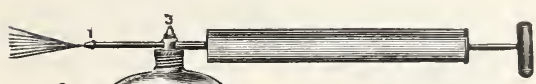

\section{COMPRESSED AIR SPRAYERS}

These Patent Sprayers give a continuous spray, reduce the liquid to a fine, mist-like spray, reduce the
vapor and throw it with great force, so that
is driven into the smallest cracks and crevices. By means of the it is driven into the smallest cracks and crevices. By means of the
universal nozzle the spray can be thrown on the underside of the leaves of plants and shrubs.

No. 50 B Brass pump and reservoir...................\$2.25

No. 50 C. Brass pump, copper reservoir................. 2.50

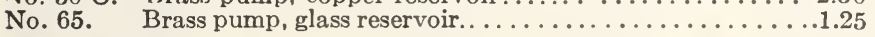
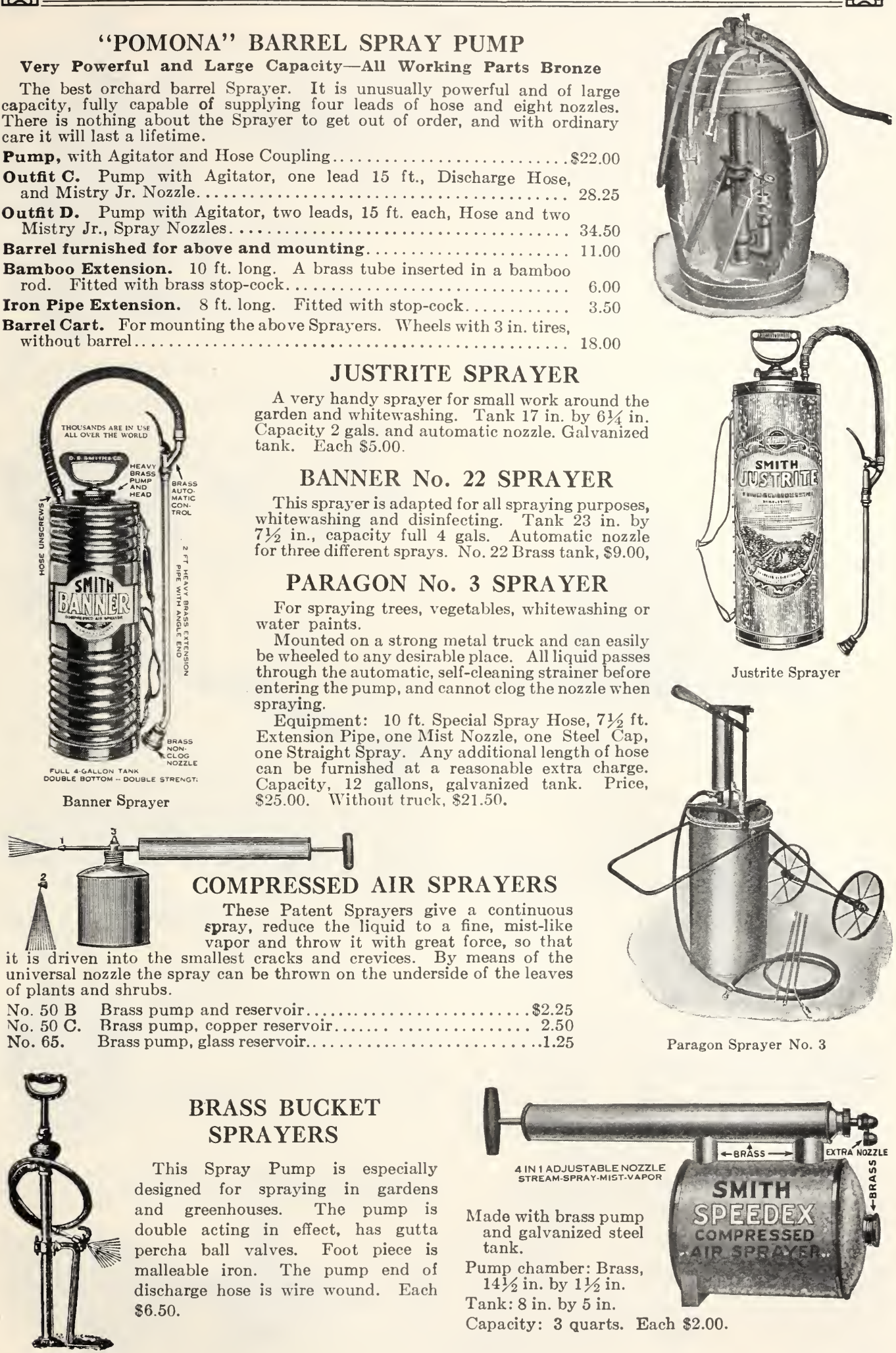

\section{BRASS BUGKET SPRA YERS}

This Spray Pump is especially designed for spraying in gardens and greenhouses. The pump is double acting in effect, has gutta percha ball valves. Foot piece is malleable iron. The pump end of discharge hose is wire wound. Each $\$ 6.50$.

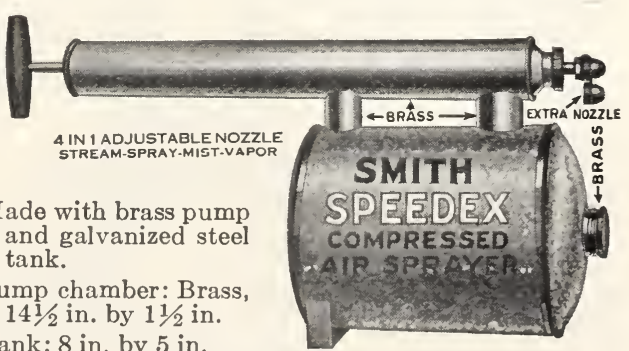

Tank: 8 in. by 5 in.

Capacity: 3 quarts. Each $\$ 2.00$. 


\section{HYDRO-AIR POWER SPRAY}

This sprayer requires only to be connected to your faucet or hose for the power to operate it. The even pressure of the water connection causes an even and constant spray of the insecticide used in the tank. It operates perfectly on any length of hose and makes a perfect sprayer for greenhouse use or for locations where garden hose can be used. Capaccity 5 gallons. 3 feet of $3 / 4$ inch hose for inlet and $103 / 8 \mathrm{ft}$. spray hose with automatic nonclog nozzle. Weight $30 \mathrm{lbs}$. Price $\$ 30.00$.

\section{THE MYER'S POWER SPRAY GUN}

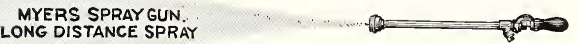

This gun utilizes the entire capacity of any power spray pump and does away with all bamboo extensions, nozzles and fittings. It can be adjusted to make a long or short distance spray and is fitted for $3 / 4$-inch hose coupling and 1/4-inch pipe. Each $\$ 7.00$.

VERMORS BRASS SPRAYER

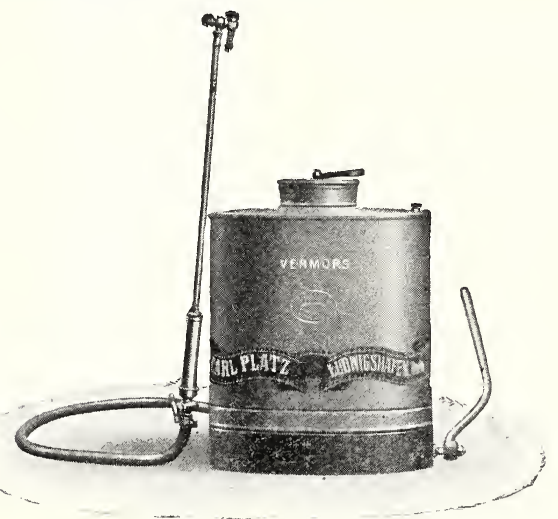

A compact, durable and efficient sprayer. The diaphragm pump is easy to operate. Capacity about four gallons. $\$ 20.00$.

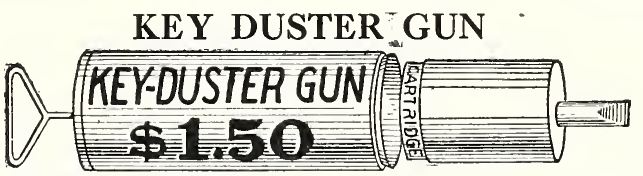

The new, quick and easy way of using insecticides and fungicides in the cartridge. No handling or mixing of chemicals and without the use of water.

The gun automatically opens the cartridge and applies the materials to the foliage.

Filling the long felt want for home garden, small orchard. Price $\$ 1.50$.

\section{KEY DUSTER GARTRIDGES}

These are filled with powder for the Key Duster Gun. For vegetables and small fruit. B. A. Cartridge.

For flowers and shrubs. Ofloro Cartridge.

For fruit and vegetables, nearly ripe. Hellebore Cartridge.

For aphis and many soft-bodied insects. Kaphis Cartridge.

For orchard fruit. L. A. S. Cartridge.

All cartridges 15c. each. Postage extra.

\section{GYANOGAS DUSTER}

The No. 1 Special Cyanogas Duster is made specially for using Cyanogas to exterminate rats, moles and other vermin. It has a 10 in. by $21 / 2$ in. barrel and an 11 in. rubber extension. Each. $\$ 1.25$.

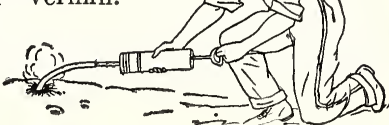

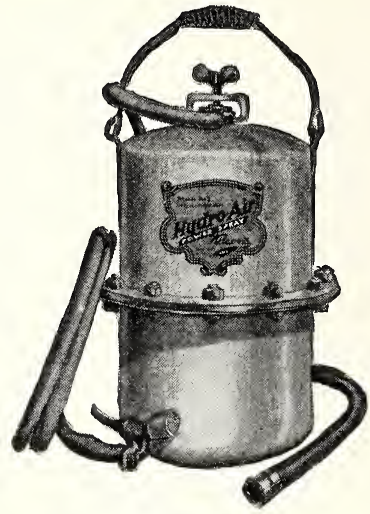

Hydro-Air Power Sprayer.

THE SAVAGE DUSTER

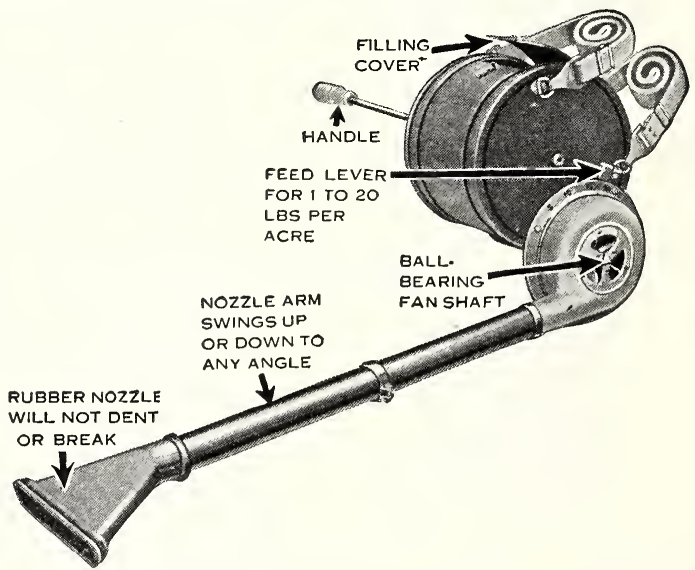

This Duster is made with the finest material and will stand long, hard service. Capacity 7 to $10 \mathrm{lbs}$. of powder. Adapted for use in dusting all kinds of plants. Easy to carry and operate. Weight, packed, 15 lbs. Price $\$ 20.00$.

\section{PLATZ GREEN HAND DUSTER}

A light, compact, sturdy and efficient duster. Capacity 2 to 4 lbs. 30 inch extension. Large. powerful bellows Each $\$ 6.00$.

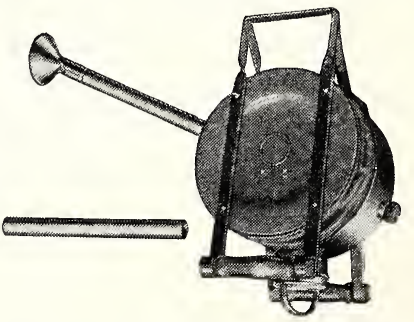

PLATZ FAMOUS HAND DUSTER

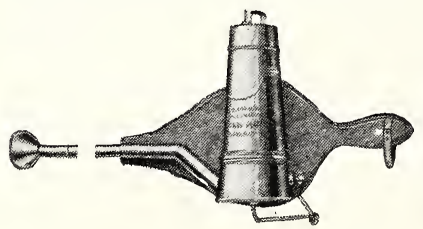

Regulator is adjustable, bellows of best leather. Extension pipe 24 in. Capacity $1 \mathrm{lb}$.

Each $\$ 5.00$, 


\section{RODENT POISON STATIONS}

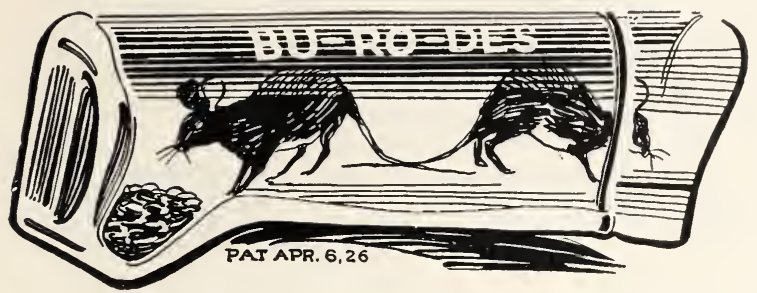

A very effective method of destroying field mice. The Poison Bait is placed in the Glass Station which is accessible only for mice. No other animals can reach it and the bait cannot be destroyed by weather conditions.

Rodent Stations. Each $25 \mathrm{c}$., doz. $\$ 2.50$, gross $\$ 20.00$. Poison Bait. Per lb. 35c., 10 lbs. $\$ 3.00,25$ lbs. $\$ 7.00$.

\section{"RAT CORN"}

A safe and sure exterminator of rats and mice. This is not a poison and can be used without fear when

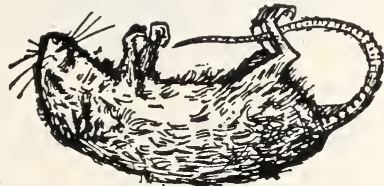
other animals are around. No smell from the dead rats is detected. as the bodies dry up after death. Pkgs. 25c.; 50c. and $\$ 1.00$. Postage extra.

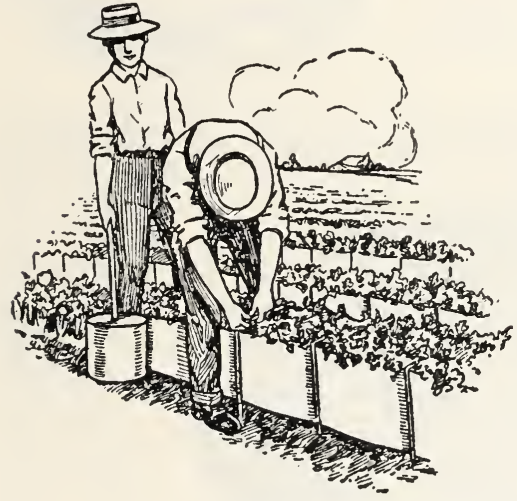

\section{GELERY BLEACHERS}

The home grower and private gardener will find this an ideal system of bleaching Celery-handy, neat and just the thing to bleach a few stalks every few days as wanted.

It only takes a week or ten days after putting on these bleachers when your Celery will be a beautiful white, and all ready for the table. No banking with soil, no hunting up boards, and it produces better results on early Celery. The same bleachers can be used over and over again the same season.

Size $7 \times 14,70$ c. per doz., $\$ 4.50$ per $100, \$ 40.00$ per 1000 .

\section{CELER Y HANDLER}

For putting on bleachers. Each $\$ 1.50$. Brass $\$ 2.50$.

\section{ELLISCO}

BEETLE GATCHERS

This beetle trap is the result of scientific researches on the destruction of the Japanese Beetle. Improvements in the trap simplify its use and increase its efficiency; the vertical wing, with perforated bait lure, attracts and holds even the most elusive of these beetles and holds them directly over the funnel into which they drop. Need be baited only once a season; bait sold separately, with full directions.

No. 2 size, as illustrated, made of galvanized metal, will last for years, $\$ 2.00$ ea

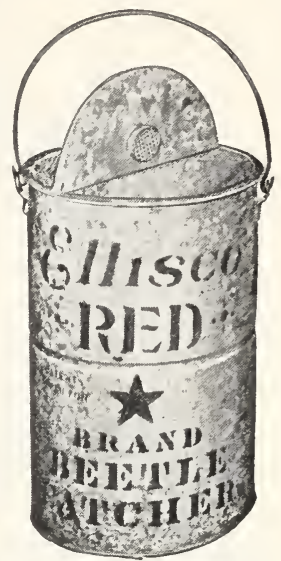

Acme Beetle Bait. $1 / 2$ pt. can for use with No. 2 trap, 60c.

\section{RAT POISON “ZELIO” PASTE}

A powerful poison for rats, mice and squirrels. The paste is easily applied to bread and is without taste or odor. $2 \mathrm{oz}$. tubes, $50 \mathrm{c}$.; $8 \mathrm{oz}$. cans, $\$ 1.50$

\section{CELERY BLEACHING PAPER}

A patented, flexible, odorless, waterproof material similar in appearance to patent roofing. It completely excludes the light, keeps the stalks clean because no dirt touches them. The strips are easily applied and a, great saving of cost and labor over using

The rolls of bleachers are placed over the holders with a roll on each side of the row, and as they are unrolled the wire arches placed over the rows to keep the bleaching paper in place.

The rolls are 100 feet long and 12 inches wide. Per roll, including 25 wire arches 42 inches long, $\$ 5.00$; handlers, $\$ 1.50$ each.

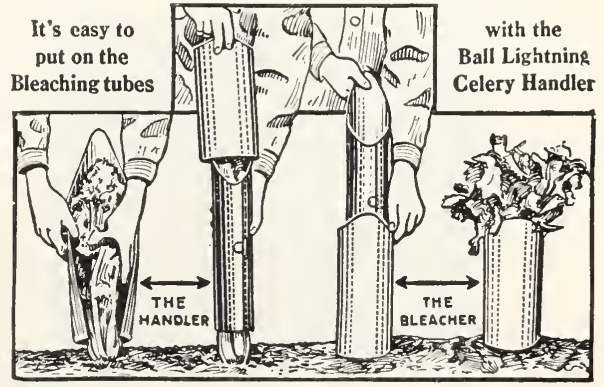

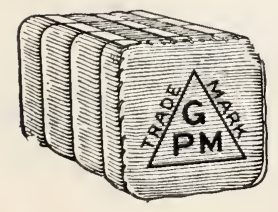

PEAT MOSS. Torf Mul

Granulated Peat Moss should be used liberally about the garden or greenhouse, for pot plants, window boxes and growing bulbs, etc. It is also useful for mulching perennial beds, lawns, Roses, etc., and mixing with sandy or clayey soils.

Small bale, enough to cover 16 square ft. 1 inch deep. Weight 15 lbs. Postage extra $\$ 1.50$ Large bale, 13 cubic ft., covers 240 square ft. 1 inch deep............... $\$ 5.00$ 
WHIRLING SHOWER SPRINKLER

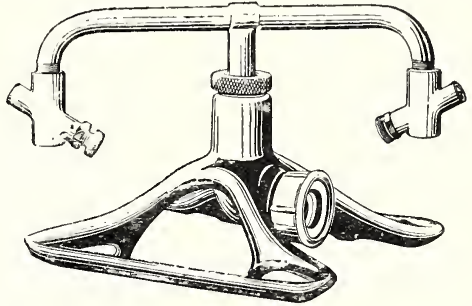

An adjustable revolving sprinkler which will cover an area of 60 feet. All made with brass except malleable iron base. Each $\$ 2.50$.

\section{THE TU-WAY SPRINKLER}

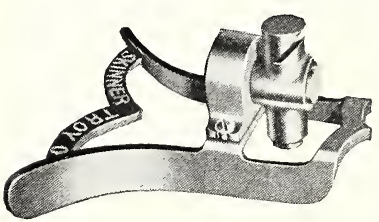

Can be used as a circle sprinkler or by giving the nozzle a half turn you have a sprinkler for a half circle to use for borders without wetting the sidewalk. Each $\$ 1.25$.

\section{RAIN KING SPRINKLER}

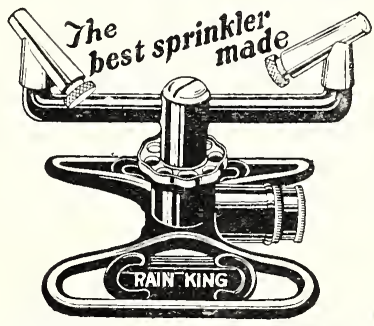

The Rain King is a real innovation in the sprinkler line, and radically different from any other sprinkler ever made. A most wonderful variety of uses. Circular or stationary spray, fine or coarse, fast or slow, large lawn, small lawn, trees, shrubs, flower beds, takes care of them all. Small, compact, easily handled. Simple adjustments. For Putting Greens it is excellent. Each $\$ 3.50$.

\section{GIRGULAR TREE SPRINKLER}

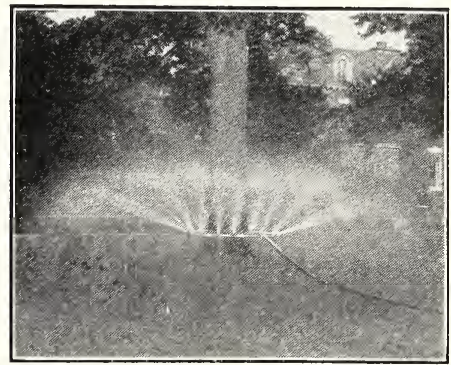

A new sprinkler, specially designed to water trees at one operation It saves time, labor, and money. It will water your trees more efficiently than by any other known method.

No. 1. Four feet in diameter............ $\$ 17.50$

No. 2. Three feet in diameter................ 15.00

No. 3. Two feet in rliameter.............. 13.75

Add $\$ 5.00$ each if Quick-as-Wink couplings are wanted.

\section{CALIFORNIA SPRINKLER}

This is the most popular Sprinkler on the market. It has four brass arms and is mounted on a sled, so that it can be easily dragged over the lawn without turning off the water. Price $\$ 2.00$.

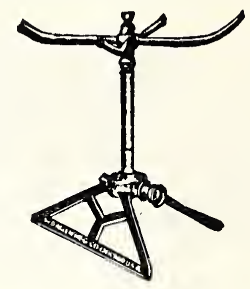

\section{"C. B. G.' SPRINKLER}

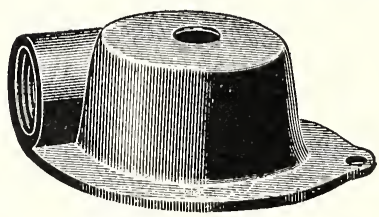

The C. B. G. Sprinkler is built on the principle of the tangential spray. Simple in construction and cannot get out of order. Each $40 \mathrm{c}$.

\section{BRASS FOUNTAIN SPRINKLER}

Very simple in construction

Cannot rust or get out of order.

Will not injure the lawn. Requires only ordinary pressure of water. Price 75c. each.

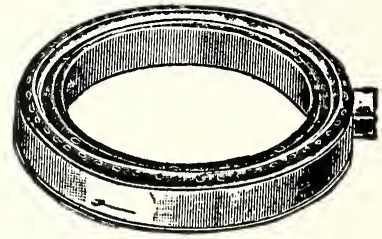

\section{THE SAUCER LAWN SPRINKLER}

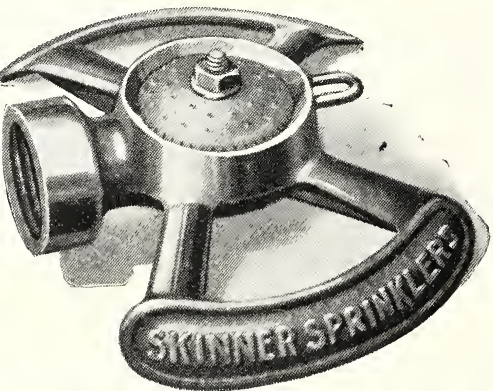

The Saucer Sprinkler will cover a circle of from 30 to 50 feet, distributing the water like a refreshing rain. With each sprinkler is a half cap which can be used for a fanshaped mist over a space of 30 by 20 feet. Simply remove the tun cap and replace the half cap and it is transformed into a half spray. Each $75 \mathrm{c}$.

\section{THE "SKINNER" LAWN MIST SPRINKLER}

For lawns, vegetables or flowers this Sprinkler throws the finest mist that can be used out of doors. Mounted on two wheels and a caster. I Length 15 feet five-spray clusters, 36 inches apart. Total 15 nozzles. Each $\$ 14.00$, f.o.b. Troy, O.

\section{PEACOCK STANDARD SPRINKLER}

Made to cover large areas in lengths of $121 / 2$ feet. Seven spray clusters of eight nozzles each. Total 56 nozzles. Mounted on a wheel truck at one end. Length $121 / 2$ ft. $\$ 16.50$, f.o.b. Troy, O. 


\section{MOR-RAIN SPRINKLER}

As a general, all-round sprinkler, a sprinkler that comis nearer to meeting all requirements for the average size lau $\mathrm{n}$ than any other sprinkler made, the Mor-Rain is without question the ideal.

It waters both full and half circles. To change from a complete circle to a half circle, just give the nozzle head a halfturn, and the job is done.

It will throw fine drops of water uniformly over a $50 \mathrm{ft}$. circle. But you can regulate the area by opening or closing your faucet. The head and arms are made of brass. The base is of iron and weighs 3 lbs. so that it cannot easily be upset. Attractively painted

Height 8 inches. And like all Skinner sprinklers, Mor-Rain is fully guaranteed. Each $\$ 3.00$.

\section{SPRAY MAKER LAWN SPRINKLER}

The Lawn Sprinkler that you can move without getting wet. Instead of sprinkling in a circle it sprinkles in a rectangular shape. It can also be used as a hoze nozzle if desired. All parts made of solid brass. Each 60c.
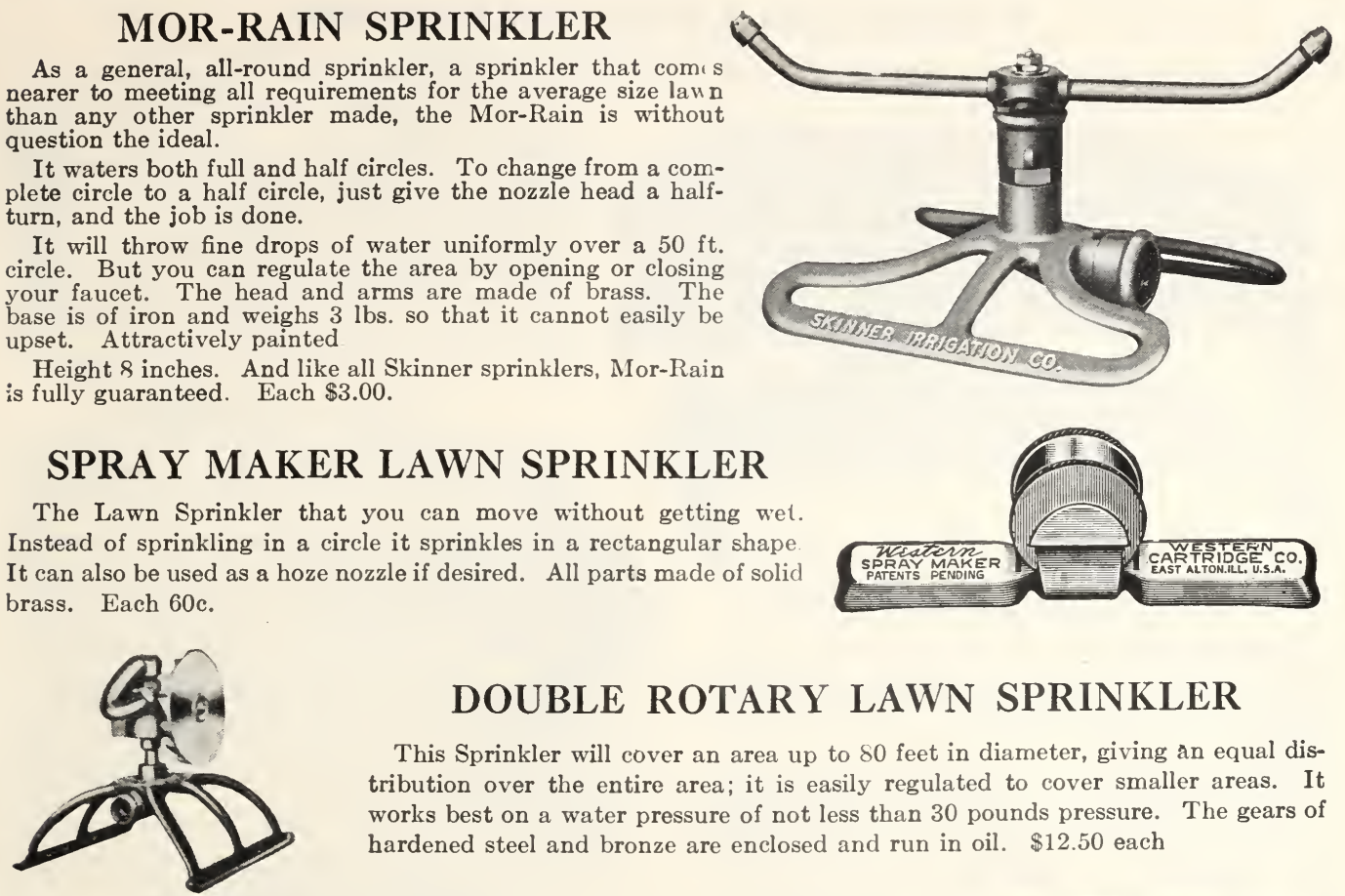

\section{DOUBLE ROTARY LAWN SPRINKLER}

This Sprinkler will cover an area up to 80 feet in diameter, giving an equal distribution over the entire area; it is easily regulated to cover smaller areas. It works best on a water pressure of not less than 30 pounds pressure. The gears of hardened steel and bronze are enclosed and run in oil. $\$ 12.50$ each

\section{WATER FAN LAWN SPRINKLERS}

The Water Fan is an automatic oscillating rain making machine. It is light, weight only $61 / 2 \mathrm{lbs}$. strongly built of brass and phosphor bronze and will work on a low or high pressure. No. 7 will cover an area of $40 \times 45$ feet with fine gentle even rain like distribution. Each $\$ 16.50$.
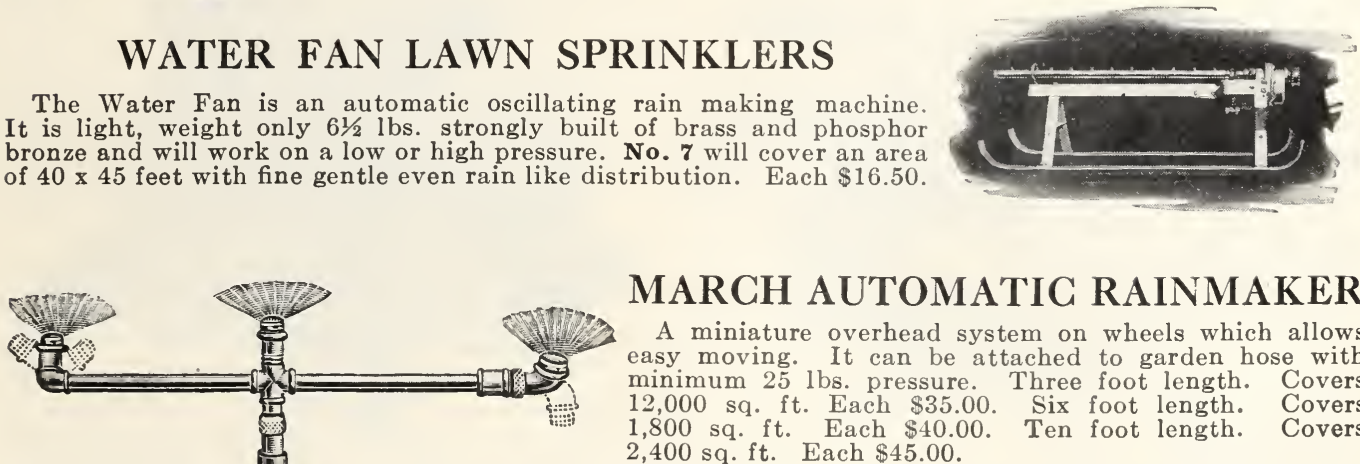

\section{MARCH AUTOMATIC RAINMAKER}

A miniature overhead system on wheels which allows easy moving. It can be attached to garden hose with minimum 25 lbs. pressure. Three foot length. Covers $12,000 \mathrm{sq}$. ft. Each $\$ 35.00$. Six foot length. Covers 1,800 sq. ft. Each $\$ 40.00$. Ten foot length. Covers 2,400 sq. ft. Each $\$ 45.00$.

\section{RED DEVIL LAWN SPRINKLER}

The "Red Devil" Sprinkler is the only correct method of watering your lawn or garden evenly without waste of water. It sprays perfectly, throwing seven streams from each head that break into a mist-like cloud. This assures perfect watering and causes the water to penetrate instead of laying in puddles.

It can be made to revolve at any speed, or made stationary by the mere tightening of the set screw collar below the arms. Setting the water heads at different angles will cause the atomizer to irrigate over a large or small area. When set correctly it will cover an area of 70 feet. It should be regulated to revolve forty times to the minute for best results. Red Devil, No. 153. Each $\$ 10.00$

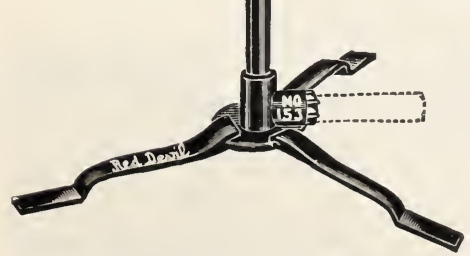

Red Devil Lawn Sprinkler

\section{GIANT RAIN KING LAWN SPRINKLER}

This Sprinkler is adjustable to height as well as distance, direction and volume of water. It plays like a gorgeous spiral fountain in any circle up to $\subseteq 0$ feet. Easily locked so it won't revolve, or will throw water in 1, 2, 3 or 4 directions. Each nozzle works independently, throwing solid stream or any desired spray. It stands 4 feet high and has 20 -inch arms. Price $\$ 14.00$.

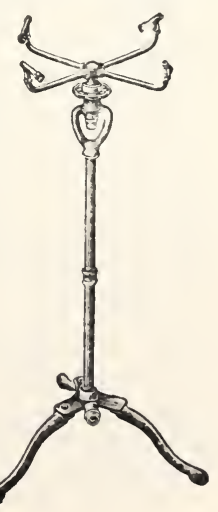




\section{BUGKEYE INCUBATORS AND BROODERS}

All the Buckeye Incubators are hot water heating system and guaranteed to do everything they claim.

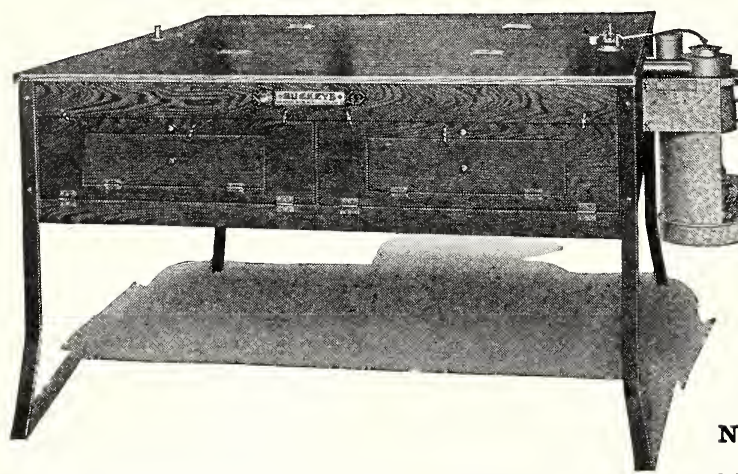

\section{BUCKEYE INCUBATORS}

Model 65. Capacity 75 eggs.........\$18.50

Model 66. Capacity 143 eggs . . . . . . 39.50

Model 67. Capacity 286 eggs. . . . . . . 57.75

Model 68. Capacity 416 eggs . . . . . . . 76.50

Model 69. Capacity 576 eggs........ 97.50

Models 66 to 69 are furnished with Automatic Egg Turners and are approved by the National Board of Fire Underwriters.

\section{BUCKEYE BROODERS}

Buckeye Coal-Burning Brooders are guaranteed to be exactly as represented and to be absolutely satisfactory when operated with makers instructions.

No. 117. Capacity 350 chicks. Hover 42 in. diameter. Coal capacity 23 lbs., $\$ 15.00$.

POULTRY GATGHING NET

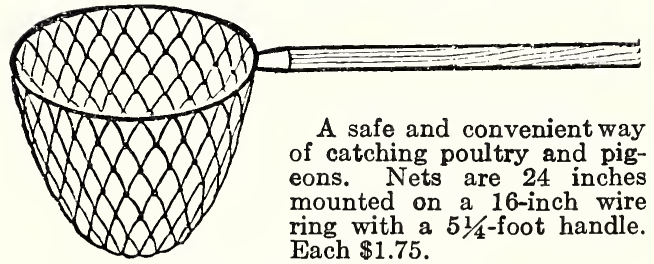

\section{THE BLUE HEN COAL BURNING COLONY BROODER}

The Blue Hen is designed right and built right. It is easy to operate and requires but very little attention because of its sensitive automatic regulation. It has extra large coal capacity which enables it to hold the fire 12 hours. The cast iron heater is powerful. It heats quickly and holds a steady fire because of its large grate area.

No. 50. Blue Hen Brooder. Capacity 1000 chicks. Diameter of hover 54 in. Coal capacity $50 \mathrm{lbs}$. Shipping weight 160 lbs. Price $\$ 18.75$.

\section{F. O. B. Lancaster, $\mathbf{P a}$.}

\section{POULTRY SUNDRIES}

Egg Preserver. Water glass. One quart with water for 15 doz. eggs. Gal. $\$ 1.25$.

Fountains.

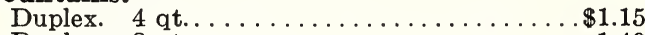

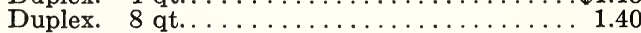

"Thermo." 1 gal...................... 2.25

"Thermo." 2 gals................. 2.75

Feeders.

Oakes. 12 in. No. $1 \ldots \ldots \ldots \ldots \ldots \ldots \ldots 1.75$

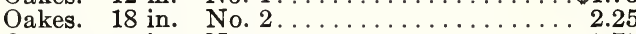

Oakes. 24 in. No. $3 \ldots \ldots \ldots . .2 .75$

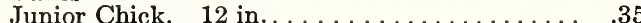

Junior Chick. 20 in . . . . . . . . . . .

Moe's Round. No. $12 \ldots \ldots \ldots \ldots \ldots \ldots \ldots . .35$

Leg Bands. Spirol. Colored. $100 \$ 1.00$

Nest Eggs, China. 3 for 10c., doz. 35c.

Oat Sprouter.

Collins. 5 pans. . . . . . . . . ........\$3.00

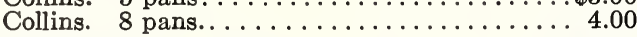

Poultry Knives. Pilling..............\$0.65

Poultry Punches. Moe's Clip and Punch. Each 30c.

Thermometers. Brooder. Each $\$ 1.00$.

Incubator. "Tycos." Each $\$ 1.00$.

Hygrometer. An indicator to show the moisture conditions in the incubator. Each $\$ 1.75$.
No. 118. Capacity 500 chicks. Hover 52 in. diameter Coal capacity 36 lbs., $\$ 17.50$.

No. 119. Capacity 1000 chicks. Hover 56 in. diameter. Coal capacity 58 lbs., $\$ 22.50$.

\section{BUCKEYE OIL BURNING BROODERS}

No. 27A. Blue Flame Brooder. Capacity up to 200 chicks. $\$ 14.50$.

No. 28A. Blue Flame Brooder. Capacity up to 350 chicks, $\$ 15.50$.

No. 29A. Blue Flame Brooder. Capacity 500 chicks. $\$ 18.50$.

Descriptive catalog of the above mailed on request.
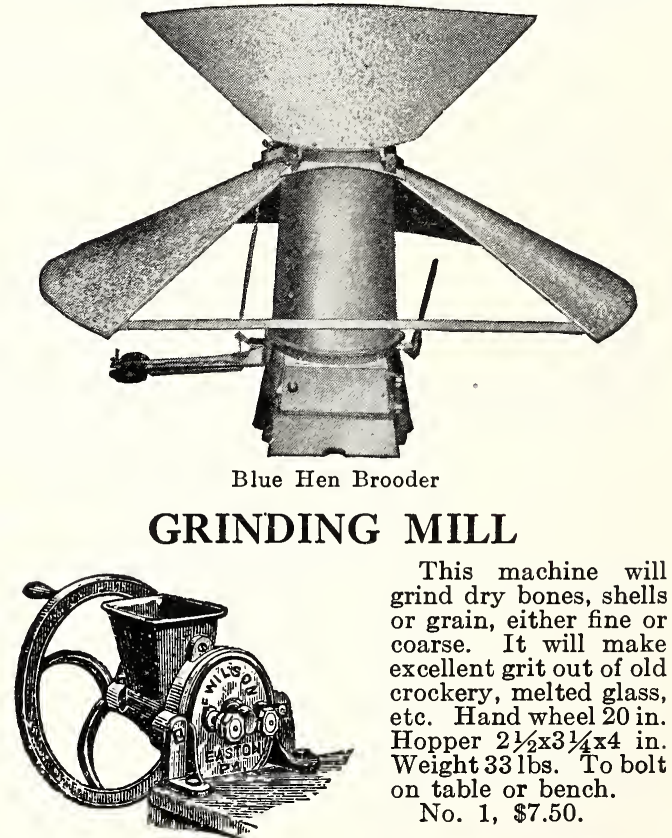

"SPRATT'S" MEAT "FIBRINE"

Vegetable Dog Cakes. The standard dog food. Used at the leading kennels and dog shows throughout the world. staple and constant food for all breeds of dogs. Per lb. 20c., 10 lbs. $\$ 1.75,100$ lbs. $\$ 16.00$. 


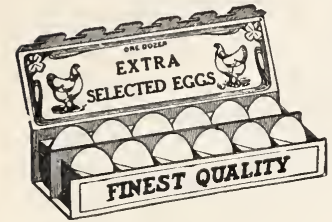

FOLDING

PAPER

EGG BOXES

Convenient for carrying a dozen eggs to local customers. Doz. $25 \mathrm{c}$., 50 for $70 \mathrm{c}$, 100 $\$ 1.20,1000 \$ 10.00$.

\section{EGG CASE}

\section{FILLERS}

Full cushion fillers for cases of eggs. Regulation $2 \times 6$ style. 50 for $85 \mathrm{c}$., $100 \$ 1.60$, $1000 \$ 15.00$.

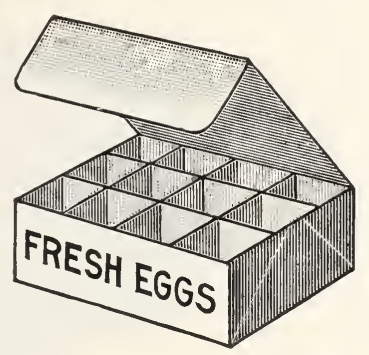

\section{SURETY GUSHION WOODEN EGG CRATES}

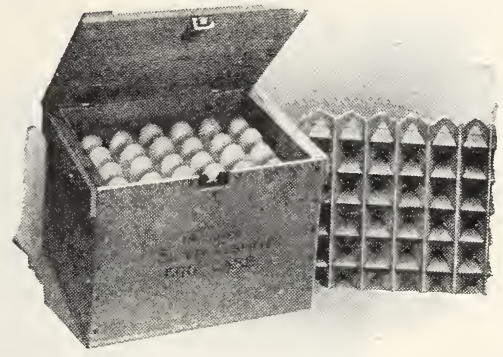

Easier and quicker to pack than ordinary egg crates. The trays are inverted one above the other which hold the eggs from coming in contact with each other. Two-doz. size, each $\$ 2.00 ; 4-d o z$. size $\$ 2.25 ; 6$-doz. size $\$ 2.50 ; 8$-doz. size $\$ 2.75 ; 10-$ doz. size $\$ 3.00 ; 12$-doz. size $\$ 3.25$.

Extra Filler Sets for 2, 4, 6, 8 and 12 doz. size cases. 25 trays $\$ 4.00$.

When ordering extra fillers, kindly state what size egg crate they are wanted for.

\section{GARDENER'S HARROW}

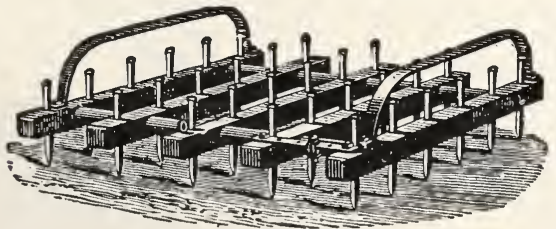

Designed for one horse, convenient to handle and get around garden plots, etc.

25 teeth with runners.................\$13.00

30 teeth with runners................... 14.00

\section{AND GRATES}

Buy eggs by mail from your country friends shipped in aluminized

\section{METAL EGG CRATES}

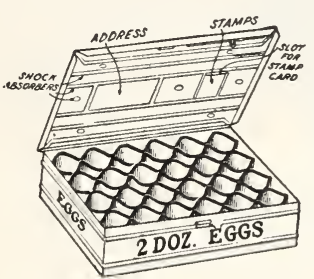

Indestructible; pays for itself in a few shipments: lasts for years; makes interchangeable shipping easy. Buy yours now and realize more money for your eggs. Your friends want them.

The Metal Edge Filler

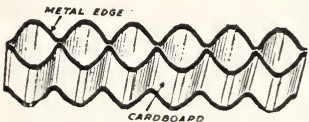
is a wonder. A new invention and cannot be beat for safely carrying eggs by mail. Light in weight but strong.

Reversible address cards are placed over eggs, address visible through opening in lid. Names of shipper and receiver are placed on each side of this card.

Write us about Butter-Egg Crates.

1-dozen size......\$1.00 4-dozen size..... $\$ 2.00$ 2-dozen size....... $1.50 \quad$ 6-dozen size...... 2.50 3-dozen size.............. 1.75 9-dozen size.... Add postage for $3 \mathrm{lbs}$. to the price for each 150 miles if wanted by mail.

\section{EGG-PAK EGG GIRRIER}

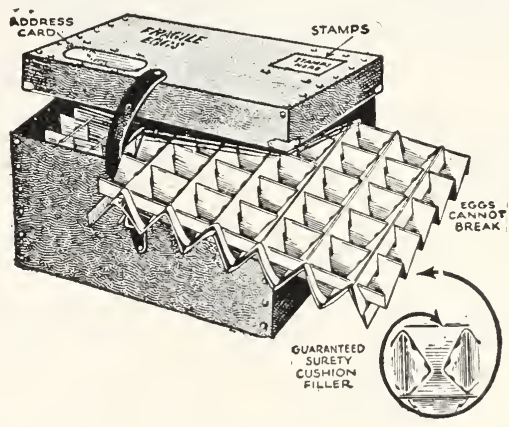

Made with unbreakable fiber with Surety Cushion Fillers. Reversible address card and stamp space. 2-dozen size. Weight empty $21 / 2$ lbs. Each $\$ 1.80$. 4 -dozen size. Weight empty $31 / 2$ lbs. Each $\$ 2.35$. 6 -dozen size. Weight empty $4 \frac{1}{2} \mathrm{lbs}$. Each $\$ 2.60$.

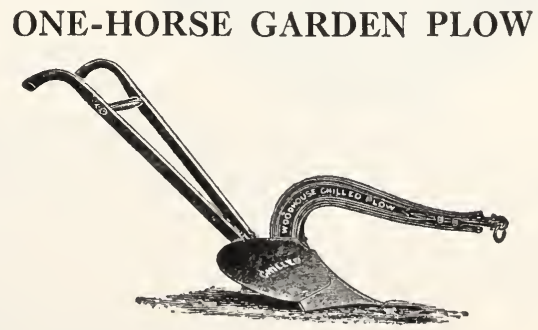

No. 6 iron beam, wood handles; cuts a 3- to 6-inch deep furrow and 7 to 10 inches wide. Weight $65 \mathrm{lbs}$ No. 6. Price, with extra point, $\$ 13.00$; with whee $\$ 2.00$ extra. 


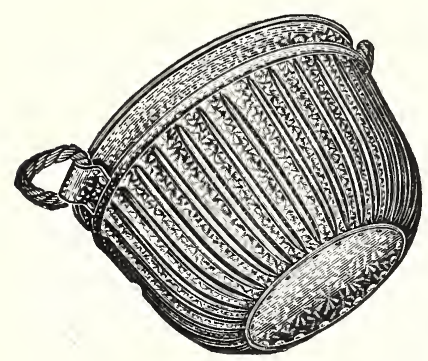

\section{GALVANIZED BASKETS}

\section{GARDENERS' BASKETS}

Adapted for gathering Fruits, Vegetables, Flowers and other purposes around the garden or greenhouse.

Made with splint and bamboo bound with metal straps. Very strong and durable.

No. 1 size 19 in. $x 11 \frac{1}{2}$ in. $x \quad 7$ in. deep.......... $\$ 2.00$

No. 2 size $201 / 2$ in. $x 13$ in. $x \quad 7$ in. deep............ 2.25

No. 3 size 23 in. $x 141 / 2$ in. $x \quad 8$ in. deep............ 2.50

No. 4 size 24 in. $x 151 / 2$ in. $x \quad 9$ in. deep............ 2.75

No. 5 size 30 in. $x 20$ in. $x 11$ in. deep............ 3.25

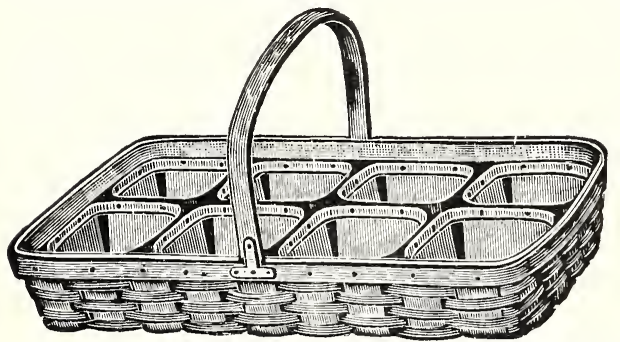

\section{FLOWER AND FRUIT BASKETS}

A handy basket for gathering flowers, vegetables and fruits.

Medium size, No. 2, $20 \times 12 \times 31 / 2$ in........ Each $\$ 1.25$ Large size, No. $3,24 \times 12 \times 3 \frac{1}{2}$ in......... Each 1.50

\section{STRAWBERRY BASKETS}

Useful for gathering strawberries and raspberries. Pint size. Per $100 \$ 1.25$. Per $1000 \$ 11.00$. One quart size. Per $100 \$ 1.50$. Per $1000 \$ 13.00$. 2 quart size per $100 \$ 3.00$. 3 quart size per $100 \$ 3.50$ 4 quart size per $100 \$ 4.00$.

\section{GENERAL FARM BASKETS}

Made with best oak splint, reinforced with hoops. Handy for carrying leaves, rubbish, wood, coal, etc.

1 bushel size......Each $\$ 2.00 \quad 2$ bushel size.......Each $\$ 3.00$

$11 / 2$ bushel size....... Each $2.50 \quad 3$ bushel size....... Each 3.50
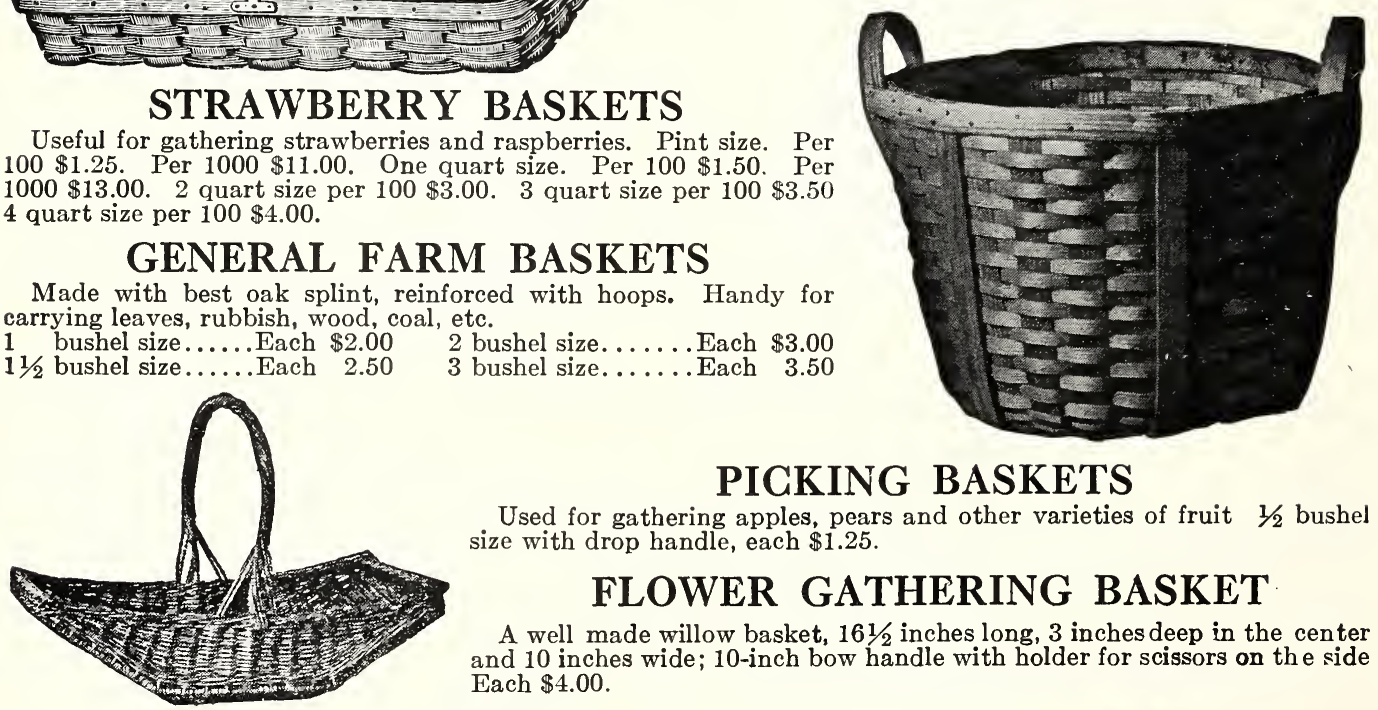

\section{PICKING BASKETS}

Used for gathering apples, pears and other varieties of fruit $1 / 2$ bushel size with drop handle, each $\$ 1.25$.

\section{FLOWER GATHERING BASKET}

A well made willow basket, $161 / 2$ inches long, 3 inches deep in the center and 10 inches wide; 10 -inch bow handle with holder for scissors on the side Each $\$ 4.00$.

\section{ENGLISH GARDEN BASKETS}

Made with wood with strong wooden handle and feet. Handy for cut flowers and vegetables.

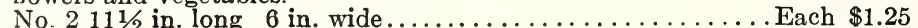

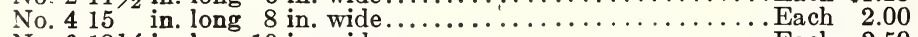

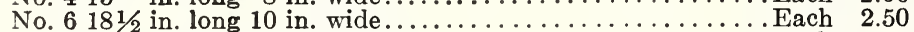

No. 823 in. long 12 in. wide................................. 3.75

\section{RUSTIC HANGING BASKETS}

Made from laurel roots, elegantly finished and rattan handle. These baskets cannot be equaled in style, finish or make. They will stand severe weather, and with a little care are good for 10 to 12 years' wear. Each, 10 in., $\$ 2.25 ; 12$ in., $\$ 2.50 ; 15$ in., $\$ 3.50$.

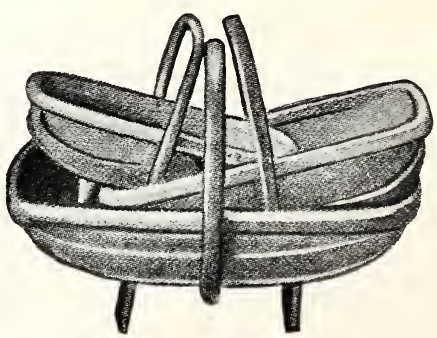




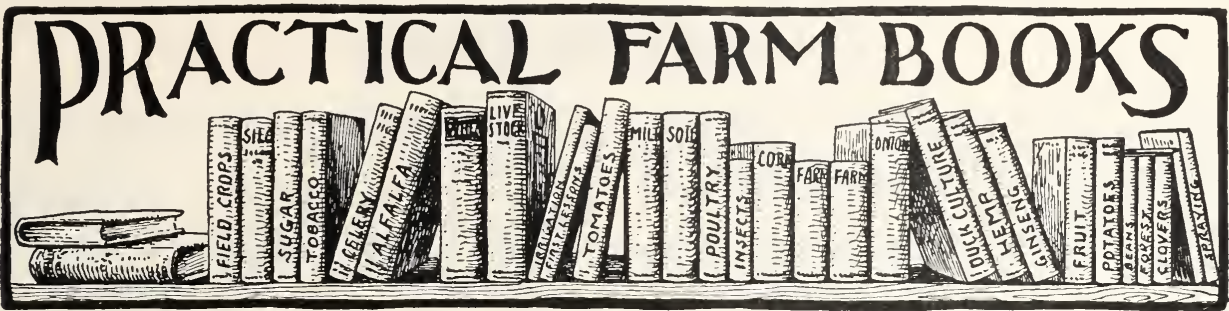

A mine of information in each book. Here is a list of standard books written by practical men in language that can easily be understood. Sound, snappy and full of meat. No matter whether you are a beginner or an old hand at the business, you can learn something from these volumes.

\section{FRUITS, FLOWERS,}

Annuals, A Little Book of. A. C. Hottes... . . \$ \$1.50

American Apple Orchard. F. A. Waugh. . . . . 1.75

Asparagus. F. M. Hexamer.............. 1.10

Around the Year in the Garden. Rockwell... 2.50

Book of Bulbs. F. F. Rockwell ......... . 3.00

Bulbs That Bloom in the Spring. Weston... . 2.00

Bush Fruit Production. R. A. Van Meter..... 1.25

Cauliflower and Broccoli Culture. A.G.B.

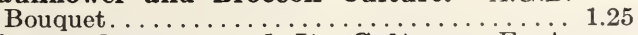

Chrysanthemum and Its Culture. E. A White.

Climbing Plants, Little Book A C Hottes.

Commercial Floriculture. Fritz Bahr. . . . . . 5.50

Culinary Herbs. M. G. Kains. . . . . . . . . . 1.25

Cyclopedia of Horticulture. L. H. Bailey.

In three volumes; new edition. . . . . . . . . 25.00

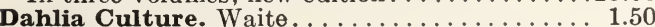

Dahlia, The. L. K. Peacock. . . . . . . . . . . . 1.25

Evergreens, Hardy. F. A. Schrepfer . . . . . 1.25

Everybody's Garden. F. A. Waugh . . . . . . . 3.50

Fertilizers. Gustafson . . . . . . ........ 1.25

Floriculture, Practical. P. Henderson. . . . . 2.00

Foundation Planting. L. H. Johnson. . . . . . . 3.50

Fruits, American. S. Fraser . 4.75

Fruit Growing, Beginner's Guide to. F. A. Waugh.

4.75

1.25

Fruits and Vegetables under Glass. W. Turner 5.00

Garden Book, The. V. H. Davis...... . . . . 1.25

Garden Cinderellas. How to Grow Lilies in the Garden. Helen M. Fox.

Garden Guide, The Amateur Gardeners Handbook. .

Gardening for Pleasure

Gardening for Profit. P. Henderson . . . . . . . 2.00

Garden Questions, 1001. Hottes. . . . . . . . 2.00

Gardener, The. L. H. Bailey. . . . . . . . . . . 2.00

Gladiolus. Rockwell . .

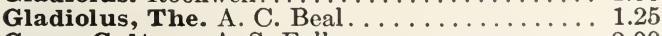

Grape Culture. A. S. Fuller. . . . . . . . . . 2.00

Greenhouses, Their Construction and Equip-

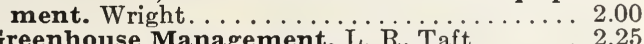

Greenhouse Management. $\dot{L}$. $\mathrm{R}$. Taft. . . . . . 2.25

Hardy Shrubs. F. A. Waugh . . . . . . . . . . 1.25

Home Flower Growing. E. C. Volz . . . . . . . 3.50

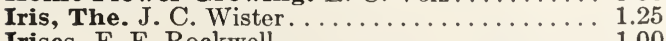

Irises. F. F. Rockwell . . . . . . . . . . . . . 1.00

Landscape Gardening, Practical. R. Cridland. 2.50

Landscape Gardening. F. A. Waugh.

\section{GARDENING, ETC.}

Landscaping the Home Grounds. L. W Ramsey.

Lawn, The. L. S. Dickson

Lawns. F. F. Rockwell

Lilac Culture. J. C. Wister.

1.25

Lilies, "Consider the Lilies". W. E. Marshall . 1.00

Lilies, Garden. I. Preston

Manual of Gardening. L. H. Bailey.

Milady's House Plants. F. E. Palmer .

Mushroom Culture. Duggar

New Onion Culture. T. Greiner ..... 1.10

Orchid Culture, American. E. A. White. . . . 4.50

Ornamental Trees, Care of

Plant Propagation and Nursery Practice. M. G. Kains

Perennials, A Little Book of. A. C. Hottes. 1.50

Plant Culture. G. W. Oliver and Hottes. ..... 3.50

Potato, The. S. Fraser. . . . . . . . . . . . 1.25

Potato Production. A. L. Nixon. . . . . 1.25

Principles of Flower Arrangement. E. A. White.

Pruning, Principles and Practice of. Kains . 2.50

Pruning Manual. L. H. Bailey .... 2.50

Rock Garden Primer. A. Thornton... . . . . . 2.00

Rock Garden and Alpine Plants. H. Correvon. 6.00

Rock Gardens. S. F. Hamblin . . . . . . . . . . 1.25

Rock Gardens. F. F. Rockwell . . . . . . . . 1.00

Rose in America, The. J. Horace McFarland... 6.00

Rose Culture, Commercial. E. Holmes . . . . 2.00

Roses and Their Culture. S. C. Hubbard. . . . . 1.25

Shrubs, The Book of. A. C. Hottes........ . 3.00

Shrubs. F. F. Rockwell .

Spraying, Dusting and Fumigating. A. F. Mason

5.00

Spring Flowering Bulbs. C. L. Thayer. . . . . 1.25

Standardized Plant Names. 546 pages. . . . 6.00

Starting Early Vegetable and Flowering Plants Under Glass. C. H. Nissley... . . . . . 3.00

Strawberry, The. S. Fraser.............. 1.25

Tomato Production. Paul Work ........... 1.25

Tomato Culture. Tracey . . . . . . 1.10

Vegetable Forcing. Watts . . . . . . . . . . . 3.00

Vegetable Gardening. R. L. Watts . . . . . . . 2.50

Violet Culture. Coon. . . . . . . . . . . . . . . 1.75

Water Gardening. Peter Bisset. ........ 5.00

Wild Flower Families. C. W. Weed ...... 1.50

\section{FARM, POULTRY}

Alfalfa. F. D. Coburn ................\$1.10

Battery Brooding. Milton $\dot{H}$. Arndt. . . . . . . 2.00

Butter Making. C. A. Publow . . . . . . . . . 1.10

Corn, The Study of. V. M. Shoesmith . . . . . . 1.10

Crops, Spraying. C. M. Weed............. 1.10

Ducks and Geese. Lamon and Slocum . . . . . . 2.00

Farm Dairying. C. Larsen . . . . . . . . . . . . . 2.00

Farm and Garden Rule Book. L. H. Bailey. . . 3.00

Farmer's Cyclopedia of Agriculture. E. V

Wilcox and C. B. Smith.

How to Select The Laying Hen.
AND ANIMALS

Products. L. L. Van Slyke.

Poultry Breeding and Management. Jas Dryden.

Poultry, Feeds and Feeding Lamon and Lee. 1.75

Practical Poultry Farming. I. M. Hurd ..... 3.50

Rabbits for Food and Fur. F. G. Ashbrook. . . . 2.00

Right Use of Lime in Soil Improvement.

Alva Agee.

Squabs for Profit. $\ddot{W}$ E. Rice.

Soils. C. W. Burkett

Turkey Raising. Lamon and Slocum.

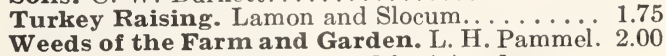
Prices of books are subject to change. 


\section{INSECTICIDES}

AGRI-PAX. A new contact insecticide, founded upon the toxic principle of Pyrethrum. It will kill Japanese Beetle, Rose Beetles, Aphis, Thrips, etc. One of the best sprays for Dahlias. Quart tin $\$ 1.25$, gal. $\$ 4.00,5$ gals. $\$ 15.00$.

ANSECT (Rose Bug Killer). Highly effective when used on Rose Bugs, many hard-bodied insects, Red Spider, Mealy Bug, and other garden pests. Use one part in thirty to fifty parts of water. Will not discolor the foliage of plants or affect the flowers. A thorough spraying is essential. $4 \mathrm{oz} .30 \mathrm{c}$., pint $\$ 1.00$, gal. $\$ 4.00$.

\section{Aphistrogèn}

A non-poisonous scientific spray for roses etc. Does not discolor the foliage. 2 oz. 50c. 1 lb. $\$ 2.25$. 2 lbs. $\$ 3.50$.

APHINE. Has no equal for the destruction of green, black or white fly, thrips, red spider, mealy bug, caterpillars, scale and other insects and blights. Use one part to forty parts of water. $1 / 4 \mathrm{pt}$. 25c., $1 / 2$ pt. 40 c., 1 pt. 65 c., qt. $\$ 1.00$, gal. $\$ 3.00$.

The Antrol System exterminates the commonly known

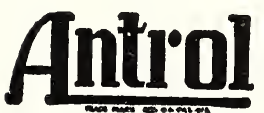
"house ant"-the species that infests kitchens and eats food and sweet substances. Unlike ordinary control methods it destroys the entire ant colony at the source.

The complete system should cover every 15 feet around the outside of the house or "ant" trails in the garden.

Prices-Antrol sets containing 4 containers and 1 4-oz. bottle of syrup, 95c.; Antrol extra containers (each), 15c.; Antrol syrup, 4-oz. bottle, 50c.; pints, $95 \mathrm{c}$.

ANT GELATIN, "Marvel." An effective remedy for destroying ants. Tin 50c.

ARSENATE OF LEAD, Powdered. Better than Paris Green and does not burn foliage. Can be used either wet or dry for dusting. With water use $1 \mathrm{lb}$. to 15 or 25 gals. Lb. $50 \mathrm{c}$., 5 lbs. $\$ 2.00$, 10 lbs. $\$ 4.00,25$ lbs. $\$ 7.50,100$ lbs. $\$ 20.00$.

BORDO-LEAD. See Key-Cide.

BORDEAUX MIXTURE, Powder. 12 per cent copper. Used same as Bordeaux Mixture, also for dusting dry. For spraying use $1 \mathrm{lb}$. to 8 gals. water. Lb. 40 c. 5 lbs. $\$ 1.80,10$ lbs. $\$ 3.50,25$ lbs. $\$ 6.50$, 100 lbs. $\$ 23.00$.

BUG DEATH. Is extensively used for Cabbage and Tomato worms, Potato and Cucumber bugs. Lb. 25c., 5 lbs. 90c., $121 / 2$ lbs. $\$ 1.75$.

CARBOLA. A disinfecting germ-killing white paint. Used instead of whitewash for stables, chicken coops, dairies, cellars, etc. 10 lbs. make 10 gals. 5 lbs. $75 \mathrm{c} ., 50 \mathrm{lbs}$. $\$ 5.50$.

CED-O-FLORA. A perfect contact spray for Mealy Bug, Red Spider and Scale. One gallon makes 26 gallons spray. Pint $\$ 1.25$, Gal. $\$ 7.00$

CYANOGAS, G Grade Fumigant (Calcium Cyanide). For fumigating greenhouses, mushroom beds and soils. 1 lb. $75 \mathrm{c} ., 5$ lbs. $\$ 3.25$.

CYANOGAS, Grade A Dust. Used destroying aphis, white fly and other insects, also exterminating moles, rats, ants, etc. 1 lb. $75 \mathrm{c} ., 5 \mathrm{lbs}$. $\$ 3.25$, 25 lbs. $\$ 10.00,100$ lbs. $\$ 30.00$.

CYANOGAS DUSTER.

No. 1, each $\$ 1.25$.
COPPER SOLUTION. For mildew, Pear and Apple scab, rust on Carnations and Violets. Qt. $\$ 1.50$, Gal. \$4.00.

CUT WORM KILLER. This is a coarse powder for sprinkling near the plants to be protected. It is harmless to birds or chickens. $1 \mathrm{lb}$. is sufficient for 175 plants or $100 \mathrm{ft}$. of drill. Lb. 50c., 5 lbs. $\$ 2.00$ 25 lbs. $\$ 7.50$.

D. \& $\mathbf{P}$. 4 in 1 SPRAY. Contains Arsenic Oxide, Copper and Nicotine, combined with a spreader. Valuable for fruit trees and garden crops. $25 \mathrm{lbs}$. $\$ 30.00,50$ lbs. $\$ 57.00,100$ lbs. $\$ 110.00$

EVER GREEN. A non-poisonous insecticide. A very effective spray for all kinds of insects. Harmless to animals or birds. Recommended for the M.G.K. 年

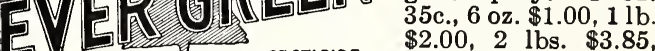
NON-POISO NOUS INSECTICIOE $\begin{aligned} & \$ 2.00,2 \text { l. } \$ 13.00 \\ & \text { gal. }\end{aligned}$

FORMALDEHYDE. A useful fungicide for Potato scab, rosette in Lettuce, Onion smut and fungus in soil. For Potatoes, use $1 \mathrm{lb}$. to 30 gals. of water and soak the tubers about $11 / 2$ hours before planting. Lb. bottle 40c.

FUNGINE. An infallible remedy for mildew and other fungus diseases. Qt. $\$ 1.00$, gal. $\$ 3.00$.

A complete spray

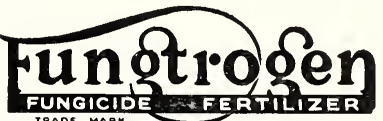

for midlew and black spot on Roses. It will not disfigure the leaves or petals. Pint $\$ 1.25$, qt. $\$ 2.00$, gal. $\$ 6.00$.

G 0-4. A simplified, safe and economical insecticide for flowers and vegetables. Effective against chewing and sucking insects. Two pkgs. make 1 qt. spray. Box of 24 pkgs. $\$ 1.00$.

GRAPE DUST. For prevention of mildew on Roses, Grapes, Gooseberries, etc. 5-lb. pkg. 90c., $10 \mathrm{lbs}$. $\$ 1.75,100$-lb. keg $\$ 16.00$.

HELLEBORE POWDER. For rose slugs, currant worms, etc. Dust on with gun or bellows while the foliage is moist. Lb. 55c., 5 lbs. $\$ 2.50$.

IMP SPRAY SOAP. Effective against green fly, aphis, red spider and thrips. Mix with 12 parts of water for spraying. Gal. $\$ 3.50$.

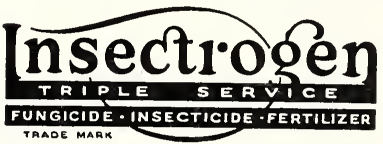

A complete spray, fungicide and fertilizer combined. Use for all leaf eating insects, red spider and mildew. $1 / 2$ Pint $\$ 1.00$. Pint $\$ 1.75$, qt. $\$ 2.75$, gal. $\$ 8.00$.

KAYSO. Used to keep spray from washing off and prevent injury to foliage. 2 lb. $65 \mathrm{c} ., 100 \mathrm{lbs}$. $\$ 30.00$.

KEY-CIDE POWDER (Bordeaux and Arsenate). A combined insecticide and fungicide. Kills bugs and prevents blight, rot, mildew and fungus. Can be used for wet spraying or dusting for fruits, vegetables and flowers, 1 lb. makes 7 gals. liquid. lb. $45 \mathrm{c}$., 5 lbs. $\$ 2.25,10$ lbs. $\$ 4.00$, 25 lbs. $\$ 9.00,100$ lbs. $\$ 32.00$.

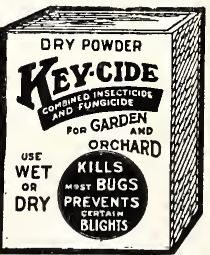

LEMON OI. For destroying mealy bugs, scale, thrips, red spider, etc. Qt. $\$ 1.25$, gal. $\$ 3.50$.

LIME SULPHUR, Liquid. For spraying fruit trees, etc. 5 gals. $\$ 4.75,30$ gals. $\$ 15.00$, barrel, 50 gals. $\$ 22.00$. 


\section{INSEGTICIDES-Continued}

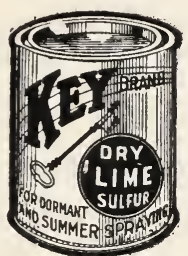

LIME SULPHUR, Dry. Used for all scale insects as a dormant spray. Has all the effectiveness of Liquid Lime Sulphur and is much easier to handle. $1 \mathrm{lb}$. makes from 4 to 10 gallons. Lb. 40 c., 5 lbs. $\$ 1.75,10$ lbs. $\$ 3.00,25$ lbs. $\$ 6.00,100 \mathrm{lbs}$. $\$ 18.00$.

MAG-O-TITE. For control of root maggot on Cabbage, Radish and other root crops. 1 lb. $50 \mathrm{c} ., 5 \mathrm{lb}$. $\$ 1.50,25$ lbs. $\$ 5.00,50$ lbs. $\$ 9.00$.

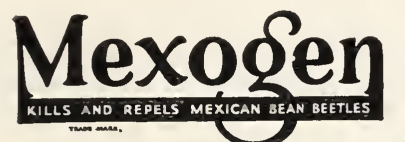

Kills and repels Mexican Bean Beetle, including the adult, larvae and eggs. $1 / 2$ pt. 75 c., qt. $\$ 2.00$, gal. $\$ 6.00$.

MO-LO. Poisoned tablets for moles and field mice. Box 25c.

NICO-FUME LIQUID. For spraying or fumigating Does not stain or injure the blooms. Lb. $\$ 2.25$, 4 lbs. $\$ 7.00,8$ lbs. $\$ 12.00$.

NICO-FUME PAPER. Extra strong tobacco paper for burning. 144 sheets $\$ 5.50,288$ sheets $\$ 9.50$.

NICO-FUME POWDER. A specially prepared tobacco powder fumigant to destroy aphis, thrips, etc., in greenhouses. 10-lb. can $\$ 7.50$.

NICOTINE SULPHATE "Black Leaf 40." For aphis, thrips, etc., 1 -oz. bottle $35 \mathrm{c} ., 1 / 2 \mathrm{lb}$. $\$ 1.25,2$ lbs. $\$ 3.75,10$ lbs. $\$ 12.00$.

PARA-DICHLORO-BENZINE. Krystal Gas. The best remedy for Peach tree borers. 1-lb. tin 75c.; 5 lbs. $\$ 3.50$.

PARIS GREEN. For potato bugs, etc. Lb. 60 c., 5 lbs. $\$ 2.75$.

POMO-GREEN. Useful for black spot and fungus diseases on Roses or other plants. 1 lb. $50 \mathrm{c}$., $5 \mathrm{lb}$. $\$ 2.00,25$ lb. $\$ 7.50$.

PYROX. Bowker's Paste. Kills all leaf-eating insects and prevents blights and fungous troubles, without injury to fruit or foliage. Sticks like paint and rain don't wash it off. Lb. 50 c., 5 lbs. $\$ 2.00$, 10 lbs. $\$ 3.50,25$ lbs. $\$ 7.50,50$ lbs. $\$ 12.00,100$ lbs. $\$ 20.00$.

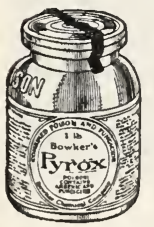

PYROX, Powdered. A dry form of Pyrox that is more convenient to handle. Can be used for dusting or mixed with water as a spray. It will keep indefinitely in containers. $1 \mathrm{lb}$. 65c., 5 lbs. $\$ 2.75,25$ lbs. $\$ 12.00,100 \mathrm{lbs}$. $\$ 30.00$.

RADIO BLIGHT SOAP. For blight, smut, red spider and fungoid diseases, use 1 lb. to 5 gals. water. Lb. $\$ 1.25$.

RED ARROW INSECT SPRAY. A Pyrethrum Spray that does not burn or stain the foliage or Howers of the tenderest plants. 1 oz. $35 \mathrm{c}, 1 / 4 \mathrm{pt}$. $\$ 1.00,1 / 2$ pt. $\$ 1.75$, qt. $\$ 6.00$, gal. $\$ 20.00$.

SCALECIDE. For San Jose scale and spraying all kinds of trees. Qt. 75c., 1 -gal. can $\$ 1.75,5$ gals. $\$ 6.50,30$ gals. $\$ 27.00,50$ gals. $\$ 38.00$.

SEMESAN. The well known plant disinfectant for rots, damping off, etc. 2 oz. $60 \mathrm{c} ., 8 \mathrm{oz} . \$ 1.60,1 \mathrm{lb}$. $\$ 2.75,5$ lbs. $\$ 13.00$

SLUG SHOT. Destroys all insects injurious to house and garden plants, vegetables and fruits of all kinds. 1 -lb. cartons $25 \mathrm{c}$., 5-lb. pkg. $75 \mathrm{c}$., 10 llbs. $\$ 1.20$, keg of 125 lbs. $\$ 13.00$.
SO-F YNE. A liquid soap used as a spreader in many Insecticides. 15 oz. 20c., qt. 50 c. gal. $\$ 1.50,5$ gals. $\$ 5.00$.

SNAROL. A new prepared meal for cutworms, slugs, snails, sow bugs and grasshoppers. Harmless to vegetation. 1-lb. carton 50c., 3 lbs. $\$ 1.00$, 15 lbs. $\$ 3.75,50$ lbs. $\$ 11.50$.

SULPHUR, Powdered. A staple preventive for mildew on Grapes, Roses, etc. Lb. 20c., $10 \mathrm{lbs}$. $\$ 1.50,25$ lbs, and

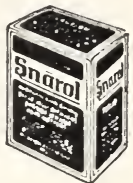
over 12c. per lb.

SULFOCIDE. A summer spray for Peaches and other fruits and mildew on flowers, etc. Gal. $\$ 3.00$, 5 gals. $\$ 8.75$.

TEROGEN. Used for destroying the spores of fungus diseases in the soil. It also acts as a fertilizer and preventative against black spot, aphides and beetles. 1 lb. 75 c., 2 lbs. $\$ 1.25,5$ lbs. $\$ 2.75,10$ lbs. $\$ 4.75,25$ lbs. $\$ 11.00,100$ lbs. $\$ 40.00$.

TREE TANGLEFOOT. A sticky substance applied directly to the bark to protect trees against climbing insect pests. $1 \mathrm{lb}$. will make a band 7 to 8 feet long. Lb. can 60c., 5 lbs. $\$ 2.75,10$ lbs. $\$ 5.25,20$ lbs. $\$ 10.00$.

TREE WOUND PAINT, Key Brand. Prevents decay. A penetrating antiseptic paint that is not affected by heat, cold or moisture. Does not peel, crack or get brittle. Stops trees bleeding and prevents decay. Qt. $\$ 1.20$, gal. $\$ 3.00,5$ gal. $\$ 13.00$.

TOBACCO DUST. Destroys Rose lice, Cabbage and Turnip fleas, etc. Lb. 15 c., 5 lbs. 60 c., 10 lbs. $\$ 1.00$, 100 lbs. $\$ 4.50$.

TOBACCO DUST FOR FUMIGATING. Used for burning in place of stems. 50 lbs. $\$ 3.50,100$ lbs. $\$ 6.00$.

TOBAKO-FUMES. A Nicotine fumigator for greenhouses and frames. 25 lbs. $\$ 7.50$.

TOBACCO STEMS FOR FUMIGATING. Clean and free from rubbish. In bales of 100 lbs. $\$ 3.50$.

VOLCK. A scientific insecticide for greenhouse and garden use. Effective against scale, mealy bug, red spider, aphides, thrips and flies. Qt. $\$ 1.00$, gal. $\$ 3.00$, 5 gals. $\$ 12.50$.

WHALE Or FISH OIL SOAP. Kills lice and sucking insects on trees, shrubs, plants, vines and Roses. Lb. 40 c., 5 lbs. $\$ 1.70$, 25 lbs. $\$ 7.00$.

WORM ERADICATOR. Used for killing worms at the roots of trees, plants and putting greens. 5-gal. kegs $\$ 20.00,10$ gals. $\$ 35.00$.

WILSON'S AWINC. For red spider, thrip, aphis, etc. Gal. $\$ 10.00$.

WILSON'S O. K. PLANT SPRAY. A powerful yet harmless and efficient insecticide in concentrated form. Useful for outside and greenhouse spraying, $1 / 2$ pt. 40 c., qt. $\$ 1.00$, gal. $\$ 3.00,5$ gals. $\$ 12.00$. 10 gals. $\$ 20.00,25$ gals. $\$ 50.00,50$ gals. $\$ 90.00$.

WILSON'S SCALE-O. The complete dormant spray for scale, bud moth, pear psylla, canker, etc. Gal. $\$ 2.00,5$ gals. $\$ 9.00,10$ gals. $\$ 15.00,30$ gals. $\$ 33.00$, 50 gals. $\$ 50.00$.

X. L. ALL INSECTICIDE. A well-known English insecticide. Original gallon cans, each $\$ 10.00$.

X.-L.-ALL VAPORIZING COMPOUND. The most effectual method of fumigating greenhouses. Bottle sufficient for $10,000 \mathrm{cu}$. ft., No. 3, $\$ 3.00$; bottle sufficient for $20,000 \mathrm{cu}$. ft., No. 2, $\$ 5.00$. Fumigators for above, $\$ 2.00$ each.

ZENKE'S FUNGICIDE. Effective remedy for leaf spot, rust, mildew and black rot. Gal. \$4.00. 


\section{BONE MEAL}

This bone meal is made from the best quality of bone and finely pulverized. Valuable for top dressing lawns, Ruses, flowers and vegetables. Apply about 1,000 lbs. per acre or $5 \mathrm{lbs}$. to $100 \mathrm{sq}$. ft. $5 \mathrm{lbs}$. $50 \mathrm{c}$., 10 lbs. 90 c., 50 lbs. $\$ 2.50,100$ lbs. $\$ 4.50,200$ lbs. $\$ 8.00$, ton $\$ 65.00$.

\section{PURE RAW BONE}

A coarser ground grade of bone than the Bone Meal. 100 lbs. $\$ 5.00$, ton $\$ 70.00$.

\section{BONE, COARSE}

A coarse grade, well adapted for Grape vine and Rose borders. 100 lbs. $\$ 7.00$.

\section{BLOOD AND BONE}

It is of value for garden crops, fruit trees, Grape vines, etc. For garden crops, drill in 300 to $500 \mathrm{lbs}$. per acre. $50 \mathrm{lbs}$. $\$ 3.50,100$ lbs. $\$ 6.50$.

\section{BON ARBOR}

This plant food has a wonderful effect on plant life. It is good for flowering plants of all kinds, vegetables, fruits and shade trees, lawn, etc. 5-lb. pkg. $\$ 2.50,50$ lbs. $\$ 18.00$

\section{CARNATION FOOD}

This Carnation food is not a chemical stimulant, but an evenly balanced ration to produce a natural growth, vitality and productiveness. $100-\mathrm{lb}$. bag $\$ 8.00$.

\section{CATTLE MANURE (SHREDDED)}

A natural fertilizer for garden crops and lawns 100 lbs. $\$ 4.50$, ton $\$ 70.00$.

\section{CHARCOAI}

Useful for sweetening sour soils or mixing with potting soil. Coarse or fine. 100 lbs. $\$ 5.50$. Very coarse, per bag $\$ 5.00$.

\section{CLAY'S FERTILIZER}

Highly recommended by leading horticulturists in the cultivation of flowers, fruits and vegetables for exhibition, etc. 56 lbs. $\$ 7.50,112$ lbs. $\$ 14.00$.

\section{DAHLIA FERTILIZER}

A brand of fertilizer containing a large percentage of Phosphoric Acid and Potash, the requirements for growing large Dahlias. $100 \mathrm{lb}$. bag $\$ 4.00$.

\section{DRICONURE}

A combination of dry Cow Manure and Peat Moss suitable for Lawns, Borders and Mulching. Free from any objectionable odor. A $50 \mathrm{lb}$. bag contains about 3 bushels of manure. $50 \mathrm{lb}$. bags $\$ 3.00,20$ bags for $\$ 40.00$.

\section{DRIED BLOOD}

For top dressing, mixing with the soil and applying in liquid form, it is one of the best and safest nitrogenous fertilizers. 100 lbs. $\$ 9.00$.

\section{FLORANID (UREA)}

An organic nitrogen fertilizer for flowers, fruits, vegetables or lawns. A quick acting stimulant containing $46 \%$ of available nitrogen. $1 \mathrm{lb}$. tin 50c., 10 lbs. $\$ 3.00,25$ lbs. $\$ 5.00$, 143 lbs. $\$ 16.00$

\section{FERTILIS TABLETS}

A concentrated fertilizer in tablet form', easy to use, clean and odorless. 50 tablets $25 \mathrm{c}$., 1,000 tablets $\$ 3.00$.

\section{HUMUS}

Valuable for all garden purposes, including lawn and greenhouse plants. $100-\mathrm{lb}$. bag $\$ 2.00,500 \mathrm{lbs}$. in bags $\$ 9.00$, ton in bags $\$ 25.00$, f.o.b. Warbasse, N. J
LIME, HYDRATED

For correcting acids in soils use $10 \mathrm{lbs}$. for $200 \mathrm{sq}$. $\mathrm{ft}$. of ground. 5 lbs. $30 \mathrm{c} ., 10 \mathrm{lbs}$. $50 \mathrm{c} ., 50 \mathrm{lbs}$. $\$ 1.50$, 100 lbs. $\$ 2.25$, ton $\$ 35.00$.

\section{LILY FOOD}

A specially prepared stimulant for Lilies. 5 lbs. $\$ 1.50$, 25 lbs. $\$ 6.00,100$ lbs. $\$ 15.00$.

\section{LIMESTONE, GROUND}

A very finely screened ground Limestone. Useful for sour soils and to correct improper conditions of the soil. Ton $\$ 10.00$, f.o.b. West Stockbridge, Mass. or Lime Crest, N. J.

\section{LOMA}

For lawns, flowering plants and vegetables. A scientifically prepared plant food that gives you startling results. $1 \mathrm{lb} .25 \mathrm{c} ., 5 \mathrm{lbs} .50 \mathrm{c} ., 10 \mathrm{lbs} .85 \mathrm{c} ., 25 \mathrm{lbs} . \$ 1.75$, 50 lbs. $\$ 3.25,100$ lbs. $\$ 6.00$.

\section{NITRATE OF SODA}

It is valuable for grain, Corn, Beets, Potatoes, grasses, Peas, Beans, Clover, etc. Being extremely soluble it should not be applied until the plants are above ground. $1 \mathrm{lb}$. $15 \mathrm{c} ., 5$ lbs. 60c., 10 lbs. $\$ 1.00$, 50 lbs. $\$ 3.50,100$ lbs. $\$ 6.00$.

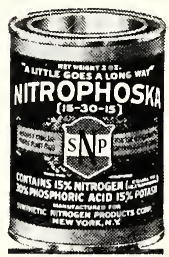

\section{NITROPHOSKA}

A new, complete concentrated fertilizer adapted to all crops, fruits and lawns. It is water-soluble and is completely available. It contains $15 \%$ Nitrogen, $30 \%$ Phosphoric Acid and $15 \%$ Potash. A total plant food of $60 \%$ or three times the value of a 6-10-5 fertilizer. $2 \mathrm{oz}$. 10 c., 1 lb. $50 \mathrm{c}, 10 \mathrm{lb} . \$ 3.00,25 \mathrm{lbs}$. $\$ 5.00,100$ lbs. $\$ 8.00$.

\section{PULVERIZED SHEEP MANURE}

A rich, pure and natural manure. Excellent as a top dressing for lawns, and mixing with the soil for greenhouse plants-one part manure and six parts soil. 5 -lb. pkg. 50c., 10 lbs. 90c., 50 lbs. $\$ 2.25,100$ lbs. $\$ 4.00$, ton $\$ 65.00$.

\section{ROSE FOOD}

Contains just what is needed for the Rose. It is a properly, balanced, organic Rose food and entirely takes the place of bone meal, sheep manure or tankage. It stimulates the vitality of the plant and produces a larger crop of more perfect blooms. 100 lbs. $\$ 8.00$.

\section{SALT, AGRICULTURAL}

Used for top dressing Asparagus beds, etc. $100 \mathrm{lbs}$ $\$ 2.00$.

\section{SMITH'S CHR YSANTHEMUM MANURE}

For Mums, Roses, Carnations, Sweet Peas and other greenhouse plants. 50 -lb. bags $\$ 5.50$.

\section{SOOT, IMPORTED SCOTCH}

A fertilizer for stimulating growth and giving a rich, dark foliage; also an excellent remedy against slugs, grubs and cutworms. Bags of 100 to $150 \mathrm{lbs}$. 7c. per lb.

\section{STIM-U-PLANT}

A plant food in tablet form for fertilizing all kinds of growing plants in the home or garden. Tablets should be used in the soil or dissolved in water and applied to the soil. 30 tablets $25 \mathrm{c}$., 100 tablets $75 \mathrm{c}$., 1000 for $\$ 3.50$.

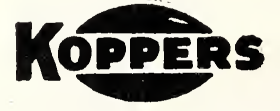

SULPHATE OF AMMONIA

For lawns, home gardens and fruits. This brand is especially prepared for top dressing, is soluble and quickly available. It feeds the grass and starves the weeds. 5 lbs. 60 c., 10 lbs. $\$ 1.15,25$ lbs. $\$ 2.25,100 \mathrm{lbs} . \$ 6 \cdot 00$. 


\section{FERTILIZERS-Continued}

\section{SULPHATE OF ALUMINA}

Used for Rhododendrons, Azaleas, Laurel and other shrubs that require an acid soil. $200 \mathrm{lb}$. bbl. $\$ 7.50$, ton $\$ 70.00$.

\section{THOMSON'S TOP DRESSING MANURE}

A special English top dressing manure to be used as a stimulant during the growing season for pot plants and benches. 28 lbs. $\$ 4.50,56$ lbs. $\$ 8.00$.

\section{THOMSON'S VINE AND PLANT MANURE}

A well-known English fertilizer. Valuable for Grape vines and fruit trees grown under glass and outside garden purposes. 56 lbs. $\$ 6.50,112$ lbs. $\$ 12.00$.

\section{TOBACCO FERTILIZER}

A double action product-a natural fertilizer and insecticide. Controls aphis, cutworms and all softbodied insects. 100 -lb. bag $\$ 3.00$, ton $\$ 45.00$.

\section{AMERICAN AGRICULTURAL "AGRICO" FERTILIZER FOR CORN}

Suitable for Corn, garden crops, small fruits, etc. Ammonia, 3 per cent; available phosphoric acid, 10 per cent; potash, 6 per cent. $100 \mathrm{lbs}$. $\$ 3.00$, ton $\$ 50.00$.

"AGRICO" FERTILIZER FOR POTATOES

Suitable for Potatoes, root crops and garden truck. Ammonia, 4 per cent available phosphoric acid, 8 per cent; potash, 6 per cent. 100 lbs. $\$ 3.50$, ton $\$ 55.00$.

\section{"AGRICO"' FERTILIZER FOR TRUCK}

A general fertilizer for farm and garden crops and Potatoes. Ammonia, 5 per cent; available phosphoric acid, 10 per cent; potash, 5 per cent. 100 lbs. $\$ 3.50$, ton $\$ 60.00$.
TREE FERTILIZER

Used in the Spring for fertilizing trees. It is best applied by making holes with a crowbar to reach the roots. Bag of 167 lbs. $\$ 6.00$, ton $\$ 70.00$.

\section{VIGORO (SWIFT'S)}

A specially prepared plant food for lawns, flowers, shrubbery and trees. Vigoro has no unpleasant odor and can be conveniently applied at any time. 5 lbs. 60 c., $25 \mathrm{lbs} . \$ 2.00$ 50 lbs. $\$ 3.50,100$ lbs. $\$ 6.00$.

\section{WOOD ASHES}

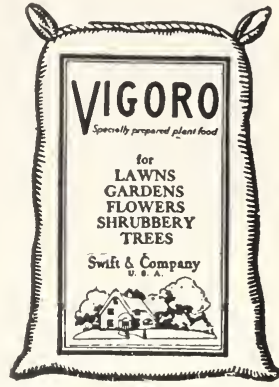

For lawns, gardens and fruits, hardwood ashes are unequaled; 1 to 2 tons per acre. $100 \mathrm{lbs}$. \$3.00, ton $\$ 50.00$.

All the above fertilizers are offered, f.o.b. factory at Carteret, N. J.

\section{ACID PHOSPHATE}

For mixing with other fertilizers to increase the phosphoric acid content. For farm crops, 16 per cent available phosphoric acid. 200 lbs. $\$ 3.00$, ton $\$ 25.00$. MURIATE OF POTASH

For Potatoes, Corn, grain, etc. Analysis, 48 per cent K 20. 100 lbs. $\$ 5.00,200$ lbs. $\$ 9.00$.

\section{SULPHATE OF AMMONIA}

Used for top dressing crops. Ammonia, 24 per cent nitrogen, 16 per cent. 100 lbs. $\$ 6.00,200$ lbs. $\$ 11.00$ SULPHATE OF POTASH

Used for root and grain crops. Analysis 48 per cent. K 20. 100 lbs. $\$ 6.00,200$ lbs. $\$ 11.00$.

\section{“ADCO" ARTIFICIAL MANURE}

A simple preparation for making stable manure from garden refuse, grass clippings, weeds, leaves, vegetable tops, etc. It contains nothing injurious to health or animal life, is odorless and weed free.

Refuse can be piled in a heap or pit and with "Adco" added to the refuse, causing the bacteria to rot and make manure. Fifty pounds of Adco makes a ton of well rotted manure.

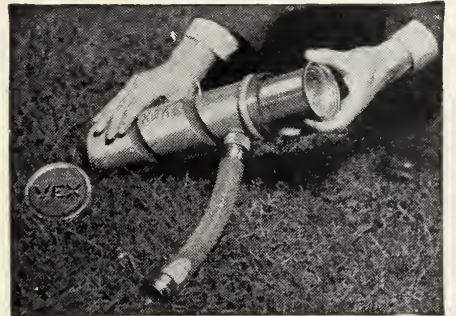

Automatic Lawn-Vex

Adco, in 25-lb. bags, enough for 12 wheelbarrows of waste or $1 / 2$ ton of manure. Each $\$ 2.00$.

Adco, in 150-lb. bags, enough to make 3 tons manure. Each $\$ 10.50$, f.o.b. Warners, N. J

\section{AUTOMATIC LAWN-VEX}

This new and simple device makes it possible for you to fertilize your lawn as you sprinkle. The Vex is an enameled brass cylinder 12 in. long and 3 in. in diameter. It has two hose connections. One for the faucet, the other for the water to pass out through the hose charged with the lawn fertilizer The cylinder contains a cartridge of Lawn Vex sufficient for a plot $4(1 \times 60 \mathrm{ft}$. Vex Container and Cartridge, \$7.50. Extra Cartridges $\$ 2.00$ each.

\section{WEED KILLERS}

ATLACIDE WEED KILLER (Non-poisonous). An effective Weed Killer in powder form which can be dusted on weeds and grasses. $1 \mathrm{lb}$. duster kills $100 \mathrm{sq}$. feet of weeds. Each 50c., 31/2 lbs. duster each $\$ 1.50,50-1 \mathrm{~b}$. drum of powder $\$ 10.00$.

KEY WEED KILLER. Destroys weeds in paths, roads and gutters. Dilute one part Weed Killer tu forty parts water. Does not discolor cement or stone. Qt. 75c., gal. $\$ 2.00,5$ gals. $\$ 7.50,30$ gals. $\$ 35.00,50$ gals. $\$ 50.00$.

HERBICIDE WEED KILLER. A liquid preparation for the killing of every kind on roadways, paths, gutters, tennis courts. One gal. makes 40 gals. liquid. Gal. $\$ 2.00,5$ gals. $\$ 7.50,10$ gals. $\$ 14.00,30$ gals. $\$ 35.00,50$ gals. $\$ 50.00$.

WILSON'S WEED KILLER. Kills all plant growth. It is a clean, odorless highly concentrated liquid. When diluted with water-1 part Weed Killer to 40 or 50 parts of water, it is a sure death to all weeds. Qt. 75c., gal. $\$ 2.00$, 5 gals. $\$ 8.00,10$ gals. $\$ 15.00,50$-gal. drum $\$ 50.00$.

“PURFECK"' CHICKWEED ELIMINATOR

This preparation is a sure method of eliminating chickweed in lawns. The liquid is added to water and sprayed on patches of chickweed in the lawn. Add two parts of water to one of Purfeck when using. Qt. $75 \mathrm{c}$, gal. $\$ 2.00,5$ gals. $\$ 9.00$.
CASIM CRAB GRASS CONTROL

Casim is best applied in September as a top dressing at the rate of $100 \mathrm{lbs}$. per 150 sq. feet. It will not burn the grass and one application is all that is required. 100 lbs. $\$ 2.75,500$ lbs. $\$ 12.00$, ton $\$ 44.00$, F.O.B. Newark, N. J. 


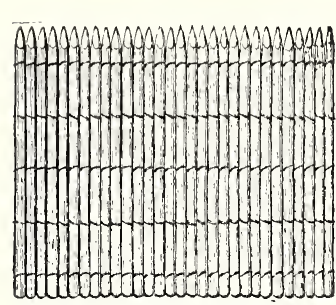

\section{$D U B O I S$}

WOVEN WOOD FENCE

\section{DUBOIS WOVEN WOOD FENGE}

It is made of split, live chestnut saplings and woven together with rust proof heavy wire. It is shipped in $5 \mathrm{ft}$. sections and is easily handled. $18 \mathrm{in.} \mathrm{high,} \mathrm{per} \mathrm{foot.}$ $3 \mathrm{ft} .10 \mathrm{in}$. high, per foot.

$4 \mathrm{ft} .11 \mathrm{in}$. high, per foot.

$6 \mathrm{ft} .6 \mathrm{in}$. high, per foot. .

$8 \mathrm{ft}$. high, per foot.

$10 \mathrm{ft}$. high, per foot.

$\$ 0.75$

1.45

1.65

1.95

2.45

2.85

\section{GLEFT CHESTNUT FENGING}

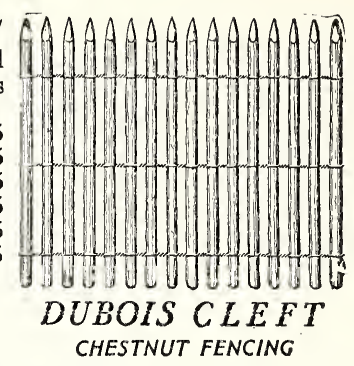

This Fence is similar to the above only that the saplings are spaced one inch apart.

$3 \mathrm{ft} .10 \mathrm{in}$. high, per foot $65 \mathrm{c}$.

$4 \mathrm{ft} .11 \mathrm{in}$. high, per foot $80 \mathrm{c}$.

$6 \mathrm{ft} .6 \mathrm{in}$. high, per foot $\$ 1.10$

Gates can be furnished for either of the above fencing. Illustrated booklet mailed on request.

\section{PORTABLE WOOD HURDLES}

They are suitable for inclosing and dividing lots or plots to suit any requirement on a gentleman's country seat, or for farmers' use in general Made with split chestnut. They measure $8 \mathrm{ft}$. 3 in. in length.

With 4 bars, suitable for horses and cows, per $100 \ldots \ldots \ldots \ldots \ldots 225.00$

With 5 bars, suitable for sheep, per $100 \ldots \ldots \ldots \ldots \ldots \ldots \ldots 235.00$

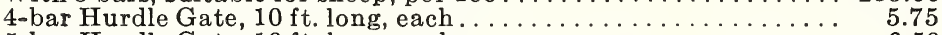

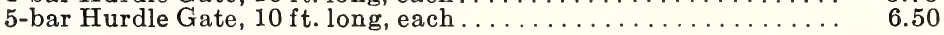

Prices subject to change. F.O.B. Dutchess Co., N. Y.

\section{REEVESHIRE ENGLISH TYPE HURDLES}

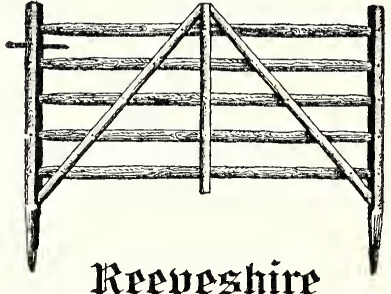

liveweshime

HURDLE FENCE

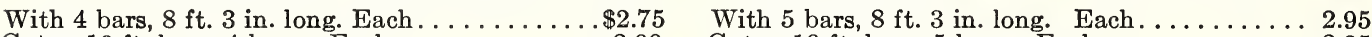

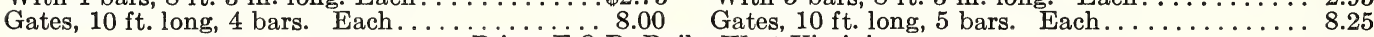
Prices F.O.B. Rails, West Virginia.

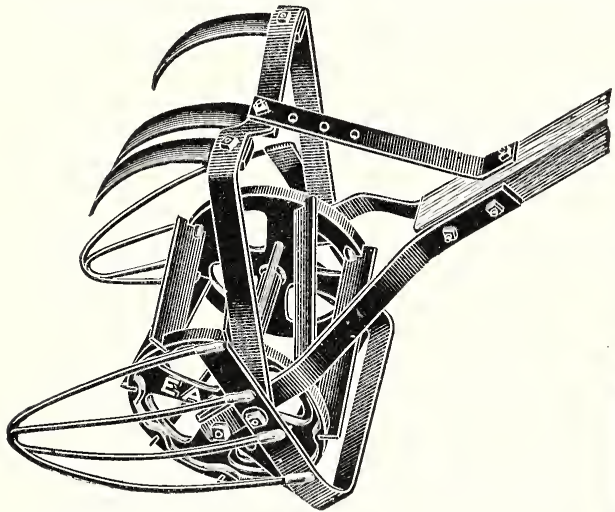

\section{EASY GARDEN GULTIVATOR}

This cultivator is very useful for cutting weeds and pulverizing the crusted surface of the soil. The revolving blades operate against the cutter bar to chop up weeds and put the soil in perfect condition. By reversing the position you have a cultivator with three shovel plows for deep cultivation. Each machine is fitted with the improved leaf lifter which can be used in either position. The underground knife is $8 \frac{1}{2}$ inches wide. Standard Model. Each $\$ 8.50$.

The Perfect is similar to the Standard only that the under cutter blade is $101 / 2$ inches wide. Each $\$ 9.00$.

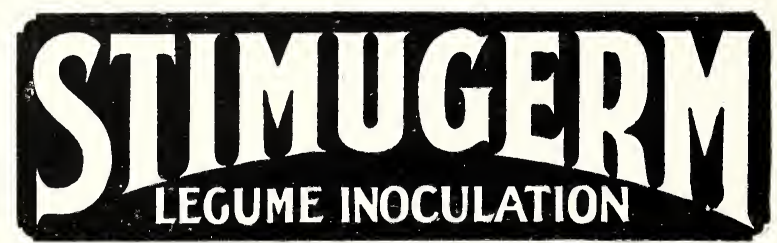

The Best Inoculation for All Legume Seeds Means Better Crops, Better Soils, Less Fertilizer Expense.

Alfalfa, Clovers, Soybeans, Cowpeas, Vetch, Peanuts, all thrive into bumper crops when properly inoculated with STIMUGERM pure-bred cultures.

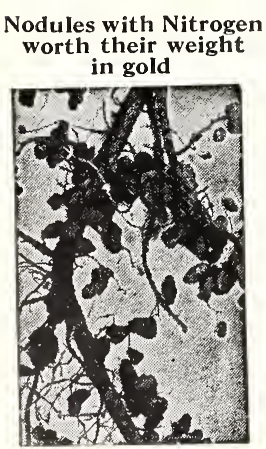

WHAT STIMUGERM IS

STIMUGERM is a culture of bacteria especially selected and bred for maximum vitality and ability to form nodules and take nitrogen from the air. They are carried in a sterilized, finely ground, porous humus medium which acts as a natural home for them-keeps them fresh, active and vigorous. EVERY CAN IS DATED and guaranteed for one year.

\section{PRICES ARE LOW}

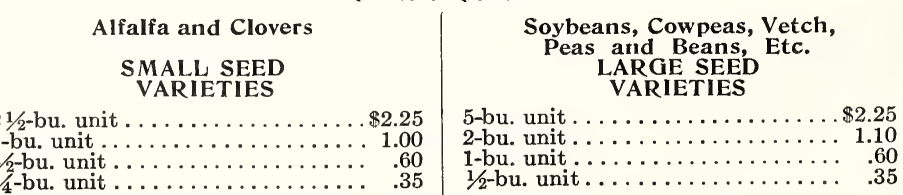

Garden Size for Peas, Beans, Lima Beans and Sweet Peas, 25c.

When ordering, be sure to state what crops you wish to inoculate, also number of bushels you will sow.

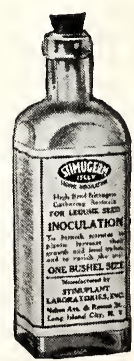




\section{INFORMATION of INTEREST to EXHIBITORS at FLOWER SHOWS}

For the guidance of exhibitors at Flower Shows; Horticultural Exhibits; Country Fairs, etc.; we have compiled the following "POINT SCHEDULES" which are now universally used in the judging of the various exhibits at such shows.

\section{CARNATIONS}

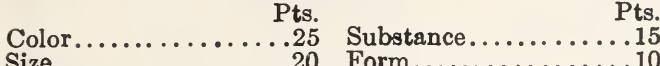

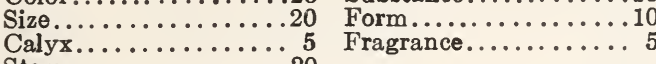

Stem...............20

\section{GHR YSANTHEMUMS}

Pts.

Color.

Pts. Substance...........20

Form

\section{DAHLIAS}

Pts.

Color.................20

Substance..............

\section{GLADIOLUS}

The following schedule of points is frequently used in judging exhibits of gladioli.

Color

Pts.

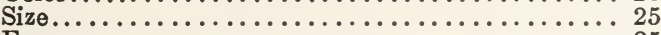

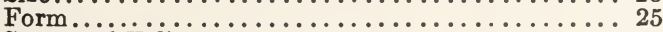

Stem and Foliage................... 15

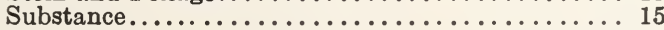

IRIS

Highest Rating 10

Pts.

Stalk and Height...... 1 Texture and Substance. 2 Number of Branches... I Color................ 1

Number of Buds...... 1 Fragrance...........

Size and Carriage...... 2

\section{PEONIES}

The following points of merit are suggested as a basis in judging Peonies.

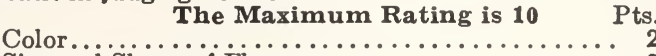

Size and Shape of Flower................ 2

Texture and Substance................... 2

Carriage......................... 1

Stem and Foliage...................11/2

Fragrance.............................

ROSES (Cut Flowers) Pts.

Size............15 Form............15

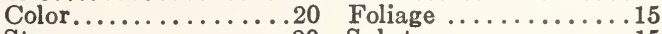

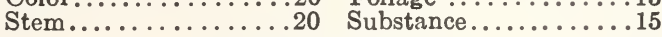

SWEET PEAS Pts.

Quality of Bloom....................6 60

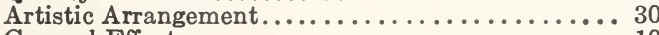

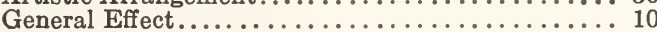

The Sweet Pea or other foliage can be used with the flowers unattached and flower stems must be free of wood, unless otherwise specified. Wiring of flowers or stems will be allowed on table decorations only.

\section{SCALE OF POINTS BY WHICH PLANT EXHIBITS MAY BE JUDGED}

No. 1 -Single Specimen Foliage Plants Pts. Size of Plant.......................... 25

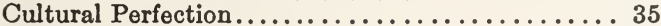

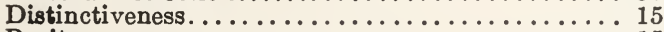

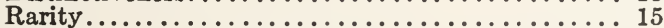

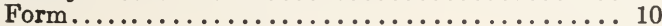

$\frac{100}{100}$

No. 2-Single Specimen Flowering Plants Pts. Size of Plant........20 Floriferousness........15 Cultural Perfection.....35 Color..................10

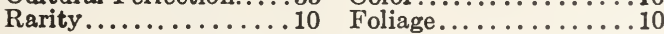

No. 3-Groups of Foliage Plants Pts.

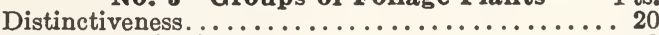

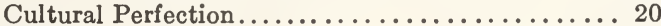

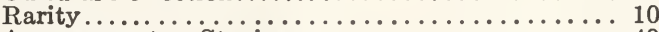

Arrangement or Staging...................... 40

Color Effect.......................... 10

No. 4-Groups of Flowering Plants Pts. Accessories..........10 Arrangement........40 Rarity....................... Color Harmony

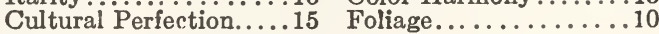

\section{SGALE OF POINTS FOR JUDGING ARTISTIC ARRANGEMENTS}

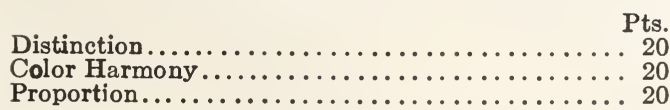

Relation of Flower to Receptacle

Pts.

Perfection of Arrangement.

\section{SGALE OF POINTS TO BE USED IN JUDGING VEGETABLES}

No. to form a

dish or to be exhibited in collection $\mathrm{Pts}$.

Artichoke, Globe....6.....100

Artichoke, Jerusalem.12..... 50

Asparagus. ........25..... 100

Beans, string, green...40 pods. 100

Beans, string, yellow.40 pods. 80

Beans, Lima.......24 pods. 100

Beans, runner.......24 pods. 75

Beets, long.........6.... 90

Beets, round .............. 6.90

Cauliflower................. 300

Cardoon............... $3 . \ldots 0$

Cabbage............... 50

Cabbage, Savoy...... 3..... 50

Cabbage, red............... 30

Carrot, long........ 6..... 90

Carrot, short.............. 65

No. to form a
dish or to be
exhibited in
collection

Peppers, red, green or

No. to form a dish or to be exhibited in red and green.... 9....65

Potatoes................. 9. 100

Pumpkin.................. 25

Radishes $\ldots \ldots \ldots 35$

Rhubarb................ 60

Salsify.................... 45

Scorzonera........12,...45

Spinach................ 35

Sprouts, Brussels. . . .40.... 75

Squash..........2.... 25

Shallots..........24..... 25

Tomatoes.....................

Turnip..........6....40

Vegetable Marrow ... 2.... 25

Arrangement............. 150 


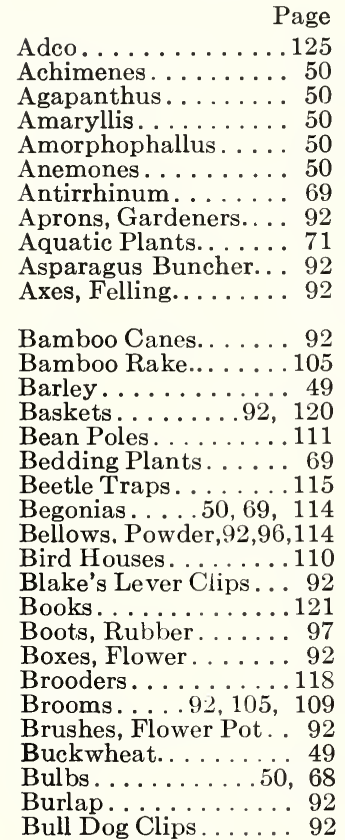

Caladiums

Callas.

50

Cannas.......51, 69

Carnations . . . . . 69, 70

Carnation Bands . . . . 92

Carnation Staples. . . . 92

Carnation Supports.. . 92

Carts, Leaf and Barrel, 101

Celery Bleachers. . 92, 115

Cel-O-Glass . . . . . . . . 92

Cinnamon Vines. . . . . 51

Chrysanthemums...70, 74

Clovers...........4 47

Corn, Field. . . . . . . . . . 49

Corn Planter. . . . . 92, 103

Cotton Batting. . . . . . 92

Cork Bark. . . . . . . . . 92

Cow Peas. . . . . . . . 49

Cucumber Gilasses. . . . . 951

Cultivators, 104, 105, 126

Cutworm Bands. . . . . . 92

Dahlias......... 54-59

Dandelion Rake. . . . . 105

Dibbles........... 92

Dirt Bands . . . . . .92, 100

Dog Biscuits. . . . . . . . 118

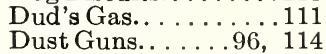

Edgers, Grass, 95, 101, 110

Evergreens. . . . . . . 87

Egg Boxes..

119

Farm Seeds.

49

Ferguson's Sprayer... 105

Fertilizers. 124, 125

Fertilizer Distributor. 109

Fertex Pots......... 93

Flats, Greenhouse.... 93

Florist's Gum. . . . . . . 99 93

Flower Guard. . . . . . . . 111

Flower Pots. . . . . . . . . 93

Flower Holders. . . . . . . 111

Flower Pot Stands. . . . 102
Page

Flower Seeds.. . . . . . 1-26

Fruit Trees. . . . . . . 89-91

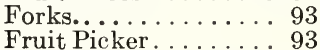

93

Fumigating Materials

Fumigators.

122,123

Garden Lines. .

Gladiolus...

Glass Cloth.

Glass Cutters

93

Glasses, Magnifying

93
$0-63$

Glazing Points .

93

Gloxinias. .

Gloves, Gardening.

Grafting Wax.

Grapes...

Grape Bags.

Grass Catchers.

Grass Edging Knives.

Grasses........46-48

Grass Hooks.

Greenhouse Plants. . . 70

Grindstones .

Hammers.

Hampers.

Hand Cart

Harrows.

Hatchets

Hedge Plants

Hedge Trimmer.

Herbs .

Hoes, Garden.

Horse Boots. .

Hose, Garden.

Hose Bands. . .

Hose Clamps.

Hose Couplings.

Hose Connections .

Hose Holder.

Hose Hydrant Attachment.

Hose Menders.

Hose Nozzles.

Hose, Rubber.

Hose Reels.

Hose Washers.

Hot-kaps. .

Humus. . . .

Hurdles.

Hyacinth Stakes

Hyacinthus.

Hydrangeas. .

Incinerators

Incubators

Insecticides.

Iris, Japanese. .

\section{4}

94
91
9

103

45
94

94

.94, 109

94
94

94

94

94

94

smene..

Kneeling Pads

Knives, Asparagus. . 92-95

Knives, Budding .

Knives, Pruning.

Labels, Garden .

Ladies' Tool Sets .

Lawn Grass .

Lawn

ener.........95,

Lawn Rollers

95,111

Lawn Seeders. . . . . . . 103

Lawn Sprinklers. 116, 117

Lawn Sweepers. . . . . 101

Lawn Trimmer.

Leafmold..... .

Leg Bands.
Lily Bulbs.

Page

.64-68

Madeira Vine....... 52

Mastica..........995

Mattocks.........999 95

Mats, Hotbed. . . . . . 95 95

Melon Nets..... . . . . 95

Millet. . . ........ 49

Mills, Grinding. . . . . 118

Mole Traps........ 96

Molo............ 96

Montbretias... . . . . . . 52
Moss, Sphagnum, etc. 96

Mulch Paper........ 96

Novelties... . . . . . . 2-3

Nails, Wall.

Netting, Bird

- 96

Nozzles. . . . . . . . . 94

Oat Sprouter.

Oats. .

118

Oil Cans.

Oxalis.

96
5

Paper,Tissue and Wax 96

Peas, Field........ 49

Peat Moss . . . . . . . . . .

ted........... 96

Pencils, Garden. . . . . 96

Perennial Plants. . .72-78

Picks . ........ . . . . . . . 96

Plant Guards . . . . . . . 96

Plant Protectors. .96, 105

Plant Stakes........ 96

Plant Stakes, Wire... . 96

Plant Supports . . .96, 110

Pliers........... 96

Plows. . . . . . 104, 119

Poison Stations. . . . . . 115
Post Hole Digger. . . 96

Post Hole Digger. . . . . 96

Potato Hooks. . . . . . . 96

Pot Hangers. . . . . . . 96

Poultry Supplies.118, 119

Powder Duster . . .96, 114

Protecting Cloth . . . . . 96

Pruners, Tree. . . . .96, 97

Pruning Shears. . . . 97-98

Pumps, Spray. . . 112-114

Pump, Kinney . . . . . . 97

Puttium.......... 97

Putty Bulbs. . . . . . 97

...... 97

Raffia Tape ........ 97

Rakes........97, 105

Rape...

Rat Killer............ 115

Refuse Burners. . 101, 110

Refuse Receptacles . . . 110

Rifles, Emery. . . . . . . 97

Rock Plants. . . . . . . 79

Roses.......... 81-83

Rubber Boots. . . . . . . 97

Rustic Baskets. . . . . . 120

Rye........... 49

Sash, Hotbed.

- 97

Saucers, Pot........ 93

Saws, Pruning, etc. . . 97

Saw Files. . . . . . . . . 97

Scissors, Grape, etc.. . 97

Scythes........... 97

Scythe Stones.

97
104

Seeders......98, 103, 104

Seedling Pricker... . . . . 98

Semesan . . . . . . . 123

Page

Shading, Greenhouse.. 98

Shears, Border. . . . . 9 98

Shears, Grass. . . . . . . 998

Shears, Hedge. . . . . . . 98

Shears, Lopping . . . 96, 97

Shears, Pruning. . . . . . 98

Sharpener, Tool......998 98

Shreds, Garden . . . . . . 98

Shovels.......... 998

Shrubs, Hara dy . . . . . 84-86

Sieves, Wire.........98 98

Signs. . . . . . . . . . 98

Smilax Twine......... 98

Silkaline..........998 98

Soap Dispenser. . . . . . 98

Sod Perforator . . . . . . . 109

Sod Tampers . . . . . . . 109

Soil Tester. . . . . . 98, 111

Spades. . . . . . . . . 98

Spiraea........53, 72

Sprayers.......112-114

Sprinklers, Rubber . . 99

Sprinklers. . 99, 116, 117

Steel Wool Pads...... . 99

Stick, Match....... 99

Stimugerm.........126

Styptic..........999

Sulphur Vaporizer. . . . 93

Sundials..........999

Sweet Peas........24, 25

Syringes.......... 99

Tan Bark . . . . . . . . 99

Tarred Felt Discs. . . . . 99

Tennis Court Broom. 109

Tennis Nets. . . . . . . . 99

Tennis Marker... . . . . 99

Thermometers........ 99

Tigridias.........5 53

Tinfoil............ 99

Tomato Stakes........ 111

Tomato Supports..... 99

Tool Sets........... 99

Toothpicks, Wired.... 99

Torches............ 99

Tractors.......... 108

Trained Fruit Trees. . . 89

Tree Climbers. . . . . . 99

Tree Guards. . . . . . . . 99

Tree Scrapers. . . . . . . . 99

Tree Sprinkler . . . . . . 116

Trees, Fruit. . . . . . 89-91

Trees, Ornamental. . 87-88

Trellis...........111

Tritoma..........5 53

Trowels, Garden . . . . . 99

Truck and Barrel. . . . . 101

Tuberoses......... 53

Tubs, Plant. . . . . . . 102

Turfing Irons . . . . . . . 99

Twine........... 99

Vases, Flower....999, 100

Vegetable Seeds... . 28-45

Vetches..........4 49

Vines and Climbers... 80

Violets........... 70

Water Lilies. . . . . . . 71

Watering Pots......... 102

Weather Vanes. . . . . . . . 100

Weed Killers. . . . . . . . . 125 


\section{W. E. MARSHALL \& CO. 150 West 23rd St., New York}

Date Forwarded by $\left(\begin{array}{l}\text { State whether wanted by } \\ \text { Mall, Espress or Freight }\end{array}\right)$

Name

Gardener's Name.

Post Office

Express Office ( $\left(\begin{array}{l}\text { If different } \\ \text { irom P. O. }\end{array}\right)$

County.

State.

\section{Amount Enclosed \\ (State whether P. O. Order, \\ Express, Money Order. Uraft,
Postage Stamps or Cash}

\section{$\$$}

We give no warranty, express or implied, as to description, purity, productiveness, or any other matter of any seeds, plants or bulbs we sell, and we will not be in any way responsible for them. If the purchsser does not accept the goods on these terms, they are at once to be returned.

W. E. MARSHALL \& CO., Inc.

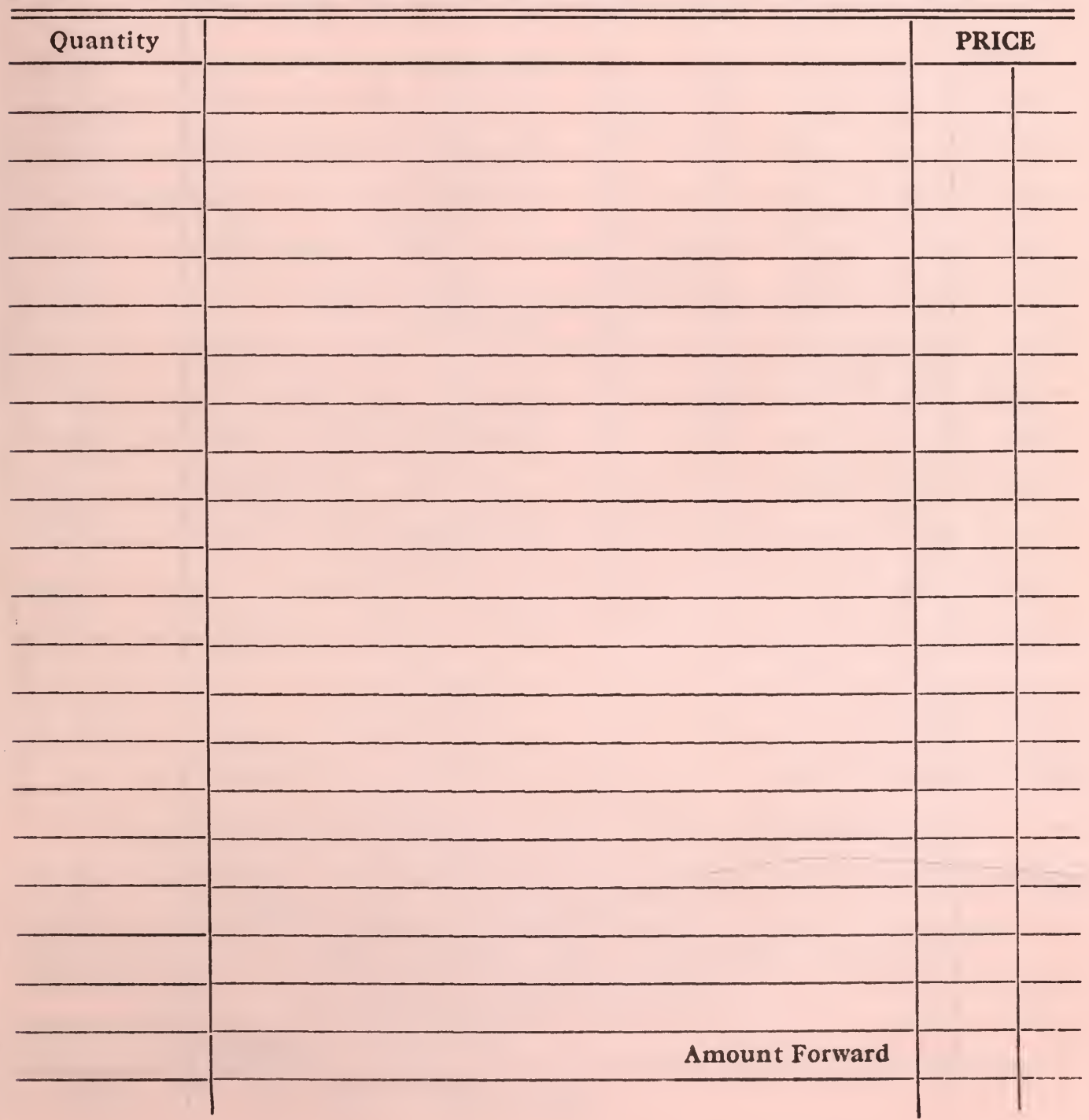




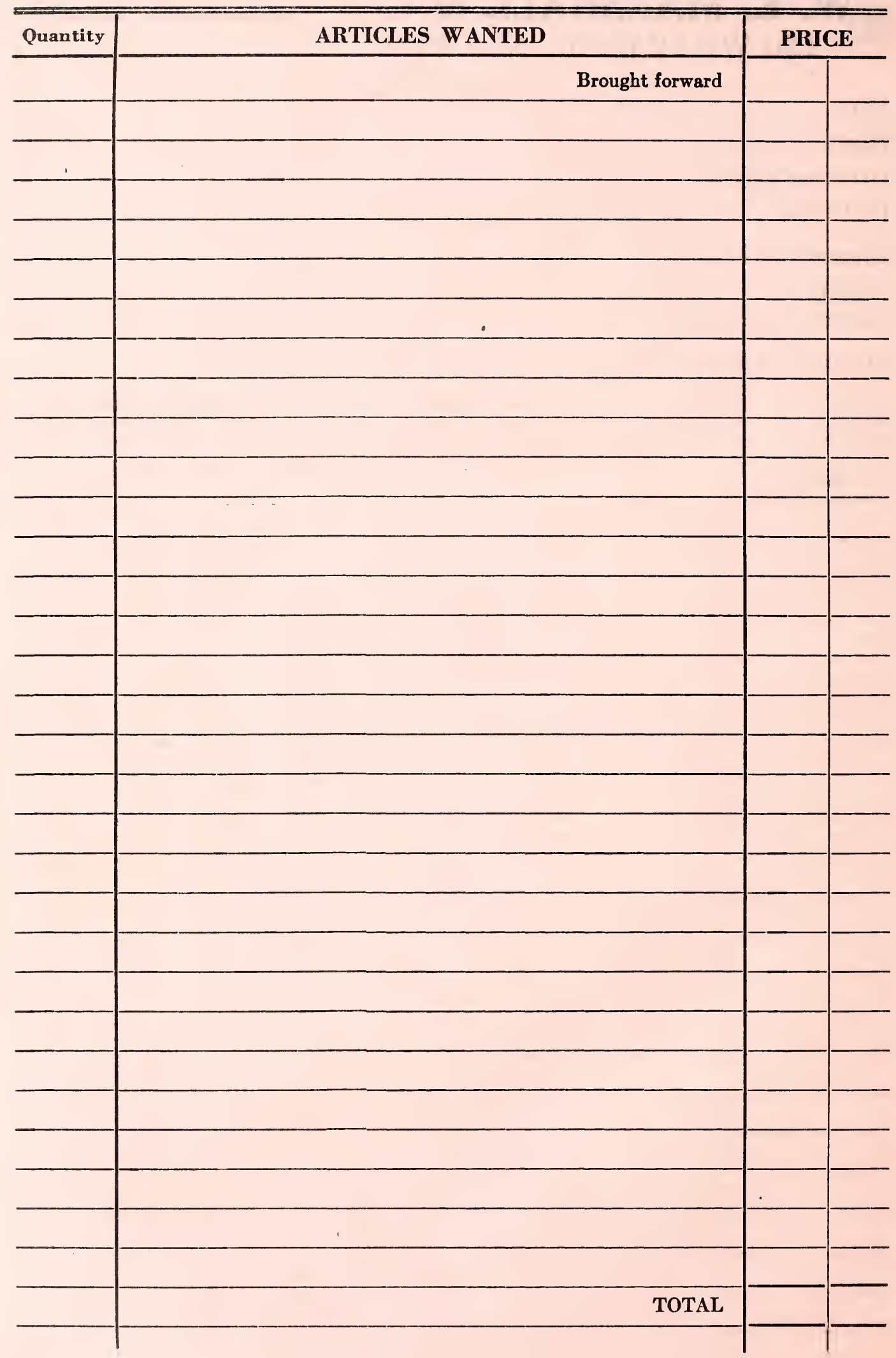


Vegetable Seeds for Planting in Hotbeds in March

BEANS

BEETS

EARLY CABBAGE

CAULIFLOWER

KOHL-RABI

CELERY

EGGPLANT

ENDIVE

LEEK

LETTUCE

ONION

PARSLEY

PEPPER

RADISH

TOMATO

\section{Seed Sowing and Planting Table for Vegetables for Home Gardeners in New York and Vicinity}

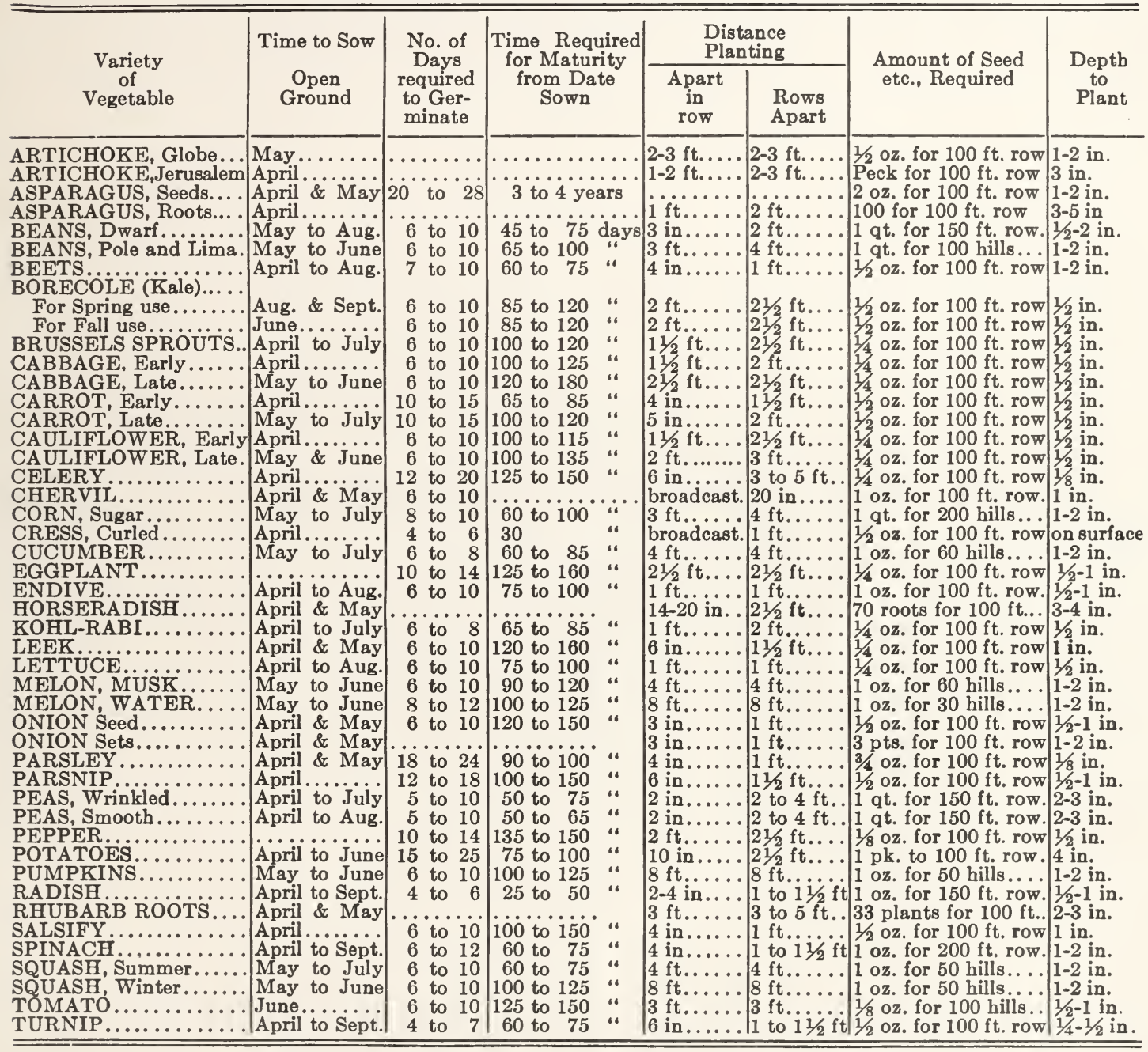

\section{Insecticides to Use for Insects and Fungous Diseases}

Insects that suck the juices from Plants and Foliage. In powder form, use Slug Shot, Hellebore or Tobacco Dust. In liquid form for spraying, use Aphine, Black Leaf 40, Kerosene Miscible Oil, Lemon Oil or Whale Oil Soap Insects that eat the Plants or Foliage. In powder form use Slug Shot, or Arsenate of Lead Powder. In liquid form use Ansecto, Aphine, Arsenate of Lead, Paris Green, or Whale Oil Soap.

Scale on Hard Wood Trees. Spray with Scale Killer, Scalecide, Lime Sulphur or Wilson's Plant Spray.

Fungous Diseases. Spray with Bordeaux, Fungine or Pyrox. Dust with Bordeaux or Grape Dust. Underground Insects. Cut Worm Killer, Tobacco Dust or Vermine.

Bone Meal. $5 \mathrm{lbs}$. to 100 sq. $\mathrm{ft}$. : $1 / 2$ to 1 ton per acre.

Blood and Bone (Tankage). 300 to 500 lbs. per acre.

Lime, Hydrated. For lawn, $100 \mathrm{lbs}$. to $400 \mathrm{sq}$. $\mathrm{ft}$., 1 ton per acre on light soils; 2 tons per acre on heavy soils.

Nitrate of Soda. $1 \mathrm{oz}$. to 2 gals. water; 100 to $200 \mathrm{lbs}$. per acre.

Sheep Manure. 1 lb. to 5 gals. of water, 500 to $600 \mathrm{lbs}$. per acre. 

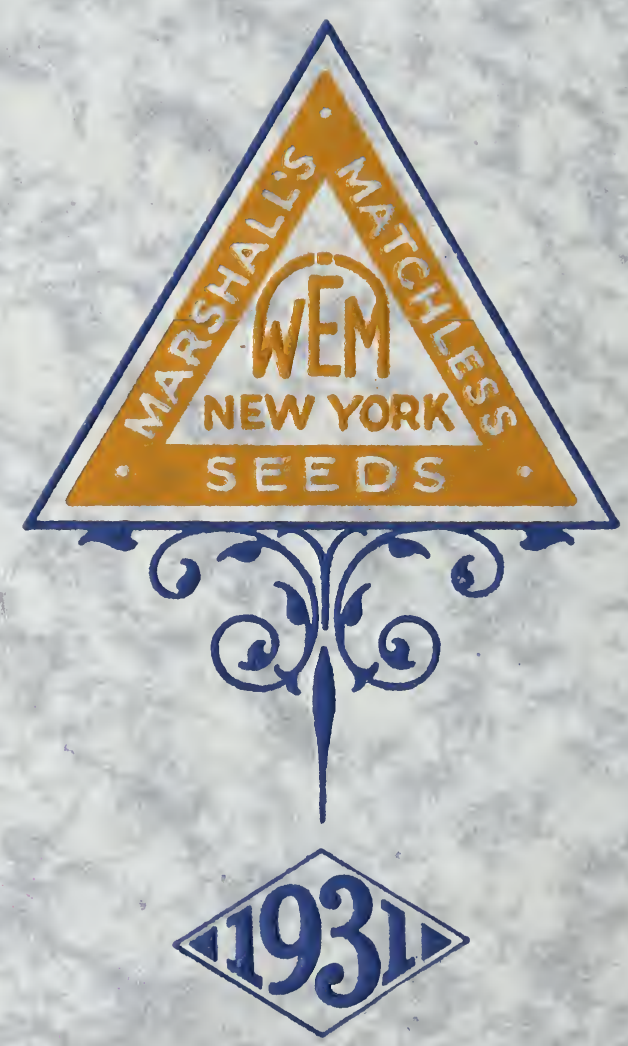

$y$

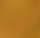

